\title{
Plant nutrient mobilization and acquisition strategies: adaptation to water and nutrient availability
}

\author{
Dissertation \\ to attain the doctoral degree \\ „Doctor rerum naturalium“ \\ of the Faculty of Forest Science and Forest Ecology \\ Georg-August-Universität Göttingen
}

Submitted by

Svenja Constanze Stock

born in Bad Neuenahr-Ahrweiler

Göttingen, October 2020 
1. Referee Prof. Dr. Michaela Dippold, Biogeochemistry of Agroecosystems, Georg-August-Universität Göttingen

2. Referee Prof. Dr. Christoph Leuschner, Plant Ecology and Ecosystem Research, Georg-August-Universität Göttingen

Date of oral examination: 14.01.2021 


\section{Table of Contents}

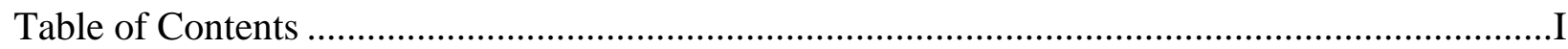

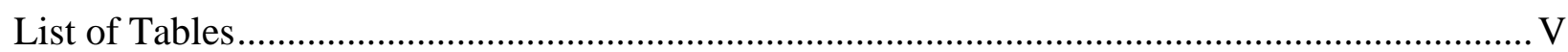

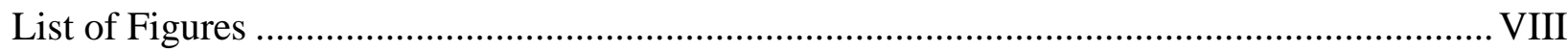

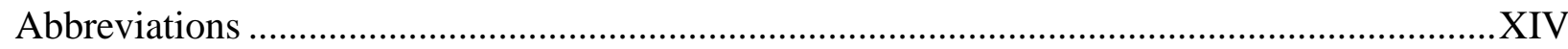

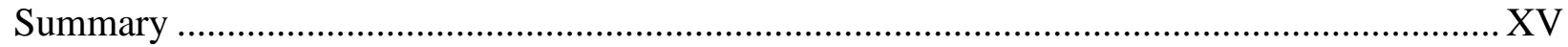

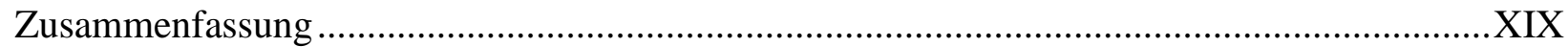

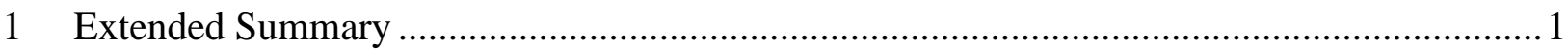

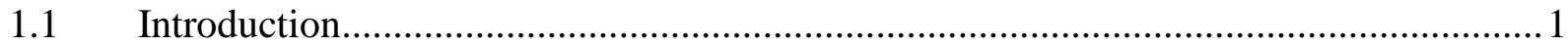

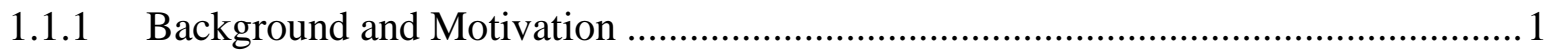

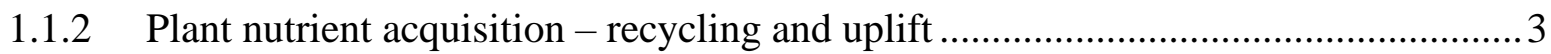

1.1.3 Plant nutrient economics - acquisitive or conservative? ......................................4

1.1.4 Plant carbon investment - agents and symbionts ..............................................

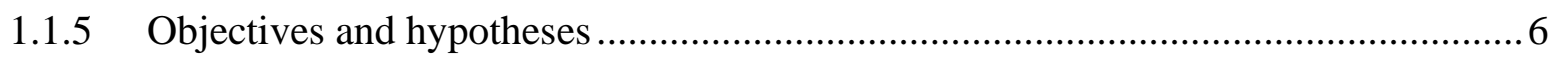

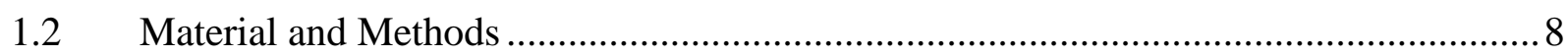

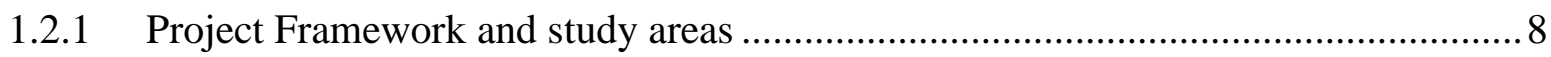

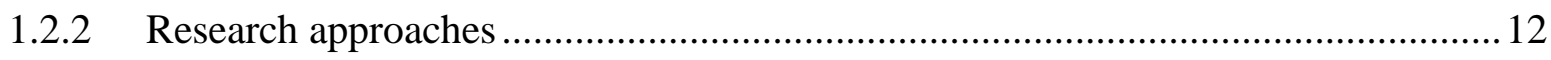

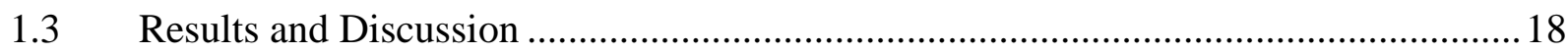

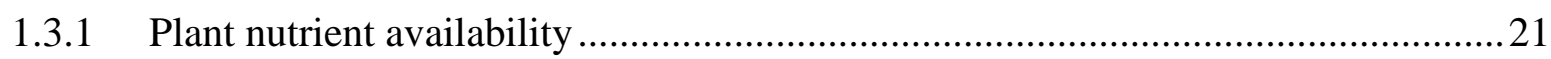

1.3.2 Nutrient mobilization and acquisition under intensive precipitation .....................22

1.3.3 Nutrient mobilization and acquisition under aridity ............................................24

1.3.4 Adaptations to high nutrient losses under Mediterranean conditions .....................27

1.4 Conclusion - Implications for ecosystem responses to precipitation shifts ................28

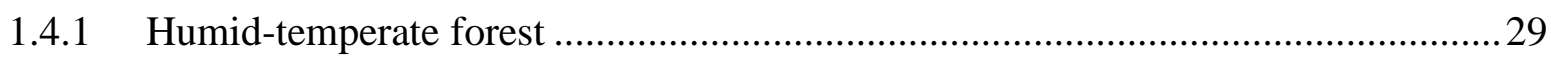

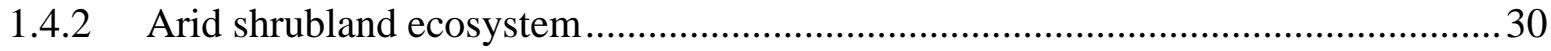

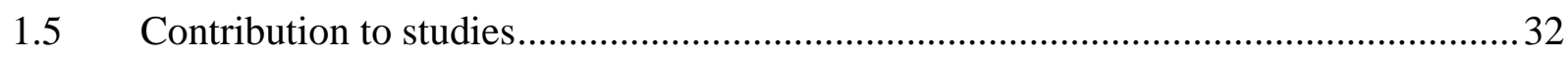

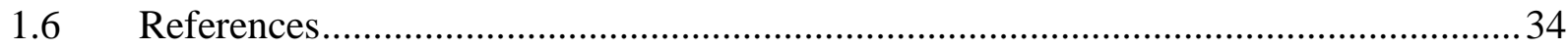

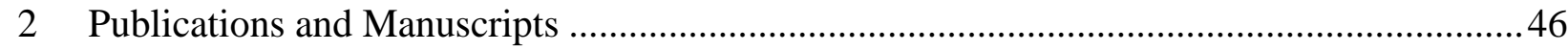

2.1 Study 1: Retention against losses: plant nutrient uplift and recycling in a continental transect of water and nutrient availability 


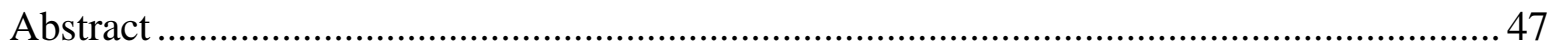

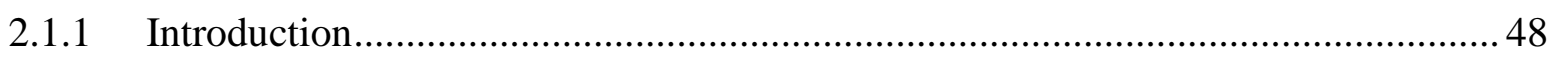

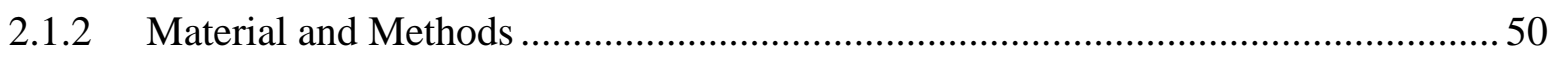

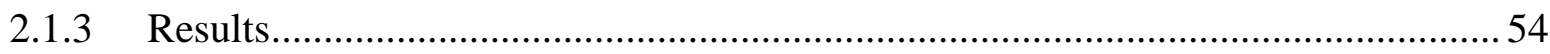

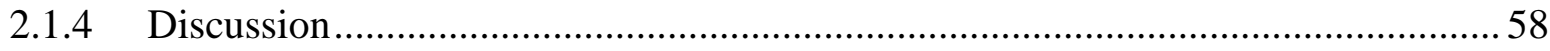

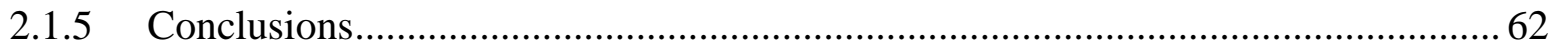

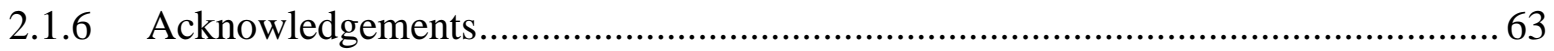

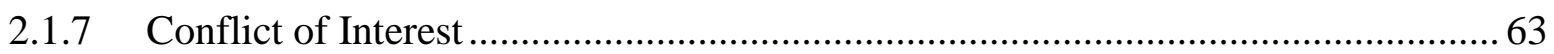

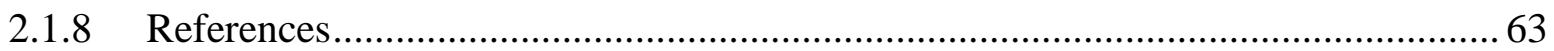

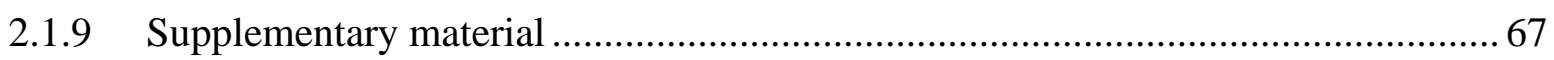

2.2 Study 2: Plant investment in arbuscular mycorrhizal fungi for $\mathrm{N}$ and $\mathrm{P}$ acquisition

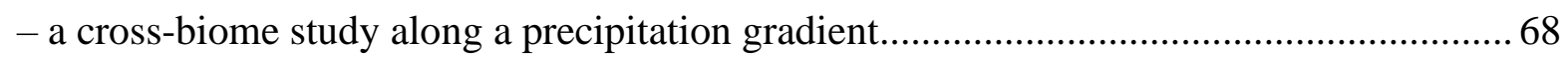

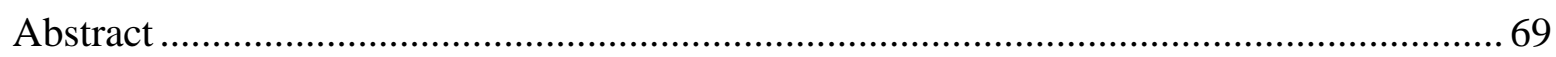

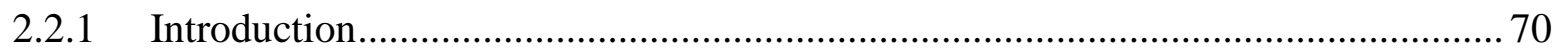

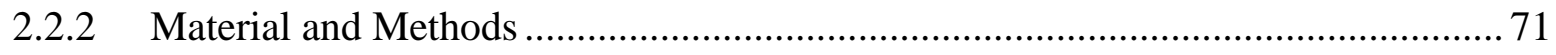

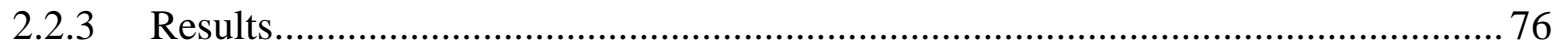

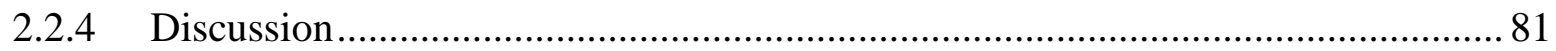

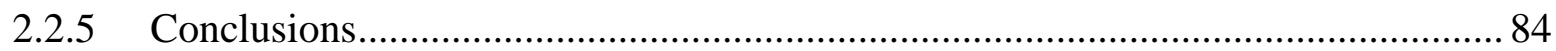

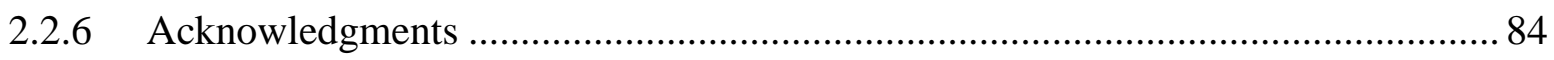

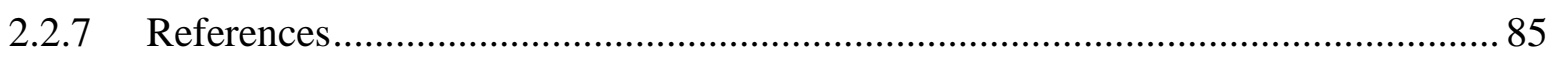

2.3 Study 3: Soil nitrogen cycling along a climatic gradient: from semidesert to

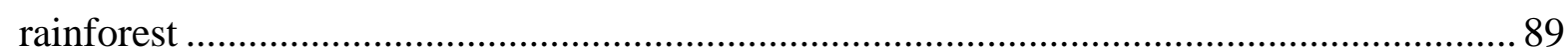

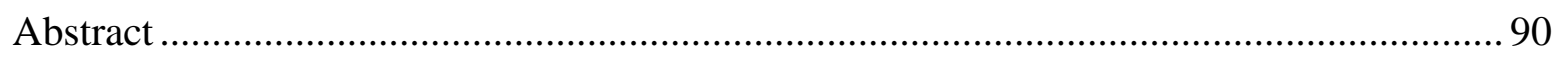

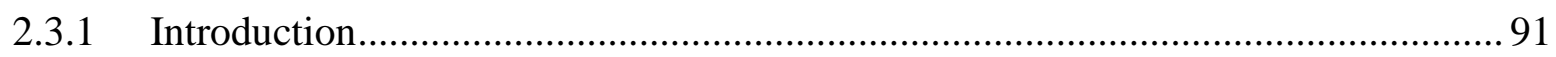

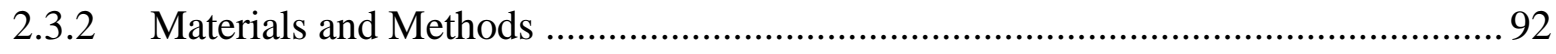

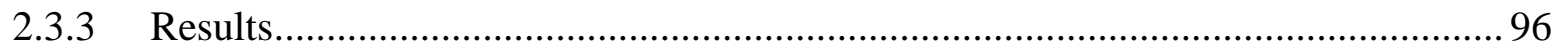

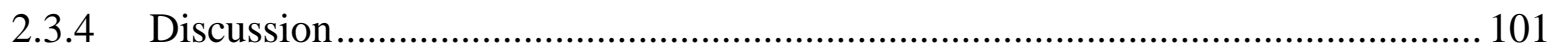

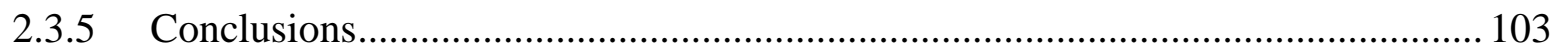

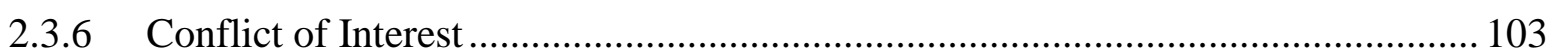

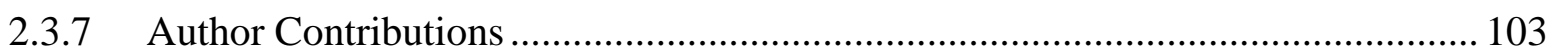

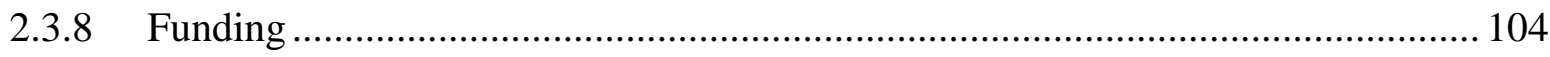

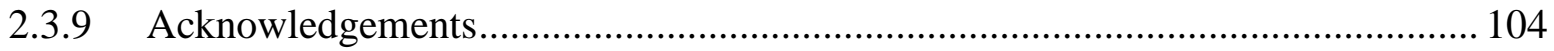

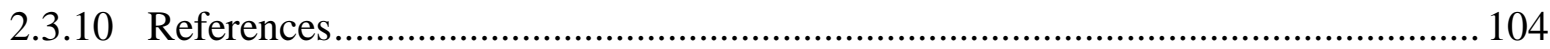


2.4 Study 4: Environmental drivers and stoichiometric constraints on enzyme activities in soils from rhizosphere to continental scale

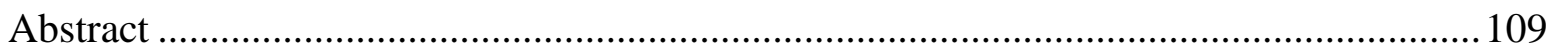

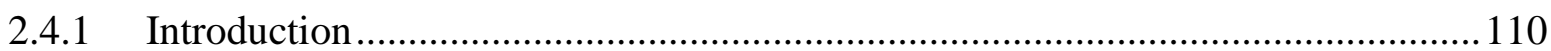

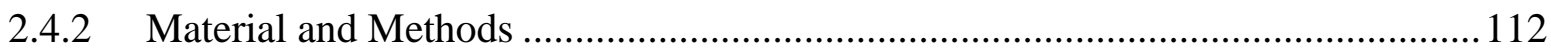

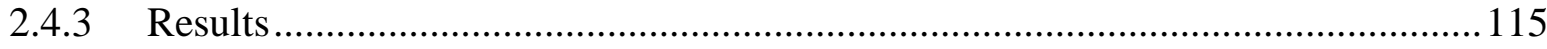

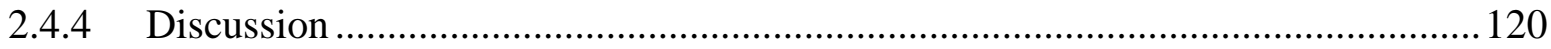

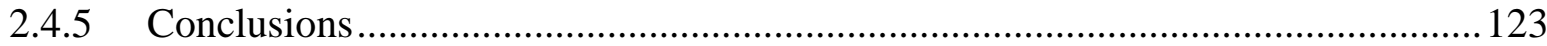

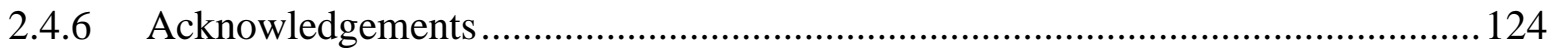

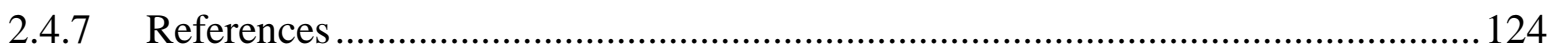

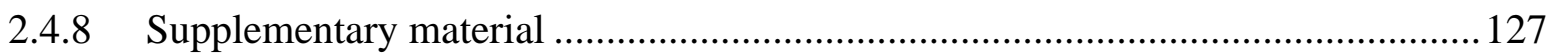

2.5 Study 5: From rock eating to vegetarian ecosystems - disentangling processes of phosphorus acquisition across biomes

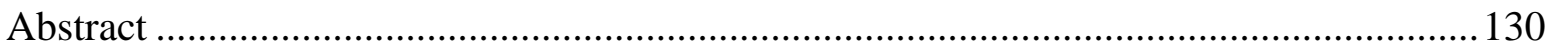

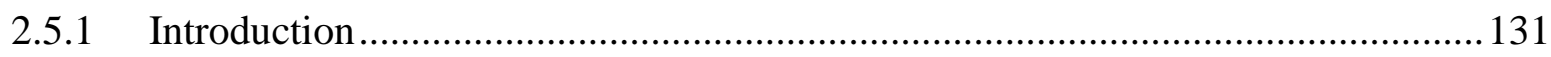

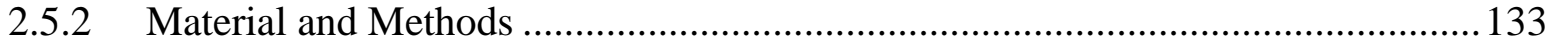

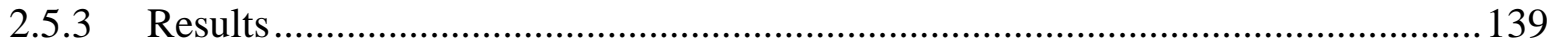

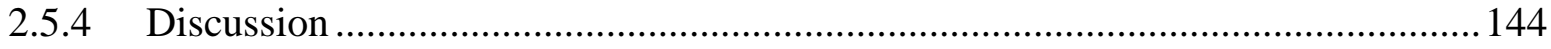

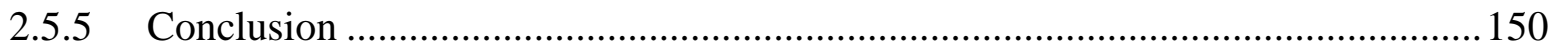

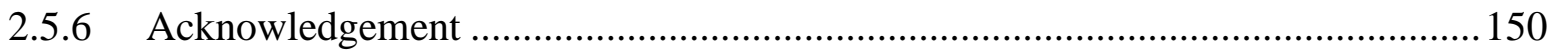

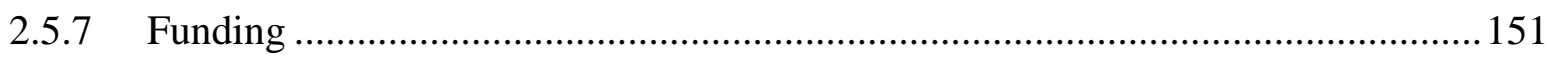

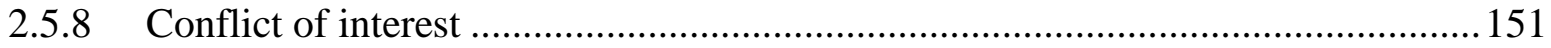

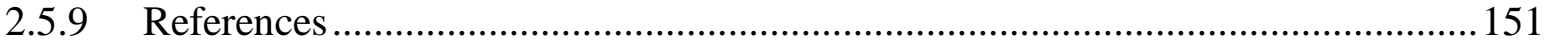

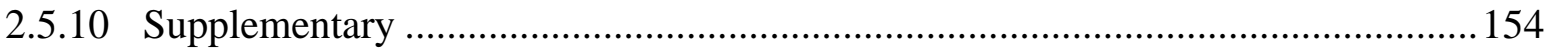

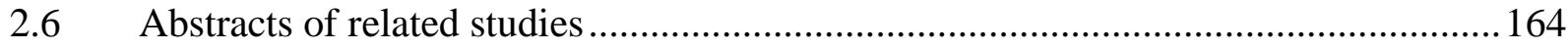

2.6.1 Chemistry and microbiology of the Critical Zone along a steep climate and vegetation gradient in the Chilean Coastal Cordillera

2.6.2 Pedogenic and microbial interrelations to regional climate and local topography: New insights from a climate gradient (arid to humid) along the Coastal Cordillera of Chile

2.6.3 Ferrous Wheel Hypothesis: Abiotic nitrate incorporation into dissolved organic matter 
2.6.4 Microbial uptake and utilization of inorganic phosphorus in soils of granidioritic origin formed under varying climatic conditions......................... 171

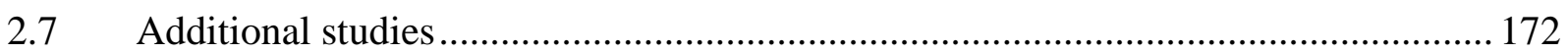

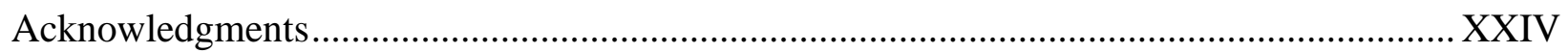

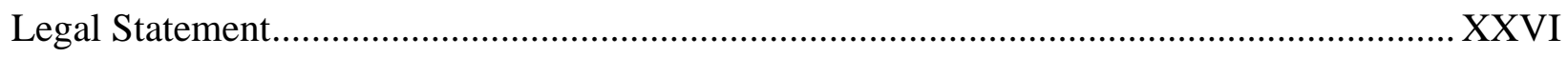




\section{List of Tables}

\section{Extended Summary}

Table 1.3-1: Overview of studies included in this thesis with main objectives, results, and conclusions

\section{$\underline{\text { Publications and Manuscripts }}$}

\section{Study 1}

Table 2.1-1: Amounts and concentrations of applied compounds and tracer elements $\left(\mathrm{Rb}, \mathrm{Cs},{ }^{15} \mathrm{~N}\right) \ldots \ldots . .51$

Table 2.2-1: Weather conditions during days of labeling and labeling durations................................. 72

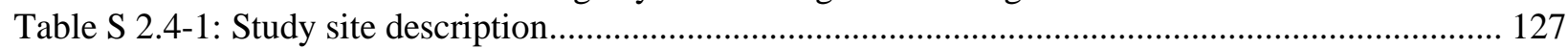

\section{Study 2}

Table 2.2-2: Carbon $(\mathrm{C})$, nitrogen $(\mathrm{N})$, total phosphorus $(\mathrm{P})$, and plant available $\mathrm{P}\left(\mathrm{P}_{\text {avail }}\right)$ contents. Data are presented as means $(n=8)$ with standard errors. Asterisks indicate significance between depths, capital letters between sites in 0-10 cm depth, and lowercase letters between sites in 20-30 $\mathrm{cm}$ depth.

Table 2.2-3: Carbon $(\mathrm{C})$, nitrogen $(\mathrm{N})$, and phosphorus $(\mathrm{P})$ stocks. Data are presented as means $(\mathrm{n}=8)$ with standard errors. Asterisks indicate significance between depths, capital letters between sites in 0-10 cm depth, and lowercase letters between sites in 20-30 cm depth.... 78

Table 2.2-4: PLFA 16:1 $15 \mathrm{c}$ and NLFA 16:1 $15 \mathrm{c}$ contents as well as NLFA:PLFA 16:1 $105 \mathrm{c}$ ratios. Data are presented as means $(n=8)$ with standard errors. Asterisks indicate significance between depths, capital letters between sites in 0-10 cm depth, and lowercase letters between sites in 20-30 cm depth.

\section{$\underline{\text { Study } 4}$}

Table 2.4-1: Overview of extracellular enzymes with respective fluorogenic substrates (Marx et al., 2001) and ecological functions.

Table S 2.4-2: Residual standard errors of the fitted non-linear saturation curves calculated by the Michaelis Menten equation. From left to right: $\mathrm{CBH}=\beta$-cellobiohydrolase, $\mathrm{BGL}=\beta$ glucosidase, $\mathrm{BXY}=\beta$-xylosidase, $\mathrm{NAG}=\beta$-N-acetylglucosaminidase, LEA $=$ leucineaminopeptidase, $\mathrm{TYA}=$ tyrosine-aminopeptidase, $\mathrm{ACP}=$ acid phosphatase

\section{$\underline{\text { Study } 5}$}

Table 2.5-1: Characteristics of the three study sites. Mean annual precipitation (MAP) and mean annual temperature (MAT) are derived from Fick and Hijmans (2017). Climate classifications from (Trabucco and Zomer, 2019). Vegetation type, soil type, $\mathrm{pH}$, and grain size distribution (sand-, silt-, and clay shares) are taken from Bernhard et al. (2018b). Grain size classes and $\mathrm{pH}$ were calculated as mean over the respective soil depths. Soil types refer to soil pits from midslope position at north- and south-facing soil pits. The sampling depth (by soil region) is given in percent classes as they were used for result presentation throughout the present work and in absolute values. Absolute sampling depth is given for the soil pit at the north facing slope in midslope position and for the south facing slope for the soil pits at top- mid- and toeslope position.....

Table 2.5-2: Standards included in the Linear combination fitting (LCF) for P species characterization of phosphorus K-edge X-ray absorption near edge structure (XANES) spectra are given in the first column. Characterization of each standard in the second column. 
Abbreviations as used in the redundancy analysis (RDA) are written in the third column.

Standards were grouped to $\mathrm{P}$ classes which are presented in column four.

Table 2.5-3: Six P pools as a sum of single standards from linear combination fitting (LCF) are shown. Values from the LCF are given in percent of total $\mathrm{P}(\mathrm{Ca}-\mathrm{P}=$ calcium phosphates, $\mathrm{Al}-\mathrm{P}=$ Al-phosphates, sorb Al-P = orthophosphate sorbed to Al-(oxy)hydroxides, Fe-P $=\mathrm{Fe}-$ phosphates, sorb $\mathrm{Fe}-\mathrm{P}=$ orthophosphates sorbed to $\mathrm{Fe}$-(oxy)hydroxides, $\mathrm{Po}=$ organically bound $\mathrm{P}$ ). The LCF was restricted to a maximum of four standards per sample. If a $\mathrm{P}$ pools was not detected in a sample this is indicated by 'n.d.' (not determined). Absolute values of $\mathrm{P}$ species were calculated by multiplying the share of a $\mathrm{P}$ pool with total $\mathrm{P}\left(\mathrm{P}_{\text {tot }}\right)$ $\left(\mathrm{Ca}-\mathrm{P}_{\text {tot }}=\right.$ calcium phosphates, Al- $\mathrm{P}_{\text {tot }}=\mathrm{Al}-$ phosphates, sorb $\mathrm{Al}-\mathrm{P}_{\text {tot }}=$ orthophosphate sorbed to Al-(oxy)hydroxides, $\mathrm{Fe}-\mathrm{P}_{\text {tot }}=\mathrm{Fe}$-phosphates, sorb $\mathrm{Fe}-\mathrm{P}_{\text {tot }}=$ orthophosphates sorbed to $\mathrm{Fe}$-(oxy)hydroxides, $\mathrm{Po}_{\mathrm{tot}}=$ organically bound $\left.\mathrm{P}\right)$. Rhizosphere $\mathrm{P}$ per root segment was calculated as total $P$ content in a cylinder around root with a length of $1 \mathrm{~cm}$ and a radius of $6 \mathrm{~mm}$, the inner diameter was set to $2 \mathrm{~mm}$ (average root thickness $(\mathrm{Ca}$ $\mathrm{P}_{\mathrm{RP}}=$ calcium phosphates, $\mathrm{Al}-\mathrm{P}_{\mathrm{RP}}=\mathrm{Al}$-phosphates, sorb Al- $\mathrm{P}_{\mathrm{RP}}=$ orthophosphate sorbed to AL-(oxy)hydroxides, Fe- $\mathrm{P}_{\mathrm{RP}}=\mathrm{Fe}$-phosphates, sorb Fe- $\mathrm{P}_{\mathrm{RP}}=$ orthophosphates sorbed to Fe-(oxy)hydroxides, $\mathrm{Po}_{\mathrm{RP}}=$ organically bound phosphor).

Table S 2.5-1: External standards included in the low-molecular-weight organic acids method. Retention time with a capillary column DB-FFAP, $30 \mathrm{~m}, 0.25 \mathrm{~mm}$ diameter and a film thickness of $1 \mu \mathrm{m}$. For settings of the gas chromatograph contact the authors. The limit of detection was calculated as the amount of analyte in the smallest standard before derivatization.

Table S 2.5-2: Total and constrained variance by the redundancy analysis (RDA). For the semiarid shrubland, Mediterranean woodland and humid-temperate forest

Table S 2.5-3: Scores of predictor variables (loadings) on redundancy analysis (RDA) axes. The values are a measure for how much variance of the variable is represented by the respective axis. Results are shown for the arid shrubland, Mediterranean woodland and humid-temperate forest.

Table S 2.5-4: Scores of explained variables (loadings) on redundancy analysis (RDA) axes. The values are a measure for how much variance of the variable is represented by the respective axis. Results are shown for the arid shrubland, Mediterranean woodland and humid-temperate forest. Please note that the values are represented in type I scaling, therefore, they do not allow to infer correlation with explaining variables. For the correlation between explaining end explained variables see Table S 2.5-6.

Table S 2.5-5: Standard deviation, explained variance per axis and cummulative explained variance from the redundancy analysis (RDA) for the arid shrubland, Mediterranean woodland and humid-temperate forest.

Table S 2.5-6: Correlations between explaining and explained variables from the redundancy analysis expressed as the cosine of the angle between the arrows resulting from the loadings in Table S 2.5-3 and type II scaled loadings of explained variables $\left(90^{\circ}=\right.$ independent, $0^{\circ}$ $=$ collinearity). Note that for the $\mathrm{P}$ species adsP-AlOH no values are reported. This is due to missing dependent variables for the two samples for which this $\mathrm{P}$ species was found. 156

Table S 2.5-7: P species results from the linear combination fitting (LCF) of phosphorus K-edge X-ray absorption near edge structure spectroscopy (XANES). The upper part shows the percentage of each species in total P. In the lower part of the table this is multiplied by the total $\mathrm{P}$ content in each sample and given as content per $\mathrm{kg}$ of soil $\left[\mathrm{mg} \mathrm{kg}^{-1}\right]$. Data are subdivided by sampling sites (arid shrubland, Mediterranean woodland and humidtemperate forest), therein by sampling depth (topsoil, subsoil and saprolite) and in each depth by three distances to the root $(0-2 \mathrm{~mm}, 2-4 \mathrm{~mm}$, and $4-6 \mathrm{~mm})$. The LCF was restricted to a maximum of four standards per sample. If a $\mathrm{P}$ pool was not detected in a sample this is indicated by n.d. (not determined).

Table S 2.5-8: Absolute contents of low-molecular-weight organic acids (LMWOA; oxalic-, malic-, citric-acid), MBC, $\mathrm{V}_{\max }$ and $\mathrm{K}_{\mathrm{m}}$ values of acid phosphatase, and LMWOA contents normalized by $\mathrm{MBC}$ are shown in the table. Values are averaged over four soil pits in each site \pm the standard error. At North facing soil pits only topsoil and the saprolite were sampled. At South facing all three depths (topsoil, subsoil, saprolite) were sampled. In 
the saprolite of the arid shrubland only root distances 0-2 $\mathrm{mm}$ and 4-6 mm were sampled, in all other sites sampled root distances were $0-2 \mathrm{~mm}, 2-4 \mathrm{~mm}$, and 4-6 mm. If a value is missing this is indicated by 'n.d.' (not detected).

Table S 2.5-9: Parameters from a linear model examining the effect of distance from the roots on microbial biomass carbon (MBC), low-molecular-weight organic acids (oxalic, malic, citric), and phosphatase kinetics $\left(\mathrm{V}_{\max }, \mathrm{K}_{\mathrm{m}}\right)$.

Table S 2.5-10: Parameters from a linear model examining the effect of distance from the roots on $\mathrm{P}$ species $(\mathrm{Ca}-\mathrm{P}=$ calcium phosphates, $\mathrm{Al}-\mathrm{P}=\mathrm{Al}$-phosphates, sorb Al-P $=$ orthophosphate sorbed to $\mathrm{Al}$-(oxy)hydroxides, Fe-P $=$ Fe-phosphates, sorb $\mathrm{Fe}-\mathrm{P}=$ orthophosphates sorbed to Fe-(oxy)hydroxides, Po = organically bound $\mathrm{P}$ ).

Table S 2.5-11: A generalized linear model (GLM) to examine the effect of soil depth on the parameters microbial biomass carbon (MBC), oxalic-, malic-, and citric acid content, maximum reaction rate of acid phosphatase $\left(\mathrm{V}_{\max }\right)$, and half saturation constant of acid phosphatase $\left(\mathrm{K}_{\mathrm{m}}\right)$ was calculated per study site. Distance from the roots was set as a fixed effect, with random slopes and random intercept. The table shows the results of the post-hoc least square means (with "Tukey" correction) pairwise comparison ( $p$ values).

Table S 2.5-12: A generalized linear model (GLM) to examine the effect of study site in each soil depth on the parameters microbial biomass carbon (MBC), oxalic-, malic-, and citric acid content, maximum reaction rate of acid phosphatase $\left(\mathrm{V}_{\max }\right)$, and half saturation constant of acid phosphatase $\left(\mathrm{K}_{\mathrm{m}}\right)$ was calculated. Distance from the roots was set as a fixed effect, with random slopes and random intercept. The table shows the results of the post-hoc least square means (with "Tukey" correction) pairwise comparison ( $p$ values)

Table S 2.5-13: A generalized linear model (GLM) to examine the effect of soil depth on P compound classes $(\mathrm{Ca}-\mathrm{P}=$ calcium phosphates, $\mathrm{Al}-\mathrm{P}=\mathrm{Al}-$ phosphates, sorb Al-P $=$ orthophosphate sorbed to $\mathrm{Al}$-(oxy)hydroxides, Fe-P $=$ Fe-phosphates, sorb Fe-P = orthophosphates sorbed to Fe-(oxy)hydroxides, $\mathrm{Po}=$ organically bound $\mathrm{P}$ ) was calculated per study site. Distance from the roots was set as a fixed effect, with random slopes and random intercept. The table shows the results of the post-hoc least square means (with "Tukey" correction) pairwise comparison ( $\mathrm{p}$ values).

Table S 2.5-14: A generalized linear model (GLM) to examine the effect of study site in each soil depth on $\mathrm{P}$ compound classes $(\mathrm{Ca}-\mathrm{P}=$ calcium phosphates, $\mathrm{Al}-\mathrm{P}=\mathrm{Al}$-phosphates, sorb $\mathrm{Al}-\mathrm{P}=$ orthophosphate sorbed to Al-(oxy)hydroxides, Fe-P = Fe-phosphates, sorb Fe-P = orthophosphates sorbed to Fe-(oxy)hydroxides, Po = organically bound $\mathrm{P}$ ) was calculated. Distance from the roots was set as a fixed effect, with random slopes and random intercept. The table shows the results of the post-hoc least square means (with "Tukey" correction) pairwise comparison ( $p$ values) 


\section{List of Figures}

\section{Extended Summary}

Figure 1.1-1: Multi-model mean changes in (a) precipitation $\left(\mathrm{mm} \mathrm{day}^{-1}\right)$, (b) soil moisture content $(\%)$, (c) runoff $\left(\mathrm{mm} \mathrm{day}^{-1}\right)$ and $(\mathrm{d})$ evaporation $\left(\mathrm{mm} \mathrm{day}^{-1}\right)$. To indicate consistency in the sign of change, regions are stippled where at least $80 \%$ of models agree on the sign of the mean change. Changes are annual means for the SRES A1B scenario (emission scenario of the IPCC Special Report on Emission Scenarios (2000) with $850 \mathrm{ppm} \mathrm{CO}_{2}$ in atmosphere 2100 for the period 2080 to 2099 relative to 1980 to 1999. Soil moisture and runoff changes are shown at land points with valid data from at least 10 models. Figure from Meehl et al. (2007)

Figure 1.1-2: Overview of the aspects investigated in objective 1 (nutrient availability), objective 2 (plant nutrient recycling and uplift and plant resource economics), and objective 3 (agents and symbionts for plant nutrient acquisition).

Figure 1.2-1: Study site overview. Showing mean annual precipitation (MAP) and mean annual temperature (MAT) along the gradient (WorldClima data Version 2, Fick and Hijmans et al., 2017). Study site locations indicated by triangles from north to south: arid shrubland, coastal matorral, Humid-temperate forest. Adapted from Stock et al. (2019).

Figure 1.2-2: Temperature and precipitation changes over Central and South America from MMD-A1B simulations (MMD: multi-model data set archived a the Program for Climate Model Diagnosis and Intercomparison PCMDI; SRES A1B: emission scenario with $850 \mathrm{ppm}$ $\mathrm{CO} 2$ in atmosphere in 2100). From left to right: annual mean, DJF (austral summer), JJA (austral winter). Top row: Temperature (top row) and precipitation (bottom row) changes between 1980 to 1999 and 2080 to 2099, average over 21 models. Modified from Christensen et al. (2007) Figure 11.15.

Figure 1.2-3: Mean annual precipitation change [\%] for the period 2070-2100 with 1960-1990 as reference. The change was normalized to the average of the current precipitation. Modelled with PRECIS-DGF (Providing REgional Climate Impact Studies) under the assumption of severe greenhouse gas emissions in the coming decades (SRES emission scenario A2 with $1250 \mathrm{ppm} \mathrm{CO}$ in atmosphere in 2100). *The region of the Atacama Desert is shown in gray as the precipitation there is (almost) $0 \mathrm{~mm}$. Taken from Garreaud,

(2011) Figure 9. Black stars indicate the approximate study site locations.

Figure 1.3-1: Three study sites across a precipitation gradient from arid to humid-temperate ecosystems were investigated, with highest denudation rates (red, solid line) under Mediterranean conditions (coastal matorral). (Study 3) Results indicated fasted N mineralization in the Mediterranean ecosystem. (Study 1) Plant N and K acquisition strategies differ across the gradient. High nutrient losses by denudation under Mediterranean climate, reduce longterm $\mathrm{N}$ recycling but stimulate intensive short-term recycling (red circling arrows). (Study 5) Plant P acquisition strategies shift along the gradient: biological weathering and uplift of inorganic $\mathrm{P}$ forms under arid conditions and in subsoil of the Mediterranean ecosystem - intensive organic $\mathrm{P}$ recycling (blue circling arrows) under forest and in topsoil under Mediterranean conditions. Functions of organic acids shift from mineral dissolution under arid to facilitation of organic $\mathrm{P}$ recycling under humid conditions. (Study 4) Nutrient recycling from organic matter increases with increasing precipitation, while the importance of the rhizosphere for $\mathrm{N}$ and $\mathrm{P}$ acquisition increases with increasing aridity. (Study 2) Root traits indicated fastest plant nutrient acquisition (green, dashed line) in the Mediterranean ecosystem. Plant C investment (solid black arrows) AMF was independent of precipitation. AMF functions shift from $\mathrm{P}$ mobilization under arid conditions to $\mathrm{N}$ and $\mathrm{P}$ acquisition under Mediterranean and humid conditions. Only in the Mediterranean ecosystem exert AMF the additional function to retain mobile nutrients (as N) and prevent losses from soil. In line with that, allocation of freshly assimilated $\mathrm{C}\left({ }^{13} \mathrm{C}\right)$ to AMF storage compounds was highest in soil under Mediterranean conditions 
Figure 1.3-2: Activities $\left(\mathrm{V}_{\max }\right)$ of chitinases, aminopeptidases, and phosphatases per nmol of SOC in absolute soil depth, corresponding to $0-50 \%, 50-100 \%$ and $>100 \%$ solumn depth (sampling set 3). Data are presented as means with standard errors.

\section{$\underline{\text { Publications and Manuscripts }}$}

\section{Study 1}

Figure 2.1-1: Monthly mean temperature (red line) and monthly mean precipitation (blue line) in the three study sites as well as total monthly precipitation (gray bars) and number of days with precipitation (numbers on top of bars) during the experiment from March till November 2016. n.a. = no data available. Monthly means are derived from Fick and Hijmans (2017) and precipitation data for 2016 are derived from Ehlers et al. (2017) and $(\mathrm{CR})^{2}$ (for details see method section). Green shading indicates favorable (dark) and semi-favorable (light) months for vegetation according to di Castri and Hajek (1976). Note that vegetation months for the humid-temperate forest are derived from the station 'Angol' which lies $50 \mathrm{~km}$ landwards from the National Park Nahuelbuta at ca. $80 \mathrm{~m}$ a. s. 1., whereas the study site within the National Park lies at ca. $1200 \mathrm{~m}$ a. s. 1.

Figure 2.1-2: Tracer recovery of $\mathrm{N}\left({ }^{15} \mathrm{~N}\right.$, left $)$ and $\mathrm{K}(\mathrm{Rb}+\mathrm{Cs}$ as $\mathrm{K}$ analogs, right) from topsoil, subsoil, and saprolite in shoots (top) and roots (bottom) in the three study sites: arid shrubland, Mediterranean coastal matorral, humid-temperate forest. ${ }^{15} \mathrm{~N}$ recovery under forest is additionally presented on a smaller $\mathrm{y}$-axis (inset box). Data are presented as means ( $\mathrm{n}=$ $8)$ with standard errors. Significant differences $(p<0.05)$ between depths are indicated with lowercase letters for shoots and with capital letters for roots within sites. Asterisks indicate significant differences between plants within sites.

Figure 2.1-3: Depth profiles of total potassium $(\mathrm{K})$ and nitrogen $(\mathrm{N})$ stocks in $10 \mathrm{~cm}$ depth increments in the arid shrubland and Mediterranean coastal matorral, and in $25 \mathrm{~cm}$ depth increments in the humid-temperate forest. Data are presented as means $(n=3)$ with standard errors. Dashed and dotted lines indicate preferential acquisition depths of the respective nutrient (blue dotted $=\mathrm{K}$; red dashed $=\mathrm{N}$ ) derived from the tracer recoveries (see Fig. 1). Note the different soil depth scales for the three sites.

Figure 2.1-4: Relative $\mathrm{K}$ analog recovery per unit $\mathrm{N}$ recovery from topsoil, subsoil, and saprolite in the three study sites: arid shrubland, Mediterranean coastal matorral, humid-temperate forest. Relative $\mathrm{K}$ analog recovery under shrubland is additionally presented on a smaller $\mathrm{y}$-axis (insert box). Data are presented as means with standard errors. Differences between depths within sites were not significant $(\mathrm{p}>0.05)$.

Figure 2.1-5: Vertical distribution of exchangeable $\mathrm{K}$ and $\mathrm{Na}(\mathrm{K}, \mathrm{Na})\left[\mu \mathrm{mol}_{\mathrm{c}} \mathrm{g}^{-1}\right]$, percentage of $\mathrm{K}$ and $\mathrm{Na}$ to total cation exchange capacity $(\% \mathrm{~K}, \% \mathrm{Na})$ as well as $\mathrm{pH}$ in the three study sites: arid shrubland, Mediterranean coastal matorral, humid-temperate forest. Data were taken from Bernhard et al. (2018) and are presented as means of top, mid, and bottom slope positioned soil pits with standard errors. Error bars for $\mathrm{pH}$ are omitted for clarity. Note the different soil depth scales for the three sites.

Figure 2.1-6: ${ }^{15} \mathrm{~N}$ natural abundance $\left(\delta^{15} \mathrm{~N}\right.$ signatures) of shoots (above the 0 -line), roots, and topsoil (left), and plant $\mathrm{C}: \mathrm{N}$ and $\mathrm{N}: \mathrm{K}$ ratios (right) in the three study sites: arid shrubland, Mediterranean coastal matorral, humid-temperate forest. Data are presented as means with standard errors. Significant differences $(\mathrm{p}<0.05)$ between sites are indicated with

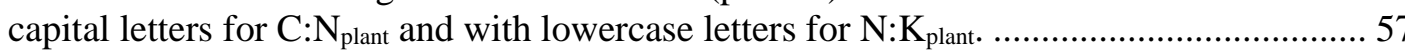

Figure 2.1-7: Cross-biome redundancy analysis (RDA) for ${ }^{15} \mathrm{~N}$ and $\mathrm{K}$ tracer recovery $\left(\mathrm{N}_{\mathrm{acq}}, \mathrm{K}_{\mathrm{acq}}\right)$, presented as type II scaling (correlation) plot. Explanatory variables: sum of precipitation (precip) and days with precipitation (frequ) during the 8 month of the experiment, $\mathrm{C}: \mathrm{N}_{\text {plant/soil, }} \mathrm{N}: \mathrm{K}_{\text {plant}}$, exchangeable $\mathrm{K}$ ( $\left.\mathrm{K}_{\text {exchange }}\right)$, and clay content as well as fungal and bacterial DNA abundance (fungi, bacteria) and protease and chitinase (NAG) activities relative to soil organic carbon. The overall RDA was significant with 999 permutations. . 58

Figure S 2.1-1: Depth profiles of total rubidium $(\mathrm{Rb})$ and cesium $(\mathrm{Cs})$ stocks in $10 \mathrm{~cm}$ depth increments in the arid shrubland and Mediterranean coastal matorral, and in $25 \mathrm{~cm}$ depth increments in the humid temperate forest. Data are presented as means $(n=3)$ with standard errors. . 67 
Figure S 2.1-2: Depth profiles of dithionite-citrate extracted (Fed) and ammonium-oxalate extracted iron (Feox) in the humid temperate forest. Data were taken from Bernhard et al. (2018) and are presented as means $(n=4)$ with standard errors. Red dashed lines indicate preferential acquisition depths of nitrogen under humid forest.

\section{Study 2}

Figure 2.2-1: Ternary plot of molar soil $\mathrm{C}, \mathrm{N}$, and plant available $\mathrm{P}$ contents. The molar C:N, C:P, and $\mathrm{N}: \mathrm{P}$ ratios increase markedly from the arid shrubland and Mediterranean coastal matorral to the humid-temperate forest

Figure 2.2-2: Root Length Density (RLD), Specific Root Length (SRL), Root Tissue Density (RTD), and Root Nitrogen Content (RNC) of fine roots $(\leq 1.0 \mathrm{~mm}$ diameter). Data are presented as means $(n=4)$ with standard errors. Asterisks indicate significant differences between depths, capital letters between sites in 0-10 $\mathrm{cm}$ depth, and lowercase letters between sites in 20-30 cm depth.

Figure 2.2-3: Percent of root area colonized by AMF, relative PLFA 16:1 $105 \mathrm{c}$ content per SOC, and relative NLFA content $16: 105 \mathrm{c}$ per SOC. Data are presented as means $(n=8)$ with standard errors. Asterisks indicate significant differences between depths, capital letters between sites in $010 \mathrm{~cm}$ depth, and lowercase letters between sites in 20-30 cm depth. ... 79

Figure 2.2-4: ${ }^{13} \mathrm{C}$ incorporation of applied tracer in root tissue, PLFA 16:1 $\omega 5 \mathrm{c}$, and NLFA 16:1 $\omega 5 \mathrm{c}$. Data are presented as means (Root $n=8$; PLFA and NLFA $n=4$ ) with standard errors. Incorporation of ${ }^{13} \mathrm{C}$ was highest in the NLFA pool in all sites. Incorporated ${ }^{13} \mathrm{C}$ in the PLFA pool is subsequently assimilated (decreasing ${ }^{13} \mathrm{C}$ incorporation over the duration of the experiment). ${ }^{13} \mathrm{C}$ incorporation in root tissue was lower than in PLFA and NLFA pools and increases with proceeding time (except in $0-10 \mathrm{~cm}$ in the Mediterranean ecosystem).

Figure 2.2-5: Principal component analyses conducted for separate sites: arid ecosystem: shrubland (left), Mediterranean ecosystem: coastal matorral (mid), and humid ecosystem: humidtemperate forest (right). $\mathrm{N}=\mathrm{N}$ stock, $\mathrm{P}=\mathrm{P}$ stock, $\mathrm{P}_{\text {avail }}=$ plant available $\mathrm{P}, \mathrm{SRL}=$ specific root length, $\mathrm{RTD}=$ root tissue density, $\mathrm{AMF} \%=\%$ root area colonization, $\mathrm{PLFA}=\mu \mathrm{g}$ PLFA 16:1 $1 \omega 5 \mathrm{~g}^{-1}$ dry soil, NLFA $=\mu \mathrm{g}$ NLFA $16: 1 \omega 5 \mathrm{~g}^{-1}$ dry soil, Act ${ }_{\mathrm{AMF}}=$ maximum ${ }^{13} \mathrm{C}$ incorporation in PLFA16:1 $\omega 5$, Inv $\mathrm{NLFA}=$ maximum ${ }^{13} \mathrm{C}$ investment in NLFA16:1 $\omega 5$, $\mathrm{Inv}_{\text {Root }}=$ maximum ${ }^{13} \mathrm{C}$ investment in root tissue. Color of variables indicates a stronger correlation to $\mathrm{N}$ (red) or $\mathrm{P}$ (blue). The explanation power increases from the arid to the humid ecosystem in $1^{\text {st }}$ dimension.

\section{Study 3}

Figure 2.3-1: Nitrogen content, soil C:N ratio, and $\delta 15 \mathrm{~N}$ signatures in soil depth profiles. Data are presented as means $(\mathrm{n}=8)$ with standard errors. Arrows indicate direction of increasing aridity. Nitrogen contents and C:N ratios decrease markedly with increasing aridity. $\delta 15 \mathrm{~N}$ values were lowest in soil under Mediterranean conditions.

Figure 2.3-2: Regressions of $\delta^{15} \mathrm{~N}$ vs. $-\ln (\% \mathrm{~N})$ for the arid shrubland (red), Mediterranean coastal matorral (blue), and humid temperate forest (black) as well as the regression slopes ( $\beta$ ) presented with the regression standard errors.

Figure 2.3-3: Extracellular enzyme activities $\left(\mathrm{V}_{\max }\right)$ of chitinases (left) and aminopeptidases (right) per $\mathrm{g}$ of soil (top row) and per nmol of SOC (bottom row). Data are presented as means with standard errors

Figure 2.3-4: Quantification of microbial abundance along the depth in $(\mathrm{A}, \mathrm{B})$ bulk soil and $(\mathrm{C}, \mathrm{D})$ rhizosphere by qPCR using bacterial (Bac27f/338r) and fungal (NL1f/LS2R) primers in humid temperate forest, Mediterranean woodland, and arid shrubland. Data in A and C are expressed as ng of DNA per $g$ soil, while in B and D they are expressed as ng of DNA per $\mathrm{g}$ organic carbon as sampled from the soil profile wall. Error bars represent standard errors of the means. Note the different Y scaling of depth for bulk and rhizosphere soil. .. 98

Figure 2.3-5: Quantification of nitrogenase reductase (nifH) gene by qPCR depending on depths in humid temperate, Mediterranean, and arid soils. (A) (B) Data are collected from bulk 
soil, while in (C) (D) data are collected from the rhizosphere of the complete profile down to the saprolith. Abundance of nifH gene is expressed in gene copy number (A and C) and percentage of diazotrophy in prokaryotic parts of community (B and D). Data are expressed as gene copy number per gram soil. Error bars represent standard error of the mean. Note different Y scaling of depths for bulk and rhizosphere soils. 99

Figure 2.3-6: Principle component analyses generated from $\mathrm{N}$ and $\mathrm{C}$ contents, $\delta 15 \mathrm{~N}$, abundance of bacterial and fungal DNA, and gene copy number of nifH and 16S genes in A) bulk and B) rhizosphere soil. Colors indicate study site and symbol shapes indicate north- or southfacing slope. Ellipses show two standard deviations of an assumed two-dimensional normal distribution for each study site.

\section{Study 4}

Figure 2.4-1: Study site overview. Showing mean annual precipitation (MAP) and mean annual temperature (MAT) along the continental gradient (WorldClima data Version 2, Fick and Hijmans et al., 2017). Study sites from north to south: Santa Gracia, La Campana, Nahuelbuta.

Figure 2.4-2: Depth profiles of carbon content, nitrogen content, C:N ratio, and soil moisture in Nahuelbuta (black triangles), La Campana (blue circles), and Santa Gracia (red diamonds), separated by root proximities - 0-2 $\mathrm{mm}$ (darkest shade), 2-4 mm, and 4-6 mm (lightest shade). Data points represent means \pm SE of south-exposed slopes $(n=3)$. C and $\mathrm{N}$ content, as well as $\mathrm{C}: \mathrm{N}$ show clear increase $(\mathrm{p}<0.05)$ from bulk soil to roots in the sites under humid temperate (Nahuelbuta) and under Mediterranean (La Campana) climate conditions; especially in the topsoil.

Figure 2.4-3: Continental gradients of potential activities $\left(\mathrm{V}_{\max }\right)$ and substrate affinities $\left(\mathrm{K}_{\mathrm{m}}\right)$ of the extracellular enzymes (from left to right): $\mathrm{CBH}=\beta$-cellobiohydrolase, $\mathrm{BGL}=\beta$ glucosidase, $\mathrm{BXY}=\beta$-xylosidase, $\mathrm{NAG}=\beta$-N-acetylglucosaminidase, $\mathrm{LEA}=$ leucineaminopeptidase, TYA = tyrosine-aminopeptidase, ACP = acid phosphatase. Sites: Santa Gracia (SG), La Campana (LC), and Nahuelbuta (NA). Data present means \pm SE of north and south slopes and all soil depths and root distances (SG, LC: $n=36$; NA: $n=24$. Letters indicate significant $(\mathrm{p}<0.05)$ differences of activities and affinities between the study sites identified by GLMM. Activities of C-, N-, and P-acquiring enzymes increase with humidity, while substrate affinities decrease (i.e. increasing $\mathrm{K}_{\mathrm{m}}$ ). Blue arrows show effects of the continental moisture gradient on the enzyme activities and affinities.

Figure 2.4-4: Potential activities $\left(\mathrm{V}_{\max }\right)$ and substrate affinities $\left(\mathrm{K}_{\mathrm{m}}\right)$ separated by soil depth $(1=$ topsoil, $2-3=$ subsoil) of (from left to right): $\mathrm{CBH}=\beta$-cellobiohydrolase, $\mathrm{BGL}=\beta$-glucosidase, $\mathrm{BXY}=\beta$-xylosidase, $\mathrm{NAG}=\beta$-N-acetylglucosaminidase, $\mathrm{LEA}=$ leucineaminopeptidase, TYA = tyrosine-aminopeptidase, ACP = acid phosphatase. Sites: Santa Gracia (SG), La Campana (LC), and Nahuelbuta (NA). Soil depths: $1=$ triangle, $2=$ square, 3 = inverted triangle - Santa Gracia: 0-40 cm, 40-80 cm, 80-200 cm; La Campana: 0-60 cm, 60-120 cm, 120-200 cm; Nahuelbuta: 0-80 cm, 80-160 cm. Data present means $\pm \mathrm{SE}$ of both slopes and all root distances separated by soil depths $(\mathrm{n}=12)$. Letters indicate significant differences $(\mathrm{p}<0.05)$ between soil depths. Activities of $\mathrm{C}-, \mathrm{N}-$, and Pacquiring enzymes are higher in the topsoil (depth 1) than subsoil (depth 2 and 3) at the sites under humid temperate (NA) and Mediterranean (LC) climate conditions. Substrate affinities of $\mathrm{C}$-acquiring enzymes are tendential ( $p>0.05)$ higher in the topsoil than subsoil, while substrate affinities of $\mathrm{N}$ - and $\mathrm{P}$-acquiring enzymes are tendential ( $\mathrm{p}>0.05)$ lower in the topsoil and higher in the subsoil

Figure 2.4-5: Enzyme activities $\left(\mathrm{V}_{\max }\right)$ from bulk soil $(6-4 \mathrm{~mm})$ to root proximity $(2-0 \mathrm{~mm})$. Nahuelbuta $=$ top row La Campana $=$ middle row; Santa Gracia $=$ bottom row. Data present means \pm SE from both slopes and all soil depths (SG, $L C: n=12 ; N A: n=8)$. From left to right: $\mathrm{CBH}=\beta$-cellobiohydrolase, $\mathrm{BGL}=\beta$-glucosidase, $\mathrm{BXY}=\beta$-xylosidase, $\mathrm{NAG}=$ $\beta$-N-acetylglucosaminidase, LEA $=$ leucine-aminopeptidase, TYA $=$ tyrosineaminopeptidase, $\mathrm{ACP}=$ acid phosphatase. GLMM only identified activity differences of acid phosphatases in La Campana (Mediterranean climate conditions) as significant ( $\mathrm{p}<0.05$; indicated by letters). Blue arrows show effects of the rhizosphere gradient on 
enzyme activities. Trends ( $\mathrm{p}>0.05$ ) of increasing activities from bulk soil to roots of $\mathrm{C}$-, $\mathrm{N}$-, and P-acquiring enzymes were detected at the sites under humid temperate (Nahuelbuta) and Mediterranean (La Campana) climate conditions. At the site under semiarid conditions (Santa Gracia) only tyrosine-aminopeptidase activities showed an increasing trend $(\mathrm{p}>0.05)$ from bulk soil to roots.

Figure 2.4-6: Substrate affinities $\left(\mathrm{K}_{\mathrm{m}}\right)$ from bulk soil $(0-6 \mathrm{~mm})$ to root proximity $(2-0 \mathrm{~mm})$. Nahuelbuta $=$ top row; La Campana $=$ middle row; Santa Gracia $=$ bottom row. Data present means \pm SE from both slopes and all soil depths (SG, LC: $n=12 ; N A: n=8)$. From left to right: $\mathrm{CBH}=\beta$-cellobiohydrolase, $\mathrm{BGL}=\beta$-glucosidase, $\mathrm{BXY}=\beta$-xylosidase, $\mathrm{NAG}=$ $\beta-\mathrm{N}$-acetylglucosaminidase, LEA $=$ leucine-aminopeptidase, TYA $=$ tyrosineaminopeptidase, ACP = acid phosphatase. GLMM only identified affinity differences of acid phosphatases in La Campana (Mediterranean climate conditions) as significant ( $<<0.05$; indicated by letters). Blue arrows show effects of the rhizosphere gradient on substrate affinities. The strongest trends of substrate affinities were detected at the site under humid temperate conditions (Nahuelbuta): Affinities of C-acquiring enzymes increased from bulk soil to root, while affinities of $\mathrm{N}$ - and $\mathrm{P}$-acquiring enzymes decreased.

Figure 2.4-7: Redundancy analysis on potential activities of cellobiohydrolase (CBH), b-glucosidase (BGL), b-xylosidase (BXY), b-N-acetylglucosaminidase (NAG), leucineaminopeptidase (LEA), tyrosine-aminopeptidase (TYA), and acid phosphatase (ACP) with $\mathrm{C}$ and $\mathrm{N}$ contents, soil moisture, $\mathrm{pH}$, and particle size fractions as constraints. The overall RDA was significant with 999 permutations. A type II scaling (correlation) plot is shown, including only significant constraining variables. The constraining variables explained $57.1 \%$ of the total variance.

Figure 2.4-8: Redundancy analysis on $\mathrm{C}$ and $\mathrm{N}$ contents with soil moisture, $\mathrm{pH}$, and particle size fractions as constraints. The overall RDA was significant with 999 permutations. A type II scaling (correlation) plot is shown, including only significant constraining variables. The constraining variables explained $87.8 \%$ of the total variance.

\section{Study 5}

Figure 2.5-1: PCA calculated for all soil samples with (A) P species from phosphorus K-edge X-ray absorption near edge structure (XANES) analysis as variables and (B) P species and lowmolecular-weight organic acids (LMWOA) (oxalic-, malic-, and citric acid) as variables. Sampling sites are indicated by color, arid shrubland in purple, Mediterranean woodland in orange and humid-temperate forest in turquoise. Marker type denotes the sampling depth: circles $=$ topsoil, diamonds $=$ subsoil, and saprolite $=$ triangles.

Figure 2.5-2: Content of low-molecular-weight organic acids (LMWOA) (citric-, malic- and oxalic acid) for north (blue circles) and south (red diamonds) facing slopes for all three sites (arid shrubland ('shrubland'), Mediterranean woodland ('woodland') and humidtemperate forest ('forest')) and three sampling depths (topsoil, subsoil and and saprolite) separated by the three horizontal panels. Whiskers indicate the magnitude of the standard error from the mean. The x-axis shows root proximity (intervals of $2 \mathrm{~mm}$ from $0-2 \mathrm{~mm}$, 2-4 mm, and 4-6 mm), y-axis plots the content of organic acids per gram soil dry weight. Sample size on the south facing slope is $n=3$, on the north facing slope single replicates are shown $(n=1)$. Arrows indicate significant changes with distance to the roots, the color of the arrow was chosen according to the respective data row. Level of significance is indicated by asterisk $(\mathrm{p}<0.05)$ and cross $(\mathrm{p}<0.1)$.

Figure 2.5-3: Contents of $\mathrm{P}$ compound classes from phosphorus K-edge X-ray absorption near edge structure (XANES) analysis: calcium phosphates(Ca-P), Al- and Fe phosphates (Al-P and $\mathrm{Fe}-\mathrm{P}$ ), orthophosphate sorbed to Al- and Fe-(oxy)hydroxides (sorbAl-P and sorbFe-P) and organic $\mathrm{P}$, split by slope facing (circles $=$ north facing; diamonds $=$ south facing) and by site (arid shrubland ('shrubland') in purple, Mediterranean woodland ('woodland') in orange and humid-temperate forest ('forest') in turquoise. Samples from different depths are separated by the three horizontal panels (topsoil, subsoil and saprolite). The $\mathrm{x}$-axis shows root proximity $(0-2 \mathrm{~mm}, 2-4 \mathrm{~mm}$, and $4-6 \mathrm{~mm})$, the $y$-axis plots the fractions of 
the respective $\mathrm{P}$ class on total $\mathrm{P}$. Red arrows indicate significant changes with root proximity $(\mathrm{p}<0.1)$. The markers present individual replicates $(\mathrm{n}=1)$.

Figure 2.5-4: Triplots of the redundancy analysis (RDA) for the arid shrubland, Mediterranean woodland, and humid-temperate forest ecosystems. With $\mathrm{P}$ species as explanatory variables and microbial biomass carbon, low-molecular-weight organic acids, phosphatase activity and -affinity as explained variables. Green arrows indicate direction of the respective explaining variables, orange arrows of explained variables. The name of the respective variable is plotted at each arrowhead. Samples from all three sampling depths (topsoil $=$ light yellow; subsoil $=$ orange; saprolite $=$ red) and root proximities (intervals of $2 \mathrm{~mm}$ : 0-2 $\mathrm{mm}=$ circles, $2-4 \mathrm{~mm}=$ diamonds and $4-6 \mathrm{~mm}=$ triangles) were included in the RDA. Red dotted ellipsoids were included to guide the reader to the main messages of the respective figure, which are discussed in the text. The bold arrows in the subfigure of the arid shrubland and the Mediterranean woodland ecosystem point out the effect of soil depth on the outcome of the RDA.

Figure S 2.5-1: Exemplary phosphorus K-edge X-ray absorption near edge structure spectroscopy (XANES) spectra along the ecosequence (A) from all three soil depths (distance 0-2 mm from roots) and (B) from the Mediterranean woodland in topsoil, and saprolite for all three distances from roots $(0-2 \mathrm{~mm}, 2-4 \mathrm{~mm}$, and 4-6 mm). Black dots represent the measured data, the red curve is the best fit chosen by the lowest $\mathrm{R}$ factor. Green dots show the residual from the data to the fit (R-factor)....

Figure S 2.5-2: Pools of rhizosphere P per root segment (total P, calcium-phosphates (Ca-P), Fe- and Al-phosphates (Fe-P, Al-P), orthophosphates sorbed to Fe- and Al-(oxy)hydroxides (sorbFe-P, sorbAl-P), and organic $\mathrm{P}\left(\mathrm{P}_{\mathrm{o}}\right)$ were calculated for a cylinder around roots. Contents in each distance to the root were converted to rhizosphere $\mathrm{P}$ per root length by multiplying with bulk density and the respective volume of the cylinder sheathing the root. Average root thickness was set to $2 \mathrm{~mm}$. For the arid shrubland ('shrubland'), Mediterranean woodland ('woodland'), and humid-temperate forest ('forest'). In each site for the topsoil, subsoil, and saprolite. 


\section{Abbreviations}
AMF
Arbuscular mycorrhizal fungi
C
Carbon
Cs
Cesium
DNA
Desoxyribonucleic acid
ENSO
El Niño/La Niña-Southern oscillation

FAME

Fatty acids methyl ester

$\mathrm{Fe}$

Iron

ICP-MS

Inductively coupled plasma mass spectrometer

ICP-OES

Inductively coupled plasma optical emission spectrometer

IRMS

Isotope ratio mass spectrometer

$\mathrm{K}$

Potassium

$\mathrm{LCF}$

Linear combination fitting

LMWOA

Low molecular weight organic acids

MAP

Mean annual precipitation

MAT

Mean annual temperature

MBC

Microbial biomass carbon

$\mathrm{N}$

Nitrogen

$\mathrm{Na}$

Sodium

nifH

Gene encoding a subunit of nitrogenase

NLFA

Neutral lipid fatty acid

NPP

Net primary production

$\mathrm{OM}$

Organic matter

$\mathrm{P}$

Phosphorus

qPCR

quantitative polymerase chain reaction

PLFA

Phospho lipid fatty acid

$\mathrm{Rb}$

Rubidium

RLD

Root length density

RTD

Root tissue density

SOC

Soil organic carbon

SON

Soil organic nitrogen

SRL

Specific root length

XANES

$\mathrm{X}$-ray absorption near-edge structure 


\section{Summary}

Distribution and variability of precipitation are predicted to shift in Chile and are expected to lead to increases in frequency and duration of droughts. These developments can lead to a cascade of environmental changes that are likely to alter biogeochemical cycles and ecosystem functioning. The ability of vegetation to adapt to changing conditions affects the response of natural ecosystems to predicted precipitation changes. The strategy to acquire and the ability to retain resources can be an important factor for determining the adaptation ability of plants. Thus, to assess the potential for adaptation, it is crucial to understand plant nutrient acquisition strategies under current climatic settings. Aim of this research project was, therefore, to identify plant nutrient acquisition strategies of natural perennial woody vegetation under three levels of aridity along the Chilean Coastal Cordillera: arid, Mediterranean, and humid-temperate. Nutrient availability can have a critical role on plant drought sensitivity. Therefore, the first objective was to determine the nutrient availability at the site of each aridity level. As second objective we assessed plant nutrient recycling and uplift at each aridity level as well as root traits that are indicative for the plant nutrient uptake capacity. The third objective was to determine the importance and function of recycling and weathering agents as well as plant symbionts for plants' nutrient acquisition. Sites with similar granitoid parent material but contrasting climatic conditions were selected for this study across a $>900 \mathrm{~km}$ long precipitation gradient in the Chilean Coastal Cordillera. From north to south, the mean annual precipitation (MAP) increased from 80 to $>1500 \mathrm{~mm} \mathrm{a}^{-1}$, accompanied by an increase of soil thickness.

Carbon $(\mathrm{C})$, nitrogen $(\mathrm{N})$, phosphorus $(\mathrm{P})$, and potassium $(\mathrm{K})$ contents in soil and plants were measured. $\mathrm{N}$ stocks in soil increased with increasing precipitation, but $\mathrm{N}$ availability declined, which was indicated by the highest $\mathrm{C}: \mathrm{N}$ ratios in soil under humid conditions. While plant available $\mathrm{P}$ increased with decreasing precipitation, water shortage in the semiarid and arid ecosystems likely restricts P mobility and accessibility.

Following a soil labeling experiment with ${ }^{15} \mathrm{~N}$ as $\mathrm{N}$ tracer and rubidium $(\mathrm{Rb})$ and cesium $(\mathrm{Cs})$ as $\mathrm{K}$ tracers, short-term ( $<1$ year) $\mathrm{N}$ and $\mathrm{K}$ plant acquisition from topsoil, subsoil, and saprolite was determined. Additionally, the vertical distribution of exchangeable $\mathrm{K}$ and the natural ${ }^{15} \mathrm{~N}$ abundance of plants and topsoil was assessed to evaluate long-term (>decades) $\mathrm{N}$ and $\mathrm{K}$ uplift and recycling. Further, the P speciation and contents of low molecular weight organic acids (LMWOA) were measured in rhizosphere soil from topsoil, subsoil, and saprolite.

Under arid conditions, $\mathrm{N}$ was not only strongly reutilized (short- and long-term) from topsoil but also from subsoil and saprolite. Similarly, the rock-born nutrient K was reutilized equally from topsoil and uplifted from subsoil and saprolite. Increasing LMWOA per microbial biomass carbon 
(MBC) with increasing depth, pointed to an intended LMWOA exudation by plants for biological weathering of minerals to cover their P demand. Under Mediterranean conditions, high denudation rates likely reduced long-term $\mathrm{N}$ recycling but induced intensive short-term reutilization of $\mathrm{N}$ as well as $\mathrm{K}$ from topsoil. This was indicated by a higher $\mathrm{N}$ (9 times) and $\mathrm{K}$ (7 times) tracer recovery in shoots from topsoil than from subsoil. Plant P acquisition seemed to rely on, both, recycling of organic $\mathrm{P}$ from topsoil as well as biological weathering and uplift of inorganic $\mathrm{P}$ from subsoil. Under humid conditions, $\mathrm{N}$ was strongly reutilized from topsoil (short- and long-term) as well as recaptured from subsoil and saprolite. Similarly, K was reutilized from topsoil and uplifted from saprolite. Short-term uplift of both nutrients, however, was lower than under arid conditions. The recycling of $\mathrm{P}$ from organic pools seemed to be the main acquisition strategy of plants growing on these $\mathrm{P}$ depleted soils under humid conditions.

Root length density (RLD), specific root length (SRL), and root tissue density (RTD) were determined to assess whether plants express acquisitive or conservative root traits. Roots with acquisitive traits have a high nutrient uptake capacity, whereas roots with conservative traits have a lower capacity but longer lifespans. Not only expressed plants at the arid site conservative root traits, but also plants at the humid site, which grow under conditions of low $\mathrm{N}$ and $\mathrm{P}$ availability. Only the plants at the Mediterranean site expressed acquisitive roots traits in the upper $10 \mathrm{~cm}$. Thereby, plants at the Mediterranean site are able to fast and efficiently exploit available topsoil nutrients; likely as an adaptation to high denudation rates and the resulting necessity to retain nutrients from ecosystem losses.

To investigate acquisition agents and symbionts, activities of the extracellular enzymes acid phosphatase, aminopeptidase, and chitinase as well as the total bacterial and fungal abundance and abundance of diazotroph bacteria (i.e. abundance of the gene nifH), were measured in rhizosphere soil from topsoil, subsoil, and saprolite. To evaluate the importance of arbuscular mycorrhizal fungi (AMF) for plant $\mathrm{N}$ and $\mathrm{P}$ acquisition, the $\mathrm{AMF}$ root colonization was determined, and $\mathrm{AMF}$ abundance in soil was assessed by AMF-specific phospho- and neutral lipid fatty acids $(16: 1 \omega 5 \mathrm{c}$ PLFA and NLFA). Further, plant allocation of freshly assimilated ${ }^{13} \mathrm{C}$ to fine roots and AMF was determined following a ${ }^{13} \mathrm{CO}_{2}$ pulse labeling of woody vegetation. Extracellular enzyme activities, microbial abundance, and abundance of diazotroph bacteria in the rhizosphere declined with increasing aridity. When normalized to the soil organic carbon (SOC), however, activities of acid phosphatases (up to 3 times) and aminopeptidase (up to 9 times) as well as bacterial abundance (>2 times) were higher in rhizosphere soil under arid than humid conditions. This pointed to a greater relative importance of the rhizosphere as hotspot of nutrient release and acquisition in dry soils. AMF abundance decreased from $45 \%$ to $20 \%$ root surface with increasing aridity. The extraradical AMF mycelium, however, was supplied with C similarly, independent of precipitation 
(max. $0.2-0.5 \%$ of assimilated ${ }^{13} \mathrm{C}$ ), to scavenge for $\mathrm{P}$ in all sites. At the site under arid conditions were no indications found that $\mathrm{AMF}$ also support plant $\mathrm{N}$ acquisition, likely because a close contact of hyphae to minerals/nutrient sources is important for the acquisition of immobile $\mathrm{P}$, but not for the acquisition of mobile N. For the acquisition of N, plants growing under arid conditions invested into their fine root system, which was indicated by higher SRL under low soil C:N. At the site under humid conditions, on the contrary, the symbiosis seemed to be strengthened for the $\mathrm{N}$ transfer from fungi to plant by increasing the root colonization. Maintaining a close contact to sources of immobile $\mathrm{P}$, while ensuring a fast transfer of mobile $\mathrm{N}$ from fungi to plant, indicates different $\mathrm{AMF}$ functions in the $\mathrm{P}$ and $\mathrm{N}$ acquisition of plants in the humid ecosystem. At the site under Mediterranean conditions, indications were found that not only root colonization is increased for the $\mathrm{N}$ transfer from fungi to plant, but that also the extraradical AMF mycelium is supplied with $\mathrm{C}$ to support saprotrophs' scavenging for $\mathrm{N}$. Thereby, AMF exert a function that was not observed at the humid or arid site: retaining mobile nutrients and preventing losses from soil. With the predicted precipitation changes in Chile, it is likely that abiotic conditions and biotic interactions in one ecosystem along the precipitation gradient shift towards the current conditions of another. Based on the results on plant nutrient acquisition strategies, an assessment was made on possible shifts and responses of the arid and humid ecosystems. Increasing durations of dry periods between rain events likely exacerbate plants' nutrient supply. To increase their $\mathrm{N}$ gain, plants invested greatly into $\mathrm{N}$ fixing bacteria at the humid-temperate site, which will likely decline with reduced water availability and primary productivity. With a potential temporal decoupling of microbial activity and plant nutrient uptake (as seen already today under Mediterranean conditions), inorganic $\mathrm{N}$ could accumulate in topsoil and be highly susceptible to leaching. Whether AMF can support the slow acquiring roots in retaining mobile nutrients in soil is unclear, as the AMF community is not adapted to prolonged drought conditions. The acquisition from subsoil and saprolite by roots, however, will be favorable under prolonged dry periods. This is only possible, however, if deep water pools are available and replenished during wet seasons and years.

In arid regions, a concentration of precipitation in fewer events could increase water availability due to a deeper infiltration and lower evaporation of water pulses. Deep rooting (shrub) species would benefit from a greater water availability in depth. Greater water availability would also allow deep rooting plants to increase their photosynthetic activity and invest more $\mathrm{C}$ in belowground processes for nutrient acquisition. Thereby, they can accelerate SOM decomposition and nutrient mineralization, which would increase OM-derived nutrient availability. Depending on the magnitude of rain events, however, fewer but more intensive rain events can lead to higher run-off, which would result in greater soil erosion and nutrient losses. Plants in this system are not 
adapted to high losses or to exploit available resources fast and could likely not retain nutrients against increased leaching and erosion.

The required shifts of nutrient acquisition traits in both ecosystems evaluated here will have to go along with a shift of species compositions and functional groups. Many of the traits beneficial under the predicted climate change scenarios exist in the Mediterranean ecosystem and, thus, are in principle available along the Chilean Coastal Cordillera. The magnitude and temporal dynamic of the climate change, however, will be decisive for whether and to which extent species with the required traits can migrate from the Mediterranean area and immigrate into the adjacent regions. This study showed that the investigation of ecosystems along a climate sequence with similar parent material allows to identify and evaluate the portfolio of available nutrient acquisition properties under different climatic conditions. The knowledge of available traits allows to assess possible and necessary shifts to maintain the functionality of ecosystems. This knowledge can improve and refine the predictions of ecosystem responses to climatic changes. 


\section{Zusammenfassung}

Aufgrund des voranschreitenden Klimawandels verändern sich die Niederschlagsverteilung und variabilität in Chile, was voraussichtlich zu einer Zunahme der Häufigkeit und Dauer von Dürren führen wird. Dies kann zu einer Kaskade von Umweltveränderungen führen, die die biogeochemischen Zyklen und die Funktionsweise des Ökosystems beeinflussen. Die Anpassungsfähigkeit der Vegetation beeinflusst die Reaktion natürlicher Ökosysteme auf diese Veränderungen. Die Strategie des Ressourcenerwerbs und die Fähigkeit Ressourcen im System zu halten, kann ein wichtiger Faktor für Pflanzen sein, mit sich ändernden Wasser- und Nährstoffverfügbarkeiten umzugehen. Zur Beurteilung des Anpassungspotentials von Pflanzen ist es wichtig, deren Strategien zum Nährstofferwerb unter den gegenwärtigen klimatischen Bedingungen $\mathrm{zu}$ verstehen.

Ziel dieses Forschungsprojektes war es Nährstofferwerbstrategien von natürlicher, mehrjähriger und holziger Vegetation in drei Ariditätsstufen zu identifizieren: arid, mediterran und humid gemäßigt. Die Verfügbarkeit von Nährstoffen kann eine entscheidende Rolle für die Dürreanfälligkeit von Pflanzen spielen. Das erste Ziel dieser Arbeit bestand darin, die Nährstoffverfügbarkeit an den Standorten in den einzelnen Ariditätsstufen zu bewerten. Als zweites Ziel wurde das Nährstoffrecycling und der Nährstoff-Uplift der Pflanzen untersucht, sowie Wurzeleigenschaften, die auf die Nährstoffaufnahmekapazität hinweisen. Das dritte Ziel bestand darin die Bedeutung und Funktion von Recycling- und Verwitterungsmitteln sowie von Pflanzensymbionten für die Nährstoffaufnahme zu bestimmen. Für diese Arbeit wurden Standorte mit ähnlichem granitoiden Ausgangsmaterial, aber kontrastierenden klimatischen Bedingungen ausgewählt. Über einen $>900 \mathrm{~km}$ langen Niederschlagsgradienten in der chilenischen Küstenkordillere nahm der mittlere Jahresniederschlag (MAP) von Norden nach Süden von 80 auf $>1500 \mathrm{~mm} \mathrm{a}^{-1} \mathrm{zu}$, begleitet von einer Zunahme der Bodendicke.

Es wurden Kohlenstoff- (C), Stickstoff- (N), Phosphor- (P) und Kalium- (K) Gehalte in Bodenund Pflanzenmaterial gemessen. Die Stickstoffvorräte im Boden nahmen mit zunehmendem Niederschlag zu, während die N-Verfügbarkeit abnahm, was sich durch hohe C:N-Verhältnisse im Boden unter feuchten Bedingungen zeigte. Pflanzenverfügbares $\mathrm{P}$ nahm mit abnehmendem Niederschlag zu, aber Wassermangel in den semiariden und ariden Ökosystemen schränkt die Mobilität und Zugänglichkeit von P ein.

Mit einem Bodenmarkierungsexperiment, mit ${ }^{15} \mathrm{~N}$, Rubidium $(\mathrm{Rb})$ und Cäsium $(\mathrm{Cs})$ als N- bzw. K-Tracern, wurde die kurzfristige ( $<1 \mathrm{Jahr}$ ) N- und K-Pflanzenaufnahme aus Oberboden, Unterboden und Saprolith bestimmt. Zusätzlich wurde die vertikale Verteilung von austauschbarem K und die natürliche ${ }^{15} \mathrm{~N}$-Häufigkeit von Pflanzen und im Oberboden bewertet, 
um die langfristige (>Dekaden) N- und K-Aufnahme und das Recycling zu bewerten. Außerdem wurden die Phosphorarten und der Gehalt an niedermolekularen organischen Säuren (LMWOA) in Rhizosphärenboden aus dem Oberboden, dem Unterboden und dem Saprolith gemessen.

Unter ariden Bedingungen wurde $\mathrm{N}$ nicht nur aus dem Oberboden, sondern auch aus dem Unterboden und dem Saprolith stark wiederverwertet (kurz- und langfristig). In ähnlicher Weise wurde $\mathrm{K}$ zu gleichen Teilen aus dem Oberboden wiederverwendet sowie aus dem Unterboden und dem Saprolith erworben. Die Zunahme der LMWOA pro mikrobiellem Biomassekohlenstoff mit zunehmender Tiefe deutete auf eine beabsichtigte LMWOA-Exsudation durch Pflanzen zur biologischen Verwitterung von Mineralien hin, um ihren P-Bedarf zu decken. Unter mediterranen Bedingungen verringern hohe Abtragungsraten wahrscheinlich die langfristige N-Rückführung, induzieren jedoch ein intensives kurzfristiges Recycling von $\mathrm{N}$ sowie von $\mathrm{K}$ aus dem Oberboden. Dies wurde durch eine höhere N- (9-mal) und K- (7-mal) Tracer-Rückgewinnung aus dem Oberboden gegenüber dem Unterboden angezeigt. Die P-Gewinnung von Pflanzen schien sowohl auf der Wiederverwertung von organischem $\mathrm{P}$ aus dem Oberboden als auch auf der biologischen Verwitterung und dem Erwerb von anorganischem $\mathrm{P}$ aus dem Unterboden zu beruhen. Unter humiden Bedingungen wurde $\mathrm{N}$ aus dem Oberboden stark recycelt sowie aus dem Unterboden und dem Saprolith wiedergewonnen. In ähnlicher Weise wurde auch K aus dem Oberboden wiederverwendet und aus dem Saprolith erworben. Das Recycling von P aus organischen Pools schien allerdings die wichtigste Erwerbsstrategie von Pflanzen zu sein, die auf diesen P-armen Böden unter feuchten Bedingungen wachsen.

Die Wurzellängendichte (RLD), die spezifische Wurzellänge (SRL) und die Wurzelgewebedichte (RTD) wurden bestimmt, um zu beurteilen, ob Pflanzen erwerbsorientierte oder konservative Wurzeleigenschaften aufweisen. Wurzeln mit erwerbsorientierten Merkmalen haben eine hohe Nährstoffaufnahmekapazität. Die Aufnahmekapazität von Wurzeln mit konservativen Merkmalen ist dagegen geringere, erreichen aber dafür längere Lebensdauern. Nicht nur Pflanzen unter ariden Bedingungen besaßen konservative Wurzelmerkmale, sondern auch Pflanzen unter humiden Bedingungen mit geringer $\mathrm{N}$ - und P-Verfügbarkeit. Nur die Pflanzen unter mediterranen Bedingungen bildeten Wurzeln mit erwerbsorientierten Merkmalen in den oberen $10 \mathrm{~cm}$. Dadurch sind die Pflanzen in der Lage, verfügbare Nährstoffe im Oberboden schnell und effizient zu nutzen; wahrscheinlich als Anpassung an hohe Abtragungsraten und die Notwendigkeit, Nährstoffe zurückzuhalten und Verlusten zu verhindern.

Zur Untersuchung von Agenzien und Symbionten für die Nährstoffakquise wurden die Aktivitäten der extrazellulären Enzyme saure Phosphatase, Aminopeptidase und Chitinase, die Gesamtabundanz von Bakterien und Pilzen, wie auch die Häufigkeit diazotropher Bakterien (d.h. die Abundanz des Gens nifH), in Rhizosphärenboden aus dem Ober- und Unterboden sowie dem 
Saprolith bestimmt. Um die Bedeutung der arbuskulären Mykorrhizapilze (AMF) für die N- und P-Akquise der Pflanzen zu beurteilen, wurde die AMF-Wurzelbesiedlung ermittelt und die AMFHäufigkeit im Boden anhand der AMF-spezifischen Phospho- und neutralen Lipidfettsäuren beurteilt (16:165c PLFA und NLFA). Darüber hinaus wurde die Allokation von frisch assimiliertem ${ }^{13} \mathrm{C}$ in Feinwurzeln und AMF nach einer ${ }^{13} \mathrm{CO}_{2}$-Pulsmarkierung der holzigen Vegetation bestimmt. Die extrazellulären Enzymaktivitäten, die Gesamtabundanz von Bakterien und die Häufigkeit diazotropher Bakterien in der Rhizosphäre nahmen mit zunehmender Trockenheit ab. Relativ zum organischen Bodenkohlenstoff waren jedoch die Aktivitäten der sauren Phosphatasen (bis zu 3-fac) und der Aminopeptidasen (bis zu 9-fach) sowie die Gesamtabundanz der Bakterien (>2-fach) im Rhizosphärenboden unter trockenen Bedingungen höher als unter feuchten Bedingungen. Dies wies auf eine größere Bedeutung der Rhizosphäre als Hotspot der Nährstofffreisetzung und -aufnahme in trockenen Böden hin. Die AMFWurzelkolonisierung nahm mit zunehmender Trockenheit von $45 \%$ auf $20 \%$ ab. Das extraradische AMF-Myzel wurde jedoch unabhängig vom Niederschlag in allen Untersuchungsgebieten ähnliche mit $\mathrm{C}$ versorgt ( $\max .0,2-0,5 \%$ des assimilierten ${ }^{13} \mathrm{C}$ ), um nach $\mathrm{P}$ zu suchen. Am Standort unter ariden Bedingungen wurden keine Hinweise darauf gefunden, dass die AMF auch den Erwerb von $\mathrm{N}$ unterstützt, wahrscheinlich weil ein enger Kontakt der Hyphen mit Mineralien/Nährstoffquellen für den Erwerb von immobilem $\mathrm{P}$ wichtig ist, nicht aber für den Erwerb des mobileren N. Für den Erwerb von $\mathrm{N}$ investierten Pflanzen, die unter ariden Bedingungen wachsen, in ihr Feinwurzelsystem, was durch eine höhere spezifische Wurzellänge bei niedrigem Boden-C: $\mathrm{N}$ angezeigt wurde.

Am Standort unter feuchten Bedingungen hingegen schien die Symbiose für den N-Transfer von Pilz zu Pflanze durch eine intensivere Wurzelbesiedlung verstärkt $\mathrm{zu}$ werden. Die Aufrechterhaltung eines engen Kontakts zu Quellen von immobilem P bei gleichzeitiger Gewährleistung einer schnellen Übertragung von mobilem N von Pilz auf Pflanze deutet auf unterschiedliche AMF-Funktionen in der P- und N-Akquise von Pflanzen im humiden Ökosystem hin. Am Standort unter mediterranen Bedingungen wurden weiter Hinweise darauf gefunden, dass nicht nur die Wurzelbesiedlung für den N-Transfer von Pilzen zur Pflanze verstärkt wird, sondern dass auch das extraradische AMF-Myzel mit $\mathrm{C}$ versorgt wird, um die Akquise von $\mathrm{N}$ durch saprotrophe Organismen zu unterstützen. Dabei üben die AMF eine Funktion aus, die im humiden oder trockenen Standort nicht beobachtet wurde: die Rückhaltung mobiler Nährstoffe und Reduzierung von Nährstoffverlusten aus dem Boden.

Mit den vorhergesagten Niederschlagsveränderungen in Chile ist es wahrscheinlich, dass sich die abiotischen Bedingungen und biotischen Interaktionen in einem der Ökosysteme hin zu den aktuellen Bedingungen in einem der anderen Ökosysteme entlang des Niederschlagsgradienten 
verschieben. Auf der Grundlage der Ergebnisse zu den Strategien für den Erwerb von Pflanzennährstoffen wurde eine Bewertung der möglichen Verschiebungen und Reaktionen des ariden und humiden Ökosystems vorgenommen. Mit zunehmender Dauer der Trockenperioden zwischen den Regenereignissen wird sich die Nährstoffversorgung der Pflanzen wahrscheinlich verschlechtern. Um ihren N-Gewinn zu erhöhen, investieren die Pflanzen stark in N-fixierende Bakterien, deren Häufigkeit wahrscheinlich mit abnehmender Wasserverfügbarkeit und Primärproduktivität in Zukunft abnehmen wird. Bei einer möglichen zeitlichen Entkopplung von mikrobieller Aktivität und pflanzlicher Nährstoffaufnahme (wie bereits heute unter mediterranen Bedingungen zu beobachten) könnte sich anorganisches $\mathrm{N}$ im Oberboden anreichern und damit sehr anfällig für Auswaschung werden. Ob die AMF die langsam wachsenden Wurzeln dabei unterstützen können, mobile Nährstoffe im Boden zurückzuhalten, ist unklar, da die AMFGemeinschaft nicht an langanhaltende Trockenheitsbedingungen angepasst ist. Die Aufnahme aus dem Unterboden und dem Saprolith durch Wurzeln wird bei längeren Trockenperioden von Vorteil sein. Dies ist jedoch nur möglich, wenn tiefe Wasserreservoirs verfügbar sind und diese sich während der Regenzeiten und in feuchten Jahren wieder auffüllen.

In ariden Regionen könnte eine Konzentration der Niederschläge in weniger Regenereignisse die Wasserverfügbarkeit aufgrund einer tieferen Infiltration und geringeren Verdunstung von Regenwasser erhöhen. Tiefwurzelnde (Strauch-) Arten würden von einer größeren Wasserverfügbarkeit in der Tiefe profitieren. Es würde tiefwurzelnden Pflanzen ebenfalls ermöglichen, ihre Photosyntheseaktivität zu erhöhen und mehr C in unterirdische Prozesse zur Nährstoffgewinnung zu investieren. Dadurch könnten sie die Zersetzung von organischer Bodensubstanz und die Nährstoffmineralisierung beschleunigen, und damit die Verfügbarkeit von Nährstoffen erhöhen. Je nach Ausmaß der Regenereignisse können jedoch weniger, aber intensivere Regenereignisse auch zu einem höheren Abfluss führen, was zu größerer Bodenerosion und Nährstoffverlusten führen würde. Die Pflanzen in diesem System sind jedoch weder an hohe Verluste noch an die schnelle Nutzung der verfügbaren Ressourcen angepasst und könnten die Nährstoffe wahrscheinlich nicht vollständig gegen verstärkte Auswaschung und Erosion zurückhalten.

Die erforderlichen Veränderungen in der Nährstoffakquise in beiden hier untersuchten Ökosystemen müssen mit einer Verschiebung der Artenzusammensetzungen und funktionellen Gruppen einhergehen. Viele der unter den vorhergesagten Szenarien des Klimawandels vorteilhaften Eigenschaften sind im mediterranen Ökosystem vorhanden und somit im Prinzip entlang der chilenischen Küstenkordillere verfügbar. Das Ausmaß und die zeitliche Dynamik des Klimawandels werden jedoch entscheidend dafür sein, ob und in welchem Ausmaß Arten mit den erforderlichen Merkmalen aus dem mediterranen Gebiet abwandern und in die angrenzenden 
Systeme einwandern können. Diese Studie zeigte, dass die Untersuchung von Ökosystemen entlang einer Klimasequenz mit vergleichbarem Ausgangsmaterial es ermöglicht, das Portfolio verfügbarer Nährstoffaufnahmeeigenschaften unter verschiedenen klimatischen Bedingungen zu erfassen. Die Kenntnis der verfügbaren Eigenschaften erlaubt es, mögliche und notwendige Verschiebungen für die Erhaltung der Funktionalität von Ökosystemen abzuschätzen. Dieses Wissen kann die Vorhersagen der Reaktionen von Ökosystemen auf klimatische Veränderungen verbessern. 


\section{Extended Summary}

\subsection{Introduction}

\subsubsection{Background and Motivation}

With a rapid proceeding climate change, the distribution of precipitation is projected to shift and precipitation variability to increase markedly (IPCC, 2014, 2013). These changes can result in a concentration of annual rainfall in fewer but stronger rain events with prolonged durations of dry periods in between (Knapp et al., 2008a; Sala et al., 2015). These shifts can lead to a cascade of environmental changes (see e.g., Figure 1.1-1) that might markedly alter biogeochemical cycles and the functioning and services ecosystems provide (Gerten et al., 2008; Knapp et al., 2008a; Kreuzwieser and Gessler, 2010).

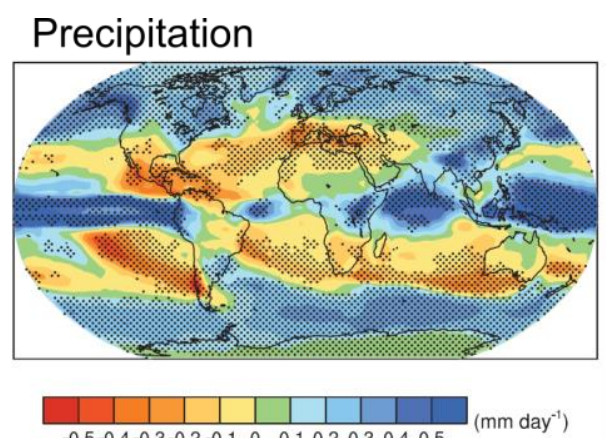

Soil moisture
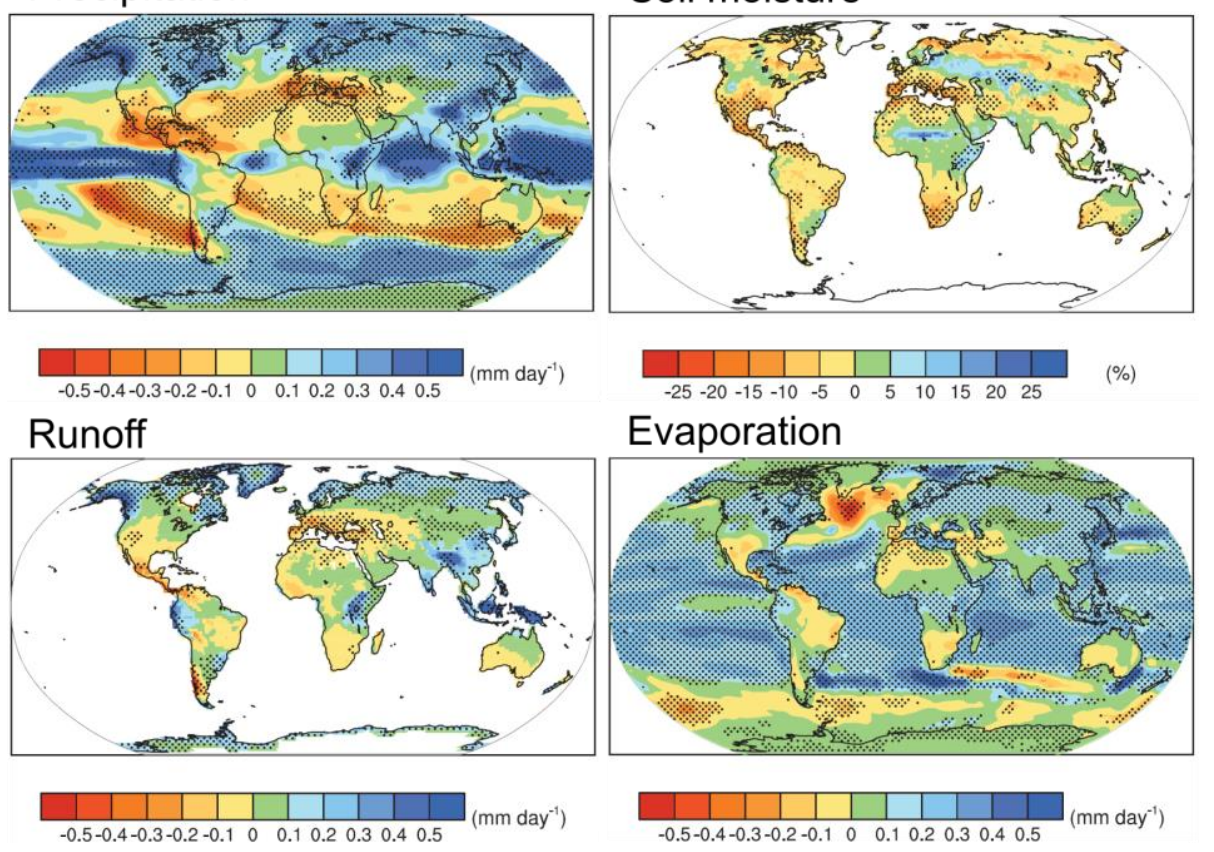

Figure 1.1-1: Multi-model mean changes in (a) precipitation (mm day $\left.{ }^{-1}\right),(b)$ soil moisture content $(\%)$, (c) runoff $\left(m m\right.$ day $\left.^{-1}\right)$ and $(d)$ evaporation $\left(m m\right.$ day $\left.^{-1}\right)$. To indicate consistency in the sign of change, regions are stippled where at least $80 \%$ of models agree on the sign of the mean change. Changes are annual means for the SRES AIB scenario (emission scenario of the IPCC Special Report on Emission Scenarios (2000) with $850 \mathrm{ppm} \mathrm{CO}_{2}$ in atmosphere 2100 for the period 2080 to 2099 relative to 1980 to 1999. Soil moisture and runoff changes are shown at land points with valid data from at least 10 models. Figure from Meehl et al. (2007)

Decreasing precipitation but increasing inter- and intra-annual precipitation variability might have opposing effects on humid and arid ecosystems (Knapp et al., 2008a; Sala et al., 2015). Arid ecosystems might profit from less frequent but larger rainfall events. Large water pulses can infiltrate deeper into soil than small water pulses, which can reduce soil evaporation losses and increasing water availability at depth (Knapp et al., 2008a; Kulmatiski and Beard, 2013; Sala et al., 2015). Depending on the magnitude of the water pulses, however, larger rainfall events could lead to increased surface run-off and erosion, and thus, nutrient losses (Boy et al., 2008; Yahdjian 
and Sala, 2010). Humid ecosystems, on the contrary, might suffer when rainfall is concentrated in few precipitation events. Here, intensive rainfall might lead to deep percolation out of reach for roots, which would reduce water availability and increase nutrient loss (Sala et al., 2015). Longer dry periods between events will further intensify water stress for plants adapted to humid conditions (Knapp et al., 2008a). Belowground processes and fine root dynamics are especially sensitive to spatial and temporal water availability (Wang et al., 2020). An offset of precipitation and plant activity can tip the fragile balance within an ecosystem (Austin et al., 2004; Knapp et al., 2008a). If the timing of precipitation shifts and it falls outside the vegetation period, the rain water cannot be utilized by plants, leading to additional water stress despite sufficient precipitation (Fernández, 2007; Hodge, 2010).

Depending on the vegetation responses to these changes, the plant community composition will be altered markedly (Pérez Navarro et al., 2019; Ploughe et al., 2019; Sala et al., 2012a). This in turn will inevitably affect biogeochemical cycles (de Vries et al., 2016; Dijkstra et al., 2010) by, for example, altered primary productivity and belowground plant $\mathrm{C}$ allocation as well as changed litter compositions and decomposability (Hsu et al., 2012; Makkonen et al., 2012; Sardans and Peñuelas, 2012). If and how vegetation adapts to reduced water availability and/or higher temporal variability will affect the continuation of an ecosystem's functionality (Knapp et al., 2008a; Schwalm et al., 2017; Zhou et al., 2020), for which multiple factors such as plant-plant interactions and community stability will be decisive (Hallett et al., 2014; Lloret et al., 2012; Ploughe et al., 2019).

Maintaining water uptake and avoiding physiological failure is often regarded as one of the main factor for plant survival under drought (Gessler et al., 2017). Nutrient availability, however, can have a critical role on plant drought sensitivity (Gessler et al., 2017; Royo and Knight, 2012). To assess the adaptation ability, it is crucial to understand plant nutrient acquisition strategies under current climatic settings (Knapp et al., 2008a; Wang et al., 2020). Whether plants exploit available resources fast or slow, or whether they acquire water and nutrients dominantly from shallow soil or from depth, determines their sensitivity to precipitation shifts: Are their roots affected by water logging in depth or drying topsoil? Can they dip into water reservoirs in depth during prolonged dry periods? Are they able to retain nutrients against leaching and run-off or can they recapture nutrients from depth? Depending on the strategy, a plant-microbe-soil system can be less or more susceptible to abiotic disturbances (Anderegg et al., 2018; Knapp et al., 2008a; Wang et al., 2020) and is therefore a prerequisite to be able to estimate and predict responses of natural ecosystems to climatic and environmental changes. 


\subsubsection{Plant nutrient acquisition - recycling and uplift}

Susceptibility of an ecosystem to climatic and environmental changes depends (inter alia) on when and where plants are active to acquire water and nutrients, and how efficient they are to (re)utilize available resources. Erosion, leaching, gaseous losses, deep weathering, and high plant and microbial nutrient demand lead to a depletion of nutrient pools over time (Chen et al., 2019; Uhlig and von Blanckenburg, 2019). The acquisition from deep soil and saprolite is an important mechanism to replenish nutrient pools in the long-term (Gao et al., 2019; Uhlig and von Blanckenburg, 2019; Vitousek et al., 2003). Especially in systems with high precipitation and, thus, intensive erosion and leaching, plant uplift can counterbalance nutrient losses (Brantley et al., 2017; Jobbágy and Jackson, 2001). On shorter time scales, fast nutrient recycling from plant litter and microbial necromass retains nutrients within a system and ensures plant nutrition (Cleveland et al., 2013; Gao et al., 2019; Perakis and Hedin, 2001).

Whether and to which extent nutrients are uplifted and reutilized depends on their initial source (rock-born vs. biological fixation), their retention by minerals and soil organic matter (SOM) (i.e. sorption and leaching potential), and the plant and microbial demand.

Nitrogen $(\mathrm{N})$ in soil is primarily bound in organic matter $(\mathrm{OM})$, which needs to be decomposed and mineralized to release $\mathrm{N}$ available for plant uptake (Blume et al., 2010). The dominant mineral $\mathrm{N}$ form in most soils (especially when well aerated) is nitrate $\left(\mathrm{NO}_{3}{ }^{-}\right)$, which is highly mobile, does not bind to clay minerals, and is easily leached down the soil profile (Blume et al., 2010).

Potassium $(\mathrm{K})$, on the contrary, is rock-born and the main pool of available $\mathrm{K}$ in soil is adsorbed to clay minerals, whereas only a small portion remains in soil solution (Sardans and Peñuelas, 2015). $\mathrm{K}$ in plant and microbial cells is only present in soluble form, which makes it prone to leaching from litter, upon it easily binds to clay minerals in soil (Sardans and Peñuelas, 2015).

When comparing the acquisition of rock-born and OM-derived nutrients, rock-born phosphorus (P) takes on a special role. Contrary to K, P can be bound in complex organic molecules and large amounts of organic P can accumulate in soil (Turner et al., 2007). Contrary to N, mobility of P in soil is low and the pool of inorganic P sorbed to primary and secondary minerals can be large (Turner et al., 2007). The dominance of either P pool (inorganic vs. organic) shifts with increasing precipitation and proceeding weathering and soil development (Feng et al., 2016; Walker and Syers, 1976; Yang and Post, 2011).

The extent and intensity of recycling and plant uplift can therefore differ markedly between arid and humid ecosystems. While in natural humid (and often strongly nutrient-limited) systems, nutrients such as $\mathrm{N}$ and organic $\mathrm{P}$ are strongly recycled and recaptured from depth (i.e. a closed cycling), semiarid ecosystems were shown to be less nutrient conservative (Feng et al., 2016; Hou 
et al., 2018; McCulley et al., 2009; Reichmann et al., 2013). The efficiency of nutrient reutilization from OM further depends on the spatial and temporal nutrient availability in an ecosystem (Dunbabin et al., 2004; Han et al., 2013). Strongly limited nutrients are more likely to be efficiently and extensively recaptured by plants and microbes and accumulate in topsoil. If the respective nutrient is not limiting for plant growth, the reutilization is likely to be less intensive (Sardans and Peñuelas, 2015; Vergutz et al., 2012; Yuan and Chen, 2015).

How deep plants scavenge for resources and how well they can utilize them, however, does not only depend on the given nutrient pools and their distribution in soil, but also on the growth form and stress adaptation strategy of plants.

\subsubsection{Plant nutrient economics - acquisitive or conservative?}

Plant nutrient acquisition strategies are strongly linked to plant growth forms and their resource management. Plants must adapt their resource acquisition to environmental conditions and have to trade-off between growth and survival, between being a fast and efficient competitor for resources to outgrow neighbors vs. the conservation of resources to enhance survival under resource limitation (Reich, 2014; Roumet et al., 2016). Plants adapt their investment into resource acquisition according to the balance between costs and benefits of such an investment, and display a plasticity of root traits when confronted with resource shortages and limitations (e.g., water, nutrients, space) (Comas et al., 2013; Croft et al., 2012; Pérez-Ramos et al., 2012; Volaire, 2008). 'Fast' or 'acquisitive' root traits such as high specific root length (i.e. high proportion of fine roots), small diameters (i.e. high surface to volume ratio), low tissue density (low carbon (C) costs), and high $\mathrm{N}$ content are advantageous under high nutrient availability, allowing plants to outcompete neighbors (de Vries et al., 2016; McCormack and Iversen, 2019; Reich, 2014). Roots with 'fast' traits have a high capability for nutrient uptake but come at the cost of shorter lifespans, as they are more sensitive to dehydration and nutrient shortage and are susceptible to decomposition (McCormack et al., 2012; McCormack and Iversen, 2019).

'Slow' or 'conservative' root traits, on the contrary, have a low capability of uptake but are favorable under low nutrient availability (McCormack and Iversen, 2019; Reich, 2014). The thicker, denser, and often shorter roots associated with a 'slow' acquisition are less capable to explore the soil for water and nutrients but are less susceptible to environmental changes. Longer lifespans of such roots provide the advantage of sustaining a functioning root system under limitation, while reducing maintenance costs (Bristiel et al., 2019; Lynch and Ho, 2005; Reich, 2014). Plants with 'slow' traits, however, are easily outcompeted by 'fast' neighbors once resource availability increases. 
Water shortage can strongly modulate root architecture and might overrule plant responses to nutrient availability. Thick and dense roots in a dehydrated topsoil reduce the risk of tissue damage and dieback, as those thick roots withstand dehydration longer than thin roots (Bristiel et al., 2019; Pérez-Ramos et al., 2013; Volaire et al., 2014). Under prolonged water shortage, however, plants can avoid dehydration while maintaining growth by extending their fine root system into deeper soil, scavenging for deep water sources (Muñoz et al., 2008; Nicotra et al., 2002; Sala et al., 2012b). Thus, root traits cannot always be ranked within the plant economic spectrum of 'acquisitive' and 'conservative' behavior (Kembel et al., 2008; Kramer-Walter et al., 2016; Valverde-Barrantes et al., 2015). This is also the case because roots exert multiple additional functions such as storage, anchorage, or vegetative reproduction (McCormack and Iversen, 2019). Further, the resource acquisition function of fine roots can be largely supported by symbiotic microorganisms, in the following called symbionts (McCormack and Iversen, 2019).

\subsubsection{Plant carbon investment - agents and symbionts}

\section{Mycorrhizal fungi}

Mycorrhizal symbiosis is one of the most common forms of mutualistic relationships, with crucial ecological and evolutionary roles in the terrestrial colonization of vascular plants (Brundrett and Tedersoo, 2018; Godoy and Marín, 2019). Approximately 80\% of terrestrial vascular plant species form a symbiosis with arbuscular mycorrhizal fungi (AMF; Brundrett and Tedersoo, 2018). Mycorrhizal fungi support plants resource acquisition by transferring water and nutrients to their host plants in exchange for photosynthetic C (Allen, 2007; Fellbaum et al., 2012; Ryan et al., 2012). AMF hyphae branch far beyond the rhizosphere (i.e. the soil directly influenced by living roots) and into soil pores. Thereby, AMF expand the range to scavenge for nutrients and water and increase the uptake surface, and can further access resources that are excluded even from finest roots (Parniske, 2008).

Other advantages of the symbiosis are that (1) the production of thin AMF hyphae is less C and nutrient expensive than the production of comparable thick fine roots (Fitter, 1991; Hodge, 2004; Pregitzer et al., 1997). This is especially important in ecosystems with restricted primary productivity and belowground $\mathrm{C}$ investment. (2) Mycorrhizal fungi can respond fast to brief water pulses that plant roots would not be able to utilize (Austin et al., 2004; Schwinning and Sala, 2004). This might even compensate for the shorter lifespans of hyphae compared to plant roots. (3) Mycorrhizal hyphae form a direct link between the surface of organic matter and minerals and photosynthetic C from plants (Godoy and Marín, 2019; Taylor et al., 2009), which can be especially advantageous in dry soils with limited nutrient mobility (Aaltonen et al., 2017; Augé, 2001; Li et al., 2014; Ruiz-Lozano et al., 2016). Via the direct pathway between plant-derived C 
and mineral surfaces, AMF can contribute to biological mineral weathering, even if to a lower extent than ectomycorrhizal fungi that possess the ability to actively secrete low molecular organic acids (LMWOA or 'organic acids') contrary to AMF (Taylor et al., 2009).

\section{Organic acids}

Not only fungi but also plants release LMWOA as well as protons into the soil to accelerate mineral dissolution by: acidifying the rhizosphere, block sorption sites for phosphate anions, and enhance the dissolution of $\mathrm{Ca}-, \mathrm{Fe}-$, and $\mathrm{Al}$-minerals by the chelation of the respective cation (Hinsinger, 2001; Jones, 1998; Jones and Darrah, 1994). Organic acids, however, cannot only increase mineral dissolution, but can also play an important role in $\mathrm{P}$ acquisition from $\mathrm{OM}$, for example, by the desorption of organic P and its exposure to enzymatic breakdown (Giles et al., 2014; Lan et al., 1995)

\section{Extracellular enzymes}

For the reutilization and uptake of nutrients bound in OM, extracellular enzymes are needed as agents to break down complex polymers into assimilable monomers (Allison and Vitousek, 2005; Sinsabaugh et al., 2008). Plant roots and saprotrophic microbes are the main source of extracellular enzymes in soil (Burns et al., 2013). Producing enzymes, however, is resource costly and depends strongly on abiotic conditions such as water or substrate availability as well as on the nutrient demand of plants and microbes (DeForest et al., 2012; Olander and Vitousek, 2000; Sanaullah et al., 2011; Treseder and Vitousek, 2001).

\section{Nitrogen fixation}

The association with diazotrophic bacteria, capable of fixing atmospheric $\mathrm{N}_{2}$, can provide an advantage for plants to sustain in an N-limited environment (Vitousek et al., 2002). The process of $\mathrm{N}$ fixation, however, is immensely $\mathrm{C}$ costly and an oxygen-free environment hast to be provided (Gallon, 2006; Vance and Heichel, 1991). Thus, the benefit of supporting symbiotic or associated free-living diazotrophs to increase the $\mathrm{N}$ gain has to outweigh the high $\mathrm{C}$ costs for plants.

\subsubsection{Objectives and hypotheses}

Climatic conditions - especially precipitation patterns - strongly modulate processes and interactions of plant nutrient acquisition as they control soil water availability, regulate plant primary productivity and belowground $\mathrm{C}$ allocation, modify decomposition of SOM and biological weathering, and control plant-microbe-interactions. Nutrient acquisition strategies of plants - with their agents and interactions (depicted in Figure 1.1-2) -therefore depend on the given environmental conditions that plants are exposed to. It is important to understand acquisition 
strategies under current environmental settings in order to estimate and predict responses of natural ecosystems to future climatic and environmental changes. Climate gradients, along which other abiotic parameters such as parent material, uplift rates, glaciation history (i.e. time of soil development), or slope are similar, are valuable study objects to evaluate acquisition strategies and biotic interactions depending on climatic conditions. Aim of this research project was, therefore, to identify plant nutrient acquisition strategies under three levels of aridity: arid, Mediterranean, and humid.

Objective 1: The first objective was to assess the nutrient availability at the sites of each aridity level.

Hypotheses: We expected that (a) $\mathrm{N}$ availability increases with increasing precipitation due to accumulation of soil organic nitrogen (SON) (Study 3), while (b) P availability decreases due to depletion of the primary mineral P stock by weathering (Study 4). Further, we assumed that (c) plants would be $\mathrm{P}$ limited under humid conditions as part of the weathered $\mathrm{P}$ is lost during ecosystem succession (Study 4), but N limited under arid and semiarid conditions as SON barely accumulates under low net primary production (NPP) (Study 1, Study 3). (d) A limitation of K was not expected across the precipitation gradient. (Study 1)

Objective 2: As second objective we assessed plant nutrient recycling and uplift as well as plant resource economics under the three levels of aridity.

Hypotheses: We anticipated that OM-derived nutrients are (a) strongly recycles in arid ecosystems (due to low input) as well as in humid ecosystems (due to high demands) (Study 1). It was further presumed that (b) plants under arid conditions, with restricted primary productivity, rely on biological weathering and uplift of rock-born nutrients, while (c) plants in humid ecosystems with high NPP rely dominantly on the recycling of rock-born nutrients (Study 1, Study 5). Further, we expected that (d) conservative root traits are expressed under arid conditions (due to droughtinduced risk of dieback), but acquisitive root traits under humid conditions (due to low risk of dieback, high nutrient demands, and great competition for nutrients) (Study 2, Study 3).

Objective 3: The third objective was to determine the importance and function of recycling and weathering agents as well as plant symbionts for plant nutrient acquisition in each aridity level. Hypotheses: We anticipated that (a) extracellular enzyme activities and abundance of diazotroph bacteria in the rhizosphere decrease with increasing aridity (as NPP declines and both agents are C-costly) (Study 3), but that (b) the relative importance of the rhizosphere as hotspot of nutrient 
release and acquisition increases with increasing aridity (due to decreasing bulk soil OM content and water availability, and, thus, microbial activity) (Study 3, Study 4). We expected (c) that AMF are important for $\mathrm{P}$ acquisition in dry soils (due to low mobility of $\mathrm{P}$ ), but that AMF are important for $\mathrm{P}$ and $\mathrm{N}$ acquisition under high precipitation (due to high demands of both nutrients) (Study 2). Finally, it was assumed that (d) the importance of AMF increases with increasing aridity, due to low nutrient mobility in soil and restrictions on root growth under water shortage (Study 2).

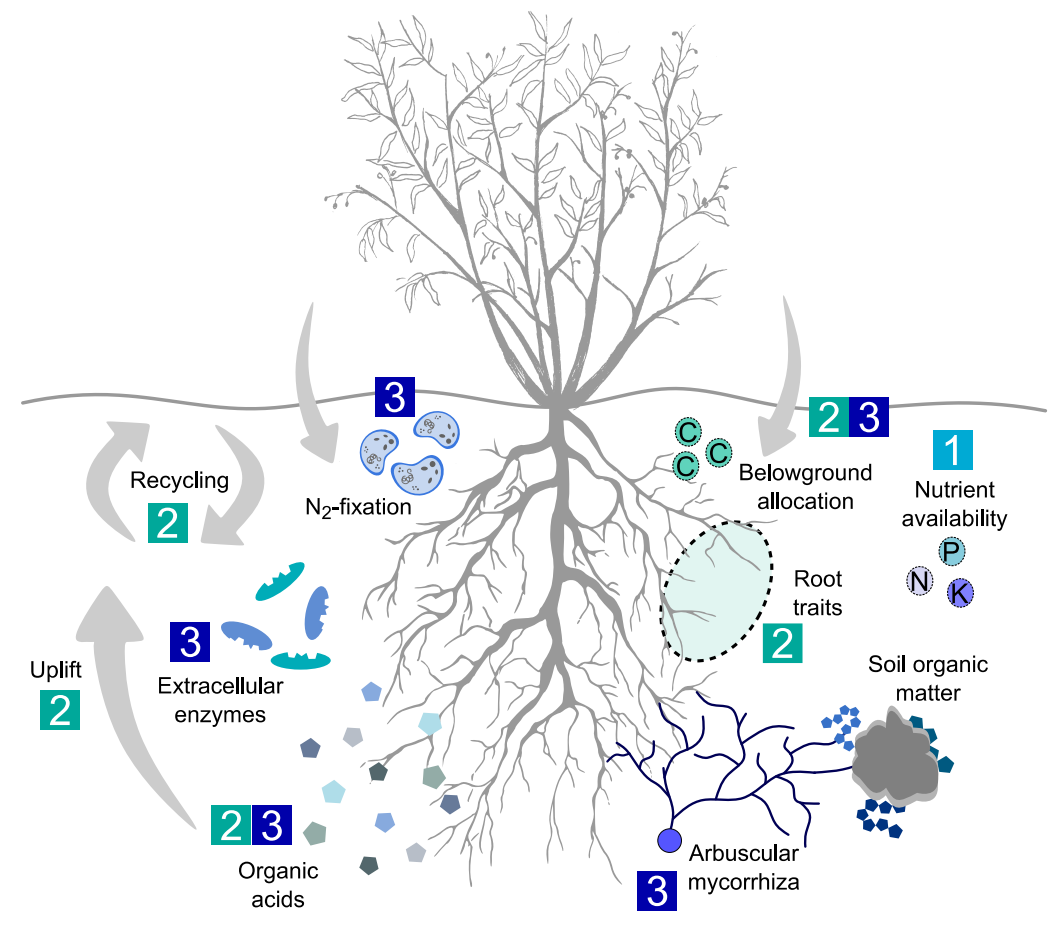

Figure 1.1-2: Overview of the aspects investigated in objective 1 (nutrient availability), objective 2 (plant nutrient recycling and uplift and plant resource economics), and objective 3 (agents and symbionts for plant nutrient acquisition).

\subsection{Material and Methods}

\subsubsection{Project Framework and study areas}

The project was conducted within the framework of the German-Chilean DFG priority program 'EarthShape - Erath Surface Shaping by Biota', which investigates the "influence of plant, animals, and microorganisms on the formation of soils and the shape of topography (earthshape.net)". The Chilean Coastal Cordillera was chosen as a study region, because sites could be selected here with similar granitoid parent material along a precipitation gradient from (hyper)arid to humid. The whole gradient was glaciation free during the last glacial maximum and well-documented climate change records exist. The four study areas studied in this thesis are located in the Cordillera from $29^{\circ}$ to $38^{\circ}$ southern latitude and cover a $>900 \mathrm{~km}$ long precipitation gradient from $80 \mathrm{~mm} \mathrm{a}^{-1}$ mean annual precipitation (MAP) in the north to $>1500 \mathrm{~mm} \mathrm{a}^{-1}$ in the south (Fick and Hijmans, 2017). 


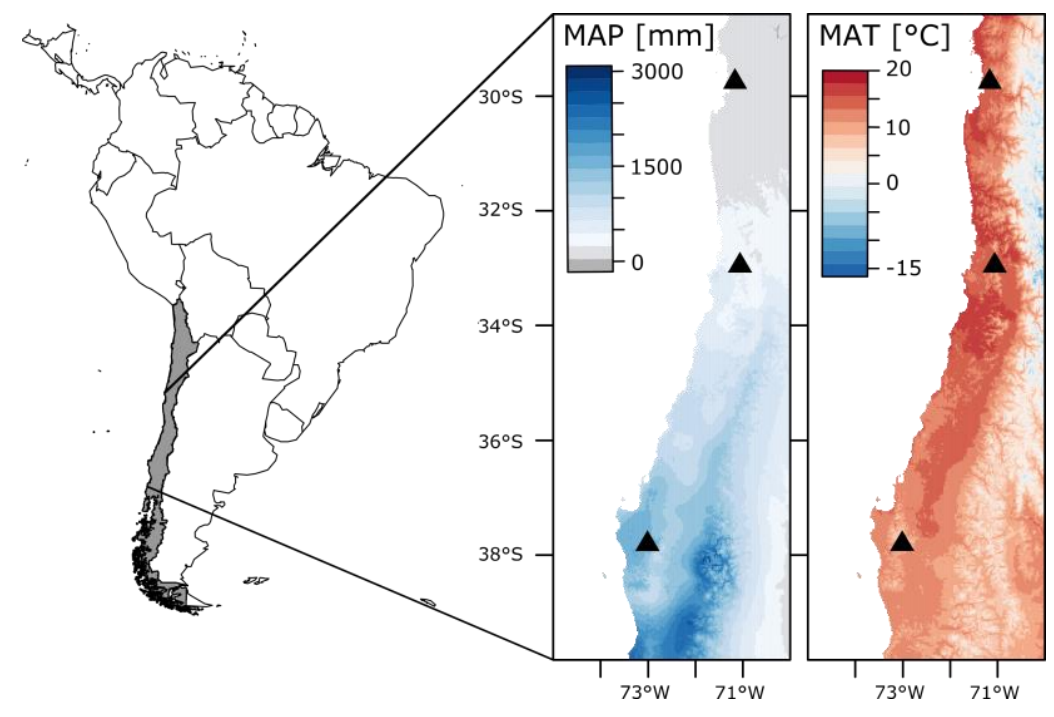

Figure 1.2-1: Study site overview. Showing mean annual precipitation (MAP) and mean annual temperature (MAT) along the gradient (WorldClima data Version 2, Fick and Hijmans et al., 2017). Study site locations indicated by triangles from north to south: arid shrubland, coastal matorral, Humid-temperate forest. Adapted from Stock et al. (2019).

The northern sites are classified as arid ecosystems ('arid shrublands') with an aridity index of 0.06 and 0.05 (Trabucco and Zomer, 2018). The first shrubland site is located in a grazing exclusion area in Quebrada de Talca (30.05 S, $71.09 \mathrm{~W})$, at an altitude of $645 \mathrm{~m}$ a.s.l. and in 23 $\mathrm{km}$ distance from the Pacific Ocean. The second arid shrubland is located in the Reserva Santa Gracia (29.76 S, $71.14 \mathrm{~W}$ ) at an altitude of $680 \mathrm{~m}$ a.s.1. and in $23 \mathrm{~km}$ distance to the Pacific Ocean as well. Both arid shrublands resemble each other in their environmental conditions, with an mean annual precipitation (MAP) and mean annual temperature (MAT) of $80 \mathrm{~mm}$ and $13.8{ }^{\circ} \mathrm{C}$ (Fick and Hijmans, 2017). Cambisols ( $\mathrm{pH}$ 5.5-7.0) are 30-40\% covered with vegetation, which is dominated by drought-deciduous shrubs and cacti.

The third site along the precipitation gradient is classified as a Mediterranean ecosystem ('Mediterranean coastal matorral') with an aridity index of 0.24 (Trabucco and Zomer, 2018), and represents the intermediate level of the three aridity intensities. The site is located in the National Park La Campana $(32.96 \mathrm{~S}, 71.06 \mathrm{~W})$ at approx. $70 \mathrm{~km}$ northwest of Santiago and $43 \mathrm{~km}$ landwards, at an altitude of $730 \mathrm{~m}$ a.s.l. and with a MAP and MAT of approx. $400 \mathrm{~mm}$ and $13.1{ }^{\circ} \mathrm{C}$ (Fick and Hijmans, 2017). The vegetation covered 100\% of the Cambisols (pH 4.5-6.1), dominated by evergreen-sclerophyllous trees, deciduous shrubs, and a dense herb layer (Bernhard et al., 2018).

The southernmost and fourth site is classified as a humid ecosystem ('humid-temperate forest') with an aridity index of 1.4 (Trabucco and Zomer, 2018). The site is located in the National Park Nahuelbuta $(37.81 \mathrm{~S}, 73.01 \mathrm{~W})$ at $1240 \mathrm{~m}$ a.s.l. elevation and in $55 \mathrm{~km}$ distance to the Pacific Ocean, with a MAP and MAT of $>1500 \mathrm{~mm}$ and $7.4{ }^{\circ} \mathrm{C}$ (Fick and Hijmans, 2017). Vegetation here covered $100 \%$ of the Umbrisols and Podzols ( $\mathrm{pH} 3.7-5.1$ ), dominated by the evergreen 
conifers Araucaria araucana (Mol.) K. Koch and winter deciduous broadleaved Nothofagus spp. trees, with a rich understory. From north to south, soils developed all on similar granitoide parent material. The extent of the soil profiles (including $\mathrm{A}, \mathrm{Bw}$, and $\mathrm{BCw}$ horizons) varied markedly between sites. Under the arid shrubland in the north, the transition from $\mathrm{BCw}$ horizon to the underlaying weathered rock is located around $50 \mathrm{~cm}$ soil depth, while under the Mediterranean coastal matorral, the transition lies at around $80 \mathrm{~cm}$ depth (Bernhard et al., 2018). Under humidtemperate forest in the south, the transition from $\mathrm{BCw}$ horizon to saprolite occurs around $100 \mathrm{~cm}$ depth (Bernhard et al., 2018). Thickness of the A horizon varies as well, with 10-20 cm under shrubland, 10-40 cm under woodland, and 30-50 cm under forest (Oeser et al., 2018). For a detailed site description, please refer to Bernhard et al. (2018) and Oeser et al. (2018).

Total precipitation $(\mathrm{mm})$ and frequency (i.e. the number of days with precipitation) from March 2016 till November 2016 (time of the conducted field experiments) are given in Figure 2.1-1 and were recorded by the EarthShape weather stations (Ehlers et al., 2017) for the arid and Mediterranean sites. As the project weather station in the National Park Nahuelbuta was only installed in November 2016, precipitation data were derived from the Center for Climate and Resilience Research (CR)² (2020) for the station Parque Nahuelbuta (37.8233 S, 72.9606 W).

\subsubsection{Predicted precipitation shifts}

In the past century precipitation patterns in Chile changed notably. In a meta-analysis of pre-published data from 271 stations between $26^{\circ} 00^{\prime} \mathrm{S}$ and $56^{\circ} 30^{\prime} \mathrm{S}$, a trend of precipitation decrease from 1960 to 2000 was detected in the Coquimbo and Valparaiso regions $\left(29^{\circ} 20^{\prime}\right.$ S to 335's) (Valdés-Pineda et al., 2014), where the arid shrublands and Mediterranean coastal
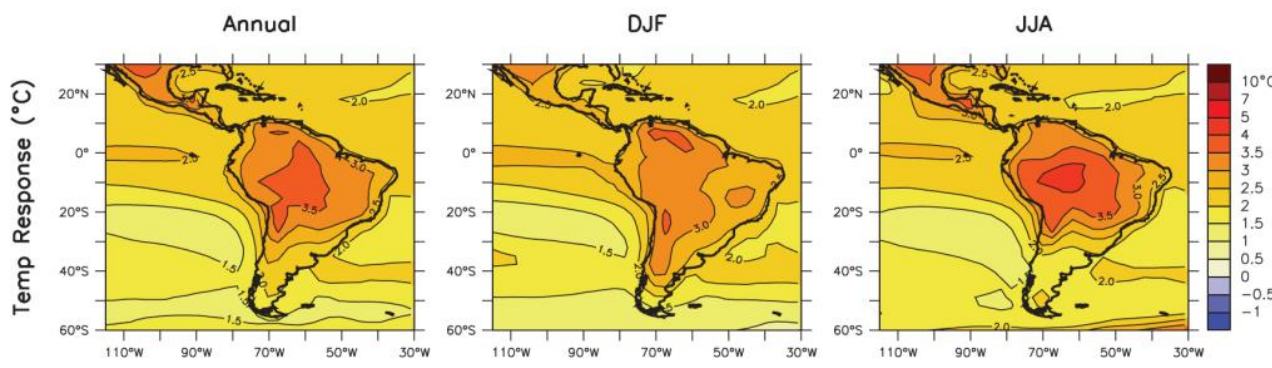

Figure 1.2-2:

Temperature and precipitation changes over Central and South America from MMD-A1B simulations (MMD:
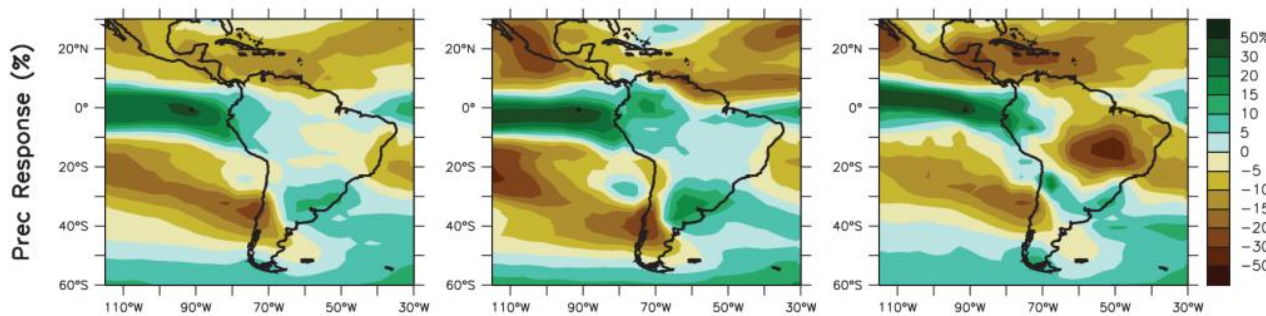
multi-model data set archived a the Program for Climate Model Diagnosis and Intercomparison PCMDI; SRES AIB: emission scenario with 850 ppm CO2 in atmosphere in 2100).

From left to right: annual mean, DJF (austral summer), JJA (austral winter). Top row: Temperature (top row) and precipitation (bottom row) changes between 1980 to 1999 and 2080 to 2099, average over 21 models. Modified from Christensen et al. (2007) Figure 11.15. 
matorral are located. In the fourth IPCC Assessment Report (IPCC, 2007) are pronounced temperature increases and precipitation decreases of up to $50 \%$ compared to the reference period 1980-1999 predicted for 2080-2100 in the region from $\sim 25^{\circ} \mathrm{S}$ to $45^{\circ} \mathrm{S}$, encompassing also the southernmost study site of the humid-temperate forest (Figure 1.2-2; Christensen et al., 2007).

Regional climate models (Figure 1.2-3) predicted as well that precipitation will decrease markedly (>50\% compared to 1960-1990) in the region of BioBío and Araucanía, where the humidtemperate forest studied here is located (Garreaud, 2011). The regional climate models project also a decrease of precipitation in the Mediterranean and arid northern part of Chile up to the Atacama Desert, but it is expected to be less pronounced than in the Chilean South (Garreaud, 2011). By 2100, an aridification of the region where the Mediterranean coastal matorral site is located is expected to be uncertain to likely (Klausmeyer and Shaw, 2009).

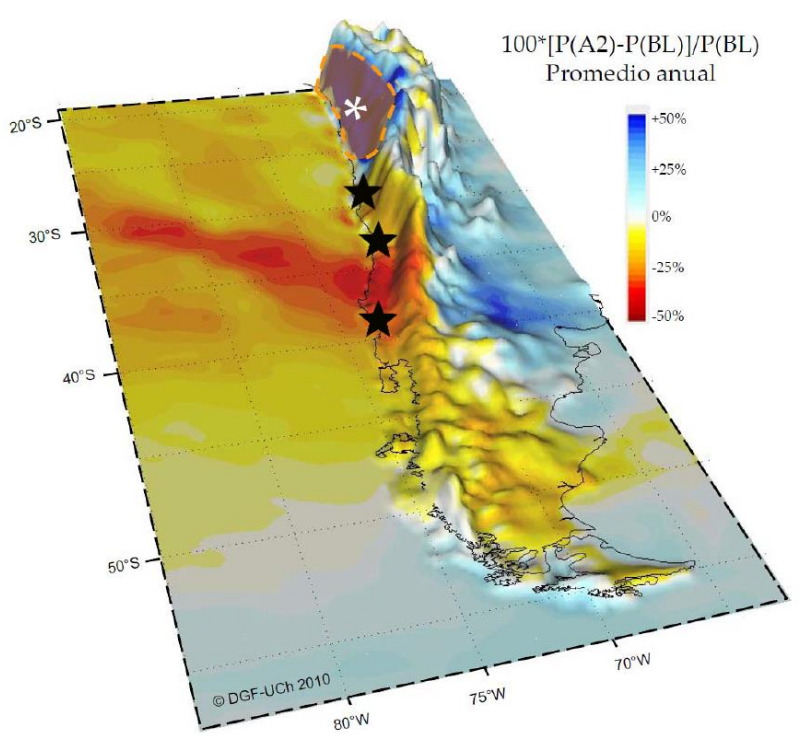

Figure 1.2-3: Mean annual precipitation change [\%] for the period 2070-2100 with 1960-1990 as reference. The change was normalized to the average of the current precipitation. Modelled with PRECIS-DGF (Providing REgional Climate Impact Studies) under the assumption of severe greenhouse gas emissions in the coming decades (SRES emission scenario A2 with 1250 ppm $\mathrm{CO}_{2}$ in atmosphere in 2100). *The region of the Atacama Desert is shown in gray as the precipitation there is (almost) $0 \mathrm{~mm}$. Taken from Garreaud, (2011) Figure 9. Black stars indicate the approximate study site locations.

Not only is a general decrease of precipitation predicted for Central Chile, but also are precipitation patterns expected to become much more variable (IPCC, 2014, 2007; Young et al., 2010), resulting in a concentration of precipitation in few events with longer dry periods in between (Knapp et al., 2008a). In the last decade, for example, was an unusual and unprecedented long period of precipitation reduction recorded from 2010 to 2015 between $30-38^{\circ} \mathrm{S}$, which was framed as the 'megadrought' (Garreaud et al., 2017). These variations can, for example, be caused by changes in the El Niño/La Niña-Southern oscillation (ENSO) (IPCC, 2012; Sala et al., 2015).

During El Niño episodes, precipitation increases above average between $30^{\circ} \mathrm{S}$ and $35^{\circ} \mathrm{S}$ in winter (JJA), but increases in late spring (ON) between $35^{\circ} \mathrm{S}$ and $38^{\circ} \mathrm{S}$ (Montecinos and Aceituno, 2003). During La Niña, patterns are opposite. Changes in the El Niño/La Niña-Southern oscillation (ENSO) lead to increased climate variability and could increase the frequencies of extreme events. The occurrence of ENSO events, however, is naturally highly variable and no consistent 
projections of changes could be made so far (IPCC, 2012; Young et al., 2010). While some models predict an increase in ENSO variability and frequency, others predict a reduction (van Oldenborgh et al., 2005). It was reported, however, that the frequency and intensity of ENSO events have increased since the 1970, which in turn leads to a decrease in frequency but an increase in intensity of rain events (Carrasco et al., 2005; Young et al., 2010). Especially such prolonged drought periods can compromise the continuity of ecosystems that rely on deep water pools when topsoils are dehydrated, if those deep pools are not replenished sufficiently.

\subsubsection{Research approaches}

\subsubsection{Tracer applications to assess nutrient uptake and C investment}

The application of naturally rare stable isotopes such as ${ }^{13} \mathrm{C}$ or ${ }^{15} \mathrm{~N}$, allows to trace element translocation/cycling in plant-microbial-soil systems. Likewise, the use of analogs, which are elements rare in natural ecosystems but behaving similar to major plant and microbial nutrients in soil and regarding plant uptake, allow to investigate plant nutrient acquisition and strategies (Fitter, 1986; Hoekstra et al., 2014). In the scope of this thesis, two field experiments with tracer applications were conducted.

The first field experiment ('Acquisition Experiment') focused on the evaluation of plant $\mathrm{K}$ and $\mathrm{N}$ acquisition from topsoil, subsoil, and saprolite. Therefore, rubidium (Rb) and cesium (Cs) as $\mathrm{K}$ analogs, and ${ }^{15} \mathrm{~N}$ were used as tracers. A common tracer solution with $\mathrm{RbCl}, \mathrm{CsCl}$, and $\mathrm{Na}^{15} \mathrm{NO}_{3}$ (99 at\%; Sigma; for concentrations see Table 2.1-1), was injected equally in three pre-cored auger holes around a plant specimen. The area around a specimen was either labeled in topsoil (A-Bw horizons), subsoil (Bw-BCw horizons), or saprolite (below BCw horizon), with 8 specimens per site and depth, distributed between south- and north-facing slopes. All specimens were chosen at a mid-slope position. Assuming quantitatively much lower tracer recovery from lowest soil depth compared to topsoil, we increased the amount of tracer from topsoil to the lowest depth (see Table 2.1-1). The labeling was conducted at the end of the austral summer (March 2016) to avoid plant inactivity due to a potential summer dormancy, especially at the sites under arid and Mediterranean conditions (di Castri and Hajek, 1976). The exposure time was 8 months, after which plant material was collected in November 2016.

The second field experiment ('C Investment Experiment') focused on the assessment of plant C investment into the fine root network as well as the extraradical mycelium of arbuscular mycorrhizal fungi. The ${ }^{13} \mathrm{CO}_{2}$ pulse-labeling experiment was conducted in November 2016. At each site, 4 plants were labeled on south-facing slopes. In 60x60x60 cm polyethylene chambers, a ${ }^{13} \mathrm{CO}_{2}$-enriched atmosphere was created. Therefore, c. $3 \mathrm{~g}$ of $\mathrm{Na}_{2}{ }^{13} \mathrm{CO}_{3}\left({ }^{13} \mathrm{C}\right.$ enrichment $99 \%$, Sigma Aldrich, Munich, Germany) were dissolved in $50 \mathrm{ml} \mathrm{H}_{2} \mathrm{O}$ and placed inside the chambers 
before sealing them. To generate ${ }^{13} \mathrm{CO}_{2}$, the $\mathrm{CO}_{2}$ moiety of $\mathrm{Na}_{2}{ }^{13} \mathrm{CO}_{3}$ was transferred into gaseous phase by adding $5 \mathrm{M} \mathrm{H}_{2} \mathrm{SO}_{4}$, which was applied with a syringe through the polyethylene foil. The labeling time varied between sites according to weather conditions (see Table 2.2-1).

\subsubsection{Labeled plant species}

For both experiments the same plant species were labeled, except in the Mediterranean coastal matorral. All species were perennial woody species that are known to form a symbiosis with AMF, and all labeled specimen ranged between 40 and $60 \mathrm{~cm}$ in height. In the arid shrublands in the North, the perennial woody shrub Gutierrezia resinosa (Hooker \& Arnott) Blake was labeled. The shrub prevails on sandy alkaline or neutral soils with low organic carbon and nitrogen contents (Solbrig, 1966). Of an overall plant cover of 30-40\%, G. resinosa accounted for $15 \%$ (i.e. $6 \%$ of the total area). In the Mediterranean coastal matorral, the shrub Aristeguietia salvia (Colla) King \& Rob (other names Eupatorium salvia (Colla), Salvia macha, or pega-pega) was labeled in the first experiment, which belongs to the Asteraceae family. It can be found in central Chile in low to mid altitudes (Chile Flora, 2020). Of an overall 100\% plant coverage, A. salvia accounted for $8 \%$ of the area (Bernhard et al., 2018). For the second field experiment, Erigeron fasciculatus (Colla) was labeled, which is a perennial subshrub with a maximum growth height of $70 \mathrm{~cm}$ (Andrus et al., 2009). It belongs to the Asteraceae family and can be found at low and mid elevations (Andrus et al., 2009; Solbrig, 1962; Valdebenito et al., 1986). Of an overall 100\% by vegetation covered area, E. fasciculatus accounted for $10 \%$. In the humid-temperate forest in the South, the coniferous tree species Araucaria araucana (Molina) K. Koch was labeled, which belongs to the family of Araucariaceae. Contrary to conifers in the Northern Hemisphere, native conifers in the Southern Hemisphere, such as A. araucana, form only mycorrhizal symbioses with arbuscular mycorrhizal fungi (Diehl and Fontenla, 2010; Godoy et al., 1994). A. araucana specimen made up $40 \%$ of the understory, which had a total coverage of $100 \%$.

\subsubsection{Sampling}

In total three sample sets, including soil and plant samples, were collected:

Set 1 - Acquisition-Experiment: The soil material that was excavated with a soil auger for the injection of the tracer solution was collected down to $60 \mathrm{~cm}$ (shrubland), $120 \mathrm{~cm}$ (coastal matorral), or $200 \mathrm{~cm}$ (forest) depth, depending on the start of the underlying weathered rock/saprolite. The cores were subdivided into $10 \mathrm{~cm}$ (shrubland and coastal matorral) or $25 \mathrm{~cm}$ (forest) depth increments. Additionally, shoots and roots of labeled and non-labeled plants were collected (Study 1, Study 3). 
Set 2 - C Investment-Experiment: For the plant $\mathrm{C}$ investment experiment, soil samples from 0-10 $\mathrm{cm}$ and 20-30 $\mathrm{cm}$ were collected at four time points: before labeling ( $0 \mathrm{~d}), 1$ day after labeling $(1 \mathrm{~d}), 3$ days after $(3 \mathrm{~d})$, and 14 days after $(14 \mathrm{~d})$. A root corer with $8 \mathrm{~cm}$ diameter was used for the sampling, the soil samples were sieved $(2 \mathrm{~mm})$ and roots were picked. The material was frozen at $-20{ }^{\circ} \mathrm{C}$ (Study 2, Study 3).

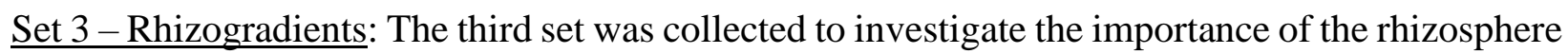
as hotspot of OM input, microbial activity, OM decomposition, and mineral weathering. Soil samples were collected from four soil pits per site. Three pits were always located on a southexposed slope arranged as a catena (top-, mid-, and toe-slope), and one pit was located at the opposing north-exposed slope at mid-slope position. To be able to compare profiles and sites with each other, each pit was divided into three depth increments according to soil thickness. The profile from ground level till the transition from soil to saprolite was defined as $100 \%$, and samples were collected from $0-50 \%, 50-100 \%$, and $>100 \%$. In each depth, composite samples from channels of young living roots were collected in 0-2 mm, 2-4 mm, and 4-6 mm, to obtain a gradient from root to bulk soil (Study 3, Study 4, Study 5). Thereby a community specific, and not species specific, sampling was achieved.

\subsubsection{Analytical methods}

\section{Soil and root analyses}

Gravimetric water content was determined of aliquots of Set 3 by drying the samples at $105{ }^{\circ} \mathrm{C}$ until constant weight. Organic $\mathrm{C}$ and total $\mathrm{N}$ contents as well as stable $\mathrm{C}$ isotope ratios $\left({ }^{13} \mathrm{C} /{ }^{12} \mathrm{C}\right)$ and stable $\mathrm{N}$ isotope ratios $\left({ }^{15} \mathrm{~N} /{ }^{14} \mathrm{~N}\right)$ were determined for all soil and root samples (Set 1-3) by an elemental analyzer coupled to an isotope ratio mass spectrometer (IRMS). Isotopic ratios are expressed in the delta notation $\left(\delta^{13} \mathrm{C}, \delta^{15} \mathrm{~N}\right)$ in parts per mill $(\%)$. $\mathrm{P}$ content was measured in soil samples of all sets, and $\mathrm{K}, \mathrm{Rb}$, and Cs contents were determined for plant (shoots and roots) and soil samples of Set 1 . Therefore, nutrients were extracted with nitric acid pressure digestion (König et al., 2005) and subsequently measured by inductively coupled plasma optical emission spectrometer (ICP-OES; Set 2, 3) or an inductively coupled plasma mass spectrometer (ICP-MS; Set 1). Additionally, plant available P data from Bernhard et al. (2018) were included in the analysis of Study 2. N and K tracer recoveries of the Acquisition-Experiment were calculated according to equations (2.1-1) and (2.1-2) in Study 1, respectively. Collected roots from Set 2 were washed and scanned with a flatbed scanner but were not separated in dead or living roots or by species and, thus, reflect the whole community root biomass. The images were analyzed with the image analyzing software WinRHIZO 2013e (Regent Instruments Inc., Québec, Canada). Root weight was determined by drying at $70{ }^{\circ} \mathrm{C}$ until constant weight, to calculate root length density 
$\left(\mathrm{RLD}, \mathrm{cm} \mathrm{cm}^{-3}\right.$ ), specific root length (SRL, $\mathrm{m} \mathrm{g}^{-1}$ ), and root tissue density ( $\mathrm{RTD}, \mathrm{g} \mathrm{cm}^{-3}$ ) of fine roots with $\leq 1.0 \mathrm{~mm}$ diameter.

\section{Estimating long-term K uplift}

Additional to the analyses for Set 1-3, exchangeable K and exchangeable sodium (Na) data from Bernhard et al. (2018) were included in the analyses of Study 1. The contrasts between exchangeable $\mathrm{K}$ and $\mathrm{Na}$ in soil profiles can be used to estimate the long-term $\mathrm{K}$ uplift by roots, based on the assumption of a preferential cycling of nutrients (Jobbágy and Jackson, 2004, 2001) and the absence of recycling for ballast elements (e.g., Na). Without plant uplift, the vertical distribution of $\mathrm{K}^{+}$would follow the pattern of $\mathrm{Na}^{+}$, which is not actively acquired by plants (Jobbágy and Jackson, 2001).

\section{Arbuscular mycorrhizal fungi analysis}

To determine root colonization with arbuscular mycorrhizal fungi, roots from Set 2 were stained following a modified method of Vierheilig et al. (1998). Percentage of root colonization with AMF was determined following a modified version of Nicolson's root segment \pm method (Nicolson, 1955) for which not AMF colonization per root length but per root area was determined. Five root segments with $1 \mathrm{~cm}$ length each were analyzed per sample with a light microscope. The whole segment was imaged and subsequently a grid was fitted onto the stitched image of each segment. Grid squares were then classified and counted as either containing only root tissue (-) or containing root tissue and fungal structures (+). The percentage of root colonized with fungi was calculated by the relation of squares containing root and fungi structures to the total number of squares containing fungi and/or root. Working at a higher resolution and determining colonization per area allowed to detect finer differences between sites.

\section{Phospholipid fatty acids analysis and ${ }^{13} \mathrm{C}$ incorporation}

A modified version of (Frostegård et al., 1991) was followed to extract phospho- and neutral lipid fatty acids (PLFA, NLFA) (Dippold and Kuzyakov, 2016; Gunina et al., 2014) from soil samples of Set 2. Neutral and phospholipids were extracted, purified, and separated using a solid phase extraction (SPE). The purified extracts were hydrolyzed and methylated to fatty acid methyl esters (FAMEs). The samples were then measured on a gas chromatograph-mass spectrometry (GC-MS) for quantification as well as on an IRMS for isotope ratio determination. The calculations and drift corrections for obtaining $\mu \mathrm{g}$ FAME $\mathrm{g}^{-1}$ soil and $a \%^{13} \mathrm{C}$ of FAMEs can be found in Dippold and

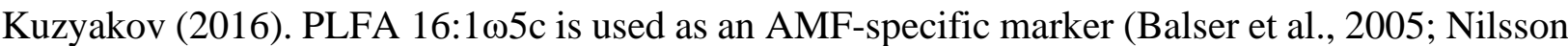
et al., 2004; Olsson et al., 1998) and was used in Study 2 as proxy for the extent of the extraradical mycelium in soil. NLFA $16: 1 \omega 5 \mathrm{c}$ is a storage compound solely produced by AMF (Ngosong et 
al., 2012; Olsson, 1999). The ${ }^{13} \mathrm{C}$ incorporation in PLFA and NLFA (and root tissue) was calculated according to equations (2.2-1) - (2.2-4) in Study 2.

\section{Quantification of microbial abundance and diazotrophy}

Total genomic DNA was extracted with the FastDNA SPIN kit for soil (MP Biomedicals, LLC, Solon, OH, USA) following the manufacturer's instructions. The extracted DNA was quantified with a NanoDrop 2000C (Thermo Fisher Scientific). The nifH gene encodes for a subunit of the nitrogenase enzyme involved in microbial $\mathrm{N}_{2}$-fixation and acts as a molecular marker for diazotrophs (Hsu and Buckley, 2009). Diazotrophs abundance and abundance of bacterial and fungal DNA were determined by quantitative polymerase chain reaction (qPCR) (for details see Study 3). qPCR reactions were performed in a total reaction volume of $10 \mu \mathrm{L}$ using the iTaq Universal SYBR Green Supermix (BioRad, Hercules, CA, USA) following the manufacturer's instructions. Quantification reactions were carried out in the CFX96 Real-Time PCR Detection System (BioRad) and data analysis was carried out using the BioRad CFX ManagerTM 3.1 (BioRad).

\section{Enzyme assays}

Kinetics of seven extracellular enzymes of the $\mathrm{C}, \mathrm{N}$, and $\mathrm{P}$ cycles were determined in the soil samples of Set 3 (rhizogradients) using synthetic fluorogenic substrates(see Table 2.4-1; Marx et al., 2001) Three analytical replicates were measured for each sample at 8 substrate concentrations $\left(0,2,4,6,8,10,20,40 \mu \mathrm{mol} \mathrm{g}^{-1}\right.$ soil $)$. Fluorescence was measured by a microplate reader (Victor ${ }^{3}$ 1420-050 Multi label Counter; extinction: $355 \mathrm{~nm}$, emission: $460 \mathrm{~nm}$ ) immediately after substrate addition ( $\left.\mathrm{t}_{0}\right)$ and $2 \mathrm{~h}$ after addition $\left(\mathrm{t}_{1}\right)$. For calibration and accounting for quenching, standard plates were additionally prepared and measured enzyme activities were calculated (nmol substrate $\mathrm{g}^{-1}$ soil $^{-1}$ ) with the regression slopes of the standard measurements. The activities were fitted by the Michaelis-Menten Equation, which describes non-linear saturation curves (equation 2.4-1) and gives the maximal rate of enzymatic activity under optimum substrate conditions $\left(\mathrm{V}_{\max }\right)$ and the half-saturation constant $\mathrm{K}_{\mathrm{m}}$ that indicates substrate affinity (high $\mathrm{K}_{\mathrm{m}}=$ low affinity).

\section{Organic acid extraction}

Organic acids contents were extracted from soil samples of Set 3 (rhizogradients) based on a modified method described by Szmigielska et al. (1997). Analytes were purified by a liquid-liquid extraction using Chloroform $\left(\mathrm{CHCl}_{3}\right)$ and were subsequently analyzed on a GC-MS. The standard for identification of acids in samples contained seven organic acids (oxalic-, malonic-, fumaric-, succinic-, maleic-, malic- and citric acid; Table S 2.5-1). 
XANES - P speciation

$\mathrm{X}$-ray absorption near edge structure (XANES) spectra at the $\mathrm{P}$ K-edge were measured at the Beamline 8 of the electron storage ring $(1.2 \mathrm{GeV}$; bending magnet; beam current: $80-150 \mathrm{~mA}$; 1.1 to $1.7 \times 10^{11}$ photons $^{-1}$ ) at Synchrotron Light Research Institute (SLRI), Nakhon Ratchasima, Thailand (Klysubun et al., 2012). Air dried samples were milled, homogenized and applied to Kapton tape (Lanmar Inc., Northbrook, IL, USA) (area $2.0 \mathrm{~cm}$ x $0.5 \mathrm{~cm}$ ). Samples were measured in fluorescence mode. Evaluation of the XANES spectra was done by using the software R Version 3.4.3 (R Core Team, 2017) and the LCF package for linear combination fitting (LCF) (Werner, 2017). Spectra of the samples were background corrected and edge-step normalized. For the fitting process a total of 13 standards (Table 2.5-2) were selected (Prietzel et al., 2016) but restricted to a maximum of 4 standards per sample. 


\subsection{Results and Discussion}

This chapter is divided into four sections: first the findings on nutrient availability in soils at the study sites are summarized (0). Then the plant nutrient acquisition strategies in each ecosystem are discussed separately $(1.3 .2,1.3 .3,1.3 .4)$. The main results and conclusions of the studies included in this thesis are given in Table 1.3-1 and are depicted in Figure 1.3-1.

Table 1.3-1: Overview of studies included in this thesis with main objectives, results, and conclusions

\begin{tabular}{|c|c|c|}
\hline Study & Objectives & Main results and conclusions \\
\hline $\begin{array}{l}\text { Study 1: Retention } \\
\text { against losses: } \\
\text { disentangling plant uplift } \\
\text { and recycling in a } \\
\text { continental transect of } \\
\text { water and nutrient } \\
\text { availability }\end{array}$ & $\begin{array}{l}\text { - Localize short-term ( }<1 \text { year) } \\
\text { plant } \mathrm{N} \text { and } \mathrm{K} \text { acquisition from } \\
\text { topsoil to saprolite } \\
\text { - Determine long-term (>decades) } \\
\mathrm{N} \text { recycling and } \mathrm{K} \text { uplift } \\
\text { - Comparing nutrient recycling } \\
\text { and uplift at the three aridity } \\
\text { levels as adaptation to water and } \\
\text { nutrient availability }\end{array}$ & $\begin{array}{l}\text { - Similar short-term } \mathrm{N} \text { and } \mathrm{K} \text { acquisition from } \\
\text { - } \quad \text { Intensive long-term } \mathrm{N} \text { recycling under arid and } \\
\text { humid conditions } \\
\text { - } \quad \text { Short-term } \mathrm{N} \text { acquisition from top- and subsoil, } \\
\text { but } \mathrm{K} \text { acquisition from topsoil and saprolite under } \\
\text { humid conditions } \\
\text { Intensive short-term } \mathrm{N} \text { and } \mathrm{K} \text { acquisition from } \\
\text { topsoil under Mediterranean conditions: plants } \\
\text { exploit upper soil fast to retain nutrients as } \\
\text { adaptation to potentially high nutrient losses. } \\
\text { Leached } \mathrm{N} \text { is recaptured from subsoil, } \mathrm{K} \text { is newly } \\
\text { acquired from subsoil and saprolite }\end{array}$ \\
\hline $\begin{array}{l}\text { Study } 2 \text { : Mycorrhiza } \\
\text { functions depend on water } \\
\text { and nutrient limitation }-a \\
\text { cross-biome study along a } \\
\text { precipitation gradient }\end{array}$ & $\begin{array}{l}\text { - Determine root traits that are } \\
\text { important for nutrient uptake } \\
\text { capacity } \\
\text { - Determine } \mathrm{C} \text { investment into } \\
\text { roots and AMF } \\
\text { - Function of AMF in plant } \mathrm{N} \text { and } \\
\text { P acquisition }\end{array}$ & $\begin{array}{l}\text { - Fast nutrient acquisition at Mediterranean site } \\
\text { (with high denudation), slow acquisition at humid } \\
\text { and arid site. } \\
\text { - Functional shift of AMF across the gradient: } \\
>\text { The extraradical AMF mycelium is supplied } \\
\text { with photosynthetic-fixed } \mathrm{C} \text { to scavenge for } \mathrm{P} \\
\text { in all ecosystems. } \\
>\text { AMF additionally support plant } \mathrm{N} \text { acquisition } \\
\text { under humid (fast } \mathrm{N} \text { transfer) and } \\
\text { Mediterranean (fast } \mathrm{N} \text { transfer and scavenging } \\
\text { for } \mathrm{N} \text { ) conditions } \\
\text { AMF exert a function in Mediterranean site not } \\
\text { observed in the humid or arid sites: retaining } \\
\text { nutrients and preventing losses from soil }\end{array}$ \\
\hline
\end{tabular}


Study

Study 3: Nitrogen cycling

depending on aridity and

vegetation cover
Objectives

- Comparison of $\mathrm{N}$ fixation in bulk topsoil (litter $\mathrm{C}$ input) and rhizosphere soil (root $\mathrm{C}$ input)

- Compare $\mathrm{N}$ fixation between ecosystem with contrasting aridity

- Potential $\mathrm{N}$ mineralization and $\mathrm{N}$ losses across the precipitation gradient

\section{Main results and conclusions}

- Greatest $\mathrm{N}$ mineralization from the Mediterranean ecosystem

- Decreasing $\mathrm{N}$ fixation with increasing aridity

- Higher $\mathrm{N}$ fixation in rhizosphere than in bulk topsoil

- Increasing aminopeptidase activity and bacterial abundance relative to SOC in the rhizosphere with increasing aridity: importance of rhizosphere as hotspot of microbial activity greater in dry soils then moist soils
Study 4: Environmental

drivers and stoichiometric

constraints on enzyme

activities in soils from

rhizosphere to continental

scale
- Determine extracellular enzyme activities related to $\mathrm{C}, \mathrm{N}$, and $\mathrm{P}$ cycling across scales: continental transect (water availability gradient), depth profile (nutrient availability gradient), rhizosphere/bulk soil (C input gradient)

- Effects of substrate availability and stoichiometric constraints on enzyme activities
- Increasing extracellular enzyme activities with increasing precipitation

- Decreasing activity with depth

- Decreasing activity from root proximity to bulk soil

- Activity of enzymes involved in $\mathrm{N}$ and $\mathrm{P}$ acquisition $=$ substrate limited (substrate availability)

- Activity of enzymes involved in (hemi)cellulose decomposition $=$ demand driven decomposition (stoichiometric constraints)
Study 5: From rock eating

to vegetarian ecosystems

- disentangling key

processes of phosphorus

acquisition along a

precipitation gradient

across biomes in the

Chilean Coastal

Cordillera
- Determine P speciation in rhizosphere compared to bulk soil

- Quantify low-molecular-weight organic acids (LMWOA) as biological weathering agents

- Disentangle the impact and functions of roots and associated microorganisms on P-cycle driving agents (organic acids and phosphatases).
- Organic P increase from arid to humid site

- Plant P acquisition strategies depend on climate: biological weathering and uplift of inorganic $\mathrm{P}$ forms under arid conditions and in subsoil under Mediterranean conditions - intensive organic $\mathrm{P}$ recycling under forest and in topsoil under

Mediterranean conditions

- Functional shift of LMWOA across gradient: from mineral dissolution under arid conditions to facilitation of organic $\mathrm{P}$ recycling under humid conditions 


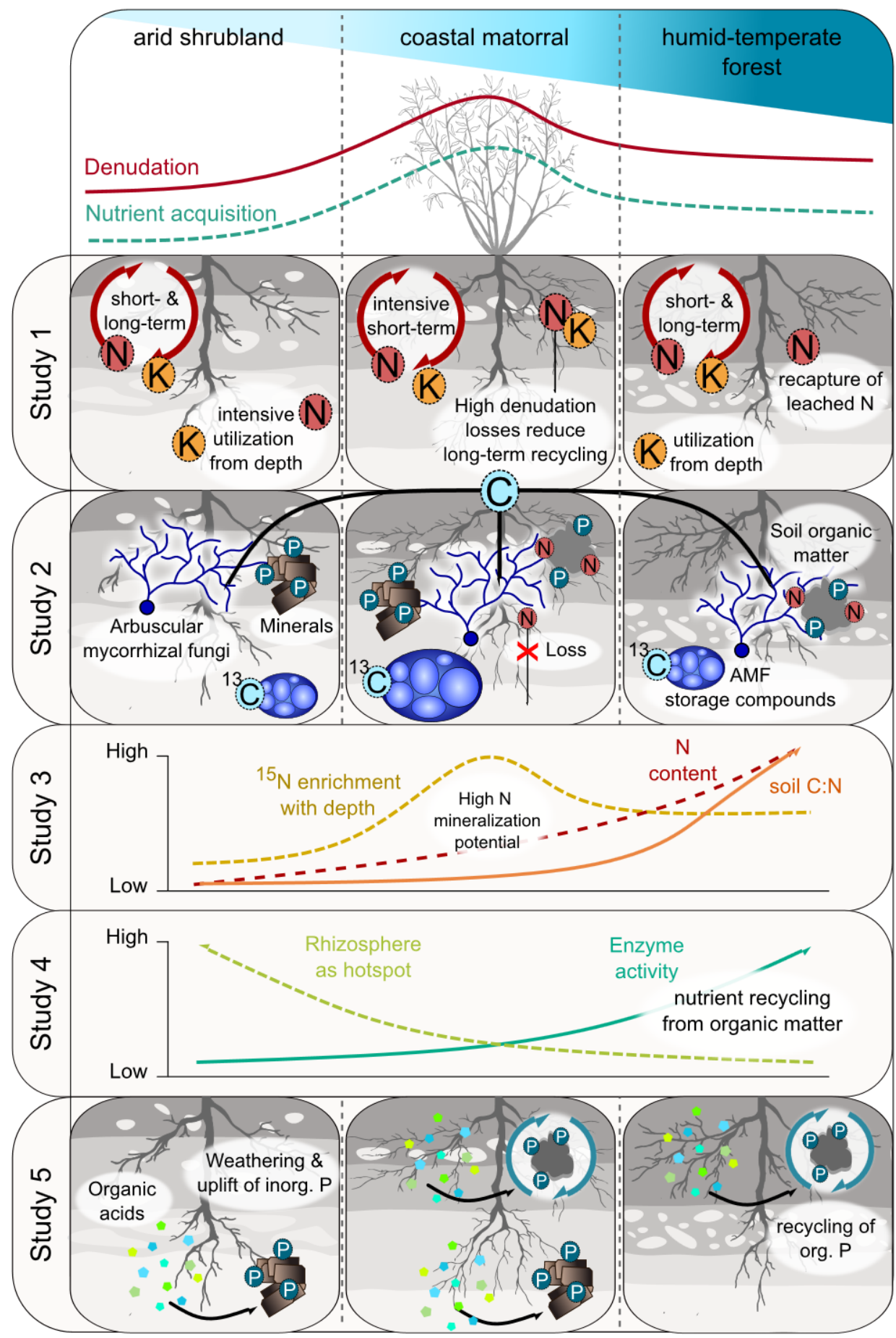

Figure 1.3-1: Three study sites across a precipitation gradient from arid to humid-temperate ecosystems were investigated, with highest denudation rates (red, solid line) under Mediterranean conditions (coastal matorral). (Study 3) Results indicated fasted $N$ mineralization in the Mediterranean ecosystem. (Study 1) Plant $N$ and $K$ acquisition strategies differ across the gradient. High nutrient losses by denudation under Mediterranean climate, reduce long-term $N$ recycling but stimulate intensive shortterm recycling (red circling arrows). (Study 5) Plant $P$ acquisition strategies shift along the gradient: biological weathering and uplift of inorganic $P$ forms under arid conditions and in subsoil of the Mediterranean ecosystem - intensive organic $P$ recycling (blue circling arrows) under forest and in topsoil under Mediterranean conditions. Functions of organic acids shift from mineral dissolution under arid to facilitation of organic P recycling under humid conditions. (Study 4) Nutrient recycling from organic matter increases with increasing precipitation, while the importance of the rhizosphere for $N$ and $P$ acquisition increases with increasing aridity. (Study 2) Root traits indicated fastest plant nutrient acquisition (green, dashed line) in the Mediterranean ecosystem. Plant C investment (solid black arrows) AMF was independent of precipitation. AMF functions shift from $P$ mobilization under arid conditions to $N$ and $P$ acquisition under Mediterranean and humid conditions. Only in the Mediterranean ecosystem exert AMF the additional function to retain mobile nutrients (as $N$ ) and prevent losses from soil. In line with that, allocation of freshly assimilated $C\left({ }^{13} \mathrm{C}\right)$ to $\mathrm{AMF}$ storage compounds was highest in soil under Mediterranean conditions 


\subsubsection{Plant nutrient availability}

Mobile nutrients such as $\mathrm{NO}_{3}{ }^{-}$have a high potential of leaching at the humid site with MAP of over $1500 \mathrm{~mm} \mathrm{a}^{-1}$. This was evident by the low $\mathrm{N}$ tracer uptake (injected as $\mathrm{NaNO}_{3}{ }^{-}$) by $A$. araucana in the humid-temperate forest in the South, compared to the uptake by shrubs in the Mediterranean and arid sites (Figure 2.1-2). High losses by leaching or run-off and a large standing biomass (Bernhard et al., 2018) lead to high nutrient demands by plants in humid regions (Godoy et al., 2014; Inselsbacher and Näsholm, 2012). High soil and plant C:N ratios and low plant available P (Bernhard et al., 2018; Figure 2.3-1) illustrated the low availability of $\mathrm{N}$ and $\mathrm{P}$ for plants and microbes in the humid-temperate forest (Cleveland and Liptzin, 2007; Xu et al., 2013; Zechmeister-Boltenstern et al., 2015). Due to the low N content of SOM, microbes likely immobilize $\mathrm{N}$ in their biomass rather than releasing inorganic N (Study 3; Bengtsson et al., 2003), which in turn increases the competition for $\mathrm{N}$ between plants and microbes (Hodge et al., 2000; Kuzyakov and Xu, 2013).

Decreasing vegetation cover, root length density, microbial biomass, and extracellular enzyme activities with decreasing MAP (Figure 2.2-2, Figure 2.4-3, Figure 2.3-4, Bernhard et al., 2018) displayed the decline of plant productivity and belowground plant $\mathrm{C}$ allocation with increasing aridity (Leuschner et al., 2004; Nadelhoffer and Raich, 1992). P stocks and plant available P were higher at the sites under arid and Mediterranean than under humid conditions (Study 2; Study 5; Bernhard et al., 2018). But water shortage can strongly modulate the mobility of P; stronger than the mobility of $\mathrm{N}$. The dominant $\mathrm{P}$ species in the arid shrubland soil were primary $\mathrm{P}$ minerals (Hydroxyapatite) and secondary P minerals (Variscite), similar as in the subsoil and saprolite in the Mediterranean coastal matorral (Study 5). Combined with the low water availability that restricts abiotic mineral dissolution as well as $\mathrm{P}$ mobility in soil, a large portion of $\mathrm{P}$ sources are only slowly accessible to plants (He and Dijkstra, 2014; Marschner and Rengel, 2012).

The $\mathrm{N}$ source for microbial decomposition shifted with increasing aridity from a peptide- and chitin-based nutrition in the humid-temperate forest to a primarily peptide-based nutrition in the coastal matorral and arid shrubland (Study 4). At the arid and Mediterranean sites, the extent to which microbes immobilize $\mathrm{N}$ in their biomass is likely lower than at the site under humid conditions. Thus, microbes rather release inorganic N (Study 3), which can reduce the competition for $\mathrm{N}$ between plants and microbes (Hodge et al., 2000; Kuzyakov and Xu, 2013). High N contents with low $\mathrm{C}: \mathrm{N}$ ratios in soil as well as the strongest ${ }^{15} \mathrm{~N}$ enrichment with decreasing $\mathrm{N}$ content with depth ( Figure 2.3-1; Figure 2.3-2), pointed to the greatest $\mathrm{N}$ mineralization in soil of the Mediterranean coastal matorral across the precipitation gradient (Study 3), for which a coupling of processes might be responsible. Microbes respond to rewetting much faster than plants (Austin 
et al., 2004; Schwinning and Sala, 2004). In semiarid ecosystems, precipitation pulses during dry season, or brief and shallow pulses during wet season, can therefore lead to a decoupling of microbial and plant activity, and thereby to an accumulation of mineralized $\mathrm{N}$ in topsoil (McCulley et al., 2009; Reichmann et al., 2013; Schwinning and Sala, 2004). The accumulated $\mathrm{N}$ is then highly susceptible to leaching and run-off during more intensive rainfall events (McCulley et al., 2009). Additionally, denudation rates were the highest at the Mediterranean site across the gradient (Oeser et al., 2018; Schaller et al., 2018; van Dongen et al., 2019), increasing the potential for nutrient losses by surface processes. But high losses do not only lead to a loss of mobile nitrate but can also lead to losses of rock-born nutrients such as K and P (Hou et al., 2018).

\subsubsection{Nutrient mobilization and acquisition under intensive precipitation}

The humid temperate forest in the South of the precipitation gradient is representative for an ecosystem under the influence of high and intensive precipitation throughout the year and is characterized by high primary productivity, proceeded weathering, and high nutrient demands (Study 5; Bernhard et al., 2018; Godoy et al., 2014; Inselsbacher and Näsholm, 2012).

High nutrient demands (Study 2), but low relative nutrient availability require a strong nutrient reutilization via plant litter recycling and recapturing of released OM- and rock-derived nutrients (Godoy et al., 2014), which was evident from short-term (<1 year) N and K tracer recovery (Figure 2.1-2). Long-term (> decades) reutilization of $\mathrm{N}$ from the forest floor was indicated by a high ${ }^{15} \mathrm{~N}$ depletion of above- and belowground plant biomass relative to bulk topsoil $\delta^{15} \mathrm{~N}$ (Study 1; Figure 2.1-6). Intensive nutrient recycling in forest ecosystems, and especially in humid temperate rainforests, is an important strategy of plants to cover their nutrient demands (Godoy et al., 2014; Huygens et al., 2008, 2007). Low specific root lengths, and high root tissue densities (Figure 2.2-2), however, result in a slow nutrient uptake of plant roots in the humid-temperate forest. Plants invest into long-living roots to save resources, but the traits resulting in longevity reduce the nutrient uptake capacity (Brunner et al., 2015; Reich, 2014; Volaire, 2018).

Thick roots, however, have a greater potential of being colonized by AMF (Eissenstat et al., 2015; McCormack and Iversen, 2019), and plant species with thick absorptive roots were shown to invest more $\mathrm{N}$ into foraging by mycorrhizal fungi hyphae than species with thin roots (Eissenstat et al., 2015). Highest abundance of AMF in soil and roots across the gradient (Figure 2.2-3, Table 2.2-4) indicated that plants invest into an extensive AMF hyphal network to increase their nutrient gain (Study 2), as it provides the possibility of maintaining a close contact to resources while reducing C and nutrient costs (Fitter, 1991; Ryan et al., 2012; Taylor et al., 2009). In the humid-temperate forest, root colonization with AMF increased with reduced $\mathrm{N}$ availability (Figure 2.2-5), indicating that the symbiosis between plant and fungi is strengthened under low $\mathrm{N}$ availability to assure the 
transfer of $\mathrm{N}$ from fungi to plant (Bücking and Kafle, 2015; Johnson et al., 2003; Leigh et al., 2009). While an intensive root colonization by AMF seems decisive under $\mathrm{N}$ limitation, nourishing the extraradical AMF mycelium seemed to be an important strategy for plant $\mathrm{P}$ acquisition in the humid-temperate forest (Study 2). Here, the extraradical mycelium is supplied with photosynthetic-fixed $\mathrm{C}$ likely to scavenge for $\mathrm{P}$, which was illustrated by the allocation of plant $\mathrm{C}$ to AMF where $\mathrm{P}$ stocks are high, and where the well $\mathrm{C}$ supplied AMF most likely contributed to the increase of plant available P in soil (Study 2; Figure 2.2-5; Li et al., 2006; Treseder, 2004; Wright et al., 1998). This difference in plant-AMF-interactions under $\mathrm{N}$ and $\mathrm{P}$ scarcity might imply a difference in the functionality of the symbiosis: the contact to immobile P sources must be close, while for mobile $\mathrm{N}$ a fast transfer from fungi to plant is more critical. Deciphering functions from AMF abundance measurements, however, is difficult and needs to be treated carefully as abundance and community composition in roots and soil can be highly variable, both, spatially and temporally (van der Heijden and Scheublin, 2007).

The largest $\mathrm{P}$ pool in the topsoil of the humid-temperate forest is of organic nature and accounted in saprolite still for $17 \%$ of total P (Study 5). The exudation of extracellular enzymes that release P from organic matter (phosphatases) is, therefore, likely of much higher importance in the humidtemperate forest compared to the drier sites of the precipitation gradient (Study 4, Study 5). Additionally, plant-exuded organic acids support the $\mathrm{P}$ acquisition from organic sources by facilitating organic $\mathrm{P}$ uptake, illustrated by strong correlations of organic acids and organic $\mathrm{P}$ (Study 5; Drever and Stillings, 1997; Giles et al., 2014).

By the reutilization of nutrients released from organic matter, plants retain nutrients in soil against leaching (Taylor et al., 2009). Even with a strong reutilization, however, intensive precipitation leads to leaching and surface discharge. Plant retention strategies in the humid-temperate forest entailed, therefore, further the recapture and uplift of already leached nutrients from subsoil. In the subsoil $\mathrm{N}$ can be partially retained from further leaching by abiotic immobilization by the reaction with Fe(III) (Study 1; Davidson et al., 2003; Matus et al., 2019). Losses of rock-born nutrients such as $\mathrm{K}$ and $\mathrm{P}$ from topsoil via surface run-off and erosion can be replenished by the uplift of leached or weathering-released nutrients from subsoil and saprolite (Brantley et al., 2017; Jobbágy and Jackson, 2004; Uhlig and von Blanckenburg, 2019). This was underlined by a high K tracer uptake from saprolite and a higher efficiency to acquire $\mathrm{K}$ of saprolite roots than topsoil roots (Study 1). Additionally, increasing LMWOA:MBC ratios with increasing soil depth (Table 2.5S8) illustrated an intended exudation of organic acids for the acquisition of mineral-bound $\mathrm{P}$ via biological mineral weathering (Study 5). High water availability, however, likely results in 
intensive abiotic dissolution of minerals and, thus, might reduce the overall need for plants to invest in weathering agents (Study 5; Maher, 2010).

Roots traits and indications for strong recycling and uplift showed that A.araucana in the studied humid-temperate forest is nutrient conservative, which can reduce relative nutrient leaching losses in A. araucana dominated stands. Despite an intensive recycling and uplift from subsoil, plant N retention is likely not sufficient to cover demands of the standing biomass (Godoy et al., 2009). To increase the $\mathrm{N}$ input, plants invest $\mathrm{C}$ in diazotrophic bacteria (Study 3). The importance of this association for plants in the humid-temperate forest was highlighted by the highest abundance of diazotrophs (absolute and relative to the total prokaryotic community) in forest bulk soil and rhizosphere across the gradient (Study 3; Figure 2.3-5). The relative abundance of diazotrophs was 16 times higher in rhizosphere than bulk soil, highlighting that litter $\mathrm{C}$ input is not sufficient to cover diazotrophs' energy demand and underlines the importance of labile root-derive $\mathrm{C}$ to supply diazotrophs with the needed energy (Study 3). The difference between rhizosphere and bulk soil was observed at all sites but was most pronounced in the humid-temperate forest, which illustrates that high primary productivity allows plants here to invest a much larger amount of photosyntheticfixed $\mathrm{C}$ into the $\mathrm{C}$-costly symbiotic $\mathrm{N}$ fixation (Study 3 ).

\subsubsection{Nutrient mobilization and acquisition under aridity}

Contrary to high leaching losses that plants have to cope with in the humid-temperate forest, plants in the arid shrublands have to deal with low water availability. Water shortage restricts primary productivity (Gherardi and Sala, 2019; Hsu et al., 2012; Huxman et al., 2004), reduces mineralization of OM-derived nutrients (Austin et al., 2004; Dijkstra et al., 2010), hampers abiotic dissolution of minerals (Belnap, 2011; Maher, 2010), and lowers nutrient mobility in soil (Marschner and Rengel, 2012). Therefore, plants need to optimize their acquisition strategy to increase their nutrient gain without wasting water or nutrients. Under arid conditions, low plant $\mathrm{N}$ demand (Figure 2.1-6) and sandy, well aerated soils (Bernhard et al., 2018) likely reduce the need but also the potential for $\mathrm{N}_{2}$ fixation from atmosphere by diazotroph bacteria (Aranibar et al., 2004; Gallon, 2006; Vance and Heichel, 1991). Therefore, it is not surprising that the abundance of diazotrophic bacteria was markedly lower in the arid shrubland than in the humid-temperate forest (Study 3; Figure 2.3-5). Higher abundance of diazotrophs in rhizosphere than in bulk soil ( 10 times) underlined that the $\mathrm{C}$ requirements of diazotrophs can hardly be met by litter input but highlights the importance of the rhizosphere as hotspot for initial $\mathrm{N}$ acquisition by $\mathrm{N}$ fixation (Study 3). The importance of root-derived $\mathrm{C}$ for the supply of $\mathrm{N}$ fixing bacteria was also shown by an increasing proportion of diazotrophs of the total prokaryotic community with increasing depth (Figure 2.3-5). 
The generally low OM input drives plants to efficiently reutilize nutrients, as shown by the strong ${ }^{15} \mathrm{~N}$ depletion of shoots $(\Delta \sim 3 \%$ ) and roots $(\Delta \sim 11 \%)$ in comparison to bulk topsoil as well as $\mathrm{N}$ and $\mathrm{K}$ tracer recovery from topsoil (Study 1; Figure 2.1-2, Figure 2.1-6). The ability of nutrient uptake by plants in the arid shrubland, however, is low as plants invest into conservative root traits to cope with low nutrient and water availability (Study 2; Figure 2.2-2; Reich, 2014). A short expansion and a low surface to volume ratio increase the longevity of roots and saves resources but reduces the ability to take up water and nutrients (Reich, 2014). Lowest enzyme activities under arid conditions across the precipitation gradient (Figure 2.4-3) illustrated that water shortage restricts plant $\mathrm{C}$ and nutrient investment into extracellular enzyme production. This contributes to a slow acquisition of OM-bound nutrients. Opposite to plants under humid conditions, plants in the arid shrubland have no need to retain nutrients against leaching. Losses that occur are mainly attributed to erosion caused by extreme rainfall events (Turnbull et al., 2011). Therefore, a slow acquisition is not disadvantageous in terms of nutrient retention.

Nutrient uptake by roots is slow, but the relative importance of the rhizosphere as hotspot of OM input (Figure 2.4-2), microbial abundance (Figure 2.3-4), and enzymatic breakdown (Figure 2.3-3; Figure 1.3-2) in the remaining water film around roots increased strongly with increasing aridity (Ahmed et al., 2018, 2014; Holz et al., 2018). Especially in the studied dry soils with low aboveground litter input, OM-input from roots can equal or surpass the input from aboveground biomass (Freschet et al., 2013; Wang et al., 2018; Zechmeister-Boltenstern et al., 2015), and serve microbial decomposers and diazotrophs as highly needed $\mathrm{C}$ and nutrient resource (Jones et al., 2009; Kuzyakov and Domanski, 2000; Pausch and Kuzyakov, 2018).

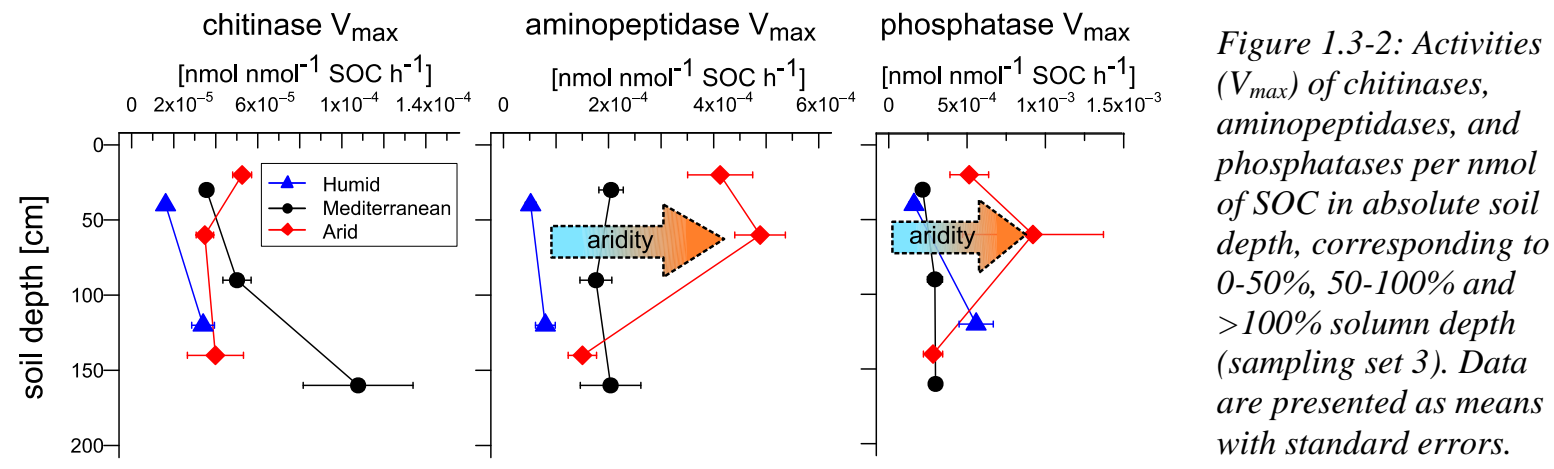

Aridity restricts the potential of plants to build up long, thin fine roots for scavenging, but forces them to invest into short, thick roots that sustain under prolonged water-shortage in topsoil (Adams et al., 2013; Comas et al., 2013; Padilla et al., 2013), As drought is not a periodical event but a permanent condition in the arid shrubland, plants need not only to be adapted to survive dry periods but to continue growth under permanent water shortage. By increasing the specific root length with depth (i.e. increasing the fine root proportion or expanding the fine root system; Figure 2.2-2) they 
can scavenge for deep water resources and avoid drought (Comas et al., 2013; Muñoz et al., 2008; Sala et al., 2012b).

Scavenging with and maintenance of an (extensive) root system, however, is C costly despite following a conservative resource management, and restricted in such an ecosystem with low plant primary productivity (Brunner et al., 2015; Poorter et al., 2012). Thick roots explore less soil volume and absorb less nutrients, but they have a greater potential of being colonized by AMF (Eissenstat et al., 2015; McCormack and Iversen, 2019). The investment in AMF is an important strategy to scavenge for nutrients when environmental conditions restrict root proliferation. This was indicated by an increase of the AMF extraradical mycelium when the extent of the fine root network decreased (Figure 2.2-5), which highlighted the trade-off of plant $\mathrm{C}$ investment between either network (Study 2). Especially the direct connection with organic matter and mineral surfaces that hyphae form, and microbes' ability to respond to and utilize brief precipitation fast, is likely of particular importance in water limited systems with low nutrient mobility (Austin et al., 2004; Schwinning and Sala, 2004; Taylor et al., 2009).

Plants provide the extraradical mycelium of AMF with photosynthetic $\mathrm{C}$ to scavenge for and transfer P to their host plant (Study 2; Ryan et al., 2012). But contrary to AMF in the humidtemperate forest, AMF seemed not to be involved in plant $\mathrm{N}$ acquisition in the arid shrubland (Study 2). Instead, plants at the arid site invested into their fine root system to exploit N-rich patches (Figure 2.2-5; Hodge, 2009; Lynch and Ho, 2005), indicating a functional shift in the role of AMF with increasing aridity (Antunes et al., 2011; Bennett and Classen, 2020; Johnson et al., 2003). The main function of AMF seemed to be the acquisition of $P$, which was present mainly in inorganic form (Study 5). AMF abundance relative to SOC was as high in the arid shrubland compared to the humid-temperate forest (Study 2; Figure 2.2-3; Table 2.2-2), which might indicate that AMF are involved in the biological weathering of minerals. Since the abiotic dissolution of minerals in the arid shrubland is low (Study 5:), biological weathering can be an important strategy for plants and microbes to cover their demands of rock-born nutrients (Drever and Stillings, 1997; Maher, 2010; Taylor et al., 2009).

The acquisition of mineral-bound $\mathrm{P}$ from subsoil and saprolite by biological weathering was indicated by more plant-released organic acids in the presence of inorganic P species (Figure 2.5-4) and by higher LMWOA:MBC ratios with increasing depth (Table S 2.5-8). Those ratios pointed to an intended excretion of organic acids by plant roots to utilize inorganic P (Study 5). Indications for an ongoing biological weathering by fungi and plants were also given by the high $\mathrm{K}$ tracer recovery from subsoil and saprolite (Figure 2.1-2), demonstrating that plants scavenge in subsoil and saprolite to acquire weathering-released $\mathrm{K}$ next to the reutilization of $\mathrm{K}$ from topsoil (Study 
1). The reutilization of OM-derived nutrients is also not restricted to the recycling of litter, but extends to the recycling of belowground biomass, displayed by the equal ${ }^{15} \mathrm{~N}$ recovery from topsoil, subsoil, and saprolite (Study 1; Figure 2.1-2). Plants in the arid shrubland reutilize the organic matter associated with their rhizosphere and explore deeper soil for additional $\mathrm{N}$ sources such as microbial necromass. Microbial DNA abundance in saprolite was highest in the arid shrubland compared to the other sites along the gradient (Oeser et al., 2018), which can serve as a valuable resource in this strongly limited ecosystem.

\subsubsection{Adaptations to high nutrient losses under Mediterranean conditions}

How will plants that are adapted to arid conditions, under which nutrients are hardly mobile and the main challenge is to 'extract' nutrients from soil, deal with increasing precipitation variability and a higher intensity of rainfall? Plants growing under humid conditions are adapted to retain nutrients against processes of nutrient losses such as run-off, erosion, and denudation, but plants growing under arid conditions are not. On the other hand, how will plants that are adapted to high water availability and only short dry periods deal with prolonged and frequent drought episodes? In the Mediterranean coastal matorral in the Chilean Cordillera, plants have to deal with both: hot and long summer droughts on the one, and concentrated, high winter precipitation on the other hand (Armesto, 2007).

High denudation rates and the possible decoupling of microbial and plant activity can lead to high $\mathrm{N}$ losses that reduce the potential for $\mathrm{N}$ reutilization by plants (Study 1). Plants in the Mediterranean coastal matorral exploit available nutrients fast and efficiently from the upper nutrient-rich soil, by a high proportion of fine roots in the upper $10 \mathrm{~cm}$ (Study 2; Figure 2.2-2, Figure 2.2-4). They developed 'acquisitive' root traits that have a fast nutrient uptake ability (Study 2). Higher N (7-times) and K (9-times) acquisition from topsoil than subsoil (Study 1; Figure 2.1-2) underlined that plants build up an efficient root system that can retain nutrients against leaching and run-off effectively (Study 1; Dunbabin et al., 2003; Ellsworth and Sternberg, 2019; McCulley et al., 2009). Additionally, such a root system allows to utilize already brief water pulses that would not percolate to deeper soil but quickly evaporate (Fernández, 2007; Hodge, 2010). Strong correlations of phosphatase activities, MBC, and oxalic acids with organic $\mathrm{P}$, indicated as well, that $\mathrm{P}$ recycling from organic matter is likely the dominant plant strategy for $\mathrm{P}$ acquisition from topsoil in the Mediterranean coastal matorral (Study 5; Figure 2.5-4).

A root system with a high proportion of fine roots, however, is $\mathrm{C}$ costly due to reduced root lifespans (Study 2; Pregitzer et al., 1997). Plants can invest into AMF as they can support plant acquisition largely but are comparable C inexpensive (Fitter, 1991; McCormack and Iversen, 2019). Shorter lifespans of AMF hyphae than fine roots, however, could reduce the benefit of such 
an investment (Lynch and Ho, 2005). Compared to losses from root dieback, however, the losses should be lower as (1) less $\mathrm{C}$ is needed to produce thin hyphae than fine roots (Fitter, 1991) and (2) the decomposition of hyphae is faster than of fine roots, allowing a faster reutilization of released nutrients and C (Freschet et al., 2013; Guo et al., 2007; Rousk and Bååth, 2007), likely further simulating the microbial community and nutrient acquisition.

Despite AMF are commonly associated with plant P acquisition (Parniske, 2008; Ryan et al., 2012), AMF abundance in soil and roots in the Mediterranean coastal matorral increased strongly with reduced $\mathrm{N}$ availability (Study 2; Figure 2.2-5). Thus, plants seemed to invest not only in strengthening the symbiosis between plant and fungi by increasing the AMF root colonization, but also in expansive extraradical mycelium to scavenge for N (Bücking and Kafle, 2015; Fellbaum et al., 2012; Leigh et al., 2009). AMF can respond faster to water pulses and resource availability than plant roots, making them an efficient partner in the fast utilization of (mobile) $\mathrm{N}$ from topsoil and, thus, its retention in soil against losses (Cavagnaro et al., 2015; Schwinning and Sala, 2004). By this, AMF exert a function not observed at the sites under humid or arid conditions: retaining nutrients from ecosystem losses instead of 'only' acquiring and transferring them to their host plants (Bowles et al., 2018; Cavagnaro et al., 2015; Hodge and Fitter, 2010; Köhl and van der Heijden, 2016).

Despite the retention strategies of plants and fungi at this site under Mediterranean conditions, nutrients will be lost by leaching and denudation. To compensate for losses, plants recapture and uplift nutrients from depth (Jobbágy and Jackson, 2001; Uhlig and von Blanckenburg, 2019), which was demonstrated by the $\mathrm{K}$ and $\mathrm{N}$ tracer recovery from subsoil and saprolite (Figure 2.1-2). Additionally, roots in subsoil and saprolite showed a higher ability of K uptake than topsoil roots (Study 1; Figure 2.1-4), which points to the importance of the uplift of rock-born nutrients for the plant supply. Correlations of organic acids with secondary P minerals in subsoil (Figure 2.5-4) further indicated that plants likely invest in biological weathering and uplift from depth for their $\mathrm{P}$ acquisition (Study 5). But organic acids were not only released for mineral weathering in subsoil and saprolite, but also to support recycling of organic P in the topsoil (Study 5).

\subsection{Conclusion - Implications for ecosystem responses to precipitation shifts}

Aim of this research project was to identify plant nutrient acquisition strategies under three levels of aridity: arid, Mediterranean, and humid. With the predicted precipitation changes in Chile, it is likely that abiotic conditions and biotic interactions in one ecosystem along the precipitation gradient shift towards the current conditions of another. Based on the results about plant nutrient acquisition strategies, an assessment is made in the following on potential shifts and responses of the arid and humid ecosystems. 


\subsubsection{Humid-temperate forest}

The focus on nutrient reutilization from topsoil in the humid-temperate forest ecosystem (Study 1, Study 5) is an efficient strategy to recycle and reutilize nutrients and to reduce losses by leaching but might be a disadvantage under decreasing water availability. Decreasing precipitation and prolonged dry periods (as predicted by climate change scenarios for that region) will result in higher evaporation and more intensive dehydration of topsoil. Reduced water availability will not only impose water stress on forest plants but also restrictions on their nutrient supply. Low microbial activity and reduced nutrient mobility in dry soils will be a challenge for plants that are adapted to a fast recycling of nutrients in moist soils. Under these conditions deep rooting strategies will be favored over shallow rooting strategies (Knapp et al., 2008b; Wang et al., 2020). Deep roots of the woody plants in the humid-temperate forest have the potential to access deep water sources, allowing them to avoid dehydrated topsoil, to recapture and uplift leached nutrients, and to maintain nutrient acquisition even under extensive dry periods (Nardini et al., 2016; Zhang et al., 2019). This is only possible if deep water pools are available and replenished during wet seasons or years. Previous-years precipitation was shown to strongly determine aboveground primary production of the subsequent year (Sala et al., 2012a). If multiple dry years occur consecutively, deep water pools might be eventually exhausted and deep rooting species will no longer survive the prolonged drought conditions (Kannenberg et al., 2019; Sala et al., 2012a).

The decrease of water availability will reduce the abiotic mineral dissolution (Belnap, 2011), and thus increase the need for plants to invest into biological weathering agents such as organic acids, to cover their demand of rock-derived nutrients. Thus, plants in the humid-temperate forest would have to intensify their investment into biological weathering agents under water shortage. Microbial SOM decomposition and nutrient mineralization in dehydrated topsoils, however, are likely more strongly hampered by drought than mineral weathering in potentially moist depths. The focus of woody plants in the humid-temperate forest on nutrient recycling from topsoil, therefore, would be a disadvantage. Additionally, under prolonged drought periods, where plant activity is suppressed stronger than microbial activity (Dijkstra et al., 2015; Knapp et al., 2008a; Yahdjian et al., 2006), the decoupling between nutrient mineralization and plant nutrient uptake can lead to an accumulation of inorganic N in topsoils (McCulley et al., 2009; Reichmann et al., 2013), as observed at the site under Mediterranean conditions (Study 1). In subsequent wet periods, plant species that can (1) recover fast from drought (Knapp et al., 2008a) and (2) can exploit available resources fast in competition against other plants but also retain mobile inorganic $\mathrm{N}$ against leaching (Austin et al., 2004; Reich, 2014) are in an advantage. Conservative root traits, as expressed by A. araucana in humid-temperate forest ecosystem (Study 2), might be 
advantageous or disadvantageous under these conditions, depending on the dominating factor. Roots with conservative traits can sustain dehydration longer than acquisitive roots, reducing tissue damage and root dieback, and allowing a faster recovery from dry conditions than for plants with acquisitive root traits. The slow acquisition that is possible with 'conservative' roots, however, reduces the potential to retain a large pool of highly mobile $\mathrm{N}$ against leaching in topsoil, especially with increasing frequencies of concentrated rainfall events (Knapp et al., 2006; Yahdjian and Sala, 2010). Increased leaching of inorganic N from topsoil even though total precipitation decreases would, therefore, favors deep rooting species that are able to recapture leached nutrients (Yahdjian and Sala, 2010).

AMF support plant nutrient and water acquisition and can, thereby, alleviate environmental stress for plants. The current AMF community, however, is not adapted to prolonged drought or to largely retain mobile nutrients against leaching losses as observed under Mediterranean conditions (Study 2). Therefore, they might not be able to provide these functions for their host plants (Hawkes et al., 2011; Millar and Bennett, 2016).

\subsubsection{Arid shrubland ecosystem}

The effects of precipitation variability on fine root biomass were shown to be higher in dry ecosystems and decreased with increasing mean annual precipitation (Wang et al., 2020). Heavy rainfall events were proposed to compensate for a reduction of total precipitation in arid regions (Knapp et al., 2015, 2008a; Kulmatiski and Beard, 2013). Greater water availability despite a decrease of total precipitation allows plants with a deeper root system to increase their photosynthetic activity (Hsu et al., 2012; Huxman et al., 2004) and to invest more C in belowground processes for nutrient acquisition. This could accelerate SOM decomposition and nutrient mineralization under greater water availability (Dijkstra et al., 2015), and might increase OM-derived nutrient availability for plants with deeper root systems as G. resinosa in the arid shrubland, which was shown to acquire nutrients uniformly from the whole soil profile (Study 1). Yahdjian and Sala (2010), however, described that larger water pulses increase N losses by nitrate leaching and gaseous losses by denitrification. With greater mineralization and thus mobility of inorganic $\mathrm{N}$ in soil, $\mathrm{N}$ leaching could increase depending on the magnitudes of rainfall events (Knapp et al., 2015). Plants in the arid shrubland are not adapted to exploit available resources fast and are likely not able to retain nutrients against leaching (contrary to plants in the Mediterranean coastal matorral), because they express neither acquisitive root traits nor have an extensive (fine) root system (Study 2).

AMF in the arid shrubland did not show a connection to plant $\mathrm{N}$ nutrition, whereas in the Mediterranean coastal matorral, characterized by high denudation rates, AMF seemed to support 
plants in retaining $\mathrm{N}$ against losses from soil (Study 2). Whether AMF in the arid shrubland are also able to provide this ecosystem function is unclear, as AMF in arid regions are not adapted to a high nutrient mobility in soil and to retain nutrients against losses.

If the magnitude of large precipitation events does not lead to run-off and nutrient loss from surfaces, shrub plants have good prerequisites to cope with changing precipitation variability (Knapp et al., 2008b; Kulmatiski and Beard, 2013), since they have deep roots and are adapted to acquire nutrients not only from topsoil, but also from subsoil and saprolite (Study 1). Increased run-off and erosion, and thus nutrient losses from topsoil, however, would likely favor fast growing, acquisitive plant species that concentrate their nutrient acquisition in the upper, nutrientricher soil and are more efficient in retaining nutrients within the soil. The overall precipitation decrease, however, will eventually favor slow growing, conservative plant species.

The required shifts of nutrient acquisition traits in both ecosystems evaluated here will have to go along with at least a partial shift of species compositions and functional groups (regarding not only plants but also their symbionts such as AMF). Many of the traits beneficial under the predicted climate change scenarios exist in the Mediterranean ecosystem and, thus, are in principle available along the Chilean Coastal Cordillera. The magnitude and temporal dynamic of the climate change and further factors such as plant-plant interactions and plant community stability (Hallett et al., 2014; Lloret et al., 2012; Ploughe et al., 2019), however, will be decisive for whether and to which extent species with the required traits can migrate from the Mediterranean area and immigrate into the adjacent regions. This study showed that the investigation of ecosystems along a climate sequence with similar parent material allows to evaluate the "toolbox" of available nutrient acquisition properties under different climatic conditions in a region. The knowledge of available traits allows to estimate possible and necessary shifts to maintain the functionality of ecosystems. This knowledge can improve and refine the predictions of ecosystem responses to climatic change. 


\subsection{Contribution to studies}

Study 1: Retention against losses: disentangling plant uplift and recycling in a continental transect of water and nutrient availability

Status: Ready for submission

\begin{tabular}{ll}
\hline Authors & Contribution \\
\hline Svenja C. Stock & Field work; Laboratory work; Data analysis; Writing \\
Moritz Köster & Field work; Data contribution; Commenting \\
Francisco Nájera & Field work; Commenting \\
Jens Boy & Supporting data analysis; Commenting \\
Francisco Matus & Field work; Commenting \\
Carolina Merino & Field work; Commenting \\
Khaled Abdallah & Data Contribution; Commenting \\
Sandra Spielvogel & Study design; Field work; Commenting \\
Anna A. Gorbushina & Study design; Commenting \\
Michaela A. Dippold & Study design; Field work; Supporting data analysis; Commenting \\
Yakov Kuzyakov & Study design; Commenting \\
\hline
\end{tabular}

Study 2: Plant investment in arbuscular mycorrhizal fungi for $\mathrm{N}$ and $\mathrm{P}$ acquisition - a cross-biome study along a precipitation gradient

Status: Submitted to Science of the Total environment, under review since 22.10.2020

\begin{tabular}{ll}
\hline Authors & Contribution \\
\hline Svenja C. Stock & Field work; Laboratory work; Data analysis; Writing \\
Moritz Köster & Field work; Supporting Data Analysis; Commenting \\
Jens Boy & Field work; Commenting \\
Roberto Godoy & Commenting \\
Francisco Nájera & Field work; Commenting \\
Francisco Matus & Field work; Commenting \\
Carolina Merino & Field work; Commenting \\
Khaled Abdallah & Commenting \\
Christoph Leuschner & Commenting \\
Sandra Spielvogel & Study Design; Commenting \\
Anna A. Gorbushina & Commenting \\
Yakov Kuzyakov & Study design; Field work; Supporting data analysis; Commenting \\
Michaela A. Dippold & Study design; Field work; Supporting data analysis; Commenting \\
\hline
\end{tabular}


Study 3: Nitrogen cycling depending on aridity and vegetation cover

Status: Manuscript in preparation

\begin{tabular}{ll}
\hline Authors & Contribution \\
\hline Khaled Abdallah* & Laboratory work; Data analysis; Writing \\
Svenja C. Stock* & Field work; Laboratory work; Data analysis; Writing \\
Felix Heeger & Supporting data analysis; Commenting \\
Moritz Köster & Field work; Commenting \\
Francisco Nájera & Field work; Commenting \\
Francisco Matus & Field work; Commenting \\
Carolina Merino & Field work; Commenting \\
Sandra Spielvogel & Study design; Field work; Commenting \\
Anna A. Gorbushina & Study design; Commenting \\
Yakov Kuzyakov & Study design; Commenting \\
Michaela A. Dippold & Study design; Field work; Supporting data analysis; Commenting
\end{tabular}

* equal contribution

Study 4: Environmental drivers and stoichiometric constraints on enzyme activities in soils from rhizosphere to continental scale

Status: Published in Geoderma (2019), 337, 973-982, doi:10.1016/j.geoderma.2018.10.030

\begin{tabular}{ll}
\hline Authors & Contribution \\
\hline Svenja C. Stock & Field work; Laboratory work; Data analysis; Writing \\
Moritz Köster & Field work; Commenting \\
Michaela A. Dippold & Study design; Field work; Supporting data analysis; Commenting \\
Francisco Nájera & Field work; Commenting \\
Francisco Matus & Field work; Commenting \\
Carolina Merino & Field work; Commenting \\
Jens Boy & Study design; Commenting \\
Sandra Spielvogel & Study design; Field work; Commenting \\
Anna A. Gorbushina & Study design; Commenting \\
Yakov Kuzyakov & Study design; Supporting data analysis; Commenting \\
\hline
\end{tabular}

Study 5: From rock eating to vegetarian ecosystems - disentangling key processes of phosphorus acquisition along a precipitation gradient across biomes in the Chilean Coastal Cordillera Status: Published in Geoderma (2021), 388, 10.1016/j.geoderma.2020.114827

\begin{tabular}{ll}
\hline Authors & Contribution \\
\hline Moritz Köster & Field work; Laboratory work; Data analysis; Writing \\
Svenja C. Stock & Field work; Data contribution; Commenting \\
Francisco Nájera & Field work; Commenting \\
Khaled Abdallah & Data contribution; Commenting \\
Anna A. Gorbushina & Commenting \\
Jörg Prietzel & Supporting data analysis; Commenting \\
Francisco Matus & Field work, Commenting \\
Wantana Klysubun & Supporting data analysis; Commenting \\
Jens Boy & Commenting \\
Yakov Kuzyakov & Commenting \\
Michaela A. Dippold & Study design; Field Work; supporting data analysis; Commenting \\
Sandra Spielvogel & Study design; Field Work; supporting data analysis; Commenting \\
\hline
\end{tabular}




\subsection{References}

Aaltonen, H., Lindén, A., Heinonsalo, J., Biasi, C., Pumpanen, J., 2017. Effects of prolonged drought stress on Scots pine seedling carbon allocation. Tree Physiol. 37, 418-427. https://doi.org/10.1093/treephys/tpw119

Adams, T.S., McCormack, M.L., Eissenstat, D.M., 2013. Foraging strategies in trees of different root morphology: the role of root lifespan. Tree Physiol. 33, 940-948. https://doi.org/10.1093/treephys/tpt067

Ahmed, M.A., Banfield, C.C., Sanaullah, M., Gunina, A., Dippold, M.A., 2018. Utilisation of mucilage C by microbial communities under drought. Biol. Fertil. Soils 54, 83-94. https://doi.org/10.1007/s00374-017-1237-6

Ahmed, M.A., Kroener, E., Holz, M., Zarebanadkouki, M., Carminati, A., 2014. Mucilage exudation facilitates root water uptake in dry soils. Funct. Plant Biol. 41, 1129. https://doi.org/10.1071/FP13330

Allen, M.F., 2007. Mycorrhizal Fungi: Highways for Water and Nutrients in Arid Soils. Vadose Zone J. 6, 291. https://doi.org/10.2136/vzj2006.0068

Allison, S.D., Vitousek, P.M., 2005. Responses of extracellular enzymes to simple and complex nutrient inputs. Soil Biol. Biochem. 37, 937-944. https://doi.org/10.1016/j.soilbio.2004.09.014

Anderegg, W.R.L., Konings, A.G., Trugman, A.T., Yu, K., Bowling, D.R., Gabbitas, R., Karp, D.S., Pacala, S., Sperry, J.S., Sulman, B.N., Zenes, N., 2018. Hydraulic diversity of forests regulates ecosystem resilience during drought. Nature 561, 538-541. https://doi.org/10.1038/s41586-018-0539-7

Andrus, N., Tye, A., Nesom, G., Bogler, D., Lewis, C., Noyes, R., Jaramillo, P., Francisco-Ortega, J., 2009. Phylogenetics of Darwiniothamnus (Asteraceae: Astereae) - molecular evidence for multiple origins in the endemic flora of the Galápagos Islands. J. Biogeogr. 36, 1055-1069. https://doi.org/10.1111/j.1365-2699.2008.02064.X

Antunes, P.M., Koch, A.M., Morton, J.B., Rillig, M.C., Klironomos, J.N., 2011. Evidence for functional divergence in arbuscular mycorrhizal fungi from contrasting climatic origins. New Phytol. 189, 507-514. https://doi.org/10.1111/j.1469-8137.2010.03480.x

Aranibar, J.N., Otter, L., Macko, S.A., Feral, C.J.W., Epstein, H.E., Dowty, P.R., Eckardt, F., Shugart, H.H., Swap, R.J., 2004. Nitrogen cycling in the soil-plant system along a precipitation gradient in the Kalahari sands. Glob. Change Biol. 10, 359-373. https://doi.org/10.1111/j.13652486.2003.00698.x

Armesto, J.J., 2007. The Mediterranean environment of central Chile. Phys. Geogr. S. Am. 7, 184.

Augé, R.M., 2001. Water relations, drought and vesicular-arbuscular mycorrhizal symbiosis. Mycorrhiza 11, 3-42. https://doi.org/10.1007/s005720100097

Austin, A.T., Yahdjian, L., Stark, J.M., Belnap, J., Porporato, A., Norton, U., Ravetta, D.A., Schaeffer, S.M., 2004. Water pulses and biogeochemical cycles in arid and semiarid ecosystems. Oecologia 141, 221-235. https://doi.org/10.1007/s00442-004-1519-1

Balser, T.C., Treseder, K.K., Ekenler, M., 2005. Using lipid analysis and hyphal length to quantify AM and saprotrophic fungal abundance along a soil chronosequence. Soil Biol. Biochem. 37, 601-604. https://doi.org/10.1016/j.soilbio.2004.08.019

Belnap, J., 2011. Biological Phosphorus Cycling in Dryland Regions, in: Bünemann, E., Oberson, A., Frossard, E. (Eds.), Phosphorus in Action, Soil Biology. Springer Berlin Heidelberg, Berlin, Heidelberg, pp. 371-406. https://doi.org/10.1007/978-3-642-15271-9_15

Bengtsson, G., Bengtson, P., Månsson, K.F., 2003. Gross nitrogen mineralization-, immobilization-, and nitrification rates as a function of soil $\mathrm{C} / \mathrm{N}$ ratio and microbial activity. Soil Biol. Biochem. 35, 143-154. https://doi.org/10.1016/S0038-0717(02)00248-1

Bennett, A.E., Classen, A.T., 2020. Climate change influences mycorrhizal fungal-plant interactions, but conclusions are limited by geographical study bias. Ecology. https://doi.org/10.1002/ecy.2978

Bernhard, N., Moskwa, L.-M., Schmidt, K., Oeser, R.A., Aburto, F., Bader, M., Baumann, K., von Blanckenburg, F., Boy, J., van den Brink, L., Brucker, E., Büdel, B., Canessa, R., Dippold, M.A., Ehlers, T.A., Fuentes, J.P., Godoy, R., Jung, P., Karsten, U., Köster, M., Kuzyakov, Y., Leinweber, P., Neidhardt, H., Matus, F., Mueller, C.W., Oelmann, Y., Oses, R., Osses, P., Paulino, L., Samolov, E., Schaller, M., Schmid, M., Spielvogel, S., Spohn, M., Stock, S., Stroncik, N., Tielbörger, K., Übernickel, K., Scholten, T., Seguel, O., Wagner, D., Kühn, P., 2018. Pedogenic 
and microbial interrelations to regional climate and local topography: new insights from a climate gradient (arid to humid) along the Coastal Cordillera of Chile. Catena.

Blume, H.-P., Brümmer, G.W., Horn, R., Kandeler, E., Kögel-Knabner, I., Kretzschmar, R., Stahr, K., Wilke, B.-M., 2010. Böden als Pflanzenstandorte, in: Blume, H.-P., Brümmer, G.W., Horn, R., Kandeler, E., Kögel-Knabner, I., Kretzschmar, R., Stahr, K., Wilke, B.-M. (Eds.), Scheffer/Schachtschabel: Lehrbuch Der Bodenkunde. Springer Berlin Heidelberg, Berlin, Heidelberg, pp. 379-448. https://doi.org/10.1007/978-3-662-49960-3_9

Bowles, T.M., Jackson, L.E., Cavagnaro, T.R., 2018. Mycorrhizal fungi enhance plant nutrient acquisition and modulate nitrogen loss with variable water regimes. Glob. Change Biol. 24, e171-e182. https://doi.org/10.1111/gcb.13884

Boy, J., Valarezo, C., Wilcke, W., 2008. Water flow paths in soil control element exports in an Andean tropical montane forest. Eur. J. Soil Sci. 59, 1209-1227. https://doi.org/10.1111/j.13652389.2008.01063.x

Brantley, S.L., Eissenstat, D.M., Marshall, J.A., Godsey, S.E., Balogh-Brunstad, Z., Karwan, D.L., Papuga, S.A., Roering, J., Dawson, T.E., Evaristo, J., Chadwick, O., McDonnell, J.J., Weathers, K.C., 2017. Reviews and syntheses: on the roles trees play in building and plumbing the critical zone. Biogeosciences 14, 5115-5142. https://doi.org/10.5194/bg-14-5115-2017

Bristiel, P., Roumet, C., Violle, C., Volaire, F., 2019. Coping with drought: root trait variability within the perennial grass Dactylis glomerata captures a trade-off between dehydration avoidance and dehydration tolerance. Plant Soil 434, 327-342. https://doi.org/10.1007/s11104-018-3854-8

Brundrett, M.C., Tedersoo, L., 2018. Evolutionary history of mycorrhizal symbioses and global host plant diversity. New Phytol. 220, 1108-1115. https://doi.org/10.1111/nph.14976

Brunner, I., Herzog, C., Dawes, M.A., Arend, M., Sperisen, C., 2015. How tree roots respond to drought. Front. Plant Sci. 6. https://doi.org/10.3389/fpls.2015.00547

Bücking, H., Kafle, A., 2015. Role of Arbuscular Mycorrhizal Fungi in the Nitrogen Uptake of Plants: Current Knowledge and Research Gaps. Agronomy 5, 587-612. https://doi.org/10.3390/agronomy5040587

Burns, R.G., DeForest, J.L., Marxsen, J., Sinsabaugh, R.L., Stromberger, M.E., Wallenstein, M.D., Weintraub, M.N., Zoppini, A., 2013. Soil enzymes in a changing environment: Current knowledge and future directions. Soil Biol. Biochem. 58, 216-234. https://doi.org/10.1016/j.soilbio.2012.11.009

Carrasco, J.F., Casassa, G., Quintana, J., 2005. Changes of the $0^{\circ} \mathrm{C}$ isotherm and the equilibrium line altitude in central Chile during the last quarter of the 20th century / Changements de l'isotherme $0^{\circ} \mathrm{C}$ et de la ligne d'équilibre des neiges dans le Chili central durant le dernier quart du 20ème siècle. Hydrol. Sci. J. 50, 11. https://doi.org/10.1623/hysj.2005.50.6.933

Cavagnaro, T.R., Bender, S.F., Asghari, H.R., Heijden, M.G.A. van der, 2015. The role of arbuscular mycorrhizas in reducing soil nutrient loss. Trends Plant Sci. 20, 283-290. https://doi.org/10.1016/j.tplants.2015.03.004

Center for Climate and Resilience Research $(\mathrm{CR})^{2}$, 2020. Datos de precipitación [WWW Document]. URL $\mathrm{http} / / / \mathrm{www} . c r 2 . c \mathrm{l} /$ datos-de-precipitacion/?cp_Precipitacion=3 (accessed 1.29.20).

Chen, J., Kuzyakov, Y., Jenerette, G.D., Xiao, G., Liu, W., Wang, Z., Shen, W., 2019. Intensified Precipitation Seasonality Reduces Soil Inorganic N Content in a Subtropical Forest: Greater Contribution of Leaching Loss Than $\mathrm{N}_{2}$ O Emissions. J. Geophys. Res. Biogeosciences 124, $494-$ 508. https://doi.org/10.1029/2018JG004821

Chile Flora, 2020. Aristeguietia salvia (Colla) R.M. King \& H. Rob [WWW Document]. URL http://chileflora.com/Florachilena/FloraSpanish/HighResPages/SH0400.htm (accessed 4.26.20).

Christensen, J.H., Hewitson, B., Busuioc, A., Chen, A., Gao, X., Held, I., Jones, R., Kolli, R.K., Laprise, R., Magaña, C.G., Menendez, C.G., Raisanen, J., Rinde, A., Sarr, A., Whetton, P., 2007. Regional Climate Projections. In: Climate Change 2007: The Physical Science Basis, Contribution of Working Group I to the Fourth Assessment Report of the Intergovernmental Panel on Climate Change. Cambridge University Press, Cambridge ; New York.

Cleveland, C.C., Houlton, B.Z., Smith, W.K., Marklein, A.R., Reed, S.C., Parton, W., Del Grosso, S.J., Running, S.W., 2013. Patterns of new versus recycled primary production in the terrestrial biosphere. Proc. Natl. Acad. Sci. 110, 12733-12737. https://doi.org/10.1073/pnas.1302768110

Cleveland, C.C., Liptzin, D., 2007. C:N:P stoichiometry in soil: is there a "Redfield ratio" for the microbial biomass? Biogeochemistry 85, 235-252. https://doi.org/10.1007/s10533-007-9132-0 
Comas, L.H., Becker, S.R., Cruz, V.M.V., Byrne, P.F., Dierig, D.A., 2013. Root traits contributing to plant productivity under drought. Front. Plant Sci. 4. https://doi.org/10.3389/fpls.2013.00442

Croft, S.A., Hodge, A., Pitchford, J.W., 2012. Optimal root proliferation strategies: the roles of nutrient heterogeneity, competition and mycorrhizal networks. Plant Soil 351, 191-206. https://doi.org/10.1007/s11104-011-0943-3

Davidson, E.A., Chorover, J., Dail, D.B., 2003. A mechanism of abiotic immobilization of nitrate in forest ecosystems: the ferrous wheel hypothesis. Glob. Change Biol. 9, 228-236. https://doi.org/10.1046/j.1365-2486.2003.00592.x

de Vries, F.T., Brown, C., Stevens, C.J., 2016. Grassland species root response to drought: consequences for soil carbon and nitrogen availability. Plant Soil 409, 297-312. https://doi.org/10.1007/s11104016-2964-4

DeForest, J.L., Smemo, K.A., Burke, D.J., Elliott, H.L., Becker, J.C., 2012. Soil microbial responses to elevated phosphorus and $\mathrm{pH}$ in acidic temperate deciduous forests. Biogeochemistry 109, 189-202. https://doi.org/10.1007/s10533-011-9619-6

di Castri, F., Hajek, E.R., 1976. Bioclimatologia de Chile. Vicerrectoria Acad. Univ. Catol. Chile 163.

Diehl, P., Fontenla, S., 2010. Arbuscular mycorrhizal infection in two morphological root types of Araucaria araucana (Molina) K. Koch. Rev. Argent. Microbiol. 42, 133-137.

Dijkstra, F.A., He, M., Johansen, M.P., Harrison, J.J., Keitel, C., 2015. Plant and microbial uptake of nitrogen and phosphorus affected by drought using $15 \mathrm{~N}$ and $32 \mathrm{P}$ tracers. Soil Biol. Biochem. 82, 135-142. https://doi.org/10.1016/j.soilbio.2014.12.021

Dijkstra, F.A., Morgan, J.A., Blumenthal, D., Follett, R.F., 2010. Water limitation and plant inter-specific competition reduce rhizosphere-induced $\mathrm{C}$ decomposition and plant $\mathrm{N}$ uptake. Soil Biol. Biochem. 42, 1073-1082. https://doi.org/10.1016/j.soilbio.2010.02.026

Dippold, M.A., Kuzyakov, Y., 2016. Direct incorporation of fatty acids into microbial phospholipids in soils: Position-specific labeling tells the story. Geochim. Cosmochim. Acta 174, 211-221. https://doi.org/10.1016/j.gca.2015.10.032

Drever, J.I., Stillings, L.L., 1997. The role of organic acids in mineral weathering. Colloids Surf. Physicochem. Eng. Asp. 120, 167-181. https://doi.org/10.1016/S0927-7757(96)03720-X

Dunbabin, V., Diggle, A., Rengel, Z., 2003. Is there an optimal root architecture for nitrate capture in leaching environments? Plant Cell Environ. 26, 835-844. https://doi.org/10.1046/j.13653040.2003.01015.x

Dunbabin, V., Rengel, Z., Diggle, A.J., 2004. Simulating form and function of root systems: efficiency of nitrate uptake is dependent on root system architecture and the spatial and temporal variability of nitrate supply. Funct. Ecol. 18, 204-211. https://doi.org/10.1111/j.0269-8463.2004.00827.x

Ehlers, T.A., von Blanckenburg, F., Übernickel, K., 2017. EarthShape weather station data collection. Retrieved from https://esdynamics.geo.uni-tuebingen.de/earthshape/index.php?id=68.

Eissenstat, D.M., Kucharski, J.M., Zadworny, M., Adams, T.S., Koide, R.T., 2015. Linking root traits to nutrient foraging in arbuscular mycorrhizal trees in a temperate forest. New Phytol. 208, 114-124. https://doi.org/10.1111/nph.13451

Ellsworth, P.Z., Sternberg, L.S.L., 2019. Linking soil nutrient availability, fine root production and turnover, and species composition in a seasonally dry plant community. Plant Soil 442, 49-63. https://doi.org/10.1007/s11104-019-04153-3

Fellbaum, C.R., Gachomo, E.W., Beesetty, Y., Choudhari, S., Strahan, G.D., Pfeffer, P.E., Kiers, E.T., Bucking, H., 2012. Carbon availability triggers fungal nitrogen uptake and transport in arbuscular mycorrhizal symbiosis. Proc. Natl. Acad. Sci. 109, 2666-2671. https://doi.org/10.1073/pnas.1118650109

Feng, J., Turner, B.L., Lü, X., Chen, Z., Wei, K., Tian, J., Wang, C., Luo, W., Chen, L., 2016. Phosphorus transformations along a large-scale climosequence in arid and semiarid grasslands of northern China: P Transformation Along Climosequence. Glob. Biogeochem. Cycles 30, 1264-1275. https://doi.org/10.1002/2015GB005331

Fernández, R.J., 2007. On the frequent lack of response of plants to rainfall events in arid areas. J. Arid Environ. 68, 688-691. https://doi.org/10.1016/j.jaridenv.2006.07.004

Fick, S.E., Hijmans, R.J., 2017. WorldClim 2: new 1-km spatial resolution climate surfaces for global land areas: New Climate Surfaces for Global Land Areas. Int. J. Climatol. 37, 4302-4315. https://doi.org/10.1002/joc.5086 
Fitter, A.H., 1991. Costs and benefits of mycorrhizas: Implications for functioning under natural conditions. Experientia 47, 350-355. https://doi.org/10.1007/BF01972076

Fitter, A.H., 1986. Spatial and temporal patterns of root activity in a species-rich alluvial grassland. Oecologia 69, 594-599. https://doi.org/10.1007/BF00410368

Freschet, G.T., Cornwell, W.K., Wardle, D.A., Elumeeva, T.G., Liu, W., Jackson, B.G., Onipchenko, V.G., Soudzilovskaia, N.A., Tao, J., Cornelissen, J.H.C., 2013. Linking litter decomposition of aboveand below-ground organs to plant-soil feedbacks worldwide. J. Ecol. 101, 943-952. https://doi.org/10.1111/1365-2745.12092

Frostegård, å., Tunlid, A., Bååth, E., 1991. Microbial biomass measured as total lipid phosphate in soils of different organic content. J. Microbiol. Methods 14, 151-163. https://doi.org/10.1016/01677012(91)90018-L

Gallon, J.R., 2006. Reconciling the incompatible: N2 fixation And O2. New Phytol. 122, 571-609. https://doi.org/10.1111/j.1469-8137.1992.tb00087.x

Gao, X.-L., Li, X.G., Zhao, L., Kuzyakov, Y., 2019. Regulation of soil phosphorus cycling in grasslands by shrubs. Soil Biol. Biochem. 133, 1-11. https://doi.org/10.1016/j.soilbio.2019.02.012

Garreaud, R.D., 2011. Cambio Climático: Bases Físicas e Impactos en Chile. Revista Tierra Adentro. 93, 14.

Garreaud, R.D., Alvarez-Garreton, C., Barichivich, J., Boisier, J.P., Christie, D., Galleguillos, M., LeQuesne, C., McPhee, J., Zambrano-Bigiarini, M., 2017. The 2010-2015 megadrought in central Chile: impacts on regional hydroclimate and vegetation. Hydrol. Earth Syst. Sci. 21, 6307-6327. https://doi.org/10.5194/hess-21-6307-2017

Gerten, D., Luo, Y., Le MAIRE, G., Parton, W.J., Keough, C., Weng, E., Beier, C., Ciais, P., Cramer, W., Dukes, J.S., Hanson, P.J., Knapp, A.A.K., Linder, S., Nepstad, D., Rustad, L., Sowerby, A., 2008. Modelled effects of precipitation on ecosystem carbon and water dynamics in different climatic zones. Glob. Change Biol. 14, 2365-2379. https://doi.org/10.1111/j.1365-2486.2008.01651.x

Gessler, A., Schaub, M., McDowell, N.G., 2017. The role of nutrients in drought-induced tree mortality and recovery. New Phytol. 214, 513-520. https://doi.org/10.1111/nph.14340

Gherardi, L.A., Sala, O.E., 2019. Effect of interannual precipitation variability on dryland productivity: A global synthesis. Glob. Change Biol. 25, 269-276. https://doi.org/10.1111/gcb.14480

Giles, C.D., Hsu, P.C. (Lisa), Richardson, A.E., Hurst, M.R.H., Hill, J.E., 2014. Plant assimilation of phosphorus from an insoluble organic form is improved by addition of an organic anion producing Pseudomonas sp. Soil Biol. Biochem. 68, 263-269. https://doi.org/10.1016/j.soilbio.2013.09.026

Godoy, R., Marín, C., 2019. Mycorrhizal Studies in Temperate Rainforests of Southern Chile, in: Pagano, M.C., Lugo, M.A. (Eds.), Mycorrhizal Fungi in South America. Springer International Publishing, Cham, pp. 315-341. https://doi.org/10.1007/978-3-030-15228-4_16

Godoy, R., Paulino, L., Valenzuela, E., Oyarzún, C., Huygens, D., Boeckx, P., 2009. Temperate ecosystems of Chile: characteristic biogeochemical cycles and disturbance regimes. Ecol. Adv. Chil. Temp. Rainfor. Acad. Press Belg. p31-39.

Godoy, R., Romero, R., Carrillo, R., 1994. Estatus micotrófico de la flora vascular en bosques de coníferas nativas del sur de Chile. Rev Chil Hist Nat 67, 209-220.

Godoy, R., Valenzuela, E., Guevara, G., Boy, J., Barrientos, M., Matus, F., 2014. Biogeoquímica en bosques templados del sur de Chile. Ecol. For. Editor. Univ. Austral Chile Valdivia 257-280.

Gunina, A., Dippold, M.A., Glaser, B., Kuzyakov, Y., 2014. Fate of low molecular weight organic substances in an arable soil: From microbial uptake to utilisation and stabilisation. Soil Biol. Biochem. 77, 304-313. https://doi.org/10.1016/j.soilbio.2014.06.029

Guo, D., Li, H., Mitchell, R.J., Han, W., Hendricks, J.J., Fahey, T.J., Hendrick, R.L., 2007. Fine root heterogeneity by branch order: exploring the discrepancy in root turnover estimates between minirhizotron and carbon isotopic methods. New Phytol. 0, 071018060445003-??? https://doi.org/10.1111/j.1469-8137.2007.02242.x

Hallett, L.M., Hsu, J.S., Cleland, E.E., Collins, S.L., Dickson, T.L., Farrer, E.C., Gherardi, L.A., Gross, K.L., Hobbs, R.J., Turnbull, L., Suding, K.N., 2014. Biotic mechanisms of community stability shift along a precipitation gradient. Ecology 95, 1693-1700. https://doi.org/10.1890/13-0895.1

Han, W., Tang, L., Chen, Y., Fang, J., 2013. Relationship between the Relative Limitation and Resorption Efficiency of Nitrogen vs Phosphorus in Woody Plants. PLoS ONE 8, e83366. https://doi.org/10.1371/journal.pone.0083366 
Hawkes, C.V., Kivlin, S.N., Rocca, J.D., Huguet, V., Thomsen, M.A., Suttle, K.B., 2011. Fungal community responses to precipitation: FUNGAL CLIMATE RESPONSE. Glob. Change Biol. 17, 1637-1645. https://doi.org/10.1111/j.1365-2486.2010.02327.x

He, M., Dijkstra, F.A., 2014. Drought effect on plant nitrogen and phosphorus: a meta-analysis. New Phytol. 204, 924-931. https://doi.org/10.1111/nph.12952

Hinsinger, P., 2001. Bioavailability of soil inorganic P in the rhizosphere as affected by root-induced chemical changes: a review. Plant Soil 173-195.

Hodge, A., 2010. Roots: The Acquisition of Water and Nutrients from the Heterogeneous Soil Environment, in: Lüttge, U., Beyschlag, W., Büdel, B., Francis, D. (Eds.), Progress in Botany 71. Springer Berlin Heidelberg, Berlin, Heidelberg, pp. 307-337. https://doi.org/10.1007/978-3-64202167-1_12

Hodge, A., 2009. Root decisions. Plant Cell Environ. 32, 628-640. https://doi.org/10.1111/j.13653040.2008.01891.x

Hodge, A., 2004. The plastic plant: root responses to heterogeneous supplies of nutrients. New Phytol. 162, 9-24. https://doi.org/10.1111/j.1469-8137.2004.01015.x

Hodge, A., Fitter, A.H., 2010. Substantial nitrogen acquisition by arbuscular mycorrhizal fungi from organic material has implications for N cycling. Proc. Natl. Acad. Sci. 107, 13754-13759. https://doi.org/10.1073/pnas.1005874107

Hodge, A., Robinson, D., Fitter, A., 2000. Are microorganisms more effective than plants at competing for nitrogen? Trends Plant Sci. 5, 304-308.

Hoekstra, N.J., Finn, J.A., Buchmann, N., Gockele, A., Landert, L., Prill, N., Scherer-Lorenzen, M., Lüscher, A., 2014. Methodological tests of the use of trace elements as tracers to assess root activity. Plant Soil 380, 265-283. https://doi.org/10.1007/s11104-014-2048-2

Holz, M., Zarebanadkouki, M., Kaestner, A., Kuzyakov, Y., Carminati, A., 2018. Rhizodeposition under drought is controlled by root growth rate and rhizosphere water content. Plant Soil 423, 429-442. https://doi.org/10.1007/s11104-017-3522-4

Hou, E., Chen, C., Luo, Y., Zhou, G., Kuang, Y., Zhang, Y., Heenan, M., Lu, X., Wen, D., 2018. Effects of climate on soil phosphorus cycle and availability in natural terrestrial ecosystems. Glob. Change Biol. 24, 3344-3356. https://doi.org/10.1111/gcb.14093

Hsu, J.S., Powell, J., Adler, P.B., 2012. Sensitivity of mean annual primary production to precipitation. Glob. Change Biol. 18, 2246-2255. https://doi.org/10.1111/j.1365-2486.2012.02687.x

Hsu, S.-F., Buckley, D.H., 2009. Evidence for the functional significance of diazotroph community structure in soil. ISME J. 3, 124-136. https://doi.org/10.1038/ismej.2008.82

Huxman, T.E., Smith, M.D., Fay, P.A., Knapp, A.K., Shaw, M.R., Loik, M.E., Smith, S.D., Tissue, D.T., Zak, J.C., Weltzin, J.F., Pockman, W.T., Sala, O.E., Haddad, B.M., Harte, J., Koch, G.W., Schwinning, S., Small, E.E., Williams, D.G., 2004. Convergence across biomes to a common rainuse efficiency. Nature 429, 651-654. https://doi.org/10.1038/nature02561

Huygens, D., Boeckx, P., Templer, P., Paulino, L., Van Cleemput, O., Oyarzún, C., Müller, C., Godoy, R., 2008. Mechanisms for retention of bioavailable nitrogen in volcanic rainforest soils. Nat. Geosci. 1, 543-548. https://doi.org/10.1038/ngeo252

Huygens, D., Rütting, T., Boeckx, P., Van Cleemput, O., Godoy, R., Müller, C., 2007. Soil nitrogen conservation mechanisms in a pristine south Chilean Nothofagus forest ecosystem. Soil Biol. Biochem. 39, 2448-2458. https://doi.org/10.1016/j.soilbio.2007.04.013

Inselsbacher, E., Näsholm, T., 2012. The below-ground perspective of forest plants: soil provides mainly organic nitrogen for plants and mycorrhizal fungi: Rapid report. New Phytol. 195, 329-334. https://doi.org/10.1111/j.1469-8137.2012.04169.x

IPCC, 2014. Climate Change 2014: Synthesis Report. Contribution of Working Groups I, II and III to the Fifth Assessment Report of the Intergovernmental Panel on Climate Change [Core Writing Team, Pachauri, R.K and Meyer, A. (eds.)]. IPCC, Geneva, Switzerland.

IPCC, 2013. Climate Change 2013: The Physical Science Basis. Contribution of Working Group I to the Fifth Assessment Report of the Intergovernmental Panel on Climate Change [Stocker, T.F., D. Qin, G.-K. Plattner, M. Tignor, S.K. Allen, J. Boschung, A. Nauels, Y. Xia, V. Bex and P.M. Midgley (eds.)]. Cambridge University Press, Cambridge ; New York.

IPCC, 2012. Managing the Risks of Extreme Events and Disasters to Advance Climate Change Adaptation: Special Report of the Intergovernmental Panel on Climate Change. Cambridge University Press, Cambridge. https://doi.org/10.1017/CBO9781139177245 
IPCC, 2007. Climate Change 2007: Synthesis Report. Contribution of Working Groups I, II and III to the Fourth Assessment Report of the Intergovernmental Panel on Climate Change [Core Writing Team, Pachauri, R.K and Reisinger, A. (eds.)]. IPCC, Geneva, Switzerland.

Jobbágy, E.G., Jackson, R.B., 2004. The uplift of soil nutrients by plants: Biogeochemical consequences across scales. Ecology 85, 2380-2389. https://doi.org/10.1890/03-0245

Jobbágy, E.G., Jackson, R.B., 2001. The distribution of soil nutrients with depth: Global patterns and the imprint of plants. Biogeochemistry 53, 51-77.

Johnson, N.C., Rowland, D.L., Corkidi, L., Egerton-Warburton, L.M., Allen, E.B., 2003. Nitrogen Enrichment Alters Mycorrhizal Allocation at Five Mesic to Semiarid Grasslands. Ecology 84, 1895-1908. https://doi.org/10.1890/0012-9658(2003)084[1895:NEAMAA]2.0.CO;2

Jones, D.L., 1998. Organic acids in the rhizosphere - a critical review. Plant Soil 25-44.

Jones, D.L., Darrah, P.R., 1994. Role of root derived organic acids in the mobilization of nutrients from the rhizosphere. Plant Soil 166, 247-257. https://doi.org/10.1007/BF00008338

Jones, D.L., Nguyen, C., Finlay, R.D., 2009. Carbon flow in the rhizosphere: carbon trading at the soilroot interface. Plant Soil 321, 5-33. https://doi.org/10.1007/s11104-009-9925-0

Kannenberg, S.A., Maxwell, J.T., Pederson, N., D’Orangeville, L., Ficklin, D.L., Phillips, R.P., 2019. Drought legacies are dependent on water table depth, wood anatomy and drought timing across the eastern US. Ecol. Lett. 22, 119-127. https://doi.org/10.1111/ele.13173

Kembel, S.W., De Kroon, H., Cahill, J.F., Mommer, L., 2008. Improving the Scale and Precision of Hypotheses to Explain Root Foraging Ability. Ann. Bot. 101, 1295-1301. https://doi.org/10.1093/aob/men044

Klausmeyer, K.R., Shaw, M.R., 2009. Climate Change, Habitat Loss, Protected Areas and the Climate Adaptation Potential of Species in Mediterranean Ecosystems Worldwide. PLoS ONE 4, e6392. https://doi.org/10.1371/journal.pone.0006392

Klysubun, W., Sombunchoo, P., Deenan, W., Kongmark, C., 2012. Performance and status of beamline BL8 at SLRI for X-ray absorption spectroscopy. J. Synchrotron Radiat. 19, 930-936. https://doi.org/10.1107/S0909049512040381

Knapp, A.K., Beier, C., Briske, D.D., Classen, A.T., Luo, Y., Reichstein, M., Smith, M.D., Smith, S.D., Bell, J.E., Fay, P.A., Heisler, J.L., Leavitt, S.W., Sherry, R., Smith, B., Weng, E., 2008a. Consequences of More Extreme Precipitation Regimes for Terrestrial Ecosystems. BioScience 58, 811-821. https://doi.org/10.1641/B580908

Knapp, A.K., Briggs, J.M., Collins, S.L., Archer, S.R., Bret-Harte, M.S., Ewers, B.E., Peters, D.P., Young, D.R., Shaver, G.R., Pendall, E., Cleary, M.B., 2008b. Shrub encroachment in North American grasslands: shifts in growth form dominance rapidly alters control of ecosystem carbon inputs. Glob. Change Biol. 14, 615-623. https://doi.org/10.1111/j.1365-2486.2007.01512.x

Knapp, A.K., Burns, C.E., Fynn, R.W.S., Kirkman, K.P., Morris, C.D., Smith, M.D., 2006. Convergence and contingency in production-precipitation relationships in North American and South African C4 grasslands. Oecologia 149, 456-464. https://doi.org/10.1007/s00442-006-0468-2

Knapp, A.K., Hoover, D.L., Wilcox, K.R., Avolio, M.L., Koerner, S.E., La Pierre, K.J., Loik, M.E., Luo, Y., Sala, O.E., Smith, M.D., 2015. Characterizing differences in precipitation regimes of extreme wet and dry years: implications for climate change experiments. Glob. Change Biol. 21, 26242633. https://doi.org/10.1111/gcb.12888

Köhl, L., van der Heijden, M.G.A., 2016. Arbuscular mycorrhizal fungal species differ in their effect on nutrient leaching. Soil Biol. Biochem. 94, 191-199. https://doi.org/10.1016/j.soilbio.2015.11.019

König, N., Versuchsanstalt, N.F., Analytik, M. des G.F., Stellvertreter, G., Blum, U., für Wald, B.L., Sachsen, L., Mitglieder, D., Bussian, B., Groeticke, K., 2005. Eine Loseblatt-Sammlung der Analysemethoden im Forstbereich Herausgegeben vom Gutachterausschuss Forstliche Analytik.

Kramer-Walter, K.R., Bellingham, P.J., Millar, T.R., Smissen, R.D., Richardson, S.J., Laughlin, D.C., 2016. Root traits are multidimensional: specific root length is independent from root tissue density and the plant economic spectrum. J. Ecol. 104, 1299-1310. https://doi.org/10.1111/13652745.12562

Kreuzwieser, J., Gessler, A., 2010. Global climate change and tree nutrition: influence of water availability. Tree Physiol. 30, 1221-1234. https://doi.org/10.1093/treephys/tpq055

Kulmatiski, A., Beard, K.H., 2013. Woody plant encroachment facilitated by increased precipitation intensity. Nat. Clim. Change 3, 833-837. https://doi.org/10.1038/nclimate1904 
Kuzyakov, Y., Domanski, G., 2000. Carbon input by plants into the soil. Review. J. Plant Nutr. Soil Sci. $163,421-431$.

Kuzyakov, Y., Xu, X., 2013. Competition between roots and microorganisms for nitrogen: mechanisms and ecological relevance. New Phytol. 198, 656-669. https://doi.org/10.1111/nph.12235

Lan, M., Comerford, N.B., Fox, T.R., 1995. Organic Anions' Effect on Phosphorus Release from Spodic $\begin{array}{llllll}\text { Horizons. } & \text { Soil } & \text { Sci. } & \text { Soc. }\end{array}$ https://doi.org/10.2136/sssaj1995.03615995005900060034x

Leigh, J., Hodge, A., Fitter, A.H., 2009. Arbuscular mycorrhizal fungi can transfer substantial amounts of nitrogen to their host plant from organic material. New Phytol. 181, 199-207. https://doi.org/10.1111/j.1469-8137.2008.02630.x

Leuschner, C., Hertel, D., Schmid, I., Koch, O., Muhs, A., Hölscher, D., 2004. Stand fine root biomass and fine root morphology in old-growth beech forests as a function of precipitation and soil fertility. Plant Soil 258, 43-56. https://doi.org/10.1023/B:PLSO.0000016508.20173.80

Li, H., Smith, S.E., Holloway, R.E., Zhu, Y., Smith, F.A., 2006. Arbuscular mycorrhizal fungi contribute to phosphorus uptake by wheat grown in a phosphorus-fixing soil even in the absence of positive growth responses. New Phytol. 172, 536-543. https://doi.org/10.1111/j.1469-8137.2006.01846.x

Li, T., Lin, G., Zhang, X., Chen, Y., Zhang, S., Chen, B., 2014. Relative importance of an arbuscular mycorrhizal fungus (Rhizophagus intraradices) and root hairs in plant drought tolerance. Mycorrhiza 24, 595-602. https://doi.org/10.1007/s00572-014-0578-3

Lloret, F., Escudero, A., Iriondo, J.M., Martínez-Vilalta, J., Valladares, F., 2012. Extreme climatic events and vegetation: the role of stabilizing processes. Glob. Change Biol. 18, 797-805. https://doi.org/10.1111/j.1365-2486.2011.02624.x

Lynch, J.P., Ho, M.D., 2005. Rhizoeconomics: Carbon costs of phosphorus acquisition. Plant Soil 269, 4556. https://doi.org/10.1007/s11104-004-1096-4

Maher, 2010. The dependence of chemical weathering rates on fluid residence time. Earth Planet. Sci. Lett. 294, 101-110. https://doi.org/10.1016/j.epsl.2010.03.010

Makkonen, M., Berg, M.P., Handa, I.T., Hättenschwiler, S., van Ruijven, J., van Bodegom, P.M., Aerts, R., 2012. Highly consistent effects of plant litter identity and functional traits on decomposition across a latitudinal gradient. Ecol. Lett. 15, 1033-1041. https://doi.org/10.1111/j.14610248.2012.01826.x

Marschner, P., Rengel, Z., 2012. Nutrient Availability in Soils, in: Marschner's Mineral Nutrition of Higher Plants. Elsevier, pp. 315-330. https://doi.org/10.1016/B978-0-12-384905-2.00012-1

Marx, M.-C., Wood, M., Jarvis, S.C., 2001. A microplate fluorimetric assay for the study of enzyme diversity in soils. Soil Biol. Biochem. 33, 1633-1640. https://doi.org/10.1016/S00380717(01)00079-7

Matus, F., Stock, S., Eschenbach, W., Dyckmans, J., Merino, C., Nájera, F., Köster, M., Kuzyakov, Y., Dippold, M.A., 2019. Ferrous Wheel Hypothesis: Abiotic nitrate incorporation into dissolved organic matter. Geochim. Cosmochim. Acta 245, 514-524. https://doi.org/10.1016/j.gca.2018.11.020

McCormack, L.M., Adams, T.S., Smithwick, E.A.H., Eissenstat, D.M., 2012. Predicting fine root lifespan from plant functional traits in temperate trees. New Phytol. 195, 823-831. https://doi.org/10.1111/j.1469-8137.2012.04198.x

McCormack, M.L., Iversen, C.M., 2019. Physical and Functional Constraints on Viable Belowground Acquisition Strategies. Front. Plant Sci. 10, 1215. https://doi.org/10.3389/fpls.2019.01215

McCulley, R.L., Burke, I.C., Lauenroth, W.K., 2009. Conservation of nitrogen increases with precipitation across a major grassland gradient in the Central Great Plains of North America. Oecologia 159, 571-581. https://doi.org/10.1007/s00442-008-1229-1

Meehl, G.A., Stocker, T.F., Collins, W.D., Friedlingstein, P., Gaye, A.T., Gregory, J.M., Kitoh, A., Knutti, R., Murphy, J.M., Noda, A., 2007. Global climate projections. Climate change 2007: the physical science basis. Contribution of Working Group I to the Fourth Assessment Report of the Intergovernmental Panel on Climate Change [Solomon, S., D. Qin, M. Manning, Z. Chen, M. Marquis, K.B. Averyt, M. Tignor and H.L. Miller (eds.)]. Cambridge University Press, Cambridge ; New York.

Millar, N.S., Bennett, A.E., 2016. Stressed out symbiotes: hypotheses for the influence of abiotic stress on arbuscular mycorrhizal fungi. Oecologia 182, 625-641. https://doi.org/10.1007/s00442-016-36737 
Montecinos, A., Aceituno, P., 2003. Seasonality of the ENSO-Related Rainfall Variability in Central Chile and Associated Circulation Anomalies. J. Clim. 16, 16.

Muñoz, M.R., Squeo, F.A., León, M.F., Tracol, Y., Gutiérrez, J.R., 2008. Hydraulic lift in three shrub species from the Chilean coastal desert. J. Arid Environ. 72, 624-632. https://doi.org/10.1016/j.jaridenv.2007.09.006

Nadelhoffer, K.J., Raich, J.W., 1992. Fine Root Production Estimates and Belowground Carbon Allocation in Forest Ecosystems. Ecology 73, 1139-1147. https://doi.org/10.2307/1940664

Nardini, A., Casolo, V., Dal Borgo, A., Savi, T., Stenni, B., Bertoncin, P., Zini, L., McDowell, N.G., 2016. Rooting depth, water relations and non-structural carbohydrate dynamics in three woody angiosperms differentially affected by an extreme summer drought: Rooting depth and plant hydraulics. Plant Cell Environ. 39, 618-627. https://doi.org/10.1111/pce.12646

Ngosong, C., Gabriel, E., Ruess, L., 2012. Use of the Signature Fatty Acid 16:1 $\omega 5$ as a Tool to Determine the Distribution of Arbuscular Mycorrhizal Fungi in Soil. J. Lipids 2012, 1-8. https://doi.org/10.1155/2012/236807

Nicolson, T.H., 1955. The mycotrophic habit in grasses. University of Nottingham.

Nicotra, A., Babicka, N., Westoby, M., 2002. Seedling root anatomy and morphology: an examination of ecological differentiation with rainfall using phylogenetically independent contrasts. Oecologia 130, 136-145. https://doi.org/10.1007/s004420100788

Nilsson, L.O., Giesler, R., Bååth, E., Wallander, H., 2004. Growth and biomass of mycorrhizal mycelia in coniferous forests along short natural nutrient gradients. New Phytol. 165, 613-622. https://doi.org/10.1111/j.1469-8137.2004.01223.x

Oeser, R.A., Stroncik, N., Moskwa, L.-M., Bernhard, N., Schaller, M., Canessa, R., van den Brink, L., Köster, M., Brucker, E., Stock, S., Fuentes, J.P., Godoy, R., Matus, F., Oses Pedraza, R., Osses McIntyre, P., Paulino, L., Seguel, O., Bader, M.Y., Boy, J., Dippold, M.A., Ehlers, T.A., Kühn, P., Kuzyakov, Y., Leinweber, P., Scholten, T., Spielvogel, S., Spohn, M., Übernickel, K., Tielbörger, K., Wagner, D., von Blanckenburg, F., 2018. Chemistry and Microbiology of the Critical Zone along a steep climate and vegetation gradient in the Chilean Coastal Cordillera. Catena.

Olander, L.P., Vitousek, P.M., 2000. Regulation of soil phosphatase and chitinase activity by N and P availability. Biogeochemistry 49, 175-191. https://doi.org/10.1023/A:1006316117817

Olsson, P.A., 1999. Signature fatty acids provide tools for determination of the distribution and interactions of mycorrhizal fungi in soil. FEMS Microbiol. Ecol. 29, 303-310. https://doi.org/10.1111/j.15746941.1999.tb00621.x

Olsson, P.A., Francis, R., Read, D.J., Söderström, B., 1998. Growth of arbuscular mycorrhizal mycelium in calcareous dune sand and its interaction with other soil microorganisms as estimated by measurement of specific fatty acids 8 .

Padilla, F.M., Aarts, B.H.J., Roijendijk, Y.O.A., de Caluwe, H., Mommer, L., Visser, E.J.W., de Kroon, H., 2013. Root plasticity maintains growth of temperate grassland species under pulsed water supply. Plant Soil 369, 377-386. https://doi.org/10.1007/s11104-012-1584-x

Parniske, M., 2008. Arbuscular mycorrhiza: the mother of plant root endosymbioses. Nat. Rev. Microbiol. 6, 763-775. https://doi.org/10.1038/nrmicro1987

Pausch, J., Kuzyakov, Y., 2018. Carbon input by roots into the soil: Quantification of rhizodeposition from root to ecosystem scale. Glob. Change Biol. 24, 1-12. https://doi.org/10.1111/gcb.13850

Perakis, S.S., Hedin, L.O., 2001. Fluxes and fates of nitrogen in soil of an unpolluted old-growth temperate forest, Southern Chile. Ecology 82, 2245-2260. https://doi.org/10.1890/00129658(2001)082[2245:FAFONI]2.0.CO;2

Pérez Navarro, M.Á., Sapes, G., Batllori, E., Serra-Diaz, J.M., Esteve, M.A., Lloret, F., 2019. Climatic Suitability Derived from Species Distribution Models Captures Community Responses to an Extreme Drought Episode. Ecosystems 22, 77-90. https://doi.org/10.1007/s10021-018-0254-0

Pérez-Ramos, I.M., Roumet, C., Cruz, P., Blanchard, A., Autran, P., Garnier, E., 2012. Evidence for a 'plant community economics spectrum' driven by nutrient and water limitations in a Mediterranean rangeland of southern France. J. Ecol. 100, 1315-1327. https://doi.org/10.1111/1365-2745.12000

Pérez-Ramos, I.M., Volaire, F., Fattet, M., Blanchard, A., Roumet, C., 2013. Tradeoffs between functional strategies for resource-use and drought-survival in Mediterranean rangeland species. Environ. Exp. Bot. 87, 126-136. https://doi.org/10.1016/j.envexpbot.2012.09.004 
Ploughe, L.W., Jacobs, E.M., Frank, G.S., Greenler, S.M., Smith, M.D., Dukes, J.S., 2019. Community Response to Extreme Drought ( CRED ): a framework for drought-induced shifts in plant-plant interactions. New Phytol. 222, 52-69. https://doi.org/10.1111/nph.15595

Poorter, H., Niklas, K.J., Reich, P.B., Oleksyn, J., Poot, P., Mommer, L., 2012. Biomass allocation to leaves, stems and roots: meta-analyses of interspecific variation and environmental control: Tansley review. New Phytol. 193, 30-50. https://doi.org/10.1111/j.1469-8137.2011.03952.x

Pregitzer, K.S., Kubiske, M.E., Yu, C.K., Hendrick, R.L., 1997. Relationships among root branch order, carbon, and nitrogen in four temperate species. Oecologia 111, 302-308. https://doi.org/10.1007/s004420050239

Prietzel, J., Harrington, G., Häusler, W., Heister, K., Werner, F., Klysubun, W., 2016. Reference spectra of important adsorbed organic and inorganic phosphate binding forms for soil $\mathrm{P}$ speciation using synchrotron-based $K$-edge XANES spectroscopy. J. Synchrotron Radiat. 23, 532-544. https://doi.org/10.1107/S1600577515023085

R Core Team, 2017. R: A Language and Environment for Statistical Computing. Vienna, Austria.

Reich, P.B., 2014. The world-wide 'fast-slow' plant economics spectrum: a traits manifesto. J. Ecol. 102, 275-301. https://doi.org/10.1111/1365-2745.12211

Reichmann, L.G., Sala, O.E., Peters, D.P.C., 2013. Water controls on nitrogen transformations and stocks in an arid ecosystem. Ecosphere 4, art11. https://doi.org/10.1890/ES12-00263.1

Roumet, C., Birouste, M., Picon-Cochard, C., Ghestem, M., Osman, N., Vrignon-Brenas, S., Cao, K., Stokes, A., 2016. Root structure-function relationships in 74 species: evidence of a root economics spectrum related to carbon economy. New Phytol. 210, 815-826. https://doi.org/10.1111/nph.13828

Rousk, J., Bååth, E., 2007. Fungal biomass production and turnover in soil estimated using the acetate-inergosterol technique. Soil Biol. Biochem. 39, 2173-2177. https://doi.org/10.1016/j.soilbio.2007.03.023

Royo, A.A., Knight, K.S., 2012. White ash (Fraxinus americana) decline and mortality: The role of site nutrition and stress history. For. Ecol. Manag. 286, 8-15. https://doi.org/10.1016/j.foreco.2012.08.049

Ruiz-Lozano, J.M., Aroca, R., Zamarreño, Á.M., Molina, S., Andreo-Jiménez, B., Porcel, R., García-Mina, J.M., Ruyter-Spira, C., López-Ráez, J.A., 2016. Arbuscular mycorrhizal symbiosis induces strigolactone biosynthesis under drought and improves drought tolerance in lettuce and tomato: Drought and AM symbiosis induce strigolactones. Plant Cell Environ. 39, 441-452. https://doi.org/10.1111/pce.12631

Ryan, M.H., Tibbett, M., Edmonds-Tibbett, T., Suriyagoda, L.D.B., Lambers, H., Cawthray, G.R., Pang, J., 2012. Carbon trading for phosphorus gain: the balance between rhizosphere carboxylates and arbuscular mycorrhizal symbiosis in plant phosphorus acquisition: Carbon trading for phosphorus gain. Plant Cell Environ. 35, 2170-2180. https://doi.org/10.1111/j.1365-3040.2012.02547.x

Sala, O.E., Gherardi, L.A., Peters, D.P.C., 2015. Enhanced precipitation variability effects on water losses and ecosystem functioning: differential response of arid and mesic regions. Clim. Change 131, 213-227. https://doi.org/10.1007/s10584-015-1389-z

Sala, O.E., Gherardi, L.A., Reichmann, L., Jobbágy, E., Peters, D., 2012a. Legacies of precipitation fluctuations on primary production: theory and data synthesis. Philos. Trans. R. Soc. B Biol. Sci. 367, 3135-3144. https://doi.org/10.1098/rstb.2011.0347

Sala, O.E., Golluscio, R.A., Lauenroth, W.K., Roset, P.A., 2012b. Contrasting nutrient-capture strategies in shrubs and grasses of a Patagonian arid ecosystem. J. Arid Environ. 82, 130-135. https://doi.org/10.1016/j.jaridenv.2012.02.015

Sanaullah, M., Blagodatskaya, E., Chabbi, A., Rumpel, C., Kuzyakov, Y., 2011. Drought effects on microbial biomass and enzyme activities in the rhizosphere of grasses depend on plant community composition. Appl. Soil Ecol. 48, 38-44. https://doi.org/10.1016/j.apsoil.2011.02.004

Sardans, J., Peñuelas, J., 2015. Potassium: a neglected nutrient in global change: Potassium stoichiometry and global change. Glob. Ecol. Biogeogr. 24, 261-275. https://doi.org/10.1111/geb.12259

Sardans, J., Peñuelas, J., 2012. The Role of Plants in the Effects of Global Change on Nutrient Availability and Stoichiometry in the Plant-Soil System. Plant Physiol. 160, 1741-1761. https://doi.org/10.1104/pp.112.208785 
Schaller, M., Ehlers, T.A., Lang, K.A.H., Schmid, M., Fuentes-Espoz, J.P., 2018. Addressing the contribution of climate and vegetation cover on hillslope denudation, Chilean Coastal Cordillera $\left(26^{\circ}-38^{\circ} \mathrm{S}\right)$. Earth Planet. Sci. Lett. 489, 111-122. https://doi.org/10.1016/j.eps1.2018.02.026

Schwalm, C.R., Anderegg, W.R.L., Michalak, A.M., Fisher, J.B., Biondi, F., Koch, G., Litvak, M., Ogle, K., Shaw, J.D., Wolf, A., Huntzinger, D.N., Schaefer, K., Cook, R., Wei, Y., Fang, Y., Hayes, D., Huang, M., Jain, A., Tian, H., 2017. Global patterns of drought recovery. Nature 548, 202-205. https://doi.org/10.1038/nature23021

Schwinning, S., Sala, O.E., 2004. Hierarchy of responses to resource pulses in arid and semi-arid ecosystems. Oecologia 141, 211-220. https://doi.org/10.1007/s00442-004-1520-8

Sinsabaugh, R.L., Lauber, C.L., Weintraub, M.N., Ahmed, B., Allison, S.D., Crenshaw, C., Contosta, A.R., Cusack, D., Frey, S., Gallo, M.E., Gartner, T.B., Hobbie, S.E., Holland, K., Keeler, B.L., Powers, J.S., Stursova, M., Takacs-Vesbach, C., Waldrop, M.P., Wallenstein, M.D., Zak, D.R., Zeglin, L.H., 2008. Stoichiometry of soil enzyme activity at global scale. Ecol. Lett. 11, 1252-1264. https://doi.org/10.1111/j.1461-0248.2008.01245.x

Solbrig, O.T., 1966. The South American species of Gutierrezia. Contrib. Gray Herb. Harv. Univ. 3-42.

Solbrig, O.T., 1962. The South American Species of Erigeron. Contrib. Gray Herb. Harv. Univ. 3-79.

Stock, S.C., Köster, M., Dippold, M.A., Nájera, F., Matus, F., Merino, C., Boy, J., Spielvogel, S., Gorbushina, A., Kuzyakov, Y., 2019. Environmental drivers and stoichiometric constraints on enzyme activities in soils from rhizosphere to continental scale. Geoderma 337, 973-982. https://doi.org/10.1016/j.geoderma.2018.10.030

Szmigielska, A.M., Van Rees, K.C.J., Cieslinski, G., Huang, P.M., 1997. Comparison of liquid and gas chromatography for analysis of low molecular weight organic acids in rhizosphere soil. Commun. Soil Sci. Plant Anal. 28, 99-111. https://doi.org/10.1080/00103629709369775

Taylor, L.L., Leake, J.R., Quirk, J., Hardy, K., Banwart, S.A., Beerling, D.J., 2009. Biological weathering and the long-term carbon cycle: integrating mycorrhizal evolution and function into the current paradigm. Geobiology 7, 171-191. https://doi.org/10.1111/j.1472-4669.2009.00194.x

Trabucco, A., Zomer, R.J., 2018. Global Aridity Index and Potential Evapo-Transpiration (ET0) Climate Database v2. CGIAR Consortium for Spatial Information (CGIAR-CSI). Published online, available from the CGIAR-CSI GeoPortal at https://cgiarcsi.community 10.

Treseder, K.K., 2004. A meta-analysis of mycorrhizal responses to nitrogen, phosphorus, and atmospheric CO2 in field studies. New Phytol. 164, 347-355. https://doi.org/10.1111/j.14698137.2004.01159.x

Treseder, K.K., Vitousek, P.M., 2001. Effects of soil nutrient availability on investment in acquisition of N and $\mathrm{P}$ in Hawaiian rain forests. Ecology 82, 946-954. https://doi.org/10.1890/00129658(2001)082[0946:EOSNAO]2.0.CO;2

Turnbull, L., Wainwright, J., Brazier, R.E., 2011. Nitrogen and phosphorus dynamics during runoff events over a transition from grassland to shrubland in the south-western United States. Hydrol. Process. 25, 1-17. https://doi.org/10.1002/hyp.7806

Turner, B.L., Condron, L.M., Richardson, S.J., Peltzer, D.A., Allison, V.J., 2007. Soil Organic Phosphorus Transformations During Pedogenesis. Ecosystems 10, 1166-1181. https://doi.org/10.1007/s10021007-9086-z

Uhlig, D., von Blanckenburg, F., 2019. How Slow Rock Weathering Balances Nutrient Loss During Fast Forest Floor Turnover in Montane, Temperate Forest Ecosystems. Front. Earth Sci. 7, 159. https://doi.org/10.3389/feart.2019.00159

Valdebenito, H., Lowrey, T.K., Stuessy, T.F., 1986. A New Species of Erigeron (Compositae: Astereae) from Chile. Brittonia 38, 1. https://doi.org/10.2307/2807408

Valdés-Pineda, R., Pizarro, R., García-Chevesich, P., Valdés, J.B., Olivares, C., Vera, M., Balocchi, F., Pérez, F., Vallejos, C., Fuentes, R., Abarza, A., Helwig, B., 2014. Water governance in Chile: Availability, management and climate change. J. Hydrol. 519, 2538-2567. https://doi.org/10.1016/j.jhydrol.2014.04.016

Valverde-Barrantes, O.J., Smemo, K.A., Blackwood, C.B., 2015. Fine root morphology is phylogenetically structured, but nitrogen is related to the plant economics spectrum in temperate trees. Funct. Ecol. 29, 796-807. https://doi.org/10.1111/1365-2435.12384

van der Heijden, M.G.A., Scheublin, T.R., 2007. Functional traits in mycorrhizal ecology: their use for predicting the impact of arbuscular mycorrhizal fungal communities on plant growth and ecosystem functioning. New Phytol. 174, 244-250. https://doi.org/10.1111/j.1469-8137.2007.02041.x 
van Dongen, R., Scherler, D., Wittmann, H., von Blanckenburg, F., 2019. Cosmogenic ${ }^{10}$ Be in river sediment: where grain size matters and why. Earth Surf. Dyn. 7, 393-410. https://doi.org/10.5194/esurf-7-393-2019

van Oldenborgh, G.J., Philip, S.Y., Collins, M., 2005. El Niño in a changing climate: a multi-model study. Ocean Sci. 16.

Vance, C.P., Heichel, G.H., 1991. Carbon in $\mathrm{N}_{2}$ Fixation: Limitation or Exquisite Adaptation. Annu. Rev. Plant Physiol. Plant Mol. Biol. 373-392.

Vergutz, L., Manzoni, S., Porporato, A., Novais, R.F., Jackson, R.B., 2012. Global resorption efficiencies and concentrations of carbon and nutrients in leaves of terrestrial plants. Ecol. Monogr. 82, 205220. https://doi.org/10.1890/11-0416.1

Vierheilig, H., Coughlan, A.P., Wyss, U., Piche, Y., 1998. Ink and Vinegar, a Simple Staining Technique for Arbuscular-Mycorrhizal Fungi 64, 4.

Vitousek, P., Chadwick, O., Matson, P., Allison, S., Derry, L., Kettley, L., Luers, A., Mecking, E., Monastra, V., Porder, S., 2003. Erosion and the Rejuvenation of Weathering-derived Nutrient Supply in an Old Tropical Landscape. Ecosystems 6, 762-772. https://doi.org/10.1007/s10021003-0199-8

Vitousek, P.M., Cassman, K., Cleveland, C., Crews, T., Field, C.B., Grimm, N.B., Howarth, R.W., Marino, R., Martinelli, L., Rastetter, E.B., Sprent, J.I., 2002. Towards an ecological understanding of biological nitrogen fixation, in: Boyer, E.W., Howarth, R.W. (Eds.), The Nitrogen Cycle at Regional to Global Scales. Springer Netherlands, Dordrecht, pp. 1-45. https://doi.org/10.1007/97894-017-3405-9_1

Volaire, F., 2018. A unified framework of plant adaptive strategies to drought: Crossing scales and disciplines. Glob. Change Biol. 24, 2929-2938. https://doi.org/10.1111/gcb.14062

Volaire, F., 2008. Plant traits and functional types to characterise drought survival of pluri-specific perennial herbaceous swards in Mediterranean areas. Eur. J. Agron. 29, 116-124. https://doi.org/10.1016/j.eja.2008.04.008

Volaire, F., Barkaoui, K., Norton, M., 2014. Designing resilient and sustainable grasslands for a drier future: Adaptive strategies, functional traits and biotic interactions. Eur. J. Agron. 52, 81-89. https://doi.org/10.1016/j.eja.2013.10.002

Walker, T.W., Syers, J.K., 1976. The fate of phosphorus during pedogenesis. Geoderma 15, 1-19. https://doi.org/10.1016/0016-7061(76)90066-5

Wang, C., Chen, Z., Brunner, I., Zhang, Z., Zhu, X., Li, J., Yin, H., Guo, W., Zhao, T., Zheng, X., Wang, S., Geng, Z., Shen, S., Jin, D., Li, M.-H., 2018. Global patterns of dead fine root stocks in forest ecosystems. J. Biogeogr. 45, 1378-1394. https://doi.org/10.1111/jbi.13206

Wang, P., Huang, K., Hu, S., 2020. Distinct fine-root responses to precipitation changes in herbaceous and woody plants: a meta-analysis. New Phytol. 225, 1491-1499. https://doi.org/10.1111/nph.16266

Werner, F., 2017. LCF: Linear Combination Fitting. R package version 1.7.0.

Wright, D.P., Read, D.J., Scholes, J.D., 1998. Mycorrhizal sink strength influences whole plant carbon balance of Trifolium repens L. Plant Cell Environ. 21, 881-891. https://doi.org/10.1046/j.13653040.1998.00351.x

Xu, X., Thornton, P.E., Post, W.M., 2013. A global analysis of soil microbial biomass carbon, nitrogen and phosphorus in terrestrial ecosystems: Global soil microbial biomass C, N and P. Glob. Ecol. Biogeogr. 22, 737-749. https://doi.org/10.1111/geb.12029

Yahdjian, L., Sala, O.E., 2010. Size of Precipitation Pulses Controls Nitrogen Transformation and Losses in an Arid Patagonian Ecosystem. Ecosystems 13, 575-585. https://doi.org/10.1007/s10021-0109341-6

Yahdjian, L., Sala, O.E., Austin, A.T., 2006. Differential Controls of Water Input on Litter Decomposition and Nitrogen Dynamics in the Patagonian Steppe. Ecosystems 9, 128-141. https://doi.org/10.1007/s10021-004-0118-7

Yang, X., Post, W.M., 2011. Phosphorus transformations as a function of pedogenesis: A synthesis of soil phosphorus data using Hedley fractionation method. Biogeosciences 8, 2907-2916. https://doi.org/10.5194/bg-8-2907-2011

Young, G., Zavala, H., Wandel, J., Smit, B., Salas, S., Jimenez, E., Fiebig, M., Espinoza, R., Diaz, H., Cepeda, J., 2010. Vulnerability and adaptation in a dryland community of the Elqui Valley, Chile. Clim. Change 98, 245-276. https://doi.org/10.1007/s10584-009-9665-4 
Yuan, Z.Y., Chen, H.Y.H., 2015. Negative effects of fertilization on plant nutrient resorption. Ecology 96, 373-380. https://doi.org/10.1890/14-0140.1

Zechmeister-Boltenstern, S., Keiblinger, K.M., Mooshammer, M., Peñuelas, J., Richter, A., Sardans, J., Wanek, W., 2015. The application of ecological stoichiometry to plant-microbial-soil organic matter transformations. Ecol. Monogr. 85, 133-155. https://doi.org/10.1890/14-0777.1

Zhang, B., Cadotte, M.W., Chen, S., Tan, X., You, C., Ren, T., Chen, M., Wang, S., Li, W., Chu, C., Jiang, L., Bai, Y., Huang, J., Han, X., 2019. Plants alter their vertical root distribution rather than biomass allocation in response to changing precipitation. Ecology 100. https://doi.org/10.1002/ecy.2828

Zhou, Y., Wigley, B.J., Case, M.F., Coetsee, C., Staver, A.C., 2020. Rooting depth as a key woody functional trait in savannas. New Phytol. nph.16613. https://doi.org/10.1111/nph.16613 


\section{Publications and Manuscripts}

2.1 Study 1: Retention against losses: plant nutrient uplift and recycling in a continental transect of water and nutrient availability

Ready for submission

$\underline{\text { Svenja C. Stock }}{ }^{1,2} *$, Moritz Köster ${ }^{1,3}$, Francisco Nájera ${ }^{4}$, Jens Boy ${ }^{5}$, Francisco Matus ${ }^{6,7}$, Carolina Merino $^{6,7}$, Khaled Abdallah ${ }^{8}$, Sandra Spielvogel ${ }^{9}$, Anna A. Gorbushina ${ }^{8,10}$, Michaela A. Dippold ${ }^{1}$, and Yakov Kuzyakov ${ }^{2,11,12}$

${ }^{1}$ Biogeochemistry of Agroecosystems, University of Goettingen, Goettingen, Germany

${ }^{2}$ Soil Science of Temperate Ecosystems, University of Goettingen, Goettingen, Germany

${ }^{3}$ Institute of Geography, University of Bern, Bern, Switzerland

${ }^{4}$ Department for Engineering and Soils, University of Chile, Santiago, Chile

${ }^{5}$ Institute of Soil Science, Leibniz University Hannover, Hannover, Germany

${ }^{6}$ Laboratory of Conservation and Dynamic of Volcanic Soils, Department of Chemical Sciences and Natural Resources, Universidad de La Frontera, Temuco, Chile.

${ }^{7}$ Network for Extreme Environmental Research (NEXER) Universidad de La Frontera, Temuco, Chile.

${ }^{8}$ Department Materials and Environment, Federal Institute for Material Research and Testing, Berlin, Germany

${ }^{9}$ Institute of Plant Nutrition and Soil Science, Christian-Albrechts University of Kiel, Kiel, Germany

${ }^{10}$ Institute of Biology and Department of Geosciences, Freie Universität Berlin, Berlin, Germany

${ }^{11}$ Institute of Environmental Sciences, Kazan Federal University, Kazan, Russia

${ }^{12}$ Agro-Technology Institute, RUDN University, Moscow, Russia

* Corresponding author: Svenja C. Stock

Keywords: subsoil tracer application, ${ }^{15} \mathrm{~N}$ and $\mathrm{K}$ analog tracer, nutrient uplift and recycling, nutrient cycles, (semi)arid to humid-temperate natural ecosystems, Chilean Coastal Cordillera 


\section{Abstract}

Proceeding climate change increases frequency and duration of droughts. Plants' ability to adapt to water shortage defines the response of natural ecosystems to such changes. Nutrient acquisition strategies affect plants' ability to cope with droughts, of which nutrient uplift and recycling are two important processes. Along a precipitation gradient from arid to humid climate in the Chilean Coastal Cordillera, we localize short-term $(<1$ year) plant nitrogen $(\mathrm{N})$ and potassium $(\mathrm{K})$ uplift from topsoil, subsoil, and saprolite by a tracer experiment with ${ }^{15} \mathrm{~N}$, rubidium $(\mathrm{Rb})$ and cesium (Cs). Long-term (>decades) processes were investigated by the vertical distribution of exchangeable $\mathrm{K}$ and the natural ${ }^{15} \mathrm{~N}$ abundance in plants and topsoil. Natural ${ }^{15} \mathrm{~N}$ depletion in shoots and roots of unlabeled reference plants vs. topsoil under arid ( $\Delta 3 \%$ for shoots and $11 \%$ for roots) and humid conditions ( $\Delta 10 \%$ and $9 \%$ ) indicated very efficient $\mathrm{N}$ recycling from topsoil over decades. Shrubs growing under arid conditions intensively recycle $\mathrm{N}$ in topsoil as well as from subsoil and saprolite over short terms. Under humid conditions, ${ }^{15} \mathrm{~N}$ recovery confirmed likewise the short-term $\mathrm{N}$ recycling from topsoil. Contrary to shrubs under arid conditions, however, plants in the humid ecosystem reacquired leached $\mathrm{N}$ from subsoil and less from saprolite. Nutrient losses due to denudation are highest under Mediterranean climate compared to the other ecosystems, which reduced long-term $\mathrm{N}$ recycling by plants. Nine times higher ${ }^{15} \mathrm{~N}$ and seven times higher $\mathrm{K}$ tracer recoveries from top- than subsoil in the Mediterranean site, however, display plants' efficient short-term nutrient reutilization from topsoil. $\mathrm{K}$ tracer recovery under humid conditions highlighted that $\mathrm{K}$ uplift from saprolite complements the nutrient budget, additional to short-term $\mathrm{K}$ reutilization from topsoil. Larger nutrient losses from soil under Mediterranean compared to arid or humid conditions strongly decrease the long-term recycling efficiency and consequently accelerate saprolite weathering under semiarid climate. 


\subsubsection{Introduction}

Precipitation patterns are predicted to shift in response to climate change (IPCC, 2014, 2007). A decrease of precipitation is projected for Central Chile (Christensen et al., 2007; Garreaud, 2011; IPCC, 2007), with most pronounced changes in the humid-temperate south (Garreaud, 2011). Additionally, the frequency and duration of extreme events are projected to increase (IPCC, 2007; Knapp et al., 2008). Higher precipitation variability can result in concentrated but less frequent precipitation and can cause increased run-off and nutrient leaching (Boy et al., 2008), but not necessarily. Depending on the magnitude of water pulses, a concentration of precipitation in fewer but larger rain events could compensate for a reduction in total precipitation in (semi)arid ecosystems by deeper infiltration (Knapp et al., 2015, 2008).

The ability to maintain water uptake and avoid physiological failure, is often regarded as the main factor for plant survival under drought (Gessler et al., 2017). Nutrient availability, however, can have a critical role on plant drought sensitivity (Gessler et al., 2017; Royo and Knight, 2012). Increasing their nutrient supply and maintaining nutrient uptake should, therefore, be part of plant drought survival strategies. Nutrient recycling and uplift are two important processes to retain nutrients in and reduce losses from soil (Porder and Chadwick, 2009; Rennenberg et al., 2009; Sala et al., 2012).

Fast nutrient recycling from plant litter and microbial necromass decomposition ensures plant nutrition on shorter time scales (Gao et al., 2019; Perakis and Hedin, 2001; Uhlig and von Blanckenburg, 2019). The extent of nutrient recycling depends on the spatial and temporal availability (Dunbabin et al., 2004; Uhlig and von Blanckenburg, 2019) as well as the plant demand of a certain nutrient (Sardans and Peñuelas, 2015; Vergutz et al., 2012). Erosion, leaching, gaseous losses, deep weathering, and high plant and microbial nutrient demand lead to a depletion of nutrient pools in topsoil over time (Chen et al., 2019; Uhlig and von Blanckenburg, 2019). The acquisition from deep soil and saprolite is an important mechanism to replenish nutrient pools over long-term scales (>decades) (Bedel et al., 2016; Dawson et al., 2020; Jobbágy and Jackson, 2004; Uhlig and von Blanckenburg, 2019). Especially in systems with high precipitation and, thus, high erosion and leaching, plant nutrient uplift from subsoil or saprolite is an important mechanism to counterbalance nutrient losses (Brantley et al., 2017; Jobbágy and Jackson, 2001). Thus, a better understanding of the function of deep roots in nutrient acquisition is needed (Newman et al., 2020). The extent and intensity of recycling and plant uplift can differ markedly between dry and wet ecosystems (Porder and Chadwick, 2009). Nutrient losses from soil were reported to be reduced by plants at dry $\left(\leq 750 \mathrm{~mm} \mathrm{yr}^{-1}\right)$ and mesic sites $\left(750-1400 \mathrm{~mm} \mathrm{yr}^{-1}\right)$ with negative water balances (i.e. potential evapotranspiration > precipitation), whereas leaching losses overwhelmed nutrient 
uplift and retention by plants at precipitation $>1500 \mathrm{~mm} \mathrm{yr}^{-1}$ (Porder and Chadwick, 2009). High nutrient demands, however, can lead to strong nutrients recycling and recapturing from depth in humid ecosystems (i.e., closed cycling), whereas semiarid ecosystems might be less nutrient conservative and relatively more prone to nutrient losses from topsoils (McCulley et al., 2009; Reichmann et al., 2013). N loss via leaching can be high in semiarid ecosystems, when microbial mineralization activity and plant demand are decoupled due to the seasonal distribution or low intensity of water pulses (Austin et al., 2004; Kuzyakov and Xu, 2013; Schwinning and Sala, 2004). Because the microbial response to rewetting is much faster than that of plants, precipitation pulses during the dry season or brief and shallow pulses during the wet season can lead to an accumulation of mineralized $\mathrm{N}$ in topsoils (McCulley et al., 2009; Reichmann et al., 2013; Schwinning and Sala, 2004). The accumulated mobile $\mathrm{N}$ is then highly susceptible to leaching during more intensive rainfall events (McCulley et al., 2009).

Uplift and reutilization of nutrients depend further on their original source (rock-born vs. biological fixation), retention by minerals and soil organic matter (SOM) (i.e. sorption and leaching potential), and microbial demand. Nitrogen in soil is primarily bound in organic matter $(\mathrm{OM})$, and thus we will refer to it as OM-derived from hereon. OM needs to be decomposed and mineralized to release $\mathrm{N}$ available for plant uptake (Blume et al., 2010). The dominant mineral $\mathrm{N}$ form in most soils (especially when well aerated) is nitrate $\left(\mathrm{NO}_{3}{ }^{-}\right)$, which is highly mobile, does not bind to clay minerals, and is easily leached down the soil profile (Blume et al., 2010). Potassium (K), on the contrary, is rock-derived, and the main pool of available $\mathrm{K}$ in soil is weakly adsorbed to clay minerals, whereas only a small portion remains in soil solution (Sardans and Peñuelas, 2015). $\mathrm{K}$ in plant and microbial cells is only present in soluble form, which makes it prone to leaching from litter (Sardans and Peñuelas, 2015). Upon leaching, K easily binds to clay minerals in soil, which reduces its reutilization compared to N. For both elements, water and nutrient availability strongly modulate plant acquisition strategies (Kautz et al., 2013).

Objective of this study was to evaluate two main nutrient retention processes in ecosystems: nutrient recycling and uplift. Within this aim, we localized short-term $(<1$ year) plant $\mathrm{N}$ and $\mathrm{K}$ acquisition from topsoil, subsoil, saprolite and determined the long-term (> decades) importance of nutrient recycling and uplift under arid, Mediterranean, and humid conditions across a continental transect. We will use the term plant nutrient 'acquisition' as we integrated the immediate process of uptake (i.e., nutrients entering roots) over eight months. This short-term acquisition was traced with the application of ${ }^{15} \mathrm{~N}$ and the trace elements rubidium $(\mathrm{Rb})$ and cesium (Cs) that act as K analogs in plant uptake (Fitter, 1986; Hoekstra et al., 2015, 2014; Schleuss et 
al., 2015). The tracer application allows to conclude about the function of roots in topsoil, subsoil, and saprolite in nutrient acquisition.

We hypothesize that (1) uplift of $\mathrm{K}$ as rock-derived nutrient increases with increasing precipitation and that (2) recycling intensity, especially of $\mathrm{N}$ as OM-derived nutrient, increases with increasing precipitation due to a greater nutrient demand. The nutrient labeling experiment of woody vegetation was conducted in three sites across a continental precipitation gradient in the Chilean Coastal Cordillera with the same granitoid parent materials, ranging from $80 \mathrm{~mm} \mathrm{yr}^{-1}$ to $1500 \mathrm{~mm} \mathrm{yr}^{-1}$ (Fick and Hijmans, 2017). Thereby, we can compare nutrients derived from the same parent material.

\subsubsection{Material and Methods}

\subsubsection{Study sites}

The three study sites are located within the Chilean Coastal Cordillera between $30^{\circ}$ and $38^{\circ}$ southern latitude on granitoid parent material. The northernmost site, with an aridity index (AI) of 0.05 (Trabucco and Zomer, 2018), is an arid ecosystem (an arid shrubland) in the Reserva Santa Gracia (29.76 S, $71.14 \mathrm{~W})$. The vegetation is dominated by cacti and drought-deciduous shrubs, growing on Cambisols with $\mathrm{pH}$ values of 5.5 to 7.0 (Bernhard et al., 2018). The second, intermediate site is a Mediterranean ecosystem (a coastal matorral) located within the National Park La Campana (32.96 S, $71.06 \mathrm{~W}$; AI=0.24). A vegetation dominated by evergreensclerophyllous trees, deciduous shrubs, and a dense herb layer developed on Cambisols with $\mathrm{pH}$ values between 4.5 and 6.1 (Bernhard et al., 2018). The third and southernmost humid ecosystem (a humid-temperate forest) is located within the National Park Nahuelbuta (37.81 S, 73.01 W; $\mathrm{AI}=1.4$ ). On Umbrisols and Podzols ( $\mathrm{pH}$ 3.7-5.1) developed a dense rainforest dominated by evergreen and winter-deciduous broadleaved trees (Bernhard et al., 2018). The mean annual precipitation (MAP) increases from $80 \mathrm{~mm} \mathrm{a}^{-1}$ in the north to $>1500 \mathrm{~mm} \mathrm{a}^{-1}$ in the south (Fick and Hijmans, 2017). For a more detailed site description, please refer to Bernhard et al. (2018) and Oeser et al. (2018).

\subsubsection{Experiment setup, conditions, and sampling}

Rubidium and Cs as K analogs (Fitter, 1986; Göransson et al., 2006; Mamolos et al., 1995) and ${ }^{15} \mathrm{~N}$ were used to evaluate short-term plant $\mathrm{K}$ and $\mathrm{N}$ acquisition, respectively. Distributed between north and south facing slopes, eight specimens per site and depth were labeled with a common tracer solution, containing $\mathrm{RbCl}, \mathrm{CsCl}$, and $\mathrm{Na}^{15} \mathrm{NO}_{3}$ (99 at\%; Sigma Aldrich, Munich, Germany; for concentrations see Table 2.1-1). The area around a specimen was either labeled in topsoil (arid shrubland $=15 \mathrm{~cm}$, Mediterranean and humid ecosystems $=30 \mathrm{~cm}$ depth), subsoil (arid shrubland 
$=40 \mathrm{~cm}$, Mediterranean and humid ecosystems $=70 \mathrm{~cm}$ depth), or saprolite (arid shrubland $=55$ $\mathrm{cm}$, coastal matorral $=120 \mathrm{~cm}$, humid-temperate forest $=200 \mathrm{~cm}$ depth). Therefore, three holes were pre-cored per specimen with a soil auger, and the tracer solution was divided equally between holes. All specimens were chosen at a mid-slope position. Assuming quantitatively much lower tracer recovery from the lowest depth compared to topsoil, we increased the amount of tracer from topsoil to saprolite (see Table 2.1-1).

Table 2.1-1: Amounts and concentrations of applied compounds and tracer elements (Rb, Cs, $\left.{ }^{15} \mathrm{~N}\right)$.

\begin{tabular}{|c|c|c|c|c|c|c|c|c|c|}
\hline \multirow[b]{2}{*}{ Depth } & \multicolumn{3}{|c|}{$\begin{array}{l}\text { Amounts of compounds } \\
{[\mathrm{g}]}\end{array}$} & \multicolumn{3}{|c|}{$\begin{array}{l}\text { Concentration of } \\
\text { compounds } \\
{\left[\mathrm{g} \mathrm{l}^{-1}\right]}\end{array}$} & \multicolumn{3}{|c|}{$\begin{array}{c}\text { Concentration of tracer } \\
\text { element (Rb, Cs, }{ }^{15} \mathrm{~N} \text {, } \\
\text { respectively) } \\
{\left[\mathrm{g} \mathrm{l}^{-1}\right]}\end{array}$} \\
\hline & topsoil & subsoil & saprolite & topsoil & subsoil & saprolite & topsoil & subsoil & saprolite \\
\hline $\mathrm{CsCl}$ & 1.3 & 2 & 2.6 & 26 & 40 & 52 & 20.5 & 31.6 & 41.1 \\
\hline $\mathrm{RbCl}$ & 1.5 & 2.2 & 3 & 30 & 44 & 60 & 21.2 & 31.1 & 42.4 \\
\hline $\mathrm{Na}^{15} \mathrm{NO}_{3}$ & 0.15 & 0.3 & 0.45 & 3 & 6 & 9 & 0.52 & 1.05 & 1.57 \\
\hline
\end{tabular}

Injection of the tracer solution was conducted with a tube-in-a-pipe concept. A pipe was used to guide a flexible Teflon tube down the auger hole to the respective depth. The tube was closed off at the end but perforated in the last $10 \mathrm{~cm}$ to avoid a single point application. The tracer solution was injected with a $30 \mathrm{ml}$ syringe attached to the tube and water was added afterwards to rinse the tube and remove tracer residues. The labeling was conducted at the end of the austral summer (March 2016) to avoid plant inactivity due to a potential summer dormancy especially in the arid and Mediterranean ecosystems (di Castri and Hajek, 1976). After eight months, plant materials of labeled and non-labeled specimens were collected in November 2016. The soil excavated for the injection holes was collected to determine the reference nutrient contents. Total precipitation and frequency (i.e. number of days with precipitation) from March 2016 till November 2016 are given in Figure 2.1-1 and were recorded by the on-site weather stations (Ehlers et al., 2017) for the arid and Mediterranean sites. As the project's weather station in the National Park Nahuelbuta was only installed in November 2016, precipitation data were derived from the Center for Climate and Resilience Research (CR)² (2020) for the station Parque Nahuelbuta (37.8233 S, 72.9606 W). 

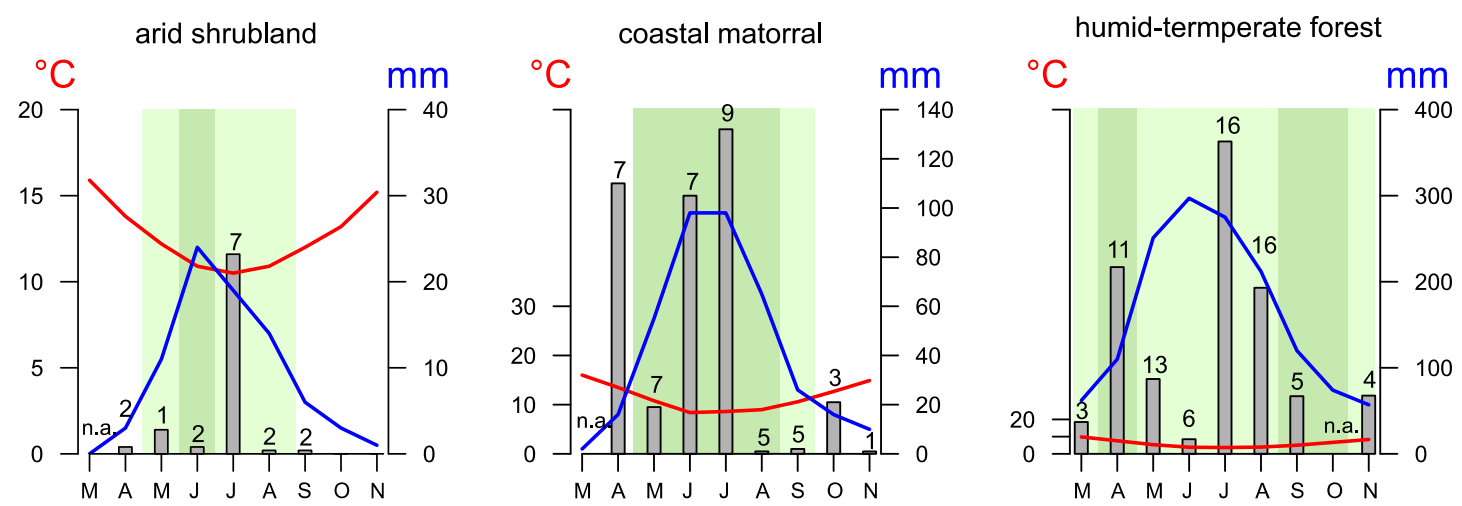

Figure 2.1-1: Monthly mean temperature (red line) and monthly mean precipitation (blue line) in the three study sites as well as total monthly precipitation (gray bars) and number of days with precipitation (numbers on top of bars) during the experiment from March till November 2016. n.a. = no data available. Monthly means are derived from Fick and Hijmans (2017) and precipitation data for 2016 are derived from Ehlers et al. (2017) and (CR $)^{2}($ for details see method section). Green shading indicates favorable (dark) and semi-favorable (light) months for vegetation according to di Castri and Hajek (1976). Note that vegetation months for the humid-temperate forest are derived from the station 'Angol' which lies $50 \mathrm{~km}$ landwards from the National Park Nahuelbuta at ca. $80 \mathrm{~m}$ a. s. l., whereas the study site within the National Park lies at ca. $1200 \mathrm{~m}$ a. s. $l$.

\subsubsection{Labeled plant species}

Plant nutrient acquisition strategies can vary strongly between growth forms such as trees, shrubs, or herbaceous plants (Sala et al., 2012). It was not possible to label the same species at each site. Therefore, we elected woody species that accounted for at least $10 \%$ of the vegetation cover. To reduce differences between the chosen tree, shrub, and subshrub species, only specimens between 40 and $60 \mathrm{~cm}$ in height were included in the study. In the arid shrubland, we labeled the perennial woody shrub Gutierrezia resinosa (Hooker \& Arnott) Blake. The shrub prevails on sandy alkaline or neutral soils with low organic carbon and nitrogen contents (Solbrig, 1966). Of an overall plant cover of $30-40 \%$, G. resinosa accounted for $15 \%$ of the area. In the Mediterranean coastal matorral, we labeled the shrub Aristeguietia salvia (Colla) King \& Rob (other names Eupatorium salvia (Colla), Salvia macha, or pega-pega), which belongs to the Asteraceae family. It can be found in central Chile in low to mid altitudes (Chile Flora, 2020). Of an overall 100\% plant coverage, $A$. salvia accounted for $8 \%$ of the area (Bernhard et al., 2018). In the humid-temperate forest, we labeled Araucaria araucana (Molina) K. Koch, a coniferous tree species that belongs to the Araucariaceae family. Of an overall coverage of $100 \%$ in the understory, A. araucana made up for $40 \%$ of the area. 


\subsubsection{Sample analyses and calculations}

Plant and soil materials were dried at $60{ }^{\circ} \mathrm{C}$ and ground. The ${ }^{15} \mathrm{~N}:{ }^{14} \mathrm{~N}$ ratio and the total $\mathrm{N}$ content of samples was determined by an isotope ratio mass spectrometer (IRMS; Delta C, Finnigan MAT, Bremen, Germany) with a Conflo III interface (Thermo Electron Cooperation, Bremen, Germany) coupled to a NA1108 element analyzer (Fisons-Instruments, Milano, Italy). K, Rb, and Cs were extracted with nitric acid pressure digestion (König et al., 2005). Their concentrations were measured with an inductively coupled plasma mass spectrometer (ICP-MS; iCAPQ, Thermo Fisher Scientific, Bremen, Germany) and their stocks calculated subsequently. C:N and N:K ratios of plants and soil were calculated as molar ratios. The ${ }^{15} \mathrm{~N}$ recovery was calculated with the following equation:

$$
\left[{ }^{15} N\right]_{\text {acqui }}=[N]_{\text {lab }} * \frac{a t \%{ }^{15} N_{\text {lab }}-a t \%{ }^{15} N_{\text {nat }}}{a t \%{ }^{15} N_{\text {tracer }}-a t \%{ }^{15} N_{\text {nat }}}
$$

With $\left[{ }^{15} \mathrm{~N}\right]$ acqui as the ${ }^{15} \mathrm{~N}$ amount taken up $\left({ }^{15} \mathrm{~N}\right.$ in total plant dry biomass $\left.\left[\mathrm{mg} \mathrm{g}^{-1}\right]\right),[\mathrm{N}]$ lab as the $\mathrm{N}$ amount of the labeled plant material ( $\mathrm{N}$ in total plant dry biomass $\left[\mathrm{mg} \mathrm{g}^{-1}\right]$ ), at $\%{ }^{15} \mathrm{~N}_{\text {lab/nat/tracer }}$ as the at $\%{ }^{15} \mathrm{~N}$ of the labeled and non-labeled plant material as well as the injected tracer (99 at $\%$ ), respectively. $\left[{ }^{15} \mathrm{~N}\right]$ acqui was then related to the amount of the injected ${ }^{15} \mathrm{~N}$ to calculate the percentage of recovered tracer.

Similarly, $\mathrm{Rb}+\mathrm{Cs}$ recovery was calculated as follows:

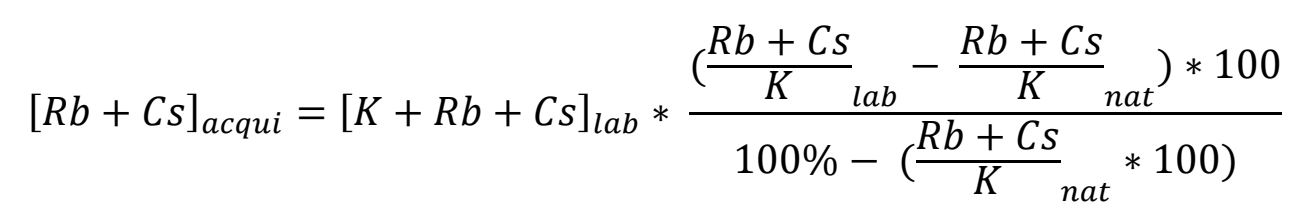

With $[\mathrm{Rb}+\mathrm{Cs}]_{\text {acqui }}$ as the $\mathrm{Rb}+\mathrm{Cs}$ amount taken up in total plant dry biomass $\left[\mathrm{mg} \mathrm{g}^{-1}\right],\left({ }^{\mathrm{Rb}+\mathrm{Cs}} / \mathrm{K}\right)_{\mathrm{lab} / \mathrm{nat}}$ as element ratios of labeled and natural abundance plant material, $[\mathrm{K}+\mathrm{Rb}+\mathrm{Cs}]_{\mathrm{lab}}$ as the sum of the element amount in the total plant dry biomass of labeled plants, and $100 \%$ as the proportion of $\mathrm{Rb}$ and $\mathrm{Cs}$ relative to the proportion of $\mathrm{K}(0 \%)$ in the added tracer. $[\mathrm{Rb}+\mathrm{Cs}]_{\mathrm{acqui}}$ was then related to the amount of injected $\mathrm{Rb}$ and $\mathrm{Cs}$ to calculate the obtained percentage of applied tracer.

\subsubsection{Statistical analyses}

R 3.6.1 (R Core Team, 2019) was used for all statistical tests. To evaluate element ratios (C:N and $\mathrm{N}: \mathrm{K}$ ) of plant material, linear mixed effect models (LME) ('lme4'; (Bates et al., 2015) with site as fixed effect were calculated. Plant compartments (shoot, root) and field replicate nested in slope and site were set as random effects. LMEs for soil stocks (of N, K, Rb, and Cs) and tracer recovery ( $\mathrm{K}$ analogs and ${ }^{15} \mathrm{~N}$ ) were calculated site separated. For soil stocks, label depth was set as fixed effect, and field replicates nested in slope as random effect. For tracer recovery and relative $\mathrm{K}$ to 
$\mathrm{N}$ recovery, depth was set as fixed effect and field replicates and plant compartments as random effects. Variables were pretested for normal distribution (Shapiro-Wilk test) and log transformed if the assumption was not met. With the multiple comparison function of the 'multcomp' package (Hothorn et al., 2008), $p$ values were extracted with a significance level of $\alpha \leq 0.05$.

Further, natural ${ }^{15} \mathrm{~N}$ abundance of plant biomass and bulk topsoil (unpublished data) as well as the vertical distribution of exchangeable $\mathrm{K}$ and sodium (Na) (from Bernhard et al., 2018), were used to evaluate the long-term plant $\mathrm{N}$ recycling and $\mathrm{K}$ uplift. The contrasts between exchangeable $\mathrm{K}$ and $\mathrm{Na}$ along soil profiles can be used to estimate the long-term $\mathrm{K}$ uplift by roots, based on the assumption of preferential cycling of nutrients (Jobbágy and Jackson, 2004, 2001; Porder and Chadwick, 2009) and the absence of recycling for ballast elements such as Na. Without plant uplift, the vertical distribution of $\mathrm{K}^{+}$would follow the pattern of $\mathrm{Na}^{+}$that is not actively acquired by plants (Jobbágy and Jackson, 2001).

A redundancy analysis (RDA) was performed to evaluate the effects of abiotic and biotic parameters on $\mathrm{K}$ and $\mathrm{N}$ acquisition (= response variables) with the 'vegan' package (Oksanen et al., 2017). Precipitation ( $\mathrm{mm}$ ) and frequency (i.e. number of days with precipitation) during the experiment, clay content, $C: \mathrm{N}_{\text {soil }}, \mathrm{C}: \mathrm{N}_{\text {plant }}$, and $\mathrm{N}: \mathrm{K}_{\text {plant }}$ were set as explanatory variables. As plant nutrient uptake also depends on the microbial activity at the place of acquisition, bacterial and fungal (DNA) abundances (unpublished data) and activities of extracellular proteases and chitinases per soil organic carbon (SOC) (from Stock et al., 2019) were included as explanatory variables. Missing values were imputed with n-components = 2 ('missMDA'; Josse and Husson, 2016). The RDA was calculated on scaled data and are presented as type II scaling (correlation) plots.

\subsubsection{Results}

\subsubsection{Nitrogen and potassium tracer recovery}

Nitrogen and $\mathrm{K}$ acquisitions from topsoil (A-Bw horizons), subsoil (Bw-BCw horizons), and saprolite (below $\mathrm{BCw}$ horizon) were determined by recovery of ${ }^{15} \mathrm{~N}$ for nitrogen and $\mathrm{Cs}+\mathrm{Rb}$ for potassium. $\mathrm{K}$ analogs and ${ }^{15} \mathrm{~N}$ recovery were similar from all depths under arid conditions (Figure 2.1-2). Under Mediterranean conditions, on the contrary, tracers for both nutrients were dominantly retrieved from the topsoil (in shoots: 190 times and 37 times higher than from saprolite for $\mathrm{N}$ and $\mathrm{K}$, respectively). Under humid conditions, ${ }^{15} \mathrm{~N}$ recovery was similar from topsoil and subsoil but was lowest from saprolite ( $50 \%$ lower than top- and subsoil) (Figure 2.1-2). 

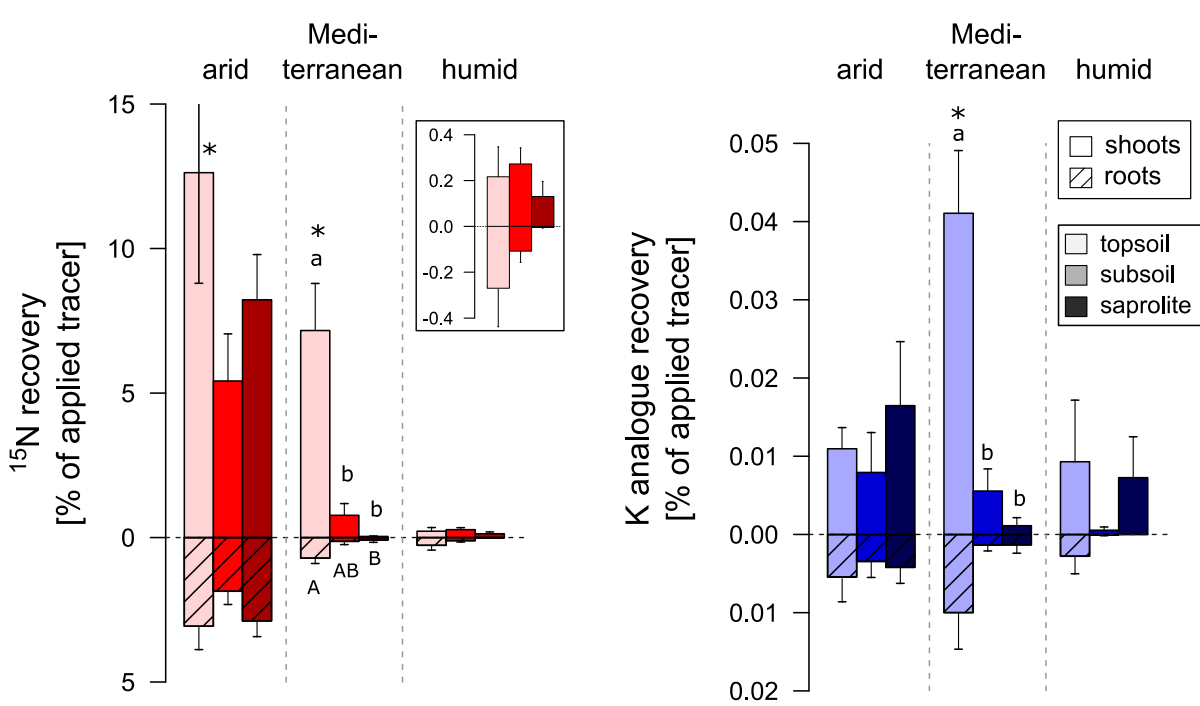

Figure 2.1-2: Tracer recovery of $N\left({ }^{15} \mathrm{~N}\right.$, left $)$ and $K(R b+C s$ as $K$ analogs, right $)$ from topsoil, subsoil, and saprolite in shoots (top) and roots (bottom) in the three study sites: arid shrubland, Mediterranean coastal matorral, humid-temperate forest. ${ }^{15} \mathrm{~N}$ recovery under forest is additionally presented on a smaller y-axis (inset box). Data are presented as means $(n=8)$ with standard errors. Significant differences $(p<0.05)$ between depths are indicated with lowercase letters for shoots and with capital letters for roots within sites. Asterisks indicate significant differences between plants within sites.

While almost no $\mathrm{K}$ analogs were retrieved from subsoil under humid conditions, recovery from topsoil and saprolite were similar. Those preferential uptake depths showed no relation to $\mathrm{N}$ and $\mathrm{K}$ stocks (Figure 2.1-3). Under Mediterranean and humid conditions, recoveries of $\mathrm{K}$ analogs relative to ${ }^{15} \mathrm{~N}$ recovery was highest from saprolite (Figure 2.1-4), with 10 (Mediterranean) and 5 (humid) times more regained from saprolite than from topsoil. Under arid conditions, on the contrary, relative K analogs recovery was similar from all depths. (Figure 2.1-4).

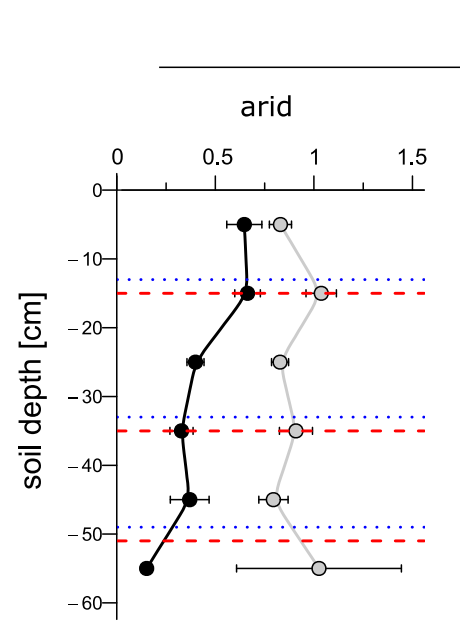

$\mathrm{K}$ and $\mathrm{N}$ stocks $\left[\mathrm{Mg} \mathrm{ha}{ }^{-1}\right]$

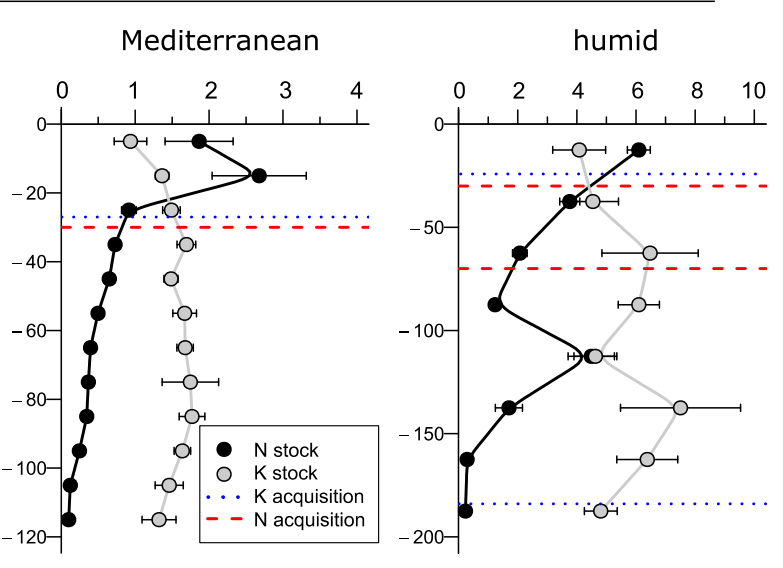

Figure 2.1-3: Depth profiles of total potassium $(K)$ and nitrogen $(N)$ stocks in $10 \mathrm{~cm}$ depth increments in the arid shrubland and Mediterranean coastal matorral, and in $25 \mathrm{~cm}$ depth increments in the humid-temperate forest. Data are presented as means $(n=3)$ with standard errors. Dashed and dotted lines indicate preferential acquisition depths of the respective nutrient (blue dotted $=$ $K$; red dashed $=N$ ) derived from the tracer recoveries (see Fig. 1). Note the different soil depth scales for the three sites. 


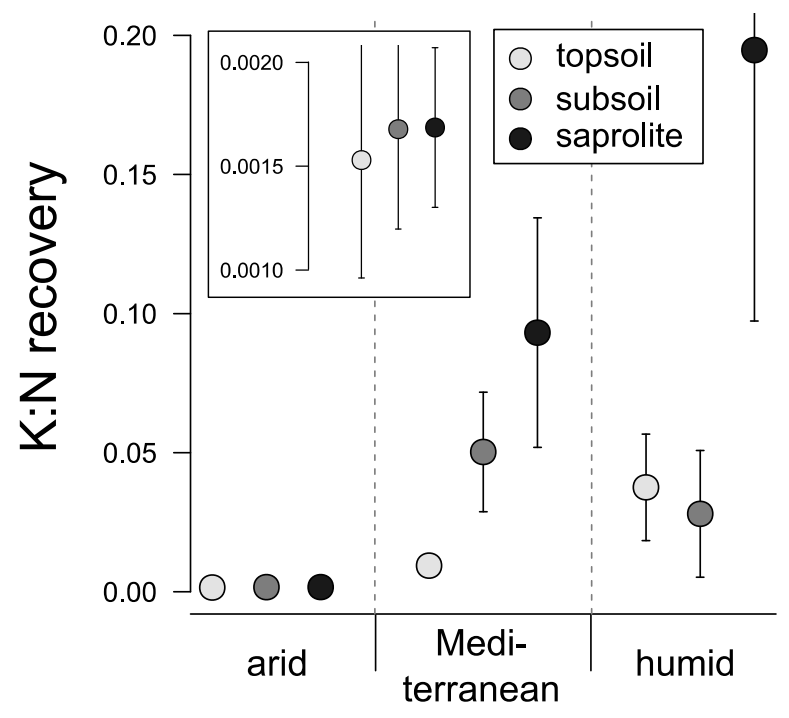

Figure 2.1-4: Relative $K$ analog recovery per unit $N$ recovery from topsoil, subsoil, and saprolite in the three study sites: arid shrubland, Mediterranean coastal matorral, humid-temperate forest. Relative $K$ analog recovery under shrubland is additionally presented on a smaller y-axis (insert box). Data are presented as means with standard errors. Differences between depths within sites were not significant $(p>0.05)$.

\subsubsection{Nutrient distributions}

Potassium and $\mathrm{N}$ stocks in soil increase with increasing precipitation (Figure 2.1-3). In the Mediterranean and humid ecosystems, $\mathrm{N}$ stocks were high in the topsoil and decreased with depth (Figure 2.1-3). The only exception was in the humid-temperate forest in 100-125 cm soil depth, at the interface of subsoil to saprolite (Oeser et al., 2018), where N (and C) stocks were exceptionally high. The $\mathrm{N}$ stocks decrease only minimal with depth under arid conditions (Figure 2.1-3). Contrary to total $\mathrm{K}$ stocks, exchangeable $\mathrm{K}$ decreased markedly with increasing depth in all ecosystems (Figure 2.1-5). Exchangeable Na, on the contrary, was close to 0 throughout the depth profiles under humid and Mediterranean conditions but increased strongly with depth under arid conditions (Figure 2.1-5). In comparison, the percentage of $\mathrm{K}$ saturation of the total cation exchange capacity (CEC) $(\% \mathrm{~K})$ was 8,78 , and 6 times higher than $\% \mathrm{Na}$ in the upper $10 \mathrm{~cm}$ in the arid, Mediterranean, and humid ecosystems, respectively (Figure 2.1-5).

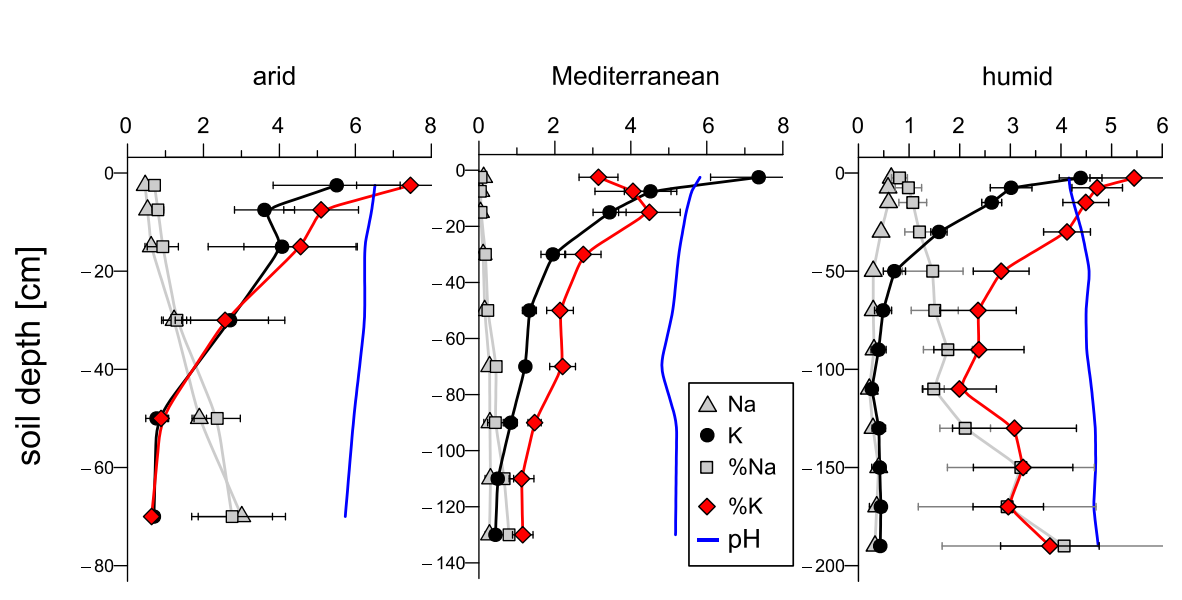

Figure 2.1-5: Vertical distribution of exchangeable $K$ and $\mathrm{Na}(\mathrm{K}, \mathrm{Na})$ [ $\mathrm{umol}_{\mathrm{c}} \mathrm{g}^{-1}$, percentage of $K$ and $N a$ to total cation exchange capacity $(\% K$, $\% \mathrm{Na}$ ) as well as $\mathrm{pH}$ in the three study sites: arid shrubland, Mediterranean coastal matorral, humid-temperate forest. Data were taken from Bernhard et al. (2018) and are presented as means of top, mid, and bottom slope positioned soil pits with standard errors. Error bars for $\mathrm{pH}$ are omitted for clarity. Note the different soil depth scales for the three sites. 


\subsubsection{Natural ${ }^{15} \mathrm{~N}$ abundance}

Shoot natural ${ }^{15} \mathrm{~N}$ abundance decreased with increasing precipitation, from $3 \% \pm 0.6$ in G. resinosa in the arid shrubland to $-5 \% \neq \pm 0.5$ in A. araucana in the humid-temperate forest (Figure 2.1-6). In each site, shoots were ${ }^{15} \mathrm{~N}$-depleted compared to topsoil $\delta^{15} \mathrm{~N}$. The strongest depletion of shoots $(\Delta>10 \%)$ was observed in the humid ecosystem. Root $\delta^{15} \mathrm{~N}$ were similar between ecosystems and strongly ${ }^{15} \mathrm{~N}$-depleted compared to topsoil $\delta^{15} \mathrm{~N}$ in all ecosystems $(\Delta 11 \%$ in the arid shrubland, $\Delta 4 \%$ in the Mediterranean coastal matorral, and $\Delta 9 \%$ in the humidtemperate forest (Figure 2.1-6)).

Plant C:N ratios of Araucaria araucana in the humid-temperate forest were 2 and 1.7 times higher than for shrubs in the Mediterranean and arid ecosystems, respectively (Figure 2.1-6). Plant N:K ratios were highest in G. resinosa in the arid ecosystem, with 1.7- and 1.5-times higher ratios than of Aristeguietia salvia and Araucaria araucana, respectively (Figure 2.1-6).
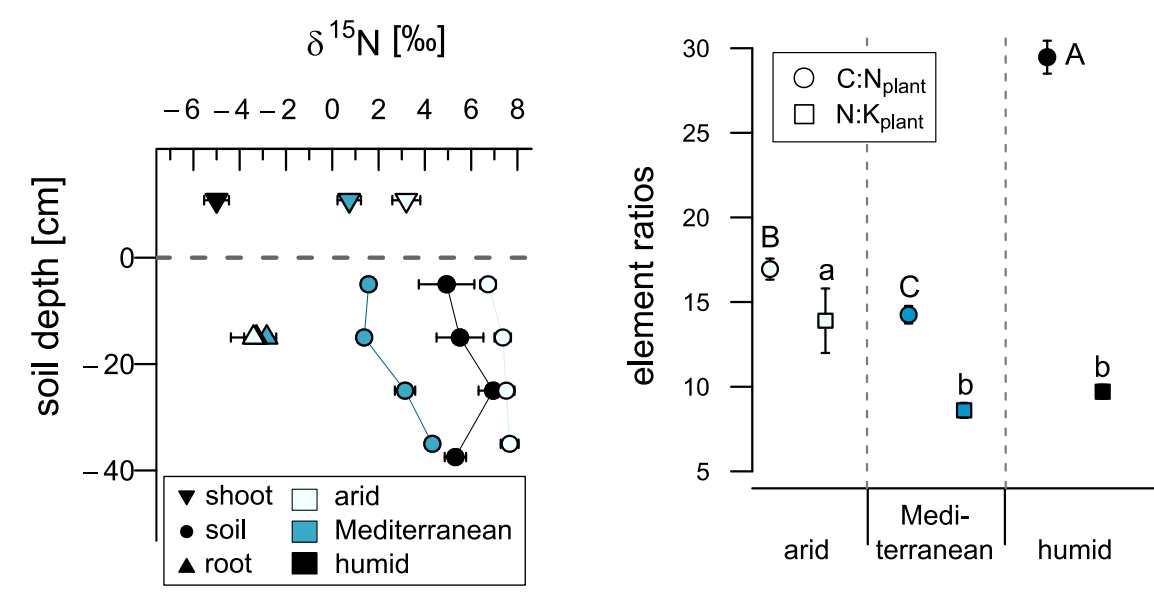

Figure 2.1-6: ${ }^{15} \mathrm{~N}$ natural abundance ( $\delta^{15} N$ signatures) of shoots (above the 0-line), roots, and topsoil (left), and plant $C: N$ and $N: K$ ratios (right) in the three study sites: arid shrubland, Mediterranean coastal matorral, humidtemperate forest. Data are presented as means with standard errors. Significant differences $(p<0.05)$ between sites are indicated with capital letters for $C: N_{\text {plant }}$ and with lowercase letters for $N$ : $K_{\text {plant }}$.

\subsubsection{Cross-biome analysis}

In the cross-biome redundancy analysis (Figure $2.1-7),{ }^{15} \mathrm{~N}$ recovery $\left(\mathrm{N}_{\mathrm{acq}}\right)$ in plants was strongly related to the relative abundance of bacteria and activity of proteases. Greater bacterial abundance and activity of $\mathrm{N}$ cycling related enzymes intensify $\mathrm{N}$ mineralization and so, support plant $\mathrm{N}$ nutrition. However, ${ }^{15} \mathrm{~N}$ recovery in plants did not relate to the relative activity of chitinase (NAG). Higher precipitation and frequency reduced plant ${ }^{15} \mathrm{~N}$ recovery (Figure 2.1-7) because of leaching. The ${ }^{15} \mathrm{~N}$ recovery was higher at lower $\mathrm{C}: \mathrm{N}_{\text {soil }}$ (i.e. greater $\mathrm{N}$ availability in soil). Higher C: $\mathrm{N}_{\text {plant }}$ (i.e. greater plant $\mathrm{N}$ demand) did not increase $\mathrm{N}$ uptake (Figure 2.1-7). Similar as for ${ }^{15} \mathrm{~N}$ recovery, increasing plant $\mathrm{K}$ demand (i.e. higher $\mathrm{N}: \mathrm{K}_{\text {plant }}$ ) did not increase recovery of $\mathrm{K}$ analogs. $\mathrm{K}$ analog recoveries were higher with greater exchangeable $\mathrm{K}$ availability in soil but clay content and precipitation, on the contrary, did not affect $\mathrm{K}$ uptake (Figure 2.1-7). Tracer recovery for $\mathrm{K}$ and $\mathrm{N}$ 
did not relate to each other, suggesting that specific factors and processes determine the uptake of both nutrients.

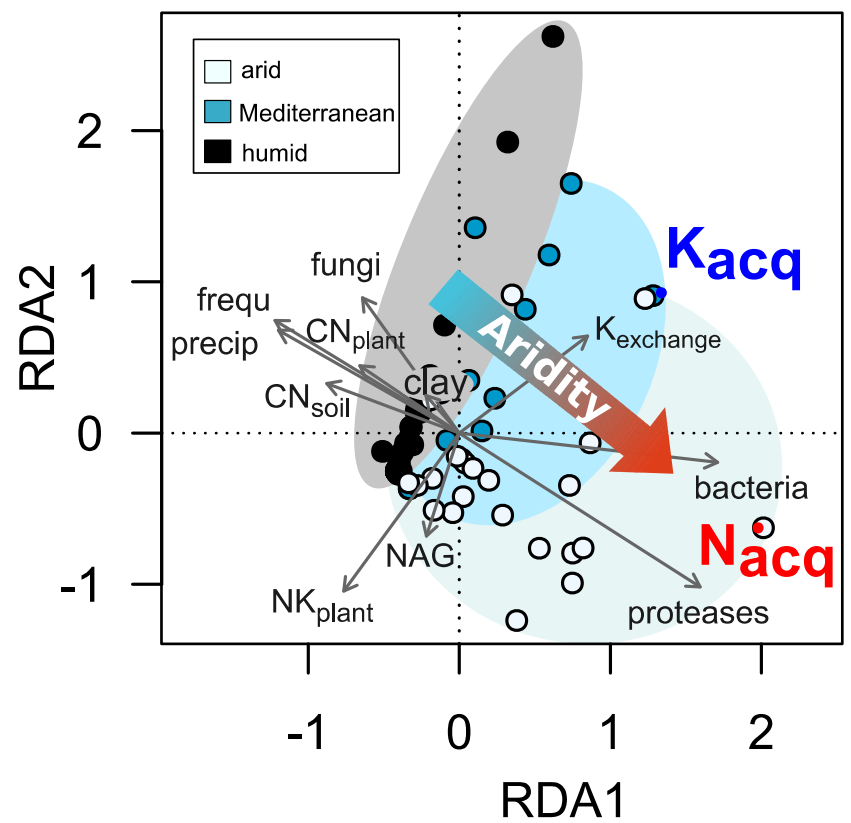

Figure 2.1-7: Cross-biome redundancy analysis (RDA) for ${ }^{15} \mathrm{~N}$ and $K$ tracer recovery $\left(N_{a c q}, K_{a c q}\right)$, presented as type II scaling (correlation) plot. Explanatory variables: sum of precipitation (precip) and days with precipitation (frequ) during the 8 month of the experiment, $C: N_{\text {plant/soil }}, N: K_{\text {plant }}$, exchangeable $K\left(K_{\text {exchange }}\right)$, and clay content as well as fungal and bacterial DNA abundance (fungi, bacteria) and protease and chitinase (NAG) activities relative to soil organic carbon. The overall RDA was significant with 999 permutations.

\subsubsection{Discussion}

\subsubsection{Plant nutrient acquisition under aridity}

Water availability in deep soil is often seen as the dominant factors driving plants to extend their root system to deeper horizons in arid ecosystems (Bleby et al., 2010; Canadell et al., 1996; Lee et al., 2018; Muñoz et al., 2008). Low nutrient availability in topsoil (e.g. due to limited diffusion in dry soils) can further drive plants to expand their root system downwards to cover their nutrient demand (Canadell et al., 1996; Hodge, 2004; McCulley et al., 2004). Deep soil horizons are nutrient-poorer (esp. in the case of $\mathrm{N}$ ) but nutrients may be easier accessible than in dry topsoils (McCulley et al., 2004). The comparison of the vertical distributions of exchangeable $\mathrm{K}$ and $\mathrm{Na}$ as well as $\mathrm{K}$ and $\mathrm{Na}$ saturation of $\mathrm{CEC}$, displayed that $\mathrm{K}$ is acquired and uplifted by plants from deep soil horizons and accumulated within the topsoil in the arid shrubland ecosystem over long terms (>decades) (Figure 2.1-5; Jobbágy and Jackson, 2004, 2001). Similar K analog recoveries throughout the soil profile demonstrated that short-term ( $<1$ year) acquisition is vertically uniform (Figure 2.1-2). The acquisition from saprolite and the $\mathrm{K}$ uplift under arid conditions might indicate ongoing biological weathering in depth. This process can be an important strategy for plants under arid conditions to acquire rock-derived nutrients in soils that are extremely water-limited most of the year (Smits et al., 2012). In line with this, Köster et al. (under review) identified biological weathering by plant-released organic acids as an important process that drives plant phosphorus acquisition in soils of the same arid shrubland. 
Contrary to $\mathrm{K}$, constant ${ }^{15} \mathrm{~N}$ natural abundance with depth (unpublished data) suggested the absence of notable vertical movement of $\mathrm{N}$ in the arid shrubland integrated over long terms. A similar ${ }^{15} \mathrm{~N}$ recovery from topsoil, subsoil, and saprolite (Figure 2.1-2), however, highlighted that plants at the arid site do explore deeper soil for $\mathrm{N}$ sources such as dead roots or microbial necromass. ${ }^{15} \mathrm{~N}$ depletion of shoots $(\Delta \sim 3 \%)$ and roots $(\Delta \sim 11 \%$ ) in comparison to bulk topsoil (Figure 2.1-6) implied the reutilization (and retention) of mineralized (and ${ }^{15} \mathrm{~N}$-depleted) $\mathrm{N}$ under aridity (McCulley et al., 2009). Low litter input and low water availability, however, likely prevent plants in the arid site to rely solely on $\mathrm{N}$ recycling from litterfall.

\subsubsection{Plant nutrient acquisition under Mediterranean conditions}

A temporal decoupling of microbial and plant activities due to brief and small water pulses under semiarid conditions can result in the accumulation of highly mobile $\mathrm{NO}_{3}{ }^{-}$in topsoil (McCulley et al., 2009; Reichmann et al., 2013; Schwinning and Sala, 2004). The regression of the soil $\delta^{15} \mathrm{~N}$ to the negative $\log$ arithm of $\mathrm{N}$ content $(-\ln (\% \mathrm{~N}))$ was analyzed as an integration of the ${ }^{15} \mathrm{~N}$ enrichment with increasing depth (i.e. soil age) (data not shown). The ${ }^{15} \mathrm{~N}$ enrichment with depth was strongest (i.e. had the largest regression slope) in the Mediterranean coastal matorral across the precipitation gradient, indicating the fastest $\mathrm{N}$ mineralization (Billings and Richter, 2006; Nadelhoffer and Fry, 1988). The great potential for nutrient losses likely results from the highest denudation rates at this site under Mediterranean conditions compared to the other sites of the precipitation gradient (Schaller et al., 2018; van Dongen et al., 2019).

In such an ecosystem with high losses, plants need to adapt to fast and efficiently exploit available nutrients from topsoil. A low ${ }^{15} \mathrm{~N}$ depletion of aboveground plant biomass $(\Delta \sim 1 \%$ ) compared to bulk topsoil as well as a lower ${ }^{15} \mathrm{~N}$ depletion of $A$. salvia roots in the Mediterranean ecosystem $(\Delta \sim 4 \%$ ) than of plants in the arid or humid ecosystems (Figure 2.1-6), however, indicated that long-term reutilization of ${ }^{15} \mathrm{~N}$-depleted mineral $\mathrm{N}$ by plants is low (McCulley et al., 2009). Low long-term retention of $\mathrm{N}$ by plants is likely related to the high $\mathrm{N}$ losses via erosion and denudation in the Mediterranean site (Schaller et al., 2018).

High $\mathrm{N}$ tracer recovery from topsoil (Figure 2.1-2), however, indicated a strong short-term reutilization of mobile and available $\mathrm{N}$. High short-term $\mathrm{N}$ acquisition from topsoil as well as a high proportion of fine roots in the upper $10 \mathrm{~cm}$ (Stock et al., under review), suggest that plants in the Mediterranean ecosystem have adapted to acquire accumulated mineral $\mathrm{N}$ fast from the upper nutrient-rich soil. An extensive root system in the topsoil can already utilize light rainfalls that do not percolate to deeper soil but quickly evaporate (Fernández, 2007; Hodge, 2010). Thereby, these fine roots can acquire available $\mathrm{N}$ fast and efficiently (Dunbabin et al., 2003; Reich, 2014). Shortterm recycling and fast utilization of available $\mathrm{N}$ is an important strategy to retain $\mathrm{N}$ within the 
ecosystem and ensure plant nutrition. ${ }^{15} \mathrm{~N}$ recovery from subsoil (Figure 2.1-2), displayed that plants further recapture and uplift $\mathrm{N}$ as an additional strategy to reduce $\mathrm{N}$ losses.

Similarly, the highest K tracer recovery from topsoil (Figure 2.1-2) pointed to an adaptation of plants to recapture $\mathrm{K}$ released from litter. Greater relative $\mathrm{K}$ acquisition (per acquired $\mathrm{N}$ ) by roots in depth than roots in topsoil (Figure 2.1-4), suggested further that subsoil and especially saprolite roots have a higher ability to take up $\mathrm{K}$ than topsoil roots. A higher efficiency could result, for example, from the expression of active high-affinity $\mathrm{K}^{+}$transporters in response to low concentrations of available $\mathrm{K}$ in depth (Ragel et al., 2019). These findings highlight that plants do not only reutilize $\mathrm{K}$ from topsoil, but also uplift the nutrient from depth. Especially in such a system with high denudation rates (Schaller et al., 2018; van Dongen et al., 2019), the uplift can be an important strategy to replenish topsoil K pools over long terms (Uhlig and von Blanckenburg, 2019). This is supported by comparing the vertical distributions of exchangeable $\mathrm{K}$ and $\mathrm{Na}$, which indicated the long-term $\mathrm{K}$ uplifted by plants and its accumulation in topsoil (Figure 2.1-5; Jobbágy and Jackson, 2004, 2001).

\subsubsection{Plant nutrient acquisition under humid conditions}

In ecosystems with high precipitation and primary productivity, nutrient recycling is intensive as resource demands of a large standing biomass are high. A strong long-term $\mathrm{N}$ recycling in the humid-temperate forest is indicated by a high ${ }^{15} \mathrm{~N}$ depletion of aboveground and belowground plant biomass compared to topsoil $\delta^{15} \mathrm{~N}(\Delta \sim 9-10 \%$; Figure 2.1-6). $\mathrm{N}$ tracer recovery, however, reveals that $\mathrm{N}$ is not only reutilized from topsoil, but also recaptured from subsoil (Figure 2.1-2, Figure 2.1-3). Mobile nutrients such as nitrate $\left(\mathrm{NO}_{3}{ }^{-}\right)$are highly susceptible to leaching at the humid site with MAP of $>1500 \mathrm{~mm} \mathrm{a}^{-1}$. But despite the high annual precipitation and the resulting high leaching, retention of mineral $\mathrm{N}$ in soils under humid temperate rainforests in southern Chile is high (Huygens et al., 2008; Perakis and Hedin, 2002, 2001). Davidson et al. (2003) described the abiotic $\mathrm{NO}_{3}{ }^{-}$immobilization in dissolved organic matter (DOM) by the reduction with $\mathrm{Fe}(\mathrm{II})$ in the 'Ferrous Wheel'. Fe(III) in anoxic microsites will be reduced to Fe(II), which can in turn reduce $\mathrm{NO}_{3}^{-}$to nitrite $\left(\mathrm{NO}_{2}^{-}\right)$. $\mathrm{NO}_{2}^{-}$can then react with DOM. This mechanism was recently confirmed under controlled conditions for an Andosol from the southern Chilean Andes (Matus et al., 2019). High primary productivity of the humid-temperate forest, large SOC in top- and subsoil as well as high precipitation, lead to intensive $\mathrm{O}_{2}$ consumption and possibly to many anaerobic microsites. Bernhard et al. (2018) determined dithionite-citrate $\left(\mathrm{Fe}_{\mathrm{d}}\right)$ and ammonium-oxalate $\left(\mathrm{Fe}_{\mathrm{ox}}\right)$ extracted iron in the humid site (see Figure S 2.1-2). Higher pedogenic and active iron oxides above than below $100 \mathrm{~cm}$ soil depth coincide with the $\mathrm{N}$ acquisition $\left({ }^{15} \mathrm{~N}\right.$ recovery) from the upper and intermediate depth (Figure $\mathrm{S}$ 2.1-2). This alignment may indicate that mobile $\mathrm{N}$ is retained 
from further leaching by the abiotic immobilization with iron and is subsequently stored in longterm plant available forms for plant uplift.

High $\mathrm{K}$ tracer recovery by $A$. araucana from topsoil indicated that $\mathrm{K}$ released from litter is reutilized and retained by plants in the humid-temperate forest (Figure 2.1-2). Similar tracer recovery from saprolite, however, highlights further that $\mathrm{K}$ is not only reutilized within the topsoil, but also uplifted by plants from saprolite (here from $2 \mathrm{~m}$ depth). Losses of $\mathrm{K}$ from topsoil (via surface run-off and erosion) are likely replenished by uplift of leached $\mathrm{K}$ or of $\mathrm{K}$ released by saprolite weathering (Brantley et al., 2017; Jobbágy and Jackson, 2004; Uhlig and von Blanckenburg, 2019). The vertical distribution of exchangeable $\mathrm{K}$ and $\mathrm{Na}$ saturation of CEC (Figure 2.1-5) indicates further that plant uplift of $\mathrm{K}$ serves to replenish topsoil pools over long terms (Jobbágy and Jackson, 2001). This is supported by a higher relative $\mathrm{K}$ acquisition from saprolite than subsoil or topsoil (Figure 2.1-4). It might indicate that roots in saprolite are more efficient in $\mathrm{K}$ uptake than roots in top- or subsoil and underlines the importance of deep roots for plant $\mathrm{K}$ acquisition under humid conditions.

\subsubsection{4 $\mathrm{N}$ and $\mathrm{K}$ acquisition on cross-biome scale}

An RDA was conducted to decipher driving factors of short-term $(<1$ year) plant $\mathrm{N}$ and $\mathrm{K}$ acquisition along the precipitation gradient. The extent to which conclusions from such a comparison can be drawn are restricted as life strategies of the included shrubs (G. resinosa, A. salvia) and the tree species (A. araucana) - and thus their resource economics - differ. As plant life strategies are adaptations to the prevailing environmental conditions, and we only chose woody perennial species of similar height $(40-60 \mathrm{~cm})$, we do, however, see the potential that especially those differences in strategies can provide insight into drivers of plant nutrient acquisition on a cross-biome scale.

A missing relation between $\mathrm{N}$ and $\mathrm{K}$ tracer recovery (Figure 2.1-7) suggested that different drivers and processes control the plant acquisition of either nutrient. Variables that changed along the precipitation gradient determined $\mathrm{N}$ acquisition such as relative bacterial abundance and activity (i.e. protease activity) and soil $\mathrm{N}$ availability (i.e. $\mathrm{C}: \mathrm{N}_{\text {soil }}$ ). With higher $\mathrm{N}$ availability, plant $\mathrm{N}$ acquisition increases and reduces plant demand for $\mathrm{N}$ (i.e. lower $\mathrm{C}: \mathrm{N}_{\text {plant }}$ ). That higher plant $\mathrm{N}$ demand did not increase $\mathrm{N}$ acquisition likely suggests that short-term plant uptake is stronger restricted by the availability in soil (as a result of microbial organic matter decomposition and $\mathrm{N}$ mineralization) than driven by the plant's need for N. Bacteria can temporary immobilize great portions of $\mathrm{N}$ in their biomass (Bengtsson et al., 2003), thereby preventing ecosystems from mineral $\mathrm{N}$ losses by leaching but often leading to strong competition between microorganisms and plants (Kuzyakov and $\mathrm{Xu}, 2013$ ). The high correspondence of bacteria and proteases with $\mathrm{N}$ 
acquisition displayed that plants take up more $\mathrm{N}$ when bacteria are abundant and active (i.e. high protease activity). Under such conditions, $\mathrm{N}$ release via $\mathrm{N}$ mineralization exceeds $\mathrm{N}$ immobilization by bacteria under (semi)arid conditions, which increases $\mathrm{N}$ acquisition.

Contrary to N, K acquisition did not relate to precipitation (Figure 2.1-7). $\mathrm{K}$ is a key regulator in plants' water balance (Cakmak, 2005; Sardans and Peñuelas, 2015) and was acquired by plants to a greater extent under aridity than under humid conditions (Rivas-Ubach et al., 2012; Sardans et al., 2012). Therefore, a stronger relation of $\mathrm{K}$ acquisition to precipitation was expected. The dominant factor driving the acquisition, however, was the availability of exchangeable $\mathrm{K}$ in soil and not $\mathrm{K}$ demand (i.e. high $\mathrm{N}: \mathrm{K}_{\text {plant }}$ ). Similar as for $\mathrm{N}$, this likely indicates that the short-term $\mathrm{K}$ acquisition is dominantly driven by $\mathrm{K}$ availability in soil and not by plant requirements.

These findings on $\mathrm{N}$ and $\mathrm{K}$ acquisition may indicate that the short-term plant acquisition ( $<1$ year) of OM-derived $(\mathrm{N})$ and rock-born $(\mathrm{K})$ nutrients is strongest restricted by environmental factors and that climate change impacts on biogeochemical cycling are most likely dominating the effect on whole ecosystem cycling and vegetation nutrient supply.

\subsubsection{Conclusions}

Objective of this study was to evaluate two main processes of nutrient retention in ecosystems nutrient recycling and uplift - for the elements $\mathrm{N}$ and $\mathrm{K}$ as an adaptation to arid, Mediterranean, or humid-temperate conditions. Understanding nutrient retention processes is important to anticipate plant community responses to climatic changes and, therefore, to evaluate the impact of such changes on ecosystem stability. Within this aim we localized plant $\mathrm{N}$ and $\mathrm{K}$ acquisition from topsoil to saprolite (up to $2 \mathrm{~m}$ depth) and determined the importance of nutrient recycling and uplift by ${ }^{15} \mathrm{~N}$ natural abundance and the vertical distribution of exchangeable $\mathrm{K}$. The focus on nutrient recycling from topsoil in the Mediterranean and humid ecosystem is an efficient strategy to retain nutrients and reduce losses against leaching. This strategy, however, might be a disadvantage under prolonged dry periods and decreasing water availability, as predicted for the Mediterranean and humid ecosystem. Prolonged drought (1) will result in intensive drying of topsoil, reducing nutrient mineralization, mobility and uptake, and (2) can lead to substantial root dieback in topsoil. This will have especially severe consequences for plant in the Mediterranean ecosystem with high proportions of fine roots in the upper $10 \mathrm{~cm}$. Deep roots (as in the humid and partially the Mediterranean ecosystem), however, will allow plants to (a) recapture previously leached nutrients and uplift newly weathering-released nutrients, and to (b) access deep water resources to maintain nutrient acquisition even under extensive dry periods. Thus, especially deeprooting plants will profit from the predicted climate change scenarios in the humid-temperate and Mediterranean ecosystem. 
If fewer but larger rain events result in deeper infiltration, lower evaporation and, thus, greater water availability for plants and microbes in depth under arid conditions, deep rooting species in the arid shrubland such as G. resinosa, are at an advantage and further shrub encroachment is promoted. Additionally, plants profit from an accelerated SOM decomposition and $\mathrm{N}$ mineralization under greater water availability. Depending on the intensity of rain events, however, fewer but larger rain events will lead to larger run-off, which would result in great soil erosion from these shallow soils, and massive losses of topsoil nutrient stocks. Plants in this system are not adapted to high losses or to exploit available resources fast and could not retain nutrients against increased leaching and erosion. Greater nutrient losses would decrease long-term (>decades) recycling efficiency from topsoil and require a reconstruction of the vegetation composition and adaptive traits similar to that of Mediterranean species, i.e. intensifying shortterm $(<1$ year) recycling and accelerating saprolite weathering.

\subsubsection{Acknowledgements}

We thank the Chilean National Park Service Corporación Nacional Forestal (CONAF) for the permission to work in the National Park La Campana and the National Park Nahuelbuta as well as the Center for Advanced Research in Arid Zones (CEAZA) for the possibility to work in the National Reserve Santa Gracia. We also thank Karin Schmidt for her support with lab analyses as well as the whole team of the Centre for Stable Isotope Research and Analysis (KOSI). This study was funded by the German Research Foundation (DFG) [project number KU 1184/36-1 and DI 2136-11] within the Priority Program 1803 'EarthShape - Earth Surface Shaping by Biota'.

\subsubsection{Conflict of Interest}

The authors declare that the research was conducted in the absence of any commercial or financial relationships that could be construed as a potential conflict of interest.

\subsubsection{References}

Austin, A.T., Yahdjian, L., Stark, J.M., Belnap, J., Porporato, A., Norton, U., Ravetta, D.A., Schaeffer, S.M., 2004. Water pulses and biogeochemical cycles in arid and semiarid ecosystems. Oecologia 141, 221-235. https://doi.org/10.1007/s00442004-1519-1

Bates, D., Mächler, M., Bolker, B., Walker, S., 2015. Fitting Linear Mixed-Effects Models Using Ime4. J. Stat. Softw. 67. https://doi.org/10.18637/jss.v067.i01

Bedel, L., Poszwa, A., van der Heijden, G., Legout, A., Aquilina, L., Ranger, J., 2016. Unexpected calcium sources in deep soil layers in low-fertility forest soils identified by strontium isotopes (Lorraine plateau, eastern France). Geoderma 264, 103-116. https://doi.org/10.1016/j.geoderma.2015.09.020

Bengtsson, G., Bengtson, P., Månsson, K.F., 2003. Gross nitrogen mineralization-, immobilization-, and nitrification rates as a function of soil $\mathrm{C} / \mathrm{N}$ ratio and microbial activity. Soil Biol. Biochem. 35, 143-154. https://doi.org/10.1016/S00380717(02)00248-1

Bernhard, N., Moskwa, L.-M., Schmidt, K., Oeser, R.A., Aburto, F., Bader, M., Baumann, K., von Blanckenburg, F., Boy, J., van den Brink, L., Brucker, E., Büdel, B., Canessa, R., Dippold, M.A., Ehlers, T.A., Fuentes, J.P., Godoy, R., Jung, P., Karsten, U., Köster, M., Kuzyakov, Y., Leinweber, P., Neidhardt, H., Matus, F., Mueller, C.W., Oelmann, Y., Oses, R., Osses, P., Paulino, L., Samolov, E., Schaller, M., Schmid, M., Spielvogel, S., Spohn, M., Stock, S., Stroncik, N., Tielbörger, K., Übernickel, K., Scholten, T., Seguel, O., Wagner, D., Kühn, P., 2018. Pedogenic and microbial 
interrelations to regional climate and local topography: new insights from a climate gradient (arid to humid) along the Coastal Cordillera of Chile. Catena.

Billings, S.A., Richter, D.D., 2006. Changes in stable isotopic signatures of soil nitrogen and carbon during 40 years of forest development. Oecologia 148, 325-333. https://doi.org/10.1007/s00442-006-0366-7

Bleby, T.M., Mcelrone, A.J., Jackson, R.B., 2010. Water uptake and hydraulic redistribution across large woody root systems to $20 \mathrm{~m}$ depth: Hydraulic redistribution across deep root systems. Plant Cell Environ. 33, 2132-2148. https://doi.org/10.1111/j.1365-3040.2010.02212.x

Blume, H.-P., Brümmer, G.W., Horn, R., Kandeler, E., Kögel-Knabner, I., Kretzschmar, R., Stahr, K., Wilke, B.-M., 2010. Böden als Pflanzenstandorte, in: Blume, H.-P., Brümmer, G.W., Horn, R., Kandeler, E., Kögel-Knabner, I., Kretzschmar, R., Stahr, K., Wilke, B.-M. (Eds.), Scheffer/Schachtschabel: Lehrbuch Der Bodenkunde. Springer Berlin Heidelberg, Berlin, Heidelberg, pp. 379-448. https://doi.org/10.1007/978-3-662-49960-3_9

Boy, J., Valarezo, C., Wilcke, W., 2008. Water flow paths in soil control element exports in an Andean tropical montane forest. Eur. J. Soil Sci. 59, 1209-1227. https://doi.org/10.1111/j.1365-2389.2008.01063.x

Brantley, S.L., Eissenstat, D.M., Marshall, J.A., Godsey, S.E., Balogh-Brunstad, Z., Karwan, D.L., Papuga, S.A., Roering, J., Dawson, T.E., Evaristo, J., Chadwick, O., McDonnell, J.J., Weathers, K.C., 2017. Reviews and syntheses: on the roles trees play in building and plumbing the critical zone. Biogeosciences 14, 5115-5142. https://doi.org/10.5194/bg-145115-2017

Cakmak, I., 2005. The role of potassium in alleviating detrimental effects of abiotic stresses in plants. J. Plant Nutr. Soil Sci. 168, 521-530. https://doi.org/10.1002/jpln.200420485

Canadell, J., Jackson, R.B., Ehleringer, J.B., Mooney, H.A., Sala, O.E., Schulze, E.-D., 1996. Maximum rooting depth of vegetation types at the global scale. Oecologia 108, 583-595. https://doi.org/10.1007/BF00329030

Center for Climate and Resilience Research $(\mathrm{CR})^{2}$, 2020. Datos de precipitación [WWW Document]. URL http://www.cr2.cl/datosde-precipitacion/?cp_Precipitacion=3 (accessed 1.29.20).

Chen, J., Kuzyakov, Y., Jenerette, G.D., Xiao, G., Liu, W., Wang, Z., Shen, W., 2019. Intensified Precipitation Seasonality Reduces Soil Inorganic N Content in a Subtropical Forest: Greater Contribution of Leaching Loss Than $\mathrm{N}_{2} \mathrm{O}$ Emissions. J. Geophys. Res. Biogeosciences 124, 494-508. https://doi.org/10.1029/2018JG004821

Chile Flora, 2020. Aristeguietia salvia (Colla) R.M. King \& H. Rob [WWW Document]. URL http://chileflora.com/Florachilena/FloraSpanish/HighResPages/SH0400.htm (accessed 4.26.20).

Christensen, J.H., Hewitson, B., Busuioc, A., Chen, A., Gao, X., Held, I., Jones, R., Kolli, R.K., Laprise, R., Magaña, C.G., Menendez, C.G., Raisanen, J., Rinde, A., Sarr, A., Whetton, P., 2007. Regional Climate Projections. In: Climate Change 2007: The Physical Science Basis, Contribution of Working Group I to the Fourth Assessment Report of the Intergovernmental Panel on Climate Change. Cambridge University Press, Cambridge ; New York.

Davidson, E.A., Chorover, J., Dail, D.B., 2003. A mechanism of abiotic immobilization of nitrate in forest ecosystems: the ferrous wheel hypothesis. Glob. Change Biol. 9, 228-236. https://doi.org/10.1046/j.1365-2486.2003.00592.x

Dawson, T.E., Hahm, W.J., Crutchfield-Peters, K., 2020. Digging deeper: what the critical zone perspective adds to the study of plant ecophysiology. New Phytol. 226, 666-671. https://doi.org/10.1111/nph.16410

di Castri, F., Hajek, E.R., 1976. Bioclimatologia de Chile. Vicerrectoria Acad. Univ. Catol. Chile 163.

Dunbabin, V., Diggle, A., Rengel, Z., 2003. Is there an optimal root architecture for nitrate capture in leaching environments? Plant Cell Environ. 26, 835-844. https://doi.org/10.1046/j.1365-3040.2003.01015.x

Dunbabin, V., Rengel, Z., Diggle, A.J., 2004. Simulating form and function of root systems: efficiency of nitrate uptake is dependent on root system architecture and the spatial and temporal variability of nitrate supply. Funct. Ecol. 18, 204211. https://doi.org/10.1111/j.0269-8463.2004.00827.x

Ehlers, T.A., von Blanckenburg, F., Übernickel, K., 2017. EarthShape weather station data collection. Retrieved from https://esdynamics.geo.uni-tuebingen.de/earthshape/index.php?id=68.

Fernández, R.J., 2007. On the frequent lack of response of plants to rainfall events in arid areas. J. Arid Environ. 68, 688-691. https://doi.org/10.1016/j.jaridenv.2006.07.004

Fick, S.E., Hijmans, R.J., 2017. WorldClim 2: new 1-km spatial resolution climate surfaces for global land areas: New Climate Surfaces for Global Land Areas. Int. J. Climatol. 37, 4302-4315. https://doi.org/10.1002/joc.5086

Fitter, A.H., 1986. Spatial and temporal patterns of root activity in a species-rich alluvial grassland. Oecologia 69, 594-599. https://doi.org/10.1007/BF00410368

Gao, X.-L., Li, X.G., Zhao, L., Kuzyakov, Y., 2019. Regulation of soil phosphorus cycling in grasslands by shrubs. Soil Biol. Biochem. 133, 1-11. https://doi.org/10.1016/j.soilbio.2019.02.012

Garreaud, R.D., 2011. Cambio Climático: Bases Físicas e Impactos en Chile 14.

Gessler, A., Schaub, M., McDowell, N.G., 2017. The role of nutrients in drought-induced tree mortality and recovery. New Phytol. 214, 513-520. https://doi.org/10.1111/nph.14340

Göransson, H., Rosengren, U., Wallander, H., Fransson, A.-M., Thelin, G., 2006. Nutrient acquisition from different soil depths by pedunculate oak. Trees 20, 292-298. https://doi.org/10.1007/s00468-005-0034-2

Hodge, A., 2010. Roots: The Acquisition of Water and Nutrients from the Heterogeneous Soil Environment, in: Lüttge, U., Beyschlag, W., Büdel, B., Francis, D. (Eds.), Progress in Botany 71. Springer Berlin Heidelberg, Berlin, Heidelberg, pp. 307-337. https://doi.org/10.1007/978-3-642-02167-1_12

Hodge, A., 2004. The plastic plant: root responses to heterogeneous supplies of nutrients. New Phytol. 162, 9-24. https://doi.org/10.1111/j.1469-8137.2004.01015.x

Hoekstra, N.J., Finn, J.A., Buchmann, N., Gockele, A., Landert, L., Prill, N., Scherer-Lorenzen, M., Lüscher, A., 2014. Methodological tests of the use of trace elements as tracers to assess root activity. Plant Soil 380, $265-283$. https://doi.org/10.1007/s11104-014-2048-2

Hoekstra, N.J., Suter, M., Finn, J.A., Husse, S., Lüscher, A., 2015. Do belowground vertical niche differences between deep- and shallow-rooted species enhance resource uptake and drought resistance in grassland mixtures? Plant Soil 394, 21-34. https://doi.org/10.1007/s11104-014-2352-x

Hothorn, T., Bretz, F., Westfall, P., 2008. Simultaneous Inference in General Parametric Models. Biom J 50, 346-363. 
Huygens, D., Boeckx, P., Templer, P., Paulino, L., Van Cleemput, O., Oyarzún, C., Müller, C., Godoy, R., 2008. Mechanisms for retention of bioavailable nitrogen in volcanic rainforest soils. Nat. Geosci. 1, 543-548. https://doi.org/10.1038/ngeo252

IPCC, 2014. Climate Change 2014: Synthesis Report. Contribution of Working Groups I, II and III to the Fifth Assessment Report of the Intergovernmental Panel on Climate Change [Core Writing Team, Pachauri, R.K and Meyer, A. (eds.)]. IPCC, Geneva, Switzerland.

IPCC, 2007. Climate Change 2007: Synthesis Report. Contribution of Working Groups I, II and III to the Fourth Assessment Report of the Intergovernmental Panel on Climate Change [Core Writing Team, Pachauri, R.K and Reisinger, A. (eds.)]. IPCC, Geneva, Switzerland.

Jobbágy, E.G., Jackson, R.B., 2004. The uplift of soil nutrients by plants: Biogeochemical consequences across scales. Ecology 85, 2380-2389. https://doi.org/10.1890/03-0245

Jobbágy, E.G., Jackson, R.B., 2001. The distribution of soil nutrients with depth: Global patterns and the imprint of plants. Biogeochemistry 53, 51-77.

Josse, J., Husson, F., 2016. missMDA: A Package for Handling Missing Values in Multivariate Data Analysis. J. Stat. Softw. 70. https://doi.org/10.18637/jss.v070.i01

Kautz, T., Amelung, W., Ewert, F., Gaiser, T., Horn, R., Jahn, R., Javaux, M., Kemna, A., Kuzyakov, Y., Munch, J.-C., Pätzold, S., Peth, S., Scherer, H.W., Schloter, M., Schneider, H., Vanderborght, J., Vetterlein, D., Walter, A., Wiesenberg, G.L.B., Köpke, U., 2013. Nutrient acquisition from arable subsoils in temperate climates: A review. Soil Biol. Biochem. 57, 1003-1022. https://doi.org/10.1016/j.soilbio.2012.09.014

Knapp, A.K., Beier, C., Briske, D.D., Classen, A.T., Luo, Y., Reichstein, M., Smith, M.D., Smith, S.D., Bell, J.E., Fay, P.A., Heisler, J.L., Leavitt, S.W., Sherry, R., Smith, B., Weng, E., 2008. Consequences of More Extreme Precipitation Regimes for Terrestrial Ecosystems. BioScience 58, 811-821. https://doi.org/10.1641/B580908

Knapp, A.K., Hoover, D.L., Wilcox, K.R., Avolio, M.L., Koerner, S.E., La Pierre, K.J., Loik, M.E., Luo, Y., Sala, O.E., Smith, M.D., 2015. Characterizing differences in precipitation regimes of extreme wet and dry years: implications for climate change experiments. Glob. Change Biol. 21, 2624-2633. https://doi.org/10.1111/gcb.12888

König, N., Versuchsanstalt, N.F., Analytik, M. des G.F., Stellvertreter, G., Blum, U., für Wald, B.L., Sachsen, L., Mitglieder, D., Bussian, B., Groeticke, K., 2005. Eine Loseblatt-Sammlung der Analysemethoden im Forstbereich Herausgegeben vom Gutachterausschuss Forstliche Analytik.

Kuzyakov, Y., Xu, X., 2013. Competition between roots and microorganisms for nitrogen: mechanisms and ecological relevance. New Phytol. 198, 656-669. https://doi.org/10.1111/nph.12235

Lee, E., Kumar, P., Barron-Gafford, G.A., Hendryx, S.M., Sanchez-Cañete, E.P., Minor, R.L., Colella, T., Scott, R.L., 2018. Impact of Hydraulic Redistribution on Multispecies Vegetation Water Use in a Semiarid Savanna Ecosystem: An Experimental and Modeling Synthesis. Water Resour. Res. 54, 4009-4027. https://doi.org/10.1029/2017WR021006

Mamolos, A.P., Elisseou, G.K., Veresoglou, D.S., 1995. Depth of Root Activity of Coexisting Grassland Species in Relation to N and P Additions, Measured Using Nonradioactive Tracers. J. Ecol. 83, 643. https://doi.org/10.2307/2261632

Matus, F., Stock, S., Eschenbach, W., Dyckmans, J., Merino, C., Nájera, F., Köster, M., Kuzyakov, Y., Dippold, M.A., 2019. Ferrous Wheel Hypothesis: Abiotic nitrate incorporation into dissolved organic matter. Geochim. Cosmochim. Acta 245, 514-524. https://doi.org/10.1016/j.gca.2018.11.020

McCulley, R.L., Burke, I.C., Lauenroth, W.K., 2009. Conservation of nitrogen increases with precipitation across a major grassland gradient in the Central Great Plains of North America. Oecologia 159, 571-581. https://doi.org/10.1007/s00442-008$1229-1$

McCulley, R.L., Jobbágy, E.G., Pockman, W.T., Jackson, R.B., 2004. Nutrient uptake as a contributing explanation for deep rooting in arid and semi-arid ecosystems. Oecologia 141, 620-628. https://doi.org/10.1007/s00442-004-1687-z

Muñoz, M.R., Squeo, F.A., León, M.F., Tracol, Y., Gutiérrez, J.R., 2008. Hydraulic lift in three shrub species from the Chilean coastal desert. J. Arid Environ. 72, 624-632. https://doi.org/10.1016/j.jaridenv.2007.09.006

Nadelhoffer, K.J., Fry, B., 1988. Controls on Natural Nitrogen-15 and Carbon-13 Abundances in Forest Soil Organic Matter. Soil Sci. Soc. Am. J. 52, 1633. https://doi.org/10.2136/sssaj1988.03615995005200060024x

Oeser, R.A., Stroncik, N., Moskwa, L.-M., Bernhard, N., Schaller, M., Canessa, R., van den Brink, L., Köster, M., Brucker, E., Stock, S., Fuentes, J.P., Godoy, R., Matus, F., Oses Pedraza, R., Osses McIntyre, P., Paulino, L., Seguel, O., Bader, M.Y., Boy, J., Dippold, M.A., Ehlers, T.A., Kühn, P., Kuzyakov, Y., Leinweber, P., Scholten, T., Spielvogel, S., Spohn, M., Übernickel, K., Tielbörger, K., Wagner, D., von Blanckenburg, F., 2018. Chemistry and Microbiology of the Critical Zone along a steep climate and vegetation gradient in the Chilean Coastal Cordillera. Catena.

Oksanen, J., Blanchet, G., Friendly, M., Kindt, R., Legendre, P., McGlinn, D., Minchin, P.R., O’Hara, R.B., Simpson, G.L., Solymos, P., Stevens, H.H., Szoecs, E., Wagner, H., 2017. vegan: Community Ecology Package.

Perakis, S.S., Hedin, L.O., 2002. Nitrogen loss from unpolluted South American forests mainly via dissolved organic compounds. Nature 415, 416-419. https://doi.org/10.1038/415416a

Perakis, S.S., Hedin, L.O., 2001. Fluxes and fates of nitrogen in soil of an unpolluted old-growth temperate forest, Southern Chile. Ecology 82, 2245-2260. https://doi.org/10.1890/0012-9658(2001)082[2245:FAFONI]2.0.CO;2

Porder, S., Chadwick, O.A., 2009. Climate and soil-age constraints on nutrient uplift and retention by plants. Ecology 90, 623636. https://doi.org/10.1890/07-1739.1

R Core Team, 2019. R: A Language and Environment for Statistical Computing. R Foundation for Statistical Computing, Vienna, Austria.

Ragel, P., Raddatz, N., Leidi, E.O., Quintero, F.J., Pardo, J.M., 2019. Regulation of K+ Nutrition in Plants. Front. Plant Sci. 10. https://doi.org/10.3389/fpls.2019.00281

Reich, P.B., 2014. The world-wide 'fast-slow' plant economics spectrum: a traits manifesto. J. Ecol. 102, $275-301$. https://doi.org/10.1111/1365-2745.12211

Reichmann, L.G., Sala, O.E., Peters, D.P.C., 2013. Water controls on nitrogen transformations and stocks in an arid ecosystem. Ecosphere 4, art11. https://doi.org/10.1890/ES12-00263.1 
Rennenberg, H., Dannenmann, M., Gessler, A., Kreuzwieser, J., Simon, J., Papen, H., 2009. Nitrogen balance in forest soils: nutritional limitation of plants under climate change stresses. Plant Biol. 11, 4-23. https://doi.org/10.1111/j.14388677.2009.00241.x

Rivas-Ubach, A., Sardans, J., Perez-Trujillo, M., Estiarte, M., Penuelas, J., 2012. Strong relationship between elemental stoichiometry and metabolome in plants. Proc. Natl. Acad. Sci. 109, 4181-4186. https://doi.org/10.1073/pnas.1116092109

Royo, A.A., Knight, K.S., 2012. White ash (Fraxinus americana) decline and mortality: The role of site nutrition and stress history. For. Ecol. Manag. 286, 8-15. https://doi.org/10.1016/j.foreco.2012.08.049

Sala, O.E., Golluscio, R.A., Lauenroth, W.K., Roset, P.A., 2012. Contrasting nutrient-capture strategies in shrubs and grasses of a Patagonian arid ecosystem. J. Arid Environ. 82, 130-135. https://doi.org/10.1016/j.jaridenv.2012.02.015

Sardans, J., Peñuelas, J., 2015. Potassium: a neglected nutrient in global change: Potassium stoichiometry and global change. Glob. Ecol. Biogeogr. 24, 261-275. https://doi.org/10.1111/geb.12259

Sardans, J., Peñuelas, J., Coll, M., Vayreda, J., Rivas-Ubach, A., 2012. Stoichiometry of potassium is largely determined by water availability and growth in Catalonian forests. Funct. Ecol. 26, 1077-1089. https://doi.org/10.1111/j.13652435.2012.02023.x

Schaller, M., Ehlers, T.A., Lang, K.A.H., Schmid, M., Fuentes-Espoz, J.P., 2018. Addressing the contribution of climate and vegetation cover on hillslope denudation, Chilean Coastal Cordillera $\left(26^{\circ}-38^{\circ} \mathrm{S}\right)$. Earth Planet. Sci. Lett. 489, $111-122$. https://doi.org/10.1016/j.epsl.2018.02.026

Schleuss, P.-M., Heitkamp, F., Sun, Y., Miehe, G., Xu, X., Kuzyakov, Y., 2015. Nitrogen Uptake in an Alpine Kobresia Pasture on the Tibetan Plateau: Localization by $15 \mathrm{~N}$ Labeling and Implications for a Vulnerable Ecosystem. Ecosystems 18, 946-957. https://doi.org/10.1007/s10021-015-9874-9

Schwinning, S., Sala, O.E., 2004. Hierarchy of responses to resource pulses in arid and semi-arid ecosystems. Oecologia 141, 211220. https://doi.org/10.1007/s00442-004-1520-8

Smits, M.M., Bonneville, S., Benning, L.G., Banwart, S.A., Leake, J.R., 2012. Plant-driven weathering of apatite - the role of an ectomycorrhizal fungus: Plant-driven fungal weathering of apatite. Geobiology 10, 445-456. https://doi.org/10.1111/j.1472-4669.2012.00331.x

Solbrig, O.T., 1966. The South American species of Gutierrezia. Contrib. Gray Herb. Harv. Univ. 3-42.

Stock, S.C., Köster, M., Dippold, M.A., Nájera, F., Matus, F., Merino, C., Boy, J., Spielvogel, S., Gorbushina, A., Kuzyakov, Y., 2019. Environmental drivers and stoichiometric constraints on enzyme activities in soils from rhizosphere to continental scale. Geoderma 337, 973-982. https://doi.org/10.1016/j.geoderma.2018.10.030

Trabucco, A., Zomer, R.J., 2018. Global Aridity Index and Potential Evapo-Transpiration (ET0) Climate Database v2. CGIAR Consortium for Spatial Information (CGIAR-CSI). Published online, available from the CGIAR-CSI GeoPortal at https://cgiarcsi.community 10.

Uhlig, D., von Blanckenburg, F., 2019. How Slow Rock Weathering Balances Nutrient Loss During Fast Forest Floor Turnover in Montane, Temperate Forest Ecosystems. Front. Earth Sci. 7, 159. https://doi.org/10.3389/feart.2019.00159

van Dongen, R., Scherler, D., Wittmann, H., von Blanckenburg, F., 2019. Cosmogenic ${ }^{10}$ Be in river sediment: where grain size matters and why. Earth Surf. Dyn. 7, 393-410. https://doi.org/10.5194/esurf-7-393-2019

Vergutz, L., Manzoni, S., Porporato, A., Novais, R.F., Jackson, R.B., 2012. Global resorption efficiencies and concentrations of carbon and nutrients in leaves of terrestrial plants. Ecol. Monogr. 82, 205-220. https://doi.org/10.1890/11-0416.1 


\subsubsection{Supplementary material}

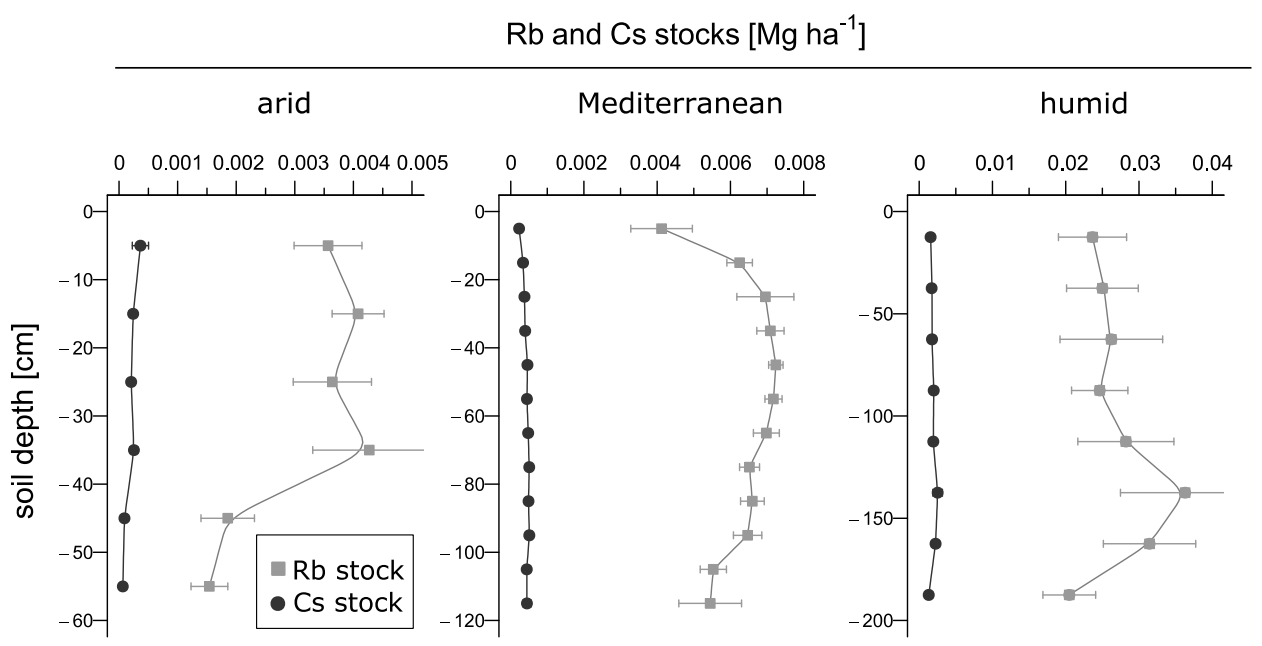

Figure S 2.1-1: Depth profiles of total rubidium ( $R b)$ and cesium (Cs) stocks in $10 \mathrm{~cm}$ depth increments in the arid shrubland and Mediterranean coastal matorral, and in $25 \mathrm{~cm}$ depth increments in the humid temperate forest. Data are presented as means $(n=3)$ with standard errors.

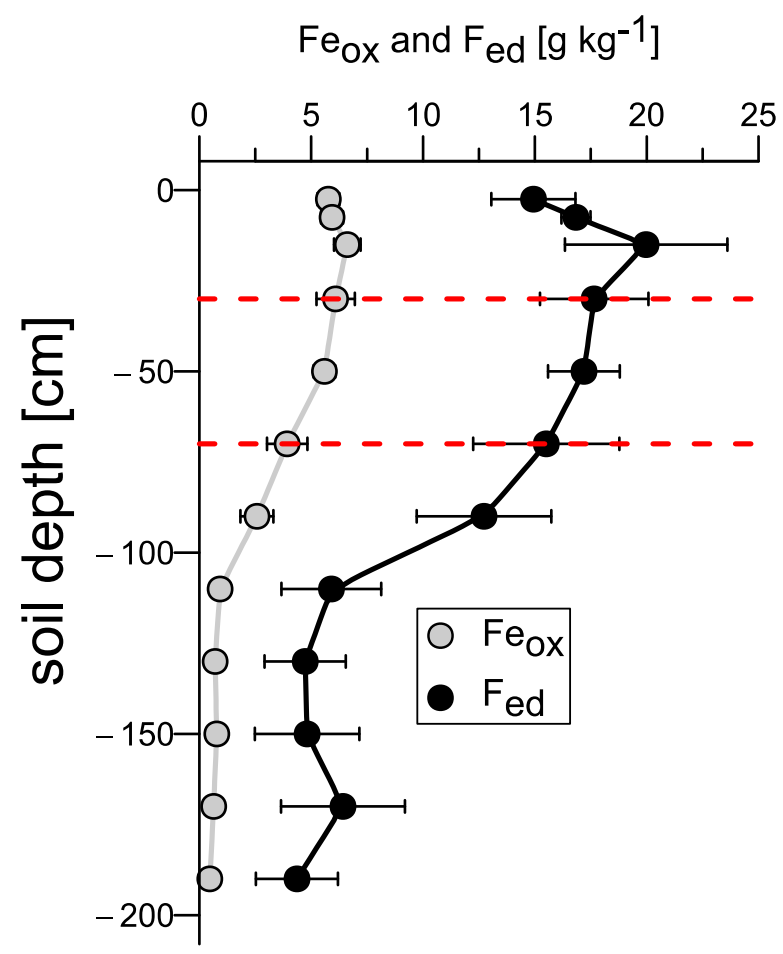

Figure S 2.1-2: Depth profiles of dithionite-citrate extracted (Fed) and ammonium-oxalate extracted iron (Feox) in the humid temperate forest. Data were taken from Bernhard et al. (2018) and are presented as means $(n=4)$ with standard errors. Red dashed lines indicate preferential acquisition depths of nitrogen under humid forest. 
2.2 Study 2: Plant investment in arbuscular mycorrhizal fungi for $\mathrm{N}$ and $\mathrm{P}$ acquisition - a cross-biome study along a precipitation gradient

Submitted to Science of the Total Environment, under review since 22.10.2020

$\underline{\text { Svenja C. Stock }}^{\mathrm{a}, \mathrm{b} * \text {, Moritz Koester }}{ }^{\mathrm{a}, \mathrm{c}}$, Jens Boy ${ }^{\mathrm{d}}$, Roberto Godoy ${ }^{\mathrm{e}}$, Francisco Nájera ${ }^{\mathrm{f}}$, Francisco Matus g,h, Carolina Merino ${ }^{\text {g,h }}$, Khaled Abdallah ${ }^{\mathrm{i}}$, Christoph Leuschner $^{\mathrm{j}}$, Sandra Spielvoge ${ }^{\mathrm{k}}$, Anna A. Gorbushina ${ }^{\mathrm{i}, \mathrm{l}}$; Yakov Kuzyakov ${ }^{\mathrm{b}, \mathrm{m}, \mathrm{n}, 1}$ and Michaela A. Dippold ${ }^{\mathrm{a}, 1}$

${ }^{1}$ Michaela A. Dippold and Yakov Kuzyakov should be considered joint senior author.

${ }^{\text {a }}$ Biogeochemistry of Agroecosystems, University of Goettingen, Goettingen, Germany

${ }^{\mathrm{b}}$ Soil Science of Temperate Ecosystems, University of Goettingen, Goettingen, Germany

${ }^{\mathrm{c}}$ Institute of Geography, University of Bern, Bern, Switzerland

${ }^{\mathrm{d}}$ Institute of Soil Science, Leibniz University Hannover, Hannover, Germany

${ }^{\mathrm{e}}$ Institute of Environmental and Evolutionary Science, Universidad Austral de Chile, Valdivia, Chile

${ }^{\mathrm{f}}$ Department of Engineering and Soils, Universidad de Chile, Santiago, Chile

${ }^{g}$ Laboratory of Conservation and Dynamic of Volcanic Soils, Department of Chemical Sciences and Natural Resources, Universidad de La Frontera, Temuco, Chile.

${ }^{\text {h }}$ Network for Extreme Environmental Research (NEXER) Universidad de La Frontera, Temuco, Chile.

${ }^{i}$ Department Materials and Environment, Federal Institute for Material Research and Testing, Berlin, Germany ${ }^{j}$ Plant Ecology and Ecosystem Research, University of Goettingen, Goettingen, Germany

${ }^{\mathrm{k}}$ Institute of Plant Nutrition and Soil Science, Christian-Albrechts University of Kiel, Kiel, Germany

${ }^{1}$ Institute of Biology and Department of Geosciences, Freie Universität Berlin, Berlin, Germany

${ }^{\mathrm{m}}$ Institute of Environmental Sciences, Kazan Federal University, Kazan, Russia

${ }^{\mathrm{n}}$ Agro-Technology Institute, RUDN University, Moscow, Russia

* Corresponding author: Svenja C. Stock

Keywords: natural ecosystems, temperate rain forest, arbuscular mycorrhiza, plant economic spectrum, nutrient retention 


\section{Abstract}

Arbuscular mycorrhizal fungi (AMF) are important partners in plant nutrition and fulfill multiple ecological functions. It remains unknown, however, which functions mycorrhiza play for which ecosystems in carbon $(\mathrm{C})$ and nutrient cycling with decreasing water availability.

At three study sites from arid (80 $\mathrm{mm} \mathrm{a}^{-1}$; arid shrubland) to Mediterranean (390 $\mathrm{mm} \mathrm{a}^{-1}$; coastal matorral), and humid conditions (>1500 $\mathrm{mm} \mathrm{a}^{-1}$; humid-temperate forest), the role of plant-AMF associations for plant nutrient acquisition was investigated. $\mathrm{A}{ }^{13} \mathrm{CO}_{2}$ pulse labeling of natural, woody vegetation was conducted and plant $\mathrm{C}$ allocation to AMF and roots assessed. Further, nitrogen $(\mathrm{N})$ and phosphorus $(\mathrm{P})$ availability, root traits, AMF root colonization and extraradical AMF mycelium (by phospho- and neutral lipid fatty acids $16: 1 \omega 5 \mathrm{c}$ )) were determined.

Traits of fine roots indicated a fast nutrient acquisition in the coastal matorral under Mediterranean conditions (experiencing high denudation rates) but indicated a slow nutrient acquisition in the humid-temperate forest (with low $\mathrm{N}$ and $\mathrm{P}$ availability) and arid shrubland (with water shortage). AMF abundance decreased from $45 \%$ to $20 \%$ root surface with increasing aridity. The extraradical AMF mycelium was supplied with $\mathrm{C}$ similarly, independent of precipitation (max. 0.2-0.5\% of assimilated ${ }^{13} \mathrm{C}$ ), to scavenge for $\mathrm{P}$ in all sites. In addition, the symbiosis between plant and fungi seemed to be strengthened for $\mathrm{N}$ transfer in the coastal matorral and humid-temperate forest by increasing root colonization. Further, the extraradical AMF mycelium seemed to be supplied with $\mathrm{C}$ to acquire $\mathrm{N}$ in the coastal matorral. Thereby, $\mathrm{AMF}$ exert a function that was not observed at the humid or arid site: retaining mobile nutrients and preventing losses from soil. Our study provides indications for the role of AMF not only in $\mathrm{P}$ but also in $\mathrm{N}$ nutrition of plants and underlines that ecosystem functions fulfilled by AMF are specific, depending on the existing environmental conditions. 


\subsubsection{Introduction}

Mycorrhizal symbiosis is one of the most common forms of mutualistic relationships, with crucial ecological and evolutionary roles in the terrestrial colonization of vascular plants (Brundrett and Tedersoo, 2018, Parniske, 2008). In exchange for photosynthetic carbon (C), arbuscular mycorrhizal fungi (AMF) transfer resources to their host plants (Allen, 2007; Fellbaum et al., 2012; Ryan et al., 2012). An extensive hyphal network enlarges the soil volume from which nutrients can be absorbed and expands the range far beyond the rhizosphere. Especially in dry soils, with low nutrient mobility, AMF can be crucial to ensure plant survival (Marulanda et al., 2003). Besides the nutritional benefits the symbiosis, AMF can provide various other ecosystem functions such as alleviating osmotic stress for plants (Aroca et al., 2013; Delavaux et al., 2017; Khalvati et al., 2005), stabilizing soil by increasing soil aggregation (Rillig and Mummey, 2006), and intermediately store and retain nutrients against leaching and gaseous losses (Bowles et al., 2018; Cavagnaro et al., 2015; Köhl and van der Heijden, 2016). The services AMF provide depend strongly on the environmental conditions the AMF community is adapted to (Antunes et al., 2011; Bennett and Classen, 2020; Johnson et al., 2003).

An expansion of the extraradical mycelium as well as the fine root system is essential for plants to assure a sufficient nutrient supply. Plants exhibit a plasticity of root traits in response to nutrient availability (Reich, 2014). 'Fast' or 'acquisitive' root traits (high specific root lengths (SRL), small diameter, low tissue density (RTD), high root $\mathrm{N}$ content) are advantageous under high nutrient availability - allowing plants to exploit resources fast and outcompete neighbors - but come at the cost of a reduced root lifespan due to increased sensitivity to dehydration and decomposition (de Vries et al., 2016; McCormack and Iversen, 2019; Reich, 2014). Roots with 'slow' or 'conservative' traits, on the contrary, have longer lifespans but a lower ability for nutrient uptake (McCormack and Iversen, 2019; Reich, 2014).

Water shortage strongly modulates root architecture and might overrule plants' reaction to nutrient availability. Under prolonged water shortage, plants can avoid dehydration while maintaining growth by extending their (fine) root system into deep soil layers, where they can scavenge for deep water sources (Muñoz et al., 2008; Nicotra et al., 2002; Sala et al., 2012). Under moderate or short droughts, on the contrary, plants mainly need to tolerate the dry period and prevent tissue damage, but do not invest to scavenge for deep water sources (Bristiel et al., 2019; Pérez-Ramos et al., 2013).

Precipitation regimes (i.e. frequency and duration of droughts) as well as the availability of nutrients (e.g. $\mathrm{N}$ and $\mathrm{P}$ ) strongly determine plant productivity and shape the symbiosis between plants and AMF. The objective of this study was to assess the nutrient acquisition strategies of 
woody species along a precipitation gradient. We hypothesized that (1) plants express 'fast'/'acquisitive' root traits under high precipitation but 'slow'/'conservative' root traits under aridity, but that (2) increasing aridity leads to a higher relative fine root proportion with depth. We expected (3) that AMF are important for $\mathrm{P}$ acquisition in dry soils (due to low mobility of $\mathrm{P}$ ), but that AMF are important for $\mathrm{P}$ and $\mathrm{N}$ acquisition under higher precipitation (due to high demands of both nutrients). Further we expected that (4) plant C investment in AMF (absolute and relative to SOC) decreases with increasing aridity.

\subsubsection{Material and Methods}

\subsubsection{Study Area}

The study sites are located in the Chilean Coastal Cordillera, along a precipitation gradient from from $80 \mathrm{~mm} \mathrm{a}^{-1}$ mean annual precipitation (MAP) in the North to $>1500 \mathrm{~mm} \mathrm{a}^{-1}$ in the South (Fick and Hijmans, 2017). The northernmost site is classified as an arid ecosystem (arid shrubland) with an aridity index of 0.06 (Trabucco and Zomer, 2018). The site is located in a grazing exclusion area in Quebrada de Talca (30.05 S, $71.09 \mathrm{~W})$, at an altitude of $645 \mathrm{~m}$ a.s.l. and in $23 \mathrm{~km}$ distance from the Pacific Ocean. The monthly mean precipitation (MMP) and monthly mean temperature (MMT) for November, the month of the experiment, are $1 \mathrm{~mm}$ and $15.7{ }^{\circ} \mathrm{C}$ (Fick and Hijmans, 2017). The dominant soil type at this site are Cambisols, which are covered 30-40\% with vegetation dominated by drought-deciduous shrubs and cacti. The intermediate site is classified as a Mediterranean ecosystem (Mediterranean coastal matorral) with an aridity index of 0.24 (Armesto, 2007; Trabucco and Zomer, 2018). The site is located in the National Park La Campana $(32.96 \mathrm{~S}, 71.06 \mathrm{~W})$ at approximately $70 \mathrm{~km}$ northwest of Santiago and $43 \mathrm{~km}$ landwards, at an altitude of $730 \mathrm{~m}$ a.s.1. MMP and MMT for November are $10 \mathrm{~mm}$ and $15.5^{\circ} \mathrm{C}$ (Fick and Hijmans, 2017). The vegetation covered $100 \%$ of the Cambisols, dominated by evergreen-sclerophyllous trees, deciduous shrubs, and a dense herb layer (Bernhard et al., 2018). The southernmost site is classified as a humid ecosystem (humid-temperate forest) with an aridity index of 1.4 (Trabucco and Zomer, 2018). The site is located in the National Park Nahuelbuta (37.81 S, 73.01 W) at 1240 $\mathrm{m}$ a.s.l. elevation and in $55 \mathrm{~km}$ distance to the Pacific Ocean. MMP and MMT for November are $59 \mathrm{~mm}$ and $7.0{ }^{\circ} \mathrm{C}$ (Fick and Hijmans, 2017). The vegetation covered $100 \%$ of the Umbrisols and Podzols, dominated by evergreen conifers Araucaria araucana (Mol.) K. Koch and winter deciduous broadleaved Nothofagus spp. trees, with a rich understory. From North to South, soils developed on similar granitoid parent material. For a more detailed site description, please refer to Bernhard et al. (2018) and Oeser et al. (2018). 


\subsubsection{2 ${ }^{13} \mathrm{CO}_{2}$ pulse labeling and sampling}

To quantify belowground $\mathrm{C}$ investment of plants, ${ }^{13} \mathrm{C}$ tracer applications are widely used (Gavito and Olsson, 2003; Kuzyakov and Domanski, 2000; Sommer et al., 2017). A ${ }^{13} \mathrm{CO}_{2}$ pulse-labeling experiment was conducted in November 2016. We used 60x60x60 cm chambers with polyethylene foil, letting through photosynthetic relevant radiation, to provide a ${ }^{13} \mathrm{CO}_{2}$-enriched atmosphere. 3 g of $\mathrm{Na}_{2}{ }^{13} \mathrm{CO}_{3}\left({ }^{13} \mathrm{C}\right.$ enrichment $99 \%$, Sigma Aldrich, Munich, Germany) were dissolved in $50 \mathrm{ml}$ $\mathrm{H}_{2} \mathrm{O}$ and placed inside the chambers before sealing them with moist soil. To generate ${ }^{13} \mathrm{CO}_{2}$, the $\mathrm{CO}_{2}$ moiety of $\mathrm{Na}_{2}{ }^{13} \mathrm{CO}_{3}$ was transferred into the gaseous phase by adding $5 \mathrm{M} \mathrm{H}_{2} \mathrm{SO}_{4}$, which was applied with a syringe through the polyethylene foil. The puncture holes were sealed to prevent ${ }^{13} \mathrm{CO}_{2}$ loss. The labeling time varied between sites according to weather conditions (see Table 2.2-1). Temperature within the chambers was checked and reduced with ice packs and ventilation to keep it below a maximum of $+10^{\circ} \mathrm{C}$ above ambient temperature. At each site, 4 plants were labeled on south-facing slopes in 2 to $3 \mathrm{~m}$ distance from each other. Soil and root samples were taken at 4 time points: before labeling ( $0 \mathrm{~d}), 1$ day after labeling $(1 \mathrm{~d}), 3$ days after $(3 \mathrm{~d})$, and 14 days after (14 d) from 0-10 cm and 20-30 cm soil depth. The samples were taken with a root corer (8 $\mathrm{cm}$ in diameter) directly next to the labeled specimen. The soil and plant samples were frozen at $-20{ }^{\circ} \mathrm{C}$.

Table 2.2-1: Weather conditions during days of labeling and labeling durations.

\begin{tabular}{|c|c|c|c|c|c|c|}
\hline & date & $\begin{array}{c}\text { duration } \\
\text { [min] }\end{array}$ & $\mathrm{T}_{\text {air }}\left[{ }^{\circ} \mathrm{C}\right]^{*}$ & $\begin{array}{c}\text { Air pressure } \\
{[\mathrm{hPa}]^{*}}\end{array}$ & $\begin{array}{l}\text { Precipitation } \\
\quad[\mathrm{mm}]^{*}\end{array}$ & $\begin{array}{c}\text { Solar } \\
\text { radiation } \\
{\left[\mathrm{W} \mathrm{m}^{-2}\right]^{*}}\end{array}$ \\
\hline arid shrubland & 12./13.11.16 & 90 & $17-18.5$ & 950 & 0 & $540-770$ \\
\hline $\begin{array}{c}\text { Mediterranean } \\
\text { coastal } \\
\text { matorral }\end{array}$ & 17./18.11.16 & 60 & $22-33$ & 965 & 0 & $890-915$ \\
\hline $\begin{array}{c}\text { humid } \\
\text { temperate } \\
\text { forest }\end{array}$ & $25 . / 26.11 .16$ & 180 & $8-9.5^{\circ} \mathrm{C}$ & 875 & $0-0.2$ & $280-400$ \\
\hline
\end{tabular}

\subsubsection{Labeled plant species}

Above and belowground plant $\mathrm{C}$ investment as well as plant nutrient acquisition strategies can vary strongly between growth forms such as trees, shrubs, or herbaceous plants (Sala et al., 2012). It was not possible to label the same species at each site. Therefore, we elected woody species that accounted for at least $10 \%$ of the vegetation cover. To reduce differences between the chosen tree, shrub, and subshrub species, only specimens between 40 and $60 \mathrm{~cm}$ in height were included in the 
study. At the arid shrubland site, the species Gutierrezia resinosa (Hooker \& Arnott) Blake was labeled, which is a perennial woody shrub from the Asteraceae family that can reach growth heights of up to $1.5 \mathrm{~m}$ (Solbrig, 1966). G. resinosa can be found mainly at low altitudes (Solbrig, 1966). The shrub prevails on sandy alkaline or neutral soils with low organic $\mathrm{C}$ and $\mathrm{N}$ contents (Solbrig, 1966). Overall, $40 \%$ of the study area was covered with vegetation, of which G. resinosa accounted for $15 \%$ (i.e., $6 \%$ of the total area).

At the Mediterranean coastal matorral, the species Erigeron fasciculatus (Colla) was labeled, which is a perennial subshrub with a maximum growth height of $70 \mathrm{~cm}$ (Andrus et al., 2009). It belongs to the Asteraceae family and is endemic to the Coquimbo-Valparaiso region and can be found at low and mid elevations (Andrus et al., 2009; Solbrig, 1962; Valdebenito et al., 1986). Of an overall $100 \%$ covered area, E. fasciculatus accounted for $10 \%$.

At the humid-temperate forest, the coniferous tree species Araucaria araucana (Molina) K. Koch was labeled, which belongs to the family of Araucariaceae. They are distributed in areas of mid and high elevations (from $600 \mathrm{~m}$ a.s.l. up to the timberline) with an annual precipitation between 1100 and $4000 \mathrm{~mm}$ (Diehl and Fontenla, 2010; Veblen, 1982). A. araucana are adapted to nutrient poor soils and can live up to 1000 years and reach growth heights of up to $45 \mathrm{~m}$ (Aguilera-Betti et al., 2017; Veblen, 1982). A. araucana accounted for $40 \%$ of the understory, which had a total coverage of $100 \%$. Contrary to conifers in the Northern Hemisphere, native conifers in the Southern Hemisphere, such as A. araucana, form only mycorrhizal symbioses with arbuscular mycorrhizal fungi (Diehl and Fontenla, 2010; Godoy et al., 1994).

\subsubsection{Analyses}

\subsection{Soil and plant analyses}

Soil samples were sieved $(2 \mathrm{~mm})$ and roots $(\varnothing<2 \mathrm{~mm})$ were picked out and collected. Organic C and total $\mathrm{N}$ contents of dried and ground soil and root material were determined with an elemental analyzer (Flash 2000, Thermo Fisher Scientific, Cambridge, UK). The stable C isotope ratios $\left({ }^{13} \mathrm{C} /{ }^{12} \mathrm{C}\right)$ of freeze-dried and ground roots were measured by an isotope ratio mass spectrometer (IRMS) (Delta V Advantage with Conflo III interface, Thermo Electron, Bremen, Germany). Total P content was extracted with nitric acid pressure digestion (König et al., 2005) and subsequently measured by an ICP-OES (Thermo Scientific iCap 6000 Series). C, N, and P stocks were calculated as the product of content, bulk density, and layer thickness. Further, plant available P ( $\left.\mathrm{P}_{\text {avail }}\right)$ that was determined by Bernhard et al. (2018) from soil samples of the same areas, was included in the analyses. The collected roots were washed and scanned with a flatbed scanner to determine root traits. The roots were not separated in dead or living roots or by species. The images were taken in $10.7 \mathrm{Mpx}$ resolution and subsequently analyzed with the image analyzing software 
WinRHIZO 2013e (Regent Instruments Inc., Québec, Canada). Roots were then dried at $70{ }^{\circ} \mathrm{C}$ until constant weight. Afterwards, root length density (RLD, $\mathrm{cm} \mathrm{cm}^{-3}$ ), specific root length (SRL, $\mathrm{m} \mathrm{g}^{-1}$ ), and root tissue density ( $\mathrm{RTD}, \mathrm{g} \mathrm{cm}^{-3}$ ) were calculated of fine roots with $\leq 1.0 \mathrm{~mm}$ diameter. SRL is calculated as the length:mass ratio, where mass can be replaced by the product of RTD and root volume (Ostonen et al., 2007).

\subsection{Root colonization with AMF}

Roots were stained following a modified method of Vierheilig et al. (1998), for which they were first heated with $10 \% \mathrm{KOH}$ in a water bath at $95{ }^{\circ} \mathrm{C}$ for 5 to 10 minutes. Strongly pigmented roots from the humid-temperate forest were additionally treated with $6 \% \mathrm{H}_{2} \mathrm{O}_{2}$ for 5 minutes. All roots were stained with a $5 \%$-ink-vinegar solution for $5 \mathrm{~min}$ at $95{ }^{\circ} \mathrm{C}$ and subsequently destained in acidified water for 30 minutes. Stained roots were then stored in glycerol at $4{ }^{\circ} \mathrm{C}$ until hyphae were counted. Percentage of root colonization with AMF was determined following a modified version of Nicolson's root segment \pm method (Nicolson, 1955) for which not AMF colonization per root length but per root area was determined. Therefore, images of stained roots were acquired using a light microscope (Olympus BX40 with Olympus CMOS-camera SC50M) with a magnification of 150x (Olympus Ach 10x/0.25 ph $\infty$ 0.17, ocular 15x, Olympus Europe SE \& Co. KG, Hamburg, Germany) in 4.9 Mpx resolution. For each sample, five root segments with $1 \mathrm{~cm}$ length each were analyzed. The whole segment was imaged and subsequently a grid was fitted onto the stitched image of each segment. Grid squares were then classified and counted as either containing only root tissue (-) or containing root tissue and fungal structures (+). A differentiation between hyphae, vesicles, and arbuscules was not done. To facilitate the classification and counting process, a software tool called 'Fungi Tagger' was developed, written in the programing language Python (see https://gitlab.gwdg.de/sstock1/fungi_tagger). The percentage of root colonized with fungi was then calculated by the relation of squares containing root and fungi structures to the total sum of squares containing fungi and/or root expressed as \% root area colonization. Working at a higher resolution and determining colonization per grid cell allowed to detect finer differences between sites, as the roots from all sites were highly colonized.

\subsection{Phospholipid and neutral lipid fatty acids}

Phospho- and neutral lipid fatty acids (PLFA, NLFA) can be used as specific biomarkers for microbial functional groups (Gavito and Olsson, 2003; Olsson et al., 1995). They were extracted by following a modified version of Frostegård et al. (1991) (see Dippold and Kuzyakov, 2016; Gunina et al., 2014): Neutral and phospholipids were extracted from $6 \mathrm{~g}$ of soil with a Bligh and Dyer solution (Bligh and Dyer, 1959). Subsequently, neutral and phospholipids were purified and separated using a solid phase extraction (SPE). The purified extracts were then hydrolyzed and 
methylated to fatty acid methyl esters (FAMEs). The samples were then measured on a gas chromatograph-mass spectrometry (GC-MS) system (GC 7820A, MS 5977B, Agilent Technologies, Waldbronn, Germany) for quantification as well as on an IRMS (Delta plus Thermo Fisher Scientific, Bremen, Germany) for isotope ratio determination. The calculations and drift corrections for obtaining $\mu \mathrm{g}$ FAME $\mathrm{g}^{-1}$ soil and $\mathrm{at} \%{ }^{13} \mathrm{C}$ of FAMES can be found in Dippold and Kuzyakov (2016).

PLFA 16:165c is used as an AMF-specific marker (Balser et al., 2005; Nilsson et al., 2004; Olsson et al., 1998) and will be used as proxy for the extent of the extraradical mycelium in soil. However, PLFA 16:1 $\omega 5 \mathrm{c}$ cannot only be produced by AMF but also by Gram-negative bacteria (Frostegård and Bååth, 1996). A more specific marker is NLFA 16:105c, which is a storage compound solely produced by AMF (Ngosong et al., 2012; Olsson, 1999). To determine whether the PLFA 16:165c is specific for AMF or originating from a background signal of bacteria, the ratio of $16: 1 \omega 5 \mathrm{c}$ NLFA:PLFA was calculated (Table 2.2-4) (Olsson, 1999). A ratio above 1 indicates that PLFA 16:1 $155 \mathrm{c}$ originate from AMF. For all sites and depths, the NLFA:PLFA ratio lay above 1, except in the upper $10 \mathrm{~cm}$ of soils at the arid site (Table 4). In the arid ecosystem the topsoil signal is likely influenced by soil biocrusts, which contain large numbers of potential PLFA 16:1 $105 \mathrm{c}$ producing bacteria. A low $\mathrm{C}$ availability at the arid site further limits the potential of AMF to build up storage compounds. Results of PLFA amounts and tracer incorporation into PLFA 16:105c, thus, must be interpreted carefully here. To be able to compare results between sites, PLFA and NLFA amounts were standardized to the soil organic carbon (SOC) content ( $\mu \mathrm{g} \mathrm{PLFA} \mathrm{g}^{-1}$ SOC).

\subsubsection{4 ${ }^{13} \mathrm{C}$ incorporation calculations}

The ${ }^{13} \mathrm{C}$ incorporation of applied tracer (parts per mill, \%o) into the pools shoot, root, soil, PLFA 16:1 $\omega 5 \mathrm{c}$, and NLFA 16:1 $\omega 5 \mathrm{c}$ was calculated by the following equation (Gearing et al., 1991):

$$
{ }^{13} C_{\text {inc }}=\frac{a t \%_{\text {lab }}-a t \%_{\text {ref }}}{a t \%_{\text {tracer }}-a t \%_{\text {ref }}} * 1000[\% 0]
$$

with at $\%_{\text {ref }}$ of the unlabeled samples, at $\%$ lab of the labeled samples, and at $\% \mathrm{t}_{\text {racer }}$ of the tracer that was applied. The at $\%$ tracer was calculated by the following equations:

$$
a t \%_{\text {tracer }}=a t \%_{\mathrm{CO}_{2} \text { air }} \frac{\left[\mathrm{CO}_{2}\right]_{\text {air }}}{\left[\mathrm{CO}_{2}\right]_{\text {air }}+\left[{ }^{13} \mathrm{CO}_{2}\right]_{\text {input }}}+a t \%_{\mathrm{CO}_{2} \text { input }} \frac{\left[{ }^{13} \mathrm{CO}_{2}\right]_{\text {input }}}{\left[\mathrm{CO}_{2}\right]_{\text {air }}+\left[{ }^{13} \mathrm{CO}_{2}\right]_{\text {input }}}
$$

with: 


$$
\left[\mathrm{CO}_{2}\right]_{\text {air }}=\frac{P_{a}}{R * T} *\left[\mathrm{CO}_{2}\right] * 10^{-6} * V_{\text {chamber }}
$$

and:

$$
\left[\mathrm{CO}_{2}\right]_{\text {input }}=\frac{m_{\text {input }}}{M\left({ }^{13} \mathrm{CO}_{2}\right)} * V_{\text {chamber }}
$$

where $\left[\mathrm{CO}_{2}\right]_{\text {air }}$ is the $\mathrm{CO}_{2}$ concentration in the chamber $\left(\mathrm{mol} \mathrm{m}{ }^{-3}\right),\left[{ }^{13} \mathrm{CO}_{2}\right]_{\text {input }}$ the ${ }^{13} \mathrm{CO}_{2}$ concentration in the chamber originating from the applied $\mathrm{Na}_{2}{ }^{13} \mathrm{CO}_{3}\left(\mathrm{~mol} \mathrm{~m}{ }^{-3}\right)$, at $\% \mathrm{CO}_{2}$ air of the reference gas measurements, and at $\% \mathrm{CO}_{2}$ input with 99 at $\% . \mathrm{P}_{\mathrm{a}}$ is the air pressure $[\mathrm{Pa}]$, $\mathrm{T}$ the air temperature $[\mathrm{K}]$, $\mathrm{R}$ the gas constant $\left(\mathrm{J} \mathrm{mol}^{-1} \mathrm{~K}^{-1}\right),\left[\mathrm{CO}_{2}\right]$ the concentration of $\mathrm{CO}_{2}$ of the reference gas measurements (ppm), $\mathrm{V}_{\text {chamber }}$ the volume of the chamber $\left(\mathrm{m}^{-3}\right)$, and $\mathrm{m}_{\text {input }}$ the ${ }^{13} \mathrm{CO}_{3}$ mass of the added $\mathrm{Na}_{2}{ }^{13} \mathrm{CO}_{3}[\mathrm{~g}]$.

\subsubsection{Statistical analyses}

All tests were conducted using R 3.6.1 (R Core Team, 2019). Variables (C, N and P contents and

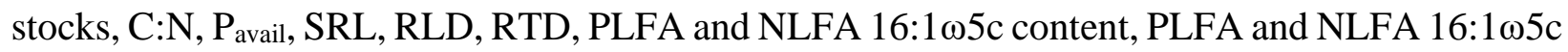
per SOC, \% root area colonization) were tested for normal distribution by the Shapiro-Wilk test. When assumptions where not met, variables were log transformed. To evaluate site and depth specific variations, we conducted linear mixed effect models ('Ime4'; (Bates et al., 2015), for which site and depth were determined as fixed effects, and field replicates as random effect nested in the fixed effect site. Adjusted $p$ values were obtained by multiple comparisons with a general linear hypothesis test of the R package 'multcomp' (Hothorn et al., 2008) with $\alpha \leq 0.05 .{ }^{13} \mathrm{C}$

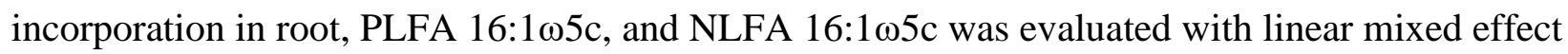
models with depth and time as fixed effects and field replicates as random effects. Principal components analyses (PCA) were conducted on scaled and log-transformed data (where assumption were not met) separated by sites, using the 'FactoMineR' package (Lê et al., 2008) and with the following variables: soil C:N, P stock, Pavail, SRL, RTD, PLFA 16:165c, NLFA $16: 1 \omega 5 \mathrm{c}$, percentage of root area colonization, as well as the maximum ${ }^{13} \mathrm{C}$ incorporation in PLFA and NLFA 16:1 $15 \mathrm{c}$ and root tissue. The results are presented as variable factor maps using the package 'factoextra' (Kassambara and Mundt, 2017).

\subsubsection{Results}

\subsubsection{Soil and root parameters}

Organic $\mathrm{C}$ as well as total $\mathrm{N}$ and $\mathrm{P}$ contents in soil increased with increasing precipitation (Table 2.2-2). $\mathrm{C}$ and $\mathrm{N}$ stocks in 0-10 cm, however, were highest in soils of the Mediterranean site (the 
coastal matorral), while P stocks were highest in soils of the arid site (the arid shrubland) (Table 2.2-3). Plant available $\mathrm{P}$ decreased markedly with increasing precipitation (Figure 2.2-1, Table 2.2-2).Soil C:N ratios were similar in soil at the arid and Mediterranean sites (9.4 - 11.7) but were 1.9 to 2.4 times higher in soil of the southern humid site (the humid-temperate forest) than in soil of the northern sites (Figure 2.2-1).

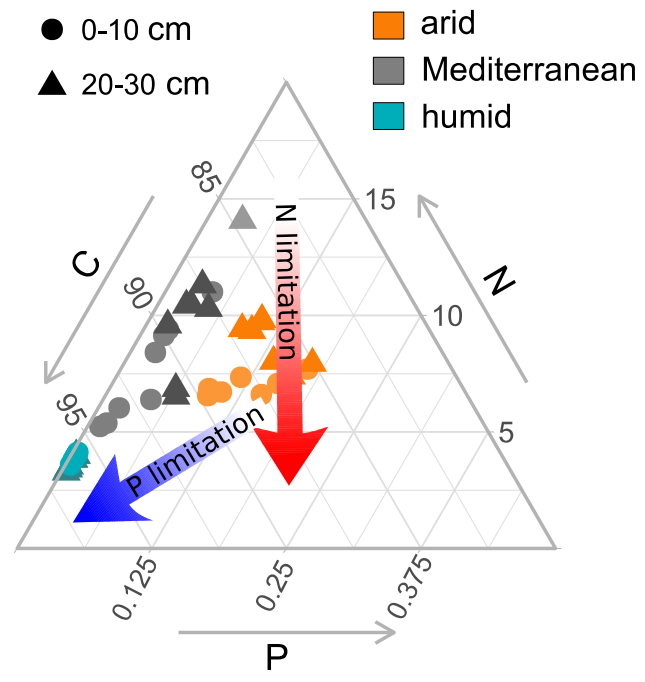

Figure 2.2-1: Ternary plot of molar soil $C, N$, and plant available $P$ contents. The molar $C: N, C: P$, and N:P ratios increase markedly from the arid shrubland and Mediterranean coastal matorral to the humid-temperate forest.

Table 2.2-2: Carbon $(C)$, nitrogen $(N)$, total phosphorus $(P)$, and plant available $P\left(P_{\text {avail }}\right)$ contents. Data are presented as means $(n=8)$ with standard errors. Asterisks indicate significance between depths, capital letters between sites in 0-10 cm depth, and lowercase letters between sites in 20-30 cm depth.

\begin{tabular}{|c|c|c|c|c|c|c|c|c|c|}
\hline & $\begin{array}{l}\text { depth } \\
{[\mathrm{cm}]}\end{array}$ & \multicolumn{2}{|l|}{$\mathrm{C}\left[\mathrm{g} \mathrm{kg}^{-1}\right]$} & \multicolumn{2}{|l|}{$\mathrm{N}\left[\mathrm{g} \mathrm{kg}^{-1}\right]$} & \multicolumn{2}{|l|}{$\mathrm{P}\left[\mathrm{g} \mathrm{kg}^{-1}\right]$} & \multicolumn{2}{|c|}{$P_{\text {avail }}\left[\mathrm{mg} \mathrm{kg}^{-1}\right]^{\dagger}$} \\
\hline arid & $0-10$ & * $11.3 \pm 0.74$ & (C) & $1.04 \pm 0.06$ & (C) & $0.49 \pm 0.01$ & (B) & $40.3 \pm 5.1$ & (A) \\
\hline shrubland & $20-30$ & $6.50 \pm 0.98$ & (c) & $0.78 \pm 0.14$ & (c) & $0.47 \pm 0.02$ & (b) & $26.1 \pm 10.1$ & (a) \\
\hline \multirow{2}{*}{$\begin{array}{c}\text { Mediterranean } \\
\text { coastal } \\
\text { matorral }\end{array}$} & $0-10$ & $23.1 \pm 3.47$ & (B) & $2.23 \pm 0.26$ & (B) & $0.46 \pm 0.02$ & (B) & $15.2 \pm 4.4$ & (B) \\
\hline & $20-30$ & $11.6 \pm 1.65$ & (b) & $1.59 \pm 0.27$ & (b) & $0.43 \pm 0.02$ & (b) & \multicolumn{2}{|l|}{$11.7 \pm 3.6$} \\
\hline humid & $0-10$ & $107 \pm 8.48$ & (A) & $5.03 \pm 0.38$ & (A) & $0.85 \pm 0.01$ & (A) & $1.9 \pm 0.3$ & (C) \\
\hline $\begin{array}{l}\text { temperate } \\
\text { forest }\end{array}$ & $20-30$ & $80.1 \pm 7.08$ & (a) & $3.51 \pm 0.26$ & (a) & $0.70 \pm 0.01$ & (a) & $1.2 \pm 0.4$ & (b) \\
\hline
\end{tabular}

${ }^{\dagger}$ Bernhard et al. (2018) 
Table 2.2-3: Carbon $(C)$, nitrogen $(N)$, and phosphorus $(P)$ stocks. Data are presented as means $(n=8)$ with standard errors. Asterisks indicate significance between depths, capital letters between sites in 0-10 cm depth, and lowercase letters between sites in 20-30 cm depth.

\begin{tabular}{|c|c|c|c|c|c|c|c|c|c|c|}
\hline & $\begin{array}{l}\text { depth } \\
{[\mathrm{cm}]}\end{array}$ & & \multicolumn{2}{|c|}{$\mathrm{C}\left[\mathrm{Mg} \mathrm{ha}^{-1}\right]$} & \multicolumn{3}{|c|}{$\mathrm{N}\left[\mathrm{Mg} \mathrm{ha}^{-1}\right]$} & \multicolumn{3}{|c|}{$\mathrm{P}\left[\mathrm{Mg} \mathrm{ha}^{-1}\right]$} \\
\hline \multirow{2}{*}{$\begin{array}{c}\text { arid } \\
\text { shrubland }\end{array}$} & $0-10$ & & $17.4 \pm 1.15$ & (B) & & $1.61 \pm 0.10$ & (B) & & $0.75 \pm 0.02$ & (A) \\
\hline & $20-30$ & & $10.6 \pm 1.59$ & (c) & & $1.27 \pm 0.22$ & (b) & & $0.77 \pm 0.04$ & (a) \\
\hline \multirow{2}{*}{$\begin{array}{l}\text { Mediterranean } \\
\text { coastal matorral }\end{array}$} & $0-10$ & \multirow{2}{*}{$*$} & $29.9 \pm 4.49$ & (A) & & $2.89 \pm 0.34$ & (A) & & $0.59 \pm 0.03$ & (B) \\
\hline & $20-30$ & & $17.4 \pm 2.46$ & (b) & & $2.38 \pm 0.40$ & (a) & & $0.65 \pm 0.02$ & (b) \\
\hline \multirow{2}{*}{$\begin{array}{l}\text { humid } \\
\text { temperate forest }\end{array}$} & $0-10$ & \multirow{2}{*}{$*$} & $22.1 \pm 1.74$ & (B) & \multirow{2}{*}{ * } & $1.03 \pm 0.08$ & (C) & \multirow{2}{*}{ * } & $0.18 \pm 0.00$ & (C) \\
\hline & $20-30$ & & $38.8 \pm 3.43$ & (a) & & $1.70 \pm 0.13$ & (ab) & & $0.34 \pm 0.00$ & (c) \\
\hline
\end{tabular}

Root length density in the upper $10 \mathrm{~cm}$ was highest in the humid-temperate forest and decreased with increasing aridity (Figure 2.2-2). With increasing depth, RLD decreased of plants at the sites under Mediterranean and humid conditions but remained constant with depth in the arid shrubland. While SRL of plants growing in arid conditions increased from $0-10 \mathrm{~cm}$ to $20-30 \mathrm{~cm}$, it decreased with depth at the sites under Mediterranean and humid conditions (Figure 2.2-2). Tissue density was highest of roots in the arid shrubland and remained constant with depth (Figure 2.2-2). On the contrary RTD increased with increasing depth at the Mediterranean (1.9 times) and humid sites (1.7 times) (Figure 2.2-2).
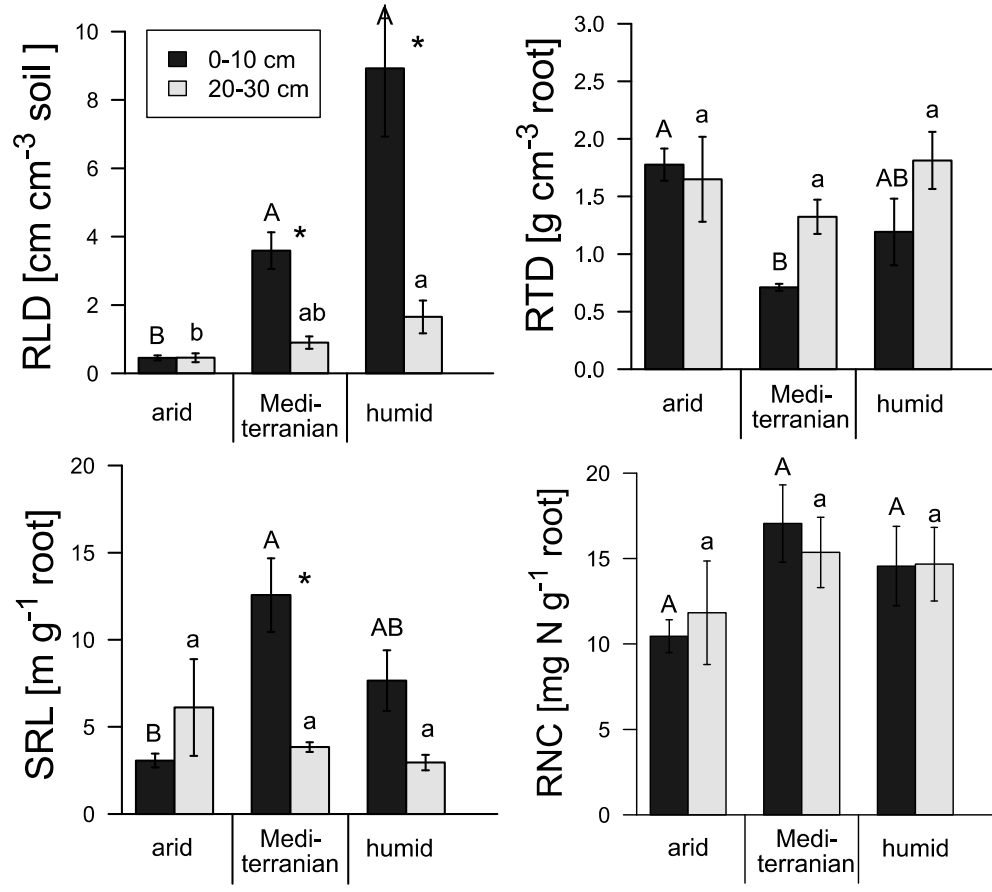

Figure 2.2-2: Root Length Density (RLD), Specific Root Length (SRL), Root Tissue Density (RTD), and Root Nitrogen Content (RNC) of fine roots ( $\leq 1.0 \mathrm{~mm}$ diameter). Data are presented as means $(n=4)$ with standard errors. Asterisks indicate significant differences between depths, capital letters between sites in $0-10 \mathrm{~cm}$ depth, and lowercase letters between sites in 20-30 cm depth. 


\subsubsection{Arbuscular mycorrhizal fungi abundance}

The percentage of root area colonized by AMF hyphae in the upper $10 \mathrm{~cm}$ soil was about 2.0 times higher of plants at the humid site than of plants at the arid and Mediterranean sites (Figure 2.2-3). In $20-30 \mathrm{~cm}$ depth, the percentage of colonized root area was 2.7 times higher of plants at the humid-temperate forest than of plants at the Mediterranean coastal matorral, but only 1.5 times higher than of plants at the arid shrubland. PLFA and NLFA 16:165c contents were markedly higher in soils of the humid-temperate forest than in the arid shrubland or Mediterranean coastal matorral (Table 2.2-4). Relative content of PLFA 16:1 $15 \mathrm{c}$ per SOC, however, were similar in soils of all sites (Figure 2.2-3). Relative content of NLFA 16:165c per SOC in the upper $10 \mathrm{~cm}$ increased with increasing precipitation (Figure 2.2-3).
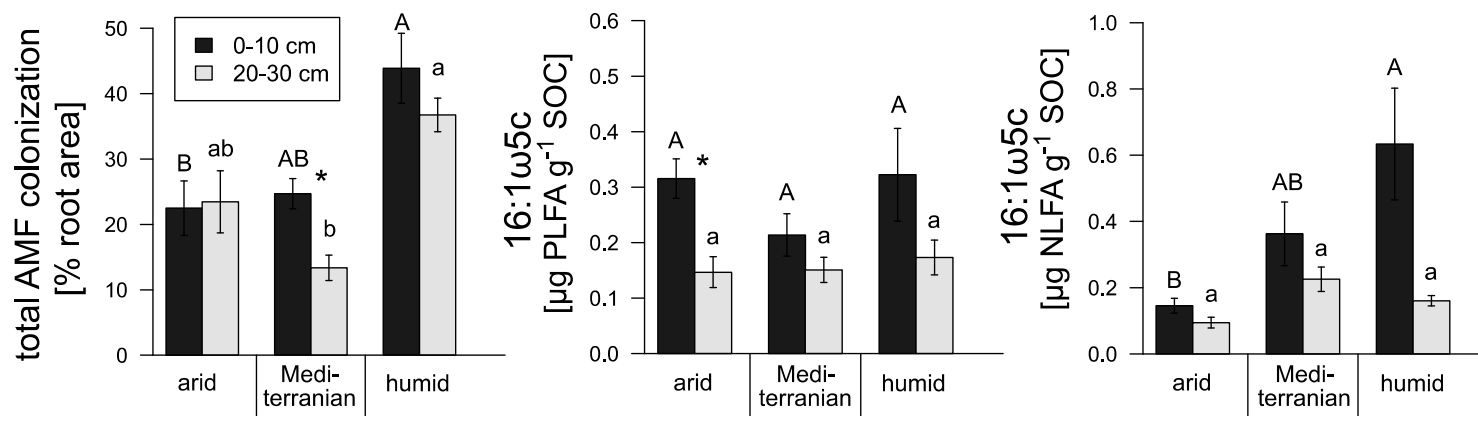

Figure 2.2-3: Percent of root area colonized by AMF, relative PLFA 16:1 15 c content per SOC, and relative NLFA content 16:1 $15 \mathrm{c}$ per SOC. Data are presented as means $(n=8)$ with standard errors. Asterisks indicate significant differences between depths, capital letters between sites in $010 \mathrm{~cm}$ depth, and lowercase letters between sites in 20 $30 \mathrm{~cm}$ depth.

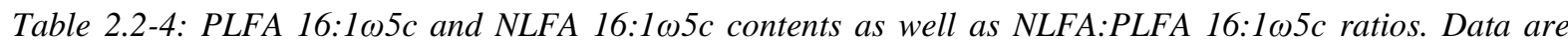
presented as means $(n=8)$ with standard errors. Asterisks indicate significance between depths, capital letters between sites in 0-10 cm depth, and lowercase letters between sites in 20-30 cm depth.

\begin{tabular}{|c|c|c|c|c|c|c|c|c|}
\hline \multirow{3}{*}{$\begin{array}{l}\text { arid } \\
\text { shrubland }\end{array}$} & \multirow{3}{*}{$\begin{array}{c}\text { depth } \\
{[\mathrm{cm}]}\end{array}$} & & \multicolumn{2}{|c|}{$\begin{array}{c}16: 1 \omega 5 \mathrm{c} \\
{\left[\mu \mathrm{g} \text { PLFA g }{ }^{-1} \text { soil] }\right.}\end{array}$} & \multicolumn{2}{|c|}{$\begin{array}{c}16: 1 \omega 5 \mathrm{c} \\
{\left[\mu \mathrm{g} \mathrm{NLFA} \mathrm{g}^{-1} \text { soil] }\right.}\end{array}$} & \multicolumn{2}{|c|}{$\begin{array}{c}\text { 16:1 } 15 \mathrm{c} \\
\text { NLFA:PLFA }\end{array}$} \\
\hline & & $*$ & $3.67 \pm 0.47$ & (B) & $1.47 \pm 0.35$ & (C) & $0.45 \pm 0.13$ & (B) \\
\hline & & & $0.74 \pm 0.29$ & (b) & $0.60 \pm 0.12$ & (b) & $3.03 \pm 1.55$ & (a) \\
\hline \multirow{2}{*}{$\begin{array}{c}\text { Mediterranean } \\
\text { coastal } \\
\text { matorral }\end{array}$} & $0-10$ & & $3.89 \pm 0.45$ & (B) & $7.32 \pm 2.68$ & (B) & $1.91 \pm 0.60$ & (A) \\
\hline & $20-30$ & * & $1.26 \pm 0.33$ & (b) & $1.48 \pm 0.30$ & (b) & $2.16 \pm 0.61$ & (a) \\
\hline \multirow{2}{*}{$\begin{array}{l}\text { humid } \\
\text { temperate } \\
\text { forest }\end{array}$} & $0-10$ & & $33.7 \pm 14.2$ & (A) & \multirow[b]{2}{*}{$13.8 \pm 1.47$} & (A) & $1.77 \pm 0.22$ & (A) \\
\hline & $20-30$ & & $10.2 \pm 1.19$ & (a) & & (a) & $1.49 \pm 0.26$ & (a) \\
\hline
\end{tabular}




\subsubsection{Belowground plant-C allocation}

Incorporation of recently assimilated $\mathrm{C}\left({ }^{13} \mathrm{C}_{\mathrm{inc}}\right)$ of the applied tracer in root tissue was highest of plants at the coastal matorral under Mediterranean conditions (Figure 2.2-4). In 0-10 cm depth, ${ }^{13} \mathrm{C}_{\mathrm{inc}}$ in root tissue peaked at 1 and 3 days after labeling at the Mediterranean site but remained constant over time at the arid and humid sites. Under Mediterranean conditions, ${ }^{13} \mathrm{C}$ incorporation in PLFA 16:1 $\omega 5 \mathrm{c}$ was similar to ${ }^{13} \mathrm{C}_{\mathrm{inc}}$ in root tissue in $0-10 \mathrm{~cm}$, but higher in $20-30 \mathrm{~cm}$ (Figure 2.2-4). ${ }^{13} \mathrm{C}_{\text {inc }}$ in PLFA 16:1 $1 \omega 5 \mathrm{c}$ decreased from day 1 to day 14 at the sites under Mediterranean and arid conditions. The incorporation in PLFA 16:1 $15 \mathrm{c}$, however, was $>3$ times higher than in root tissue at the arid shrubland during the first days of the experiment. Incorporation of $\mathrm{C}$ in NLFA 16:1 $15 \mathrm{c}$ was even up to 127 times higher than in root tissue (humid, 20-30 cm, 3 days after labeling) and up to 8.5 times higher than the ${ }^{13} \mathrm{C}_{\text {inc }}$ in PLFA $16: 1 \omega 5 \mathrm{c}$ (Figure 2.2-4). Freshly assimilated $\mathrm{C}$ is quickly allocated to AMF belowground to feed the present hyphal network and is used by AMF to build up storage compounds. Only subsequently roots use parts of the assimilated $\mathrm{C}$ to form new root tissue.

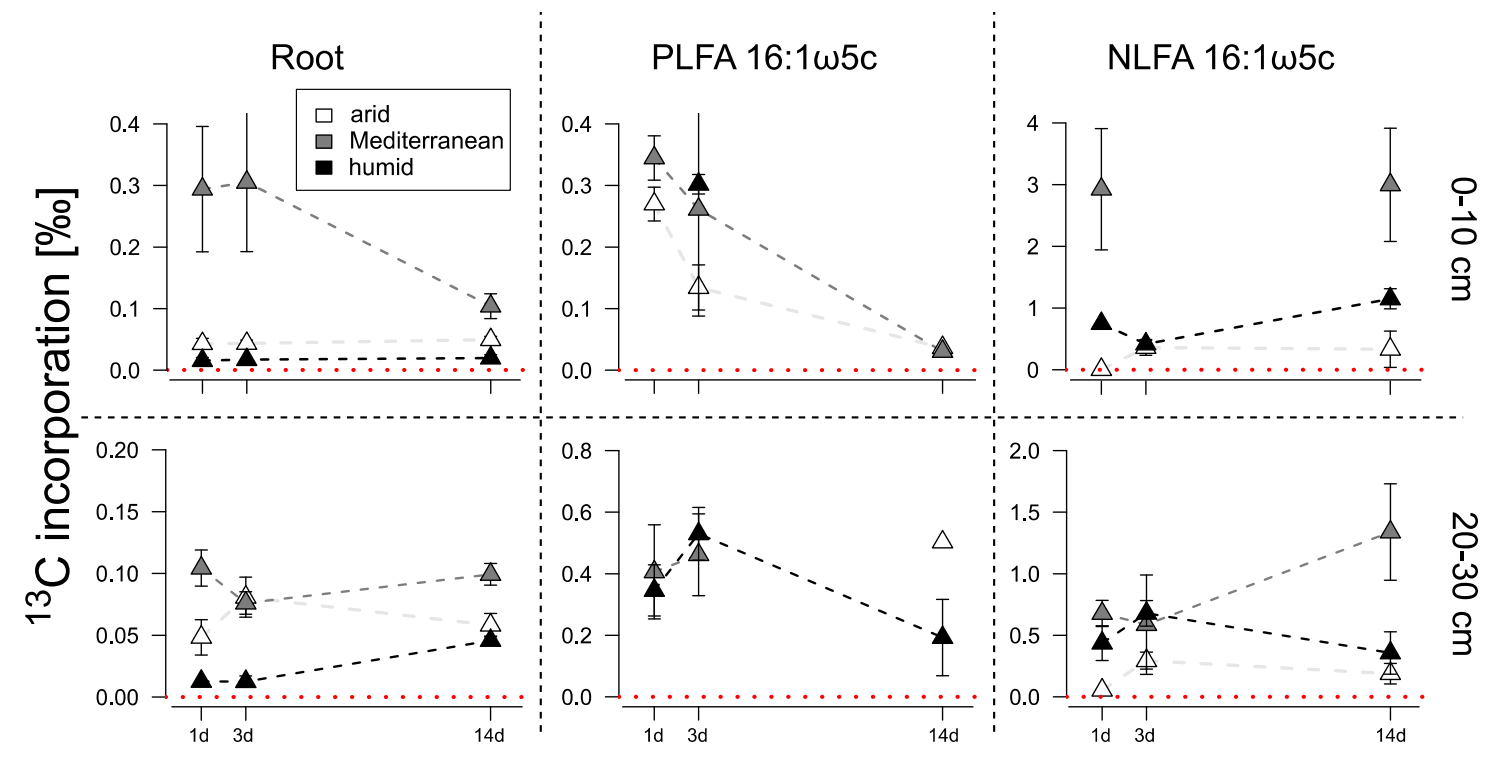

Figure 2.2-4: ${ }^{13} \mathrm{C}$ incorporation of applied tracer in root tissue, PLFA 16:1 55 c, and NLFA 16:1 $15 \mathrm{c}$. Data are presented as means (Root $n=8 ;$ PLFA and NLFA $n=4$ ) with standard errors. Incorporation of ${ }^{13} C$ was highest in the NLFA pool in all sites. Incorporated ${ }^{13} \mathrm{C}$ in the PLFA pool is subsequently assimilated (decreasing ${ }^{13} \mathrm{C}$ incorporation over the duration of the experiment). ${ }^{13} \mathrm{C}$ incorporation in root tissue was lower than in PLFA and NLFA pools and increases with proceeding time (except in $0-10 \mathrm{~cm}$ in the Mediterranean ecosystem).

\subsubsection{Relation of biotic and abiotic parameters}

At the arid shrubland, PLFA and NLFA 16:1 $\omega 5 \mathrm{c}$ contents in soil were high when plant available $\mathrm{P}$ was high but showed no relation to $\mathrm{P}$ stocks (Figure 2.2-5). On the contrary, root parameters were stronger related to soil C:N than to P availability. RTD increased while SRL decreased with 
lower $\mathrm{N}$ availability (i.e., higher $\mathrm{C}: \mathrm{N}$ ). ${ }^{13} \mathrm{C}$ incorporation in root tissue increased with greater $\mathrm{N}$ availability.

At the coastal matorral under Mediterranean conditions, PLFA and NLFA 16:1 $\omega 5 \mathrm{c}$ contents in soil as well as AMF root colonization were related stronger to $\mathrm{N}$ than $\mathrm{P}$ availability, while RTD and SRL related strongest to $\mathrm{P}$ availability (Figure 2.2-5). $\mathrm{P}$ stocks, however, had a negative effect

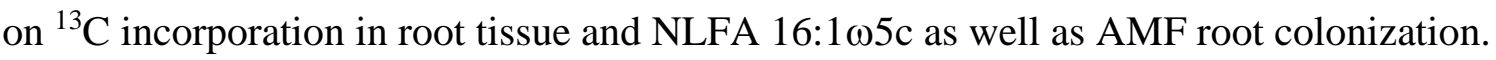

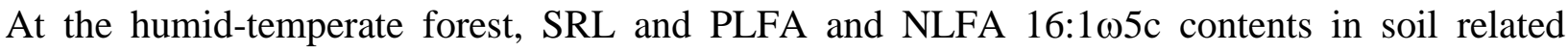
positively to plant available $\mathrm{P}$ (Figure $2.2-5$ ). Plant ${ }^{13} \mathrm{C}$ incorporation in PLFA, however, was negatively affected by plant available $\mathrm{P}$ and positively by $\mathrm{P}$ stocks. Higher $\mathrm{N}$ availability at the humid site decreased mainly AMF root colonization and increased ${ }^{13} \mathrm{C}$ incorporation in root tissue.
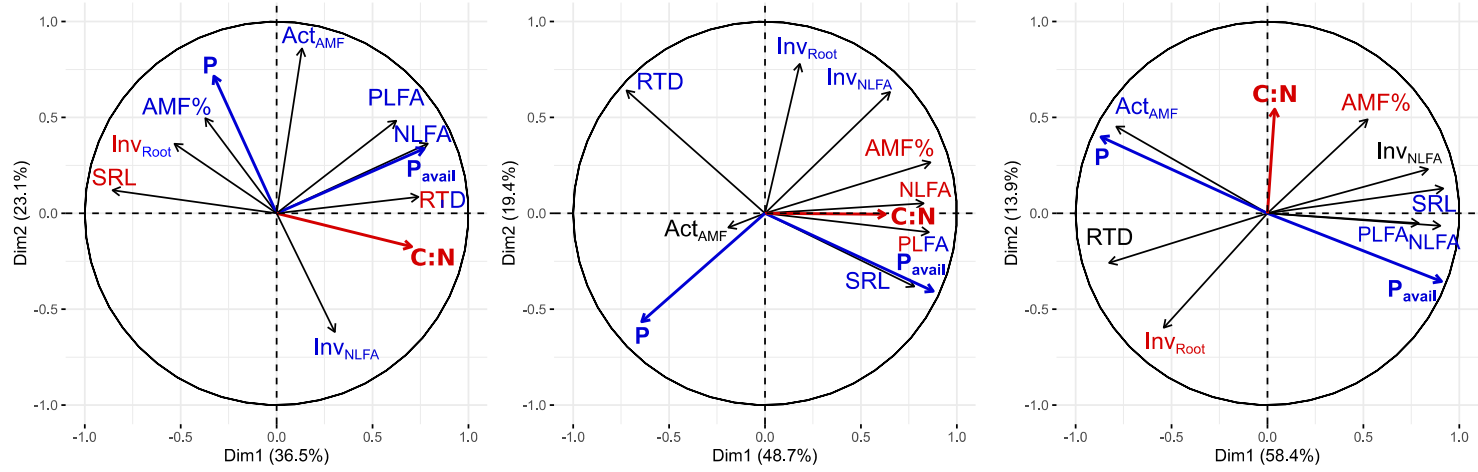

Figure 2.2-5: Principal component analyses conducted for separate sites: arid ecosystem: shrubland (left), Mediterranean ecosystem: coastal matorral (mid), and humid ecosystem: humid-temperate forest (right). $N=N$ stock, $P=P$ stock, $P_{\text {avail }}=$ plant available $P, S R L=$ specific root length, $R T D=$ root tissue density, AMF\% $=\%$ root area

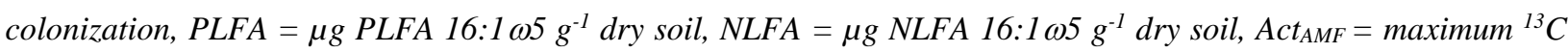
incorporation in PLFA16:1 $\omega 5$, Inv $v_{N L F A}=$ maximum ${ }^{13}$ C investment in NLFA16:1 $\omega 5$, Inv ${ }_{\text {Root }}=$ maximum ${ }^{13}$ C investment in root tissue. Color of variables indicates a stronger correlation to $N$ (red) or P (blue). The explanation power increases from the arid to the humid ecosystem in $1^{\text {st }}$ dimension.

\subsubsection{Discussion}

\subsubsection{Fine root traits}

In the upper $10 \mathrm{~cm}$ of soil, plants growing in the arid shrubland produced dense roots with low specific root length, which are 'conservative' root traits. These traits point to a slow nutrient acquisition (Reich, 2014; McCormack and Iversen, 2019). Under arid conditions, plants not only need to avoid dehydration to survive but also to continue to grow. An increase of the specific root length with depth (Figure 2.2-2; i.e. an increase of the fine root proportion or an expansion of the fine root system), might indicate that plants extent their fine root network into the subsoil to scavenge for possible water resources (Comas et al., 2013; Muñoz et al., 2008; Sala et al., 2012). In this context, similar tissue densities of roots in top- and subsoil are important to point out (Figure 
2.2-2). It indicates that even fine roots produced in depth are built to sustain (Figure 2.2-2) (de Vries et al., 2016; Nicotra et al., 2002), as an adaptation to the prevailing water shortage.

Plants growing in the Mediterranean coastal matorral, on the contrary, produce fine roots with high specific root length and low tissue densities in the upper $10 \mathrm{~cm}$ of soil, pointing to a fast nutrient acquisition (Reich, 2014; McCormack and Iversen, 2019). Denudation rates at this site are the highest across the precipitation gradient (Oeser et al., 2018; Schaller et al., 2018; van Dongen et al., 2019), likely resulting in high nutrient losses. Plants at this site would have to exploit and retain available resources fast and efficiently to reduce nutrient losses.

Contrary to what was expected (hypothesis 1), the fine root proportion did not increase with increasing precipitation throughout the precipitation gradient. Roots collected form the humidtemperate forest site, had lower specific root length but higher root tissue densities than roots collected from the Mediterranean site in the upper $10 \mathrm{~cm}$. This pointed to a slow nutrient acquisition by plants in the humid-temperate forest.

Plants in the coastal matorral as well as the humid-temperate forest decreased their proportion of fine roots with increasing soil depth, contrary to plants in the arid shrubland, which supports hypothesis 2 that increasing aridity leads to a higher relative fine root proportion with depth (Figure 2.2-2). These patterns may indicate that these plants at the Mediterranean and humid sites reduce their needs under water shortage rather than forage for remaining water resources in deeper soil horizons. This strategy allows plants to tolerate summer droughts (di Castri and Hajek, 1976; Pérez-Ramos et al., 2013), and withstand until the next rainfall.

\subsubsection{Arbuscular mycorrhizal fungi in $N$ and $P$ acquisition}

$\mathrm{N}$ content in soil increased, with increasing precipitation (Table 2.2-2). Highest $\mathrm{C}: \mathrm{N}$ ratios in soil at the humid site, however, indicated that $\mathrm{N}$ availability decreased with increasing precipitation (Figure 2.2-1, Table 2.2-2). Plant available $\mathrm{P}$ decreased with increasing precipitation, showing a reduction of $\mathrm{P}$ availability along the gradient. Low soil moisture as well as high $\mathrm{Ca}^{2+}$ contents in soil solution at the site under arid conditions, however, likely reduce P mobility strongly and limit plant $\mathrm{P}$ access even if $\mathrm{P}$ stocks were sufficient to provide for the standing biomass (Cole et al., 1953; He and Dijkstra, 2014; Marschner and Rengel, 2012).

In the arid shrubland, plants supply the extraradical AMF mycelium with $\mathrm{C}$ to scavenge for $\mathrm{P}$ (Figure 2.2-5). An extensive hyphal network provides the advantage to access and maintain a close contact to immobile P sources (Ryan et al., 2012; Smith and Smith, 2011). But AMF seemed not to be involved in plant $\mathrm{N}$ acquisition, as no relation to $\mathrm{N}$ availability in soil was observed (Figure 2.2-5). 
Root traits indicated that the plants in the Mediterranean coastal matorral exploit available resources fast from topsoil. The fast utilization was underlined by an increased fine root proportion and AMF abundance in soil with higher P plant availability (Figure 2.2-5). Higher AMF abundance in roots and soil with lower $\mathrm{N}$ availability (Figure 2.2-5) highlighted, further, that AMF contribute as well to a fast $\mathrm{N}$ acquisition. Plants in the coastal matorral seemed not only to invest in the colonization of root with AMF (i.e. strengthening the symbiosis between plant and fungi), but also in an active extraradical mycelium to scavenge for N (Figure 2.2-5; Bücking and Kafle, 2015; Fellbaum et al., 2012; Leigh et al., 2009). AMF can respond faster to water pulses and resource availability than plant roots, making them an efficient partner for the fast utilization of (mobile) nutrients from topsoil and their retention in soil against losses (Köhl and van der Heijden, 2016; Cavagnaro et al., 2015; van der Heijden, 2010; Schwinning and Sala, 2004).

Under humid conditions, root colonization of with AMF but not AMF abundance in soil increased with reduced $\mathrm{N}$ availability (Figure 2.2-5), indicating that a strong root colonization with AMF is important to ensure sufficient $\mathrm{N}$ transfer from fungi to plant under low $\mathrm{N}$ availability (Bücking and Kafle, 2015; Leigh et al., 2009). Nourishing the extraradical AMF mycelium, on the contrary, is more important for plant $\mathrm{P}$ acquisition in the humid-temperate forest, illustrated by the allocation of plant $\mathrm{C}$ to $\mathrm{AMF}$ where $\mathrm{P}$ stocks are high, and where the well $\mathrm{C}$ supplied AMF most likely contributed to the increase of plant available P in soil (Figure 2.2-5; Li et al., 2006; Treseder, 2004; Wright et al., 1998). These finding support hypothesis 3 and indicate further that AMF fulfill different function in the $\mathrm{N}$ acquisition in the Mediterranean coastal matorral and humid-temperate forest.

\subsubsection{Plant $C$ investment in $A M F$ and roots}

A decrease of root length density with decreasing MAP (Figure 2.2-2) displays the decline of plant productivity with increasing aridity (Leuschner et al., 2004; Nadelhoffer and Raich, 1992). Plant investment in AMF, however, was similar across the precipitation gradient, which was illustrated by max. $0.2-0.5 \%$ of assimilated ${ }^{13} \mathrm{C}$ allocated to PLFA $16: 1 \omega 5 \mathrm{c}$, and similar PLFA 16:1 $155 \mathrm{c}$ contents per SOC at all sites (Figure 2.2-3, Figure 2.2-4). This underlines the common importance of the fungal partner for plants and disproves hypothesis 4 that not only absolute but also relative plant $\mathrm{C}$ investment in $\mathrm{AMF}$ decreases with increasing aridity. Higher ${ }^{13} \mathrm{C}$ allocation to $\mathrm{AMF}$ than roots plants in the humid-temperate forest further pointed to the importance of AMF for the nutrient acquisition.

For plants in the arid shrubland, indications were found that AMF support plant $\mathrm{P}$ acquisition but not $\mathrm{N}$ acquisition. Instead, plants seemed to invest into their fine root system to exploit N-rich patches, as displayed by higher SRL and ${ }^{13} \mathrm{C}$ allocation to roots at higher $\mathrm{N}$ availability (Figure 
2.2-5). Plant economics seem to provoke a coupling of $\mathrm{C}$ investments to a sufficient $\mathrm{N}$ return (Hodge, 2009, 2004). The extent of the fine root network decreased where the extent of the extraradical AMF mycelium increased (Figure 2.2-5), indicating a trade-off of plant C investment in either network under aridity.

Similar ${ }^{13} \mathrm{C}$ allocation to roots and AMF extraradical mycelium in the upper $10 \mathrm{~cm}$ by plants in the Mediterranean coastal matorral (Figure 2.2-4) indicated that AMF and roots are equally supplied with freshly assimilated $\mathrm{C}$ and, thus, might be equally important for the nutrient acquisition. Further, high allocation of ${ }^{13} \mathrm{C}$ to the $\mathrm{AMF}$ storage compound - even higher than to membrane lipids - might indicate that AMF not only fulfill a function of direct nutrient acquisition, but also of nutrient storage to retain them against ecosystem losses (Gavito and Olsson, 2003; Hodge and Fitter, 2010; Köhl and van der Heijden, 2016). A greater allocation of freshly assimilated C to AMF in the subsoil indicated that AMF are important for the plant resource acquisition from depth.

\subsubsection{Conclusions}

The objective of this study was to assess the nutrient acquisition strategies of woody species along a precipitation gradient. Water shortage in the arid shrubland and likely nutrient limitations in the humid-temperate forest lead to an expression of conservative root traits, likely indicating a slow plant nutrient uptake. In the Mediterranean coastal matorral, with high denudation rates, acquisitive root traits indicated a fast nutrient uptake. Similar plant investment in AMF across the precipitation gradient (max. $0.2-0.5 \%$ of assimilated ${ }^{13} \mathrm{C}$ ) underlined the common importance of the fungal partner for nutrient uptake by roots. The extraradical AMF mycelium was supplied with $\mathrm{C}$ to scavenge for $\mathrm{P}$ in all ecosystems, but further functions differed across the precipitation gradient. In the arid shrubland, AMF did not seem to support plant $\mathrm{N}$ acquisition, while in the humid-temperate forest the symbiosis between plant and fungi seemed to be strengthened for the transfer of $\mathrm{N}$ by increasing root colonization. In the Mediterranean coastal matorral was not only a close symbiosis maintained, but also the extraradical AMF mycelium supplied with $\mathrm{C}$ to scavenge for N. Thereby, AMF likely exert a function not observed in the arid shrubland or humidtemperate forest: retaining mobile nutrients to prevent ecosystem losses.

\subsubsection{Acknowledgments}

We thank the Chilean National Park Service Corporación Nacional Forestal (CONAF) for the permission to work in the National Park La Campana and the National Park Nahuelbuta as well as the Comunidad Agrícola Quebrada de Talca for the possibility to work in the local 'exclusion area for studying biodiversity and conservation'. We also thank Karin Schmidt for her support with lab analyses as well as the whole team of the Centre for Stable Isotope Research and Analysis (KOSI). 


\section{This study was funded by the German Research Foundation (DFG) [project number KU 1184/36-} 1, GO 896/13-1, and DI 2136-11] within the Priority Program 1803 'EarthShape - Earth Surface Shaping by Biota'. We thank the Robert Bosch Foundation for funding Michaela A. Dippold and Moritz Köster. The study was further supported by the Government Program of Competitive Growth of Kazan Federal University and with the support of the 'RUDN University program 5100 .

\subsubsection{References}

Aguilera-Betti, I., Muñoz, A.A., Stahle, D., Figueroa, G., Duarte, F., González-Reyes, Á., Christie, D., Lara, A., González, M.E., Sheppard, P.R., Sauchyn, D., Moreira-Muñoz, A., Toledo-Guerrero, I., Olea, M., Apaz, P., Fernandez, A., 2017. The First Millennium-Age Araucaria Araucana in Patagonia. Tree-Ring Res. 73, 53-56. https://doi.org/10.3959/1536-109873.1 .53

Allen, M.F., 2007. Mycorrhizal Fungi: Highways for Water and Nutrients in Arid Soils. Vadose Zone J. 6, 291. https://doi.org/10.2136/vzj2006.0068

Andrus, N., Tye, A., Nesom, G., Bogler, D., Lewis, C., Noyes, R., Jaramillo, P., Francisco-Ortega, J., 2009. Phylogenetics of Darwiniothamnus (Asteraceae: Astereae) - molecular evidence for multiple origins in the endemic flora of the Galápagos Islands. J. Biogeogr. 36, 1055-1069. https://doi.org/10.1111/j.1365-2699.2008.02064.x

Antunes, P.M., Koch, A.M., Morton, J.B., Rillig, M.C., Klironomos, J.N., 2011. Evidence for functional divergence in arbuscular mycorrhizal fungi from contrasting climatic origins. New Phytol. 189, 507-514. https://doi.org/10.1111/j.14698137.2010.03480.x

Armesto, J.J., 2007. The Mediterranean environment of central Chile. Phys. Geogr. S. Am. 7, 184.

Aroca, R., Ruiz-Lozano, J.M., Zamarreño, Á.M., Paz, J.A., García-Mina, J.M., Pozo, M.J., López-Ráez, J.A., 2013. Arbuscular mycorrhizal symbiosis influences strigolactone production under salinity and alleviates salt stress in lettuce plants. J. Plant Physiol. 170, 47-55. https://doi.org/10.1016/j.jplph.2012.08.020

Balser, T.C., Treseder, K.K., Ekenler, M., 2005. Using lipid analysis and hyphal length to quantify AM and saprotrophic fungal abundance along a soil chronosequence. Soil Biol. Biochem. 37, 601-604. https://doi.org/10.1016/j.soilbio.2004.08.019

Bates, D., Mächler, M., Bolker, B., Walker, S., 2015. Fitting Linear Mixed-Effects Models Using Ime4. J. Stat. Softw. 67. https://doi.org/10.18637/jss.v067.i01

Bennett, A.E., Classen, A.T., 2020. Climate change influences mycorrhizal fungal-plant interactions, but conclusions are limited by geographical study bias. Ecology. https://doi.org/10.1002/ecy.2978

Bernhard, N., Moskwa, L.-M., Schmidt, K., Oeser, R.A., Aburto, F., Bader, M., Baumann, K., von Blanckenburg, F., Boy, J., van den Brink, L., Brucker, E., Büdel, B., Canessa, R., Dippold, M.A., Ehlers, T.A., Fuentes, J.P., Godoy, R., Jung, P., Karsten, U., Köster, M., Kuzyakov, Y., Leinweber, P., Neidhardt, H., Matus, F., Mueller, C.W., Oelmann, Y., Oses, R., Osses, P., Paulino, L., Samolov, E., Schaller, M., Schmid, M., Spielvogel, S., Spohn, M., Stock, S., Stroncik, N., Tielbörger, K., Übernickel, K., Scholten, T., Seguel, O., Wagner, D., Kühn, P., 2018. Pedogenic and microbial interrelations to regional climate and local topography: new insights from a climate gradient (arid to humid) along the Coastal Cordillera of Chile. Catena.

Bligh, E.G., Dyer, W.J., 1959. A Rapid Method of Total Lipid Extraction and Purification. Can. J. Biochem. Physiol. 37, $911-917$. https://doi.org/10.1139/y59-099

Bowles, T.M., Jackson, L.E., Cavagnaro, T.R., 2018. Mycorrhizal fungi enhance plant nutrient acquisition and modulate nitrogen loss with variable water regimes. Glob. Change Biol. 24, e171-e182. https://doi.org/10.1111/gcb.13884

Bristiel, P., Roumet, C., Violle, C., Volaire, F., 2019. Coping with drought: root trait variability within the perennial grass Dactylis glomerata captures a trade-off between dehydration avoidance and dehydration tolerance. Plant Soil 434, 327-342. https://doi.org/10.1007/s11104-018-3854-8

Brundrett, M.C., Tedersoo, L., 2018. Evolutionary history of mycorrhizal symbioses and global host plant diversity. New Phytol. 220, 1108-1115. https://doi.org/10.1111/nph.14976

Bücking, H., Kafle, A., 2015. Role of Arbuscular Mycorrhizal Fungi in the Nitrogen Uptake of Plants: Current Knowledge and Research Gaps. Agronomy 5, 587-612. https://doi.org/10.3390/agronomy5040587

Cavagnaro, T.R., Bender, S.F., Asghari, H.R., Heijden, M.G.A. van der, 2015. The role of arbuscular mycorrhizas in reducing soil nutrient loss. Trends Plant Sci. 20, 283-290. https://doi.org/10.1016/j.tplants.2015.03.004

Cole, C.V., Olsen, S.R., Scott, C.O., 1953. The Nature of Phosphate Sorption by Calcium Carbonate. Soil Sci. Soc. Am. J. 17, 352356. https://doi.org/10.2136/sssaj1953.03615995001700040013x

Comas, L.H., Becker, S.R., Cruz, V.M.V., Byrne, P.F., Dierig, D.A., 2013. Root traits contributing to plant productivity under drought. Front. Plant Sci. 4. https://doi.org/10.3389/fpls.2013.00442 
Delavaux, C.S., Smith-Ramesh, L.M., Kuebbing, S.E., 2017. Beyond nutrients: a meta-analysis of the diverse effects of arbuscular mycorrhizal fungi on plants and soils. Ecology 98, 2111-2119. https://doi.org/10.1002/ecy.1892

de Vries, F.T., Brown, C., Stevens, C.J., 2016. Grassland species root response to drought: consequences for soil carbon and nitrogen availability. Plant Soil 409, 297-312. https://doi.org/10.1007/s11104-016-2964-4

di Castri, F., Hajek, E.R., 1976. Bioclimatologia de Chile. Vicerrectoria Acad. Univ. Catol. Chile 163.

Diehl, P., Fontenla, S., 2010. Arbuscular mycorrhizal infection in two morphological root types of Araucaria araucana (Molina) K. Koch. Rev. Argent. Microbiol. 42, 133-137.

Dippold, M.A., Kuzyakov, Y., 2016. Direct incorporation of fatty acids into microbial phospholipids in soils: Position-specific labeling tells the story. Geochim. Cosmochim. Acta 174, 211-221. https://doi.org/10.1016/j.gca.2015.10.032

Fellbaum, C.R., Gachomo, E.W., Beesetty, Y., Choudhari, S., Strahan, G.D., Pfeffer, P.E., Kiers, E.T., Bucking, H., 2012. Carbon availability triggers fungal nitrogen uptake and transport in arbuscular mycorrhizal symbiosis. Proc. Natl. Acad. Sci. 109, 2666-2671. https://doi.org/10.1073/pnas.1118650109

Fick, S.E., Hijmans, R.J., 2017. WorldClim 2: new 1-km spatial resolution climate surfaces for global land areas: New Climate Surfaces for Global Land Areas. Int. J. Climatol. 37, 4302-4315. https://doi.org/10.1002/joc.5086

Fitter, A.H., 1991. Costs and benefits of mycorrhizas: Implications for functioning under natural conditions. Experientia 47, 350355. https://doi.org/10.1007/BF01972076

Frostegård, A., Bååth, E., 1996. The use of phospholipid fatty acid analysis to estimate bacterial and fungal biomass in soil. Biol. Fertil. Soils 22, 59-65. https://doi.org/10.1007/BF00384433

Frostegård, å., Tunlid, A., Bååth, E., 1991. Microbial biomass measured as total lipid phosphate in soils of different organic content. J. Microbiol. Methods 14, 151-163. https://doi.org/10.1016/0167-7012(91)90018-L

Gavito, M.E., Olsson, P.A., 2003. Allocation of plant carbon to foraging and storage in arbuscular mycorrhizal fungi. FEMS Microbiol. Ecol. 45, 181-187. https://doi.org/10.1016/S0168-6496(03)00150-8

Gearing, P.J., Gearing, J.N., Maughan, J.T., Oviatt, C.A., 1991. Isotopic distribution of carbon from sewage sludge and eutrophication in the sediments and food web of estuarine ecosystems. Environ. Sci. Technol. 25, $295-301$. https://doi.org/10.1021/es00014a012

Godoy, R., Romero, R., Carrillo, R., 1994. Estatus micotrófico de la flora vascular en bosques de coníferas nativas del sur de Chile. Rev Chil Hist Nat 67, 209-220.

Gunina, A., Dippold, M.A., Glaser, B., Kuzyakov, Y., 2014. Fate of low molecular weight organic substances in an arable soil: From microbial uptake to utilisation and stabilisation. Soil Biol. Biochem. 77, $304-313$. https://doi.org/10.1016/j.soilbio.2014.06.029

He, M., Dijkstra, F.A., 2014. Drought effect on plant nitrogen and phosphorus: a meta-analysis. New Phytol. 204, $924-931$. https://doi.org/10.1111/nph.12952

Hodge, A., 2009. Root decisions. Plant Cell Environ. 32, 628-640. https://doi.org/10.1111/j.1365-3040.2008.01891.x

Hodge, A., 2004. The plastic plant: root responses to heterogeneous supplies of nutrients. New Phytol. 162, 9-24. https://doi.org/10.1111/j.1469-8137.2004.01015.x

Hodge, A., Fitter, A.H., 2010. Substantial nitrogen acquisition by arbuscular mycorrhizal fungi from organic material has implications for N cycling. Proc. Natl. Acad. Sci. 107, 13754-13759. https://doi.org/10.1073/pnas.1005874107

Hothorn, T., Bretz, F., Westfall, P., 2008. Simultaneous Inference in General Parametric Models. Biom J 50, $346-363$.

Johnson, N.C., Rowland, D.L., Corkidi, L., Egerton-Warburton, L.M., Allen, E.B., 2003. Nitrogen Enrichment Alters Mycorrhizal Allocation at Five Mesic to Semiarid Grasslands. Ecology 84, 1895-1908. https://doi.org/10.1890/00129658(2003)084[1895:NEAMAA]2.0.CO;2

Kassambara, A., Mundt, F., 2017. factoextra: Extract and Visualize the Results of Multivariate Data Analyses.

Khalvati, M.A., Hu, Y., Mozafar, A., Schmidhalter, U., 2005. Quantification of Water Uptake by Arbuscular Mycorrhizal Hyphae and its Significance for Leaf Growth, Water Relations, and Gas Exchange of Barley Subjected to Drought Stress. Plant Biol. 7, 706-712. https://doi.org/10.1055/s-2005-872893

Köhl, L., van der Heijden, M.G.A., 2016. Arbuscular mycorrhizal fungal species differ in their effect on nutrient leaching. Soil Biol. Biochem. 94, 191-199. https://doi.org/10.1016/j.soilbio.2015.11.019

König, N., Versuchsanstalt, N.F., Analytik, M. des G.F., Stellvertreter, G., Blum, U., für Wald, B.L., Sachsen, L., Mitglieder, D., Bussian, B., Groeticke, K., 2005. Eine Loseblatt-Sammlung der Analysemethoden im Forstbereich Herausgegeben vom Gutachterausschuss Forstliche Analytik.

Kuzyakov, Y., Domanski, G., 2000. Carbon input by plants into the soil. Review. J. Plant Nutr. Soil Sci. 163, 421-431.

Lê, S., Josse, J., Husson, F., 2008. FactoMineR: An R Package for Multivariate Analysis. J. Stat. Softw. 25. https://doi.org/10.18637/jss.v025.i01

Leigh, J., Hodge, A., Fitter, A.H., 2009. Arbuscular mycorrhizal fungi can transfer substantial amounts of nitrogen to their host plant from organic material. New Phytol. 181, 199-207. https://doi.org/10.1111/j.1469-8137.2008.02630.x

Leuschner, C., Hertel, D., Schmid, I., Koch, O., Muhs, A., Hölscher, D., 2004. Stand fine root biomass and fine root morphology in old-growth beech forests as a function of precipitation and soil fertility. Plant Soil 258, 43-56. https://doi.org/10.1023/B:PLSO.0000016508.20173.80 
Li, H., Smith, S.E., Holloway, R.E., Zhu, Y., Smith, F.A., 2006. Arbuscular mycorrhizal fungi contribute to phosphorus uptake by wheat grown in a phosphorus-fixing soil even in the absence of positive growth responses. New Phytol. 172, 536-543. https://doi.org/10.1111/j.1469-8137.2006.01846.x

Marschner, P., Rengel, Z., 2012. Nutrient Availability in Soils, in: Marschner's Mineral Nutrition of Higher Plants. Elsevier, pp. 315-330. https://doi.org/10.1016/B978-0-12-384905-2.00012-1

Marulanda, A., Azcon, R., Ruiz-Lozano, J.M., 2003. Contribution of six arbuscular mycorrhizal fungal isolates to water uptake by Lactuca sativa plants under drought stress. Physiol. Plant. 119, 526-533. https://doi.org/10.1046/j.13993054.2003.00196.x

McCormack, M.L., Iversen, C.M., 2019. Physical and Functional Constraints on Viable Belowground Acquisition Strategies. Front. Plant Sci. 10, 1215. https://doi.org/10.3389/fpls.2019.01215

Muñoz, M.R., Squeo, F.A., León, M.F., Tracol, Y., Gutiérrez, J.R., 2008. Hydraulic lift in three shrub species from the Chilean coastal desert. J. Arid Environ. 72, 624-632. https://doi.org/10.1016/j.jaridenv.2007.09.006

Nadelhoffer, K.J., Raich, J.W., 1992. Fine Root Production Estimates and Belowground Carbon Allocation in Forest Ecosystems. Ecology 73, 1139-1147. https://doi.org/10.2307/1940664

Ngosong, C., Gabriel, E., Ruess, L., 2012. Use of the Signature Fatty Acid 16:1 $\omega 5$ as a Tool to Determine the Distribution of Arbuscular Mycorrhizal Fungi in Soil. J. Lipids 2012, 1-8. https://doi.org/10.1155/2012/236807

Nicolson, T.H., 1955. The mycotrophic habit in grasses. University of Nottingham.

Nicotra, A., Babicka, N., Westoby, M., 2002. Seedling root anatomy and morphology: an examination of ecological differentiation with rainfall using phylogenetically independent contrasts. Oecologia 130, 136-145. https://doi.org/10.1007/s004420100788

Nilsson, L.O., Giesler, R., Bååth, E., Wallander, H., 2004. Growth and biomass of mycorrhizal mycelia in coniferous forests along short natural nutrient gradients. New Phytol. 165, 613-622. https://doi.org/10.1111/j.1469-8137.2004.01223.x

Oeser, R.A., Stroncik, N., Moskwa, L.-M., Bernhard, N., Schaller, M., Canessa, R., van den Brink, L., Köster, M., Brucker, E., Stock, S., Fuentes, J.P., Godoy, R., Matus, F., Oses Pedraza, R., Osses McIntyre, P., Paulino, L., Seguel, O., Bader, M.Y., Boy, J., Dippold, M.A., Ehlers, T.A., Kühn, P., Kuzyakov, Y., Leinweber, P., Scholten, T., Spielvogel, S., Spohn, M., Übernickel, K., Tielbörger, K., Wagner, D., von Blanckenburg, F., 2018. Chemistry and Microbiology of the Critical Zone along a steep climate and vegetation gradient in the Chilean Coastal Cordillera. Catena.

Olsson, P.A., 1999. Signature fatty acids provide tools for determination of the distribution and interactions of mycorrhizal fungi in soil. FEMS Microbiol. Ecol. 29, 303-310. https://doi.org/10.1111/j.1574-6941.1999.tb00621.x

Olsson, P.A., Bååth, E., Jakobsen, I., Söderström, B., 1995. The use of phospholipid and neutral lipid fatty acids to estimate biomass of arbuscular mycorrhizal fungi in soil. Mycol. Res. 99, 623-629. https://doi.org/10.1016/S0953-7562(09)80723-5

Olsson, P.A., Francis, R., Read, D.J., Söderström, B., 1998. Growth of arbuscular mycorrhizal mycelium in calcareous dune sand and its interaction with other soil microorganisms as estimated by measurement of specific fatty acids 8 .

Olsson, P.A., van Aarle, I.M., Gavito, M.E., Bengtson, P., Bengtsson, G., 2005. 13C Incorporation into Signature Fatty Acids as an Assay for Carbon Allocation in Arbuscular Mycorrhiza. Appl. Environ. Microbiol. 71, 2592-2599. https://doi.org/10.1128/AEM.71.5.2592-2599.2005

Ostonen, I., Püttsepp, ü., Biel, C., Alberton, O., Bakker, M.R., Lõhmus, K., Majdi, H., Metcalfe, D., Olsthoorn, A.F.M., Pronk, A., Vanguelova, E., Weih, M., Brunner, I., 2007. Specific root length as an indicator of environmental change. Plant Biosyst. - Int. J. Deal. Asp. Plant Biol. 141, 426-442. https://doi.org/10.1080/11263500701626069

Parniske, M., 2008. Arbuscular mycorrhiza: the mother of plant root endosymbioses. Nat. Rev. Microbiol. 6, $763-775$. https://doi.org/10.1038/nrmicro1987

Pérez-Ramos, I.M., Volaire, F., Fattet, M., Blanchard, A., Roumet, C., 2013. Tradeoffs between functional strategies for resourceuse and drought-survival in Mediterranean rangeland species. Environ. Exp. Bot. 87, 126-136. https://doi.org/10.1016/j.envexpbot.2012.09.004

R Core Team, 2019. R: A Language and Environment for Statistical Computing. R Foundation for Statistical Computing, Vienna, Austria.

Reich, P.B., 2014. The world-wide 'fast-slow' plant economics spectrum: a traits manifesto. J. Ecol. 102, $275-301$. https://doi.org/10.1111/1365-2745.12211

Rillig, M.C., Mummey, D.L., 2006. Mycorrhizas and soil structure. New Phytol. 171, 41-53. https://doi.org/10.1111/j.14698137.2006.01750.x

Ryan, M.H., Tibbett, M., Edmonds-Tibbett, T., Suriyagoda, L.D.B., Lambers, H., Cawthray, G.R., Pang, J., 2012. Carbon trading for phosphorus gain: the balance between rhizosphere carboxylates and arbuscular mycorrhizal symbiosis in plant phosphorus acquisition: Carbon trading for phosphorus gain. Plant Cell Environ. 35, 2170-2180. https://doi.org/10.1111/j.1365-3040.2012.02547.x

Sala, O.E., Golluscio, R.A., Lauenroth, W.K., Roset, P.A., 2012. Contrasting nutrient-capture strategies in shrubs and grasses of a Patagonian arid ecosystem. J. Arid Environ. 82, 130-135. https://doi.org/10.1016/j.jaridenv.2012.02.015

Schaller, M., Ehlers, T.A., Lang, K.A.H., Schmid, M., Fuentes-Espoz, J.P., 2018. Addressing the contribution of climate and vegetation cover on hillslope denudation, Chilean Coastal Cordillera $\left(26^{\circ}-38^{\circ} \mathrm{S}\right)$. Earth Planet. Sci. Lett. $489,111-122$. https://doi.org/10.1016/j.epsl.2018.02.026 
Schwinning, S., Sala, O.E., 2004. Hierarchy of responses to resource pulses in arid and semi-arid ecosystems. Oecologia 141, 211220. https://doi.org/10.1007/s00442-004-1520-8

Smith, S.E., Smith, F.A., 2011. Roles of Arbuscular Mycorrhizas in Plant Nutrition and Growth: New Paradigms from Cellular to Ecosystem Scales. Annu. Rev. Plant Biol. 62, 227-250. https://doi.org/10.1146/annurev-arplant-042110-103846

Solbrig, O.T., 1966. The South American species of Gutierrezia. Contrib. Gray Herb. Harv. Univ. 3-42.

Solbrig, O.T., 1962. The South American Species of Erigeron. Contrib. Gray Herb. Harv. Univ. 3-79.

Sommer, J., Dippold, M.A., Zieger, S.L., Handke, A., Scheu, S., Kuzyakov, Y., 2017. The tree species matters: Belowground carbon input and utilization in the myco-rhizosphere. Eur. J. Soil Biol. 81, 100-107. https://doi.org/10.1016/j.ejsobi.2017.07.001

Trabucco, A., Zomer, R.J., 2018. Global Aridity Index and Potential Evapo-Transpiration (ET0) Climate Database v2. CGIAR Consortium for Spatial Information (CGIAR-CSI). Published online, available from the CGIAR-CSI GeoPortal at https://cgiarcsi.community 10 .

Treseder, K.K., 2004. A meta-analysis of mycorrhizal responses to nitrogen, phosphorus, and atmospheric CO2 in field studies. New Phytol. 164, 347-355. https://doi.org/10.1111/j.1469-8137.2004.01159.x

Valdebenito, H., Lowrey, T.K., Stuessy, T.F., 1986. A New Species of Erigeron (Compositae: Astereae) from Chile. Brittonia 38, 1. https://doi.org/10.2307/2807408

van der Heijden, M.G.A. van der, 2010. Mycorrhizal fungi reduce nutrient loss from model grassland ecosystems. Ecology 91, 1163-1171. https://doi.org/10.1890/09-0336.1

van Dongen, R., Scherler, D., Wittmann, H., von Blanckenburg, F., 2019. Cosmogenic ${ }^{10}$ Be in river sediment: where grain size matters and why. Earth Surf. Dyn. 7, 393-410. https://doi.org/10.5194/esurf-7-393-2019

Veblen, T.T., 1982. Regeneration Patterns in Araucaria araucana Forests in Chile. J. Biogeogr. $9,11$. https://doi.org/10.2307/2844727

Vierheilig, H., Coughlan, A.P., Wyss, U., Piche, Y., 1998. Ink and Vinegar, a Simple Staining Technique for ArbuscularMycorrhizal Fungi 64, 4.

Wright, D.P., Read, D.J., Scholes, J.D., 1998. Mycorrhizal sink strength influences whole plant carbon balance of Trifolium repens L. Plant Cell Environ. 21, 881-891. https://doi.org/10.1046/j.1365-3040.1998.00351.x 
2.3 Study 3: Soil nitrogen cycling along a climatic gradient: from semidesert to rainforest

Manuscript in preparation

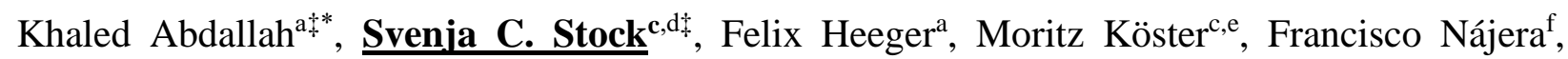
Francisco Matus ${ }^{\mathrm{f}, \mathrm{h}}$, Carolina Merino ${ }^{\mathrm{f}, \mathrm{h}, \mathrm{i}}$, Sandra Spielvogel ${ }^{\mathrm{e}, \mathrm{g}}$, Anna Gorbushina ${ }^{\mathrm{a}, \mathrm{b}}$, Yakov Kuzyakov $^{\mathrm{d}}$, Michaela A. Dippold ${ }^{\mathrm{c}, \mathrm{d}}$

Equal contributors

${ }^{a}$ Federal Institute for Material Research and Testing, Berlin, Germany

${ }^{\text {b} F r e i e ~ U n i v e r s i t a ̈ t ~ B e r l i n, ~ D e p a r t m e n t ~ o f ~ E a r t h ~ S c i e n c e s ~ \& ~ D e p a r t m e n t ~ o f ~ B i o l o g y ~ C h e m i s t r y ~ P h a r m a c y, ~}$ Malterserstr. 74-100, D-12249 Berlin, Germany

${ }^{\mathrm{c} B i o g e o c h e m i s t r y ~ o f ~ A g r o e c o s y s t e m s, ~ U n i v e r s i t y ~ o f ~ G o e t t i n g e n, ~ G o e t t i n g e n, ~ G e r m a n y ~}$

${ }^{\mathrm{d}}$ Soil Science of Temperate Ecosystems, University of Goettingen, Goettingen, Germany

'Instiute of Geography, University of Bern, Bern, Switzerland

${ }^{\mathrm{f}}$ Laboratory of Conservation and Dynamic of Volcanic Soils, Department of Chemical Sciences and Natural Resources, Universidad de La Frontera, Temuco, Chile

Institute for Plant Nutrition and Soil Science, Christian-Albrechts University Kiel, Kiel, Germany

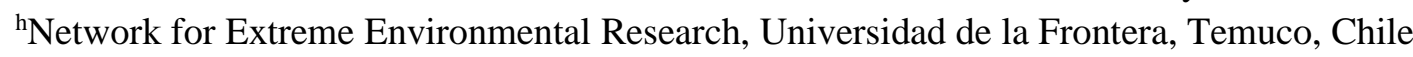

${ }^{\mathrm{i}}$ Center of Plant, Soil Interaction and Natural Resources Biotechnology Scientific and Technological Bioresource Nucleus (BIOREN), Temuco, Chile

*Corresponding author: Khaled Abdallah

Keywords: Nitrogen, rhizosphere, microbial abundance, natural abundance of $\mathrm{N}$, nitrogen fixation, nitrogen uptake 


\section{Abstract}

Plants and microorganisms have an important role in the acquisition and cycling of nutrients in the ecosystems. To better understand how microbial communities contribute to nitrogen $(\mathrm{N})$ recycling in soil, we measured the abundance of bacteria and fungi as well as the abundance of diazotrophs by quantifying nifH gene copy numbers using qPCR along three sites in Chile with a unique precipitation gradient ranging from $80 \mathrm{~mm} \mathrm{a}^{-1}$ to $>1500 \mathrm{~mm} \mathrm{a}^{-1}$. The sites differ by their vegetation cover which ranges from arid semidesert to humid temperate rainforest, but all soils are derived from the granitoid parent material. Abundance of diazotrophs was measured using qPCR and expressed as nifH gene copy number. Carbon (C) and $\mathrm{N}$ contents, and $\delta^{15} \mathrm{~N}$ signatures were combined with activities of $\mathrm{N}$ acquiring extracellular enzymes to determine $\mathrm{N}$ mineralization and immobilization processes in bulk topsoil samples as well as rhizosphere samples. The abundance of bacterial and fungal DNA, as well as nifH gene copy number decreased from humid temperate to arid sites along climate gradient. $\delta^{15} \mathrm{~N}$ values increased with depth in Mediterranean and humid temperate soils, probably due to $\mathrm{N}$ leaching. High soil $\mathrm{C}: \mathrm{N}$ ratios in all horizons under humid temperate forests show that $\mathrm{N}$ is limited, and microbial $\mathrm{N}$ immobilization is high. In contrast, the soil C:N ratios in arid shrubland and Mediterranean woodland is low and suggests $\mathrm{N}$ mineralization over microbial $\mathrm{N}$ immobilization. Activity of $\mathrm{N}$ acquiring enzymes was high under humid forest and Mediterranean woodland because of high $\mathrm{N}$ demand and losses. The extracellular enzyme activity $\left(\mathrm{V}_{\max }\right)$ of $\beta-1,4-\mathrm{N}$-acetylglucosaminidase (NAG) increased with increasing precipitation from $\sim 20 \mathrm{nM} \mathrm{g}^{-1} \mathrm{~h}^{-1}$ (arid) to $\sim 100 \mathrm{nM} \mathrm{g}^{-1} \mathrm{~h}^{-1}$ (humid temperate), whereas aminopeptidase activities remained stable. These data indicate a shift in the organic nitrogen sources from a peptide-based $\mathrm{N}$ nutrition in arid conditions to a peptide- and chitin- based $\mathrm{N}$ nutrition in humid forest. In bulk soil, relative fungal abundance per soil organic carbon (SOC) was similar at all sites, which indicate equal importance of fungi for nutrient acquisition irrespective of aridity. On the contrary, higher relative fungal abundance per SOC in the rhizosphere of woodland and humid forests indicate that plants invest more into fungi than plants under arid conditions. The abundance of the diazotrophic community was higher in the rhizosphere in comparison to bulk soil. In bulk soil, the percentage of diazotrophs in prokaryotic parts of community varied between $0.18 \%$ and $0.64 \%$, while diazotrophs percentage in the rhizosphere increased for more than 10 times suggesting the key role of easily available $\mathrm{C}$ as prerequisite for $\mathrm{N}$ fixation. These results, in addition to the high aminopeptidase activity and relative bacterial abundance per SOC in rhizosphere of shrubland and woodland, highlights the importance of $\mathrm{N}$-fixation and protein-based nutrition as a $\mathrm{N}$ acquiring hotspot under dry conditions. 


\subsubsection{Introduction}

Soils are characterized by their extreme microbial and structural heterogeneity (Kuzyakov and Blagodatskaya, 2015; Regan et al., 2017) making them very complex parts of ecosystems (Jacoby et al, 2017). Soil microorganisms compete with plants for nitrogen (N) (Kuzyakov \& Xu, 2013), one of the essential nutrients limiting the net primary production in terrestrial ecosystems (Vitousek and Howarth, 1991). Biological fixation by free-living and symbiotic diazotrophic microorganisms is the major natural source of $\mathrm{N}$ fixation in most terrestrial ecosystems (Bradley et al, 2014; Galloway et al., 2004). Several bacterial groups possess the nifH gene (Hirsch and Mauchline, 2015), a key structural gene for the nitrogenase enzyme which catalyzes the $\mathrm{N}_{2}$ reduction to ammonium (Burk, 1934; Duc et al., 2009). While $\mathrm{N}$ fixation provides diazotrophs with an ecological advantage in $\mathrm{N}$ limited environments (Inomura et al., 2018), the growth efficiency of diazotrophs is negatively affected due to the high energy costs of $\mathrm{N}_{2}$ fixation (Heijnen and Roels, 1981) as well as additional costs of managing an oxygen-free environment as prerequisite for the dinitrogenase activity (Gallon, 1981). In fact, nitrogen fixation is downregulated with increasing $\mathrm{N}$ availability in soil (Menge and Hedin, 2009). However, during initial soil development, this is nearly the only $\mathrm{N}$ source providing a rate-limiting element for the progress of soil formation (Schulz et al., 2013). In addition, aerobic conditions can significantly reduce the rate of biological $\mathrm{N}$ fixation as the presence of oxygen inhibits the activity of nitrogenase enzymes (Gallon, 1981; Oelze, 2000). Therefore, rates of biological $\mathrm{N}$ fixation can be directly affected by soil moisture content (Hicks et al., 2003).

Depth profiles of stable nitrogen isotope ratios (given as delta notation $\delta 15 \mathrm{~N}$ ) can provide indications for processes of $\mathrm{N}$ input - such as $\mathrm{N}_{2}$-fixation - and $\mathrm{N}$ losses (Robinson, 2001). Low $\delta^{15} \mathrm{~N}$ values of surface layers and an increasing ${ }^{15} \mathrm{~N}$ enrichment with soil depth are common (Amundson et al., 2003; Billings and Richter, 2006). The ${ }^{15} \mathrm{~N}$ enrichment with depth is often attributed to isotopic discrimination against ${ }^{15} \mathrm{~N}$ during biochemical reactions - mainly microbial utilization, resulting in a ${ }^{15} \mathrm{~N}$ depleted product pool in comparison to a ${ }^{15} \mathrm{~N}$ enrichment in the source material. If one of these product pools is subsequently removed from the soil (e.g. by plant assimilation, leaching, or volatilization), a ${ }^{15} \mathrm{~N}$ enrichment in the isotopic signature occurs (Hobbie and Ouimette, 2009; Robinson 2001).

Since more than $90 \%$ of soil $\mathrm{N}$ is present in soil organic matter (SOM), the availability of $\mathrm{N}$ in most of the terrestrial ecosystems is controlled by mineralization. However, the availability of mineral $\mathrm{N}$ depends on whether the ecosystem's $\mathrm{N}$ is in excess or limited (Turpin-jelfs et al., 2018), because heterotrophic soil microbial communities immobilize or liberate the mineralized $\mathrm{N}$ depending on their own demand, i.e. when $\mathrm{N}$ is limiting or in excess, respectively (Hassink, 1994). 
In addition to bacteria, saprotrophic and mycorrhizal fungi also play an important role in degrading organic compounds (Hobbie and Hobbie, 2008). Ectomycorrhizal and ericoid mycorrhizal fungi harbor a set of enzymes capable of accessing recalcitrant $\mathrm{N}$ forms (Chalot and Brun, 1998). This ability of these mycorrhizal fungi to efficiently mine for $\mathrm{N}$ in the SOM, in combination with their large surface area for absorption of the released $\mathrm{N}$ compound, is an effective strategy to access organic N from complex polymers such as proteins and chitin (Read and Perez-Moreno, 2003). Therefore, plants effectively use that strategy to access resources beyond mineral $\mathrm{N}$ forms, and in return supply the mycorrhizal symbionts with carbohydrates as energy and carbon source (Hobbie and Wallander, 2006). This process is essential in N-limited ecosystems, where mineralization is insufficient to sustain plants' $\mathrm{N}$ requirements. During decomposition, energy available to saprophytic microorganisms declines as compounds are degraded by secreted enzymes (Ågren and Bosatta, 1998). But since mycorrhizal fungi do not rely on C and energy supply from the SOM they decompose, but their energy sources are supplied by the plants, they can effectively compete for organic $\mathrm{N}$ compounds against free-living microbes (Lindahl et al., 2007).

In this study, we investigated the effect of climate (abiotic factor), vegetation and microorganisms (biotic factors) on nitrogen cycling in soil. We hypothesize that (1) increasing precipitation along the climatic gradient leads to higher total $\mathrm{N}$ losses (mainly by leaching). (2) Microorganisms compensate for $\mathrm{N}$ losses differently depending on aridity. (3) Activity of primary $\mathrm{N}_{2}$ fixation is negatively coupled to the $\mathrm{N}$ content. To test the previously mentioned hypothesis, soil samples were collected along the depth profile of four sites along a climatic gradient ranging from arid to humid temperate. Abundance of bacterial and fungal populations, as well as activities of $\mathrm{N}$ acquiring extracellular enzymes, and $\delta^{15} \mathrm{~N}$ signatures were measured in soil samples. We also investigated the abundance of diazotrophs by measuring nifH gene copy numbers in bulk and rhizosphere soil of all sites.

\subsubsection{Materials and Methods}

\subsubsection{Study sites}

The four study areas are located in the Coastal Cordillera of Chile (from $29^{\circ}$ to $38^{\circ}$ southern latitude). They cover a climate gradient ranging from arid (Santa Gracia Natural Reserve (shrubland-SG) and Quebrada de Talca (shrubland-QdT) to Mediterranean (La Campana National Park (woodland -LC) and humid temperate (Nahuelbuta National Park (humid-termperate forestNA)). The mean annual precipitation and temperature changed from $80 \mathrm{~mm}$ a-1 and $18.8^{\circ} \mathrm{C}$ in the arid site, to about $400 \mathrm{~mm}$ a- 1 and $13.1{ }^{\circ} \mathrm{C}$ in the Mediterranean site, and to $>1500 \mathrm{~mm}$ a- 1 and $7.4{ }^{\circ} \mathrm{C}$ in the humid-temperate site (Fick and Hijmans, 2017). From similar granitoid parent material developed Cambisols under arid ( $\mathrm{pH}$ 5.5-7.0) and Mediterranean ( $\mathrm{pH} 4.5-6.1)$ conditions, 
and Umbrizols and Podzols (pH 3.7 5.1) under humid conditions (Bernhard et al., 2018). A more detailed descriptions regarding the study sites, vegetation, and climate can be found in the studies by Oeser et al. (2018), Bernhard et al. (2018) and Stock et al. (2019).

\subsubsection{Soil sampling}

To evaluate long-term $\mathrm{N}$ cycling, bulk samples to a depth of max. $60 \mathrm{~cm}$ (shrubland-SG), $120 \mathrm{~cm}$ (woodland -LC), and $200 \mathrm{~cm}$ (humid-temperate forest-NA) were collected with a soil auger. The samples were divided into $10 \mathrm{~cm}$ (shrubland-SG, woodland -LC) and $25 \mathrm{~cm}$ (humid-temperate forest-NA) depth increments, respectively. Bulk topsoil samples were additionally collected from $010 \mathrm{~cm}, 10-20 \mathrm{~cm}$, and 20-30 $\mathrm{cm}$ depth to evaluate the effect of litter $\mathrm{C}$ input on $\mathrm{N}$ cycling. Rhizodeposits are a further important $\mathrm{C}$ input source. Therefore, rhizosphere soil (0-6 mm distance from root) was collected from soil profiles (4 in each site) in 3 depth increments. The soil profile from ground level till the transition from soil to saprolite was defined as $100 \%$, and samples were collected from $0-50 \%, 50-100 \%$, and $>100 \%$. In each site and for each sample set, sampling was done on both a north- and a south-facing slope.

\subsubsection{Stable nitrogen isotopic ratios, $N$ and C contents}

Stable isotope ratios of nitrogen $\left(\delta^{15} \mathrm{~N}\right)$ were simultaneously determined with $\mathrm{N}$ and $\mathrm{C}$ contents of dried and grounded soil from each samples set, using an elemental analyzer (Flash Elemental Analyzer, Thermo Fisher Scientific, Bremen, Germany) coupled to an isotope ratio mass spectrometer (Delta Plus with Confo III, Thermo Fisher Scientific, Bremen, Germany).

As an integration of the soil ${ }^{15} \mathrm{~N}$ enrichment with depth (i.e., with soil age), the slope of the regression between soil $\delta^{15} \mathrm{~N}$ and $-\ln (\% \mathrm{~N})$ was calculated, called 'discrimination factor $(\beta)$ (Billings and Richter, 2006; Natelhoffer and Fry, 1988). Therefore, the $\delta^{15} \mathrm{~N}$ signature of the first sample set taken by an auger were used down to a maximum of $100 \mathrm{~cm} . \delta^{15} \mathrm{~N}$ signatures below $100 \mathrm{~cm}$ were excluded as $\mathrm{N}$ (and C) contents were exceptionally high in 100-125 cm soil depth under the humid-temperate forest (see Figure 2.3-1).

\subsubsection{Extracellular chitinase and protease activities}

Extracellular activities of chitinases $(\beta-1,4-\mathrm{N}$-acetylglucosaminidase) and proteases were determined in a previous study (Stock et al., 2019) in aliquots of the rhizosphere soils (third sample set). Protease activity was calculated as the sum of individually determined tyrosineaminopeptidase and leucine-aminopeptidase activities. 


\subsubsection{Bacterial and fungal cultures}

Four fungal and four bacterial strains, isolated in pure cultures from bulk topsoil samples of the humid-temperate forest-NA, were used in this study as reference strains in qPCR analysis (Table S1). Genomic DNA extraction was performed as described earlier by Martin-Sanchez et al. (2018). Molecular identification of isolated strains was performed by PCR and sequencing of ribosomal markers, rDNA internal transcribed spacers (ITS) for fungi, and 16S rRNA gene (16S) for bacteria. All primers used are listed in Table S2. The following molecular markers were analyzed by conventional PCR, a fragment of $16 \mathrm{~S}$ using the primers Bac27F (Jiang et al., 2006) and Bac 1492R (Turner et al., 1999) for bacteria, and the ITS region using the primers ITS4a (Hannula et al., 2012) and ITS5 (White, Bruns, Lee, \& Taylor, 1990) for fungi. PCR reactions were performed in a BioRad C1000 Thermal Cycler (BioRad, Hercules, CA, USA). Cycling parameters for 16S were $95^{\circ} \mathrm{C}$ for $5 \mathrm{~min}$, followed by 35 cycles of $95^{\circ} \mathrm{C}$ for $20 \mathrm{~s}, 55^{\circ} \mathrm{C}$ for $30 \mathrm{~s}$, and $72{ }^{\circ} \mathrm{C}$ for $2 \mathrm{~min}$, with a final step at $72{ }^{\circ} \mathrm{C}$ for $10 \mathrm{~min}$. For ITS, cycling parameters were $95{ }^{\circ} \mathrm{C}$ for $5 \mathrm{~min}$, followed by 35 cycles of $95{ }^{\circ} \mathrm{C}$ for $30 \mathrm{~s}, 50{ }^{\circ} \mathrm{C}$ for $30 \mathrm{~s}$, and $72{ }^{\circ} \mathrm{C}$ for $1 \mathrm{~min}$ (ITS), with a final extension at $72{ }^{\circ} \mathrm{C}$ for 10 min. Each PCR trial included a negative control (containing no DNA). All PCR products were checked by electrophoresis on $1 \%$ (w/v) agarose gels stained with GelRed dye (Genaxxon Bioscience GmbH, Ulm, Germany) and visualized under UV light. PCR products were purified using the Monarch PCR and DNA Cleanup kit (New England BioLabs) in accordance with the manufacturer's instructions. Nucleotide sequencing was carried out commercially (Eurofins MWG Operon, Ebersberg, Germany) and strains were identified by comparing their rDNA sequences with GenBank using the BLAST algorithm from NCBI.

\subsubsection{Development of standard curves}

A mix of bacterial genomic DNA from four species isolated from soil samples, Pseudomonas sp., Pseudarthrobacter defluvii strain, Bacillus sp., and Streptomyces sp., was used as a template to generate bacterial standard curve. Target template was subjected to serial dilutions, ranging from $100 \mathrm{ng}$ to $10 \mathrm{pg}$, and run in triplicates. Mixed genomic DNA of four fungal species isolated from soil samples, Penicillium sp., Cordyceps sp., Penicillium canescens, and Aspergillus lentulus strain, was used as a template for creating fungal standard curve. Target template was subjected to serial dilutions, ranging from $10 \mathrm{ng}$ to $1 \mathrm{pg}$, and run in triplicates. The DNA of Vibrio ruber Gal42 (Ullrich and Alfaro-Espinosa Master's thesis) was used as a template for PolF/PolR primers and Bac27F/338R. To generate a standard curve for the nifH and $16 S$ gene copy number, the purified PCR product was subjected to serial dilutions, ranging from $10^{7}$ to $10^{3}$ and $10^{6}$ to $10^{3}$ gene copy numbers respectively, and run in triplicates. 


\subsubsection{Quantification of microbial abundance by $q P C R$}

qPCR reactions were performed in a total reaction volume of $10 \mu \mathrm{L}$ using the iTaq Universal SYBR Green Supermix (BioRad, Hercules, CA, USA) following the manufacturer's instructions. Quantification reactions were carried out in the CFX96 Real-Time PCR Detection System (BioRad) with the following cycling parameters for all primer sets: initial denaturation at $95{ }^{\circ} \mathrm{C}$ for $5 \mathrm{~min}$, followed by 40 cycles of denaturation at $95{ }^{\circ} \mathrm{C}$ for $5 \mathrm{~s}$ and annealing-extension at $60{ }^{\circ} \mathrm{C}$ for $1 \mathrm{~min}$. For real-time data collections during the annealing-extension step, fluorescence at 520 $\mathrm{nm}$ was monitored. The melting curve was constructed by increasing temperature by $0.5^{\circ} \mathrm{C}$ (from $65^{\circ} \mathrm{C}$ to $95^{\circ} \mathrm{C}$ ) and measuring fluorescence at $520 \mathrm{~nm}$ after each step. Every qPCR run included calibration standards previously used to construct standard curves and negative controls. At least one dilution of each soil sample was included to avoid inhibitory effects of co-extracted substrates. All samples were run in triplicates. Data analysis was carried out using the BioRad CFX Manager $^{\mathrm{TM}} 3.1$ (BioRad).

\subsubsection{Quantification of nifH gene abundance by $q P C R$}

The nifH gene, which encodes for a subunit of the nitrogenase enzyme involved in microbial $\mathrm{N}_{2}$ fixation, acts as a molecular marker for diazotrophs (Hsu and Buckley, 2009). Abundance of bacterial and fungal DNA in addition to diazotrophs were determined by quantitative polymerase chain reaction (qPCR). Bacterial abundance and gene copy number of $16 S$ gene were quantified using the primer pair Bac27F (Nakatsu and Marsh, 2007; Wilson et al., 1990) and Bac338R (Stevenson et al., 2011) targeted on 16S marker. Fungal abundance was quantified using the primer pair NL1F (O'Donnell, 1992) and LS2r (Cocolin et al., 2001) targeted on 28S rDNA. Gene copy number of the nifH gene was determined using the primer pair PolF and PolR (Poly et al., 2001).

\subsubsection{Statistics}

Statistical analyses were conducted with R 3.5.2 (R Core Team, 2018). To test for significance of differences between sites and between soil depths, mixed linear models were calculated, using the R package 'Ime4' (Bates et al., 2015). The interaction of site and depth was set as fixed effect, while slope, slope position, and field replicate were set as random effects. The $\mathrm{R}$ package 'multcomp' (Hothorn et al., 2008) and multiple comparisons with a general linear hypothesis test function were used to obtain $\mathrm{p}$ values with a significance level of $p \leq 0.05$. Regression coefficients of $\delta^{15} \mathrm{~N} \sim-\ln (\mathrm{N} \%)$ were tested with a $\mathrm{Z}$ test (Clogg et al., 1995). Principal component analyses (PCA) were performed after variables were scaled and centered using R 3.6.3 (R Core Team, 2018). The variables included: $\mathrm{N}$ and $\mathrm{C}$ contents, $\delta^{15} \mathrm{~N}$, abundance of bacterial and fungal DNA, 
and gene copy number of nifH and $16 \mathrm{~S}$ genes. A biplot (scaled for correlation) of the PCA was generated using the package 'ggbilpot' ( $\mathrm{Vu}, 2011)$.

\subsubsection{Results}

\subsubsection{Nitrogen contents and $\delta^{15} \mathrm{~N}$ signatures}

Nitrogen contents in soil were up to 2.7-fold and 6.8-fold higher under humid temperate forest than under Mediterranean woodland and arid shrubland, respectively ( Figure 2.3-1). Soil C:N ratios were highest under humid-temperate conditions. In Mediterranean woodland and arid shrubland, soil C:N ratios decreased in the upper $30 \mathrm{~cm}$ but were similar below $30 \mathrm{~cm}$ ( Figure 2.3-1). Soil $\delta^{15} \mathrm{~N}$ under humid temperate forest and Mediterranean woodland increased with increasing depth, while no change was observed under arid conditions ( Figure 2.3-1). In the first $20 \mathrm{~cm}, \delta^{15} \mathrm{~N}$ values were lowest under Mediterranean conditions - between 1 and $2 \%$ - compared to the other two sites, where $\delta^{15} \mathrm{~N}$ ranged between 3 and $10 \%$. The ${ }^{15} \mathrm{~N}$ discrimination factor was 1.7-fold and 5.9-folds higher under Mediterranean woodland than under humid temperate forest and arid shrubland, respectively (Figure 2.3-2).
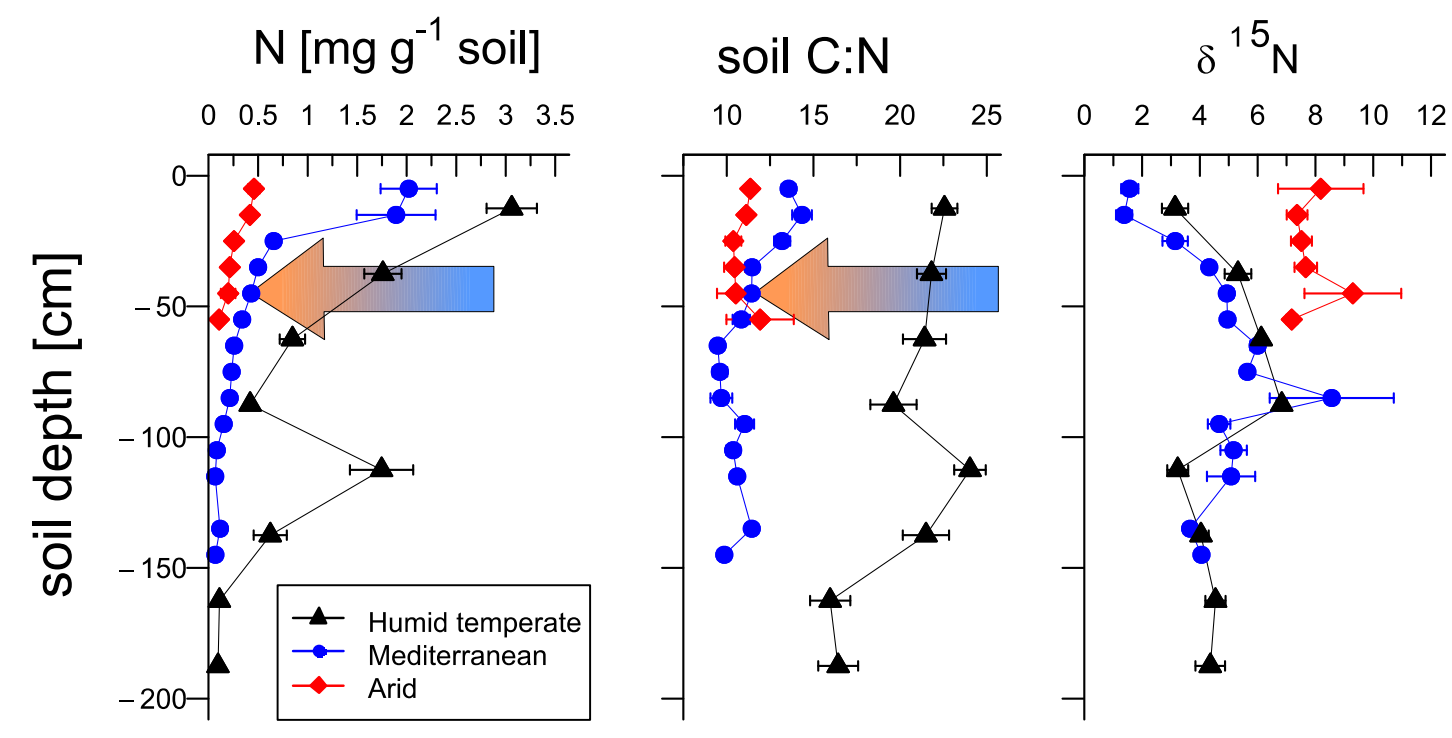

Figure 2.3-1: Nitrogen content, soil C:N ratio, and $\delta 15 N$ signatures in soil depth profiles. Data are presented as means $(n=8)$ with standard errors. Arrows indicate direction of increasing aridity. Nitrogen contents and $C: N$ ratios decrease markedly with increasing aridity. $\delta 15 N$ values were lowest in soil under Mediterranean conditions. 

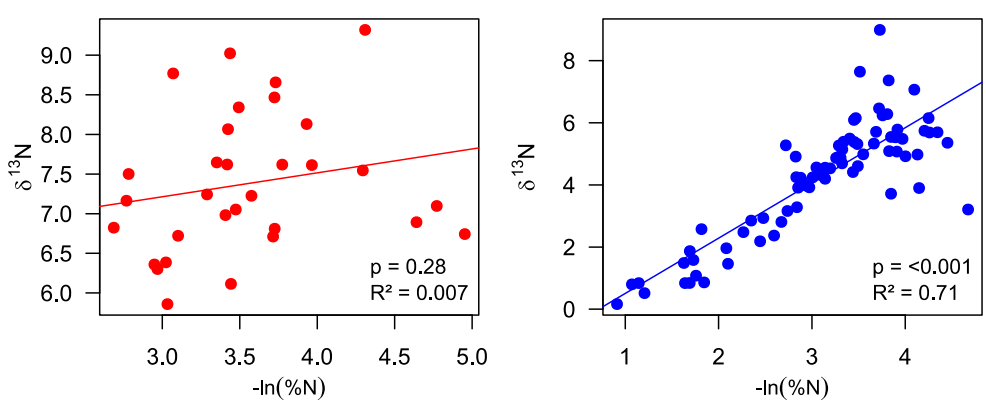

Figure 2.3-2: Regressions of $\delta^{15} \mathrm{~N}$ vs. $-\ln (\% N)$ for the arid shrubland (red), Mediterranean coastal matorral (blue), and humid temperate forest (black) as well as the regression slopes $(\beta)$ presented with the regression standard errors.
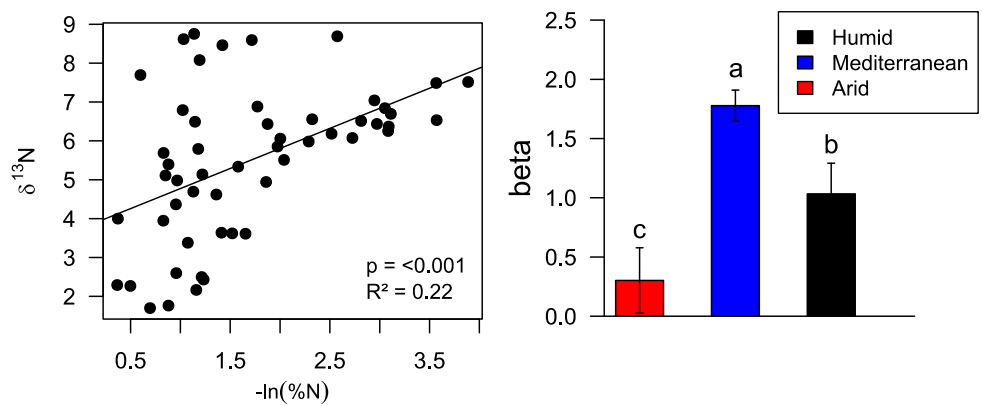

\subsubsection{Activities of proteases and chitinases}

Activities of proteases and chitinases decreased with increasing soil depths in all sites, except for chitinase activities under arid shrubland (Figure 2.3-3). Chitinase activities in the topsoil decreased with decreasing precipitation and were 6.5 times higher under humid temperate than under arid conditions. Protease activities were also lowest under arid shrubland (1.8 times lower than under humid temperate forest) but were similar between humid temperate forest and Mediterranean woodland (Figure 2.3-3). In the mineral soil, chitinases and proteases activities were similar between all sites. Chitinase activities per SOC, on the contrary, were similar across biomes, while protease activities per SOC were highest in soil under arid conditions (Figure 2.3-3).

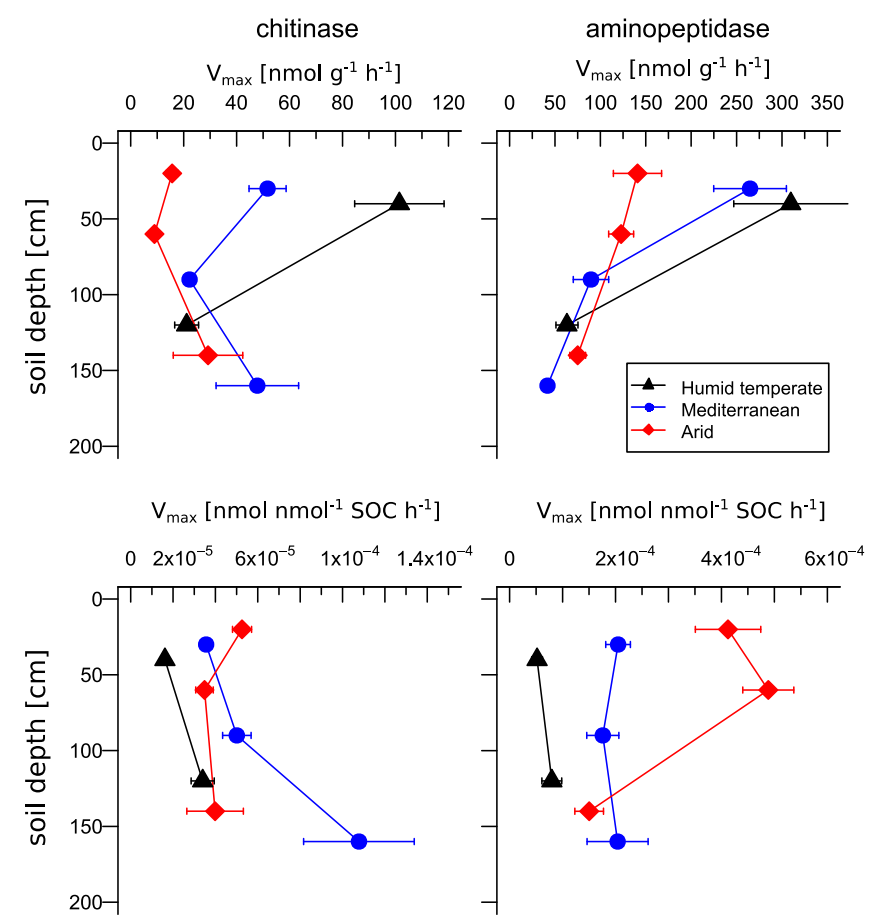

Figure 2.3-3: Extracellular enzyme activities $\left(V_{\max }\right)$ of chitinases (left) and aminopeptidases (right) per $g$ of soil (top row) and per nmol of SOC (bottom row). Data are presented as means with standard errors. 


\subsubsection{Bacterial and fungal abundance along the soil depths}
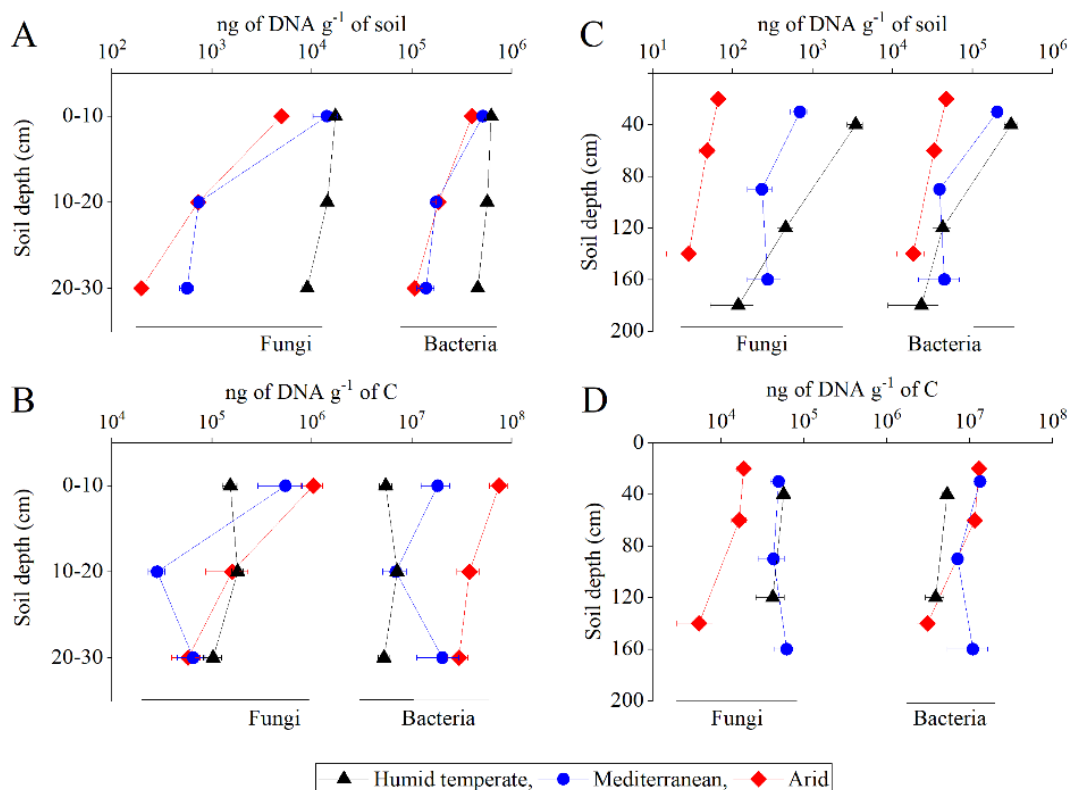

Figure 2.3-4: Quantification of microbial abundance along the depth in (A, B) bulk soil and (C, D) rhizosphere by qPCR using bacterial (Bac27f/338r) and fungal (NL1f/LS2R) primers in humid temperate forest, Mediterranean woodland, and arid shrubland. Data in A and $C$ are expressed as ng of DNA per $g$ soil, while in $B$ and D they are expressed as ng of DNA per $g$ organic carbon as sampled from the soil profile wall. Error bars represent standard errors of the means. Note the different $Y$ scaling of depth for bulk and rhizosphere soil.

DNA quantification by qPCR showed a decrease in the abundance of bacterial and fungal DNA in soil along the decreased precipitation (Figure 2.3-4). If solely topsoils are considered, bulk soil samples from humid temperate forest had the highest abundance in bacterial and fungal DNA with a maximum amount of $4.58 \times 10^{5}$ and $9.03 \times 10^{3} \mathrm{ng}$ of DNA g ${ }^{-1}$ soil at depth 20-30 cm, respectively. Amounts are considerably lower with decreasing ecosystem precipitation and reach a minimum at the arid shrublands with $1.08 \times 10^{5}$ and $1.98 \times 10^{2}$ ng of DNA g ${ }^{-1}$ soil, respectively (Figure 2.3-4). Differences between sites were always lowest in the top $10 \mathrm{~cm}$ of the profile and increased already in the topsoil significantly with depth. Very pronounced site-specific differences in DNA content could be found when rhizosphere soil over up to two-meter-deep profiles were compared. Similarly, the abundance of bacteria and fungi in the rhizosphere was highest in soil under humidtemperate forest in comparison to the Mediterranean woodland and arid shrubland. At depth of 0$50 \mathrm{~cm}$, forest rhizosphere soil had a maximum abundance of bacterial and fungal DNA of $3.04 \times 10^{5}$ and $3.48 \times 10^{3} \mathrm{ng} \mathrm{g}^{-1}$ soil, respectively. Then they decreased at the arid shrublands to a minimum of $4.71 \times 10^{4}$ and $6.64 \times 10^{1} \mathrm{ng}$ of DNA g ${ }^{-1}$ of soil, respectively (Figure 2.3-4).

Whereas the depth effect was present in nearly all datasets when considering absolute amounts of DNA, it largely disappeared when normalizing the DNA amounts per g of soil C (Figure 2.3-4). This suggests SOC as microbial growth resource largely determining microbial distribution along soil profiles with, with exception of the most arid site where a pronounced decrease in microbial 
DNA per SOC was visible in rhizosphere as well as bulk topsoil. Regardless of the sampling site or soil depth, bacterial DNA was $\sim 36$ to $\sim 710$ folds more abundant in comparison to fungal DNA.

\subsubsection{Abundance of the diazotrophic community in soil}

A

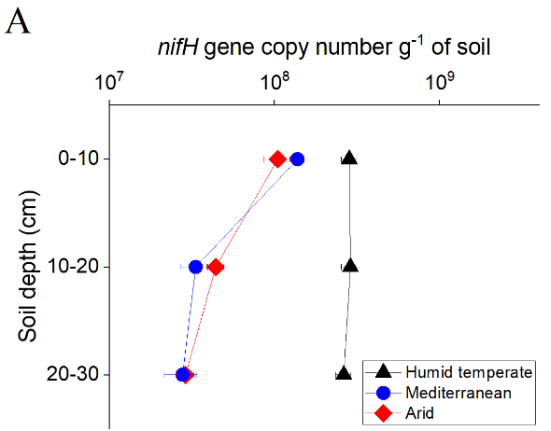

$\mathrm{B}$

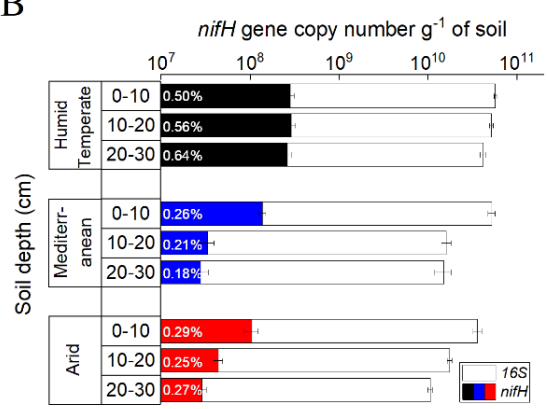

$\mathrm{C}$

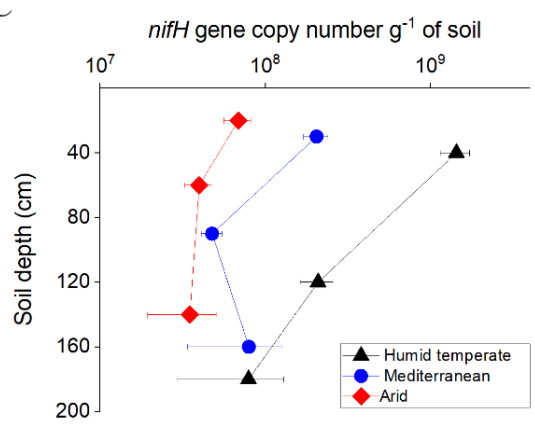

$\mathrm{D}$

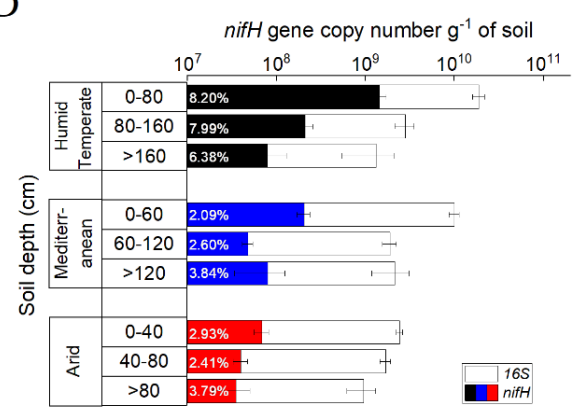

Figure 2.3-5: Quantification of nitrogenase reductase (nifH) gene by qPCR depending on depths in humid temperate, Mediterranean, and arid soils. (A) (B) Data are collected from bulk soil, while in $(C)(D)$ data are collected from the rhizosphere of the complete profile down to the saprolith. Abundance of nifH gene is expressed in gene copy number $(A$ and $C)$ and percentage of diazotrophy in prokaryotic parts of community $(B$ and $D)$. Data are expressed as gene copy number per gram soil. Error bars represent standard error of the mean. Note different $Y$ scaling of depths for bulk and rhizosphere soils.

In bulk topsoil, nifH gene copy number varied from $2.89 \times 10^{8}$ to $2.77 \times 10^{7}$ copies $^{-1}$ of soil (Figure 2.3-5). While in the rhizosphere, it varied from $1.44 \times 10^{9}$ to $3.50 \times 10^{7}$ copies $\mathrm{g}^{-1}$ of soil (Figure 2.3-5). In bulk topsoil as well as in rhizosphere soil, the nifH gene copy numbers decreased along the climatic gradient with decreased precipitation. At depth $0-10 \mathrm{~cm}$, bulk soil from humid temperate forest had a maximum amount of $2.84 \times 10^{8}$ nifH copy numbers $\mathrm{g}^{-1}$ of soil, whereas soil from Mediterranean and arid sites contained $1.38 \times 10^{8}$ and $1.05 \times 10^{8}$ gene copy numbers $\mathrm{g}^{-1}$ of soil, respectively (Figure 2.3-5). Similarly, rhizosphere soil of humid temperate forest at depth 0$40 \mathrm{~cm}$ had maximum nifH gene copy number $\mathrm{g}^{-1}$ of soil of $1.44 \times 10^{9}$ and decreased to a minimum of $3.50 \times 10^{7}$ in arid shrublands (Figure 2.3-5). In bulk topsoils the site effect was weakest in the top $10 \mathrm{~cm}$ and increased - at least for the comparioson of humid-temperate forests to the more arid sites - in the deeper depth increment. However, when comparing rhizosphere soil along the complete profile down to the saprolith, nifH gene number was not different at the lowest depth (i.e. in the saprolith) but pronounced site effects in the nif $H$ abundance could be found in the topsoil rhizopheres. 
The percentage of diazotrophs in prokaryotic community was determined by comparing the total copy number of the nifH gene to that of $16 S \mathrm{rRNA}$. Quantification of nifH genes indicate cells that can fix nitrogen, while 16S rRNA genes reflect total cell number. Rhizosphere had a frequently more than factor 10 higher percentage of diazotrophs compared to bulk soil at all sites. The percentage of diazotrophs in the rhizosphere varied between $2.09 \%$ and $8.20 \%$, while those from bulk soil varied between $0.18 \%$ and $0.64 \%$ diazotrophs. Soil under humid temperate forest had the highest percentage of diazotrophs regardless of depth (Figure 2.3-5).

\subsubsection{Relation between microbial abundance and soil biochemical properties}
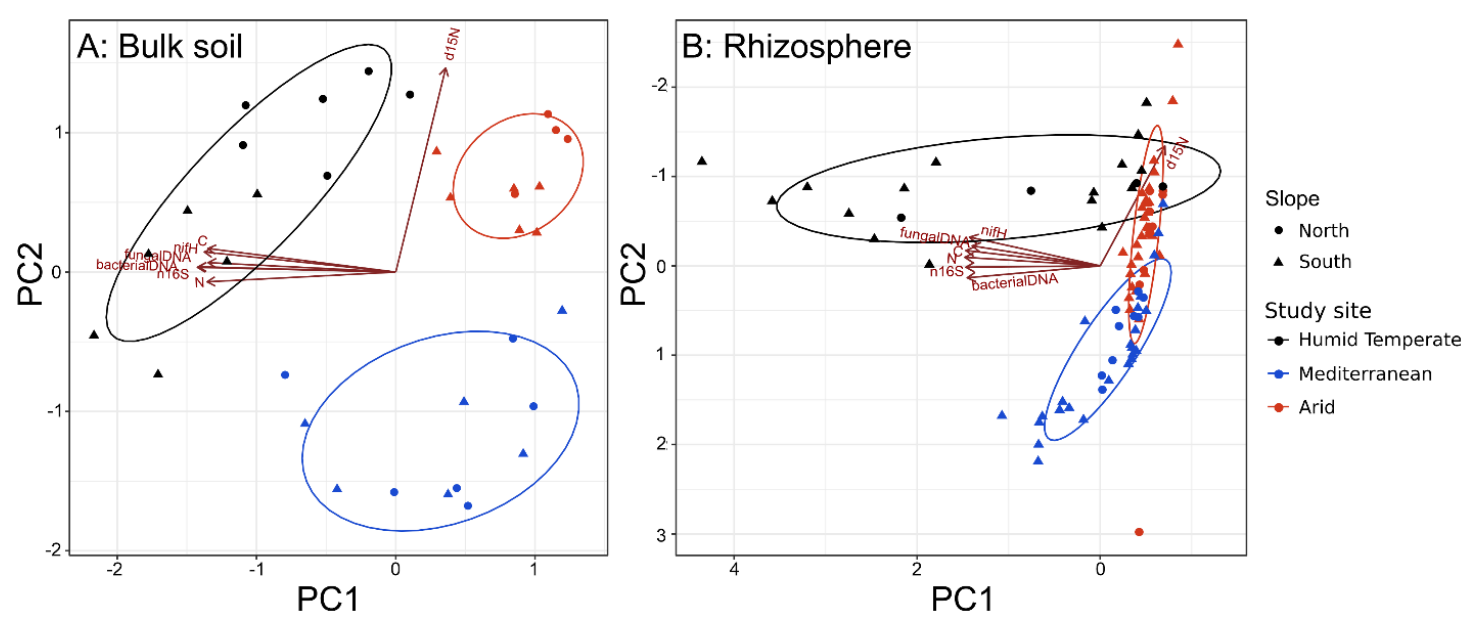

Figure 2.3-6: Principle component analyses generated from $N$ and $C$ contents, $\delta 15 N$, abundance of bacterial and fungal DNA, and gene copy number of nifH and $16 S$ genes in A) bulk and B) rhizosphere soil. Colors indicate study site and symbol shapes indicate north-or south-facing slope. Ellipses show two standard deviations of an assumed two-dimensional normal distribution for each study site.

PCA of biotic and abiotic soil properties showed separation of sites to a different degree for bulk soil and rhizosphere soil, but not between north and south-facing slopes. For bulk topsoil, all sites were clearly separated (Figure 2.3-6). The humid forest was separated from the arid shrubland and the Mediterranean woodland by all variables (except $\delta^{15} \mathrm{~N}$ ) along principal component 1 (PC1, $72.4 \%$ of variance). $\delta^{15} \mathrm{~N}$ on the other hand separated the Mediterranean woodland from the two other sites and was correlated with principal component 2 (PC2, 13.9\% of variance). In the rhizosphere, the humid temperate forest was also largely separated from the other two sites by all variables except $\delta^{15} \mathrm{~N}$ along PC1 (80.9\% of variance) but showed some overlap with the arid shrubland (Figure 2.3-6). $\delta^{15} \mathrm{~N}$, which was correlated with PC2 (12.4\% of variance) separated the forest form the Mediterranean woodland, while the arid shrubland overlapped with both sites along this axis. 


\subsubsection{Discussion}

\subsubsection{Precipitation and vegetation shape $N$ losses}

During biochemical processes $\mathrm{N}$ bearing compounds will be isotopically fractionated by discrimination against the heavier ${ }^{15} \mathrm{~N}$ isotope (Hogberg, 1997). Whenever one or more $\mathrm{N}$ pools are translocated (even if the respective translocation process is not fractionating itself, like leaching), the re-allocation of a depleted or enriched fraction within the profile leads to distinct depth profiles in $\delta^{15} \mathrm{~N}$ (Hobbie and Ouimette, 2009). The $\delta^{15} \mathrm{~N}$ increased with depth in soil under humid-temperate and Mediterranean conditions, indicating a loss of nitrogen from soil. High C:N ratios in soil under humid-temperate forest indicate greater microbial $\mathrm{N}$ immobilization than $\mathrm{N}$ mineralization ( Figure 2.3-1; Bengtsson et al., 2003; Janssen, 1996), which reduces the leaching potential of $\mathrm{N}$. On the contrary, high $\mathrm{N}$ contents but low $\mathrm{C}: \mathrm{N}$ ratios indicated that microbial $\mathrm{N}$ mineralization is high in the soil at the Mediterranean site ( Figure 2.3-1; Bengtsson et al., 2003; Janssen, 1996). A fast $\mathrm{N}$ mineralization in soil under Mediterranean woodland, was also indicated by the highest discrimination factor across the gradient (i.e., the strongest ${ }^{15} \mathrm{~N}$ enrichment with decreasing N content with depth) (Figure 2.3-2; Natelhoffer and Fry, 1988). By a decoupling of microbial activity and plant activity during dry seasons (Kuzyakov and $\mathrm{Xu}, 2013$ ), inorganic $\mathrm{N}$ can accumulate in arid and semiarid systems (McCulley et al., 2009; Reichmann et al., 2013). Accumulated mineral $\mathrm{N}$ is highly susceptible to leaching during the wet season (Chen et al., 2019; McCulley et al., 2009; Reichmann et al., 2013). While soil C:N ratios at the arid shrubland are also low and indicate greater $\mathrm{N}$ mineralization than microbial $\mathrm{N}$ immobilization ( Figure 2.3-1; Bengtsson et al., 2003; Janssen, 1996), the annual precipitation is insufficient to translocate mobile $\mathrm{N}$ pools downwards, as indicated by constant $\delta^{15} \mathrm{~N}$ with soil depth ( Figure 2.3-1).

Thus, it is like that the greatest $\mathrm{N}$ losses from soil occur from the woodland under Mediterranean conditions, which would be in line with highest denudation rates observed in the Mediterranean woodland across the precipitation gradient (Schaller et al., 2018; van Dongen et al., 2019). This was also supported by the PCA (Figure 2.3-6), which showed a clear separation of the Mediterranean woodland from the other two sites by $\delta^{15} \mathrm{~N}$.

\subsubsection{Microbial N fixation contributes to ecosystem $N$ gain}

High $\mathrm{N}$ losses under Mediterranean woodland and high $\mathrm{N}$ demand in humid temperate forest call for an efficient $\mathrm{N}$ recycling. This became evident with high $\mathrm{N}$ acquiring enzyme activities under Mediterranean woodland and humid forest (Figure 2.3-3). While protease activities did not differ between the two sites, activities of NAG, a chitinase important for mineralizing $\mathrm{N}$ from chitin 
(Olander and Vitousek, 2000), increased with precipitation (Figure 2.3-3). Increasing NAG activities reflect a source shift of organic N, from a peptide-based dominated nutrition under arid and semiarid conditions to a peptide- and chitin-based $\mathrm{N}$ nutrition for microorganisms under humid forest (Stock et al., 2019). The nutritional shift was also reflected in the bacterial and fungal abundance relative to SOC (Figure 2.3-4).

Greater relative bacterial abundance under arid shrubland and semiarid woodland in comparison to humid forest underlines the greater importance of bacteria (as peptide-rich biomass) as $\mathrm{N}$ source under dry than under humid conditions. Higher bacterial abundance as well as protease activity per SOC in the rhizosphere under shrubland and woodland than under forest (Figure 2.3-3, Figure 2.3-4) highlighted, further, the increasing importance of the rhizosphere as hotspot of plant nutrient acquisition with decreasing water availability (Ahmed et al., 2014; Carminati et al., 2010; Holz et al., 2018). This was supported by markedly higher diazotrophs percentages in the rhizosphere than in bulk soil in all sites $(\sim 10, \sim 8$, and $\sim 16$ folds under shrubland, woodland, and forest, respectively) (Figure 2.3-5) which is consistent with the rhizosphere effect (Burgmann et al., 2005; Kuzyakov and Razavi, 2019). High abundance of diazotrophs in the rhizosphere showed that N-fixation is greater in root proximity than in bulk soil (Figure 2.3-5), which underlines the importance of rhizosphere as $\mathrm{N}$ acquisition hotspot. Symbiotic $\mathrm{N}$-fixing microorganisms, such as Rhizobia, and free-living $\mathrm{N}$-fixing bacteria, such as Azotobacter, are both profiting from the benefits a root association provides (Poole et al., 2018; Smercin et al., 2019).

Generally, importance of N-fixation decreased from humid forest to arid shrubland (Figure 2.3-5). Biological N-fixation is an immensely $\mathrm{C}$ costly process, which can only be supported if environmental conditions (such as nutrient, water, or light availability) allow sufficient plant primary production and, thus, plant $\mathrm{C}$ investment in diazotrophs (Burgmann et al., 2005; Klucas, 1991). Under arid and semiarid conditions, however, water shortage likely hampers the investment in $\mathrm{N}$-fixing microorganisms. In addition, mean annual precipitation increases from arid shrubland to humid forest which increases the soil moisture content (Bernhard et al., 2018). As this occurs, formation of anaerobic conditions favorable for diazotrophs also increases since biological Nfixation requires anaerobic conditions (Hicks et al., 2003).

Soil fungal biomass positively correlate to enzyme activity of NAGs (Parham and Deng, 2000) because their cell walls contain $\mathrm{N}$-acetylglucosamine, a main substrate of NAGs (Rietl and Jackson, 2012). On the other hand, several publications showed a negative correlation between fungal biomass and N availability (Boyle et al., 2008; M. N. Hogberg et al., 2007; Myers et al., 2001). This is consistent with our results in which abundance of fungi per SOC was found highest in the humid temperate rhizosphere characterized by highest NAG activity (Figure 2.3-4). Lower 
fungal abundance in the rhizosphere per SOC under arid shrubland than in the rhizosphere of the other sites (Figure 2.3-4) indicated that plants under arid conditions invest not only less into $\mathrm{N}$ fixation but also into fungi than plants under Mediterranean or humid conditions. The similar relative fungal abundance in bulk soil between all sites (Figure 2.3-4), however, shows that fungi are of similar importance for nutrient acquisition regardless of aridity intensity.

\subsubsection{Conclusions}

Microbes played an important role in recycling of organically bound N. Major factors causing N losses in soil were annual precipitation and vegetation cover. As precipitation increased from arid shrubland to humid forest, more $\mathrm{N}$ losses were observed. However, high dense vegetation cover in humid forests reduced the impact of high precipitation on NO3- leaching and soil loss by erosion. Thus, highest $\mathrm{N}$ losses were found in Mediterranean woodland because of the high annual precipitation compared to arid shrubland, but low vegetation cover compared to humid forests. $\mathrm{NAG}$ activities and relative bacterial and fungal abundance indicate a $\mathrm{N}$ source shift from a protein-based nutrition recycling under arid and semiarid conditions to a protein- and chitin-based $\mathrm{N}$ nutrition under humid forest. The percentage of diazotrophy in prokaryotic parts of bulk soil community was found between $0.18 \%$ and $0.64 \%$ diazotrophs and increased to $2.09 \%$ and $8.20 \%$ in the rhizosphere. Higher abundance of diazotrophs in the rhizosphere than in bulk soil highlights the importance of the rhizosphere as hotspot for initial $\mathrm{N}$ acquisition $-\mathrm{N}$ fixation from atmosphere. Greater relative bacterial abundance and aminopeptidase activities with increasing aridity underline, additionally, the rhizosphere importance as hotspot for $\mathrm{N}$ acquisition with intensifying aridity.

\subsubsection{Conflict of Interest}

The authors declare that the research was conducted in the absence of any commercial or financial relationships that could be construed as a potential conflict of interest.

\subsubsection{Author Contributions}

Khaled Abdallah and Svenja C. Stock contributed equally to the writing of this manuscript. 


\subsubsection{Funding}

This study was funded by the German Research Foundation (DFG) [project number KU 1184/3611 and DI 2136-11] within the Priority Program 1803 'EarthShape - Earth Surface Shaping by Biota'.

\subsubsection{Acknowledgements}

We thank the Chilean National Park Service Corporación Nacional Forestal (CONAF) for the permission to work in the National Park La Campana and the National Park Nahuelbuta as well as the Comunidad Agrícola Quebrada de Talca for the possibility to work in the local 'exclusion area for studying biodiversity and conservation'. We are also thankful to the Center for Advanced Research in Arid Zones (CEAZA) for providing the possibility to work in the National Reserve Santa Gracia and the Centre for Stable Isotope Research and Analysis (KOSI).

\subsubsection{References}

Ågren, G., \& Bosatta, E. (1998). Theoretical Ecosystem Ecology [mdash] Understanding Element Cycles.

Ahmed, M. A., Kroener, E., Holz, M., Zarebanadkouki, M., \& Carminati, A. (2014). Mucilage exudation facilitates root water uptake in dry soils. Funct Plant Biol, 41(11), 1129-1137. doi:10.1071/FP13330

Bates, D., Machler, M., Bolker, B. M., \& Walker, S. C. (2015). Fitting Linear Mixed-Effects Models Using lme4. Journal of Statistical Software, 67(1), 1-48. doi:DOI 10.18637/jss.v067.i01

Bengtsson, J., Angelstam, P., Elmqvist, T., Emanuelsson, U., Folke, C., Ihse, M., . . Nyström, M. (2003). Reserves, Resilience and Dynamic Landscapes. AMBIO: A Journal of the Human Environment, 32(6), 389-396, 388. Retrieved from https://doi.org/10.1579/0044-7447-32.6.389

Bernhard, N., Moskwa, L. M., Schmidt, K., Oeser, R. A., Aburto, F., Bader, M. Y., . . Kuhn, P. (2018). Pedogenic and microbial interrelations to regional climate and local topography: New insights from a climate gradient (arid to humid) along the Coastal Cordillera of Chile. CATENA, 170, 335-355. doi:10.1016/j.catena.2018.06.018

Billings, S. A., \& Richter, D. D. (2006). Changes in stable isotopic signatures of soil nitrogen and carbon during 40 years of forest development. Oecologia, 148(2), 325-333. doi:10.1007/s00442-006-0366-7

Boyle, S. A., Yarwood, R. R., Bottomley, P. J., \& Myrold, D. D. (2008). Bacterial and fungal contributions to soil nitrogen cycling under Douglas fir and red alder at two sites in Oregon. Soil Biology \& Biochemistry, 40(2), 443-451. doi:10.1016/j.soilbio.2007.09.007

Bradley, J. A., Singarayer, J. S., \& Anesio, A. M. (2014). Microbial community dynamics in the forefield of glaciers. Proc Biol Sci, 281(1795). doi:10.1098/rspb.2014.0882

Burgmann, H., Meier, S., Bunge, M., Widmer, F., \& Zeyer, J. (2005). Effects of model root exudates on structure and activity of a soil diazotroph community. Environ Microbiol, 7(11), 1711-1724. doi:10.1111/j.1462-2920.2005.00818.x

Burk, D. (1934). Azotase and nitrogenase in Azotobacter. Ergeb. Enzymforsch, 3, 23-56.

Carminati, A., Moradi, A. B., Vetterlein, D., Vontobel, P., Lehmann, E., Weller, U., . . Oswald, S. E. (2010). Dynamics of soil water content in the rhizosphere. Plant and Soil, 332(1-2), 163-176. doi:10.1007/s11104-010-0283-8

Chalot, M., \& Brun, A. (1998). Physiology of organic nitrogen acquisition by ectomycorrhizal fungi and ectomycorrhizas. FEMS Microbiol Rev, 22(1), 21-44. doi:10.1111/j.1574-6976.1998.tb00359.x

Chen, J., Kuzyakov, Y., Jenerette, G. D., Xiao, G., Liu, W., Wang, Z., \& Shen, W. (2019). Intensified Precipitation Seasonality Reduces Soil Inorganic N Content in a Subtropical Forest: Greater Contribution of Leaching Loss Than N2O Emissions. Journal of Geophysical Research: Biogeosciences, 124(3), 494-508. doi:10.1029/2018jg004821

Clogg, C.C., Petkova, E., Haritou, A., 1995. Statistical Methods for Comparing Regression Coefficients Between Models. Am. J. Sociol. 100, 1261-1293. https://doi.org/10.1086/230638

Cocolin, L., Manzano, M., Aggio, D., Cantoni, C., \& Comi, G. (2001). A novel polymerase chain reaction (PCR) - denaturing gradient gel electrophoresis (DGGE) for the identification of Micrococcaceae strains involved in meat fermentations. Its application to naturally fermented Italian sausages. Meat Sci, 58(1), 59-64. doi:10.1016/s0309-1740(00)00131-5 
Duc, L., Noll, M., Meier, B. E., Burgmann, H., \& Zeyer, J. (2009). High diversity of diazotrophs in the forefield of a receding alpine glacier. Microb Ecol, 57(1), 179-190. doi:10.1007/s00248-008-9408-5

Fick, S.E., Hijmans, R.J., 2017. WorldClim 2: new 1-km spatial resolution climate surfaces for global land areas: New Climate Surfaces for Global Land Areas. Int. J. Climatol. 37, 4302-4315. https://doi.org/10.1002/joc.5086

Gallon, J. (1981). The oxygen sensitivity of nitrogenase: a problem for biochemists and micro-organisms. Trends in Biochemical Sciences, 6, 19-23.

Galloway, J. N., Dentener, F. J., Capone, D. G., Boyer, E. W., Howarth, R. W., Seitzinger, S. P., . . Vorosmarty, C. J. (2004). Nitrogen cycles: past, present, and future. Biogeochemistry, 70(2), 153-226. doi:DOI 10.1007/s10533-004-0370-0

Hannula, S. E., Boschker, H. T., de Boer, W., \& van Veen, J. A. (2012). 13C pulse-labeling assessment of the community structure of active fungi in the rhizosphere of a genetically starch-modified potato (Solanum tuberosum) cultivar and its parental isoline. New Phytol, 194(3), 784-799. doi:10.1111/j.1469-8137.2012.04089.x

Hassink, J. (1994). Effects of Soil Texture and Grassland Management on Soil Organic C and N and Rates of C and N Mineralization. Soil Biology \& Biochemistry, 26(9), 1221-1231. doi:Doi 10.1016/0038-0717(94)90147-3

Heijnen, J. J., \& Roels, J. A. (1981). A Macroscopic Model Describing Yield and Maintenance Relationships in Aerobic Fermentation Processes. Biotechnology and Bioengineering, 23(4), 739-763. doi:DOI 10.1002/bit.260230407

Hicks, W. T., Harmon, M. E., \& Griffiths, R. P. (2003). Abiotic controls on nitrogen fixation and respiration in selected woody debris from the Pacific Northwest, U.S.A. Écoscience, 10(1), 66-73. Retrieved from www.jstor.org/stable/42901510

Hirsch, P. R., \& Mauchline, T. H. (2015). The Importance of the Microbial N Cycle in Soil for Crop Plant Nutrition. Adv Appl Microbiol, 93, 45-71. doi:10.1016/bs.aambs.2015.09.001

Hobbie, E. A., \& Hobbie, J. E. (2008). Natural Abundance of 15N in Nitrogen-Limited Forests and Tundra Can Estimate Nitrogen Cycling Through Mycorrhizal Fungi: A Review. Ecosystems, 11(5), 815-830. doi:10.1007/s10021-008-9159-7

Hobbie, E. A., \& Ouimette, A. P. (2009). Controls of nitrogen isotope patterns in soil profiles. Biogeochemistry, 95(2-3), 355-371. doi:10.1007/s10533-009-9328-6

Hobbie, E. A., \& Wallander, H. (2006). Integrating ectomycorrhizal fungi into quantitative frameworks of forest carbon and nitrogen cycling. Fungi in Biogeochemical Cycles, 98-128.

Hogberg, M. N., Hogberg, P., \& Myrold, D. D. (2007). Is microbial community composition in boreal forest soils determined by $\mathrm{pH}, \mathrm{C}-\mathrm{to}-\mathrm{N}$ ratio, the trees, or all three? Oecologia, 150(4), 590-601. doi:10.1007/s00442-006-0562-5

Hogberg, P. (1997). Tansley Review No. 95. 15N natural abundance in soil-plant systems. New Phytologist, 137(2), 179-203. doi:10.1046/j.1469-8137.1997.00808.x

Holz, M., Zarebanadkouki, M., Kaestner, A., Kuzyakov, Y., \& Carminati, A. (2018). Rhizodeposition under drought is controlled by root growth rate and rhizosphere water content. Plant and Soil, 423(1-2), 429-442. doi:10.1007/s11104-017-3522-4

Hothorn, T., Bretz, F., \& Westfall, P. (2008). Simultaneous inference in general parametric models. Biom J, 50(3), 346-363. doi:10.1002/bimj.200810425

Hsu, S. F., \& Buckley, D. H. (2009). Evidence for the functional significance of diazotroph community structure in soil. Isme j, 3(1), 124-136. doi:10.1038/ismej.2008.82

Inomura, K., Bragg, J., Riemann, L., \& Follows, M. J. (2018). A quantitative model of nitrogen fixation in the presence of ammonium. PLOS ONE, 13(11), e0208282. doi:10.1371/journal.pone.0208282

Jacoby, R., Peukert, M., Succurro, A., Koprivova, A., \& Kopriva, S. (2017). The Role of Soil Microorganisms in Plant Mineral Nutrition-Current Knowledge and Future Directions. Frontiers in plant science, 8, 1617. doi:10.3389/fpls.2017.01617

Janssen, B. H. (1996). Nitrogen mineralization in relation to C:N ratio and decomposability of organic materials. Plant and Soil, 181(1), 39-45. doi:Doi 10.1007/Bf00011290

Jiang, H., Dong, H., Zhang, G., Yu, B., Chapman, L. R., \& Fields, M. W. (2006). Microbial diversity in water and sediment of Lake Chaka, an athalassohaline lake in northwestern China. Appl Environ Microbiol, 72(6), 3832-3845. doi:10.1128/AEM.02869-05

Klucas, R. V. (1991). Associative nitrogen fixation in plants. Studies in plant science.

Kögel-Knabner, I. (2002). The macromolecular organic composition of plant and microbial residues as inputs to soil organic matter. Soil Biology and Biochemistry, 34(2), 139-162. doi:10.1016/s0038-0717(01)00158-4

Kuzyakov, Y., \& Blagodatskaya, E. (2015). Microbial hotspots and hot moments in soil: Concept \& review. Soil Biology \& Biochemistry, 83, 184-199. doi:10.1016/j.soilbio.2015.01.025

Kuzyakov, Y., \& Razavi, B. S. (2019). Rhizosphere size and shape: Temporal dynamics and spatial stationarity. Soil Biology and Biochemistry, 135, 343-360. doi:https://doi.org/10.1016/j.soilbio.2019.05.011

Kuzyakov, Y., \& Xu, X. (2013). Competition between roots and microorganisms for nitrogen: mechanisms and ecological relevance. New Phytol, 198(3), 656-669. doi:10.1111/nph.12235

Lindahl, B. D., Ihrmark, K., Boberg, J., Trumbore, S. E., Hogberg, P., Stenlid, J., \& Finlay, R. D. (2007). Spatial separation of litter decomposition and mycorrhizal nitrogen uptake in a boreal forest. New Phytol, 173(3), 611-620. doi:10.1111/j.1469-8137.2006.01936.x

Martin-Sanchez, P. M., Gorbushina, A. A., \& Toepel, J. (2018). Quantification of of microbial load in diesel storage tanks using culture and qPCR-based approaches. International Biodeterioration \& Biodegradation, 126, 216-223. doi:10.1016/j.ibiod.2016.04.009 
McCulley, R. L., Burke, I. C., \& Lauenroth, W. K. (2009). Conservation of nitrogen increases with precipitation across a major grassland gradient in the Central Great Plains of North America. Oecologia, 159(3), 571-581. doi:10.1007/s00442-0081229-1

Menge, D. N., \& Hedin, L. O. (2009). Nitrogen fixation in different biogeochemical niches along a 120000 -year chronosequence in New Zealand. Ecology, 90(8), 2190-2201. doi:10.1890/08-0877.1

Myers, R. T., Zak, D. R., White, D. C., \& Peacock, A. (2001). Landscape-level patterns of microbial community composition and substrate use in upland forest ecosystems. Soil Science Society of America Journal, 65(2), 359-367. doi:DOI $10.2136 /$ sssaj2001.652359x

Nakatsu, C. H., \& Marsh, T. L. (2007). Analysis of Microbial Communities with Denaturing Gradient Gel Electrophoresis and Terminal Restriction Fragment Length Polymorphism. In Methods for General and Molecular Microbiology, Third Edition (pp. 909-923): American Society of Microbiology.

Natelhoffer, K. J., \& Fry, B. (1988). Controls on Natural Nitrogen-15 and Carbon-13 Abundances in Forest Soil Organic Matter. Soil Science Society of America Journal, 52(6), 1633-1640. doi:10.2136/sssaj1988.03615995005200060024x

O'Donnell, K. (1992). Fusarium and its near relatives. The fungal holomorph: mitotic, meiotic and pleomorphic speciation in fungal systematics. Retrieved from

Oelze, J. (2000). Respiratory protection of nitrogenase in Azotobacter species: is a widely held hypothesis unequivocally supported by experimental evidence? FEMS Microbiol Rev, 24(4), 321-333. doi:10.1111/j.1574-6976.2000.tb00545.x

Oeser, R. A., Stroncik, N., Moskwa, L. M., Bernhard, N., Schaller, M., Canessa, R., . . von Blanckenburg, F. (2018). Chemistry and microbiology of the Critical Zone along a steep climate and vegetation gradient in the Chilean Coastal Cordillera. CATENA, 170, 183-203. doi:10.1016/j.catena.2018.06.002

Olander, L. P., \& Vitousek, P. M. (2000). Regulation of soil phosphatase and chitinase activityby N and P availability. Biogeochemistry, 49(2), 175-191. doi:10.1023/a:1006316117817

Parham, J. A., \& Deng, S. P. (2000). Detection, quantification and characterization of $\beta$-glucosaminidase activity in soil. Soil Biology and Biochemistry, 32(8-9), 1183-1190. doi:10.1016/s0038-0717(00)00034-1

Poly, F., Monrozier, L. J., \& Bally, R. (2001). Improvement in the RFLP procedure for studying the diversity of nifH genes in communities of nitrogen fixers in soil. Res Microbiol, 152(1), 95-103. doi:https://doi.org/10.1016/S09232508(00)01172-4

Poole, P., Ramachandran, V., \& Terpolilli, J. (2018). Rhizobia: from saprophytes to endosymbionts. Nat Rev Microbiol, 16(5), 291-303. doi:10.1038/nrmicro.2017.171

Read, D. J., \& Perez-Moreno, J. (2003). Mycorrhizas and nutrient cycling in ecosystems - a journey towards relevance? New Phytologist, 157(3), 475-492. doi:10.1046/j.1469-8137.2003.00704.x

Regan, K., Stempfhuber, B., Schloter, M., Rasche, F., Prati, D., Philippot, L., . . Marhan, S. (2017). Spatial and temporal dynamics of nitrogen fixing, nitrifying and denitrifying microbes in an unfertilized grassland soil. Soil Biology \& Biochemistry, 109, 214-226. doi:10.1016/j.soilbio.2016.11.011

Reichmann, L. G., Sala, O. E., \& Peters, D. P. C. (2013). Water controls on nitrogen transformations and stocks in an arid ecosystem. Ecosphere, 4(1), art11. doi:Unsp 11

10.1890/Es12-00263.1

Rietl, A. J., \& Jackson, C. R. (2012). Effects of the ecological restoration practices of prescribed burning and mechanical thinning on soil microbial enzyme activities and leaf litter decomposition. Soil Biology \& Biochemistry, 50, 47-57. doi:10.1016/j.soilbio.2012.03.008

Robinson, D. (2001). $\delta 15 \mathrm{~N}$ as an integrator of the nitrogen cycle. Trends in Ecology \& Evolution, 16(3), $153-162$. doi:10.1016/s0169-5347(00)02098-x

Schaller, M., Ehlers, T. A., Lang, K. A. H., Schmid, M., \& Fuentes-Espoz, J. P. (2018). Addressing the contribution of climate and vegetation cover on hillslope denudation, Chilean Coastal Cordillera (26 degrees-38 degrees S). Earth and Planetary Science Letters, 489, 111-122. doi:10.1016/j.epsl.2018.02.026

Schulz, S., Brankatschk, R., Dümig, A., Kögel-Knabner, I., Schloter, M., \& Zeyer, J. (2013). The role of microorganisms at different stages of ecosystem development for soil formation. Biogeosciences, 10(6), 3983-3996.

Smercina, D. N., Evans, S. E., Friesen, M. L., \& Tiemann, L. K. (2019). To Fix or Not To Fix: Controls on Free-Living Nitrogen Fixation in the Rhizosphere. Appl Environ Microbiol, 85(6), e02546-02518. doi:10.1128/AEM.02546-18

Stevenson, B. S., Drilling, H. S., Lawson, P. A., Duncan, K. E., Parisi, V. A., \& Suflita, J. M. (2011). Microbial communities in bulk fluids and biofilms of an oil facility have similar composition but different structure. Environ Microbiol, 13(4), 1078-1090. doi:10.1111/j.1462-2920.2010.02413.x

Stock, S. C., Koster, M., Dippold, M. A., Najera, F., Matus, F., Merino, C., . . Kuzyakov, Y. (2019). Environmental drivers and stoichiometric constraints on enzyme activities in soils from rhizosphere to continental scale. Geoderma, 337, 973-982. doi:10.1016/j.geoderma.2018.10.030

Team, R. C. (2018). R-A language and environment for statistical computing. Vienna: R Foundation for Statistical Computing. https://www.R-project.org/. In.

Turner, S., Pryer, K. M., Miao, V. P., \& Palmer, J. D. (1999). Investigating deep phylogenetic relationships among cyanobacteria and plastids by small subunit rRNA sequence analysis. J Eukaryot Microbiol, 46(4), 327-338. Retrieved from https://www.ncbi.nlm.nih.gov/pubmed/10461381 
Turpin-jelfs, T., Michaelides, K., Blacker, J. J., Benning, L. G., Williams, J. M., \& Anesio, A. M. (2018). Distribution of soil nitrogen and nitrogenase activity in the forefield of a High Arctic receding glacier. Annals of Glaciology, 59(77), 87-94. doi:10.1017/aog.2018.35

van Dongen, R., Scherler, D., Wittmann, H., Blanckenburg, F. von, 2019. Cosmogenic 10 Be in river sediment: where grain size matters and why. Earth Surf. Dynam. 7 (2), 393-410.

Vitousek, P., \& Howarth, R. (1991). Nitrogen limitation on land and in the sea: How can it occur? Biogeochemistry, 13(2), 87115. doi: $10.1007 / \mathrm{bf00002772}$

$\mathrm{Vu}$, V. Q. (2011). ggbiplot: A ggplot2 based biplot. R package, 342 . Retrieved from http://github.com/vqv/ggbiplot/tree/experimental

White, T. J., Bruns, T., Lee, S., \& Taylor, J. (1990). Amplification and Direct Sequencing of Fungal Ribosomal Rna Genes for Phylogenetics. In M. A. Innis, D. H. Gelfand, J. J. Sninsky, \& T. J. White (Eds.), PCR Protocols (pp. 315-322). San Diego: Academic Press.

Wilson, K. H., Blitchington, R. B., \& Greene, R. C. (1990). Amplification of bacterial 16S ribosomal DNA with polymerase chain reaction. J Clin Microbiol, 28(9), 1942-1946. Retrieved from https://www.ncbi.nlm.nih.gov/pubmed/2095137 
2.4 Study 4: Environmental drivers and stoichiometric constraints on enzyme activities in soils from rhizosphere to continental scale

Published in Geoderma (2019), 337, 973-982, doi: 10.1016/j.geoderma.2018.10.030

$\underline{\text { Svenja C. Stock }}^{\text {a }}{ }$, Moritz Köster $^{b}$, Michaela A. Dippold ${ }^{b}$, Francisco Nájera ${ }^{c}$, Francisco Matus

${ }^{\mathrm{c}}$, Carolina Merino ${ }^{\mathrm{c}}$, Jens Boy ${ }^{\mathrm{d}}$, Sandra Spielvogel ${ }^{\mathrm{e}}$, Anna Gorbushina ${ }^{\mathrm{f}}$, and Yakov Kuzyakov $\mathrm{a}, \mathrm{g}, \mathrm{h}$

${ }^{a}$ Soil Science of Temperate Ecosystems, University of Göttingen, Göttingen, Germany

${ }^{\mathrm{b}}$ Biogeochemistry of Agroecosystems, University of Göttingen, Göttingen, Germany

c Departamento de Ciencias Químicas y Recursos Naturales, Universidad de La Frontera, Temuco, Chile

${ }^{\mathrm{d}}$ Institute of Soil Science, Leibniz University Hannover, Hannover, Germany

${ }^{\mathrm{e}}$ Soil Science, University of Kiel, Kiel, Germany

${ }^{\mathrm{f}}$ Department Materials and Environment, Federal Institute for Material Research and Testing, Berlin, Germany

${ }^{g}$ Institute of Environmental Sciences, Kazan Federal University, 420049 Kazan, Russia

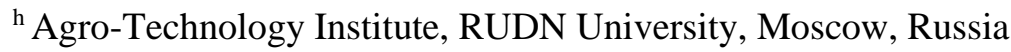

*Corresponding author: Svenja C. Stock

Keywords: Extracellular enzymes, stoichiometric homeostasis, rhizosphere effect, nutrient acquisition, multi-scale study 


\section{Abstract}

Microbial activity and functioning in soils are strongly limited by the availability of C, of which a great proportion is released by roots. Root exudates stimulate microbial activity and growth, or shift the stoichiometric balance between $\mathrm{C}, \mathrm{N}$, and P. Thereby, exudates heighten microbial nutrient demand and acquisition of $\mathrm{N}$ and $\mathrm{P}$, leading to an increase in enzyme production. Aim of this study was to determine environmental controls of extracellular enzyme production, and hence on potential enzyme activities $\left(\mathrm{V}_{\max }\right)$ and substrate affinities $\left(\mathrm{K}_{\mathrm{m}}\right)$. To determine the controlling factors, we worked on four scales from the microscale (i.e. rhizosphere) through the mesoscale (i.e. soil depth) and landscape scale (relief positions), and finally to the continental scale (1200 km transect within the Coastal Cordillera of Chile). Kinetics of seven hydrolyzing enzymes of the C, $\mathrm{N}$, and $\mathrm{P}$ cycles (cellobiohydrolase, $\beta$-glucosidase, $\beta$-xylosidase, $\beta$ - $\mathrm{N}$-acetylglucosaminidase, leucine-aminopeptidase, tyrosine-aminopeptidase, and acid phosphatase) were related to soil texture, $\mathrm{C}$ and $\mathrm{N}$ contents, $\mathrm{pH}$, and soil moisture via redundancy analysis (RDA). Potential activities of $\mathrm{C}, \mathrm{N}$, and $\mathrm{P}$ acquiring enzymes increased up to 7-times on the continental scale with rising humidity of sites and $\mathrm{C}$ and $\mathrm{N}$ contents, while substrate affinities simultaneously declined. On the landscape scale, neither $\mathrm{V}_{\max }$ nor $\mathrm{K}_{\mathrm{m}}$ of any enzyme differed considerably between north and south slopes. From top- to subsoil (down to $120 \mathrm{~cm}$ depth) potential activities decreased (strongest of aminopeptidases under humid temperate conditions with up to 90\%). Substrate affinities, however, increased with greater soil depth only for $\mathrm{N}$ and $\mathrm{P}$ acquiring enzymes. Affinities of cellobiohydrolase and $\beta$-xylosidase, on the contrary, were 1.5- to 3-times higher in top- than in subsoil. A rise of potential activities from bulk soil to root was observed for $\mathrm{N}$ and $\mathrm{P}$ acquiring enzymes and $\beta$-glucosidase. Simultaneously, substrate affinities of $\mathrm{N}$ and $\mathrm{P}$ acquiring enzymes declined, whereas affinities of $\beta$-glucosidase increased. These trends of activities and affinities in the rhizosphere were significant only for acid phosphatase. The RDA displayed a strong relation of potential activities of $\mathrm{C}$ and $\mathrm{P}$ acquiring enzymes and $\beta$ - $\mathrm{N}$-acetylglucosaminidase to $\mathrm{C}$ and $\mathrm{N}$ contents as well as to the silt and clay contents. Aminopeptidase activity was mainly dependent on soil moisture and $\mathrm{pH}$. We conclude that substrate availability for microorganisms mainly determined enzyme activity patterns on the continental scale (i.e. the humidity gradient). Patterns on the meso- and microscale are primarily controlled by nutrient limitation, which is induced by a shift of the stoichiometric balance due to input of easily available $\mathrm{C}$ by roots in the rhizosphere. 


\subsubsection{Introduction}

Extracellular enzymes, originating largely from plant roots and soil microorganisms (Burns et al., 2013), catalyze soil organic matter decomposition (SOM). Enzymes split organic polymers into soluble molecules and ions, which can be assimilated by microorganisms and taken up by plant roots (Allison and Vitousek, 2005; Sinsabaugh et al., 2008). Microbial activity in soil is mainly limited by available carbon (C) (Blagodatsky and Richter, 1998; Hodge et al., 2000; Schimel and Weintraub, 2003), of which root exudates and decaying litter are the largest source (Bertin et al., 2003; Kuzyakov, 2002a; Pausch and Kuzyakov, 2018). Exudates are easily degradable and are thus highly available substrate for microorganisms (Bertin et al., 2003; Schimel and Weintraub, 2003; Meier et al., 2017), which can stimulate microbial activity and growth (Blagodatskaya et al., 2014; de Graaff et al., 2010; 2014, de Nobili et al., 2001), and in turn increase C demand and investment into $\mathrm{C}$ and nutrient acquisition (i.e. enzyme synthesis) (Hernández and Hobbie, 2010). Labile $\mathrm{C}$ stimulates not only microbial activity as readily available energy source, but also shifts the stoichiometric balance between $\mathrm{C}$, nitrogen $(\mathrm{N})$, and phosphorus $(\mathrm{P})$ (Cheng and Kuzyakov, 2005; Phillips et al., 2011; Sinsabaugh and Moorhead, 1994). Thereby, labile C heightens microbial nutrient demand, which can be compensated by an upregulation of enzyme synthesis and a degradation of nutrient-rich compounds to maintain stoichiometric homeostasis (Chen et al., 2014; Cheng and Kuzyakov, 2005; Phillips et al., 2011; Sinsabaugh and Follstad Shah, 2012; Sinsabaugh et al., 2014). The upregulation of enzyme synthesis does not necessarily aim to boost enzyme activities, but also to produce enzymatic systems with higher substrate affinities to strengthen the competitiveness of microorganisms by a more efficient SOM and litter decomposition (Klipp and Heinrich, 1994; Kuzyakov and Xu, 2013; Stone and Plante, 2014). Whether enzyme production is upregulated depends on the cost efficiency of resource allocation into enzyme production in relation to microbial growth (Moorhead et al., 2012; Sinsabaugh and Follstad Shah, 2012).

Biochemical reaction products or a high availability of the target element (e.g. C, N, or P) can suppress enzyme activity. If sufficient easily available compounds are present to cover the cells' energy demands, the synthesis of new extracellular enzymes can be inhibited, (Sinsabaugh et al., 1993), as reported for $\mathrm{N}$ and $\mathrm{P}$ acquiring enzymes (DeForest et al., 2012; Olander and Vitousek, 2000; Turner and Wright, 2014). Alternatively, enzyme activity can be stimulated by the presence of their target substrate (Allison and Vitousek, 2005; Kielak et al., 2013). Microbial nutrient acquisition strategies (i.e. the allocation of resources into the synthesis of specific enzymes), therefore, likely change according to substrate and nutrient availability. 
Extracellular enzyme activities are affected further by abiotic factors such as soil moisture, $\mathrm{pH}$, and soil particle size distribution (Acosta-Martínez and Tabatabai, 2000; Sanaullah et al., 2011; Stemmer et al. 1998). They either directly modify enzyme activities, e.g. via conformation changes, binding onto soil particles, or the dependence on diffusion rates (Davidson and Janssens, 2006; Quiquampoix et al., 1992; Turner, 2010), or indirectly such as via altering substrate solubility, substrate concentration and accessibility, or grazing pressure on microorganisms (Burns et al., 2013; Kuzyakov and Mason-Jones, 2018 (in press); Ruamps et al., 2011). Responses of enzyme activities to moisture and $\mathrm{pH}$ changes are complex and vary depending on the ecosystem settings, scales, and ambient conditions to which enzymes are adapted (Allison and Jastrow, 2006; Dick and Tabatabai. 1987; Burns et al., 2013; German et al., 2012; Turner, 2010), rising a challenge for studies on enzyme driven SOM decomposition and nutrient release across and within ecosystems. Former and recent studies well covered the response of extracellular enzymes to moisture shifts (e.g. Burns et al., 2013; Sanaullah et al., 2011; Steinweg et al., 2012) as well as rhizosphere effects (e.g. Dakora and Phillips, 2002; Phillips et al., 2011; Tarafdar and Jungk, 1987; Weintraub et al., 2007). Studies on enzyme kinetics were conducted on several scales, ranging from a continental scale (as the global distribution of activities (e.g. Sinsabaugh et al., 2008)) to focusing on microscales (as activity distribution in the rhizosphere (e.g. Razavi et al., 2016)). Directions and responses, however, are not consistent and simultaneous measurements of enzyme activities on multiple scales are scares.

By working on four spatial scales, we aimed to gain deeper insights on the regulatory effects of substrate availability and stoichiometric constraints on extracellular enzyme activities. Therefore, we analyzed kinetics of seven hydrolyzing enzymes of the $\mathrm{C}, \mathrm{N}$, and P cycles, responsible for cellulose and hemicellulose degradation, chitin and protein decomposition, and $\mathrm{P}$ acquisition via dissociation of phosphoric acid, and which are representative for decomposers of easily and complex substrates, on four scales: continental, landscape, meso-, and microscale.

We hypothesize that (1) on the continental scale, i.e. across ecosystems with a strong gradient in mean annual precipitation (MAP) and vegetation cover, enzyme activities are stimulated while substrate affinities decrease in response to increasing precipitation and plant biomass (litter) input (i.e. substrate availability). (2) On the landscape scale, represented by opposite slopes with different vegetation cover induced by deviating moisture regime, we also expect enzyme activities to rise with higher soil moisture. (3) On the medium scale of the soil profile (characterized by decreasing $\mathrm{C}$ and $\mathrm{N}$ contents with depth), we hypothesize enzyme activities to decrease from topto subsoil, while substrate affinities enhance, in response to substrate scarcity in the subsoil. (4) On the microscale, i.e. from bulk soil to rhizosphere characterized by a C, N, and C:N increase, 
we hypothesize enzyme activities are stimulated, while substrate affinities decline in response to higher substrate availability.

\subsubsection{Material and Methods}

\subsubsection{Study area}

Study areas are located within the Coastal Cordillera of Chile between $29^{\circ}$ and $38^{\circ}$ southern latitude (Figure 2.4-1). The study sites cover a climate gradient from humid temperate (Parque National Nahuebluta (NA)) to Mediterranean (Parque National La Campana (LC)) and semiarid (Reserva Santa Gracia (SG)), with soils developed on granitoid parent material in all sites. Altitude and distance to the Pacific Ocean of the sites increase from north to south. In Nahuelbuta, Umbrisols and Podzols are present ( $\mathrm{pH}$ 3.7-5.1), covered with a dense coniferous forest (Table S 2.4-1; Bernhard et al., 2018). In La Campana, a patchy deciduous forest and evergreen sclerophyllous shurbs cover primarily Cambisols (pH 4.5-6.1) (Table S 2.4-1; Bernhard et al., 2018). In Santa Gracia, the developed Cambisols ( $\mathrm{pH}$ 5.48-7.0) are covered mainly with sclerophyllous shrubs and cacti (Table S 2.4-1; Bernhard et al., 2018). For a more detailed description of the study sites see Table S 2.4-1 as well as Bernhard et al. (2018) and Oeser et al. (2018).

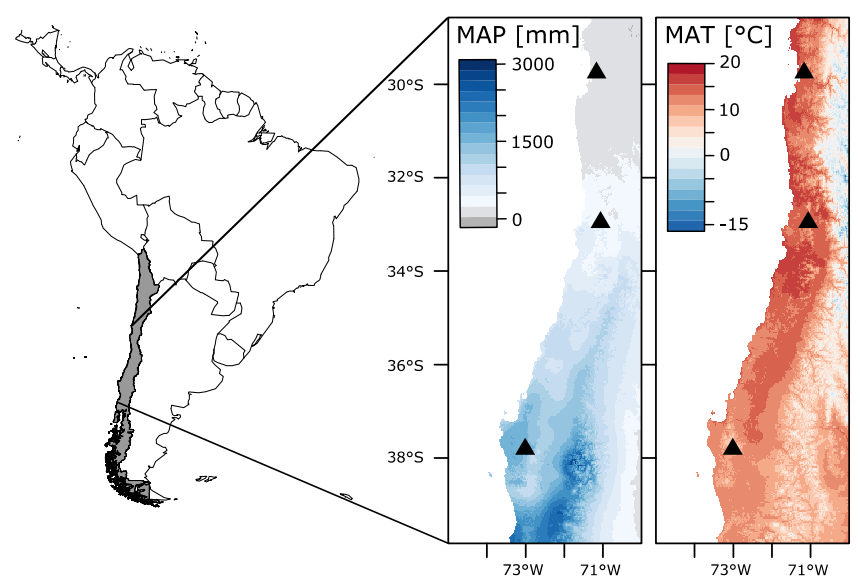

Figure 2.4-1: Study site overview. Showing mean annual precipitation (MAP) and mean annual temperature (MAT) along the continental gradient (WorldClima data Version 2, Fick and Hijmans et al., 2017). Study sites from north to south: Santa Gracia, La Campana, Nahuelbuta.

\subsubsection{Soil sampling and analyses}

Soil samples were collected in summer 2016 from four soil pits in each study site; three on a southexposed slope, arranged as a catena encompassing a soil pit at top-, mid-, and toe-slope positions, and one on a north-exposed slope at mid-slope position. Soil was sampled in three distances from channels of young living roots $(0-2 \mathrm{~mm}, 2-4 \mathrm{~mm}, 4-6 \mathrm{~mm})$, in three soil increments. Depth increments were chosen as percentage of depth until saprolite. The upper $30 \%$ of the soil profile encompassed the topsoil, the increment between $30 \%$ and $70 \%$ the subsoil. The third increment 
encompassed the lower part of the soil profile down to the start of the saprolite. In total, 97 samples were collected. After sampling, the material was directly cooled and stored at $4{ }^{\circ} \mathrm{C}$ until analyses. Gravimetric water content was determined by drying aliquots of the samples at $105{ }^{\circ} \mathrm{C}$ until constant weight. For determining $\mathrm{C}$ and $\mathrm{N}$ contents, aliquots of the samples were dried $\left(50{ }^{\circ} \mathrm{C}\right)$ and subsequently ground milled. The measurement of $\mathrm{C}$ and $\mathrm{N}$ was conducted simultaneously by an elemental analyzer (NA1500, Fisons instruments, Milano, Italy). Soil particle size fraction and pH data were acquired by Bernhard et al. (2018) from samples taken in the same soil pits and during the same time as our samples. These samples, however, were collected in different soil depth increments and not in rhizosphere gradients.

\subsection{Enzyme assays}

Activities of the extracellular enzymes were determined using synthetic fluorogenic substrates (Marx et al., 2001) (see Table 2.4-1). Subsamples (0.5 g) of the cooled $\left(4{ }^{\circ} \mathrm{C}\right)$ soil samples were pre-incubated $24 \mathrm{~h}$ in sterile $100 \mathrm{ml}$ jars. After pre-incubation, $50 \mathrm{ml}$ of sterile water was added to the jars and shaken for $30 \mathrm{~min}$. Subsequently, the soil solution was sonicated $\left(40 \mathrm{~J} \mathrm{~s}^{-1} ; 2 \mathrm{~min}\right)$ before aliquots of $50 \mu \mathrm{l}$ were pipetted into black polystyrene 96-well microplates (Brand, Germany). Afterwards, $50 \mu 1$ of buffer (0.1 M MES (pH 6.1) for 4-methylumbelliferone (MUF) linked substrates; $0.05 M$ TRIZMA (pH 7.8) for 7-amino-4-methylcoumarin (AMC) associated substrates) and $100 \mu \mathrm{l}$ of substrate solution $\left(0,10,20,30,40,50,100\right.$, and $\left.200 \mu \mathrm{mol} \mathrm{g}^{-1}\right)$ were added. Three analytical replicates were measured for each sample at each substrate concentration. Fluorescence was measured by a microplate reader (Victor ${ }^{3}$ 1420-050 Multi label Counter; extinction: $355 \mathrm{~nm}$, emission: $460 \mathrm{~nm}$ ) immediately after substrate addition $\left(\mathrm{t}_{0}\right)$ and $2 \mathrm{~h}$ after addition $\left(\mathrm{t}_{1}\right)$. For calibration and accounting for quenching, standard plates were prepared with $50 \mu \mathrm{l}$ of a composite soil solution (for each site and depth), with 150, 145, 140, 130, 100, 70, and $30 \mu 1$ of buffer (MES or TRIZMA) and 0, 5, 10, 20, 50, 80, and $120 \mu 1$ standard (MUF or AMC), respectively. Plates were measured at $\mathrm{t}_{0}$ and $\mathrm{t}_{1}$. With the regression slopes of the standard measurements, enzyme activities of the samples were calculated [nmol substrate $\mathrm{g}^{-1}$ soil h$^{-1}$ ]. Activities were fitted by the Michaelis-Menten Equation, which describes non-linear saturation curves:

$$
\mathrm{v}=\left(\mathrm{V}_{\max } \mathrm{x}[\mathrm{S}]\right) /\left(\mathrm{K}_{\mathrm{m}}+[\mathrm{S}]\right)
$$

with $\mathrm{S}$ as the added substrate concentrations, $\mathrm{V}_{\max }$ as the maximal rate of enzymatic activity under optimum substrate conditions, and $\mathrm{K}_{\mathrm{m}}$ as the half-saturation constant as indicator for substrate affinity. The residual standard errors (RSE) of the fitted non-linear saturation curves are given in Table S 2.4-2. 
Table 2.4-1: Overview of extracellular enzymes with respective fluorogenic substrates (Marx et al., 2001) and ecological functions.

\begin{tabular}{|c|c|c|}
\hline Enzyme & Fluorogenic substrate & Function \\
\hline $\begin{array}{l}\beta \text {-cellobiohydrolase } \\
\text { (EC 3.2.1.91) }\end{array}$ & $\begin{array}{l}\text { 4-methylumbelliferone- } \beta \text {-D- } \\
\text { cellobioside }\end{array}$ & hydrolysis of cellulose \\
\hline $\begin{array}{l}\beta \text {-glucosidase } \\
(\text { EC 3.2.1.21) }\end{array}$ & $\begin{array}{l}\text { 4-methylumbelliferone- } \beta \text {-D- } \\
\text { glucoside }\end{array}$ & hydrolysis of simple sugars \\
\hline $\begin{array}{l}\beta \text {-xylosidase } \\
(\text { EC 3.2.2.37) }\end{array}$ & $\begin{array}{l}\text { 4-methylumbelliferone- } \beta \text {-D- } \\
\text { xylopyranoside }\end{array}$ & hydrolysis of hemicellulose \\
\hline $\begin{array}{l}\beta \text {-N-acetylglucosaminidase } \\
\text { (EC 3.2.1.14) }\end{array}$ & $\begin{array}{l}\text { 4-methylumbelliferone-acetyl- } \\
\beta \text {-D-glucosaminide }\end{array}$ & $\begin{array}{l}\text { hydrolysis of } \\
\text { chitooligosaccharides into N- } \\
\text { acetylglucosamine }\end{array}$ \\
\hline $\begin{array}{l}\text { leucine-aminopeptidase } \\
\text { (EC 3.4.11.1) }\end{array}$ & $\begin{array}{l}\text { L-leucine-7-amino-4- } \\
\text { methylcoumarin }\end{array}$ & $\begin{array}{l}\text { cleaving of peptide bonds in } \\
\text { proteins }\end{array}$ \\
\hline $\begin{array}{l}\text { tyrosine-aminopeptidase } \\
\text { (EC 3.4.11) }\end{array}$ & $\begin{array}{l}\text { L-tyrosine-7-amino-4- } \\
\text { methylcoumarin }\end{array}$ & $\begin{array}{l}\text { cleaving of peptide bonds in } \\
\text { proteins }\end{array}$ \\
\hline $\begin{array}{l}\text { acid phosphatase } \\
\text { (EC 3.1.3.2) }\end{array}$ & $\begin{array}{l}\text { 4-methylumbelliferone- } \\
\text { phosphate }\end{array}$ & $\begin{array}{l}\text { P-acquisition via dissociation } \\
\text { of phosphoric acid }\end{array}$ \\
\hline
\end{tabular}

\subsubsection{Statistical analysis}

All statistical analyses were conducted using R 3.4.3 (R Core Team, 2017). To evaluate the differences of soil parameters $\left(\mathrm{C}, \mathrm{N}, \mathrm{C}: \mathrm{N}\right.$, soil moisture) and enzyme kinetics $\left(\mathrm{V}_{\max }\right.$ and $\left.\mathrm{K}_{\mathrm{m}}\right)$ between sites, slope aspects, soil depths, and root proximity, generalized linear mixed effect models (GLMM) were calculated using the R package 'Ime4' (Bates et al., 2015). To determine the fixed effect 'site', we specified slope aspect as further fixed effect, and soil profile and soil depth as nested random effects. To determine the fixed effect of 'slope aspect', 'soil depth' and 'root proximity' (without interaction terms), we specified soil profile as nested random effect. $p$ values were obtained by multiple comparisons with a general linear hypotheses test function using the R package ‘multcomp' (Hothorn et al., 2008).

Redundancy analyses (RDA) were calculated to determine the effects of the soil variables $\mathrm{C}, \mathrm{N}$, $\mathrm{C}: \mathrm{N}$, moisture, $\mathrm{pH}$, and particle size fractions on enzyme activities, as well as to test for the effects of these factors on $\mathrm{C}$ and $\mathrm{N}$ contents in soil. RDAs were conducted with the 'vegan' package (Oksanen et al., 2017) on scaled and log-transformed data. Type II scaling (correlation) plots are shown in the results including only significant constraining variables. 


\subsubsection{Results}

\subsubsection{Soil properties}

C content in soil increased stronger on the continental and landscape scale than $\mathrm{N}$ content (3- to 4times compared to 2- to 3-times) (Figure 2.4-2). On the mesoscale, $\mathrm{C}$ content decreased between $20 \%$ (in Santa Gracia) and 85\% (in Nahuelbuta) from top- to subsoil, while N content declined between 25\% (SG) and 80\% (NA). On the microscale, C content was1.5- to 2-times higher in root proximity than bulk soil, while $\mathrm{N}$ content was similar, resulting in 1.1- to 1.2-times higher $\mathrm{C}: \mathrm{N}$

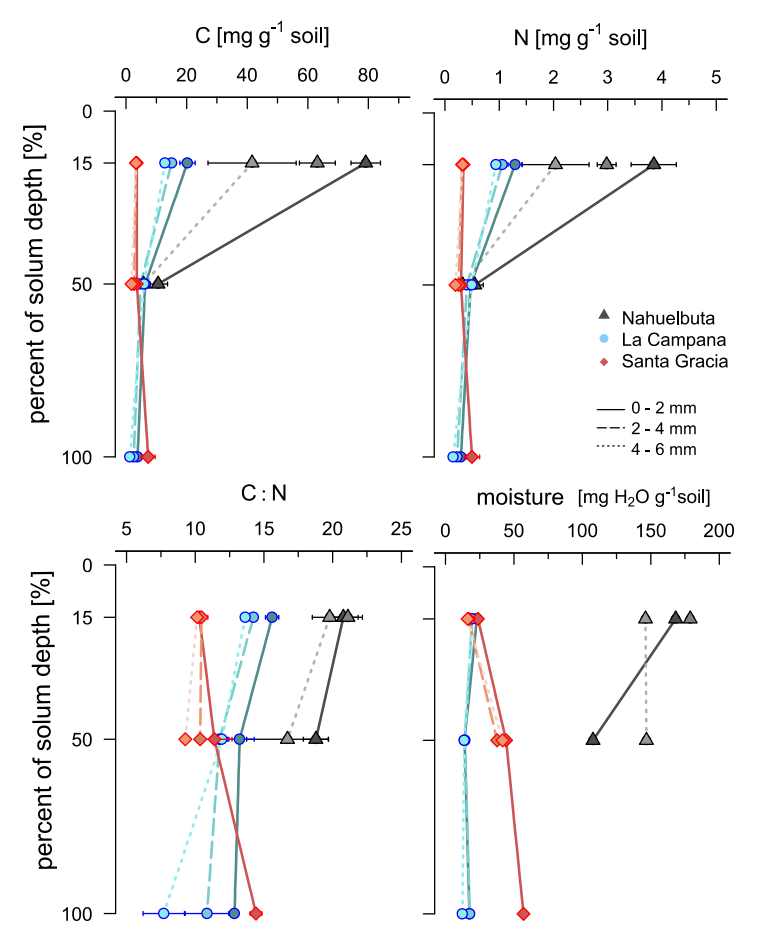
ratios in root proximity $(0-2 \mathrm{~mm})$ than in bulk soil (4-6 mm) (Figure 2.4-2).

Figure 2.4-2: Depth profiles of carbon content, nitrogen content, C:N ratio, and soil moisture in Nahuelbuta (black triangles), La Campana (blue circles), and Santa Gracia (red diamonds), separated by root proximities - 0-2 $\mathrm{mm}$ (darkest shade), 2-4 mm, and 4-6 mm (lightest shade). Data points represent means $\pm S E$ of south-exposed slopes $(n=3)$. $C$ and $N$ content, as well as $C: N$ show clear increase $(\mathrm{p}<0.05)$ from bulk soil to roots in the sites under humid temperate (Nahuelbuta) and under Mediterranean (La Campana) climate conditions; especially in the topsoil.

\subsubsection{Enzyme activities}

Potential activities $\left(\mathrm{V}_{\max }\right)$ of $\mathrm{C}, \mathrm{N}$, and $\mathrm{P}$ acquiring enzymes increased on the continental scale with higher soil moisture (Figure 2.4-3). The strongest rise (up to 7-times) was observed for $\beta$ xylosidase, $\beta$-N-acetylglucosaminidase, and acid phosphatase. On the landscape scale, activities of $\mathrm{C}, \mathrm{N}$, and $\mathrm{P}$ acquiring enzymes (except tyrosine-aminopeptidase) showed trends $(p>0.05)$ of higher activities on the south than north slope at the sites under humid temperate (Nahuelbuta) and Mediterranean (La Campana) climate. Activities for most enzymes decreased from top- to subsoil (Figure 2.4-4). The strongest decrease was detected at the site under humid temperate climate conditions (up to $90 \%$ for both aminopeptidases). Under semiarid climate conditions (Santa Gracia), only the protein degrading leucine-aminopeptidases decreased with soil depth. Root effects on enzyme activities (i.e. higher activities in root proximity than in bulk soil) were similar at sites under humid temperate and Mediterranean climate conditions, for $\mathrm{C}, \mathrm{N}$, and $\mathrm{P}$ acquiring enzymes $(p>0.05)$ (Figure 2.4-5). Root effects on enzyme activities were mostly absent at the site under semiarid conditions (except for tyrosine-aminopeptidase). 

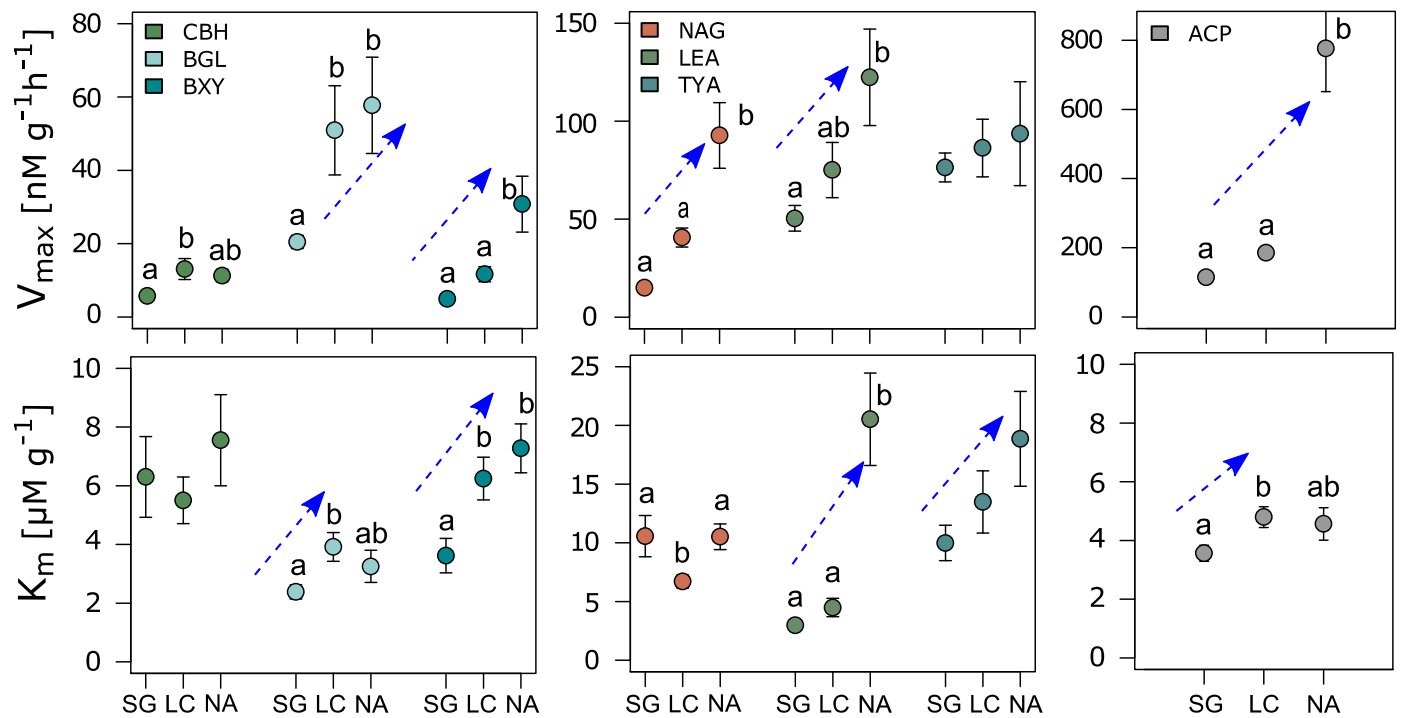

Figure 2.4-3: Continental gradients of potential activities $\left(V_{\max }\right)$ and substrate affinities $\left(K_{m}\right)$ of the extracellular enzymes (from left to right): $C B H=\beta$-cellobiohydrolase, $B G L=\beta$-glucosidase, $B X Y=\beta$-xylosidase, $N A G=\beta$ - $N$ acetylglucosaminidase, $L E A=$ leucine-aminopeptidase, $T Y A=$ tyrosine-aminopeptidase, $A C P=$ acid phosphatase . Sites: Santa Gracia (SG), La Campana (LC), and Nahuelbuta (NA). Data present means \pm SE of north and south slopes and all soil depths and root distances (SG, LC: $n=36 ; N A: n=24$. Letters indicate significant (p<0.05) differences of activities and affinities between the study sites identified by GLMM. Activities of C-, $N$-, and Pacquiring enzymes increase with humidity, while substrate affinities decrease (i.e. increasing $K_{m}$ ). Blue arrows show effects of the continental moisture gradient on the enzyme activities and affinities.
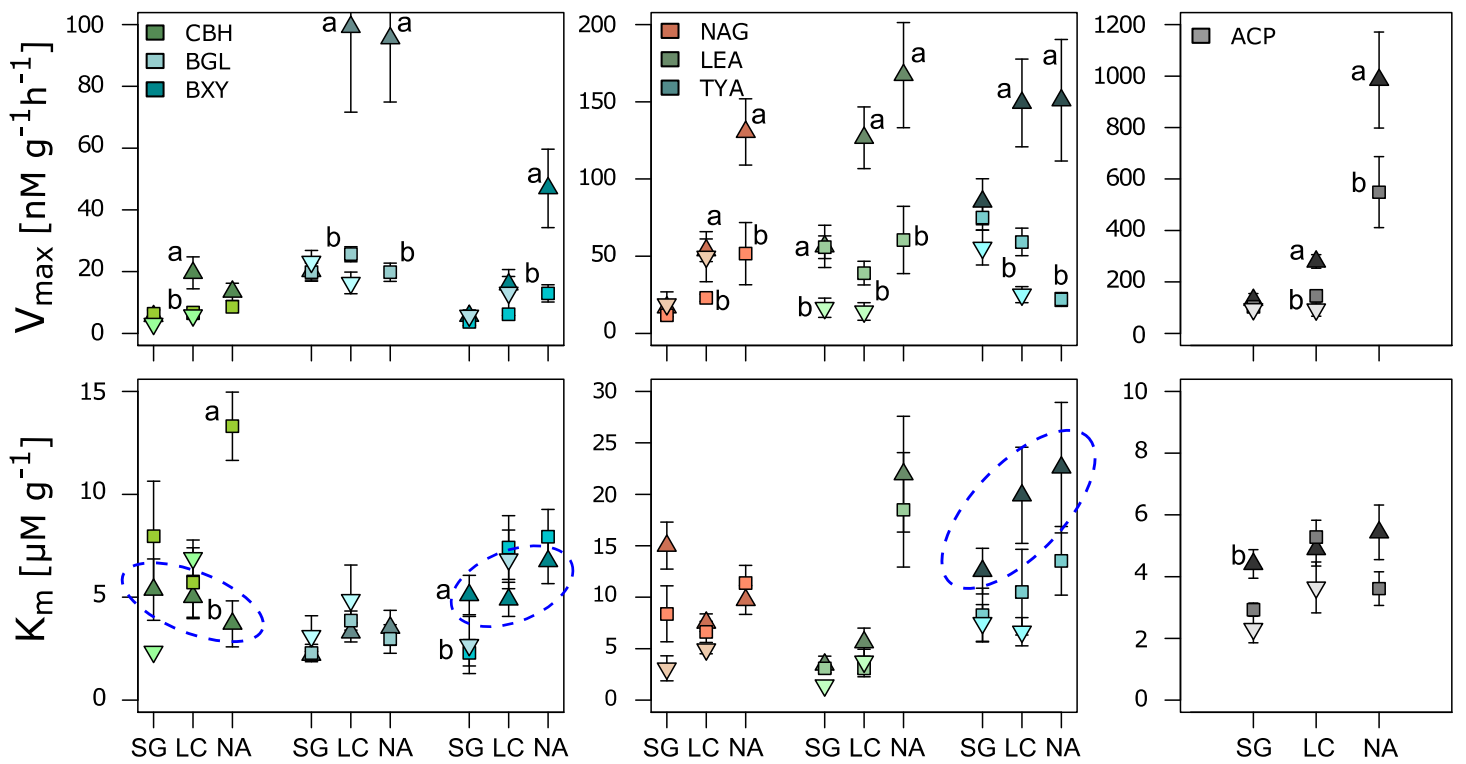

Figure 2.4-4: Potential activities $\left(V_{\max }\right)$ and substrate affinities $\left(K_{m}\right)$ separated by soil depth $(1=$ topsoil, 2-3 = subsoil) of (from left to right): $C B H=\beta$-cellobiohydrolase, $B G L=\beta$-glucosidase, $B X Y=\beta$-xylosidase, $N A G=\beta$ - $N$ acetylglucosaminidase, $L E A=$ leucine-aminopeptidase, $T Y A=$ tyrosine-aminopeptidase, $A C P=$ acid phosphatase . Sites: Santa Gracia (SG), La Campana (LC), and Nahuelbuta (NA). Soil depths: $1=$ triangle, $2=$ square, $3=$ inverted triangle - Santa Gracia: 0-40 cm, 40-80 cm, 80-200 cm; La Campana: 0-60 cm, 60-120 cm, 120-200 cm; Nahuelbuta: 
0-80 cm, 80-160 cm. Data present means $\pm S E$ of both slopes and all root distances separated by soil depths $(n=12)$. Letters indicate significant differences $(\mathrm{p}<0.05)$ between soil depths. Activities of $C$-, $N$-, and P-acquiring enzymes are higher in the topsoil (depth 1) than subsoil (depth 2 and 3) at the sites under humid temperate (NA) and Mediterranean (LC) climate conditions. Substrate affinities of C-acquiring enzymes are tendential ( $\mathrm{p}>0.05)$ higher in the topsoil than subsoil, while substrate affinities of $N$ - and P-acquiring enzymes are tendential (p>0.05) lower in the topsoil and higher in the subsoil.
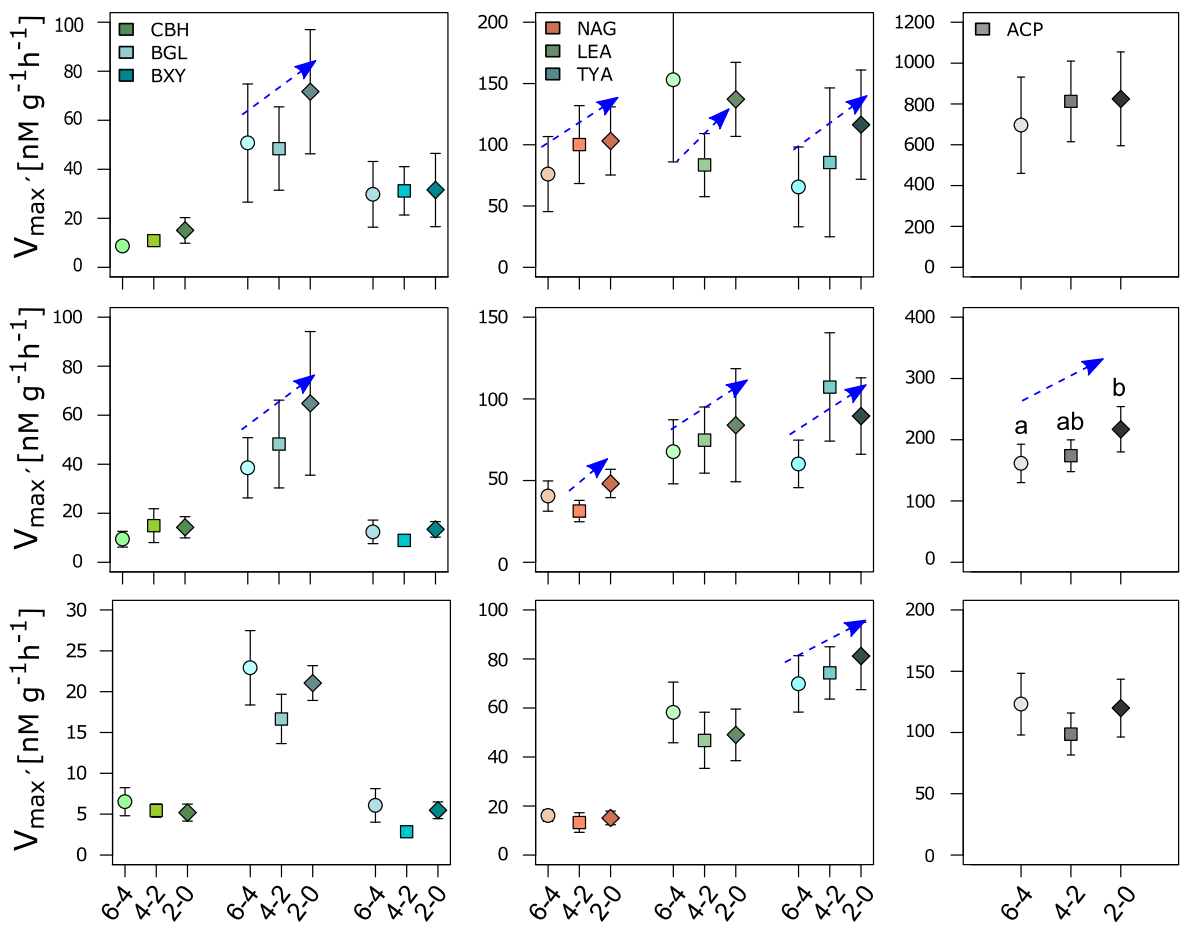

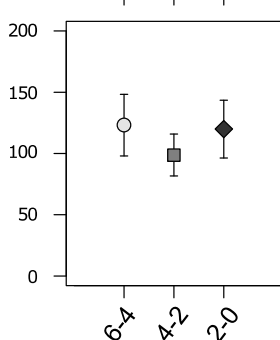

Figure 2.4-5: Enzyme activities $\left(V_{\max }\right)$ from bulk soil (6-4 $\mathrm{mm})$ to root proximity $(2-$ $0 \mathrm{~mm})$. Nahuelbuta $=$ top row; La Campana $=$ middle row; Santa Gracia $=$ bottom row. Data present means $\pm S E$ from both slopes and all soil depths (SG, LC: $n=12 ; N A$ : $n=8)$. From left to right: $C B H=\beta$-cellobiohydrolase, $B G L=\beta$-glucosidase, $B X Y=$ $\beta$-xylosidase, $N A G=\beta-N$ acetylglucosaminidase, LEA $=$ leucine-aminopeptidase, TYA = tyrosine aminopeptidase, $A C P=$ acid phosphatase. GLMM only identified activity differences of acid phosphatases in La Campana (Mediterranean climate conditions) as significant ( $\mathrm{p}<0.05$; indicated by letters). Blue arrows show effects of the rhizosphere gradient on enzyme activities. Trends $(\mathrm{p}>0.05)$ of increasing activities from bulk soil to roots of C, $N$-, and P-acquiring enzymes were detected at the sites under humid temperate (Nahuelbuta) and Mediterranean (La Campana) climate conditions. At the site under semiarid conditions (Santa Gracia) only tyrosine-aminopeptidase activities showed an increasing trend ( $\mathrm{p}>0.05)$ from bulk soil to roots.

\subsubsection{Enzyme substrate affinities}

Substrate affinities of $\mathrm{C}, \mathrm{N}$, and $\mathrm{P}$ acquiring enzymes declined (i.e. increasing $\mathrm{K}_{\mathrm{m}}$ ) on the continental scale from semiarid to humid climate conditions, while potential enzyme activities $\left(\mathrm{V}_{\max }\right)$ grew (Figure 2.4-3). On the landscape scale, the only clear trend $(p>0.05)$ was observed for $\beta$-cellobiohydrolase, which had lower substrate affinities on the south than north slope at the sites under humid temperate and Mediterranean conditions. $\mathrm{N}$ and $\mathrm{P}$ acquiring enzymes had generally higher substrate affinities in the subsoil, while substrate affinities of $\mathrm{C}$ acquiring enzymes were higher in the topsoil (up to 1.5- to 3-times) (Figure 2.4-4). Higher affinities of $\mathrm{C}$ acquiring enzymes 
in the subsoil than in the topsoil were common only under semiarid climate conditions. From root to bulk soil, affinities of $\mathrm{C}$ acquiring enzymes generally decreased ( $p>0.05)$, while affinities of $\mathrm{N}$ and $\mathrm{P}$ acquiring enzymes increased $(p>0.05)$ (Figure 2.4-6).
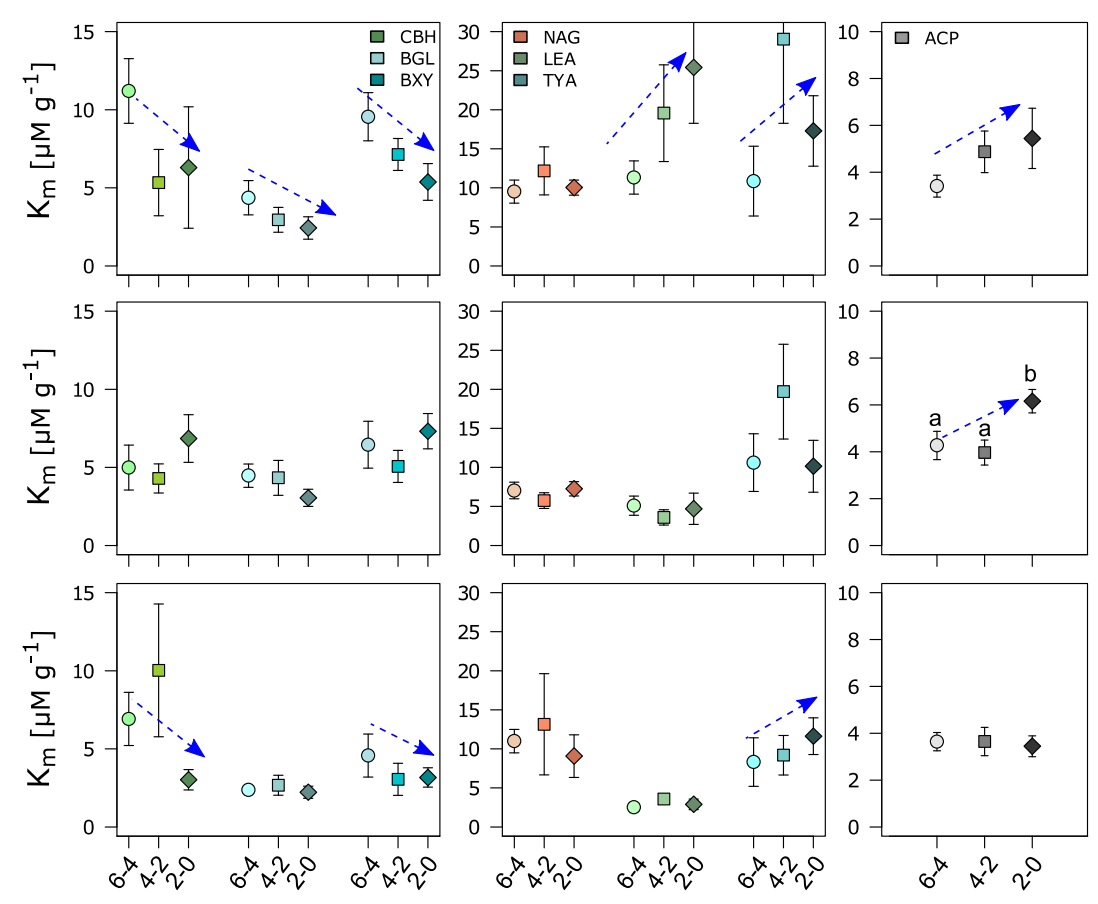

\section{a (Mediterranean climate conditions) as signifi}

phosphatases in La Campana (Mediterranean climate conditions) as significant ( $\mathrm{p}<0.05$; indicated by letters). Blue arrows show effects of the rhizosphere gradient on substrate affinities. The strongest trends of substrate affinities were detected at the site under humid temperate conditions (Nahuelbuta): Affinities of C-acquiring enzymes increased from bulk soil to root, while affinities of $N$ - and P-acquiring enzymes decreased.

\subsubsection{Effects of abiotic and biotic factors on enzyme activities}

Constrained axes of the RDA on potential enzyme activities were able to explain $57.1 \%$ of their variation. The first and second axis of the RDA accounted for $41.4 \%$ and $8.6 \%$, respectively (Figure 2.4-7). $\mathrm{C}$ and $\mathrm{N}$ contents strongly determine potential activities of all enzymes except of aminopeptidases (Figure 2.4-7). All these enzymes were primarily associated with the medium silt $(6.3-20 \mu \mathrm{m})$, fine silt $(2-6.3 \mu \mathrm{m})$, and clay $(<2 \mu \mathrm{m})$ fraction of soil particles, whereas aminopeptidases were rather associated to the coarse silt fraction $(20-63 \mu \mathrm{m})$ (Figure 2.4-7). Variance of aminopeptidases, and especially tyrosine-aminopeptidases, activities were primarily explained by soil moisture and $\mathrm{pH}$ (Figure 2.4-7). While soil moisture exerted a negative and $\mathrm{pH}$ a positive effect on aminopeptidase activities, these relations were reversed for the other enzymes. Only potential activities of $\beta$-glucosidase seemed less affected by $\mathrm{pH}$ (Figure 2.4-7). 


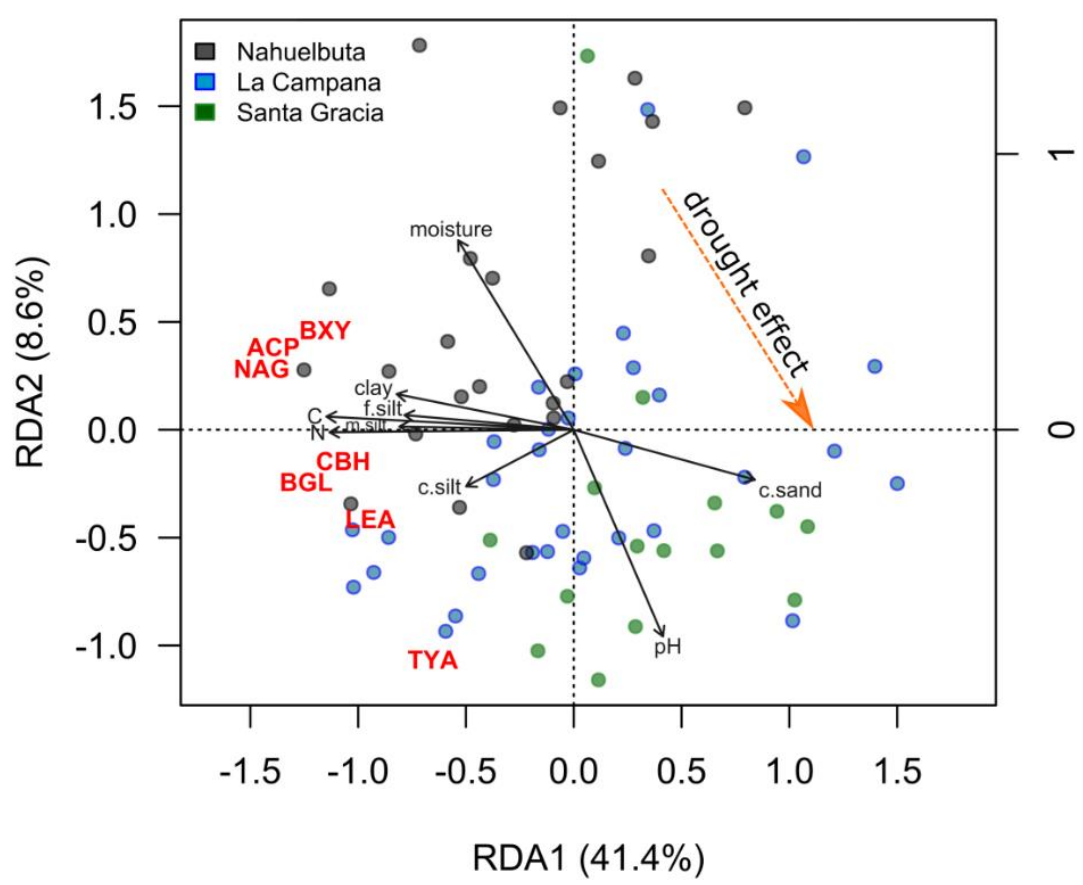

Figure 2.4-7: Redundancy analysis on potential activities of cellobiohydrolase $\quad(\mathrm{CBH}), \quad b-$ glucosidase (BGL), b-xylosidase (BXY), b-N-acetylglucosaminidase (NAG), leucine-aminopeptidase (LEA), tyrosine-aminopeptidase (TYA), and acid phosphatase (ACP) with $C$ and $N$ contents, soil moisture, $\mathrm{pH}$, and particle size fractions as constraints. The overall RDA was significant with 999 permutations. A type II scaling (correlation) plot is shown, including only significant constraining variables. The

constraining variables explained $57.1 \%$ of the total variance.

Constrained axes of the RDA on $\mathrm{C}$ and $\mathrm{N}$ contents were able to explain $87.8 \%$ of the variation. The first and second axis of the RDA accounted for $87.4 \%$ and $0.4 \%$ of the variation of $\mathrm{C}$ and $\mathrm{N}$ contents (Figure 2.4-8). C and $\mathrm{N}$ contents were strongest determined by small size soil particles (silt and clay fraction), whereas soil moisture and $\mathrm{pH}$ determined contents to a much lower extend (Figure 2.4-8). Soil particle size fractions strongest correlated with soil depth, while soil moisture and $\mathrm{pH}$ were stronger related to the factor site (Figure 2.4-8).

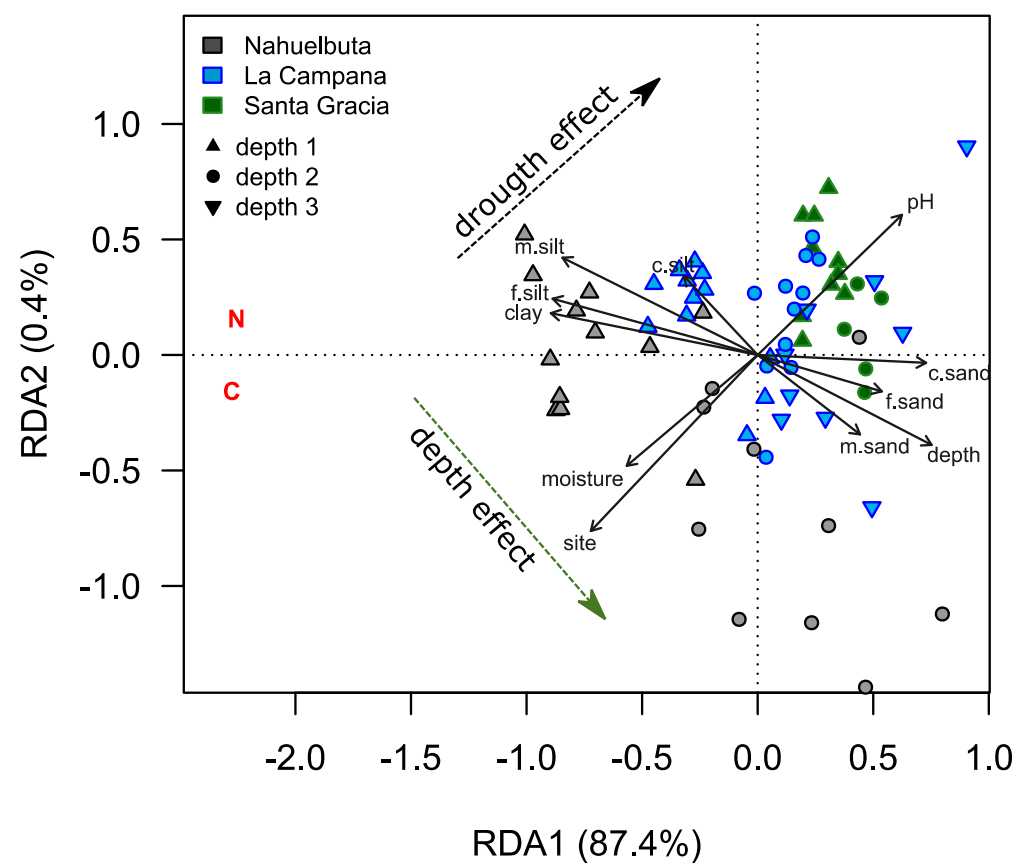

Figure 2.4-8: Redundancy analysis on $C$ and $N$ contents with soil moisture, $\mathrm{pH}$, and particle size fractions as constraints. The overall RDA was significant with 999 permutations. A type II scaling (correlation) plot is shown, including only significant constraining variables. The constraining variables explained $87.8 \%$ of the total variance. 


\subsubsection{Discussion}

\subsubsection{Activation of microbial activity in response to labile carbon}

Microbial activity in soil is strongly limited by the availability of C (Blagodatsky and Richter, 1998; Hodge et al., 2000). On the continental scale, vegetation cover and plant species composition change fundamentally (Bernhard et al., 2018). Denser vegetation cover and higher productivity result in greater above- and belowground biomass input, which was apparent by higher $\mathrm{C}$ and $\mathrm{N}$ contents in the southern than in the northern sites (Figure 2.4-2). With greater amounts of biomass entering the soil, greater amounts of substrate and easily accessible $\mathrm{C}$ are available, enabling microorganisms to invest into nutrient acquisition (i.e. extracellular enzyme synthesis), as costs will be balanced off by energy and nutrients gained by soil organic matter decomposition (Allison et al., 2014; Hernández and Hobbie, 2010). In response, enzyme activities are stimulated, as was observed for $\mathrm{C}, \mathrm{N}$, and $\mathrm{P}$ acquiring enzymes on the continental scale from north to south (Figure 2.4-3). This was also displayed by the RDA as $\mathrm{C}$ and $\mathrm{N}$ contents explained a high degree of variances in enzyme activities (Figure 2.4-7) (Allison and Vistousek, 2005; Cheng et al., 2003; Hernández and Hobbie, 2010). Growing enzyme activities along with declining substrate affinities (i.e. high $\mathrm{K}_{\mathrm{m}}$ ) from north to south, suggest that especially on the continental scale the substrate availability is driving enzyme activities.

On the mesoscale - the soil depth profile - substrate availability, likewise, seemed to be a driving force for $\mathrm{N}$ and $\mathrm{P}$ acquiring enzymes in the subsoil. Enzymes with high substrate affinities in the subsoil, as seen for $\mathrm{N}$ and $\mathrm{P}$ acquiring enzymes (Figure 2.4-4), increase the competitiveness of microbes for nutrients under substrate limitation (Blagodatskaya et al., 2009; Hernández and Hobbie, 2010; Klipp and Heinrich, 1994).

Root exudates are one of the largest sources of labile C input (Bertin et al., 2003; Kuzyakov, 2002a; Pausch and Kuzyakov, 2018). Coinciding, measured C and N contents increased from bulk soil to root proximity (Figure 2.4-2). This rise of $\mathrm{C}$ content concurs with trends of ascending $\beta$ glucosidase and $\mathrm{N}$ and $\mathrm{P}$ acquiring enzyme activities from bulk soil to roots (Figure 2.4-5), indicating a stimulation of microbial activity by root-derived C (Blagodatskaya et al., 2010; Kuzyakov, 2002b; Meier et al., 2017). Root effects on enzyme activities were only significant for acid phosphatases under Mediterranean conditions, which is likely related to the sampling strategy. Razavi et al. (2016) and Ma et al. (2018) demonstrated that rhizosphere extension significantly differs for enzymes and plant species. Activity radii extended mostly less than $2 \mathrm{~mm}$ from roots, with the greatest extension detected for acid phosphatases (Razavi et al., 2016). The successful determination of phosphatase activities from rhizosphere to bulk soil, however, suggests that 
activities for $\mathrm{C}$ and $\mathrm{N}$ cycling enzymes would be fully captured with a finer resolution of sampling distances.

\subsubsection{Nutrient mining for stoichiometric homeostasis}

Labile $\mathrm{C}$ does not only stimulate microbial activity as easily available energy source but can also induce a relative increase of microbial nutrient limitation by stoichiometric imbalance, which stimulates nutrient acquisition from other sources, e.g. from SOM (Cheng and Kuzyakov, 2005; Hernández and Hobbie, 2010; Phillips et al., 2011; Sinsabaugh and Moorhead, 1994). Activities of $\mathrm{C}$ acquiring enzymes did not only increase with higher $\mathrm{C}$ content (as shown in section 2.4.4.1) but also with greater $\mathrm{N}$ content, indicated by the strong relation observed in the RDA (Figure 2.4-7). In fact, the strong effect of $\mathrm{N}$ on $\mathrm{C}$ acquiring enzymes supports the conclusion that an upregulation of $\mathrm{C}$ acquisition in response to greater $\mathrm{N}$ availability is dominantly driving activities of these respective enzymes. Greater $\mathrm{N}$ availability (1) allows microorganisms to invest $\mathrm{N}$ into enzyme synthesis and (2) heightens the demand for $\mathrm{C}$ for microbial growth (Allison and Vitousek, 2005; Saiya-Cork et al., 2002; Sinsabaugh and Follstad Shah, 2012). C acquiring enzymes seemed to be driven by stoichiometric constraints on the meso- and microscale, which was supported by higher substrate affinities of $\beta$-cellobiohydrolase and $\beta$-xylosidase in topsoil and root proximity than in bulk soil (Figure 2.4-4, Figure 2.4-6). Increase of microbial activity and growth by labile carbon input surges microbial $\mathrm{C}$ demand (Hernández and Hobbie, 2010) and, thus, promotes the investment into $\mathrm{C}$ mining via enzyme production.

A similar dependence on stoichiometric constraints was also seen for $\mathrm{N}$ and $\mathrm{P}$ acquiring enzymes. Activities of $\mathrm{N}$ acquiring enzymes (Figure 2.4-3 - 2.4-5) increased towards places with great $\mathrm{N}$ limitation (i.e. site under humid temperate conditions, topsoil, root proximity) indicated by high $\mathrm{C}: \mathrm{N}$ ratios (Figure 2.4-2). This elevation of activities in response to $\mathrm{N}$ limitation indicates an upregulation of $\mathrm{N}$ acquisition in response to stoichiometric imbalance, initiated by available $\mathrm{C}$ input and microbial activity stimulation (Loeppmann et al., 2016a; Sinsabaugh et al., 2009; Treseder and Vitousek, 2001). RDA results supported this response for activities of $\beta-\mathrm{N}$ acetylglucosaminidases, as they $\mathrm{C}$ and $\mathrm{N}$ explained most of their variance (Figure 2.4-7). Patterns of activities of aminopeptidases, however, were better explained by $\mathrm{pH}$ and soil moisture (Figure 2.4-7).

Substrate affinities of $\mathrm{N}$ acquiring enzymes, which were lower in the topsoil than subsoil (Figure 2.4-4), and in root proximity than in bulk soil (Figure 2.4-6), indicate further that enzyme activities are not substrate limited but N demand driven (Loeppmann et al., 2016a; Stone and Plante, 2014). The same relations of affinities and activities as for $\mathrm{N}$ acquiring enzymes in the topsoil and in root 
proximity were also seen for acid phosphatases. High activities but low substrate affinities indicate $\mathrm{P}$ demand to be driving the investment into enzymatic $\mathrm{P}$ acquisition.

\subsubsection{Switch of $N$ acquisition strategy on the continental scale}

Higher activities of aminopeptidases, and especially of tyrosine-aminopeptidases, than of $\beta-\mathrm{N}$ acetylglucosaminidases (Figure 2.4-3) in the northern (dry) site than in the southern sites, suggest that cleaving of amino acids is the dominant pathway of microorganisms to acquire $\mathrm{N}$ from organic sources at the moisture limited site. Peptides are the most important organic $\mathrm{N}$ source and easier to decompose than chitin (Derenne and Largeau, 2001; Kögel-Knabner, 2006; Sinsabaugh and Follstad Shah, 2012). In the site under semiarid (and also Mediterranean) conditions, peptides are more abundant than chitin due to less fungal biomass (seen as decrease of bacterial and fungal DNA from south to north; data not shown). Therefore, microorganisms need to primarily synthesize aminopeptidases to cover their basic $\mathrm{N}$ demand at the site under semiarid and Mediterranean conditions (Sinsabaugh and Follstad Shah, 2012). Ascending activities of $\beta-\mathrm{N}$ acetylglucosaminidases with increasing humidity on the continental scale indicate a growing importance of chitin hydrolysis as $\mathrm{N}$ acquiring strategy as organic biomass input rises as well.

\subsubsection{Soil moisture, $\mathrm{pH}$, and soil particle size effect}

Water availability affects plant productivity and, thus, organic matter input as litter and rootderived C into soil (Knapp et al., 2006) - this is on the continental scale. On the microscale, water limitation reduces water film thickness, reduces the substrate dissolution, and decreases its diffusion rates (Allison and Treseder, 2008; Davidson and Janssens, 2006; Schimel et al., 2007). Nutrient resources can, therefore, be accessed by roots and microorganisms only with sufficient water content in soil. Rising water availability stimulated potential activities of all enzymes except aminopeptidases (Figure 2.4-7). A positive effect of water availability on C content, but a negative effect on $\mathrm{N}$ content indicate that substrate availability (as $\mathrm{C}$ content) and the accessibility of $\mathrm{N}$ are modulated by water availability, which in turn can considerably affect enzyme activities (Figire 2.4-8).

Soil $\mathrm{pH}$ is an important factor regulating enzyme activities (Sinsabaugh et al., 2008). Acidity affects enzyme conformation (and thus its affinity to the substrate), binding of enzymes onto soil particles, breakdown of molecules, and nutrient availability (Carrino-Kyker et al., 2016; Quiquampoix et al., 1992; Turner, 2010). The RDA shows that pH had an especially marked effect on the activities of aminopeptidases (Figure 2.4-7), which coincided with the positive effect on $\mathrm{N}$ content (Figure 2.4-8). 
Distribution of pores and particle size fractions are important for microbial habitats in soil (Kirchmann and Gerzabek 1999; Ruamps et al., 2011; Kravchenko and Guber, 2017). Depending on the size, microhabitats within pores can markedly differ in water supply, availability of substrates, or grazing pressure on microorganisms (Kuzyakov and Mason-Jones, 2019; Ruamps et al., 2011). Smaller particles are associated with greater C and N contents (Kandeler et al., 1999; Stemmer et al., 1998) and microbial biomass (Seesitsch et al., 2001; vanGestel et al., 1996). Smaller soil particles can form stable complexes with organic compounds, such as extracellular enzymes. Enzyme immobilization reduces their efficiency but protects them from decomposition and stabilizes their activity for a longer period (Demkina et al. 2017; Dick and Tabatabai 1987; Tietjen and Wetzel 2003). Greater proportions of silt and clay increased enzyme activities: 20 $63 \mu \mathrm{m}$ fraction for aminopeptidases, and $<2-20 \mu \mathrm{m}$ for the other enzymes (Figure 2.4-7).

\subsubsection{Conclusions}

Substrate availability and nutrient limitation (initiated by microbial activity stimulation and a shift in the stoichiometric balance) are two strong drivers of enzyme activities in soil. The results suggest that activities on the continental scale are mainly driven by substrate availability (i.e. belowground $\mathrm{C}$ input by plants). Additionally, from the arid north to the humid south, the chitinbased $\mathrm{N}$ acquisition got more relevant. Low potential activities and high substrate affinities of $\mathrm{N}$ and $\mathrm{P}$ acquiring enzymes in the subsoil and in the root free soil, suggested that substrate limitation is driving the investment into $\mathrm{N}$ and $\mathrm{P}$ acquisition on these scales. In the topsoil and in the rhizosphere, however, high potential activities and low substrate affinities of $\mathrm{N}$ and $\mathrm{P}$ acquiring enzymes, together with high $\mathrm{C}: \mathrm{N}$ ratios, suggested that the $\mathrm{C}$ input increased microbial nutrient limitation, which primarily controlled activities of $\mathrm{N}$ and $\mathrm{P}$ acquiring enzymes at these sites. Likewise, stoichiometric constraints (i.e. C demand and $\mathrm{N}$ limitation) seemed to primarily control investment into cellulose and hemicellulose degrading enzymes on the meso- and microscale. A high degree of $\mathrm{C}$ and $\mathrm{N}$ contents being explained by clay and silt contents, and by soil moisture and $\mathrm{pH}$ to a smaller extent, indicated that the effects of substrate availability and nutrient limitation on the resource allocation for enzyme production indirectly depend on texture and are altered by water availability and acidity. A greater correlation of particle size fractions with soil depth than with study sites indicated further that texture becomes especially important when comparing enzyme activity patterns on the mesoscale, while the impact of soil moisture and $\mathrm{pH}$ dominates activity patterns stronger on the continental scale. 


\subsubsection{Acknowledgements}

We thank the Chilean National Park Service Corporación Nacional Forestal (CONAF) for the possibility to work in the National Parks La Campana and Nahuelbuta. We also thank the Center for Advanced Research in Arid Zones (CEAZA) for the possibility to work in the National Reserve Santa Gracia. Further, we express our gratitude to Susann Enzmann for her help during laboratory work as well as the Centre for Stable Isotope Research and Analysis (KOSI). This work was supported by the German Research Foundation (DFG) [project number KU 1184/36-1] within the Priority Program 1803 'EarthShape: Earth Surface Shaping by Biota'.

\subsubsection{References}

Acosta-Martínez, V., Tabatabai, M.A., 2000. Enzyme activities in a limed agricultural soil. Biol. Fertil. Soils 31, 85-91. https://doi.org/10.1007/s003740050628

Allison, S.D., Chacon, S.S., German, D.P., 2014. Substrate concentration constraints on microbial decomposition. Soil Biol. Biochem. 79, 43-49. https://doi.org/10.1016/j.soilbio.2014.08.021

Allison, S.D., Jastrow, J.D., 2006. Activities of extracellular enzymes in physically isolated fractions of restored grassland soils. Soil Biol. Biochem. 38, 3245-3256. https://doi.org/10.1016/j.soilbio.2006.04.011

Allison, S.D., Treseder, K.K., 2008. Warming and drying suppress microbial activity and carbon cycling in boreal forest soils. Glob. Change Biol. 14, 2898-2909. https://doi.org/10.1111/j.1365-2486.2008.01716.x

Allison, S.D., Vitousek, P.M., 2005. Responses of extracellular enzymes to simple and complex nutrient inputs. Soil Biol. Biochem. 37, 937-944. https://doi.org/10.1016/j.soilbio.2004.09.014

Bates, D., Mächler, M., Bolker, B., Walker, S., 2015. Fitting Linear Mixed-Effects Models Using lme4. J. Stat. Softw. 67. https://doi.org/10.18637/jss.v067.i01

Bernhard, N., Moskwa, L.-M., Schmidt, K., Oeser, R.A., Aburto, F., Bader, M., Baumann, K., von Blanckenburg, F., Boy, J., van den Brink, L., Brucker, E., Büdel, B., Canessa, R., Dippold, M.A., Ehlers, T.A., Fuentes, J.P., Godoy, R., Jung, P., Karsten, U., Köster, M., Kuzyakov, Y., Leinweber, P., Neidhardt, H., Matus, F., Mueller, C.W., Oelmann, Y., Oses, R., Osses, P., Paulino, L., Samolov, E., Schaller, M., Schmid, M., Spielvogel, S., Spohn, M., Stock, S., Stroncik, N., Tielbörger, K., Übernickel, K., Scholten, T., Seguel, O., Wagner, D., Kühn, P., 2018. Pedogenic and microbial interrelations to regional climate and local topography: new insights from a climate gradient (arid to humid) along the Coastal Cordillera of Chile. Catena.

Bertin, C., Yang, X., Weston, L.A., 2003. The role of root exudates and allelochemicals in the rhizosphere. Plant Soil 256, 67-83. https://doi.org/10.1023/A:1026290508166

Blagodatskaya, E., Blagodatsky, S., Anderson, T.-H., Kuzyakov, Y., 2014. Microbial Growth and Carbon Use Efficiency in the Rhizosphere and Root-Free Soil. PLoS ONE 9, e93282. https://doi.org/10.1371/journal.pone.0093282

Blagodatskaya, E., Blagodatsky, S., Dorodnikov, M., Kuzyakov, Y., 2010. Elevated atmospheric $\mathrm{CO}_{2}$ increases microbial growth rates in soil: results of three $\mathrm{CO}_{2}$ enrichment experiments. Glob. Change Biol. 16, 836-848. https://doi.org/10.1111/j.1365-2486.2009.02006.x

Blagodatskaya, E.V., Blagodatsky, S.A., Anderson, T.-H., Kuzyakov, Y., 2009. Contrasting effects of glucose, living roots and maize straw on microbial growth kinetics and substrate availability in soil. Eur. J. Soil Sci. 60, $186-197$. https://doi.org/10.1111/j.1365-2389.2008.01103.x

Blagodatsky, S.A., Richter, O., 1998. Microbial growth in soil and nitrogen turnover: a theoretical model considering the activity state of microorganisms. Soil Biol. Biochem. 30, 1743-1755. https://doi.org/10.1016/S0038-0717(98)00028-5

Burns, R.G., DeForest, J.L., Marxsen, J., Sinsabaugh, R.L., Stromberger, M.E., Wallenstein, M.D., Weintraub, M.N., Zoppini, A., 2013. Soil enzymes in a changing environment: Current knowledge and future directions. Soil Biol. Biochem. 58, 216234. https://doi.org/10.1016/j.soilbio.2012.11.009

Carrino-Kyker, S.R., Kluber, L.A., Petersen, S.M., Coyle, K.P., Hewins, C.R., DeForest, J.L., Smemo, K.A., Burke, D.J., 2016. Mycorrhizal fungal communities respond to experimental elevation of soil $\mathrm{pH}$ and $\mathrm{P}$ availability in temperate hardwood forests. FEMS Microbiol. Ecol. 92, fiw024. https://doi.org/10.1093/femsec/fiw024

Chen, R., Senbayram, M., Blagodatsky, S., Myachina, O., Dittert, K., Lin, X., Blagodatskaya, E., Kuzyakov, Y., 2014. Soil C and $\mathrm{N}$ availability determine the priming effect: microbial $\mathrm{N}$ mining and stoichiometric decomposition theories. Glob. Change Biol. 20, 2356-2367. https://doi.org/10.1111/gcb.12475

Cheng, W., Johnson, D.W., Fu, S., 2003. Rhizosphere effects on decomposition. Soil Sci. Soc. Am. J. 67, $1418-1427$.

Cheng, W., Kuzyakov, Y., 2005. Root effects on soil organic matter decomposition. Roots Soil Manag. Interact. Roots Soil 119143. 
Dakora, F.D., Phillips, D.A., 2002. Root exudates as mediators of mineral acquisition in low-nutrient environments. Plant Soil 245, 35-47. https://doi.org/10.1023/A:1020809400075

Davidson, E.A., Janssens, I.A., 2006. Temperature sensitivity of soil carbon decomposition and feedbacks to climate change. Nature 440, 165-173. https://doi.org/10.1038/nature04514

de Graaff, M.-A., Classen, A.T., Castro, H.F., Schadt, C.W., 2010. Labile soil carbon inputs mediate the soil microbial community composition and plant residue decomposition rates. New Phytol. 188, 1055-1064. https://doi.org/10.1111/j.14698137.2010.03427.x

de Graaff, M.-A., Jastrow, J.D., Gillette, S., Johns, A., Wullschleger, S.D., 2014. Differential priming of soil carbon driven by soil depth and root impacts on carbon availability. Soil Biol. Biochem. 69, 147-156. https://doi.org/10.1016/j.soilbio.2013.10.047

Demkina, E.V., Shanenko, E.F., Nikolaev, Y.A., El'-Registan, G.I., 2017. Model of the regulation of activity of immobilized enzymes (amylases) in soil. Microbiology 86, 231-240. https://doi.org/10.1134/S0026261717020060

De Nobili, M., Contin, M., Mondini, C., Brookes, P., 2001. Soil microbial biomass is triggered into activity by trace amounts of substrate. Soil Biol. Biochem. 33, 1163-1170. https://doi.org/10.1016/S0038-0717(01)00020-7

Derenne, S., Largeau, C., 2001. A review of some important families of refractory macromolecules: composition, origin, and fate in soils and sediments. Soil Sci. 166

Dick, W.A., Tabatabai, M.A., 1987. Kinetics and activities of phosphatase-clay-complexes 1. Soil Sci. 143.

German, D.P., Marcelo, K.R.B., Stone, M.M., Allison, S.D., 2012. The Michaelis-Menten kinetics of soil extracellular enzymes in response to temperature: a cross-latitudinal study. Glob. Change Biol. 18, 1468-1479. https://doi.org/10.1111/j.13652486.2011.02615.x

Hernández, D.L., Hobbie, S.E., 2010. The effects of substrate composition, quantity, and diversity on microbial activity. Plant Soil 335, 397-411. https://doi.org/10.1007/s11104-010-0428-9

Hodge, A., Robinson, D., Fitter, A., 2000. Are microorganisms more effective than plants at competing for nitrogen? Trends Plant Sci. 5, 304-308.

Hothorn, T., Bretz, F., Westfall, P., 2008. Simultaneous Inference in General Parametric Models. Biom J 50, $346-363$.

Kandeler, E., Stemmer, M., Klimanek, E.-M., 1999. Response of soil microbial biomass, urease and xylanase within particle size fractions to long-term soil management. Soil Biol. Biochem. 31, 261-273. https://doi.org/10.1016/S00380717(98)00115-1

Kielak, A.M., Cretoiu, M.S., Semenov, A.V., Sørensen, S.J., van Elsas, J.D., 2013. Bacterial chitinolytic communities respond to chitin and pH alteration in soil. Appl. Environ. Microbiol. 79, 263-272. https://doi.org/10.1128/AEM.02546-12

Kirchmann, H., Gerzabek, M.H., 1999. Relationship between soil organic matter and micropores in a long-term experiment at Ultuna, Sweden. J. Plant Nutr. Soil Sci. 162, 493-498. https://doi.org/10.1002/(SICI)15222624(199910)162:5<493::AID-JPLN493>3.0.CO;2-S

Knapp, A.K., Burns, C.E., Fynn, R.W.S., Kirkman, K.P., Morris, C.D., Smith, M.D., 2006. Convergence and contingency in production-precipitation relationships in North American and South African C4 grasslands. Oecologia 149, 456-464. https://doi.org/10.1007/s00442-006-0468-2

Klipp, E., Heinrich, R., 1994. Evolutionary Optimization of Enzyme Kinetic Parameters; Effect of Constraints. J. Theor. Biol. 171, 309-323. https://doi.org/10.1006/jtbi.1994.1234

Kögel-Knabner, I., 2006. Chemical structure of organic N and organic P in soil. Nucleic Acids Proteins Soil $23-48$.

Kravchenko, A.N., Guber, A.K., 2017. Soil pores and their contributions to soil carbon processes. Geoderma 287, 31-39. https://doi.org/10.1016/j.geoderma.2016.06.027

Kuzyakov, Y., 2002a. Factors affecting rhizosphere priming effects. J. Plant Nutr. Soil Sci. 165, 382-396.

Kuzyakov, Yakov, 2002b. Separating microbial respiration of exudates from root respiration in non-sterile soils: a comparison of four methods. Soil Biol. Biochem. 34, 1621-1631. https://doi.org/10.1016/S0038-0717(02)00146-3

Kuzyakov, Y., Mason-Jones, K., 2019. Nano-scale undead drivers of microbial life, biogeochemical turnover and ecosystem functions. Soil Biol. Biochem. https://doi.org/10.1016/j.soilbio.2018.09.032

Kuzyakov, Y., Xu, X., 2013. Competition between roots and microorganisms for nitrogen: mechanisms and ecological relevance. New Phytol. 198, 656-669. https://doi.org/10.1111/nph.12235

Loeppmann, S., Blagodatskaya, E., Pausch, J., Kuzyakov, Y., 2016. Enzyme properties down the soil profile - A matter of substrate quality in rhizosphere and detritusphere. Soil Biol. Biochem. 103, 274-283. https://doi.org/10.1016/j.soilbio.2016.08.023

Ma, X., Zarebanadkouki, M., Kuzyakov, Y., Blagodatskaya, E., Pausch, J., Razavi, B.S., 2018. Spatial patterns of enzyme activities in the rhizosphere: Effects of root hairs and root radius. Soil Biol. Biochem. 118, 69-78. https://doi.org/10.1016/j.soilbio.2017.12.009

Manzoni, S., Schimel, J.P., Porporato, A., 2012. Responses of soil microbial communities to water stress: results from a metaanalysis. Ecology 93, 930-938. https://doi.org/10.1890/11-0026.1

Marx, M.-C., Wood, M., Jarvis, S.., 2001. A microplate fluorimetric assay for the study of enzyme diversity in soils. Soil Biol. Biochem. 33, 1633-1640. https://doi.org/10.1016/S0038-0717(01)00079-7

Meier, I.C., Finzi, A.C., Phillips, R.P., 2017. Root exudates increase N availability by stimulating microbial turnover of fast-cycling N pools. Soil Biol. Biochem. 106, 119-128. https://doi.org/10.1016/j.soilbio.2016.12.004 
Moorhead, D.L., Lashermes, G., Sinsabaugh, R.L., 2012. A theoretical model of C- and N-acquiring exoenzyme activities, which balances microbial demands during decomposition. Soil Biol. Biochem. 53, 133-141. https://doi.org/10.1016/j.soilbio.2012.05.011

Oeser, R.A., Stroncik, N., Moskwa, L.-M., Bernhard, N., Schaller, M., Canessa, R., van den Brink, L., Köster, M., Brucker, E., Stock, S., Fuentes, J.P., Godoy, R., Matus, F., Oses Pedraza, R., Osses McIntyre, P., Paulino, L., Seguel, O., Bader, M.Y., Boy, J., Dippold, M.A., Ehlers, T.A., Kühn, P., Kuzyakov, Y., Leinweber, P., Scholten, T., Spielvogel, S., Spohn, M., Übernickel, K., Tielbörger, K., Wagner, D., von Blanckenburg, F., 2018. Chemistry and Microbiology of the Critical Zone along a steep climate and vegetation gradient in the Chilean Coastal Cordillera. Catena.

Oksanen, J., Blanchet, G., Friendly, M., Kindt, R., Legendre, P., McGlinn, D., Minchin, P.R., O'Hara, R.B., Simpson, G.L., Solymos, P., Stevens, H.H., Szoecs, E., Wagner, H., 2017. vegan: Community Ecology Package.

Olander, L.P., Vitousek, P.M., 2000. Regulation of soil phosphatase and chitinase activity by N and P availability. Biogeochemistry 49, 175-191. https://doi.org/10.1023/A:1006316117817

Pausch, J., Kuzyakov, Y., 2018. Carbon input by roots into the soil: Quantification of rhizodeposition from root to ecosystem scale. Glob. Change Biol. 24, 1-12. https://doi.org/10.1111/gcb.13850

Phillips, R.P., Finzi, A.C., Bernhardt, E.S., 2011. Enhanced root exudation induces microbial feedbacks to N cycling in a pine forest under long-term CO2 fumigation: Rhizosphere feedbacks in CO2-enriched forests. Ecol. Lett. 14, $187-194$. https://doi.org/10.1111/j.1461-0248.2010.01570.x

Quiquampoix, H., Staunton, S., Baron, M.-H., Ratcliffe, R.G., 1993. Interpretation of the pH dependence of protein adsorption on clay mineral surfaces and its relevance to the understanding of extracellular enzyme activity in soil. Colloids Surf. Physicochem. Eng. Asp. 75, 85-93. https://doi.org/10.1016/0927-7757(93)80419-F

R Core Team, 2017. R: A Language and Environment for Statistical Computing. Vienna, Austria.

Razavi, B.S., Zarebanadkouki, M., Blagodatskaya, E., Kuzyakov, Y., 2016. Rhizosphere shape of lentil and maize: Spatial distribution of enzyme activities. Soil Biol. Biochem. 96, 229-237. https://doi.org/10.1016/j.soilbio.2016.02.020

Rosseel, Y., 2012. lavaan : An R Package for Structural Equation Modeling. J. Stat. Softw. 48. https://doi.org/10.18637/jss.v048.i02

Ruamps, L.S., Nunan, N., Chenu, C., 2011. Microbial biogeography at the soil pore scale. Soil Biol. Biochem. 43, $280-286$. https://doi.org/10.1016/j.soilbio.2010.10.010

Saiya-Cork, K.., Sinsabaugh, R.., Zak, D.., 2002. The effects of long term nitrogen deposition on extracellular enzyme activity in an Acer saccharum forest soil. Soil Biol. Biochem. 34, 1309-1315. https://doi.org/10.1016/S0038-0717(02)00074-3

Sanaullah, M., Blagodatskaya, E., Chabbi, A., Rumpel, C., Kuzyakov, Y., 2011. Drought effects on microbial biomass and enzyme activities in the rhizosphere of grasses depend on plant community composition. Appl. Soil Ecol. 48, 38-44. https://doi.org/10.1016/j.apsoil.2011.02.004

Schimel, J., Balser, T.C., Wallenstein, M., 2007. Microbial Stress-Response Physiology and Its Implications for Ecosystem Function. Ecology 88, 1386-1394.

Schimel, J., Weintraub, M.N., 2003. The implications of exoenzyme activity on microbial carbon and nitrogen limitation in soil: a theoretical model. Soil Biol. Biochem. 35, 549-563. https://doi.org/10.1016/S0038-0717(03)00015-4

Sessitsch, A., Weilharter, A., Gerzabek, M.H., Kirchmann, H., Kandeler, E., 2001. Microbial Population Structures in Soil Particle Size Fractions of a Long-Term Fertilizer Field Experiment. Appl. Environ. Microbiol. 67, 4215-4224. https://doi.org/10.1128/AEM.67.9.4215-4224.2001

Sinsabaugh, R.L., Antibus, R.K., Linkins, A.E., McClaugherty, C.A., Rayburn, L., Repert, D., Weiland, T., 1993. Wood Decomposition: Nitrogen and Phosphorus Dynamics in Relation to Extracellular Enzyme Activity. Ecology 74, 15861593. https://doi.org/10.2307/1940086

Sinsabaugh, R.L., Belnap, J., Findlay, S.G., Shah, J.J.F., Hill, B.H., Kuehn, K.A., Kuske, C.R., Litvak, M.E., Martinez, N.G., Moorhead, D.L., Warnock, D.D., 2014. Extracellular enzyme kinetics scale with resource availability. Biogeochemistry 121, 287-304. https://doi.org/10.1007/s10533-014-0030-y

Sinsabaugh, R.L., Follstad Shah, J.J., 2012. Ecoenzymatic Stoichiometry and Ecological Theory. Annu. Rev. Ecol. Evol. Syst. 43, 313-343. https://doi.org/10.1146/annurev-ecolsys-071112-124414

Sinsabaugh, R.L., Hill, B.H., Follstad Shah, J.J., 2009. Ecoenzymatic stoichiometry of microbial organic nutrient acquisition in soil and sediment. Nature 462, 795-798. https://doi.org/10.1038/nature08632

Sinsabaugh, R.L., Lauber, C.L., Weintraub, M.N., Ahmed, B., Allison, S.D., Crenshaw, C., Contosta, A.R., Cusack, D., Frey, S., Gallo, M.E., Gartner, T.B., Hobbie, S.E., Holland, K., Keeler, B.L., Powers, J.S., Stursova, M., Takacs-Vesbach, C., Waldrop, M.P., Wallenstein, M.D., Zak, D.R., Zeglin, L.H., 2008. Stoichiometry of soil enzyme activity at global scale. Ecol. Lett. 11, 1252-1264. https://doi.org/10.1111/j.1461-0248.2008.01245.x

Sinsabaugh, R.L., Moorhead, D.L., 1994. Resource allocation to extracellular enzyme production: A model for nitrogen and phosphorus control of litter decomposition. Soil Biol. Biochem. 26, 1305-1311. https://doi.org/10.1016/00380717(94)90211-9

Spiers, G.A., McGill, W.B., 1979. Effects of phosphorus addition and energy supply on acid phosphatase production and activity in soils. Soil Biol. Biochem. 11, 3-8. https://doi.org/10.1016/0038-0717(79)90110-X

Steinweg, J.M., Dukes, J.S., Wallenstein, M.D., 2012. Modeling the effects of temperature and moisture on soil enzyme activity: Linking laboratory assays to continuous field data. Soil Biol. Biochem. 55, 85-92. https://doi.org/10.1016/j.soilbio.2012.06.015 
Stemmer, M., Gerzabek, M.H., Kandeler, E., 1998. Organic matter and enzyme activity in particle-size fractions of soils obtained after low-energy sonication. Soil Biol. Biochem. 30, 9-17. https://doi.org/10.1016/S0038-0717(97)00093-X

Stone, M.M., Plante, A.F., 2014. Changes in phosphatase kinetics with soil depth across a variable tropical landscape. Soil Biol. Biochem. 71, 61-67. https://doi.org/10.1016/j.soilbio.2014.01.006

Tarafdar, J.C., Jungk, A., 1987. Phosphatase activity in the rhizosphere and its relation to the depletion of soil organic phosphorus. Biol. Fertil. Soils 3, 199-204. https://doi.org/10.1007/BF00640630

Tietjen, T., G. Wetzel, R., 2003. Extracellular enzyme-clay mineral complexes: Enzyme adsorption, alteration of enzyme activity, and protection from photodegradation. Aquat. Ecol. 33, 339. https://doi.org/10.1023/B:AECO.0000007044.52801.6b

Treseder, K.K., Vitousek, P.M., 2001. Effects of soil nutrient availability on investment in acquisition of N and P in Hawaiian rain forests. Ecology 82, 946-954. https://doi.org/10.1890/0012-9658(2001)082[0946:EOSNAO]2.0.CO;2

Tscherko, D., Hammesfahr, U., Marx, M.-C., Kandeler, E., 2004. Shifts in rhizosphere microbial communities and enzyme activity of Poa alpina across an alpine chronosequence. Soil Biol. Biochem. 36, 1685-1698. https://doi.org/10.1016/j.soilbio.2004.07.004

Turner, B.L., 2010. Variation in pH Optima of Hydrolytic Enzyme Activities in Tropical Rain Forest Soils. Appl. Environ. Microbiol. 76, 6485-6493. https://doi.org/10.1128/AEM.00560-10

Turner, B.L., Wright, J.S., 2014. The response of microbial biomass and hydrolytic enzymes to a decade of nitrogen, phosphorus, and potassium addition in a lowland tropical rain forest. Biogeochemistry 117, 115-130. https://doi.org/10.1007/s10533013-9848-y

Weintraub, M.N., Scott-Denton, L.E., Schmidt, S.K., Monson, R.K., 2007. The effects of tree rhizodeposition on soil exoenzyme activity, dissolved organic carbon, and nutrient availability in a subalpine forest ecosystem. Oecologia 154, 327-338. https://doi.org/10.1007/s00442-007-0804-1

Van Gestel, M., Merckx, R., Vlassak, K., 1996. Spatial distribution of microbial biomass in microaggregates of a silty-loam soil and the relation with the resistance of microorganisms to soil drying. Soil Biol. Biochem. 28, 503-510. https://doi.org/10.1016/0038-0717(95)00192-1

\subsubsection{Supplementary material}

Table S 2.4-1: Study site description

\begin{tabular}{|c|c|c|c|c|}
\hline & Parque National Nahuebluta & Parque National La Campana & Reserva Santa Gracia & References \\
\hline Abbreviation & NA & LC & SG & \\
\hline Location & $37.81^{\circ} \mathrm{S}, 73.01^{\circ} \mathrm{W}$ & $32.96^{\circ} \mathrm{S}, 71.06^{\circ} \mathrm{W}$ & $29.76^{\circ} \mathrm{S}, 71.14^{\circ} \mathrm{W}$ & \\
\hline Altitude [m a.s.l.] & 1240 & 730 & 680 & \\
\hline Distance to Pacific Ocean [km] & 55 & 43 & 23 & \\
\hline Climate & humid & mediterranean & semiarid & Muñoz et al. 2007; Bernhard et al., 2018 \\
\hline MAT $\left[{ }^{\circ} \mathrm{C}\right]$ & 6.1 & 13.6 & 13.9 & WorldClim data, Hijmans et al., 2005 \\
\hline MAP [mm] & 1600 & 358 & 81 & WorldClim data, Hijmans et al., 2005 \\
\hline Parent material & granitoid & granitoid & granitoid & Bernhard et al., 2018; Oeser et al., 2018 \\
\hline Soil type & Umbrisol & Cambisol & Cambisol & Bernhard et al., 2018 \\
\hline Vegetation cover & coniferous forest & $\begin{array}{l}\text { decidous forest } \\
\text { sclerophyllous shrubs }\end{array}$ & $\begin{array}{l}\text { sclerophyllous shrubs } \\
\text { cacti }\end{array}$ & Bernhard et al., 2018 \\
\hline \multicolumn{5}{|l|}{ Dominant species } \\
\hline south slopes & $\begin{array}{l}\text { Araucaria araucana } \\
\text { Nothofagus antarctica } \\
\text { Chusquea coleu }\end{array}$ & $\begin{array}{l}\text { Colliguaja oderifera } \\
\text { Lithrea caustic } \\
\text { Aristeguietia salvia } \\
\text { Podanthus mitiqui }\end{array}$ & $\begin{array}{l}\text { Proustia cuneifolia } \\
\text { Balbisia peduncularis } \\
\text { Senna cumingii }\end{array}$ & Bernhard et al., 2018 \\
\hline north slopes & $\begin{array}{l}\text { Nothofagus obliqua } \\
\text { Araucaria araucana } \\
\text { Gaultheria mucronata }\end{array}$ & $\begin{array}{l}\text { Lithrea caustic } \\
\text { Jubaea chilensis } \\
\text { Retamilla trinervia }\end{array}$ & $\begin{array}{l}\text { Cordia decandra } \\
\text { Adesmia spp. } \\
\text { Baccharis paniculatum } \\
\text { Eulychnia acida } \\
\text { Cumulopuntia sphaerica }\end{array}$ & \\
\hline
\end{tabular}


Table S 2.4-2: Residual standard errors of the fitted non-linear saturation curves calculated by the Michaelis Menten equation. From left to right: $C B H=\beta$-cellobiohydrolase, $B G L=\beta$-glucosidase, $B X Y=\beta$-xylosidase, $N A G$ $=\beta$ - $N$-acetylglucosaminidase, $L E A=$ leucine-aminopeptidase, $T Y A=$ tyrosine-aminopeptidase, $A C P=$ acid phosphatase

\begin{tabular}{|c|c|c|c|c|c|c|}
\hline site & $\begin{array}{l}\text { slope } \\
\text { aspect }\end{array}$ & $\begin{array}{c}\text { slope } \\
\text { position }\end{array}$ & $\begin{array}{c}\text { soil } \\
\text { depth } \\
{[\mathrm{cm}]}\end{array}$ & $\begin{array}{c}\text { root } \\
\text { proximity } \\
{[\mathrm{mm}]}\end{array}$ & CBH & BGL \\
\hline NA & S & top & $0-80$ & $0-2$ & 1.61 & 10.44 \\
\hline NA & $\mathrm{s}$ & top & $0-80$ & $2-4$ & 3.23 & 14.65 \\
\hline NA & s & top & $0-80$ & $4-6$ & na & 13.85 \\
\hline NA & s & mid & $0-80$ & $0-2$ & 1.77 & 9.70 \\
\hline NA & s & mid & $0-80$ & $2-4$ & 4.91 & na \\
\hline NA & s & mid & $0-80$ & $4-6$ & 0.87 & 1.52 \\
\hline NA & $\mathrm{s}$ & bottom & $0-80$ & $0-2$ & 4.50 & 11.48 \\
\hline NA & $\mathrm{s}$ & bottom & $0-80$ & $2-4$ & 0.54 & 6.78 \\
\hline NA & $\mathrm{s}$ & bottom & $0-80$ & $4-6$ & 1.57 & 14.80 \\
\hline NA & $\mathrm{S}$ & top & $80-160$ & $0-2$ & 0.84 & 2.35 \\
\hline NA & $\mathrm{S}$ & top & $80-160$ & $4-6$ & 0.76 & 1.28 \\
\hline NA & s & mid & $80-160$ & $0-2$ & 1.76 & 1.82 \\
\hline NA & s & mid & $80-160$ & $2-4$ & 1.35 & 1.51 \\
\hline NA & s & mid & $80-160$ & $4-6$ & 0.88 & 0.99 \\
\hline NA & $\mathrm{s}$ & bottom & $80-160$ & $0-2$ & 0.75 & 1.71 \\
\hline NA & $\mathrm{s}$ & bottom & $80-160$ & $2-4$ & 1.22 & 1.63 \\
\hline NA & $\mathrm{s}$ & bottom & $80-160$ & $4-6$ & 1.04 & 1.48 \\
\hline NA & $\mathrm{N}$ & mid & $0-80$ & $0-2$ & na & 1.60 \\
\hline NA & $\mathrm{N}$ & mid & $0-80$ & $2-4$ & 0.82 & 2.55 \\
\hline NA & $\mathrm{N}$ & mid & $0-80$ & $4-6$ & 1.03 & 1.04 \\
\hline NA & $\mathrm{N}$ & mid & $80-160$ & $0-2$ & na & 2.18 \\
\hline NA & $\mathrm{N}$ & mid & $80-160$ & $2-4$ & 0.59 & 0.62 \\
\hline NA & $\mathrm{N}$ & mid & $80-160$ & $4-6$ & 0.38 & 1.39 \\
\hline LC & $\mathrm{S}$ & top & $0-60$ & $0-2$ & 4.30 & 35.92 \\
\hline LC & $\mathrm{s}$ & top & $0-60$ & $2-4$ & 2.23 & 9.66 \\
\hline LC & s & top & $0-60$ & $4-6$ & 1.95 & 8.05 \\
\hline LC & s & mid & $0-60$ & $0-2$ & 0.79 & 1.55 \\
\hline LC & $\mathrm{s}$ & mid & $0-60$ & $2-4$ & 1.45 & 4.34 \\
\hline LC & $\mathrm{s}$ & mid & $0-60$ & $4-6$ & 1.12 & 6.34 \\
\hline LC & $\mathrm{s}$ & bottom & $0-60$ & $0-2$ & 1.15 & 8.34 \\
\hline LC & $\mathrm{s}$ & bottom & $0-60$ & $2-4$ & 41 & \\
\hline LC & s & bottom & $0-60$ & $4-6$ & 0.93 & 3.44 \\
\hline LC & $\mathrm{S}$ & top & $60-120$ & $0-2$ & 0.51 & 1.72 \\
\hline LC & $\mathrm{s}$ & top & $60-120$ & $2-4$ & 0.81 & 2.20 \\
\hline LC & $\mathrm{s}$ & top & $60-120$ & $4-6$ & 0.58 & 1.54 \\
\hline LC & $\mathrm{s}$ & mid & $60-120$ & $0-2$ & na & 1.12 \\
\hline LC & $\mathrm{S}$ & mid & $60-120$ & $2-4$ & 0.48 & 1.37 \\
\hline LC & s & mid & $60-120$ & $4-6$ & 74 & 1.57 \\
\hline LC & $\mathrm{s}$ & bottom & $60-120$ & $0-2$ & 1.77 & 4.43 \\
\hline LC & $\mathrm{s}$ & bottom & $60-120$ & $2-4$ & 0.92 & 4.55 \\
\hline LC & s & bottom & $60-120$ & $4-6$ & 1.55 & 3.99 \\
\hline LC & $\mathrm{s}$ & mid & $>120$ & $0-2$ & 0.51 & 1.45 \\
\hline LC & s & mid & $>120$ & $2-4$ & na & 1.66 \\
\hline LC & s & mid & $>120$ & $4-6$ & na & 0.66 \\
\hline LC & $\mathrm{s}$ & bottom & $>120$ & $0-2$ & na & 0.69 \\
\hline LC & $\mathrm{s}$ & bottom & $>120$ & $2-4$ & na & 1.01 \\
\hline LC & s & bottom & $>120$ & $4-6$ & na & 0.54 \\
\hline LC & $\mathrm{N}$ & mid & $0-60$ & $0-2$ & 0.76 & 2.82 \\
\hline LC & $\mathrm{N}$ & mid & $0-60$ & $2-4$ & 60 & 2.71 \\
\hline LC & $\mathrm{N}$ & mid & $0-60$ & $4-6$ & 1.35 & 1.40 \\
\hline LC & $\mathrm{N}$ & mid & $60-120$ & $0-2$ & 0.56 & 1.57 \\
\hline LC & $\mathrm{N}$ & mid & $60-120$ & $2-4$ & 0.96 & 2.2 \\
\hline LC & $\mathrm{N}$ & mid & $60-120$ & $4-6$ & na & 2.23 \\
\hline LC & $\mathrm{N}$ & mid & $>120$ & $0-2$ & 0.68 & 1.40 \\
\hline LC & $\mathrm{N}$ & mid & $>120$ & 2-4 & 0.89 & 1.64 \\
\hline LC & $\mathrm{N}$ & mid & $>120$ & $4-6$ & 0.61 & 1.24 \\
\hline SG & S & top & $0-40$ & $0-2$ & 1.38 & 3.07 \\
\hline SG & $\mathrm{s}$ & top & $0-40$ & & 0.78 & 2.24 \\
\hline SG & s & top & $0-40$ & $4-6$ & na & 2.30 \\
\hline SG & s & mid & $0-40$ & $0-2$ & & 5.8 \\
\hline SG & s & mid & $0-40$ & $2-4$ & 0.49 & 2.30 \\
\hline SG & s & mid & $0-40$ & $4-6$ & & 1.57 \\
\hline SG & $\mathrm{s}$ & lower & $0-40$ & $0-2$ & na & 0.94 \\
\hline SG & $\mathrm{s}$ & & $0-40$ & $2-4$ & & \\
\hline SG & $\mathrm{s}$ & lower & $0-40$ & $4-6$ & 0.88 & 0.76 \\
\hline SG & s & bottom & $0-40$ & $0-2$ & & 0.96 \\
\hline SG & $\mathrm{s}$ & tom & $0-40$ & & & 1. \\
\hline SG & $\mathrm{s}$ & bottom & $0-40$ & & & 2.19 \\
\hline SG & $\mathrm{s}$ & top & $40-80$ & $0-2$ & & 1. \\
\hline SG & $\mathrm{s}$ & top & $40-80$ & $2-4$ & 1.05 & 0.84 \\
\hline SG & s & to & $40-80$ & $4-6$ & & 1.2 \\
\hline SG & $\mathrm{s}$ & $\mathrm{mi}$ & $40-80$ & $0-2$ & na & 2.58 \\
\hline SG & $S$ & $\mathrm{~m}$ & $40-80$ & $2-4$ & & 9.4 \\
\hline SG & $\mathrm{s}$ & mid & $40-80$ & $4-6$ & na & 1.52 \\
\hline SG & $\mathrm{s}$ & & $40-80$ & $0-2$ & & \\
\hline SG & s & & $40-80$ & 2. & & \\
\hline SG & $\mathrm{s}$ & & $40-80$ & & & \\
\hline SG & $\mathrm{s}$ & bottom & $40-80$ & $0-2$ & 29 & 1.4 \\
\hline SG & s & bottom & $40-80$ & & & 1.7 \\
\hline SG & $\mathrm{s}$ & bottom & $40-80$ & $4-6$ & & 1. \\
\hline SG & S & top & $>80$ & 0 & & 2.7 \\
\hline SG & $\mathrm{S}$ & mid & $>80$ & $0-2$ & 0.71 & 2.23 \\
\hline SG & $\mathrm{s}$ & lower & $>80$ & $0-2$ & & 1.72 \\
\hline SG & $\mathrm{s}$ & bottom & $>80$ & $0-2$ & na & 0.97 \\
\hline SG & $\mathrm{N}$ & $\mathrm{mic}$ & $0-40$ & $0-2$ & 1.31 & 2.02 \\
\hline SG & $\mathrm{N}$ & & & & & \\
\hline SG & $\mathrm{N}$ & mid & $0-40$ & $4-6$ & 0.71 & 2.5 \\
\hline SG & $\mathrm{N}$ & mid & $40-80$ & & na & 0.97 \\
\hline SG & $\mathrm{N}$ & mid & $40-80$ & $2-4$ & na & 0.82 \\
\hline SG & $\mathrm{N}$ & $\mathrm{m}$ & $40-80$ & & & \\
\hline SG & $\mathrm{N}$ & mid & $>80$ & $0-2$ & 0.26 & 1.64 \\
\hline
\end{tabular}


2.5 Study 5: From rock eating to vegetarian ecosystems - disentangling processes of phosphorus acquisition across biomes

Published in Geoderma (2021), 388, 10.1016/j.geoderma.2020.114827

Moritz Koester ${ }^{\mathrm{a}, \mathrm{b}}, \underline{\text { Svenja C. Stock }}{ }^{\mathbf{b}, \mathrm{c}}$, Francisco Nájera $^{\mathrm{d}, \mathrm{e}}$, Khaled Abdallah $^{\mathrm{f}}$, Anna Gorbushina ${ }^{\mathrm{f}, \mathrm{g}}$, Jörg Prietzel ${ }^{\mathrm{h}}$, Francisco Matus ${ }^{\mathrm{i}, \mathrm{j}}$, Wantana Klysubun ${ }^{\mathrm{k}}$, Jens Boy ${ }^{\mathrm{l}}$, Yakov Kuzyakov ${ }^{\mathrm{c}}$, Michaela A. Dippold $^{\mathrm{b}}$, Sandra Spielvogel ${ }^{\mathrm{a}, \mathrm{m}}$

${ }^{a}$ Instiute of Geography, University of Bern, Bern, Switzerland

${ }^{b}$ Biogeochemistry of Agroecosystems, University of Goettingen, Goettingen, Germany

'Soil Science of Temperate Ecosystems, Agricultural Soil Science, University of Goettingen, Goettingen, Germany

${ }^{\mathrm{d} D e p a r t m e n t}$ of Chemical Sciences and Natural Resources, Universidad de La Frontera, Chile ${ }^{\mathrm{e}}$ Faculty of Agricultural Sciences, Universidad de Chile, Santiago, Chile ${ }^{\mathrm{f}}$ Federal Institute for Material Research and Testing, Berlin, Germany ${ }^{9}$ Freie Universität Berlin, Department of Earth Sciences \& Department of Biology Chemistry Pharmacy, Malterserstr. 74-100, D-12249 Berlin, Germany

${ }^{\text {h} R e s e a r c h ~ D e p a r t m e n t ~ E c o l o g y ~ a n d ~ E c o s y s t e m ~ M a n a g e m e n t, ~ C h a i r ~ o f ~ S o i l ~ S c i e n c e, ~ T e c h n i c a l ~ U n i v e r s i t y ~}$ of Munich, Freising, Germany

'Laboratory of Conservation and Dynamic of Volcanic Soils, Universidad de La Frontera, Chile ${ }^{\mathrm{j} N e t w o r k ~ f o r ~ E x t r e m e ~ E n v i r o n m e n t ~ R e s e a r c h, ~ N E X E R-C h i l e, ~ U n i v e r s i d a d ~ d e ~ L a ~ F r o n t e r a ~}$ ${ }^{k}$ Synchrotron Light Research Institute, Nakhon Ratchasima, Thailand ${ }^{1}$ Institute of Soil Science, Leibniz Universität Hannover, Hannover, Germany ${ }^{\mathrm{m}}$ Institute for Plant Nutrition and Soil Science, Christian-Albrechts University Kiel, Kiel, Germany

Corresponding Author: Moritz Koester

Keywords: rhizosphere processes; phosphorus K-edge-XANES spectroscopy; low-molecularweight organic substances; organic phosphorus breakdown; biogenic weathering; climate gradient 


\section{Abstract}

Low-molecular-weight organic acids (LMWOAs) are crucial for the mobilization and acquisition of mineral phosphorus forms by plants. However, the role of LMWOAs in mobilising organic phosphorus, which is the predominant phosphorus form in at least half of the world's ecosystems, especially in humid climates, is unclear. The mechanisms of phosphorus mobilization by LMWOAs depend on climate, mainly precipitation, and shape the phosphorus nutrition strategies of plants.

We disentangled the impact and mechanisms of roots and associated microorganisms on phosphorus cycling mediated by LMWOAs by studying soils along an ecosystem-sequence (ecosequence): from arid shrubland ( $70 \mathrm{~mm} \mathrm{yr}^{-1}$ precipitation), and Mediterranean woodland $\left(\sim 370 \mathrm{~mm} \mathrm{yr}^{-1}\right.$ precipitation) to humid-temperate forest $\left(\sim 1470 \mathrm{~mm} \mathrm{yr}^{-1}\right.$ precipitation). Phosphorus speciation in soil was examined by X-ray absorption near edge structure analysis (XANES). LMWOAs were quantified as biological rock-weathering and organic phosphorus mobilization agents and compared with kinetics of acid phosphatase as a proxy for organic phosphorus mineralization.

Calcium-bound phosphorus in topsoils decreased from $126 \mathrm{mg} \mathrm{kg}^{-1}$ in the arid shrubland, to 19 $\mathrm{mg} \mathrm{kg}^{-1}$ in the Mediterranean woodland and was undetectable in the humid-temperate forest. In contrast, organic phosphorus in topsoils in close root proximity $(0-2 \mathrm{~mm}$ distance to roots) was absent in the arid shrubland but raised to $220 \mathrm{mg} \mathrm{kg}^{-1}$ in the Mediterranean woodland and to $291 \mathrm{mg} \mathrm{kg}^{-1}$ in the humid-temperate forest. The organic phosphorus content in topsoils was 1.6 to 2.4 times higher in close root proximity (0-2 $\mathrm{mm}$ distance to roots) compared to bulk soil (4-6 mm distance to roots) in the Mediterranean woodland and humid-temperate forest, showing intensive bioaccumulation of $\mathrm{P}$ in the rhizosphere. Redundancy analysis (RDA) revealed that LMWOAs were explained by the content of hydroxyapatite and variscite phosphorus-species in the arid shrubland, indicating that LMWOAs contribute to mineral weathering in this soil. LMWOA contents, phosphatase activity, and microbial biomass carbon correlated strongly with organic phosphorus in the humid-temperate forest soil, which implies a high relevance of LMWOAs for organic phosphorus recycling. In the Mediterranean woodland soil, however, oxalic acid correlated with organic phosphorus in the topsoil (suggesting phosphorus recycling), whereas in the subsoil malic and citric acid were correlated with primary and secondary phosphorus minerals (implying mineral weathering). We conclude that phosphorus acquisition and cycling depend strongly on climate and that the functions of LMWOAs in the rhizosphere change fundamentally along the ecosequence. In the arid shrubland LMWOAs facilitate biochemical weathering (rock eating), 
while in the humid-temperate forest their functions change towards supporting organic $\mathrm{P}$ recycling (vegetarian).

\subsubsection{Introduction}

Chemical and physical weathering depend on climate and have a strong control over plant's phosphorus (P) accessibility. In general, apatite weathering is strongly driven by water availability (Maher, 2010). Phosphate $\left(\mathrm{H}_{2} \mathrm{PO}_{4}^{-}, \mathrm{HPO}_{4}^{2-}\right.$ and $\left.\mathrm{PO}_{4}^{3-}\right)$ concentrations in soil solution are low and constantly have to be replenished from undissolved pools to sustain plants' $\mathrm{P}$ demands (Kirkby and Johnston, 2008). Beyond abiotic dissolution by water, plants and associated microorganisms modify biochemical conditions in the rhizosphere (Kuzyakov and Razavi, 2019), e.g. by the exudation of low-molecular-weight organic acids (LMWOAs) and simultaneous release of protons. Thereby, plants and microorganisms enhance mineral weathering (biochemical weathering) in root proximity and the mobilization of scarce nutrients, but also facilitate the uptake of organic P.

There are three mechanisms by which LMWOAs enhance the dissolution of P minerals. (1) The exudation of organic anions, associated with the exudation of a proton as counterion, lowers rhizosphere pH (Ma et al., 2019) and, subsequently, leads to the dissolution of calcium-phosphates.

(2) Organic anions chelate bi- and trivalent cations and decrease the concentration of iron $\left(\mathrm{Fe}^{3+}\right)$, aluminum $\left(\mathrm{Al}^{2+}\right)$, and $\mathrm{Ca}^{2+}$ in soil solution (Jones, 1998). This process forces the dissolution of Ca-, Fe- and Al-P and hampers phosphate precipitation. (3) Organic anions block sorption sites, especially at sesquioxides (Hinsinger, 2001; Jones, 1998; Jones and Darrah, 1994). Several authors have reported that LMWOAs are also capable of organic P mobilization (Giles et al., 2014; Lan et al., 1995), especially citric acid was demonstrated to be highly effective in liberating organic $\mathrm{P}$ species in tropical natural and plantation soils (Wei et al., 2010). Because sorption of organic P species to metal ions occurs analogously to that of free phosphates, it was suggested that the liberating mechanisms are similar (Wei et al., 2010). LMWOAs could on the one hand serve to desorb organic $\mathrm{P}$, exposing it to enzymatic attack, and on the other hand hamper the precipitation of liberated phosphates by keeping Fe and $\mathrm{Al}$ concentrations in the soil solution low. Different LMWOAs are differently effective in dissolving the various $\mathrm{P}$ forms in soils. Johnson and Loeppert (2006) showed that citrate is the most effective LMWOA in desorbing P from Fe surfaces. This is likely due to its tricarboxylic structure and the ability to complex trivalent metal cations. On the other hand, oxalate is most effective in releasing $\mathrm{P}$ from Ca-phosphates (Jones, 1998). The effect of malate was only tested in mixtures with other organic acids and never for this acid alone (e.g. Fox et al., 1990). 
To date, it is unclear how crucial LMWOAs are for biochemical weathering (Jones, 1998; LópezArredondo et al., 2014; Ryan et al., 2001). Furthermore, there are only few data on the concentrations of LMWOAs in soil under field conditions. It was demonstrated that oxalate at concentrations of about $1 \mathrm{mM}$ effectively dissolves feldspars in a batch experiment (Hinsinger, 2001). However, LMWOAs' concentrations in bulk soil in most cases are lower than the concentrations used in batch experiments to dissolve pure minerals (Neaman et al., 2006). Nevertheless, concentrations in some microenvironments such as the rhizosphere, can exceed by far those in bulk soil (Drever, 1994; Neaman et al., 2006).

It has repeatedly been shown that $\mathrm{P}$ starvation enhances the exudation of LMWOA by roots (Hedley et al., 1982; Kirk et al., 1999; Lipton et al., 1987). More specifically, citric acid exudation was high under $\mathrm{P}$ deficiency in rhizosphere soil under cabbage, but not in rhizosphere soil under carrot and potato (Dechassa and Schenk, 2004). A study by Gaume et al. (2001) comparing a low$\mathrm{P}$ resistant maize (Zea mays L.) cultivar with a non-low-P resistant breed showed that the ability to exude organic acids in response to $\mathrm{P}$ deficiency can vary even among genotypes of the same species.

Several studies that investigated the change in $\mathrm{P}$ speciation along climosequences conclude that climate, mediated by vegetation, is the main driver of apatite transformation to secondary $\mathrm{Fe}$ - and Al-phosphates, phosphates adsorbed to sesquioxides, and organic P (Feng et al., 2016; Ippolito et al., 2010; Pinheiro Junior et al., 2019). Precipitation is particularly important because the addition of water with low ion concentrations $(\mathrm{P}, \mathrm{Fe}, \mathrm{Al}, \mathrm{Ca})$ to the soil solution promotes the abiotic dissolution of $\mathrm{P}$ minerals and desorption of $\mathrm{P}$ due to concentration gradients. Ippolito et al. (2010) found that the loss of Ca-P from soil was related to mean annual precipitation (MAP) and explained this by the loss of Ca. On the other hand, Walker and Syers (1976) postulate highest P leaching rates at the beginning of pedogenesis. This implies that MAP needs to exceed a certain threshold for P leaching to occur, but weathering and soil mineral composition has to be in a state where $\mathrm{P}$ retention by sesquioxides is still low.

It is widely understood that different ecosystems have contrasting strategies to acquire nutrients. Moreover, it has been demonstrated that during ecosystem development a change from acquisition to recycling of nutrients within an ecosystem often occurs via a transition of the plant community from short living individuals to a more complex, interacting community (Lambers et al., 2008; Odum, 1969). Under arid conditions P must largely be acquired from the parent material, because low primary productivity transforms only a small amount of mineral P to organic P. Moreover, physical and chemical weathering, but also enzymatic processes, are restricted by water limitation under arid and semiarid climate for most of the time. In periods when water is available, it is 
mandatory for plants to accelerate mineral weathering by the production of weathering agents (Banfield et al., 1999; Lenton and Watson, 2004). Recycling of organic P becomes increasingly important with increasing humidity of the climate, as it can help to prevent leaching and associated P-losses caused by precipitation (Feng et al., 2016; Hou et al., 2018). Moreover, humid climates are correlated with high primary productivity and thus a higher proportion of $\mathrm{P}$ is bound in the organic pool as compared to arid ecosystems (Feng et al., 2016). The amount of total P decreases with proceeding soil development (Turner et al., 2018; Yang and Post, 2011; Walker and Syers, 1976) with proceeding soil development (Turner et al., 2018; Yang and Post, 2011). At the same time the proportion of $\mathrm{P}$ occluded in organomineral complexes was highest in the most weathered soils (Yang and Post, 2011). Lang et al. (2017) indicate that deeply weathered humid ecosystems intensively recycle $\mathrm{P}$ within the organic pool, rather than acquiring it from the parent material. We address the concept of acquiring versus recycling ecosystems (Lang et al., 2017) and propose that the P-source preferred by the ecosystems depends on mean annual precipitation, as driver of the biotas' productivity and, thus, $\mathrm{P}$ demand. We hypothesize that (1) under arid climate, LMWOAs facilitate the dissolution of primary $\mathrm{P}$ species (weathering), with partial re-precipitation of the $\mathrm{P}$ as secondary inorganic $\mathrm{P}$ minerals. (2) In soils under humid conditions, we expect LMWOAs to support recycling of organic $\mathrm{P}$ species, induced by a high risk for $\mathrm{P}$ losses by precipitation. This would indicate a high importance of nutrient recycling under humid conditions because suggested weathering rates are too low to provide sufficient $\mathrm{P}$ to the ecosystems' biota. This is supported by a study of Oeser and Blanckenburg (2020), who examined the same study sites, and found no increase in weathering depths with increasing precipitation. At the same time, net primary productivity, and thus, $\mathrm{P}$ demand along the same ecosequence increased strongly from arid to humid ecosystems (Werner et al., 2018).

We tested our hypotheses at three sites of similar parent material located along the Coastal Cordillera of Chile, comprising a gradient (north to south) in MAP from about $70 \mathrm{~mm} \mathrm{yr}^{-1}$ to more than $1400 \mathrm{~mm} \mathrm{yr}^{-1}$ and mean annual temperature (MAT) from $13.7^{\circ} \mathrm{C}$ to $6.6^{\circ} \mathrm{C}$ (Fick and Hijmans, 2017) (Table 2.5-1).

\subsubsection{Material and Methods}

\subsubsection{Experimental sites}

We focused on three study sites that represent a gradient across biomes (ecosequence) and extend from $29^{\circ}$ to $38^{\circ}$ of southern latitude. They are located along the Coastal Cordillera of Chile, and all soils have developed from granodioritic parent material. Mean annual precipitation (MAP) increases from $66 \mathrm{~mm} \mathrm{yr}^{-1}$ to $1469 \mathrm{~mm} \mathrm{yr}^{-1}$ and mean annual temperature (MAT) decreases from $13.7^{\circ} \mathrm{C}$ to $6.6^{\circ} \mathrm{C}$, from north to south (Fick and Hijmans, 2017) (Table 2.5-1). The study sites 
comprise an ecosequence from arid shrubland (Reserva Nacional Santa Gracia) in the north to Mediterranean woodland (Parque Nacional La Campana) and humid-temperate forest (Parque Nacional Nahuelbuta) in the most southern site. Important site specifics are shown in Table 2.5-1. For a comprehensive description of vegetation, soils and geology see Bernhard et al. (2018b) and Oeser et al. (2018).

Table 2.5-1: Characteristics of the three study sites. Mean annual precipitation (MAP) and mean annual temperature (MAT) are derived from Fick and Hijmans (2017). Climate classifications from (Trabucco and Zomer, 2019). Vegetation type, soil type, $\mathrm{pH}$, and grain size distribution (sand-, silt-, and clay shares) are taken from Bernhard et al. (2018b). Grain size classes and $\mathrm{pH}$ were calculated as mean over the respective soil depths. Soil types refer to soil pits from midslope position at northand south-facing soil pits. The sampling depth (by soil region) is given in percent classes as they were used for result presentation throughout the present work and in absolute values. Absolute sampling depth is given for the soil pit at the north facing slope in midslope position and for the south facing slope for the soil pits at top-mid-and toeslope position.

\begin{tabular}{|c|c|c|c|c|c|c|c|c|c|c|c|c|c|c|c|}
\hline \multirow[t]{3}{*}{ Site } & \multirow{3}{*}{$\begin{array}{l}\text { Soil } \\
\text { region }\end{array}$} & \multirow{3}{*}{$\begin{array}{l}\text { Percentage } \\
\text { soil depth } \\
\text { (\%) }\end{array}$} & \multicolumn{4}{|c|}{ Absolute depth $[\mathrm{cm}]$} & \multirow{3}{*}{$\begin{array}{l}\text { MAP }^{\mathbf{a}} \\
{\left[\mathrm{mm}_{\mathrm{yr}}{ }^{1}\right]}\end{array}$} & \multirow{3}{*}{$\begin{array}{l}\mathrm{MAT}^{\mathrm{a}} \\
{\left[{ }^{\circ} \mathrm{C}\right]}\end{array}$} & \multirow[t]{3}{*}{ Climate $^{b}$} & \multirow[t]{3}{*}{ Vegetation $^{c}$} & \multirow[t]{3}{*}{ Soil-type ${ }^{c}$} & \multirow[t]{3}{*}{$\mathrm{pH}^{\mathrm{c}}$} & \multirow{3}{*}{$\begin{array}{l}\text { Sand } \\
\text { (\%) }\end{array}$} & \multirow{3}{*}{$\begin{array}{l}\text { Silt }^{c} \\
(\%)\end{array}$} & \multirow{3}{*}{$\begin{array}{l}\text { Clay } \\
(\%)\end{array}$} \\
\hline & & & North & & South & & & & & & & & & & \\
\hline & & & Mid & Top & Mid & Toe & & & & & & & & & \\
\hline \multirow[t]{3}{*}{ Arid shrubland } & topsoil & $0-50$ & 15 & 15 & 22.5 & 25 & \multirow[t]{3}{*}{66} & \multirow[t]{3}{*}{13.7} & \multirow[t]{3}{*}{ Arid } & \multirow{3}{*}{$\begin{array}{l}\text { Sclerophyllous } \\
\text { shrubs } \\
\text { cacti }\end{array}$} & \multirow{3}{*}{$\begin{array}{l}\text { Cambisol/ } \\
\text { Leptosol }\end{array}$} & 6.4 & 77.4 & 14.6 & 8.0 \\
\hline & subsoil & $50-100$ & 30 & 30 & 45 & 50 & & & & & & 6.3 & 73.4 & 14.3 & 11.4 \\
\hline & saprolite & $>100$ & $>30$ & $>30$ & $>45$ & $>50$ & & & & & & 6.4 & 78.5 & 13.0 & 8.6 \\
\hline \multirow{3}{*}{$\begin{array}{l}\text { Mediterranean } \\
\text { woodland }\end{array}$} & topsoil & $0-50$ & 30 & 15 & 24 & 35 & \multirow[t]{3}{*}{367} & \multirow[t]{3}{*}{14.1} & \multirow[t]{3}{*}{ Semiarid } & \multirow{3}{*}{$\begin{array}{l}\text { Deciduous } \\
\text { forest } \\
\text { sclerophyllous } \\
\text { shrubs }\end{array}$} & \multirow[t]{3}{*}{ Cambisol } & 5.5 & 73.0 & 17.6 & 9.5 \\
\hline & subsoil & $50-100$ & 70 & 30 & 48 & 70 & & & & & & 5.0 & 78.0 & 13.4 & 8.6 \\
\hline & saprolite & $>100$ & $>70$ & $>30$ & $>48$ & $>70$ & & & & & & 5.4 & 88.3 & 7.6 & 4.1 \\
\hline \multirow{3}{*}{$\begin{array}{l}\text { Humid- } \\
\text { temperate } \\
\text { forest }\end{array}$} & topsoil & $0-50$ & 57.5 & 45 & 80 & 65 & \multirow[t]{3}{*}{1469} & \multirow[t]{3}{*}{6.6} & \multirow[t]{3}{*}{ Humid } & \multirow{3}{*}{$\begin{array}{l}\text { Coniferous } \\
\text { forest }\end{array}$} & Orthodystric & 4.3 & 56.4 & 21.1 & 22.5 \\
\hline & subsoil & $50-100$ & 115 & 90 & 160 & 130 & & & & & Umbrisol/ & 4.6 & 81.7 & 11.1 & 7.3 \\
\hline & saprolite & $>100$ & $>115$ & $>90$ & $>160$ & $>130$ & & & & & $\begin{array}{l}\text { Umbric } \\
\text { Podzol }\end{array}$ & 4.6 & 84.6 & 10.1 & 5.3 \\
\hline
\end{tabular}

\subsubsection{Soil sampling and sample preparation}

Soil sampling was done in austral summer 2016. At each site samples were taken from three soil pits on the south-facing slope, arranged as a catena (top-, mid-, and toe-slope), and one soil pit at the opposing north-facing slope (mid-slope) (Bernhard et al., 2018b). Soil pits were sampled at three depths. To compare sites and profiles among each other, depth increments were determined in percent of the total soil depth; with $100 \%$ defined as the boundary of soil to saprolite. Samples were taken from $0-50 \%$ ('topsoil'), 50-100\% of soil depth ('subsoil'), and >100\% ('saprolite'). For absolute sampling depths in each soil pit see Table 1. To obtain a gradient from rhizosphere to bulk soil, samples were taken at three distances $(0-2 \mathrm{~mm}, 2-4 \mathrm{~mm}, 4-6 \mathrm{~mm})$ from root channels of young living roots. The $0-2 \mathrm{~mm}$ and $2-4 \mathrm{~mm}$ distance increments were defined as rhizosphere soil, the distance 4-6 mm was considered as bulk soil. Due to the coarse texture of the parent material in the arid shrubland saprolite, it was not possible to accurately sample increments of two millimeters.

Therefore, only distance increments 0-2 $\mathrm{mm}$ and 4-6 mm were sampled. Roots were found in all sampled horizons, but in different abundances. Rooting density decreased with increasing soil 
depth and increased with increasing MAP. For more details about the rooting density and pictures of the soil pits the reader is referred to Oeser et al. (2018).

We did not distinguish roots on species level but sampled an average of all roots occurring in the respective soil pit and depth. Roots with a diameter of $\leq 2 \mathrm{~mm}$ were considered as young roots. To confirm that the sampled roots were still active, we removed the root bark to observe if the underlying tissues was moist, hence transporting water.

All analyses were run in all three depth increments for south-facing slopes (with mentioned exception for the arid shrubland ecosystem) and depth increments 0-50\% (e.g. topsoil) and >100\% (e.g. saprolite) for north facing slopes. We aliquoted the samples and immediately froze and stored the samples meant for DNA analyses and LMWOA measurement at $-20{ }^{\circ} \mathrm{C}$. Samples for X-ray absorption near edge structure (XANES) analysis were dried and ball milled at $200 \mathrm{rpm}$ for $2 \mathrm{~min}$. Gravimetric water content was measured by drying the samples at $105^{\circ} \mathrm{C}$ until weight constancy. Total $\mathrm{P}$ content was determined by pressure digestion with $\mathrm{HNO}_{3}$ (König et al., 2014). Samples (100 mg) were placed into Teflon beakers and $2 \mathrm{ml}$ of $65 \% \mathrm{HNO}_{3}$ were added. Beakers were tightly closed and heated to $190{ }^{\circ} \mathrm{C}$ for $12 \mathrm{~h}$. Subsequently, the extract was diluted with double distilled water (ultrapure) and analyzed on an inductively coupled plasma-optical emission spectrometer (ICP-OES) (Thermo Scientific iCap 6000 Series, Bremen, Germany).

\subsubsection{DNA content and phosphatase kinetics}

Total genomic DNA extraction for soil samples was performed using the FastDNA SPIN Kit for Soil (MP Biomedicals, Solon, USA) following the manufacturer's instructions. Samples of maximally $0.25 \mathrm{~g}$ were homogenized in three processing cycles with 2 min ice incubations between cycles. The extracted DNA was eluted in $80 \mu \mathrm{L}$ sterile ultrapure water and quantified with a NanoDrop 2000C (Thermo Fisher Scientific, Bremen, Germany). Diluted DNA extracts were stored at $-80^{\circ} \mathrm{C}$ until qPCR analyses. Bacterial and fungal DNA content was used to calculate microbial biomass carbon (MBC) in the samples by using a conversion factor of 5 (Anderson and Martens, 2013). Besides DNA contents, kinetics of acid phosphatase, determined by Stock et al. (2019) from the same sample set, were included in the multivariate statistical approaches (see section "Statistical analysis"). To describe phosphatase kinetics from a Michaelis-Menten fit, the maximum phosphatase reaction rate $\mathrm{V}_{\max }$ and the half-saturation constant $\mathrm{K}_{\mathrm{m}}$, were reported. $\mathrm{V}_{\max }$ represents the maximum enzyme activity at substrate saturation and $\mathrm{K}_{\mathrm{m}}$ the substrate concentration required for half-maximal activity. 


\subsubsection{LMWOA extraction}

LMWOAs were extracted based on a method after Szmigielska et al. (1997), with modifications. LMWOAs were extracted with $0.5 \mathrm{M} \mathrm{HCl}$ in methanol $(\mathrm{MeOH})$ with a soil to solution ratio of $1: 1$ $(\mathrm{v} / \mathrm{v})$ by shaking for one hour. After centrifugation at $950 \mathrm{~g}$ for $15 \mathrm{~min}$ the supernatant was transferred to a reaction vessel and dried under a gentle stream of $\mathrm{N}_{2}$. For derivatization, $3 \mathrm{ml}$ of $\mathrm{MeOH}$ and $300 \mu \mathrm{l}$ of $\mathrm{H}_{2} \mathrm{SO}_{4}(50 \%)$ were added to the samples which then were placed in a heating block at $60{ }^{\circ} \mathrm{C}$ for $30 \mathrm{~min}$. Analytes were purified by liquid-liquid extraction using chloroform $\left(\mathrm{CHCl}_{3}\right)$ as final solvent. Samples were analyzed on a GC-MS (GC 7890A, MS 7000A Series Triple Quad, Agilent Technologies, Waldbronn, Germany) with a capillary column (DB-FFAP, $30 \mathrm{~m}$ length, $1 \mu \mathrm{m}$ film thickness, $0.25 \mathrm{~mm}$ diameter; Agilent Technologies, Waldbronn, Germany). Standard solutions contained the following organic acids: oxalic-, malonic-, fumaric-, succinic-, maleic-, malic- and citric acid (Table S 2.5-1). Contents of LMWOAs were determined for three south-facing and one north-facing soil pit in each ecosystem, respectively. As organic acids as well as their anions are co-extracted by the presented approach, the abbreviation for LMWOAs refers to acids and their respective anions.

\subsubsection{P speciation by XANES $P$ K-edge spectroscopy}

Spectra at the P K-edge were measured at the Beamline 8 of the electron storage ring $(1.2 \mathrm{GeV}$; bending magnet; beam current: $80-150 \mathrm{~mA} ; 1.1$ to $1.7 \times 10^{11}$ photons s${ }^{-1}$ ) at the Synchrotron Light Research Institute (SLRI), Nakhon Ratchasima, Thailand (Klysubun et al., 2012). Air dried, milled samples were homogenized and applied to P free 'Kapton tape' (Lanmar Inc., Northbrook, IL, USA) (area $2.0 \mathrm{~cm} \times 0.5 \mathrm{~cm}$ ). Samples were measured in fluorescence mode. The chamber was flushed with He 2 min before, and during measurement. The energy of the X-ray beam was modulated by an InSb (111) double crystal monochromator, with an energy resolution $(\Delta \mathrm{E} / \mathrm{E})$ of $3 \times 10^{-4}$ (i.e. about $0.6 \mathrm{eV}$ at the $\mathrm{P}$ K-edge). Energy calibration was done with elemental $\mathrm{P}$ powder $\left(\mathrm{E}_{0}=2145.5 \mathrm{eV}\right.$; precision $\left.0.11 \mathrm{eV}\right)$. Depending on the P content of the sample, 3 to 5 scans were recorded.

Evaluation of the XANES spectra was done using the software R Version 3.4.3 (R Core Team, 2017) and the LCF package for linear combination fitting (LCF) (Werner, 2017). Spectra of the samples were background corrected and edge-step normalized by allowing energy levels to float in a defined range. For the lower pre-edge point this was between $-48 \mathrm{eV}$ to $-28 \mathrm{eV}$ and for the upper pre-edge point between $-18 \mathrm{eV}$ to $-8 \mathrm{eV}$, relative to $\mathrm{E}_{0}$, with energy steps of $1 \mathrm{eV}$. The postedge energy was allowed to vary between $29 \mathrm{eV}$ to $39 \mathrm{eV}$, energy steps of $0.5 \mathrm{eV}$, for the lower point and $60 \mathrm{eV}$ to $70 \mathrm{eV}$, energy steps of $1 \mathrm{eV}$, for the upper point, relative to $\mathrm{E}_{0}$. All fits which deviated from 1 by less than 0.0005 were chosen and those with the lowest $\mathrm{R}$ values selected as to 
best fit the data. In a second step the optimized background correction and normalization parameters were used in the fit_athena environment of the LCF package (which uses the same algorithm as the Athena Software (Ravel and Newville, 2005)). The number of total standards allowed in the final fit was constrained to 4 , the sum of weights of the standards was forced to one. If the second-best fit diverged from the best fit in at least one $\mathrm{P}$ species by more than five percent, out of these two fits, we selected the one that was most similar to the third-best fit. For the fitting process a total of 13 standards (Table 2.5-2) was selected (Gustafsson et al., 2020; Prietzel et al.,

2016).

Table 2.5-2: Standards included in the Linear combination fitting (LCF) for $P$ species characterization of phosphorus K-edge X-ray absorption near edge structure (XANES) spectra are given in the first column. Characterization of each standard in the second column. Abbreviations as used in the redundancy analysis (RDA) are written in the third column. Standards were grouped to P classes which are presented in column four.

\begin{tabular}{|c|c|c|c|}
\hline Standard ${ }^{a}$ & Description & Abbreviation & P class \\
\hline Hydroxyapatite $^{a}$ & Primary $\mathrm{P}$ mineral in the soils of this study. & HydAp & calcium \\
\hline Brushite $^{b}$ & Secondary Ca-phosphate. & $\mathrm{BRU}$ & phosphates \\
\hline Octa-Ca-phosphate ${ }^{b}$ & Secondary Ca-phosphate & OCP & (Ca-P) \\
\hline AlPO4-amorphous ${ }^{\mathrm{a}}$ & $\begin{array}{l}\text { Secondary Al phosphates with short range ordered } \\
\text { crystal lattice. }\end{array}$ & sroAl-P & $\begin{array}{l}\text { Al phosphates } \\
\text { (Al-P) }\end{array}$ \\
\hline Variscite ${ }^{b}$ & Secondary Al phosphate. & VAR & \\
\hline Boehmite-PO4 ${ }^{\mathrm{a}}$ & Phosphate adsorbed to Boehmite. & adsP-BOE & orthophosphate \\
\hline adsP-AlOH ${ }_{3}^{b}$ & Phosphate adsorbed to Al-hydroxide. & adsP-AlOH & sorbed to Al- \\
\hline adsP-Al-Montmorillonite ${ }^{a}$ & Phosphate adsorbed to Al saturated clay. & adsP-Al_clay & (oxy)hydroxides \\
\hline adsP-Al-SOM ${ }^{\mathrm{a}}$ & Phosphate adsorbed to soil organic matter. & adsP-SŌM & (sorbAl-P) \\
\hline FePO4-amorphous ${ }^{\mathrm{a}}$ & $\begin{array}{l}\text { Secondary Fe phosphates with short range ordered } \\
\text { crystal lattice. }\end{array}$ & sroFe-P & $\begin{array}{l}\text { Fe-phosphates } \\
\text { (Fe-P) }\end{array}$ \\
\hline adsP-Ferrihydrite ${ }^{a}$ & Phosphate adsorbed to Ferrihydrite. & adsP-FER & orthophosphate \\
\hline adsP-Goethite ${ }^{b}$ & Phosphate adsorbed to Goethite. & adsP-GOE & $\begin{array}{l}\text { sorbed to Fe- } \\
\text { (oxy)hydroxides } \\
\text { (sorbFe-P) }\end{array}$ \\
\hline Inositolhexakisphosphate ${ }^{a}$ & $\begin{array}{l}\text { Organic P: the spectrum was obtained from } \\
\text { inositolhexakisphosphate. Due to missing characteristics } \\
\text { of organic P species in XANES spectra it was used in this } \\
\text { study to represents organic P in general. }\end{array}$ & Po & $\begin{array}{l}\text { organically bound } \\
\text { P } \\
\text { (Po) }\end{array}$ \\
\hline
\end{tabular}

a) (Prietzel et al., 2016)

b) (Gustafsson et al., 2020)

The $13 \mathrm{P}$ species used for the fitting procedure were summarized in six soil $\mathrm{P}$ classes: Ca-bound $\mathrm{P}$ (Ca-P), Fe- and Al-phosphates (Fe-P, Al-P), P adsorbed to Fe- and Al-oxyhydroxides (sorbFe-P, sorbAl-P), and organic $\mathrm{P}\left(\mathrm{P}_{\mathrm{o}}\right)$. The Ca-P class contained the $\mathrm{P}$ species hydroxyapatite (HydAp), octacalciumphosphate $(O C P)$ and brushite $(B R U)$ as they represent the most important primary $\mathrm{P}$ mineral (HydAp) and secondary calcium-phosphates in these granodiorite-derived neutral to acidic soils. The Fe-P class consists only of a standard for short-range order Fe-phosphates (sroFe-P) (which was the only P standard available in the fitting that accounts for Fe-phosphates) while the Al-P class was composed of short-range order Al-phosphates (sroAl-P), and variscite $(V A R)$. Both classes were included to account for secondary P minerals. The sorbFe-P compound class entailed $\mathrm{P}$ sorbed to ferrihydrite (adsP-FER), and $\mathrm{P}$ sorbed to goethite (adsP-GOE), whereas the sorbAl-P compound class consisted of P sorbed to Al saturated clay (adsP-Al_clay), P sorbed to Al- 
hydroxides $(a d s P-A l O H), \mathrm{P}$ sorbed to boehmite (adsP-BOE), and $\mathrm{P}$ sorbed to $\mathrm{Al}$ saturated soil organic matter (SOM) $(a d s P-S O M) . \quad \mathrm{P}_{\mathrm{o}}$ is represented by a standard of pure Inositolhexakisphosphate. An overview over P standards and how they were classified is given in Table 2.5-2.

A total of 43 samples were specifically chosen to cover gradients in three dimensions (climate, soil depth and rhizosphere to bulk soil), and to be most representative for the respective site. Therefore, always the north- and south-facing mid-slope profiles from each site were analyzed.

To be able to combine the $\mathrm{P}$ contents in the different distances to roots the 'rhizosphere P per root length segment' was calculated as total P content in a cylindrical shaped volume around roots with a length of $1 \mathrm{~cm}$ and an outer diameter of $8 \mathrm{~mm}$. We assumed an average root thickness of $2 \mathrm{~mm}$ to calculate the volume of the cylinder, sheathing the roots, e.g the cylinder volume in $0-2 \mathrm{~mm}$ root distance was calculated as the difference of a cylinder with a radius of $4 \mathrm{~mm}$ minus a cylinder with a radius of $2 \mathrm{~mm}$, and so forth. The total $\mathrm{P}$ content (in $\mathrm{mg} \mathrm{P}$ per $\mathrm{kg}$ soil) and the content in the P compound classes, respectively, were multiplied by the bulk density (derived from Bernhard et al. (2018a)) and multiplied by the volume of the cylinder in the respective root distance (0$\left.2 \mathrm{~mm}=0.38 \mathrm{~cm}^{3}, 2-4 \mathrm{~mm}=0.63 \mathrm{~cm}^{3}, 4-6 \mathrm{~mm}=0.88 \mathrm{~cm}^{3}\right)$.

\subsubsection{Statistical analyses}

All statistical analyses were conducted using R Version 3.4.3 (R Core Team, 2017). Principal component analysis (PCA) was carried out by using the function prcomp() of the 'stats' package of R. Data from all soil pits were included and were normalized to a mean of zero and a standard deviation of one. Linear models for LMWOAs and P speciation, respectively, at each depth, and with root distance as explaining variable, where calculated using the $\operatorname{lm}()$ function, as well of the package 'stats'. The linear model was fitted separately for north- and south-facing slopes. Differences in all three LMWOAs, MBC, Vmax, Km, and P speciation with depth and between sites at one depth were also tested by a linear model. Pairwise comparison between the sites or depths was done by the function lsmeans() of the 'lsmeans' package (Lenth, 2016) with Tukey adjustment. The Redundancy analysis (RDA) was calculated by the rda() function of the package 'vegan' (Oksanen et al., 2018). The RDA was calculated separately for each site and included samples from all soil pits and depths at each site. Explaining and explained variables were normalized to a mean of zero and standard deviation of one. For the RDA, any sample with a missing value in one of the explanatory variables was excluded from the analysis in the respective site. Data are presented in type II scaling, hence, angles between arrows can directly be interpreted in terms of correlation. The correlation between variables is expressed as the $\operatorname{cosine}(\cos (\alpha))$ of the angle between the arrows of two variables. Except for the RDA plots (done by the plot() function 
of R) the package 'ggplot2' was used to produce all graphical outputs of data (Wickham, 2016). Considering an ongoing debate about the meaning of $p$ values and their interpretation, and our study design with highly variable parameters of natural ecosystems, the threshold for significance was set to $p<0.1$ (Amrhein et al., 2019).

\subsubsection{Results}

Two PCAs were calculated to identify the influence of $\mathrm{P}$ speciation alone and the influence of $\mathrm{P}$ speciation together with LMWOA contents on the variability within the dataset. The PCA for P speciation alone (Figure 2.5-1A) explained on the first principal component axis $49.5 \%$ and on the second axis $17.2 \%$ of the total variance within $\mathrm{P}$ species. The humid-temperate forest and the arid shrubland samples were clearly separated along PC 1. In the Mediterranean woodland some topsoil samples forced the woodland polygon to overlap with the polygon comprising samples from the humid-temperate forest soil, whereas all subsoil and saprolite and some topsoil samples of the Mediterranean woodland ecosystem overlapped with the arid shrubland. When LMWOAs (oxalic, malic, citric) were included in the PCA (Figure 2.5-1B) the clear separation of ecosystems along PC 1 was less expressed, but more variance was explained by PC 2, resulting in a more equally distributed explained variance among the two axes. PC 2 ordinated the samples from the humidtemperate forest and Mediterranean woodland by sampling depth, which was not discerned when only P species were used for the PCA. The latter PCA clearly indicated a systematic, presumably process-based, interaction between P-speciation and LMWOAs, since the separation was kept, and the explained variance was more evenly distributed between the first two principal components.

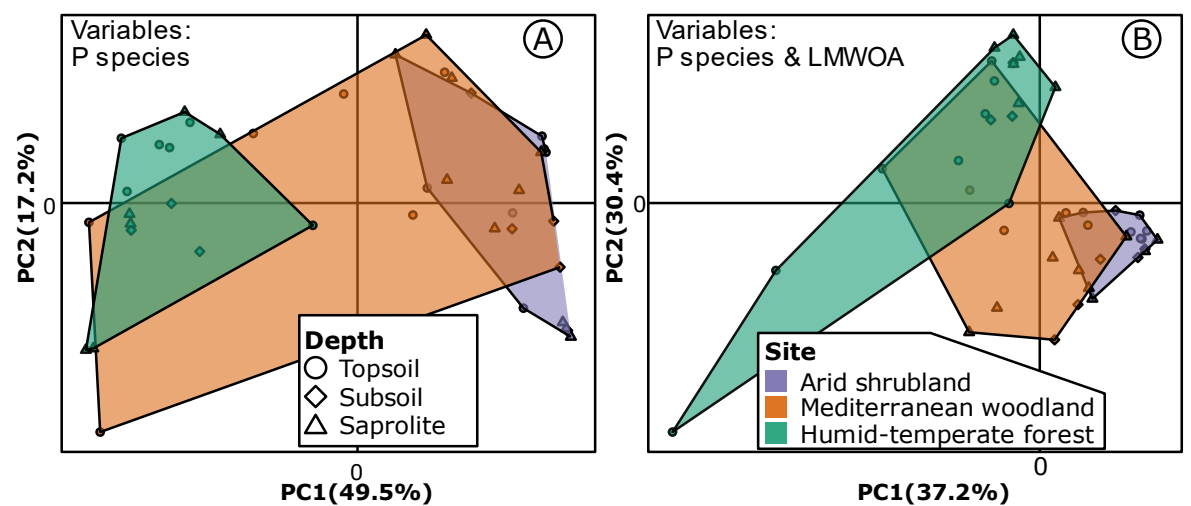

Figure 2.5-1: PCA calculated for all soil samples with (A) P species from phosphorus K-edge X-ray absorption near edge structure (XANES) analysis as variables and (B) $P$ species and low-molecular-weight organic acids (LMWOA) (oxalic-, malic-, and citric acid) as variables. Sampling sites are indicated by color, arid shrubland in purple, Mediterranean woodland in orange and humid-temperate forest in turquoise. Marker type denotes the sampling depth: circles $=$ topsoil, diamonds $=$ subsoil, and saprolite $=$ triangles . 


\subsubsection{Microbial biomass carbon and enzyme kinetics}

MBC content (in $\mu \mathrm{g}$ MBC per g soil) in the topsoil increased with increasing precipitation along the ecosequence (Table S 2.5-8). Within the soil profile, MBC content decreased in all three sites with greater soil depth (Table S 2.5-8). Furthermore, in all sites the MBC content was always significantly different when comparing the topsoil with the saprolite $(p<0.01)$. In the humidtemperate forest, the content of MBC was higher in root proximity compared to bulk soil (Table $\mathrm{S}$ 2.5-8). Along the ecosequence, the maximum reaction rate of acid phosphatase $\left(\mathrm{V}_{\max }\right.$, in mmol substrate $\mathrm{g}^{-1}$ soil $^{-1}$ ) increased with increasing humidity (Table S 2.5-8, after Stock et al. (2019)). The $\mathrm{V}_{\max }$ was lower in the topsoil and saprolite of the Mediterranean woodland and the topsoil of the arid shrubland, compared to the humid-temperate forest.

\subsubsection{LMWOA contents}

Contents of oxalic, malic, and citric acid together accounted for more than $97 \%$ of all extracted LMWOAs. These acids also represent the most-efficient $\mathrm{P}$ dissolving di- and tricarboxylic acids in soils (Gerke et al., 2000). Therefore, we only present the results for these three acids (Figure 2.5-2 and Table S 2.5-8). When comparing between sites, only malic acid contents in the topsoil were always higher in the humid-temperate forest compared to the arid shrubland (Figure 2.5-2). No difference in terms of acid contents in the topsoil were found between the humid temperate forest and the Mediterranean woodland. Next, when assessing the differences with soil depth, the contents of malic and citric acid increased significantly from the topsoil to the saprolite in the arid shrubland soil. LMWOA contents in the Mediterranean woodland ecosystem were more uniformly distributed with soil profile depth (only malic acid increased significantly from the topsoil to the subsoil). Malic acid contents under humid-temperate forest strongly decreased from the topsoil to the saprolite. Finally, when comparing by root proximity we found higher citric acid content in root proximity compared to bulk soil in the topsoil at the south-facing slope of the Mediterranean woodland, and in the saprolite at the north-facing slope of the humid-temperate forest (Figure 2.5-2, red and blue arrows). Contents of malic acid were higher in root proximity $(0-2 \mathrm{~mm})$ than bulk soil in the subsoil of the south-facing slope under humid-temperate forest. Oxalic acid contents were higher in root proximity than bulk soil in the arid shrubland in the subsoil of the south-facing profile. The same was true in all three depths at the south-facing slope in the Mediterranean woodland, and in the saprolite at the south-facing slope of the humid-temperate forest. 


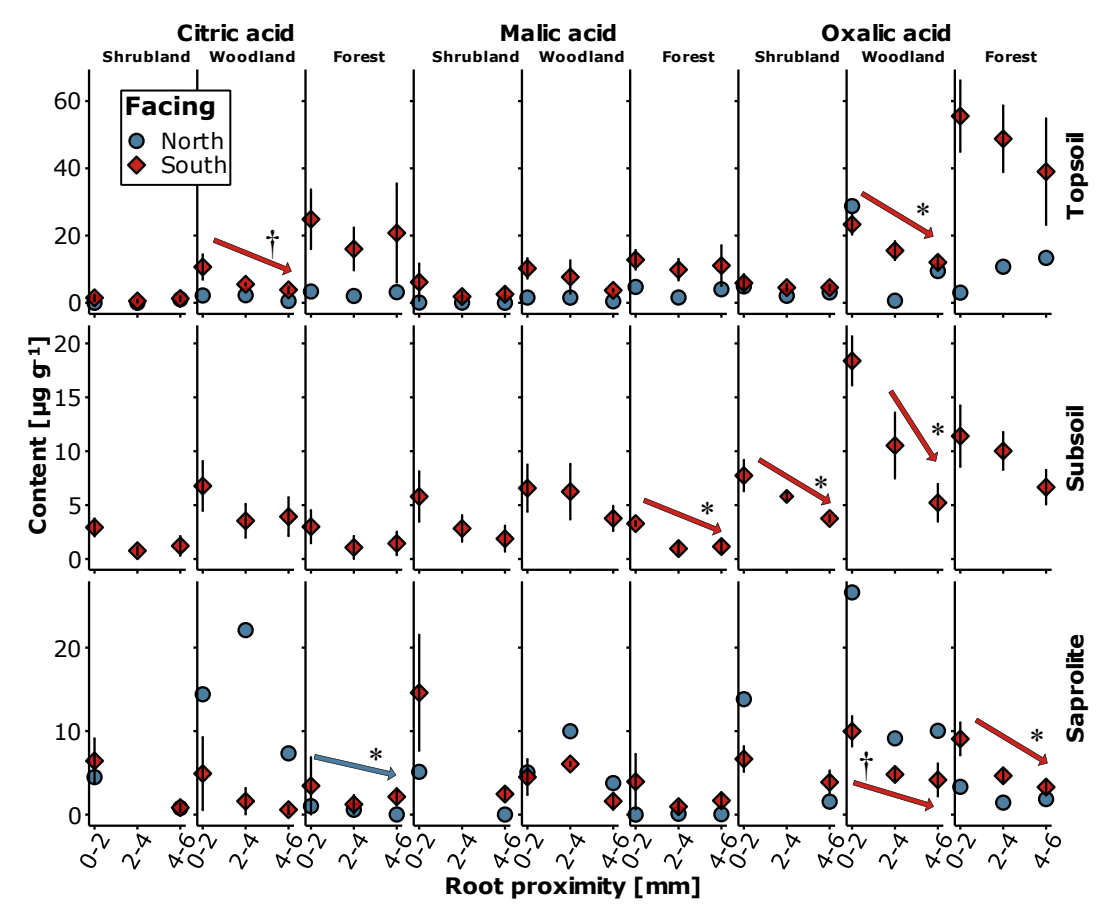

Figure 2.5-2: Content of low-molecular-weight organic acids (LMWOA) (citric-, malic-and oxalic acid) for north (blue circles) and south (red diamonds) facing slopes for all three sites (arid shrubland ('shrubland'), Mediterranean woodland ('woodland') and humid-temperate forest ('forest')) and three sampling depths (topsoil, subsoil and and saprolite) separated by the three horizontal panels. Whiskers indicate the magnitude of the standard error from the mean. The x-axis shows root proximity (intervals of $2 \mathrm{~mm}$ from 0-2 $\mathrm{mm}, 2-4 \mathrm{~mm}$, and 4$6 \mathrm{~mm}), y$-axis plots the content of organic acids per gram soil dry weight. Sample size on the south facing slope is $n=3$, on the north facing slope single replicates are shown $(n=1)$. Arrows indicate significant changes with distance to the roots, the color of the arrow was chosen according to the respective data row. Level of significance is indicated by asterisk $(p<0.05)$ and cross $(p<0.1)$.

\subsubsection{P XANES K edge measurements}

When comparing between sites, Ca-P generally declined with increased precipitation, except for the saprolite of the Mediterranean woodland and the arid shrubland (Figure 2.5-3; Table 2.5-3). When focusing on the differences by soil depth, the Ca-P content increased from topsoil to subsoil and saprolite in the Mediterranean woodland. There was no difference in Ca-P content between the subsoil and the saprolite in the Mediterranean woodland and no effect of soil depth in the arid shrubland. In the humid-temperate forest Ca-P was only found in two samples in the saprolite. When assessing the differences within root proximity, the Ca-P content in the topsoil declined with increasing distance from the root at the north-facing slope of the arid shrubland (Figure 2.5-3, Table S 2.5-7). 


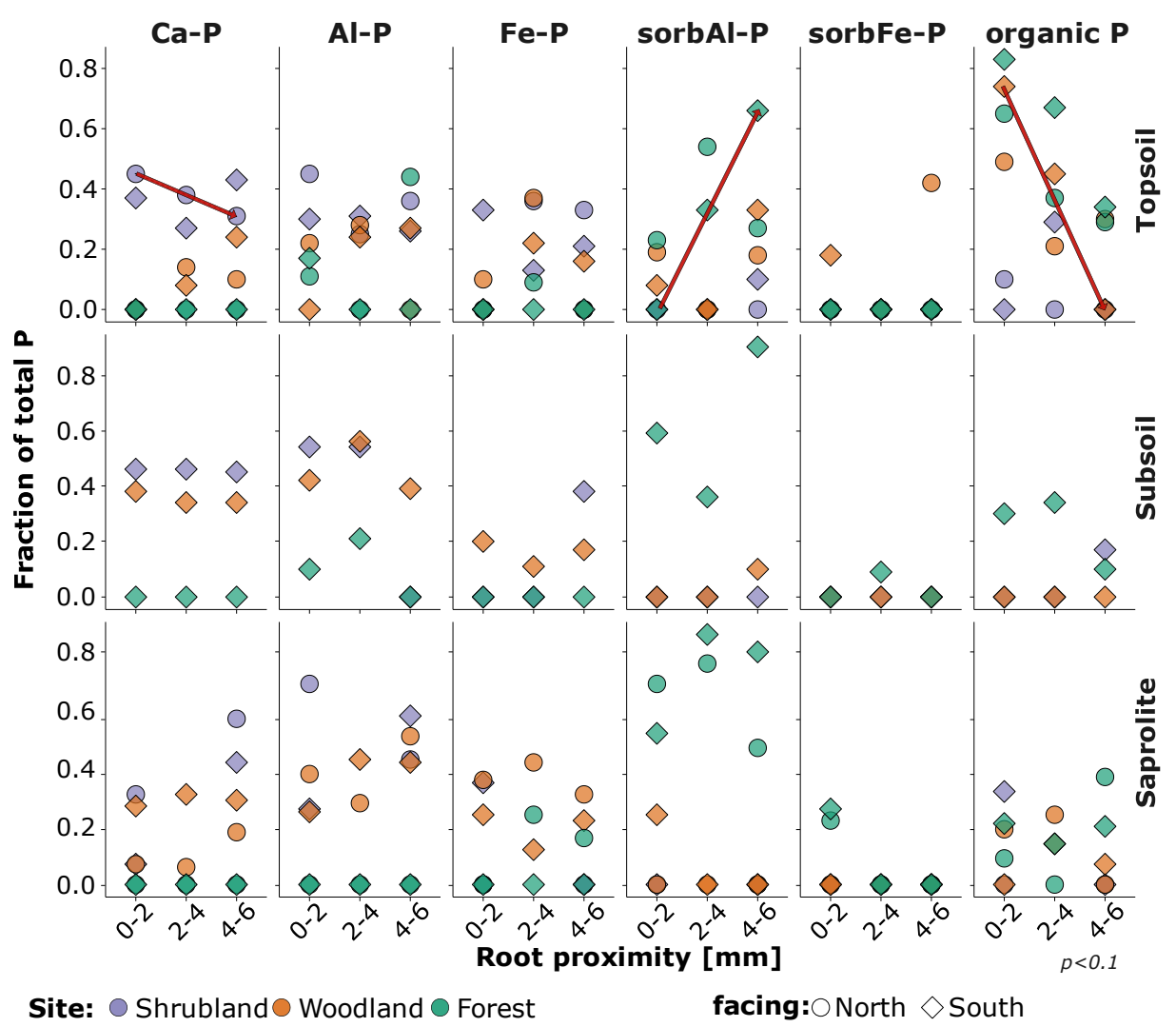

Figure 2.5-3: Contents of $P$ compound classes from phosphorus K-edge X-ray absorption near edge structure (XANES) analysis: calcium phosphates( $\mathrm{Ca}-\mathrm{P}), \mathrm{Al}$ - and $\mathrm{Fe}$ phosphates (Al-P and $\mathrm{Fe}-\mathrm{P})$, orthophosphate sorbed to $A l$ - and $\mathrm{Fe}$-(oxy)hydroxides (sorbAl-P and sorbFe-P) and organic P, split by slope facing (circles $=$ north facing; diamonds = south facing) and by site (arid shrubland ('shrubland') in purple, Mediterranean woodland ('woodland') in orange and humid-temperate forest ('forest') in turquoise. Samples from different depths are separated by the three horizontal panels (topsoil, subsoil and saprolite). The $x$-axis shows root proximity $(0-2 \mathrm{~mm}$, 2-4 mm, and 4-6 mm), the y-axis plots the fractions of the respective $P$ class on total P. Red arrows indicate significant changes with root proximity $(p<0.1)$. The markers present individual replicates $(n=1)$.

Fe-P and Al-P in the topsoil were higher in the arid shrubland than in the humid-temperate forest. In the saprolite Al-P was higher in both, the arid shrubland and Mediterranean woodland, compared to the humid-temperate forest (Figure 2.5-3, Table S 2.5-7). P sorbed to Al(oxy)hydroxides (sorbAl-P) was significantly higher in the humid-temperate forest than in the two other sites. In the topsoil at the south-facing slope of the humid-temperate forest the sorbAl-P contents increased with increasing distance from the root.

The $\mathrm{P}_{\mathrm{o}}$ content in the topsoil was lower under arid shrubland than under Mediterranean woodland and humid-temperate forest. $\mathrm{P}_{\mathrm{o}}$ decreased from topsoil to saprolite in the humid-temperate forest. In the topsoil at the south-facing slope of the Mediterranean woodland $\mathrm{P}_{\mathrm{o}}$ was higher in the rhizosphere than bulk soil.

Rhizosphere P per root segment in soils decreased with increasing precipitation. Average values were: $440 \mu \mathrm{g} \mathrm{cm}^{-1}, 238 \mu \mathrm{g} \mathrm{cm}^{-1}$, and $216 \mu \mathrm{g} \mathrm{cm}^{-1}$ in the topsoil, for the arid shrubland, Mediterranean woodland and humid-temperate forest, respectively. In the saprolite, the 
rhizosphere $\mathrm{P}$ per root segment was $418 \mu \mathrm{g} \mathrm{cm}^{-1}$ in the arid shrubland, $296 \mu \mathrm{g} \mathrm{cm}^{-1}$ in the Mediterranean woodland and $497 \mu \mathrm{g} \mathrm{cm}^{-1}$ in the humid-temperate forest.

\subsubsection{Relating $P$ speciation to $P$ mobilizing processes}

Based on the outcomes of the PCA (Figure 2.5-1) and the expected site-specific relations between P speciation and LMWOAs, phosphatase kinetics $\left(\mathrm{V}_{\max }, \mathrm{K}_{\mathrm{m}}\right)$, and MBC (Figure 2.5-2, Figure 2.5-3 and Table S 2.5-8), a RDA was calculated for each of the sites separately (Figure 2.5-4). P species were taken as explanatory variables and LMWOAs, MBC, acid phosphatase activity $\left(\mathrm{V}_{\max }\right)$, and acid phosphatase half saturation constant $\left(\mathrm{K}_{\mathrm{m}}\right)$ as explained variables. The explanatory variables constrain $75 \%, 67 \%$, and $80 \%$ of the variance for the arid shrubland, the Mediterranean woodland, and the humid-temperate forest, respectively.

In the arid shrubland, variscite and hydroxyapatite were highly correlated with LMWOA contents. Hydroxyapatite shows values of $\cos (\alpha)=0.99,0.98,0.92$ for oxalic, malic, and citric acid, respectively. Variscite shows values of $\cos (\alpha)=0.99,1.00,1.00$, for oxalic, malic, and citric acid, respectively (Table S 2.5-6). Variscite and hydroxyapatite together accounted for $61 \%, 66 \%$, and $82 \%$ of total P content in the arid shrubland's topsoil, subsoil and saprolite, respectively. Biotic parameters $\mathrm{V}_{\max }, \mathrm{K}_{\mathrm{m}}$, and $\mathrm{MBC}$ were mainly independent of $\mathrm{P}$ speciation under arid shrubland.

In the Mediterranean woodland soils $\mathrm{V}_{\max }, \mathrm{K}_{\mathrm{m}}, \mathrm{MBC}$, and oxalic acid showed the strongest positive correlation with $\mathrm{P}_{\mathrm{o}}$ and $\mathrm{P}$ sorbed to goethite. The correlation parameter $\cos (\alpha)$ was 0.92 , 1.0, 0.96, 0.96, for Po and 0.59, 0.88, 0.97, 0.97 for P sorbed to goethite, each for MBC, $\mathrm{V}_{\max }, \mathrm{K}_{\mathrm{m}}$, and oxalic acid, respectively, (Table S 2.5-6). $\mathrm{P}_{\mathrm{o}}$ was mostly found in the topsoil and was absent in the subsoil at this site (Table S 2.5-7). In the Mediterranean woodland subsoil and saprolite hydroxyapatite, variscite and short-range order Fe-P together made up at least $70 \%$ of total $\mathrm{P}$ in each root distance (Table S 2.5-7). Malic and citric acid were highly to moderately correlated with variscite and short-range order Fe-P $(\cos (\alpha)=0.93$, and 0.62 for variscite and 0.98 , and 0.75 for short-range order Fe-P, each for malic- and citric acid, respectively; Figure 2.5-4 and Table S 2.5-6). 


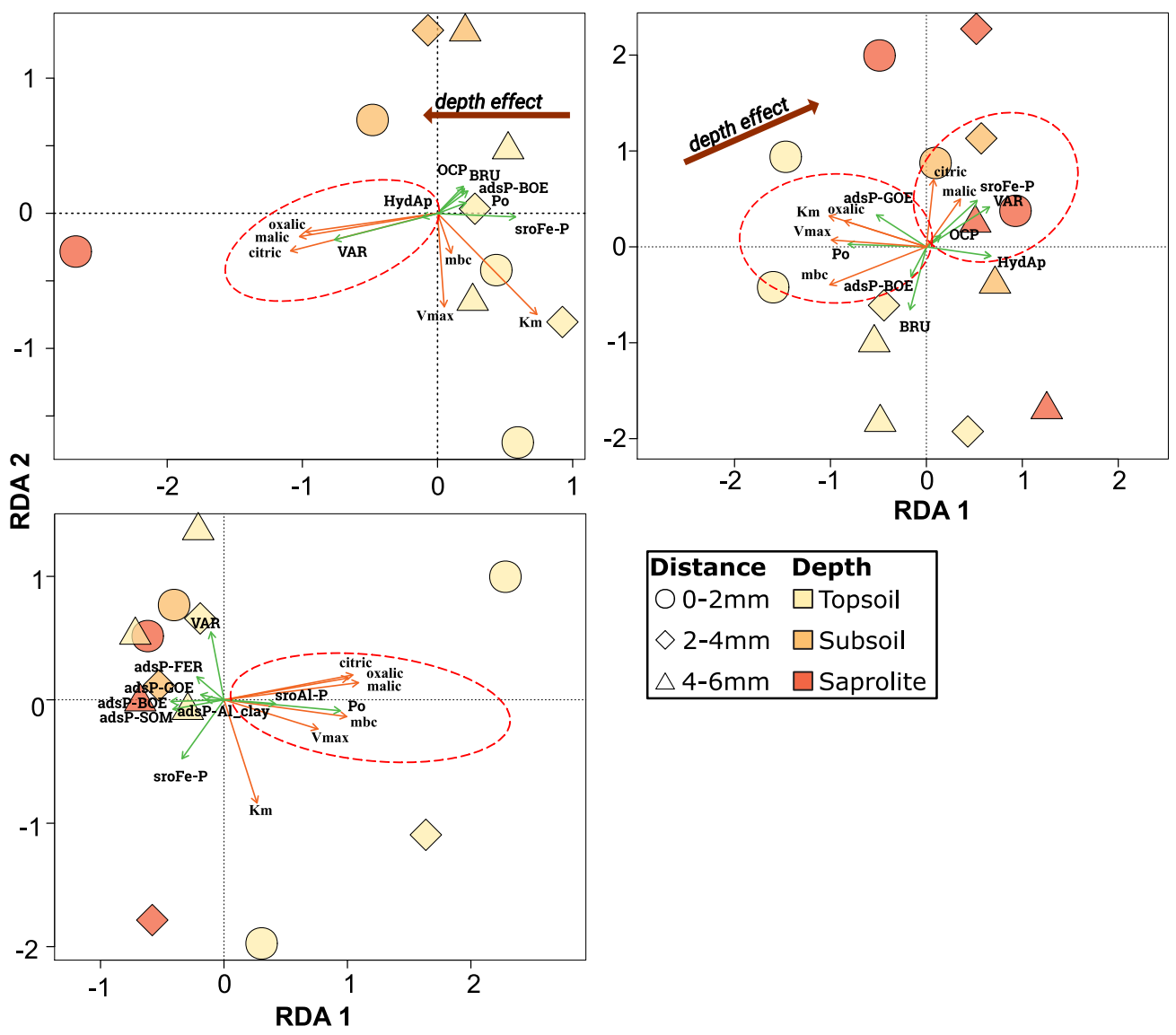

Figure 2.5-4: Triplots of the redundancy analysis (RDA) for the arid shrubland, Mediterranean woodland, and humid-temperate forest ecosystems. With P species as explanatory variables and microbial biomass carbon, lowmolecular-weight organic acids, phosphatase activity and-affinity as explained variables. Green arrows indicate direction of the respective explaining variables, orange arrows of explained variables. The name of the respective variable is plotted at each arrowhead. Samples from all three sampling depths (topsoil = light yellow; subsoil $=$ orange; saprolite $=$ red) and root proximities (intervals of $2 \mathrm{~mm}: 0-2 \mathrm{~mm}=$ circles, $2-4 \mathrm{~mm}=$ diamonds and 4-6 mm = triangles) were included in the RDA. Red dotted ellipsoids were included to guide the reader to the main messages of the respective figure, which are discussed in the text. The bold arrows in the subfigure of the arid shrubland and the Mediterranean woodland ecosystem point out the effect of soil depth on the outcome of the RDA.

The RDA for the humid-temperate forest soils revealed a strong (except for $\mathrm{Km}$ ) positive correlation of all dependent variables with $\mathrm{P}_{\mathrm{o}}(\cos (\alpha)=0.96,0.98,0.96,1.00,0.98,0.39$, for oxalic, malic-, citric acid, $\mathrm{MBC}, \mathrm{V}_{\max }$, and $\mathrm{K}_{\mathrm{m}}$, respectively; Figure 2.5-4, Table S 2.5-6). $\mathrm{P}_{\mathrm{o}}$ represents on average $51 \%$ of the total $\mathrm{P}$ in the topsoil and $17 \%$ in the saprolite. LMWOAs, MBC, and $\mathrm{V}_{\max }$ were strongly positively correlated with $\mathrm{P}_{\mathrm{o}}$. All explained variables showed moderate to strong negative correlations with all other $\mathrm{P}$ species in the humid-temperate forest ecosystem (Figure 2.5-4 and Table S 2.5-6, Table S 2.5-7, and Table S 2.5-8).

\subsubsection{Discussion}

Mature ecosystems are characterized by well-established nutrient cycles, i.e. each atom of a certain nutrient is used by the vegetation multiple times, thereby passing through various nutrient pools (Chadwick et al., 1999; Lang et al., 2017). As the focus of this study was on plant P acquisition and recycling strategies along an ecosequence, we first explored specifics and common features 
of $\mathrm{P}$ speciation and LMWOAs in the soils of the study sites, i.e. the arid shrubland, the Mediterranean woodland, and the humid-temperate forest ecosystem, by performing a PCA (Figure 2.5-1). The PCA confirmed a clear separation of the soils from the most arid and most humid ecosystems in terms of $\mathrm{P}$ speciation. If LMWOA contents were included, the separation of the humid-temperate forest and the Mediterranean woodland ecosystems improved. The samples were ordered by soil depth along PC 2. The overall variance accounted for by the PCA remained constant but was more evenly distributed between the two axes. Thus, we conclude that LMWOAs represent an ecosystem specific variable interaction with $\mathrm{P}$ speciation, which points toward a systematic dependency of LMWOAs on P minerals in the respective ecosystems. Along the ecosequence (arid to humid), the vegetation-community changes from shrub to tree dominated, at the same time the belowground carbon allocation and leaf area index incease (Bernhard et al., 2018). The PCA (including both P speciation and LMWOAs) clearly separated top- from subsoils in the humid-temperate forest and the Mediterranean woodland, indicating that $\mathrm{P}$ mobilization mechanisms are different the various soil layers. Although it is likely that all plants possess the ability to exudate LMWOAs, it can be speculated that soil regions with low $\mathrm{P}$ availability provide an ecological niche for species with an exceptionally high ability to exudate LMWOAs.

\subsubsection{The arid shrubland ecosystem}

The most important finding for the arid ecosystem is the strong dependence of LMWOA contents on hydroxyapatite and variscite in the subsoil and saprolite. This clearly suggests a mechanistic relation between primary $\mathrm{P}$ (hydroxyapatite), which is still available in high amounts, secondary Al-P, and LMWOAs of biotic origin (Figure 2.5-4). Therefore, the arid shrubland is considered to be a rock eating ecosystem. Contents of LMWOAs always increased in root proximity, except for citric acid in the topsoils of the arid shrubland (Figure 2.5-2). This results from the fact that the roots exude these acids, which is in accordance with many other studies (e.g. Cieśliński et al., 1998; Hinsinger, 2001; Szmigielska et al., 1996). However, biotic activity in these soils is rather low, which can be explained by the low vegetation cover (30-40\%) (Table 2.5-1) (Bernhard et al., 2018 b) leading to low microbial biomass in the soils of the arid ecosystem (Table S 2.5-8).

Ecosystems with low and seasonally variable water availability are characterized by vegetation that produces nutrient-poor litter which is resistant to decomposition (Becker and Kuzyakov, 2018; Makkonen et al., 2012). As expected, the pool of organically bound P in these soils was small (Figure 2.5-3). Abiotic processes involved in the dissolution of $\mathrm{P}$ minerals are strongly influenced by the availability of water and, thus, limited under arid shrubland (Maher, 2010). However, the high hydroxyapatite (Table S 2.5-7) contents in the arid shrubland ecosystem compared to the two other sites indicates that not only the net primary productivity and vegetation cover, but also the 
overall weathering is generally low. Additionally, enzymatic activity (Stock et al., 2019) and MBC are also low, suggesting that all biotic processes occur at a low rate. Biota-driven mineral dissolution processes include the exudation of organic anions and the release of protons (Banfield et al., 1999; Drever and Stillings, 1997; Neaman et al., 2006; Plassard et al., 2011), but only occur in root proximity, where plants can partially control the microenvironmental conditions, e.g. by maintaining a moist soil via mucilage exudation (Carminati and Vetterlein, 2013; Kroener et al., 2018). Therefore, it is likely that plants growing under such conditions have to acquire most of their mineral nutrients, through biochemical weathering, from the subsoil and saprolite where $\mathrm{P}$ minerals are still abundant.

In contrast to the subsoil and saprolite, the RDA does not resolve which processes are involved in the topsoil at this site. Despite of low enzymatic activities it cannot be excluded that organic $\mathrm{P}$ plays a certain role in the topsoil. Low contents of organic P could also be an indication for strong utilization, i.e. rapid turnover, or mineralization of these compounds.

\subsubsection{Humid-temperate forest ecosystem}

In this site, the weathering of granodioritic parent material is most advanced compared to the two northern ecosystems. This is reflected by the absence of hydroxyapatite and other Ca-phosphates (Figure 2.5-3 and Table S 2.5-7). Brucker and Spohn (2019), who investigated the same ecosequence, reported lowest apatite contents, and highest contents of secondary P minerals in the soils of the humid-temperate forest. Rhizosphere P per root segment was lowest in the top- and subsoils of this ecosystem (Table S 2.5-5) compared to the two northern ecosystems. This demonstrates the general pattern of decreasing $\mathrm{P}$ contents with increasing precipitation and, thus, soil development (Hou et al., 2018; Turner et al., 2018; Walker and Syers, 1976). This interpretation is supported by the fact that the rhizosphere $\mathrm{P}$ per root segment in the saprolite of the humid-temperate forest is highest among the three ecosystems, suggesting that this depletion is not due to a lower $\mathrm{P}$ content in the parent material, but indeed results from the processes that take place during ecosystem and soil development.

As shown by Stock et al. (2019), phosphatase kinetics indicate the highest relevance of breakdown of organic compounds (recycling) for P nutrition in the humid-temperate forest compared to the two other ecosystems. The RDA supports these previous results and, most importantly, implies that LMWOAs in the humid-temperate forest serve to support plant $\mathrm{P}_{\mathrm{o}}$ mobilization, so we refer to the humid temperate forest as a vegetarian ecosystem. Thus, ther function of LMWOA is, in contrast to the arid shrubland, neither the weathering nor the mobilization of hydroxyapatite or variscite (Figure 2.5-4). Alternatively, increased $\mathrm{P}_{\mathrm{o}}$ in root proximity of this ecosystem's topsoil reflects the accumulation of $\mathrm{P}_{\mathrm{o}}$ around roots, likely from a thriving microbial community (Figure 
2.5-2 for $\mathrm{P}_{\mathrm{o}}$ and Table S 2.5-8 for MBC contents) induced by high root exudation rates. Therefore, it is reasonable to assume that more frequent recycling occurs within the topsoil of the humidtemperate forests. However, even if a tight $\mathrm{P}$ cycle is established, there will still be leaching and erosional losses that have to be replenished by $\mathrm{P}$ acquisition from mineral sources (Uhlig et al., 2017).

$\mathrm{P}$ losses due to leaching affect, not only inorganic $\mathrm{P}$ in the soil solution, but also dissolved inorganic and organic $\mathrm{P}$ species. This results from the increase in the breaking up of organic $\mathrm{P}$ and the leaching of dissolved inorganic $\mathrm{P}$ and particulate organic or inorganic $\mathrm{P}$ species transported in the soil pore system after heavy rainfall (Bol et al., 2016). Finer grain sizes in the humid-temperate forest compared to the two other sites (Bernhard et al., 2018b) are a factor that may contribute to reduced P losses e.g. by leaching or particulate transport (Hou et al., 2018; Sims et al., 1998). This is because they have a higher specific surface area, which provides sorption sites for $\mathrm{P}$ in the soil. Moreover, from $\mathrm{P}$ adsorption experiments (data not shown) it is clear the $\mathrm{P}$ availability in this site is lowest along the ecosequence. On the other hand, MAP is more than three times higher compared to the Mediterranean woodland. MAP is a strong driver of abiotic $\mathrm{P}$ weathering and is negatively correlated with primary $\mathrm{P}$ and plant available $\mathrm{P}$. This is also shown for primary $\mathrm{P}$ in this study and for plant available P in Bernhard et al. (2018a). On the contrary, increased MAP enhances primary production and thus the $\mathrm{C}$ availability in soils, which is positively correlated with organic $\mathrm{P}$ accumulation.

Higher $\mathrm{C}$ availability results in microbial growth and $\mathrm{P}$ uptake and consequently organic $\mathrm{P}$ accumulation in soils and enhanced $\mathrm{P}$ flux through the soil solution. In general soil $\mathrm{pH}$ is negatively correlated with the solubility of Ca-phosphates and the degradation of organic $\mathrm{P}$, whereas it is positively correlated with the formation of secondary P minerals (Hou et al., 2018). The positive effect on secondary $\mathrm{P}$ minerals originates from decreasing solubility of $\mathrm{Fe}$ and $\mathrm{Al}$ with decreasing $\mathrm{pH}$. In this study, the $\mathrm{pH}$ in topsoils dropped from 6.4 in the arid shrubland to 5.5 in the Mediterranean woodland and 4.3 in the humid-temperate forest (Table 2.5-1). P sorbed to Al(oxy)hydroxides was in all three sampling depths lower in the arid shrubland or the Mediterranean woodland compared to the humid-temperate forest (Figure 2.5-3, Table 2.5-3 (for absolute values), Table S 2.5-14 for $\mathrm{p}$ values). Consequently, it seems that a high flux of $\mathrm{P}$ through the soil solution, due to elevated $\mathrm{C}$ availability and related biological activity, in concert with stabilizing conditions for $\mathrm{Al}$ and $\mathrm{Fe}-(\mathrm{oxy})$ hydoxides, caused by a low $\mathrm{pH}$, enhances $\mathrm{P}$ sorption to Al-(oxy)hydroxides. Because rhizosphere P per root segment in the topsoil of the humid-temperate forest is low, it seems likely that the elevated $\mathrm{P}$ flux in combination with high water availability in soil also causes high P leaching losses despite a high sorption capacity. 
As indicated by lower plant available $\mathrm{P}$ in the humid-temperate forest compared to the two other sites (Bernhard et al., 2018a) the sorption seems to be rather strong and only a small proportion of the sorbed $\mathrm{P}$ can be expected to contribute to plant nutrition under these circumstances. A strategy to overcome P limitation due to leaching losses is biological uplift (Gao et al., 2019). As shown by the RDA (Figure 2.5-4) in the humid-temperate forest, primary $\mathrm{P}$ acquisition happens in the deep subsoil and saprolite. This interpretation is supported by the fact that LMWOA contents per MBC ratios (Table S 2.5-8) increased with soil depth (this was true in all ecosystems), indicating an intended higher exudation of acids deeper in the soil profile to gain access to this $\mathrm{P}$ source (Table S 2.5-8).

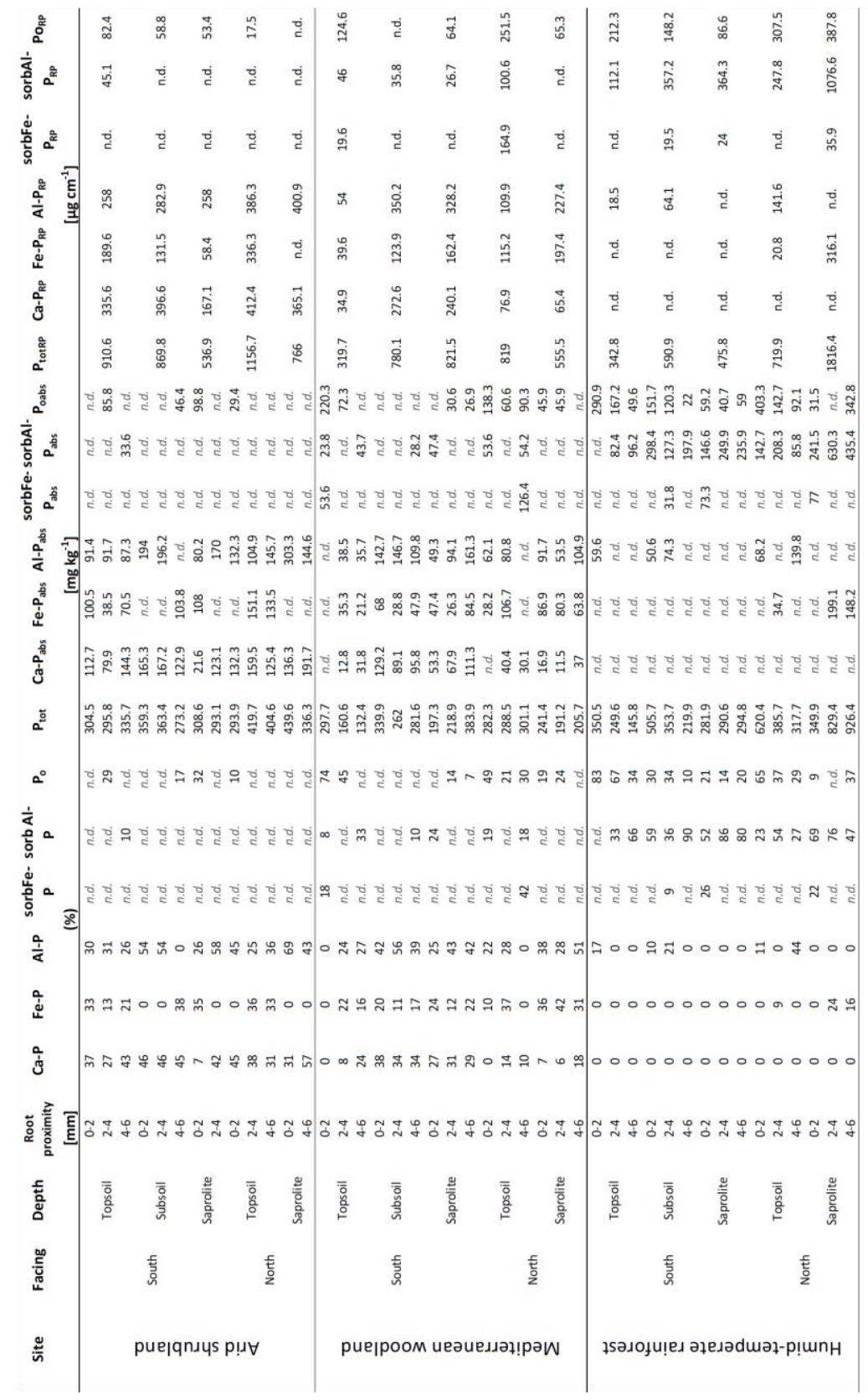

Table 2.5-3: Six P pools as a sum of single standards from linear combination fitting (LCF) are shown. Values from the LCF are given in percent of total $P(\mathrm{Ca}-\mathrm{P}=$ calcium phosphates, Al-P = Al-phosphates, sorb Al-P = orthophosphate sorbed to Al-(oxy)hydroxides, $\mathrm{Fe}-\mathrm{P}=\mathrm{Fe}$ phosphates, sorb $F e-P=$ orthophosphates sorbed to $\mathrm{Fe}$ (oxy)hydroxides, $P o=$ organically bound $P$ ). The LCF was restricted to a maximum of four standards per sample. If a P pools was not detected in a sample this is indicated by 'n.d.' (not determined). Absolute values of $P$ species were calculated by multiplying the share of a P pool with total $P\left(P_{t o t}\right)$ $\left(\mathrm{Ca}-\mathrm{P}_{\text {tot }}=\right.$ calcium phosphates, Al$P_{\text {tot }}=A l$ - phosphates, sorb Al$P_{\text {tot }}=$ orthophosphate sorbed to Al(oxy)hydroxides, $\quad \mathrm{Fe}-\mathrm{P}_{\text {tot }}=\mathrm{Fe}$ phosphates, sorb $\mathrm{Fe}$ $P_{\text {tot }}=$ orthophosphates sorbed to $\mathrm{Fe}$ (oxy)hydroxides, $\quad P o_{\text {tot }}=$ organically bound P). Rhizosphere $P$ per root segment was calculated as total $P$ content in a cylinder around root with a length of $1 \mathrm{~cm}$ and a radius of $6 \mathrm{~mm}$, the inner diameter was set to $2 \mathrm{~mm}$ (average root thickness (Ca$P_{R P}=$ calcium phosphates, Al$P_{R P}=$ Al-phosphates, sorb Al$P_{R P}=$ orthophosphate sorbed to $A L$ (oxy)hydroxides, $\quad \mathrm{Fe}-\mathrm{P}_{R P}=\mathrm{Fe}$ phosphates, sorb $\mathrm{Fe}$ $P_{R P}=$ orthophosphates sorbed to $\mathrm{Fe}$ (oxy)hydroxides, $\quad P_{R P}=$ organically bound phosphor). 


\subsubsection{Mediterranean woodland ecosystem}

The vegetation in the Mediterranean woodland ecosystems is generally adapted to seasonal rainfall and longer droughts (Amigo Vázquez and Flores Toro, 2013; Nardini et al., 2014). Plants reduce water loss through transpiration during these dry and mostly hot periods by producing sclerophylloud leaves (Nardini et al., 2014). Litterfall is higher than in the arid shrubland, leaving a bigger pool of organically bound nutrients to be cycled within the Mediterranean woodland ecosystem (Figure 2.5-2). The PCA results support the theoretical assumption that this ecosystem is in an intermediate state between the two endmembers of the studied ecosequence (Figure 2.5-1), which were discussed in the previous paragraphs. This theory is verified by the RDA, which identifies recycling of $\mathrm{P}$ in the topsoil and biochemical weathering of secondary $\mathrm{P}$ minerals in the subsoil (Figure 2.5-4). The RDA also provides indications about several underlying processes. Phosphatase kinetics $\left(\mathrm{V}_{\max }, \mathrm{K}_{\mathrm{m}}\right), \mathrm{MBC}$, oxalic acid (explained variables), and $\mathrm{P}_{\mathrm{o}}$ (explaining variable) have high values in samples from topsoil and root proximity. The clear correlation between $\mathrm{P}_{\mathrm{o}}$ and the explained variables $\mathrm{V}_{\max }, \mathrm{K}_{\mathrm{m}}, \mathrm{MBC}$, and oxalic acids verifies that $\mathrm{P}$ recycling is the main process in the topsoil, and it is driven by roots. Surprisingly, in contradiction to Wei et al. (2010), it also implies that oxalic acid in the topsoil of this ecosystem is involved in the recycling of organic $\mathrm{P}$. In contrast, biochemical weathering of short-range order Fe-P (sroFe-P) and variscite (VAR) in the subsoil and saprolite is mediated by malic and citric acid as biotic drivers (Figure 2.5-4, inferred from the strong correlation between these variables). We found a weak correlation, however, of malic and citric acid with hydroxyapatite, which all showed high contents in samples from the subsoil and saprolite in the Mediterranean woodland. It is, therefore, reasonable to assume that chemical weathering also contributes to mineral dissolution in this ecosystem. Hence, $\mathrm{P}$ dynamics in this ecosystem might be controlled by biological uplift of $\mathrm{P}$ (Bullen and Chadwick, 2015; Gao et al., 2019) from subsoil horizons and recycling of these nutrients once they entered the biological cycle. It has been shown that deep-rooting plants can act as nutrient pumps, that lift up nutrients from the subsoil, subsequently accumulating in the topsoil as organically bound nutrients, once undergone transformation within plants (Bullen and Chadwick, 2015; Gao et al., 2019; Wu et al., 2019). Nutrient uplift is driven by plants demand and mediated via roots.

Soil erosion rates in the Mediterranean woodland were highest among all sites (Schaller et al., 2018; van Dongen et al., 2019), which leads to a rapid removal of the upper soil layer. This may explain why intense recycling only occurs in the upper soil layer. This is because with high erosion only a shallow soil horizon with organic $\mathrm{P}$ accumulation remains. However, it is unclear to what extend $\mathrm{P}$ is lost from the system by erosion and runoff, but they are most likely not identical 
between the two investigated slopes (north- and south-facing). At the north-facing slope, total rhizosphere P per root segment decreased with depth $\left(819 \mu \mathrm{g} \mathrm{cm}^{-1}\right.$ in the topsoil and $556 \mu \mathrm{g} \mathrm{cm}^{-1}$ in the saprolite), whereas at the south-facing slope it increased from $320 \mu \mathrm{g} \mathrm{cm}^{-1}$ in the topsoil to $822 \mu \mathrm{g} \mathrm{cm}^{-1}$ in the saprolite (Table 2.5-3). The higher content of sand at the south-facing soil (>70\%), combined with a MAP of about $370 \mathrm{~mm} \mathrm{yr}^{-1}$ (Table 2.5-1) likely facilitates the leaching and erosion of plant available P from the soil on the south-facing slope. Hou et al. (2018) have shown that coarse grain sizes and high MAP are key factors determining P losses.

\subsubsection{Conclusion}

This study shows that $\mathrm{P}$ acquisition and cycling along the investigated ecosequence strongly depend on climate. It contributes to resolve plant strategies of P nutrition under natural conditions. Low-molecular-weight organic acids (LMWOAs) exuded by roots induce not only biochemical weathering of phosphate minerals, but also support organic phosphorus mobilization under field conditions. The functions of LMWOAs change along the ecosequence - with increasing precipitation. Under arid shrubland oxalic, malic, and citric acid support the dissolution of phosphorus minerals, whereas under Mediterranean woodland malic and citric acid support biochemical weathering in the subsoil and oxalic acid mobilizes organic phosphorus in the topsoil. Under humid-temperate forest, all LMWOAs support the mobilization of organic phosphorus in the topsoil. As a result, phosphorus dynamics across biomes vary strongly and show a shift of the phosphorus acquisition strategy along the ecosequence with increasing precipitation from $70 \mathrm{~mm} \mathrm{yr}^{-1}$ to $1470 \mathrm{~mm} \mathrm{yr}^{-1}$.

In the soils under arid shrubland, phosphorus cycling is actively driven by biochemical weathering of parent material (rock eating ecosystem). In the soils under humid-temperate forest, however, there was no direct evidence for biochemical weathering but intensive phosphorus recycling (vegetarian ecosystem). Phosphorus losses in the Mediterranean woodland are likely to be very high and the need for phosphorus creates an incentive for a strong phosphorus supply from (biological) weathering in the subsoil, while at the same time organic phosphorus is recycled in the topsoil.

\subsubsection{Acknowledgement}

We thank the Chilean National Park Service Corporación Nacional Forestal (CONAF) for granting permission to work in the National parks Nahuelbuta and La Campana. We also thank the Center for Advanced Research in Arid Zones (CEAZA) for the opportunity to work in the Nacional Reserve Santa Gracia. We express gratitude to the team of Beamline 8 at the Synchrotron Light Research Institute Nakhon Ratchasima. Without their help in setting up the beamline we would 
not have been able to produce high quality spectra. Further we thank Karin Schmid for her help with laboratory analysis.

\subsubsection{Funding}

This study was funded by the German Research Foundation (DFG) within the frame of the priority program 1803, EarthShape: Earth surface shaping by biota (DFG SPP 1803; project number 255469939) under the subproject „Fire-Induced Redistribution and Losses of Elements in the Weathering Zone“ (DFG DI 2136/11)

\subsubsection{Conflict of interest}

The authors have no conflict of interest to declare, the research was conducted in the absence of any commercial or financial relationships that could be construed as a potential conflict of interest.

\subsubsection{References}

Amigo Vázquez, F.J., Flores Toro, L., 2013. A new contribution to the syntaxonomy of the sclerophyllous forests and pre-forests of Central Chile: the Lithraeion causticae alliance. International Journal of Geobotanical Research 3 (1), $47-67$.

Amrhein, V., Greenland, S., McShane, B., 2019. Scientists rise up against statistical significance. Nature 567 (7748), $305-307$.

Anderson, T.-H., Martens, R., 2013. DNA determinations during growth of soil microbial biomasses. Soil Biology and Biochemistry 57, 487-495.

Banfield, J.F., Barker, W.W., Welch, S.A., Taunton, A., 1999. Biological impact on mineral dissolution: application of the lichen model to understanding mineral weathering in the rhizosphere. Proceedings of the National Academy of Sciences 96 (7), 3404-3411.

Becker, J.N., Kuzyakov, Y., 2018. Teatime on Mount Kilimanjaro: Assessing climate and land-use effects on litter decomposition and stabilization using the Tea Bag Index. Land Degrad Dev 29 (8), 2321-2329.

Bernhard, N., Moskwa, L.-M., Schmidt, K., Oeser, R.A., Aburto, F., Bader, M.Y., Baumann, K., Blanckenburg, F. von, Boy, J., van den Brink, L., Brucker, E., Büdel, B., Canessa, R., Dippold, M.A., Ehlers, T.A., Fuentes, J.P., Godoy, R., Jung, P., Karsten, U., Köster, M., Kuzyakov, Y., Leinweber, P., Neidhardt, H., Matus, F., Mueller, C.W., Oelmann, Y., Oses, R., Osses, P., Paulino, L., Samolov, E., Schaller, M., Schmid, M., Spielvogel, S., Spohn, M., Stock, S., Stroncik, N., Tielbörger, K., Übernickel, K., Scholten, T., Seguel, O., Wagner, D., Kühn, P., 2018a. Data supplement to "Pedogenic and microbial interrelations to regional climate and local topography: New insights from a climate gradient (arid to humid) along the Coastal Cordillera of Chile".

Bernhard, N., Moskwa, L.-M., Schmidt, K., Oeser, R.A., Aburto, F., Bader, M.Y., Baumann, K., Blanckenburg, F. von, Boy, J., van den Brink, L., Brucker, E., Büdel, B., Canessa, R., Dippold, M.A., Ehlers, T.A., Fuentes, J.P., Godoy, R., Jung, P., Karsten, U., Köster, M., Kuzyakov, Y., Leinweber, P., Neidhardt, H., Matus, F., Mueller, C.W., Oelmann, Y., Oses, R., Osses, P., Paulino, L., Samolov, E., Schaller, M., Schmid, M., Spielvogel, S., Spohn, M., Stock, S., Stroncik, N., Tielbörger, K., Übernickel, K., Scholten, T., Seguel, O., Wagner, D., Kühn, P., 2018b. Pedogenic and microbial interrelations to regional climate and local topography: New insights from a climate gradient (arid to humid) along the Coastal Cordillera of Chile. CATENA 170, 335-355.

Bol, R., Julich, D., Brödlin, D., Siemens, J., Kaiser, K., Dippold, M.A., Spielvogel, S., Zilla, T., Mewes, D., Blanckenburg, F. von, Puhlmann, H., Holzmann, S., Weiler, M., Amelung, W., Lang, F., Kuzyakov, Y., Feger, K.-H., Gottselig, N., Klumpp, E., Missong, A., Winkelmann, C., Uhlig, D., Sohrt, J., Wilpert, K. von, Wu, B., Hagedorn, F., 2016. Dissolved and colloidal phosphorus fluxes in forest ecosystems-an almost blind spot in ecosystem research. J. Plant Nutr. Soil Sci. 179 (4), 425-438.

Brucker, E., Spohn, M., 2019. Formation of soil phosphorus fractions along a climate and vegetation gradient in the Coastal Cordillera of Chile. CATENA 180, 203-211.

Bullen, T., Chadwick, O., 2015. Evidence for Nutrient Biolifting in Hawaiian Climosequence Soils as Revealed by Alkaline Earth Metal Stable Isotope Systematics. Procedia Earth and Planetary Science 13, 312-315.

Carminati, A., Vetterlein, D., 2013. Plasticity of rhizosphere hydraulic properties as a key for efficient utilization of scarce resources. Ann Bot 112 (2), 277-290.

Chadwick, O.A., Derry, L.A., Vitousek, P.M., Huebert, B.J., Hedin, L.O., 1999. Changing sources of nutrients during four million years of ecosystem development. Nature 397 (6719), 491-497. 
Chapin, F.S., 2003. Effects of plant traits on ecosystem and regional processes: a conceptual framework for predicting the consequences of global change. Annals of botany 91 (4), 455-463.

Cieśliński, G., van Rees, K.C.J., Szmigielska, A.M., Krishnamurti, G.S.R., Huang, P.M., 1998. Low-molecular-weight organic acids in rhizosphere soils of durum wheat and their effect on cadmium bioaccumulation. Plant and soil 203 (1), 109-117.

Dechassa, N., Schenk, M.K., 2004. Exudation of organic anions by roots of cabbage, carrot, and potato as influenced by environmental factors and plant age. J. Plant Nutr. Soil Sci. 167 (5), 623-629.

Drever, J.I., 1994. The effect of land plants on weathering rates of silicate minerals. Geochimica et Cosmochimica Acta 58 (10), $2325-2332$.

Drever, J.I., Stillings, L.L., 1997. The role of organic acids in mineral weathering. Colloids and Surfaces A: Physicochemical and Engineering Aspects 120 (1-3), 167-181.

Feng, J., Turner, B.L., Lü, X., Chen, Z., Wei, K., Tian, J., Wang, C., Luo, W., Chen, L., 2016. Phosphorus transformations along a large-scale climosequence in arid and semiarid grasslands of northern China. Global Biogeochem. Cycles 30 (9), 12641275.

Fick, S.E., Hijmans, R.J., 2017. WorldClim 2: new 1-km spatial resolution climate surfaces for global land areas. Int. J. Climatol 37 (12), 4302-4315.

Gao, X.-L., Li, X.G., Zhao, L., Kuzyakov, Y., 2019. Regulation of soil phosphorus cycling in grasslands by shrubs. Soil Biology and Biochemistry 133, 1-11.

Gaume, A., Mächler, F., León, C. de, Narro, L., Frossard, E., 2001. Low-P tolerance by maize (Zea mays L.) genotypes: Significance of root growth, and organic acids and acid phosphatase root exudation. Plant and soil 228 (2), 253-264.

Gerke, J., Beißner, L., Römer, W., 2000. The quantitative effect of chemical phosphate mobilization by carboxylate anions on P uptake by a single root. I. The basic concept and determination of soil parameters. J. Plant Nutr. Soil Sci. 163 (2), 207212.

Giles, C.D., Hsu, P.-C., Richardson, A.E., Hurst, M.R.H., Hill, J.E., 2014. Plant assimilation of phosphorus from an insoluble organic form is improved by addition of an organic anion producing Pseudomonas sp. Soil Biology and Biochemistry 68, 263-269.

Gustafsson, J.P., Braun, S., Tuyishime, J.R.M., Adediran, G.A., Warrinnier, R., Hesterberg, D., 2020. A Probabilistic Approach to Phosphorus Speciation of Soils Using P K-edge XANES Spectroscopy with Linear Combination Fitting. Soil Syst. 4 (2), 26.

Hedley, M.J., White, R.E., Nye, P.H., 1982. Plant-Indced Changes in the Rhizosphere of Rape (Brassica napus Var. Emerald) Seedlings. III . Changes in L Value, Soil Phosphate Fractions and Phosphatase Activity. New Phytol 91, 45-56.

Hinsinger, P., 2001. Bioavailability of soil inorganic P in the rhizosphere as affected by root-induced chemical changes: a review. Plant and soil 237 (2), 173-195.

Hou, E., Chen, C., Luo, Y., Zhou, G., Kuang, Y., Zhang, Y., Heenan, M., Lu, X., Wen, D., 2018. Effects of climate on soil phosphorus cycle and availability in natural terrestrial ecosystems. Global change biology 24 (8), 3344-3356.

Ippolito, J.A., Blecker, S.W., Freeman, C.L., McCulley, R.L., Blair, J.M., Kelly, E.F., 2010. Phosphorus biogeochemistry across a precipitation gradient in grasslands of central North America. Journal of Arid Environments 74 (8), 954-961.

Johnson, S.E., Loeppert, R.H., 2006. Role of Organic Acids in Phosphate Mobilization from Iron Oxide. Soil Science Society of America Journal 70 (1), 222-234.

Jones, D.L., 1998. Organic acids in the rhizosphere - A critical review. Plant Soil 205, 25-44.

Jones, D.L., Darrah, P.R., 1994. Role of root derived organic acids in the mobilization of nutrients from the rhizosphere. Plant Soil 166 (2), 247-257.

Kirk, G., Santos, E., Findenegg, G., 1999. Phosphate solubilization by organic anion excretion from rice (Oryza sativa L.) growing in aerobic soil. Plant Soil 211, 11-18.

Kirkby, E.A., Johnston, A.E., 2008. SOIL AND FERTILIZER PHOSPHORUS IN RELATION TO CROP NUTRITION, in: Hammond, J.P., White, P.J. (Eds.), The Ecophysiology of Plant-Phosphorus Interactions, vol. 7. Springer, Dordrecht, pp. 177-223.

Klysubun, W., Sombunchoo, P., Deenan, W., Kongmark, C., 2012. Performance and status of beamline BL8 at SLRI for X-ray absorption spectroscopy. Journal of synchrotron radiation 19 (6), 930-936.

König, N., Blum, U., Symossek, F., Bussian, B., Furtmann, K., Gärtner, A., Groeticke, K., Gutwasser, F., Höhle, J., Hauenstein, M., Kiesling, G., Klingenberg, U., Klinger, T., Nack, T., Stahn, M., Trefz-Malcher, G., Wies, K., 2014. Handbuch Forstliche Analytik.

Kroener, E., Holz, M., Zarebanadkouki, M., Ahmed, M., Carminati, A., 2018. Effects of Mucilage on Rhizosphere Hydraulic Functions Depend on Soil Particle Size. Vadose Zone Journal 17 (1), 170056.

Kuzyakov, Y., Razavi, B.S., 2019. Rhizosphere size and shape: Temporal dynamics and spatial stationarity. Soil Biology and Biochemistry 135, 343-360.

Lambers, H., Raven, J.A., Shaver, G.R., Smith, S.E., 2008. Plant nutrient-acquisition strategies change with soil age. Trends in ecology \& evolution 23 (2), 95-103.

Lan, M., Comerford, N.B., Fox, T.R., 1995. Organic Anions' Effect on Phosphorus Release from Spodic Horizons. Soil Science Society of America Journal 59 (6), 1745-1749. 
Lang, F., Krüger, J., Amelung, W., Willbold, S., Frossard, E., Bünemann, E.K., Bauhus, J., Nitschke, R., Kandeler, E., Marhan, S., Schulz, S., Bergkemper, F., Schloter, M., Luster, J., Guggisberg, F., Kaiser, K., Mikutta, R., Guggenberger, G., Polle, A., Pena, R., Prietzel, J., Rodionov, A., Talkner, U., Meesenburg, H., Wilpert, K. von, Hölscher, A., Dietrich, H.P., Chmara, I., 2017. Soil phosphorus supply controls P nutrition strategies of beech forest ecosystems in Central Europe. Biogeochemistry 136 (1), 5-29.

Lenth, R.V., 2016. Least-Squares Means: The R Package lsmeans, Journal of Statistical Software.

Lipton, D.S., Blanchar, R.W., Blevins, D.G., 1987. Citrate, Malate, and Succinate Concentration in Exudates from P-Sufficient and P-Stressed Medicago sativa L. Seedlings. Plant physiology 85 (2), 315-317.

López-Arredondo, D.L., Leyva-González, M.A., González-Morales, S.I., López-Bucio, J., Herrera-Estrella, L., 2014. Phosphate nutrition: improving low-phosphate tolerance in crops. Annual review of plant biology 65, 95-123.

Ma, X., Mason-Jones, K., Liu, Y., Blagodatskaya, E., Kuzyakov, Y., Guber, A., Dippold, M.A., Razavi, B.S., 2019. Coupling zymography with $\mathrm{pH}$ mapping reveals a shift in lupine phosphorus acquisition strategy driven by cluster roots. Soil Biology and Biochemistry 135, 420-428.

Maher, K., 2010. The dependence of chemical weathering rates on fluid residence time. Earth and Planetary Science Letters 294 (1-2), 101-110.

Makkonen, M., Berg, M.P., Handa, I.T., Hättenschwiler, S., van Ruijven, J., van Bodegom, P.M., Aerts, R., 2012. Highly consistent effects of plant litter identity and functional traits on decomposition across a latitudinal gradient. Ecology letters 15 (9), 1033-1041.

Nardini, A., Lo Gullo, M.A., Trifilò, P., Salleo, S., 2014. The challenge of the Mediterranean climate to plant hydraulics: Responses and adaptations. Environmental and Experimental Botany 103, 68-79.

Neaman, A., Chorover, J., Brantley, S.L., 2006. Effects of organic ligands on granite dissolution in batch experiments at pH 6. American Journal of Science 306 (6), 451-473.

Niinemets, Ü., 2001. Global-scale climatic controls of leaf dry mass per area, density, and thickness in trees and shrubs. Ecology $82,453-469$.

Odum, E.P., 1969. The strategy of ecosystem development. Science (New York, N.Y.) 164 (3877), 262-270.

Oeser, R.A., Blanckenburg, F. von, 2020. Decoupling silicate weathering from primary productivity \&\#8211; how ecosystems regulate nutrient uptake along a climate and vegetation gradient.

Oeser, R.A., Stroncik, N., Moskwa, L.-M., Bernhard, N., Schaller, M., Canessa, R., van den Brink, L., Köster, M., Brucker, E., Stock, S., Fuentes, J.P., Godoy, R., Matus, F.J., Oses Pedraza, R., Osses McIntyre, P., Paulino, L., Seguel, O., Bader, M.Y., Boy, J., Dippold, M.A., Ehlers, T.A., Kühn, P., Kuzyakov, Y., Leinweber, P., Scholten, T., Spielvogel, S., Spohn, M., Übernickel, K., Tielbörger, K., Wagner, D., Blanckenburg, F. von, 2018. Chemistry and microbiology of the Critical Zone along a steep climate and vegetation gradient in the Chilean Coastal Cordillera. CATENA 170, 183-203.

Oksanen, J., Blanchet,, F.G., Friendly, M., Kindt, R., Legendre, P., McGlinn, D., Minchin, P.R., O'Hara, R.B., Simpson, G.L., Solymos, P., Stevens, M.H.H., Szoecs, E., Wagner, H., 2018. vegan: Community Ecology Package.

Pinheiro Junior, C.R., Pereira, M.G., Fontana, A., Luz, L.R.Q.P.d., Corrêa Neto, T.d.A., 2019. Pedogenesis in a topo-climosequence in the Agreste region of Pernambuco. REVISTA CIÊNCIA AGRONÔMICA 50 (2).

Plassard, C., Louche, J., Ali, M.A., Duchemin, M., Legname, E., Cloutier-Hurteau, B., 2011. Diversity in phosphorus mobilisation and uptake in ectomycorrhizal fungi. Annals of Forest Science 68 (1), 33-43.

Prietzel, J., Harrington, G., Häusler, W., Heister, K., Werner, F., Klysubun, W., 2016. Reference spectra of important adsorbed organic and inorganic phosphate binding forms for soil $\mathrm{P}$ speciation using synchrotron-based K-edge XANES spectroscopy. Journal of synchrotron radiation 23 (2), 532-544.

R Core Team, 2017. R: A Language and Environment for Statistical Computing. R Foundation for Statistical Computing, Vienna, Austria.

Ravel, B., Newville, M., 2005. ATHENA, ARTEMIS, HEPHAESTUS: data analysis for X-ray absorption spectroscopy using IFEFFIT (eng).

Ryan, P.R., Delhaize, E., Jones, D.L., 2001. FUNCTION AND MECHANISM OF ORGANIC ANION EXUDATION FROM PLANT ROOTS. Annual Review of Plant Physiology and Plant Molecular Biology 52, 527-560.

Schaller, M., Ehlers, T.A., Lang, K.A.H., Schmid, M., Fuentes-Espoz, J.P., 2018. Addressing the contribution of climate and vegetation cover on hillslope denudation, Chilean Coastal Cordillera $\left(26^{\circ}-38^{\circ} \mathrm{S}\right)$. Earth and Planetary Science Letters 489, 111-122.

Sims, J.T., Simard, R.R., Joern, B.C., 1998. Phosphorus Loss in Agricultural Drainage: Historical Perspective and Current Research. Journal of Environment Quality 27 (2), 277-293.

Stock, S.C., Köster, M., Dippold, M.A., Nájera, F., Matus, F., Merino, C., Boy, J., Spielvogel, S., Gorbushina, A., Kuzyakov, Y., 2019. Environmental drivers and stoichiometric constraints on enzyme activities in soils from rhizosphere to continental scale. Geoderma 337, 973-982.

Szmigielska, A.M., Van Rees, K. C. J., Cieslinski, G., Huang, P.M., 1997. Comparison of liquid and gas chromatography for analysis of low molecular weight organic acids in rhizosphere soil. Communications in Soil Science and Plant Analysis 28 (1-2), 99-111.

Szmigielska, A.M., Van Rees, Ken C. J., Cieslinski, G., Huang, P.M., 1996. Low Molecular Weight Dicarboxylic Acids in Rhizosphere Soil of Durum Wheat. J. Agric. Food Chem. 44 (4), 1036-1040. 
Trabucco, A., Zomer, R., 2019. Global Aridity Index and Potential Evapotranspiration (ET0) Climate Database v2. Figshare. doi:10.6084/M9.FIGSHARE.7504448.V3.

Turner, B.L., Hayes, P.E., Laliberté, E., 2018. A climosequence of chronosequences in southwestern Australia. Eur J Soil Sci 69 (1), 69-85.

Uhlig, D., Schuessler, J.A., Bouchez, J., Dixon, J.L., Blanckenburg, F. von, 2017. Quantifying nutrient uptake as driver of rock weathering in forest ecosystems by magnesium stable isotopes. Biogeosciences 14 (12), 3111-3128.

van Dongen, R., Scherler, D., Wittmann, H., Blanckenburg, F. von, 2019. Cosmogenic 10 Be in river sediment: where grain size matters and why. Earth Surf. Dynam. 7 (2), 393-410.

Walker, T.W., Syers, J.K., 1976. The fate of phosphorus during pedogenesis. Geoderma 15 (1), 1-19.

Wei, L., Chen, C., Xu, Z., 2010. Citric acid enhances the mobilization of organic phosphorus in subtropical and tropical forest soils. Biol Fertil Soils 46 (7), 765-769.

Werner, C., Schmid, M., Ehlers, T.A., Fuentes-Espoz, J.P., Steinkamp, J., Forrest, M., Liakka, J., Maldonado, A., Hickler, T., 2018. Effect of changing vegetation and precipitation on denudation - Part 1: Predicted vegetation composition and cover over the last 21 thousand years along the Coastal Cordillera of Chile. 2196632X 6 (4), 829-858.

Werner, F., 2017. LCF: Linear Combination Fitting: R package version.

Wickham, H., 2016. ggplot2: Elegant Graphics for Data Analysis.

Wu, H., Xiang, W., Chen, L., Ouyang, S., Xiao, W., Li, S., Forrester, D.I., Lei, P., Zeng, Y., Deng, X., Zeng, L., Kuzyakov, Y., 2019. Soil Phosphorus Bioavailability and Recycling Increased with Stand Age in Chinese Fir Plantations. Ecosystems 12, 5635.

Yang, X., Post, W.M., 2011. Phosphorus transformations as a function of pedogenesis: A synthesis of soil phosphorus data using Hedley fractionation method. Biogeosciences 8 (10), 2907-2916.

\subsubsection{Supplementary}

Table S 2.5-1: External standards included in the lowmolecular-weight organic acids method. Retention time with a capillary column DB-FFAP, $30 \mathrm{~m}, 0.25 \mathrm{~mm}$ diameter and a film thickness of $1 \mu \mathrm{m}$. For settings of the gas chromatograph contact the authors. The limit of detection was calculated as the amount of analyte in the smallest standard before derivatization.

\begin{tabular}{lll} 
Analyte & $\begin{array}{l}\text { Retention time } \\
{[\mathrm{min}]}\end{array}$ & $\begin{array}{l}\text { Limit of detection } \\
{[\mu \mathrm{g}]}\end{array}$ \\
\hline Oxalic acid & 6.6 & 5.5 \\
Malonic acid & 8.8 & 5.5 \\
Fumaric acid & 9.5 & 5.5 \\
Succinic acid & 10.6 & 5.5 \\
Maleic acid & 12.5 & 5.5 \\
Malic acid & 19.1 & 5.5 \\
Citric acid & 26.3 & 5.5
\end{tabular}

Table S 2.5-2: Total and constrained variance by the redundancy analysis (RDA). For the semiarid shrubland, Mediterranean woodland and humidtemperate forest.

\begin{tabular}{llll} 
Site & & Inertia & Proportion \\
\hline Arid shrubland & Total & 5.96 & 1.00 \\
& Constrained & 4.49 & 0.75 \\
Mediterranean & Unconstrained & 1.47 & 0.25 \\
woodland & Total & 6.20 & 1.00 \\
& Constrained & 4.16 & 0.67 \\
Humid- & Unconstrained & 2.04 & 0.33 \\
temperate & Total & 6.67 & 1.00 \\
forest & Constrained & 5.34 & 0.80 \\
& Unconstrained & 1.33 & 0.20 \\
\hline
\end{tabular}


Table S 2.5-3: Scores of predictor variables (loadings) on redundancy analysis (RDA) axes. The values are a measure for how much variance of the variable is represented by the respective axis. Results are shown for the arid shrubland, Mediterranean woodland and humid-temperate forest.

\begin{tabular}{llcccccc} 
Site & Variable & RDA1 & RDA2 & RDA3 & RDA4 & RDA5 & RDA6 \\
\hline Semiarid & HypAp & -0.11 & -0.03 & 0.17 & -0.07 & -0.51 & -0.13 \\
shrubland & BRU & 0.23 & 0.17 & 0.43 & -0.12 & 0.18 & 0.16 \\
& OCP & 0.19 & 0.20 & -0.26 & 0.24 & 0.23 & 0.02 \\
& VAR & -0.76 & -0.19 & -0.10 & -0.07 & -0.41 & -0.34 \\
& SroFeP & 0.58 & -0.02 & -0.04 & 0.51 & 0.55 & 0.21 \\
& adsP-BOE & 0.20 & 0.18 & -0.16 & 0.16 & -0.42 & 0.79 \\
Mediterranean & Po & 0.21 & 0.08 & 0.00 & -0.82 & 0.49 & 0.15 \\
woodland & HypAp & 0.65 & -0.09 & -0.43 & 0.33 & -0.17 & 0.24 \\
& BRU & -0.17 & -0.64 & 0.09 & -0.19 & -0.24 & -0.25 \\
& OCP & 0.14 & 0.11 & 0.14 & -0.28 & -0.20 & -0.67 \\
& VAR & 0.64 & 0.41 & -0.61 & 0.05 & 0.11 & -0.09 \\
& SroFeP & 0.51 & 0.47 & 0.19 & -0.37 & 0.57 & -0.08 \\
& adsP-BOE & -0.16 & -0.30 & -0.03 & 0.23 & 0.34 & -0.05 \\
Humid- & adsP-GOE & -0.51 & 0.33 & 0.43 & 0.24 & -0.56 & 0.29 \\
temperate & Po & -0.80 & 0.03 & 0.35 & 0.05 & -0.03 & 0.32 \\
& SrOAIP & 0.41 & -0.03 & 0.06 & 0.24 & -0.24 & 0.06 \\
& VAR & -0.11 & 0.55 & 0.22 & -0.27 & -0.38 & -0.58 \\
& SroFeP & -0.34 & -0.48 & 0.16 & 0.38 & 0.43 & -0.33 \\
& adsP-AI_clay & -0.15 & 0.00 & -0.68 & 0.14 & 0.12 & -0.30 \\
& adsP-BOE & -0.43 & -0.01 & 0.09 & 0.15 & 0.02 & -0.08 \\
& adsP-SOM & -0.41 & -0.08 & 0.35 & -0.18 & 0.20 & 0.70 \\
& adsP-FER & -0.22 & 0.19 & -0.31 & -0.03 & -0.32 & 0.60 \\
& adsP-GOE & -0.19 & 0.04 & -0.28 & 0.00 & -0.04 & -0.09 \\
& Po & 0.94 & -0.09 & 0.01 & -0.12 & -0.05 & -0.11
\end{tabular}

\begin{tabular}{|c|c|c|c|c|c|c|c|c|}
\hline Table S 2.5-4: Scores of & Site & Variable & RDA1 & RDA2 & RDA3 & RDA4 & RDA5 & RDA6 \\
\hline explained variables & Arid shrubland & Oxalic & -0.51 & -0.12 & 0.03 & -0.80 & 0.19 & 0.22 \\
\hline (loadings) on redundancy & & Malic & -0.53 & -0.15 & -0.22 & 0.06 & -0.59 & -0.54 \\
\hline analysis (RDA) axes. The & & Citric & -0.56 & -0.25 & -0.14 & 0.56 & 0.51 & 0.19 \\
\hline values are a measure for & & $\mathrm{MBC}$ & 0.05 & -0.26 & -0.35 & 0.07 & -0.52 & 0.73 \\
\hline how much variance of the & & $\mathrm{V}_{\max }$ & 0.03 & -0.62 & 0.77 & 0.08 & -0.16 & 0.02 \\
\hline variable is represented by & & $\mathrm{K}_{\mathrm{m}}$ & 0.38 & -0.67 & -0.47 & -0.17 & 0.26 & -0.29 \\
\hline the respective axis. Results & Mediterranean & Oxalic & -0.43 & 0.26 & -0.56 & 0.08 & 0.65 & 0.06 \\
\hline are shown for the arid & & Malic & 0.18 & 0.48 & 0.03 & 0.83 & -0.12 & -0.20 \\
\hline shrubland, Mediterranean & & Citric & 0.04 & 0.68 & 0.54 & -0.41 & 0.28 & -0.10 \\
\hline woodland and humid- & & $\mathrm{MBC}$ & -0.51 & -0.38 & 0.46 & 0.22 & 0.23 & -0.53 \\
\hline temperate forest. Please & & $\mathrm{V}_{\max }$ & -0.50 & 0.07 & 0.34 & 0.21 & -0.17 & 0.74 \\
\hline note that the values are & & $\mathrm{K}_{\mathrm{m}}$ & -0.51 & 0.31 & -0.27 & -0.23 & -0.64 & -0.33 \\
\hline represented in type I & Humid- & Oxalic & 0.45 & 0.19 & -0.29 & 0.01 & 0.67 & -0.48 \\
\hline scaltng, therefore, they do & $\begin{array}{l}\text { temperate } \\
\text { forest }\end{array}$ & Malic & 0.49 & 0.15 & 0.19 & 0.28 & -0.63 & -0.47 \\
\hline not allow to infer & & Citric & 0.47 & 0.22 & 0.06 & 0.48 & 0.14 & 0.69 \\
\hline explaining variables. For & & $\mathrm{MBC}$ & 0.45 & -0.15 & 0.55 & -0.67 & 0.09 & 0.14 \\
\hline the correlation between & & $V_{\max }$ & 0.34 & -0.26 & -0.75 & -0.33 & -0.32 & 0.21 \\
\hline explaining end explained & & $\mathrm{K}_{\mathrm{m}}$ & 0.12 & -0.90 & 0.11 & 0.37 & 0.15 & -0.10 \\
\hline
\end{tabular}
variables see Table $S 2.5$ 6. 
Table S 2.5-5: Standard deviation, explained variance per axis and cummulative explained variance from the redundancy analysis (RDA) for the arid shrubland, Mediterranean woodland and humid-temperate forest.

\begin{tabular}{|c|c|c|c|c|c|c|c|}
\hline Site & & RDA1 & RDA2 & RDA3 & RDA4 & RDA5 & RDA6 \\
\hline \multirow[t]{3}{*}{ Arid shrubland } & SD & 1.74 & 1.01 & 0.50 & 0.40 & 0.16 & 0.10 \\
\hline & Proportion & 0.67 & 0.23 & 0.06 & 0.04 & 0.01 & 0.00 \\
\hline & Cumulative & 0.67 & 0.90 & 0.96 & 0.99 & 1.00 & 1.00 \\
\hline \multirow{3}{*}{$\begin{array}{l}\text { Mediterranean } \\
\text { woodland }\end{array}$} & SD & 1.64 & 0.86 & 0.66 & 0.46 & 0.27 & 0.16 \\
\hline & Proportion & 0.64 & 0.18 & 0.10 & 0.05 & 0.02 & 0.01 \\
\hline & Cumulative & 0.64 & 0.82 & 0.93 & 0.98 & 0.99 & 1.00 \\
\hline \multirow{3}{*}{$\begin{array}{l}\text { Humid- } \\
\text { temperate } \\
\text { forest }\end{array}$} & SD & 1.96 & 0.82 & 0.65 & 0.58 & 0.22 & 0.10 \\
\hline & Proportion & 0.72 & 0.13 & 0.08 & 0.06 & 0.01 & 0.00 \\
\hline & Cumulative & 0.72 & 0.85 & 0.93 & 0.99 & 1.00 & 1.00 \\
\hline
\end{tabular}

Table S 2.5-6: Correlations between explaining and explained variables from the redundancy analysis expressed as the cosine of the angle between the arrows resulting from the loadings in Table S 2.5-3 and type II scaled loadings of explained variables $\left(90^{\circ}=\right.$ independent, $O^{\circ}=$ collinearity). Note that for the P species adsP-AlOH no values are reported. This is due to missing dependent variables for the two samples for which this $P$ species was found.

\begin{tabular}{|c|c|c|c|c|c|c|c|c|c|c|c|c|c|c|}
\hline Site & Variable & HydAp & ОСР & BRU & sroAl-P & VAR & sroFe-P & $\begin{array}{c}\text { adsP- } \\
\text { Al_clay }\end{array}$ & adsP-AlOH & $I$ adsP-BOE & adsP-SOM & I adsP-FER & adsP-GOE & Po \\
\hline \multirow{6}{*}{$\begin{array}{c}\text { Arid } \\
\text { shrubland }\end{array}$} & Oxalic & 0.99 & -0.8 & -0.9 & n.d. & 0.99 & -0.98 & n.d. & n.d. & -0.83 & n.d. & n.d. & n.d. & -1 \\
\hline & Malic & 1 & -0.8 & -0.9 & n.d. & 1 & -0.98 & n.d. & n.d. & -0.84 & n.d. & n.d. & n.d. & -1 \\
\hline & Citric & 1 & -0.9 & -0.9 & n.d. & 1 & -0.96 & n.d. & n.d. & -0.88 & n.d. & n.d. & n.d. & -1 \\
\hline & MBC & -0.09 & -0.5 & -0.3 & n.d. & -0.1 & 0.36 & n.d. & n.d. & -0.4 & n.d. & n.d. & n.d. & -0 \\
\hline & $\mathrm{V}_{\max }$ & 0.17 & -0.7 & -0.5 & n.d. & 0.18 & 0.11 & n.d. & n.d. & -0.62 & n.d. & n.d. & n.d. & -0.3 \\
\hline & $\mathrm{K}_{\mathrm{m}}$ & -0.51 & -0 & 0.14 & n.d. & -0.5 & 0.73 & n.d. & n.d. & 0.04 & n.d. & n.d. & n.d. & 0.4 \\
\hline \multirow{6}{*}{$\begin{array}{l}\text { Mediterrane } \\
\text { an } \\
\text { woodland }\end{array}$} & Oxalic & -0.99 & -0.6 & -0.1 & n.d. & -0.6 & -0.5 & n.d. & n.d. & 0.18 & n.d. & n.d. & 0.97 & 0.96 \\
\hline & Malic & 0.46 & 0.96 & -0.9 & n.d. & 0.93 & 0.98 & n.d. & n.d. & -0.99 & n.d. & n.d. & -0.05 & -0.6 \\
\hline & Citric & -0.03 & 0.71 & -1 & n.d. & 0.62 & 0.75 & n.d. & n.d. & -0.93 & n.d. & n.d. & 0.45 & -0.1 \\
\hline & $\mathrm{MBC}$ & -0.87 & -1 & 0.59 & n.d. & -1 & -0.93 & n.d. & n.d. & 0.76 & n.d. & n.d. & 0.59 & 0.92 \\
\hline & $\mathrm{V}_{\max }$ & -1 & -0.7 & 0.18 & n.d. & -0.8 & -0.69 & n.d. & n.d. & 0.4 & n.d. & n.d. & 0.88 & 1 \\
\hline & $\mathrm{K}_{\mathrm{m}}$ & -0.99 & -0.6 & -0.1 & n.d. & -0.6 & -0.5 & n.d. & n.d. & 0.18 & n.d. & n.d. & 0.97 & 0.96 \\
\hline \multirow{6}{*}{$\begin{array}{l}\text { Humid- } \\
\text { temperate } \\
\text { forest }\end{array}$} & Oxalic & n.d. & n.d. & n.d. & 0.97 & -0 & -0.71 & -0.98 & n.d. & -0.99 & -1 & -0.64 & -0.92 & 0.96 \\
\hline & Malic & n.d. & n.d. & n.d. & 0.98 & -0.1 & -0.68 & -0.99 & n.d. & -1 & -1 & -0.68 & -0.94 & 0.98 \\
\hline & Citric & n.d. & n.d. & n.d. & 0.96 & 0 & -0.72 & -0.98 & n.d. & -0.99 & -1 & -0.63 & -0.92 & 0.96 \\
\hline & $\mathrm{MBC}$ & n.d. & n.d. & n.d. & 1 & -0.3 & -0.46 & -0.99 & n.d. & -0.99 & -0.95 & -0.84 & -1 & 1 \\
\hline & $\mathrm{V}_{\max }$ & n.d. & n.d. & n.d. & 0.97 & -0.5 & -0.31 & -0.96 & n.d. & -0.95 & -0.89 & -0.92 & -1 & 0.98 \\
\hline & $\mathrm{K}_{\mathrm{m}}$ & n.d. & n.d. & n.d. & 0.37 & -1 & 0.6 & -0.31 & n.d. & -0.27 & -0.13 & -0.85 & -0.5 & 0.39 \\
\hline
\end{tabular}


Table S 2.5-7: P species results from the linear combination fitting (LCF) of phosphorus K-edge X-ray absorption near edge structure spectroscopy (XANES). The upper part shows the percentage of each species in total P. In the lower part of the table this is multiplied by the total P content in each sample and given as content per kg of soil [mg $\mathrm{kg}^{-1}$ ]. Data are subdivided by sampling sites (arid shrubland, Mediterranean woodland and humid-temperate forest), therein by sampling depth (topsoil, subsoil and saprolite) and in each depth by three distances to the root ( 0 $2 \mathrm{~mm}, 2-4 \mathrm{~mm}$, and 4-6 mm). The LCF was restricted to a maximum of four standards per sample. If a P pool was not detected in a sample this is indicated by n.d. (not determined).

\begin{tabular}{|c|c|c|c|c|c|c|c|c|c|c|}
\hline Site & Facing & Depth & $\begin{array}{l}\text { Root } \\
\text { proximity } \\
{[\mathrm{mm}]}\end{array}$ & HydAp & OCP & BRU & sroAl-P & & VAR & srofe-P \\
\hline & & & $0-2$ & n.d. & 30 & 7 & n.d. & & 30 & 33 \\
\hline & & Topsoil & $2-4$ & 27 & n.d. & n.d. & n.d. & & 31 & 13 \\
\hline & & & $4-6$ & 43 & n.d. & n.d. & n.d. & & 26 & 21 \\
\hline & South & & $0-2$ & 46 & n.d. & n.d. & n.d. & & 54 & n.d. \\
\hline ㅁ & Soutn & Subsoil & $2-4$ & 46 & n.d. & n.d. & n.d. & & 54 & n.d. \\
\hline$\frac{\mathrm{T}}{0.0}$ & & & $4-6$ & n.d. & 23 & 22 & n.d. & & n.d. & 38 \\
\hline ᄅ & & & $0-2$ & n.d. & 7 & n.d. & n.d. & & 26 & 35 \\
\hline$\frac{\bar{n}}{0}$ & & Saprolite & $4-6$ & 42 & n.d. & n.d. & n.d. & & 58 & n.d. \\
\hline 安 & & & $0-2$ & 34 & n.d. & 10 & n.d. & & 45 & n.d. \\
\hline & & Topsoil & $2-4$ & 38 & n.d. & n.d. & n.d. & & 25 & 36 \\
\hline & North & & $4-6$ & 31 & n.d. & n.d. & n.d. & & 36 & 33 \\
\hline & & & e-2 & 31 & n.d. & n.d. & n.d. & & 69 & n.d. \\
\hline & & Saprolite & $4-6$ & 57 & n.d. & n.d. & n.d. & & 43 & n.d. \\
\hline & & & $0-2$ & n.d. & n.d. & n.d. & n.d. & & n.d. & n.d. \\
\hline & & Topsoil & $2-4$ & 8 & n.d. & n.d. & n.d. & & 24 & 22 \\
\hline & & & $4-6$ & 24 & n.d. & n.d. & n.d. & & 27 & 16 \\
\hline & & & $0-2$ & 11 & 26 & n.d. & n.d. & & 42 & 20 \\
\hline 总 & South & Subsoil & $2-4$ & 34 & n.d. & n.d. & n.d. & & 56 & 11 \\
\hline 立 & & & $4-6$ & 34 & n.d. & n.d. & n.d. & & 39 & 17 \\
\hline o & & & $0-2$ & 27 & n.d. & n.d. & n.d. & & 25 & 24 \\
\hline 胥 & & Saprolite & e $2-4$ & 31 & n.d. & n.d. & n.d. & & 43 & 12 \\
\hline 施 & & & $4-6$ & 29 & n.d. & n.d. & n.d. & & 42 & 22 \\
\hline 比 & & & $0-2$ & n.d. & n.d. & n.d. & n.d. & & 22 & 10 \\
\hline 吾 & & Topsoil & $2-4$ & n.d. & 14 & n.d. & n.d. & & 28 & 37 \\
\hline & & & $4-6$ & n.d. & n.d. & 10 & n.d. & & n.d. & n.d. \\
\hline & Nortn & & $0-2$ & 7 & n.d. & n.d. & n.d. & & 38 & 36 \\
\hline & & Saprolite & e $2-4$ & n.d. & 6 & n.d. & n.d. & & 28 & 42 \\
\hline & & & $4-6$ & 18 & n.d. & n.d. & n.d. & & 51 & 31 \\
\hline & & & $0-2$ & n.d. & n.d. & n.d. & 17 & & n.d. & n.d. \\
\hline & & Topsoil & $2-4$ & n.d. & n.d. & n.d. & n.d. & & n.d. & n.d. \\
\hline & & & $4-6$ & n.d. & n.d. & n.d. & n.d. & & n.d. & n.d. \\
\hline & & & $0-2$ & n.d. & n.d. & n.d. & n.d. & & 10 & n.d. \\
\hline 苛 & South & Subsoil & $2-4$ & n.d. & n.d. & n.d. & 21 & & n.d. & n.d. \\
\hline$\frac{0}{\alpha}$ & & & $4-6$ & n.d. & n.d. & n.d. & n.d. & & n.d. & n.d. \\
\hline है & & & $0-2$ & n.d. & n.d. & n.d. & n.d. & & n.d. & n.d. \\
\hline పू & & Saprolite & e $2-4$ & n.d. & n.d. & n.d. & n.d. & & n.d. & n.d. \\
\hline E్ & & & 4-6 & n.d. & n.d. & n.d. & n.d. & & n.d. & n.d. \\
\hline$\frac{t}{0.0}$ & & & $0-2$ & n.d. & n.d. & n.d. & 11 & & n.d. & n.d. \\
\hline$\underline{\underline{\underline{T}}}$ & & Topsoil & $2-4$ & n.d. & n.d. & n.d. & n.d. & & n.d. & 9 \\
\hline & & & $4-6$ & n.d. & n.d. & n.d. & n.d. & & 44 & n.d. \\
\hline & North & & $0-2$ & n.d. & n.d. & n.d. & n.d. & & n.d. & n.d. \\
\hline & & Saprolite & e $2-4$ & n.d. & n.d. & n.d. & n.d. & & n.d. & 24 \\
\hline & & & $4-6$ & n.d. & n.d. & n.d. & n.d. & & n.d. & 16 \\
\hline Site & & Depth & $\begin{array}{l}\text { Root } \\
\text { proximity } \\
\text { [mm] }\end{array}$ & HydAp & OCP & BRU & sroAl-P & VAR & srofe-p & $\begin{array}{r}\text { adsP- } \\
\text { Al_clay } \\
{[\mathrm{m}} \\
\end{array}$ \\
\hline & & & $0-2$ & n.d. & 91.4 & 21.3 & n.d. & $\begin{array}{l}91.4 \\
\end{array}$ & 100.5 & n.d. \\
\hline & & Topsoil & $2-4$ & 79.9 & n.d. & n.d. & n.d. & 91.7 & 38.5 & n.d. \\
\hline & & & $4-6$ & 144.3 & n.d. & n.d. & n.d. & 87.3 & 70.5 & n.d. \\
\hline & & & $0-2$ & 165.3 & n.d. & n.d. & n.d. & 194 & n.d. & n.d. \\
\hline & South & Subsoil & $2-4$ & 167.2 & n.d. & n.d. & n.d. & 196.2 & n.d. & n.d. \\
\hline 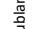 & & & $4-6$ & n.d. & 62.8 & 60.1 & n.d. & n.d. & 103.8 & n.d. \\
\hline 㐏 & & & $0-2$ & n.d. & 21.6 & n.d. & n.d. & 80.2 & 108 & n.d. \\
\hline 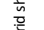 & & Saprolite & 4.6 & 123.1 & n.d. & n.d. & n.d. & 170 & n.d. & n.d. \\
\hline 娄 & & & $0-2$ & 99.9 & n.d. & 29.4 & n.d. & 132.3 & n.d. & n.d. \\
\hline & & Topsoil & $2-4$ & 159.5 & n.d. & n.d. & n.d. & 104.9 & 151.1 & n.d. \\
\hline & North & & $4-6$ & 125.4 & n.d. & n.d. & n.d. & 145.7 & 133.5 & n.d. \\
\hline & & & $0-2$ & 136.3 & n.d. & n.d. & n.d. & 303.3 & n.d. & n.d. \\
\hline & & Saprolite & $4-6$ & 191.7 & n.d. & n.d. & n.d. & 144.6 & n.d. & n.d. \\
\hline & & & $0-2$ & n.d. & n.d. & n.d. & n.d. & n.d. & n.d. & n.d. \\
\hline & & Topsoil & $2-4$ & 12.8 & n.d. & n.d. & n.d. & 38.5 & 35.3 & n.d. \\
\hline & & & $4-6$ & 31.8 & n.d. & n.d. & n.d. & 35.7 & 21.2 & n.d. \\
\hline & & & $0-2$ & 37.4 & 88.4 & n.d. & n.d. & 142.7 & 68 & n.d. \\
\hline & South & Subsoil & $2-4$ & 89.1 & n.d. & n.d. & n.d. & 146.7 & 28.8 & n.d. \\
\hline 흥 & & & $4-6$ & 95.8 & n.d. & n.d. & n.d. & 109.8 & 47.9 & n.d. \\
\hline 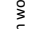 & & & $0-2$ & 53.3 & n.d. & n.d. & n.d. & 49.3 & 47.4 & n.d. \\
\hline 亳 & & Saprolite & $2-4$ & 67.9 & n.d. & n.d. & n.d. & 94.1 & 26.3 & n.d. \\
\hline 总 & & & $4-6$ & 111.3 & n.d. & n.d. & n.d. & 161.3 & 84.5 & n.d. \\
\hline 旁 & & & $0-2$ & n.d. & n.d. & n.d. & n.d. & 62.1 & 28.2 & n.d. \\
\hline$\frac{\bar{z}}{5}$ & & Topsoil & 2-4 & n.d. & 40.4 & n.d. & n.d. & 80.8 & 106.7 & n.d. \\
\hline & & & 4.6 & n.d. & n.d. & 30.1 & n.d. & n.d. & n.d. & n.d. \\
\hline & North & & $0-2$ & 16.9 & n.d. & n.d. & n.d. & 91.7 & 86.9 & n.d. \\
\hline & & Saprolite & $2-4$ & n.d. & 11.5 & n.d. & n.d. & 53.5 & 80.3 & n.d. \\
\hline & & & $4-6$ & 37 & n.d. & n.d. & n.d. & 104.9 & 63.8 & n.d. \\
\hline & & & $0-2$ & n.d. & n.d. & n.d. & 59.6 & n.d. & n.d. & n.d. \\
\hline & & Topsoil & $2-4$ & n.d. & n.d. & n.d. & n.d. & n.d. & n.d. & 82.4 \\
\hline & & & $4-6$ & n.d. & n.d. & n.d. & n.d. & n.d. & n.d. & n.d. \\
\hline & & & $0-2$ & n.d. & n.d. & n.d. & n.d. & 50.6 & n.d. & 126.4 \\
\hline & South & Subsoil & $2-4$ & n.d. & n.d. & n.d. & 74.3 & n.d. & n.d. & 127.3 \\
\hline$\frac{5}{0}$ & & & $4-6$ & n.d. & n.d. & n.d. & n.d. & n.d. & n.d. & 30.8 \\
\hline 总 & & & $0-2$ & n.d. & n.d. & n.d. & n.d. & n.d. & n.d. & 87.4 \\
\hline 离 & & Saprolite & 2-4 & n.d. & n.d. & n.d. & n.d. & n.d. & n.d. & 81.4 \\
\hline 䔍 & & & 4.6 & n.d. & n.d. & n.d. & n.d. & n.d. & n.d. & 159.2 \\
\hline 豈 & & & $0-2$ & n.d. & n.d. & n.d. & 68.2 & n.d. & n.d. & n.d. \\
\hline 疍 & & Topsoil & $2-4$ & n.d. & n.d. & n.d. & n.d. & n.d. & 34.7 & n.d. \\
\hline & North & & $4-6$ & n.d. & n.d. & n.d. & n.d. & 139.8 & n.d. & n.d. \\
\hline & North & & $0-2$ & n.d. & n.d. & n.d. & n.d. & n.d. & n.d. & 42 \\
\hline & & Saprolite & $2-4$ & n.d. & n.d. & n.d. & n.d. & n.d. & 199.1 & n.d. \\
\hline & & & $4-6$ & n.d. & n.d. & n.d. & n.d. & n.d. & 148.2 & 435.4 \\
\hline
\end{tabular}


Table S 2.5-8: Absolute contents of low-molecular-weight organic acids (LMWOA; oxalic-, malic-, citric-acid), MBC, $V_{\max }$ and $K_{m}$ values of acid phosphatase, and LMWOA contents normalized by MBC are shown in the table. Values are averaged over four soil pits in each site \pm the standard error. At North facing soil pits only topsoil and the saprolite were sampled. At South facing all three depths (topsoil, subsoil, saprolite) were sampled. In the saprolite of the arid shrubland only root distances 0-2 $\mathrm{mm}$ and 4-6 $\mathrm{mm}$ were sampled, in all other sites sampled root distances were 0$2 \mathrm{~mm}, 2-4 \mathrm{~mm}$, and 4-6 mm. If a value is missing this is indicated by 'n.d.' (not detected).

\begin{tabular}{|c|c|c|c|c|c|c|c|c|c|c|c|}
\hline Site & Depth & $\begin{array}{c}\text { Distance } \\
{[\mathrm{mm}]}\end{array}$ & Oxalic & 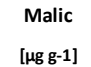 & Citric & MBC & Oxalic/MBC & $\begin{array}{c}\text { Malic/MBC } \\
{\left[\mathrm{ng} \mathrm{\mu g}^{-1}\right]}\end{array}$ & Citric/MBC & $\mathrm{V}_{\max }$ & $\mathrm{K}_{\mathrm{m}}$ \\
\hline \multirow{8}{*}{ 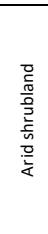 } & \multirow{4}{*}{ Topsoil } & $0-2$ & $5.6 \pm 1.8$ & $4.6 \pm 4.2$ & $1.1 \pm 0.8$ & $275.2 \pm 34.4$ & $22.9 \pm 8.8$ & $19.4 \pm 18$ & $4.4 \pm 3.3$ & $153.5 \pm 79.1$ & $4.3 \pm 1$ \\
\hline & & $2-4$ & $3.9 \pm 0.9$ & $1.4 \pm 1.1$ & $0.4 \pm 0.3$ & $207.6 \pm 32$ & $18.5 \pm 2.6$ & $6.2 \pm 4.4$ & $1.9 \pm 1.2$ & $94.2 \pm 31.2$ & $4.6 \pm 1.3$ \\
\hline & & $4-6$ & $4.2 \pm 0.7$ & $1.9 \pm 1.2$ & $1.2 \pm 0.5$ & $261.3 \pm 37.9$ & $16.8 \pm 3.2$ & $7.4 \pm 5$ & $5 \pm 1.7$ & $143.1 \pm 43.2$ & $4.4 \pm 0.3$ \\
\hline & & $0-2$ & $7.7 \pm 1.4$ & $5.8 \pm 2.3$ & $2.9 \pm 0.8$ & $278 \pm 36.2$ & $27.4 \pm 1.8$ & $19.6 \pm 7$ & $10.1 \pm 2$ & $104.8 \pm 14.1$ & $2.9 \pm 0.3$ \\
\hline & \multirow[t]{2}{*}{ Subsoil } & $2-4$ & $5.8 \pm 0.4$ & $2.8 \pm 1.2$ & $0.8 \pm 0.4$ & $142 \pm 25.1$ & $42.8 \pm 5.5$ & $22.4 \pm 9.4$ & $6.8 \pm 4$ & $103.9 \pm 26.9$ & $3.1 \pm 0.4$ \\
\hline & & $4-6$ & $3.8 \pm 0.3$ & $1.9 \pm 1.2$ & $1.2 \pm 0.9$ & $168.7 \pm 40.1$ & $25.3 \pm 6.6$ & $12.8 \pm 6.4$ & $7.5 \pm 4.3$ & $98.5 \pm 18$ & $2.7 \pm 0.4$ \\
\hline & \multirow{2}{*}{ Saprolite } & $0-2$ & $8.5 \pm 2.1$ & $12.2 \pm 5.4$ & $5.9 \pm 2$ & $164.5 \pm 40.7$ & $64.5 \pm 25$ & $105.2 \pm 64.1$ & $45.2 \pm 16.7$ & $93.4 \pm 3.6$ & $2.3 \pm 0.4$ \\
\hline & & $4-6$ & $3.3 \pm 1.1$ & $1.9 \pm 0.8$ & $0.8 \pm 0.3$ & $4.5 \pm 0.8$ & $818.4 \pm 277.3$ & $487.3 \pm 242.9$ & $178.2 \pm 70.6$ & n.d. & n.d. \\
\hline \multirow{9}{*}{ 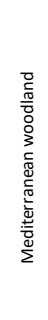 } & \multirow{3}{*}{ Topsoil } & $0-2$ & $24.7 \pm 2.5$ & $8.1 \pm 3$ & $8.5 \pm 3.4$ & $\begin{array}{c}1163.4 \pm 321 \\
4\end{array}$ & $31.3 \pm 13.4$ & $7.3 \pm 2.6$ & $7.2 \pm 2.4$ & $348.4 \pm 43.8$ & $7.1 \pm 0.6$ \\
\hline & & $2-4$ & $11.8 \pm 4.2$ & $6.1 \pm 3.8$ & $4.7 \pm 0.8$ & $817.4 \pm 207.1$ & $15.5 \pm 7.6$ & $10.1 \pm 7.2$ & $6.4 \pm 1.5$ & $233.9 \pm 41.8$ & $3.4 \pm 0.5$ \\
\hline & & $4-6$ & $11.4 \pm 1.3$ & $2.9 \pm 0.8$ & $3 \pm 1$ & $\begin{array}{c}1092.2 \pm 205 \\
1\end{array}$ & $11.5 \pm 2.1$ & $2.4 \pm 0.6$ & $2.5 \pm 0.7$ & $254.3 \pm 39.9$ & $4.1 \pm 0.3$ \\
\hline & \multirow{4}{*}{ Subsoil } & $0-2$ & $18.4 \pm 2.3$ & $6.6 \pm 2.2$ & $6.8 \pm 2.3$ & $250.3 \pm 91.8$ & $93 \pm 32.7$ & $38.1 \pm 20.5$ & $31 \pm 13.5$ & $164.8 \pm 20.1$ & $5.9 \pm 0.4$ \\
\hline & & $2-4$ & $10.5 \pm 3$ & $6.3 \pm 2.6$ & $3.5 \pm 1.6$ & $180.2 \pm 19.7$ & $63.7 \pm 25.2$ & $38.7 \pm 19.8$ & $21.3 \pm 11.1$ & $150.8 \pm 9.7$ & $5.3 \pm 0.9$ \\
\hline & & $4-6$ & $5.2 \pm 1.7$ & $3.8 \pm 1.2$ & $3.9 \pm 1.8$ & $143.9 \pm 22.2$ & $37.6 \pm 11.1$ & $29.3 \pm 12.1$ & $31.9 \pm 17.9$ & $121.2 \pm 16.9$ & $4.7 \pm 1.5$ \\
\hline & & $0-2$ & $15.5 \pm 5.6$ & $4.7 \pm 1.2$ & $8.1 \pm 4$ & $177.4 \pm 68.2$ & $96.4 \pm 25.9$ & $30.8 \pm 8.8$ & $39.6 \pm 17.2$ & $111 \pm 38.5$ & $10.4 \pm 5.6$ \\
\hline & \multirow[t]{2}{*}{ Saprolite } & $2-4$ & $6.3 \pm 1.5$ & $7.4 \pm 1.3$ & $8.4 \pm 6.9$ & $427.9 \pm 355.7$ & $71.4 \pm 36.3$ & $97.6 \pm 56.7$ & $65.1 \pm 63.7$ & $100.2 \pm 74.1$ & $2.4 \pm 0.9$ \\
\hline & & $4-6$ & $6.1 \pm 2.3$ & $2.3 \pm 0.9$ & $2.8 \pm 2.3$ & $70.3 \pm 43.6$ & $167.8 \pm 107.1$ & $67.6 \pm 47.6$ & $26.9 \pm 11.9$ & $55.8 \pm 38.9$ & $3.6 \pm 1.5$ \\
\hline \multirow{9}{*}{ 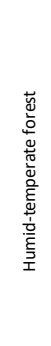 } & \multirow{3}{*}{ Topsoil } & $0-2$ & $42.4 \pm 15.1$ & $10.8 \pm 2.9$ & $19.5 \pm 8.2$ & $\begin{array}{c}2187.5 \pm 440 \\
8\end{array}$ & $20.4 \pm 6.6$ & $5.1 \pm 1.1$ & $9.7 \pm 4.1$ & $1277 \pm 506.4$ & $9.7 \pm 0.7$ \\
\hline & & $2-4$ & $39.3 \pm 11.8$ & $7.8 \pm 3$ & $12.5 \pm 5.7$ & $\begin{array}{c}1734.1 \pm 320 \\
6\end{array}$ & $21.8 \pm 4.9$ & $4 \pm 1.1$ & $6 \pm 2.2$ & $898.4 \pm 391.1$ & $3.6 \pm 0.8$ \\
\hline & & $4-6$ & $32.6 \pm 12.9$ & $9.3 \pm 4.6$ & $16.4 \pm 11.3$ & $\begin{array}{c}1073.9 \pm 484 \\
7\end{array}$ & $71.5 \pm 46.5$ & $20.3 \pm 14.4$ & $20.6 \pm 10.9$ & $\begin{array}{c}1030.3 \pm 489 \\
9\end{array}$ & $3.2 \pm 1.4$ \\
\hline & \multirow{3}{*}{ Subsoil } & $0-2$ & $11.4 \pm 2.8$ & $3.3 \pm 0.2$ & $3 \pm 1.5$ & $393.1 \pm 100.3$ & $30.1 \pm 3.7$ & $9.8 \pm 2.9$ & $8.9 \pm 4$ & $526.1 \pm 189.2$ & $2.4 \pm 0.1$ \\
\hline & & $2-4$ & $10 \pm 1.7$ & $0.9 \pm 0.7$ & $1.2 \pm 1$ & $251.1 \pm 68.9$ & $46.5 \pm 13$ & $2.6 \pm 1.8$ & $3.2 \pm 2.5$ & $627 \pm 291.1$ & $5.3 \pm 1.7$ \\
\hline & & $4-6$ & $6.7 \pm 1.6$ & $1.2 \pm 0.6$ & $1.4 \pm 1.1$ & $212.5 \pm 41.1$ & $40.5 \pm 14.4$ & $8.2 \pm 0.4$ & $1.7 \pm 0$ & $512.1 \pm 307.4$ & $3.5 \pm 0.2$ \\
\hline & \multirow{3}{*}{ Saprolite } & $0-2$ & $7.6 \pm 2$ & $3 \pm 2.5$ & $2.8 \pm 2.5$ & $161.5 \pm 51.1$ & $71.7 \pm 43.4$ & $49.8 \pm 45.8$ & $46.6 \pm 46.3$ & n.d. & n.d. \\
\hline & & $2-4$ & $3.9 \pm 0.9$ & $0.7 \pm 0.5$ & $1.1 \pm 0.8$ & $97.9 \pm 86.3$ & $266.8 \pm 243.6$ & $90.3 \pm 86.2$ & $148.3 \pm 147$ & n.d. & n.d. \\
\hline & & $4-6$ & $2.9 \pm 0.7$ & $1.3 \pm 0.8$ & $1.6 \pm 0.9$ & $437.5 \pm 431.4$ & $226.6 \pm 220.8$ & $146.1 \pm 142.4$ & $333.1 \pm 332.1$ & n.d. & n.d. \\
\hline
\end{tabular}


Table S 2.5-9: Parameters from a linear model examining the effect of distance from the roots on microbial biomass carbon (MBC), low-molecular-weight organic acids (oxalic, malic, citric), and phosphatase kinetics $\left(V_{\max }, K_{m}\right)$.

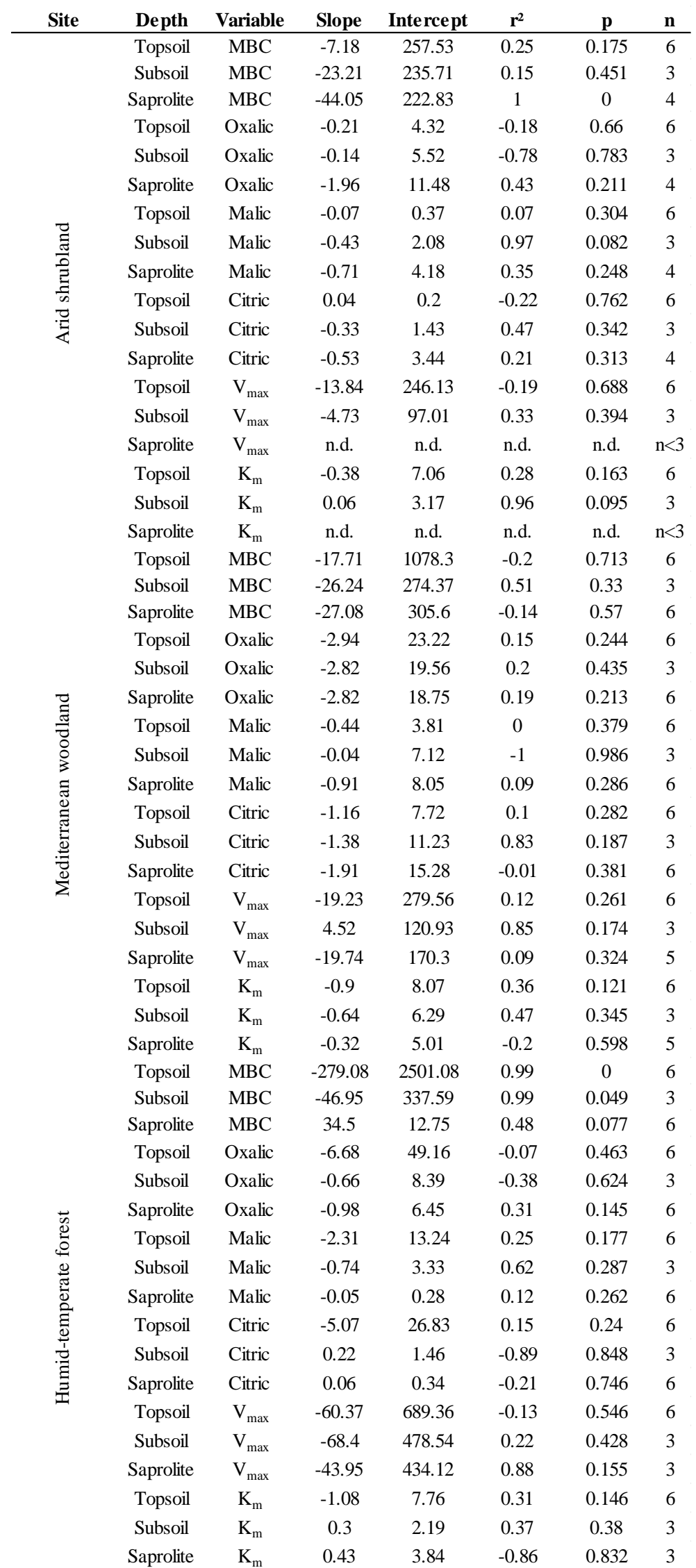


Table S 2.5-10: Parameters from a linear model examining the effect of distance from the roots on $P$ species $(C a-P$ = calcium phosphates, Al-P = Al-phosphates, sorb Al-P = orthophosphate sorbed to Al-(oxy)hydroxides, Fe-P = Fe-phosphates, sorb Fe-P = orthophosphates sorbed to Fe-(oxy)hydroxides, Po = organically bound P ).

\begin{tabular}{|c|c|c|c|c|c|c|c|}
\hline Site & Depth & Facing & Variable & Slope & Intercept & $r$ & p \\
\hline & Topsoil & North & $\mathrm{Ca}-\mathrm{P}$ & -0.04 & 0.49 & 1 & 0 \\
\hline & Topsoil & South & $\mathrm{Ca}-\mathrm{P}$ & 0.02 & 0.31 & -0.72 & 0.758 \\
\hline & Subsoil & South & $\mathrm{Ca}-\mathrm{P}$ & 0 & 0.46 & 0.5 & 0.333 \\
\hline & Saprolite & North & Ca-P & n.d. & n.d. & n.d. & n.d. \\
\hline & Saprolite & South & Ca-P & n.d. & n.d. & n.d. & n.d. \\
\hline & Topsoil & North & Fe-P & 0.08 & -0.02 & 0.36 & 0.381 \\
\hline & Topsoil & South & Fe-P & -0.03 & 0.31 & -0.29 & 0.593 \\
\hline & Subsoil & South & Fe-P & 0.1 & -0.16 & 0.5 & 0.333 \\
\hline & Saprolite & North & Fe-P & n.d. & n.d. & n.d. & n.d. \\
\hline & Saprolite & South & Fe-P & n.d. & n.d. & n.d. & n.d. \\
\hline & Topsoil & North & Al-P & -0.02 & 0.42 & -0.6 & 0.703 \\
\hline & Topsoil & South & Al-P & -0.01 & 0.32 & 0.14 & 0.454 \\
\hline & Subsoil & South & Al-P & -0.14 & 0.77 & 0.5 & 0.333 \\
\hline$\frac{\pi}{0}$ & Saprolite & North & Al-P & n.d. & n.d. & n.d. & n.d. \\
\hline ? & Saprolite & South & Al-P & n.d. & n.d. & n.d. & n.d. \\
\hline & Topsoil & North & sorbFe-P & n.d. & n.d. & n.d. & n.d. \\
\hline . & Topsoil & South & sorbFe-P & n.d. & n.d. & n.d. & n.d. \\
\hline & Subsoil & South & sorbFe-P & n.d. & n.d. & n.d. & n.d. \\
\hline & Saprolite & North & sorbFe-P & n.d. & n.d. & n.d. & n.d. \\
\hline & Saprolite & South & sorbFe-P & n.d. & n.d. & n.d. & n.d. \\
\hline & Topsoil & North & sorbAl-P & n.d. & n.d. & n.d. & n.d. \\
\hline & Topsoil & South & sorbAl-P & 0.03 & -0.04 & 0.5 & 0.333 \\
\hline & Subsoil & South & sorbAl-P & n.d. & n.d. & n.d. & n.d. \\
\hline & Saprolite & North & sorbAl-P & n.d. & n.d. & n.d. & n.d. \\
\hline & Saprolite & South & sorbAl-P & n.d. & n.d. & n.d. & n.d. \\
\hline & Topsoil & North & Po & -0.03 & 0.11 & 0.5 & 0.333 \\
\hline & Topsoil & South & Po & 0 & 0.1 & -1 & 1 \\
\hline & Subsoil & South & Po & 0.04 & -0.07 & 0.5 & 0.333 \\
\hline & Saprolite & North & Po & n.d. & n.d. & n.d. & n.d. \\
\hline & Saprolite & South & Po & n.d. & n.d. & n.d. & n.d. \\
\hline & Topsoil & North & $\mathrm{Ca}-\mathrm{P}$ & 0.03 & 0 & -0.04 & 0.512 \\
\hline & Topsoil & South & Ca-P & 0.06 & -0.07 & 0.93 & 0.121 \\
\hline & Subsoil & South & Ca-P & -0.01 & 0.38 & 0.5 & 0.333 \\
\hline & Saprolite & North & $\mathrm{Ca}-\mathrm{P}$ & 0.03 & 0.02 & 0.36 & 0.381 \\
\hline & Saprolite & South & Ca-P & 0 & 0.28 & -0.5 & 0.667 \\
\hline & Topsoil & North & Fe-P & -0.03 & 0.23 & -0.86 & 0.832 \\
\hline & Topsoil & South & Fe-P & 0.04 & 0.01 & -0.01 & 0.503 \\
\hline & Subsoil & South & $\mathrm{Fe}-\mathrm{P}$ & -0.01 & 0.18 & -0.79 & 0.788 \\
\hline & Saprolite & North & Fe-P & -0.01 & 0.4 & -0.59 & 0.7 \\
\hline & Saprolite & South & Fe-P & -0.01 & 0.21 & -0.95 & 0.901 \\
\hline$\Xi$ & Topsoil & North & Al-P & -0.06 & 0.33 & 0.11 & 0.464 \\
\hline$\stackrel{\frac{\pi}{z}}{z}$ & Topsoil & South & Al-P & 0.07 & -0.03 & 0.66 & 0.269 \\
\hline 8 & Subsoil & South & Al-P & -0.01 & 0.48 & -0.95 & 0.894 \\
\hline 3 & Saprolite & North & Al-P & 0.03 & 0.29 & -0.36 & 0.619 \\
\hline ₹ & Saprolite & South & Al-P & 0.04 & 0.24 & 0.41 & 0.365 \\
\hline$\cong$ & Topsoil & North & sorbFe-P & 0.11 & -0.18 & 0.5 & 0.333 \\
\hline 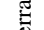 & Topsoil & South & sorbFe-P & -0.05 & 0.2 & 0.5 & 0.333 \\
\hline. $\bar{\Xi}$ & Subsoil & South & sorbFe-P & n.d. & n.d. & n.d. & n.d. \\
\hline$\overline{7}$ & Saprolite & North & sorbFe-P & n.d. & n.d. & n.d. & n.d. \\
\hline & Saprolite & South & sorbFe-P & n.d. & n.d. & n.d. & n.d. \\
\hline & Topsoil & North & sorbAl-P & 0 & 0.13 & -1 & 0.97 \\
\hline & Topsoil & South & sorbAl-P & 0.06 & -0.05 & 0.05 & 0.483 \\
\hline & Subsoil & South & sorbAl-P & 0.03 & -0.04 & 0.5 & 0.333 \\
\hline & Saprolite & North & sorbAl-P & n.d. & n.d. & n.d. & n.d. \\
\hline & Saprolite & South & sorbAl-P & -0.06 & 0.26 & 0.5 & 0.333 \\
\hline & Topsoil & North & Po & -0.05 & 0.48 & -0.12 & 0.537 \\
\hline & Topsoil & South & Po & -0.19 & 0.95 & 0.97 & 0.079 \\
\hline & Subsoil & South & Po & n.d. & n.d. & n.d. & n.d. \\
\hline & Saprolite & North & Po & -0.05 & 0.29 & 0.13 & 0.46 \\
\hline & Saprolite & South & Po & 0.02 & 0.02 & -0.5 & 0.667 \\
\hline & Topsoil & North & Ca-P & n.d. & n.d. & n.d. & n.d. \\
\hline & Topsoil & South & $\mathrm{Ca}-\mathrm{P}$ & n.d. & n.d. & n.d. & n.d. \\
\hline & Subsoil & South & $\mathrm{Ca}-\mathrm{P}$ & n.d. & n.d. & n.d. & n.d. \\
\hline & Saprolite & North & Ca-P & n.d. & n.d. & n.d. & n.d. \\
\hline & Saprolite & South & $\mathrm{Ca}-\mathrm{P}$ & n.d. & n.d. & n.d. & n.d. \\
\hline & Topsoil & North & Fe-P & 0 & 0.03 & -1 & 1 \\
\hline & Topsoil & South & Fe-P & n.d. & n.d. & n.d. & n.d. \\
\hline & Subsoil & South & Fe-P & n.d. & n.d. & n.d. & n.d. \\
\hline & Saprolite & North & $\mathrm{Fe}-\mathrm{P}$ & 0.04 & 0.01 & -0.14 & 0.546 \\
\hline & Saprolite & South & Fe-P & n.d. & n.d. & n.d. & n.d. \\
\hline & Topsoil & North & Al-P & 0.08 & -0.06 & 0.04 & 0.488 \\
\hline రั & Topsoil & South & Al-P & -0.04 & 0.18 & 0.5 & 0.333 \\
\hline & Subsoil & South & Al-P & -0.03 & 0.18 & -0.55 & 0.684 \\
\hline ت्ञ & Saprolite & North & Al-P & n.d. & n.d. & n.d. & n.d. \\
\hline$\overline{0}$ & Saprolite & South & Al-P & n.d. & n.d. & n.d. & n.d. \\
\hline$\vec{z}$ & Topsoil & North & sorbFe-P & n.d. & n.d. & n.d. & n.d. \\
\hline 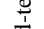 & Topsoil & South & sorbFe-P & n.d. & n.d. & n.d. & n.d. \\
\hline : & Subsoil & South & sorbFe-P & 0 & 0.03 & -1 & 1 \\
\hline$\Xi$ & Saprolite & North & sorbFe-P & -0.06 & 0.24 & 0.5 & 0.333 \\
\hline & Saprolite & South & sorbFe-P & -0.07 & 0.28 & 0.5 & 0.333 \\
\hline & Topsoil & North & sorbAl-P & 0.01 & 0.32 & -0.97 & 0.924 \\
\hline & Topsoil & South & sorbAl-P & 0.17 & -0.17 & 1 & 0 \\
\hline & Subsoil & South & sorbAl-P & 0.08 & 0.38 & -0.35 & 0.612 \\
\hline & Saprolite & North & sorbAl-P & -0.06 & 0.81 & 0.06 & 0.482 \\
\hline & Saprolite & South & sorbAl-P & 0.07 & 0.52 & 0.19 & 0.439 \\
\hline & Topsoil & North & Po & -0.09 & 0.71 & 0.81 & 0.198 \\
\hline & Topsoil & South & Po & -0.12 & 0.98 & 0.92 & 0.126 \\
\hline & Subsoil & South & Po & -0.05 & 0.4 & 0.21 & 0.433 \\
\hline & Saprolite & North & Po & 0.07 & -0.06 & 0.05 & 0.483 \\
\hline & Saprolite & South & Po & 0 & 0.19 & -0.97 & 0.916 \\
\hline
\end{tabular}


Table S 2.5-11: A generalized linear model (GLM) to examine the effect of soil depth on the parameters microbial biomass carbon $(M B C)$, oxalic-, malic-, and citric acid content, maximum reaction rate of acid phosphatase $\left(V_{\text {max }}\right)$, and half saturation constant of acid phosphatase $\left(K_{m}\right)$ was calculated per study site. Distance from the roots was set as a fixed effect, with random slopes and random intercept. The table shows the results of the post-hoc least square means (with "Tukey” correction) pairwise comparison ( $p$ values).

\begin{tabular}{lllll} 
Site & Variable & $\begin{array}{l}\text { Topsoil } \\
\text { Subsoil }\end{array}$ & $\begin{array}{l}\text { Topsoil } \\
\text { Saprolite }\end{array}$ & $\begin{array}{l}\text { Subsoil } \\
\text { Saprolite }\end{array}$ \\
\hline Arid shrubland & MBC & 0.266 & 0.001 & 0.268 \\
& Oxalic & 0.821 & 0.651 & 0.980 \\
& Malic & 0.768 & 0.059 & 0.404 \\
& Citric & 0.984 & 0.074 & 0.209 \\
& $\mathrm{~V}_{\max }$ & 0.192 & 0.585 & 0.989 \\
& $\mathrm{~K}_{\mathrm{m}}$ & 0.000 & 0.006 & 0.918 \\
Mediterranean & MBC & 0.000 & 0.000 & 0.961 \\
woodland & Oxalic & 0.854 & 0.691 & 0.990 \\
& Malic & 0.057 & 0.184 & 0.669 \\
& Citric & 0.764 & 0.242 & 0.812 \\
& $\mathrm{~V}_{\max }$ & 0.099 & 0.007 & 0.855 \\
& $\mathrm{~K}_{\mathrm{m}}$ & 0.773 & 0.546 & 0.977 \\
forest & MBC & 0.000 & 0.000 & 0.937 \\
& Oxalic & 0.265 & 0.081 & 0.979 \\
& Malic & 0.196 & 0.033 & 0.945 \\
& Citric & 0.396 & 0.151 & 0.974 \\
& $\mathrm{~V}_{\max }$ & 0.445 & 0.536 & 0.991 \\
& $\mathrm{~K}_{\mathrm{m}}$ & 0.726 & 0.946 & 0.617
\end{tabular}

Table S 2.5-12: A generalized linear model (GLM) to examine the effect of study site in each soil depth on the parameters microbial biomass carbon $(M B C)$, oxalic-, malic-, and citric acid content, maximum reaction rate of acid phosphatase $\left(V_{\max }\right)$, and half saturation constant of acid phosphatase $\left(K_{m}\right)$ was calculated. Distance from the roots was set as a fixed effect, with random slopes and random intercept. The table shows the results of the posthoc least square means (with "Tukey" correction) pairwise comparison (p values).

\begin{tabular}{|c|c|c|c|c|}
\hline Variable & Depth & $\begin{array}{l}\text { Humid- } \\
\text { temperate forest } \\
- \\
\text { Mediterranean } \\
\text { woodland }\end{array}$ & $\begin{array}{l}\text { Mediterranean } \\
\text { woodland } \\
\text { Arid shrubland }\end{array}$ & $\begin{array}{l}\text { Humid-temperate } \\
\text { forest } \\
\text { Arid shrubland }\end{array}$ \\
\hline $\mathrm{MBC}$ & Topsoil & 0.001 & 0.000 & 0.000 \\
\hline MBC & Subsoil & 1.000 & 0.875 & 0.866 \\
\hline MBC & Saprolite & 0.283 & 0.214 & 0.945 \\
\hline Oxalic & Topsoil & 0.379 & 0.598 & 0.056 \\
\hline Oxalic & Subsoil & 0.397 & 0.223 & 0.932 \\
\hline Oxalic & Saprolite & 0.137 & 0.465 & 0.859 \\
\hline Malic & Topsoil & 0.210 & 0.558 & 0.018 \\
\hline Malic & Subsoil & 0.009 & 0.005 & 0.988 \\
\hline Malic & Saprolite & 0.000 & 0.055 & 0.367 \\
\hline Citric & Topsoil & 0.372 & 0.753 & 0.098 \\
\hline Citric & Subsoil & 0.008 & 0.000 & 0.574 \\
\hline \multirow{2}{*}{$\begin{array}{l}\text { Citric } \\
V_{\max }\end{array}$} & Saprolite & 0.004 & 0.038 & 0.907 \\
\hline & Topsoil & 0.053 & 0.989 & 0.037 \\
\hline $\mathrm{V}_{\max }$ & Subsoil & 0.213 & 0.807 & 0.055 \\
\hline $\mathrm{V}_{\max }$ & Saprolite & 0.002 & 0.989 & 0.060 \\
\hline $\mathrm{K}_{\mathrm{m}}$ & Topsoil & 0.787 & 0.905 & 0.523 \\
\hline \multirow{2}{*}{$\begin{array}{l}\mathrm{K}_{\mathrm{m}} \\
\mathrm{K}_{\mathrm{m}}\end{array}$} & Subsoil & 0.224 & 0.396 & 0.933 \\
\hline & Saprolite & 0.828 & 0.912 & 0.728 \\
\hline
\end{tabular}


Table S 2.5-13: A generalized linear model (GLM) to examine the effect of soil depth on P compound classes (Ca-P = calcium phosphates, Al-P = Al-phosphates, sorb Al-P = orthophosphate sorbed to Al-(oxy)hydroxides, $F e-P=F e-$ phosphates, sorb Fe-P = orthophosphates sorbed to Fe-(oxy)hydroxides, $P o=$ organically bound $P$ ) was calculated per study site. Distance from the roots was set as a fixed effect, with random slopes and random intercept. The table shows the results of the post-hoc least square means (with "Tukey" correction) pairwise comparison ( $p$ values).

\begin{tabular}{lllll} 
Site & Variable & $\begin{array}{l}\text { Topsoil } \\
\text { Subsoil }\end{array}$ & $\begin{array}{l}\text { Topsoil - } \\
\text { Saprolite }\end{array}$ & $\begin{array}{l}\text { Subsoil - } \\
\text { Saprolite }\end{array}$ \\
\hline Arid shrubland & Ca-P & 0.574 & 0.575 & 0.138 \\
& Fe-P & 0.805 & 0.957 & 0.957 \\
& Al-P & 0.921 & 0.798 & 0.953 \\
& sorbFe-P & n.d. & n.d. & n.d. \\
& sorbAl-P & 0.503 & 0.577 & 1.000 \\
Mediterranean & Po & 0.949 & 0.900 & 0.757 \\
woodland & Ca-P & 0.000 & 0.006 & 0.535 \\
& Fe-P & 0.866 & 0.563 & 0.866 \\
& Al-P & 0.007 & 0.095 & 0.608 \\
& sorbFe-P & 0.438 & 0.438 & 1.000 \\
Humid- & sorbAl-P & 0.602 & 0.858 & 0.902 \\
temperate forest & Po & 0.068 & 0.161 & 0.919 \\
& Ca-P & n.d. & n.d. & n.d. \\
& Al-P & n.d. & n.d. & n.d. \\
& sorbFe-P & 0.770 & 0.681 & 0.279 \\
& sorbAl-P & 0.389 & 0.479 & 0.730 \\
& Po & 0.017 & 0.004 & 0.885
\end{tabular}

Table S 2.5-14: A generalized linear model (GLM) to examine the effect of study site in each soil depth on P compound classes $(\mathrm{Ca}-\mathrm{P}=$ calcium phosphates, Al-P = Al-phosphates, sorb Al-P = orthophosphate sorbed to Al(oxy)hydroxides, $F e-P=F e$-phosphates, sorb Fe-P = orthophosphates sorbed to Fe-(oxy)hydroxides, Po = organically bound $P$ ) was calculated. Distance from the roots was set as a fixed effect, with random slopes and random intercept. The table shows the results of the post-hoc least square means (with "Tukey" correction) pairwise comparison ( $p$ values).

\begin{tabular}{|c|c|c|c|c|}
\hline Variable & Depth & $\begin{array}{l}\text { Humid- } \\
\text { temperate } \\
\text { forest } \\
\text { Mediterranean } \\
\text { woodland } \\
\end{array}$ & $\begin{array}{l}\text { Mediterranean } \\
\text { woodland - } \\
\text { Arid shrubland }\end{array}$ & $\begin{array}{l}\text { Humid- } \\
\text { temperate } \\
\text { forest } \\
\text { Arid } \\
\text { shrubland }\end{array}$ \\
\hline $\mathrm{Ca}-\mathrm{P}$ & Topsoil & 0.037 & 0.000 & 0.000 \\
\hline Ca-P & Subsoil & 0.000 & 0.000 & 0.000 \\
\hline Ca-P & Saprolite & 0.015 & 0.155 & 0.000 \\
\hline $\mathrm{Fe}-\mathrm{P}$ & Topsoil & 0.149 & 0.422 & 0.005 \\
\hline $\mathrm{Fe}-\mathrm{P}$ & Subsoil & 0.284 & 0.947 & 0.454 \\
\hline $\mathrm{Fe}-\mathrm{P}$ & Saprolite & 0.010 & 0.049 & 0.964 \\
\hline Al-P & Topsoil & 0.802 & 0.111 & 0.023 \\
\hline Al-P & Subsoil & 0.072 & 0.820 & 0.248 \\
\hline $\mathrm{Al}-\mathrm{P}$ & Saprolite & 0.000 & 0.247 & 0.000 \\
\hline sorbFe-P & Topsoil & 0.191 & 0.191 & 1.000 \\
\hline sorbFe-P & Subsoil & 0.438 & 1.000 & 0.438 \\
\hline sorbFe-P & Saprolite & 0.172 & 1.000 & 0.244 \\
\hline sorbAl-P & Topsoil & 0.054 & 0.420 & 0.001 \\
\hline sorbAl-P & Subsoil & 0.000 & 0.965 & 0.000 \\
\hline sorbAl-P & Saprolite & 0.000 & 0.851 & 0.000 \\
\hline Po & Topsoil & 0.370 & 0.031 & 0.000 \\
\hline Po & Subsoil & 0.003 & 0.738 & 0.034 \\
\hline Po & Saprolite & 0.672 & 0.942 & 0.521 \\
\hline
\end{tabular}




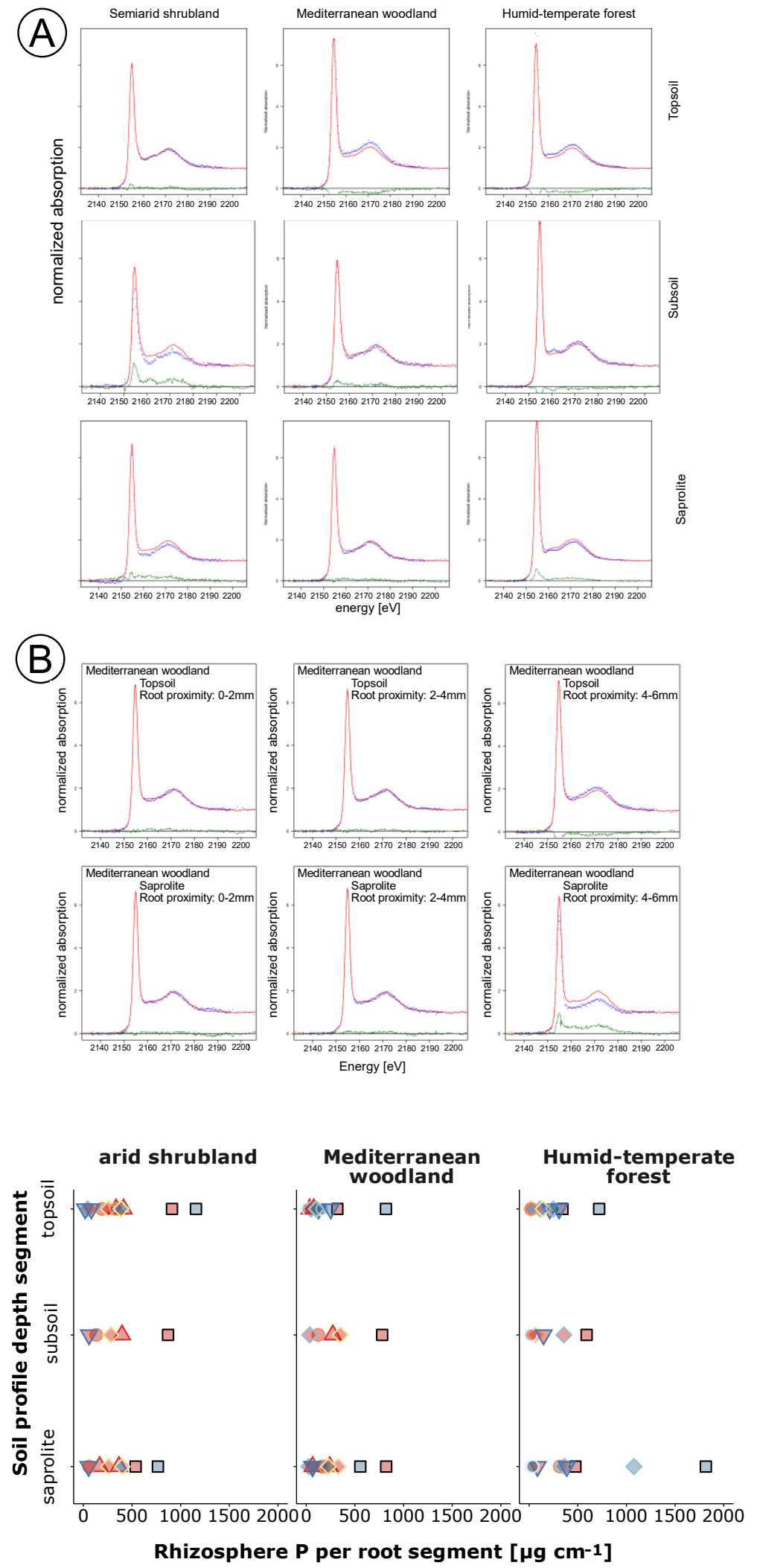

$P$ compound class Facing

$\square$ Ptot $\triangle$ Ca-P $\bigcirc$ Fe-P Al-P sorbFe-P $\diamond$ sorbAl-P $\nabla$ Po $\bigcirc$ North South
Figure $\quad S \quad$ 2.5-1: Exemplary phosphorus $K$-edge X-ray absorption near edge structure spectroscopy (XANES) spectra along the ecosequence (A) from all three soil depths (distance 0-2 $\mathrm{mm}$ from roots) and $(B)$ from the Mediterranean woodland in topsoil, and saprolite for all three distances from roots $(0$ $2 \mathrm{~mm}, 2-4 \mathrm{~mm}$, and 4-6 mm). Black dots represent the measured data, the red curve is the best fit chosen by the lowest $R$ factor. Green dots show the residual from the data to the fit $(R-$ factor).
Figure S 2.5-2: Pools of rhizosphere $P$ per root segment (total $P$, calciumphosphates (Ca-P), $\mathrm{Fe}$ - and $\mathrm{Al}$ phosphates (Fe-P, Al-P), orthophosphates sorbed to $\mathrm{Fe}$ - and Al-(oxy)hydroxides (sorbFe-P, sorbAl-P), and organic $P\left(P_{o}\right)$ were calculated for a cylinder around roots. Contents in each distance to the root were converted to rhizosphere $P$ per root length by multiplying with bulk density and the respective volume of the cylinder sheathing the root. Average root thickness was set to $2 \mathrm{~mm}$. For the arid shrubland ('shrubland'), Mediterranean woodland ('woodland'), and humid-temperate forest ('forest'). In each site for the topsoil, subsoil, and saprolite. 


\subsection{Abstracts of related studies}

\subsubsection{Chemistry and microbiology of the Critical Zone along a steep climate and vegetation gradient in the Chilean Coastal Cordillera}

Published in Catena (2018), 170, 183-203, doi: 10.1016/j.catena.2018.06.002

Ralf A. Oeser ${ }^{\mathrm{a}, *}$, Nicole Stroncik ${ }^{\mathrm{a}, \mathrm{d}}$, Lisa-Marie Moskwa ${ }^{\mathrm{b}}$, Nadine Bernhard ${ }^{\mathrm{e}}$, Mirjam Schaller ${ }^{\mathrm{f}}$, Rafaella Canessa $^{\mathrm{g}}$, Liesbeth van den Brink ${ }^{\mathrm{h}}$, Moritz Köster ${ }^{\mathrm{i}}$, Emanuel Brucker ${ }^{\mathrm{j}}$, Svenja Stock $^{\mathbf{k}}$, Juan Pablo Fuentes ${ }^{1}$, Roberto Godoy ${ }^{\mathrm{m}}$, Francisco Javier Matus ${ }^{\mathrm{n}}$, Rómulo Oses Pedraza ${ }^{\mathrm{o}, \mathrm{p}}$, Pablo Osses McIntyre ${ }^{\mathrm{q}}$, Leandro Paulino ${ }^{\mathrm{r}}$, Oscar Seguel ${ }^{\mathrm{s}}$, Maaike Y. Bader ${ }^{\mathrm{g}}$, Jens Boy ${ }^{\mathrm{t}}$, Michaela A. Dippold $^{\mathrm{i}}$, Todd A. Ehlers ${ }^{\mathrm{f}}$, Peter Kühn ${ }^{\mathrm{e}}$, Yakov Kuzyakov ${ }^{\mathrm{k}}$, Peter Leinweber ${ }^{\mathrm{u}}$, Thomas Scholten ${ }^{\mathrm{e}}$, Sandra Spielvogel ${ }^{\mathrm{v}}$, Marie Spohn ${ }^{\mathrm{j}}$, Kirstin Übernickel $^{\mathrm{f}}$, Katja Tielbörger ${ }^{\mathrm{h}}$, Dirk Wagner ${ }^{\mathrm{b}, \mathrm{w}}$, Friedhelm von Blanckenburg ${ }^{\mathrm{a}, \mathrm{c}}$

\footnotetext{
a GFZ German Research Centre for Geosciences, Section 3.3 Earth Surface Geochemistry, Telegrafenberg, D-14473 Potsdam, Germany

${ }^{\mathrm{b}}$ GFZ German Research Centre for Geosciences, Section 5.3 Geomicrobiology, Telegrafenberg, D-14473 Potsdam, Germany

${ }^{c}$ Freie Universität Berlin; Institute of Geological Science, Malteserstr. 74-100, Building N, D-12249 Berlin, Germany

${ }^{d}$ GFZ German Research Centre for Geosciences, Section 3.1 Inorganic and Isotope Geochemistry, Telegrafenberg, D-14473 Potsdam, Germany

e University of Tübingen, Soil Science and Geomorphology, Rümelinstraße 19-23, D-72070 Tübingen, Germany

${ }^{\mathrm{f}}$ University of Tübingen, Department of Geosciences, Wilhelmstraße 56, D-72074 Tübingen, Germany

g Philipps-University Marburg, Ecological Plant Geography, Deutschhausstraße 10, D-35032 Marburg, Germany

${ }^{\text {h }}$ University of Tübingen, Plant Ecology, Auf der Morgenstelle 5, D-72076 Tübingen, Germany

${ }^{\text {i }}$ Georg-August-University Göttingen, Biogeochemistry of Agroecosystems, Büsgenweg 2, D-37077 Göttingen, Germany

${ }^{j}$ University of Bayreuth, Institute of Soil Ecology, Dr.-Hans-Frisch-Straße 1-3, D-95448 Bayreuth, Germany

${ }^{k}$ Georg-August-University Göttingen, Soil Science of Temperate Ecosystems, Büsgenweg 2, D-37077 Göttingen, Germany

${ }^{1}$ Universidad de Chile, Facultad de Ciencias Forestales y de la Conservación de la Naturaleza, Av. Santa Rosa, 11315 La Pintana, Santiago, Chile

${ }^{\mathrm{m}}$ Universidad Austral de Chile, Instituto de Ciencias Ambientales y Evolutivas, Avenida Eduardo Morales Miranda, Campus Isla Teja, Valdivia, Chile

${ }^{\mathrm{n}}$ Universidad de La Frontera, Departamento de Ciencias Químicas y Recursos Naturales, Scientific and Technological Bioresource Nucleus (BIORENUFRO), Temuco, Chile

${ }^{\circ}$ Centro de Estudios Avanzados en Zonas Aridas (CEAZA), Raúl Britán \#1305, Campus Andrés Bello Universidad de La Serena, La Serena, Chile p Universidad de Atacama, CRIDESAT, Copayapu 484, Copaipó, Chile

q Pontificia Universidad Católica de Chile, Instituto de Geografía, Vicuña Mackenna 4860, Macul, Santiago, Chile

${ }^{\mathrm{r}}$ Universidad de Concepción, Departamento de Suelos y Recursos Naturales, Facultad de Agronomía, Avda. Vicente Méndez 595, Chillán, Chile

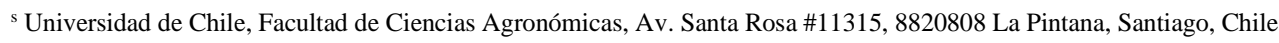

${ }^{t}$ Leibniz University Hannover, Institute of Soil Science, Herrenhäuser Straße 2, D-30419 Hannover, Germany

" University of Rostock, Faculty of Agricultural and Environmental Sciences, Soil Science, Justus-von-Liebig-Weg 6, D-18059 Rostock, Germany

${ }^{v}$ Christian-Albrechts-University Kiel, Institute of Soil Science, Herman-Rodewlad-Straße 2, D-24118 Kiel, Germany

${ }^{w}$ University of Potsdam, Institute of Earth and Environmental Science, Karl-Liebknecht-Strasse 24-25, 14476 Potsdam, Germany
} 


\section{Abstract}

The Chilean Coastal Cordillera features a spectacular climate and vegetation gradient, ranging from arid and unvegetated areas in the north to humid and forested areas in the south. The EarthShape project ("Earth Surface Shaping by Biota”) uses this natural gradient to investigate how climate and biological processes shape the Earth's surface. We explored the Critical Zone, the Earth's uppermost layer, in four key sites located in desert, semidesert, Mediterranean, and temperate climate zones of the Coastal Cordillera, with the focus on weathering of granitic rock. Here, we present first results from 16 approximately 2 m-deep regolith profiles to document: (1) architecture of weathering zone; (2) degree and rate of rock weathering, thus the release of mineralderived nutrients to the terrestrial ecosystems; (3) denudation rates; and (4) microbial abundances of bacteria and archaea in the saprolite. From north to south, denudation rates from cosmogenic nuclides are $\sim 10 \mathrm{t} \mathrm{km}-2 \mathrm{yr}-1$ at the arid Pan de Azúcar site, $\sim 20 \mathrm{t} \mathrm{km}-2 \mathrm{yr}-1$ at the semi-arid site of Santa Gracia, $\sim 60 \mathrm{t} \mathrm{km}-2 \mathrm{yr}-1$ at the Mediterranean climate site of La Campana, and $\sim 30 \mathrm{t}$ $\mathrm{km}-2 \mathrm{yr}-1$ at the humid site of Nahuelbuta. A and B horizons increase in thickness and elemental depletion or enrichment increases from north $\left(\sim 26^{\circ} \mathrm{S}\right)$ to south $\left(\sim 38^{\circ} \mathrm{S}\right)$ in these horizons. Differences in the degree of chemical weathering, quantified by the chemical depletion fraction (CDF), are significant only between the arid and sparsely vegetated site and the other three sites. Differences in the CDF between the sites, and elemental depletion within the sites are sometimes smaller than the variations induced by the bedrock heterogeneity. Microbial abundances (bacteria and archaea) in saprolite substantially increase from the arid to the semi-arid sites. With this study, we provide a comprehensive dataset characterizing the Critical Zone geochemistry in the Chilean Coastal Cordillera. This dataset confirms climatic controls on weathering and denudation rates and provides prerequisites to quantify the role of biota in future studies. 


\subsubsection{Pedogenic and microbial interrelations to regional climate and local topography:} New insights from a climate gradient (arid to humid) along the Coastal Cordillera of Chile

Published in Catena (2018), 170, 335-355, doi: 10.1016/j.catena.2018.06.018

Nadine Bernhard $^{\mathrm{a}, *, 1}$, Lisa-Marie Moskwa ${ }^{\mathrm{b}, 1}$, Karsten Schmidt ${ }^{\mathrm{a}}$, Ralf A. Oeser ${ }^{\mathrm{c}}$, Felipe Aburto ${ }^{\mathrm{d}}$, Maaike Y. Bader $^{\mathrm{e}}$, Karen Baumann ${ }^{\mathrm{f}}$, Friedhelm von Blanckenburg ${ }^{\mathrm{c}, \mathrm{g}}$, Jens Boy ${ }^{\mathrm{h}}$, Liesbeth van den Brink ${ }^{\mathrm{i}}$, Emanuel Brucker $^{\mathrm{j}}$, Burkhard Büdel ${ }^{\mathrm{k}}$, Rafaella Canessa ${ }^{\mathrm{e}}$, Michaela A. Dippoldl, Todd A. Ehlers ${ }^{\mathrm{m}}$, Juan Pablo Fuentes $^{\mathrm{n}}$, Roberto Godoy ${ }^{\circ}$, Patrick Jung ${ }^{\mathrm{k}}$, Ulf Karsten ${ }^{\mathrm{p}}$, Moritz Köster ${ }^{\mathrm{l}}$, Yakov Kuzyakov ${ }^{\mathrm{q}}$, Peter Leinweber ${ }^{\mathrm{f}}$, Harald Neidhardt ${ }^{\mathrm{r}}$, Francisco Matus ${ }^{\mathrm{s}}$, Carsten W. Mueller ${ }^{\mathrm{t}}$, Yvonne Oelmann ${ }^{\mathrm{r}}$, Rómulo Oses ${ }^{\mathrm{u}}$, v, Pablo Osses ${ }^{\mathrm{w}}$, Leandro Paulino ${ }^{\mathrm{x}}$, Elena Samolov ${ }^{\mathrm{p}}$, Mirjam Schaller ${ }^{\mathrm{m}}$, Manuel Schmid ${ }^{\mathrm{m}}$, Sandra Spielvogel ${ }^{\mathrm{y}}$, Marie Spohn ${ }^{\mathrm{j}}$ Svenja Stock ${ }^{\mathrm{q}}$, Nicole Stroncik ${ }^{\mathrm{c}}$, Katja Tielbörger ${ }^{\mathrm{i}}$, Kirstin Übernickel ${ }^{\mathrm{m}}$, Thomas Scholten ${ }^{\mathrm{a}}$, Oscar Seguel ${ }^{\mathrm{z}}$, Dirk Wagner ${ }^{\mathrm{b}}$, aa, Peter Kühn $^{\mathrm{a}}$

a University of Tübingen, Department of Geosciences, Soil Science and Geomorphology, Rümelinstraße 19-23, D-72070 Tübingen, Germany b GFZ German Research Centre for Geosciences, Section 5.3 Geomicrobiology, Telegrafenberg, D-14473 Potsdam, Germany c GFZ German Research Centre for Geosciences, Section 3.3 Earth Surface Geochemistry, Telegrafenberg, D-14473 Potsdam, Germany d Universidad de Concepción, Departamento de Silvicultura, Facultad de Ciencias Forestales, Victoria 631, Concepción, Chile e University of Marburg, Faculty of Geography, Plant Ecological Biogeography, Deutschhausstrasse 10, D-35032 Marburg, Germany f University of Rostock, Faculty of Agricultural and Environmental Sciences, Soil Science, Justus-von-Liebig-Weg 6, D-18059 Rostock, Germany $\mathrm{g}$ Freie Universität Berlin, Institute of Geological Science, Malteserstr. 74-100, Building N, D-12249 Berlin, Germany h Leibniz University of Hannover, Institute of Soil Science, Herrenhäuser Straße 2, D-30419 Hannover, Germany i University of Tübingen, Plant Ecology, Auf der Morgenstelle 5, D-72076 Tübingen, Germany j University of Bayreuth, Institute of Soil Ecology, Dr.-Hans-Frisch-Straße 1-3, D-95448 Bayreuth, Germany k Technical University Kaiserslautern, Department Plant Ecology and Systematics, Institute of Biology, Erwin-Schrödinger-Str. 13, D-67663 Kaiserslautern, Germany

1 Georg-August-University of Göttingen, Biogeochemistry of Agroecosystems, Büsgenweg 2, D-37077 Göttingen, Germany $\mathrm{m}$ University of Tübingen, Department of Geosciences, Wilhelmstraße 56, D-72074 Tübingen, Germany

n Universidad de Chile, Facultad de Ciencias Forestales y de la Conservación de la Naturaleza, Av. Santa Rosa, 11315 La Pintana, Santiago, Chile o Universidad Austral de Chile, Instituto de Ciencias Ambientales y Evolutivas, Avenida Eduardo Morales Miranda, Campus Isla Teja, 5090000 Valdivia, Chile

p University of Rostock, Institute of Biological Sciences, Applied Ecology and Phycology, Albert-Einstein-Strasse 3, D-18059 Rostock, Germany q Georg-August-University of Göttingen, Soil Science of Temperate Ecosystems, Büsgenweg 2, D-37077 Göttingen, Germany

r University of Tübingen, Geoecology, Rümelinstraße 19-23, D-72070 Tübingen, Germany

s Universidad de La Frontera, Departamento de Ciencias Químicas y Recursos Naturales, Scientific and Technological Bioresource Nucleus (BIORENUFRO), Temuco, Chile

t Technical University of Munich, Research Department Ecology and Ecosystem Management, Freising, Germany

u Centro de Estudios Avanzados en Zonas Aridas (CEAZA), Raúl Britán \#1305, Campus Andrés Bello Universidad de La Serena, La Serena, Chile

v Universidad de Atacama, CRIDESAT, Copayapu 484, Copiapó, Chile

w Pontificia Universidad Católica de Chile, Instituto de Geografía, Vicuña Mackenna, 4860 Macul, Santiago, Chile

x Universidad de Concepción, Departamento de Suelos y Recursos Naturales, Facultad de Agronomía, Avda. Vicente Méndez 595, Chillán, Chile

y Christian-Albrechts-University of Kiel, Institute of Soil Science, Hermann-Rodewald-Straße 2, D-24118 Kiel, Germany

z Universidad de Chile, Facultad de Ciencias Agronómicas, Av. Santa Rosa \#11315, 8820808 La Pintana, Santiago, Chile 


\section{Abstract}

The effects of climate and topography on soil physico-chemical and microbial parameters were studied along an extensive latitudinal climate gradient in the Coastal Cordillera of Chile $\left(26^{\circ}\right.$ $38^{\circ} \mathrm{S}$ ). The study sites encompass arid (Pan de Azúcar), semiarid (Santa Gracia), mediterranean (La Campana) and humid (Nahuelbuta) climates and vegetation, ranging from arid desert, dominated by biological soil crusts (biocrusts), semiarid shrubland and mediterranean sclerophyllous forest, where biocrusts are present but do have a seasonal pattern to temperatemixed forest, where biocrusts only occur as an early pioneering development stage after disturbance. All soils originate from granitic parent materials and show very strong differences in pedogenesis intensity and soil depth.

Most of the investigated physical, chemical and microbiological soil properties showed distinct trends along the climate gradient. Further, abrupt changes between the arid northernmost study site and the other semi-arid to humid sites can be shown, which indicate non-linearity and thresholds along the climate gradient. Clay and total organic carbon contents (TOC) as well as Ah horizons and solum depths increased from arid to humid climates, whereas bulk density (BD), $\mathrm{pH}$ values and base saturation (BS) decreased. These properties demonstrate the accumulation of organic matter, clay formation and element leaching as key-pedogenic processes with increasing humidity. However, the soils in the northern arid climate do not follow this overall latitudinal trend, because texture and BD are largely controlled by aeolian input of dust and sea salts spray followed by the formation of secondary evaporate minerals. Total soil DNA concentrations and TOC increased from arid to humid sites, while areal coverage by biocrusts exhibited an opposite trend. Relative bacterial and archaeal abundances were lower in the arid site, but for the other sites the local variability exceeds the variability along the climate gradient. Differences in soil properties between topographic positions were most pronounced at the study sites with the mediterranean and humid climate, whereas microbial abundances were independent on topography across all study sites. In general, the regional climate is the strongest controlling factor for pedogenesis and microbial parameters in soils developed from the same parent material. Topographic position along individual slopes of limited length augmented this effect only under humid conditions, where water erosion likely relocated particles and elements downward. The change from alkaline to neutral soil $\mathrm{pH}$ between the arid and the semi-arid site coincided with qualitative differences in soil formation as well as microbial habitats. This also reflects non-linear relationships of pedogenic and microbial processes in soils depending on climate with a sharp threshold between arid and semi-arid conditions. Therefore, the soils on the transition between arid and semi-arid conditions are especially sensitive and may be well used as indicators of long 
and medium-term climate changes. Concluding, the unique latitudinal precipitation gradient in the Coastal Cordillera of Chile is predestined to investigate the effects of the main soil forming factor - climate - on pedogenic processes. 


\title{
2.6.3 Ferrous Wheel Hypothesis: Abiotic nitrate incorporation into dissolved organic matter
}

Published in Geochimica et Cosmochimica Acta (2019), 245, 514-524, doi: 10.1016/j.gca.2018.11.020

Francisco Matus ${ }^{\mathrm{ab}}, \underline{\text { Svenja Stock }}^{\mathrm{c}}$, Wolfram Eschenbach ${ }^{\mathrm{d}}$, Jens Dyckmans ${ }^{\mathrm{d}}$, Carolina Merino $^{\mathrm{b}}$, Francisco Nájera $^{\mathrm{b}}$, Moritz Köster ${ }^{\mathrm{e}}$, Yakov Kuzyakov ${ }^{\mathrm{cfg}}$, Michaela A. Dippold ${ }^{\mathrm{eh}}$

\begin{abstract}
${ }^{a}$ Department of Chemical Sciences and Natural Resources, University La Frontera, Temuco, Chile ${ }^{b}$ Laboratory of Soil Conservation and Dynamic of Volcanic Soils, University La Frontera, Temuco, Chile ${ }^{c}$ Department of Soil Science of Temperate Ecosystems, University of Goettingen, Goettingen, Germany ${ }^{\mathrm{d} C e n t r e}$ for Stable Isotope Research and Analysis, University of Goettingen, Goettingen, Germany ${ }^{\mathrm{e} B i o g e o c h e m i s t r y}$ of Agroecosystems, University of Goettingen, 37077 Geottingen, Germany ${ }^{\mathrm{f}}$ Agro-Technological Institute, RUDN University, 117198 Moscow, Russia ${ }^{9}$ Soil Science Consulting, 37077 Goettingen, Germany ${ }^{\text {h}}$ Department of Agricultural Soil Science, University of Goettingen, Goettingen, Germany
\end{abstract}

\section{Abstract}

We evaluated the abiotic formation of dissolved organic nitrogen (DON) by the fast reaction of iron $(\mathrm{Fe})$ with nitrate $\left(\mathrm{NO}_{3}{ }^{-}\right)$in the dissolved organic matter (DOM) of volcanic soils in a temperate rainforest ( $>5000 \mathrm{~mm}$ precipitation per year). During five days, the educts and products of abiotic reactions under anoxic conditions were measured in a microcosm experiment depending on the $\mathrm{Fe}$ and $\mathrm{NO}_{3}{ }^{-}$concentrations. A control zero-Fe was not used because there was no chemical reaction with nitrate addition. Using a novel technique of automated sample preparation for inorganic N (SPIN) attached to a membrane inlet quadrupole mass spectrometry (MIMS), the ${ }^{15} \mathrm{~N}$ abundances and inorganic $\mathrm{N}$ concentrations were determined directly in aqueous solutions. The results were explained in the context of the Ferrous Wheel Hypothesis which states that $\mathrm{Fe}(\mathrm{II})$ is utilized to reduce $\mathrm{NO}_{3}{ }^{-}$to nitrite $\left(\mathrm{NO}_{2}{ }^{-}\right)$that is incorporated into DOM. Fe(II) is regenerated from $\mathrm{Fe}(\mathrm{III})$ in anaerobic soil microsites. Here we tested one part of this hypothesis, the processes occurring in DOM (instead of soil organic matter). Using the SPIN-MIMS technique, we could overcome Ferrous Wheel Hypothesis criticism regarding possible $\mathrm{Fe}$ interference during $\mathrm{NO}_{3}{ }^{-}$ analysis. The total recovery of ${ }^{15} \mathrm{~N}$ added as $\mathrm{NO}_{3}{ }^{-}$fluctuated between 63 and $101 \%$, and the remaining ${ }^{15} \mathrm{~N}$ was measured as gaseous $\mathrm{N}_{2} \mathrm{O}$. The ${ }^{15} \mathrm{~N}$-labelled $\mathrm{NO}_{3}{ }^{-}$added decreased immediately after 15 min of incubation. After five days of incubation, approximately $25 \%$ of the labelled $\mathrm{NO}_{3}{ }^{-}$( $\mathrm{e}^{-}$acceptors) added was transformed to DON in the presence of a high amount of $\mathrm{Fe}(\mathrm{II})$ ( $\mathrm{e}^{-}$donors). Small amounts of $\mathrm{N}_{2} \mathrm{O}$ and $\mathrm{CO}_{2}$ provided further evidence of $\mathrm{NO}_{3}{ }^{-}$reduction 
and DOM oxidation, respectively. From these results, we propose a new theoretical model that includes the Ferrous Wheel Hypothesis, where only the transformation of $\mathrm{NO}_{3}{ }^{-}$to $\mathrm{DON}$ was proven. The present results explain the high retention of $\mathrm{NO}_{3}{ }^{-}$in $\mathrm{DOM}$ from volcanic soils in ecosystems with high precipitation. 


\subsubsection{Microbial uptake and utilization of inorganic phosphorus in soils of granidioritic} origin formed under varying climatic conditions

Manuscript in preparation

Moritz Koester $^{\mathrm{a}, \mathrm{b}}$, Michaela A. Dippold ${ }^{\mathrm{b}}$, Yue Hue ${ }^{\mathrm{b}, \mathrm{c}}$, Werner Häusler ${ }^{\mathrm{d}}$, Francisco Matus Baeza ${ }^{\mathrm{e}, \mathrm{f}}$, Francisco Nájera $^{\mathrm{g}, \mathrm{h}}, \underline{\text { Svenja C. Stock }}^{\mathrm{b}, \mathrm{i}}$, Sandra Spielvogel ${ }^{\mathrm{j}}$

${ }^{a}$ Instiute of Geography, University of Bern, Bern, Switzerland

${ }^{b}$ Biogeochemistry of Agroecosystems, University of Goettingen, Goettingen, Germany

${ }^{\mathrm{c}}$ Genebank Department, Leibniz Institute of Plant Genetics and Crop Plant Research (IPK), Rostock, Germany

${ }^{\mathrm{d}}$ Research Department Ecology and Ecosystem Management, Chair of Soil Science, Technical University of Munich, Freising, Germany

${ }^{\mathrm{e}}$ Laboratory of Conservation and Dynamic of Volcanic Soils, Universidad de La Frontera, Chile

${ }^{\mathrm{f}}$ Network for Extreme Environment Research, NEXER-Chile, Universidad de La Frontera, Chile

sDepartment of Chemical Sciences and Natural Resources, Universidad de La Frontera, Chile

${ }^{\text {h}}$ Faculty of Agricultural Sciences, Universidad de Chile, Santiago, Chile

institute of Geography and Geoecology, Karlsruhe Institute of Technology, Karlsruhe

Institute for Plant Nutrition and Soil Science, Christian-Albrechts University Kiel, Kiel, Germany

\section{Abstract}

Phosphor (P) sorption in soil is a multivariate process strongly dependent on soil mineralogy, organic carbon (C) content, reactive surface area, and $\mathrm{pH}$, all of which are influenced by climate. $\mathrm{P}$ availability to plants is often limited by strong and fast sorption within soils. Microorganisms can actively desorb $\mathrm{P}$ at which they become more effective the more they are limited by this nutrient. The goal of this study was to gain insight in inorganic P sorption to the soil solid phase and, subsequently, microbial $\mathrm{P}$ uptake along an aridity gradient across biomes (ecosequence) in the Coastal Cordillera of Chile. To investigate these differences that arose from the different climates under which the soils developed, a combined approach of an ion-exchange kinetics experiment, with subsequent laboratory incubation of the soils was conducted. Rhizosphere conditions for $\mathrm{P}$ sorption and microbial uptake are very different from bulk soil and characterized by increased availability of easily degradable $\mathrm{C}$. Therefore, the experimental setup included a subset of mesocosms in the incubation experiment, which received a defined amount of glucose. $\mathrm{P}$ sorption followed a unimodal distribution along the ecosequence. The hyperarid desert soil adsorbed $64.1 \%$ and $38.5 \%$ of added $\mathrm{P}$ in the top- and subsoil, respectively. The forest soils showed strongest sorption capacity of all soils, $98.2 \%$ and $99.6 \%$ of added $\mathrm{P}$ sorbed for in top- and subsoil, respectively. At the two transitional sites, only $31.6 \%$ in the topsoil and $26.6 \%$ in the subsoil of the arid shrubland, and $35.7 \%$ and $33.1 \%$ in topsoil and subsoil of/ the Coastal Matorral, of added 
P were sorbed to the soil. Microbial P uptake differed significantly among the ecosystems. It was below the detection limit in the hyperarid desert and highest in the in the Coastal Matorral with up to $39.1 \mu \mathrm{g}$ g-1dry soil. However, a comparison of $\mathrm{P}$ in the soil solution of the incubated soils to sterile soils suggested a strong effect of microbes on $\mathrm{P}$ in soil solution in the desert soil.

\subsection{Additional studies}

Nájera, F., Dippold, M.A., Boy, J., Sequel, O., Koester, M., Stock, S., Merino, C., Kuzakov, Y., Matus, F. (2020). Effects of drying/rewetting on soil aggregate dynamics and implications for organic matter turnover. Biology and Fertility of Soils, doi: 10.1007/s00374-02001469-6

Merino, C., Matus, F., Kuzyakov, Y., Dyckmans, J., Stock, S., Dippold, M.A. Contribution of Fenton reaction and ligninolytic enzymes to soil organic matter mineralization under anoxic conditions. Accepted for publication in Science of the Total Environment. 


\section{Acknowledgments}

I am thankful for everyone who supported me on this journey in one way or the other and enabled me to complete my thesis. I especially thank Michaela Dippold, for her tireless commitment, support, and assurance during the past years. I am grateful for her mentorship, for giving me direction in times needed and paving my way to become an independent researcher.

I thank Yakov Kuzyakov, for giving me the chance to conduct an exciting research project, the opportunity to develop and contribute my own ideas, and for supporting me with his advice during this journey.

I further thank Christoph Leuschner and Anna Gorbushina for their support as part of my committee and providing valuable input to my work from new perspectives.

I thank the DFG for funding this project within the priority program 1803 "EarthShape - Earth Surface Shaping by Biotia", and I thank the EarthShape coordination team Todd Ehlers, Friedhelm von Blanckenburg, Kirstin Übernickel, and Leandro Paulino, who always managed to make our project meetings fun happenings with their energy.

Without the help of student assistants and the laboratory technicians in Göttingen this work would not have been possible. I want to thank especially Karin Schmidt and Susann Enzmann, who's support went beyond mere lab work, as well as the team of the Centre for Stable Isotope Analysis (KOSI) in Göttingen.

Over the past years, I have been lucky to have met and been accompanied by many amazing people. Francisco Nájera, Carolina Merino, Francisco Matus y Roberto Godoy, gracias por recibirme con los brazos abiertos al llegar a Chile y por apoyarme a lo largo de los años. ¡Espero seguir trabajando con ustedes y comenzar nuevos proyectos juntos! Jens Boy, thank you for your insights on the small things and the bigger context. Matthias Gube, thank you for being always a source of advice and for introducing me to the world of fungi, and thank you Johanna Pausch and Richard Phillips, for supporting me in my quest to explore this fascinating world and expand my knowledge. Moritz Köster, you were not only the best colleague I could have wished for to master this project together, but you became a great friend. Thank you for all the support, the many discussions, trusting conversations, and making this journey so much more enjoyable! Nina Hennings, no matter what was going on, you always came to the conclusion that "we can, and we will do this!" Thank you for your trust, your assurance, and simply being there when needed. Andy Breidenbach, you had (and have) the talent to lighten the mood and make me laugh, even when everything went south; thank you for your moral support through all the times. Sara Halicki, thank you for all the evenings to take off our minds from science. Adrienne Keller, you impressed and inspired me with your warmth, positive energy, and scientific curiosity, and I hope to join you on 
many more hikes and projects in the coming years. Francisco Nájera, thank you for your immediate friendship, for an amazing journey through Chile, and for introducing me to the best cat I have ever met. Leonie Göbel, you always impressed me with your energy and your "everything is possible" and "ready to help" attitude. Maire Holz, thank you for lending an ear when needed, your advice, and putting things in perspective. And especially, thank you Johannes, for always being by my side. 


\section{Legal Statement}

Hiermit erkläre ich, dass diese Arbeit weder in gleicher noch in ähnlicher Form bereits anderen Prüfungsbehörden vorgelegen hat und ich mich an keiner anderen Hochschule um einen Doktorgrad beworben habe. Weiter erkläre ich eidesstattlich, dass diese Dissertation selbstständig und ohne unerlaubte Hilfe angefertigt wurde.

Göttingen, den

(Unterschrift) 